\title{
Diversity in fossil fungal spores
}

\section{Saxena RK${ }^{1}$, Wijayawardene $\mathrm{NN}^{2,3}$, Dai $\mathrm{DQ}^{3}$, Hyde $\mathrm{KD}^{4}$ and Kirk $\mathrm{PM}^{5}$}

\author{
${ }^{1}$ Birbal Sahni Institute of Palaeosciences, 53 University Road, Lucknow-226007, India \\ ${ }^{2}$ State Key Laboratory of Functions and Applications of Medicinal Plants, Guizhou Medical University, Guiyang \\ 550014, P.R. China \\ ${ }^{3}$ Center for Yunnan Plateau Biological Resources Protection and Utilization, College of Biological Resource and Food \\ Engineering, Qujing Normal University, Qujing, Yunnan 655011, P.R. China \\ ${ }^{4}$ Center of Excellence in Fungal Research, Mae Fah Luang University, Chiang Rai 57100, Thailand \\ ${ }^{5}$ Royal Botanic Gardens, Kew, Richmond, Surrey TW9 3DS, UK
}

Saxena RK, Wijayawardene NN, Dai DQ, Hyde KD, Kirk PM 2021 - Diversity in fossil fungal spores. Mycosphere 12(1), 670-874, Doi 10.5943/mycosphere/12/1/8

\begin{abstract}
Diverse types of fungal spores, exhibiting a variety of morphological variations, have been added to the fossil records from time to time. These may be unicellate (unicellular), dicellate, tricellate, tetracellate, multicellate, muriform, filiform, spirally coiled and star-like. Similarly, these may be inaperturate, monoaperturate, diaperturate, triaperturate and multiaperturate. The present paper documents all published fossil fungal spore genera and species. Assignment of fossil fungal spores to extant fungal taxa is seldom possible. These are therefore placed into artificial suprageneric taxa based on morphological characters, e.g. number and nature of cells and characters associated with size, symmetry, apertures, septa and spore wall. These supra-generic taxa are: Amerosporae (unicellate spores; 61 genera), Didymosporae (dicellate spores; 21 genera), Phragmosporae (tri- or pluricellate, transversely septate spores; 41 genera), Dictyosporae (muriform spores divided by intersecting longitudinal and transverse or diagonal septa; 18 genera), Helicosporae (one to many celled, spirally coiled spores with curved axis; 9 genera) and Staurosporae (pluricellate, stellate spores, with more than one axis; 9 genera). In addition, a number of species of fossil fungal spores, described under 26 modern fungal genera, have also been included. Genera are arranged in alphabetical order under each of the above groups. Similarly, species are also arranged under each genus in alphabetical order. Five new species, viz. Dicellaesporites vermae, Dyadosporites singhii, Fusiformisporites sahii, Diporicellaesporites tiruchirappalliensis and Multicellites tamilensis, and four new combinations, viz. Hypoxylonites disciformis (Sheffy \& Dilcher), Hypoxylonites lanceolatus (Debi Mukh.), Melanospora primigenia (Casp.) and Thecaphora mohgaoensis (Chitaley \& Yawale) are proposed here. The dominant genera, both in number and variety, are: Brachysporisporites R.T. Lange \& P.H. Sm., Dicellaesporites Elsik, Diporicellaesporites Elsik, Diporisporites Hammen, Dyadosporites R.T. Clarke, Fusiformisporites Rouse, Hypoxylonites Elsik, Inapertisporites Hammen, Multicellaesporites Elsik, Multicellites Kalgutkar \& Janson., Pluricellaesporites Hammen and Staphlosporonites Sheffy \& Dilcher. Fossil fungal spores are known from all parts of the globe and in the sediments ranging from the Precambrian era to most recent age. Their distribution in time and space is presented. A comparison of the fossil fungal spores with extant taxa is also made and affinity of a good number of fossil genera and species could be traced with the extant genera or
\end{abstract}


higher taxa. Palaeoenvironmental and stratigraphic implications of fungal spores are also discussed.

Keywords - Amerosporae - Classification - Dictyosporae - Didymosporae - Fungi Imperfecti Helicosporae - Phragmosporae - Staurosporae

\section{Introduction}

The last few decades witnessed a substantial increase in the number of publications dealing with the study of microfossils, e.g. spores and pollen of vascular plants, dinoflagellate cysts and fungi, having multiple applications in the field of earth and life sciences, viz. determination of palaeoenvironment, evolution of morphographic characters and biostratigraphy.

Fossil fungi form the ancestors of extant fungi which evolved relatively early, probably more than 1500 million years ago. Fossil fungal remnants are found in sedimentary rocks in the form of spores, mycelia, sporophores and symbiotic associations and are commonly observed in macerated residues prepared for palynological studies. Fungal remains have been recorded from sediments of all ages, but are abundant in the Tertiary Period. The fossil records clearly indicate that Ascomycota, the largest and most diversified group of modern fungi, became established during the Cretaceous Period and became abundant in the Tertiary Period (Elsik 1968, Jain 1974, Kar \& Saxena 1976, Jansonius 1976, Jain \& Kar 1979, Ramanujam 1982, Kalgutkar \& Jansonius 2000, Tripathi 2009, Saxena \& Tripathi 2011). The majority of fossil fungal spores, found in palynological preparations, belong to Ascomycota whereas only a few belong to Basidiomycota. In members of Ascomycota, ascospores are produced inside the ascus by the sexual morph (teleomorph) whereas the asexual morph (anamorph) may produce several types of asexual vegetative spores, named conidiospores (or conidia) which may be unicellate to multicellate and variously shaped. Saprobic Ascomycota may produce ascomata of macroscopic size and definite shape.

Fragments of fossil fungi, commonly observed in the palynological preparations, have been sporadically recorded since Williamson (1878, 1880), Conwentz (1892), Meschinelli (1892, 1902), Felix (1894), Kidston \& Lang (1921), Edwards (1922) and Van der Hammen (1954, 1955, 1956). Tiffney \& Barghoorn (1974) observed that the palaeomycological record is too scanty to allow the introduction of a firm phylogeny. The paucity of the fungal records before the Cenozoic has often been cited as a principal reason for lack of interest in their stratigraphic potential. Ramanujam \& Rao (1978) postulated that fungal spores are not suitable for stratigraphical interpretations on a lack of interest in, and insufficient appreciation of, the spore morphology of modern fungi. Stubblefield \& Taylor (1988) opined that the avoidance of fossil fungi is most likely to be explained by the difficulties of properly recognizing, manipulating and interpreting them.

However, since the 1950s studies on fossil fungi received more attention with the amplification of palynological studies (Rouse 1959, 1962, Varma \& Rawat 1963, Clarke 1965, Elsik 1968, 1969, 1990a, Elsik \& Jansonius 1974, Kar \& Saxena 1976, 1981, Ramanujam \& Rao 1978, Ramanujam \& Srisailam 1980, Chandra et al. 1984, Glass et al. 1986, Jarzen \& Elsik 1986, Song et al. 1989, Kumar 1990, Saxena 1991, 2006, Saxena \& Khare 1992, Kalgutkar 1993, 1997, Kalgutkar \& Sigler 1995 Parsons \& Norris 1999, Kagutkar \& Jansonius 2000, Gupta 2002, Nandi et al. 2003, Kar et al. 2010, Saxena \& Tripathi 2011, Mukherjee 2012, Guimarães et al. 2013, Martinez et al. 2016, O'Keefe et al. 2017, Premaor et al. 2018). Although fossil fungi are encountered in sediments of all ages, their frequency remarkably increases in the Tertiary Period, which suggests that their proliferation is linked with diversification of angiosperms. Serious efforts have been made on the study of dispersed fossil fungi from Cretaceous-Tertiary sediments, including spores, microscopic sporangia, sporophores, hyphae or fragmented mycelia and mycorrhiza.

\section{Organization of the paper}

The main objective of the paper is to document all published genera and species of fossil fungal spores described to date. For the sake of convenience, the paper is arranged in three parts. 
The first part contains a general introduction and history of the studies on fossil fungi, classification of fossil fungal spores, terms related to fossil fungi, geological time and life on earth, field and laboratory investigation procedures, sources of information and method of data presentation.

The second part provides an account of the fossil fungal spores. Details of this section are provided under Materials and Methods. Furthermore, in this part, five new species are proposed. These forms were earlier described under different genera as informal un-named species. Specimens of these forms were restudied and careful observations led to the proposal of new species. The following information is given for each new species: Names of the new species, Index Fungorum Registration Identifier, Holotype and its Repository details, Diagnosis, Location, Age and Notes, including comparison and derivation of names. In addition, four new combinations are proposed. The following information is given for each new combination: Name of the new combination followed by the author of the basionym, Index Fungorum Registration Identifier, Full and direct reference to the basionym with full bibliographical details, Holotype and its Repository details, Diagnosis, Location, Age and Notes, including comparison and derivation of names.

The third part is a discussion on the diagnostic characters of the commonly occurring fossil fungal spore genera and their relationship with extant fungal taxa, palaeoenvironmental and biostratigraphic implications of fossil fungi and suggestions for future studies.

Efforts were made to include, in this paper, all genera and species of fossil fungal spores published worldwide, as far as known to us, including later synonyms and homonyms with their current names. Even taxa, that were not validly published, have also been included. However, it is possible that some papers might have escaped our attention. Although, we feel that there are quite a good number of species that may be later taxonomic synonyms, we did not make any attempt to point them out because we did not see most of the original material. Similarly, we also refrained from emending the generic and specific diagnoses for the same reason.

\section{Classification of fossil fungal spores}

Since the very beginning of studies on fossil fungi, diverse types of fungal spores have been added to the fossil records from time to time. The morphological features of these spores are sometimes distinct to allow identification and comparison with their extant counterparts and help to assign them to a natural classification system. This, however, is seldom possible. Except for some distinctive Tertiary forms, fossil fungal spores cannot generally be ascribed to modern taxa and their classification with extant fungi does not become possible. To overcome this difficulty, these are described under Artificial System of Classification which is based only on morphological characters, e.g. characters associated with size, symmetry, apertures, septa and spore wall.

In a classification system proposed by Van der Hammen (1956), fossil fungal spores were grouped under various morphologic categories having the suffix 'sporites'. Clarke (1965) proposed the suffix 'sporonites' for naming the fossil fungal spores. Both of these are still being followed. Elsik (1976a) attempted to prepare a comprehensive applicable taxonomy for the fossil fungal spores on the basis of morphological features. He considered septal and apertural characters as the most stable and primary characters, whereas size, shape, symmetry and wall sculpture as the subsidiary characters. He proposed artificial supra-generic categories of family rank for classification of fossil fungal spores, viz. Sporae Monocellae, Sporae Dicellae, Sporae Tricellae, Sporae Tetracellae, Sporae Multicellae and Sporae Cellae Indeterminatae. These categories were primarily based on the cell number and presence or absence and number of apertures. Under these categories, artificial genera and species could be conveniently described.

Pirozynski \& Weresub (1979) suggested a system named as 'Saccardoan System' for classifying the fungal spore types which are not referable to extant families. Kendrick \& Nag Raj (1979) modified the Saccardoan System to eliminate some of its inconsistencies, and listed characters of specific importance to separate different groups. This scheme is based on the shape and number of cells and fungal spores are recognized as Amerospores, Didymospores, 
Phragmospores, Dictyospores, Helicospores, Staurospores (star-like) or Scolecospores. Characteristic features of each of these groups are as follows:

1. Amerosporae: Spores unicellate, inaperturarate or aperturate; aperturate spores with one pore or hilum, two or more pores, or variable apertures.

2. Didymosporae: Spores dicellate, inaperturate or aperturate; aperturate spores with one pore or hilum at the proximal end, or two pores, one each at or near the proximal and distal end.

3. Phragmosporae: Spores tri- or pluricellate, only transversely septate, inaperturate or aperturate; aperturate spores with a pore or hilum at the proximal end; with or without attenuated distal end, or with two pores, one each at the proximal and distal end.

4. Dictyosporae: Spores muriform divided by few or many intersecting longitudinal and transverse or diagonal septa; shapes variable, inaperturate or with a more or less distinct hilum, that may be a scar or protruding.

5. Helicosporae: Spores uni- or pluricellate; with curved axis (spirally coiled), coiled in one plane or twisted in three planes.

6. Staurosporae: Spores pluricellate; with more than one axis, or stellate (star-shaped).

7. Scolecosporae: Elongate pluricellate spores with ladder-like septation; length/width ratio of spore body exceeding 15:1; spores narrow, filamentous, transversely septate, with a pore or hilum at the proximal end or two pores, one each at the proximal and distal terminations.

This system was included in Wijayawardene et al. (2020a) who provided a current classification of fungi. Nevertheless, we encourage the readers, palaeomycologists to provide missing information or new opinions (on classification, generic concepts) according Wijayawardene et al. (2020a) since the corrections could be done in newly launched website, outlineoffungi.org (Wijayawardene et al. 2020b)

\section{Terms related to fossil fungi}

Common terms related to fossil fungi and used in their descriptions are defined below (based on The A.A.S.P., INC. Workgroup on fossil fungal palynomorphs 1963, Kalgutkar \& Jansonius 2000, Saxena \& Tripathi 2011, Taylor et al. 2015).

Acrogenous: Conidia growing at the apex of a conidiophore.

Acropetal: Conidia produced in succession forming a chain toward the apex; young conidia occurring at the tip.

Acervulus (pl. acervuli): A mat of hyphae giving rise to short conidiophores grouped together forming a specialized mycelial mass. The immersed conidioma consists of a flat layer of pseudoparenchyma upon which conidia are initiated and produced while still covered by the host tissues.

$A m b$ (short for Latin ambitus, circuit, orbit): Term used in palynology to refer to the optical section of a spore or pollen grain, or to the outline of such a grain when seen in polar view.

Amerospore: A one-celled spore.

Amphigenous: A mycelium growing on both sides of the host leaf (as in microthyriaceous fungi).

Apothecium (pl. apothecia): An open ascocarp in which a layer of asci (hyminium) lies exposed on the surface or hollow part of the disc or variously shaped structure.

Arbuscule: Shrub-like growth; as in a tuft of conidiophores, or the haustoria-like intracellular development of mycorrhizal fungi.

Ascocarp/Ascophore (= ascoma, pl. ascomata): Any open or closed organ containing asci of Ascomycota.

Ascospore: A sexual spore produced as a free cell by meiosis and mitotic processes in an ascus.

Ascostroma (pl. ascostromata): Simple type of ascomycetous body consisting of an undifferentiated mass of tissue forming a stroma, on or in which the asci are developed.

Ascus (pl. asci): An enlarged sac-like cell containing a specific number of ascospores (often four, typically eight). 
Aseptate (= nonseptate): Lacking cross-walls or septa.

Asexual morph (Anamorph): The asexual vegetative form of an ascomycetous or basidiomycetous fungus.

Astomate: Without an ostiole.

Basidiophore/ Basidiocarp: A sporophore of Basidiomycota, bearing basidia and basidiospores.

Basidiospore: A sexual spore borne externally on a basidium.

Basidium (pl. basidia): A specialized, club-shaped cell bearing four basidiospores.

Basipetal: Conidia produced in succession, or in a chain, from the base (proximal); older conidia occurring at the tip.

Blastospore: A spore formed by budding.

Catenate (or catenulate): Produced in chains.

Chlamydospore: 1. A thick-walled, secondary spore developed from hyphae, usually intercalary that generally functions as a resting spore; 2. An endogenous, multinucleate thick-walled spore, variable in volume, commonly found in parasitic fungi.

Cleistocarp: Synonymous with cleistothecium.

Cleistothecium (pl. cleistothecia): A closed ascocarp, from which ascospores are liberated by rupture or decay of the structure.

Coenobium (pl. coenobia): A colony.

Conidiophore: Simple or branched specialized hypha, arising from a vegetative mycelial hypha and bearing, at its tip or side, one or more conidiogenous cells.

Conidium (pl. conidia): A nonmotile exogenous asexual spore.

Dictyospore: Conidium divided into cells by longitudinal and transverse septa.

Didymospore: Monoseptate (dicellate) conidium.

Dimidiate: Appearing to lack one half of the wall of an ascoma or having one half very much smaller than the other.

Dolipore: A septum of a dikaryotic basidiomycete hypha which flares out in the middle portion forming a barrel-shaped structure with open ends.

Ectomycorrhiza: A mycorrhiza in which fungal hyphae grow intercellularly in the host tissue.

Endomycorrhiza: A mycorrhiza in which the fungal hyphae penetrate into the cells of the host; also called vesicular arbuscular mycorrhiza (VAM).

Foliicolous: Growing on leaves.

Fungi Imperfecti: The Ascomycota are divided into those fungi representing the perfect stage (teleomorphs) in which sexual spores are produced, or those (anamorphs, representing the imperfect stage), in which only vegetative spores are produced. Holomorphs are those in which both sexual and asexual spores have been observed. The group of anamorph fungi are also referred to as Fungi Imperfecti.

Helicospore: A coiled or helical conidium.

Hilum (pl. hila): A mark or scar on spores appearing like a dot, flat spot or pore, indicating the point of attachment of the spore to a conidiophore, conidiogenous cell, hypha or sterigma.

Hypha (pl. hyphae): Basic tubular, septate or aseptate, elements of the fungi that may form a mycelium (thallus).

Hyphomycetous: Relating to the hyphomycetes; moldlike, cobwebby.

Imperfect stage (anamorph): The (conidial) asexual morph of an ascomycetous or basidiomycetous fungus.

Intramatrical: Hyphae located within the matrix or substratum.

Macronematous: Refers to any conidiophore that is differentiated from the normal hyphal cells.

Miospore: Collective designation for dispersed small or large spores and pollen grains, as found in palynological preparations, of which it may not be possible to differentiate their biological function of micro- or macrospore (megaspore).

Muriform (of conidia): Being divided by intersecting septa in more than one plane.

Mycelium (pl. mycelia): Collective term for a mass or group of hyphae or fungal filaments (the fungal thallus). 
Mycorrhiza (pl. mycorrhizae): The symbiotic association between certain fungi and the roots of plants.

Ostiole (adj. ostiolate): A pore, often at the end of a neck-like structure, in an ascocarp or a pycnidium.

Perfect stage (teleomorph): The (gametangial) sexual morph of an ascomycetous or basidiomycetous fungus.

Perithecium (pl. perithecia): A rounded, oval, pyriform or beaked ascocarp (ascoma), characteristic of the Pyrenomycetes, with a pore (ostiole) or slit at the top, and within which asci are borne in a characteristic manner.

Phragmospore: A spore with two or more transverse septa.

Pseudoparenchyma (adj. pseudoparenchymatous): A type of plectenchyma consisting of closely packed, more or less isodiametric or oval cells resembling the parenchyma of vascular plants.

Pycnidiospore: A conidium borne in a pycnidium.

Pycnidium (pl. pycnidia): An asexual hollow body lined inside with conidiophores bearing conidia. It may be fully enclosed, or have an opening (ostiole).

Saccardoan system: The grouping of conidia (and dispersed ascospores) proposed by Saccardo, mostly of the Ascomycota and Fungi imperfecti, based on the number of cells and the organization of the septa in each spore, as well as the intensity of the pigmentation. The main groups are: Amerosporae, Didymosporae, Phragmosporae, Dictyosporae, Scolecosporae, Helicosporae and Staurosporae.

Sclerotium (pl. sclerotia): A resting body composed of a hardened mass of hyphae, from which stromata or conidiophores may develop.

Scolecospore: An elongated needle- or worm-like spore.

Septate: Provided with (longitudinal or) transverse partitions.

Septum (pl. septa): Internal partition in a hypha or spore.

Sexual morph (Teleomorph): Form of an ascomycetous or basidiomycetous fungus bearing a sexual organ.

Sporangiospore: A spore produced in a sporangium.

Sporangium (pl. sporangia): A sac-like structure producing spores endogenously.

Sporophore: A spore-bearing structure in fungi; a fungal hypha specialized to bear spores.

Staurospore: stellate conidium.

Stroma (pl. stromata): A compact vegetative tissue of hyphae in which ascomata are formed.

Teleutospore: An old term for 'teliospore'.

Teliospore: A thick-walled resting spore of the terminal stage of Uredinales and Ustilaginales (rusts and smuts).

Thallospore: A spore formed on the thallus (mycelium), either singly or in chains within a hypha and liberated by disintegration of the hyphal wall; or terminal, as the swollen end of a hypha (and not a distinct structure). It includes blastospores, arthrospores, Chlamydospores and oidia. In part synonymous with conidia and aleurospores.

Thallus (pl. thalli): General term for the vegetative part of a non-vascular plant, particularly the Thallophytes; of the fungi, the entire assimilative phase of the individual.

Thyriothecium (pl. thyriothecia): Shield-shaped body (in Hemisphaerales or Microthyriales) that is oriented not by the mycelium, but by the host, with the generative tissue hanging downward, i.e. inverted. It may be considered as half a perithecium, with the tip lying beneath.

Vesicular-arbuscular mycorrhiza (VAM): A mycorrhiza in which the fungal hyphae penetrate into the cells of the host; also called endomycorrhiza.

Uredium (pl. uredia): The sorus of the Uredinales, bearing the spores.

Zoospore: A motile asexual spore.

Zygospore/Zygote: Thick-walled resting spore resulting from the conjugation of isogametes (as in Zygomycota), or the fusion of similar gametangia. 


\section{Geological time and life on earth}

While studying past life, it is essential to know the Geological Time Scale. In geology, time provides a frame of reference that is essential to the interpretation of extremely diverse types of study involving all the materials and inhabitants of the earth and all the forces and processes that have shaped it. Geologic time is often discussed in two forms: 1. Relative time (chronostratic), referring to the Earth's geology in a specific order based upon relative age relationships (most commonly, vertical/ stratigraphic position). These subdivisions are given names, most of which can be recognized globally, usually on the basis of fossils; and 2. Absolute time (chronometric), referring to the numerical ages in 'millions of years' or some other measurement. These are most commonly obtained via radiometric dating methods performed on appropriate rock types. In the present stage of its development, geology is more concerned with relative time and the sequence of events in the history of the earth than with the actual dating of these events. The development of the Earth took place during past billions of years. The evolution of life on earth is also a part of the Earth's long history. The Geological Time Scale was constructed using the evidences collected from field observations, fossil records, stratigraphic correlations, radioactive dating, palaeomagnetic orientation, orbital revolution and rotation of the earth. Several major incidences happened in the history of the earth, e.g. mass extinctions, appearance of new life forms (genera and species), mountain-building movements, drifting of continents, spreading of ocean floors, widespread glaciations, dominance of certain species and massive migration of life between land and water. These factors are considered while accounting the Geological Time Scale.

The passage of time can be related to a series of events. In order to construct the history of past events, one must determine how much time elapsed between the events and how long it took for the events to occur. Time is also marked by certain characteristic or unique set of events. When we list the events in an order in which they took place, we establish a chronological sequence of all the events. Time has been flowing since the beginning of the earth. Time will continue to flow long after the present generation also. To understand the past, we should know the present. To understand the present, we should know the past. The age of the earth is one important aspect in Earth Science studies. The relative ages of most of the rocks of the earth's surface were dated by following the principles of superposition, fossil correlation and relative dating of atomic clocks in rocks, the Geologic Time Scale was prepared. Continuous annual deposition of sediments with life remains in water bodies, can create sequential beds of sediments containing the fossils of animals and plants. These are called as stratigraphic sequences. These stratigraphic sequences were correlated to evaluate the evolutionary trend of ancient life and the geological formations.

The geologic time scale is a reference scale for the entire Earth's history. It helps to understand the entire history of the earth into workable units. Based on all the available evidences, the earth is found to be around 4500 million years old since the starting point of the hot universe, which gave birth to the galaxies. The geologic time of the earth is divided into five major eras, as follows (oldest to youngest): i. Archean Era, ii. Proterozoic Era (4600-540 Ma.), iii. Palaeozoic Era (540-245 Ma), iv. Mesozoic Era (245-66 Ma.) and v. Cenozoic Era (66 Ma-Present). The subdivisions of era are periods and epochs. Various geological time units (eras, periods and epochs) and significant events and life during the entire history of earth are summarized in Table 1. Stratigraphic ranges and origins of some major groups of Animals, Plants and Fungi are given in Fig. 1.

Table 1 Geological Time Scale (eras, periods and epochs with their absolute ages) and significant events and life during the entire history of earth. Ma = mega annum (millions of years).

\begin{tabular}{|c|c|c|c|c|}
\hline Eras & Periods & Epochs & Significant events & Life on earth \\
\hline & & $\begin{array}{l}\text { Holocene } \\
(0.01 \mathrm{Ma} \text { to } \\
\text { Present) }\end{array}$ & $\begin{array}{l}\text { Palaeolithic and Neolithic cultures } \\
\text { (beginning ca. } 10000 \text { BC), Copper, } \\
\text { Bronze and Iron ages (beginning } \\
\text { ca. } 3500 \text { BC), man used iron } \\
\text { implements in } 1350 \text { BC, youthful }\end{array}$ & $\begin{array}{l}\text { Modern plants and animals as } \\
\text { of today, rise of human } \\
\text { civilization, major habitat } \\
\text { changes and deforestations } \\
\text { caused by introduction of }\end{array}$ \\
\hline
\end{tabular}


Table 1 Continued.

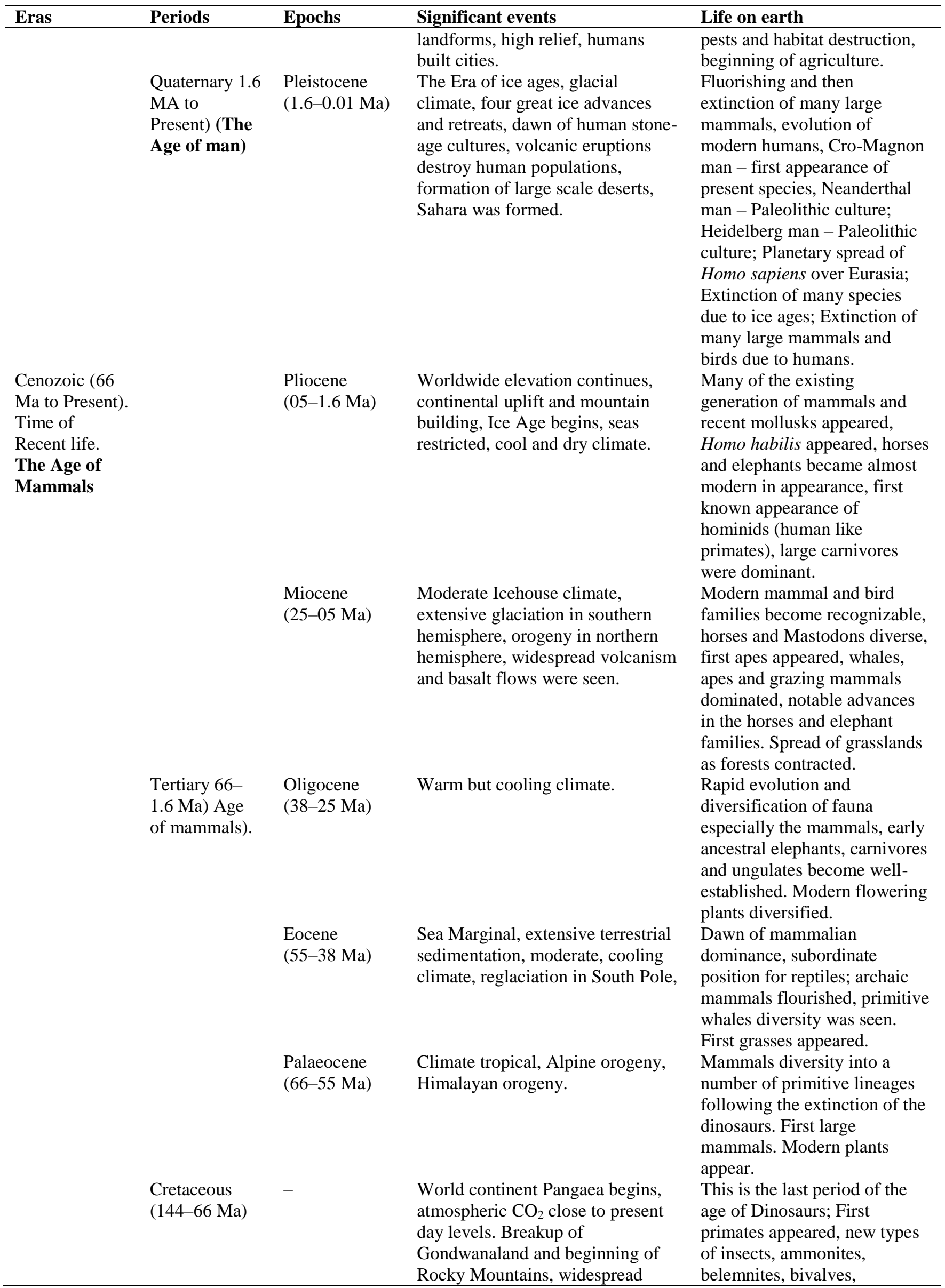


Table 1 Continued.

\begin{tabular}{|c|c|c|c|}
\hline Eras & Periods & Epochs & Significant events \\
\hline & & & $\begin{array}{l}\text { epicontinental seas, extensive } \\
\text { chalk deposits. }\end{array}$ \\
\hline $\begin{array}{l}\text { Mesozoic } \\
\text { (245-66 Ma). } \\
\text { Time of } \\
\text { Middle life; } \\
\text { The Age of } \\
\text { reptiles }\end{array}$ & $\begin{array}{l}\text { Jurassic } \\
(208-144 \mathrm{Ma})\end{array}$ & - & $\begin{array}{l}\text { The world's most famous period is } \\
\text { the Jurassic period. Atmospheric } \\
\mathrm{CO}_{2} \text { levels } 4-5 \text { times more than the } \\
\text { present day levels ( } 1200-1500 \\
\text { ppmv), formation of oilfields of } \\
\text { North Sea happened. Breakup of } \\
\text { Pangaea into Gondwana and } \\
\text { Laurasia happened during this } \\
\text { period. }\end{array}$ \\
\hline
\end{tabular}

Life on earth

echinoids and sponges were all common. Many new types of dinosaurs and crocodilians appeared on land; Modern sharks appeared in the sea; Primitive birds appeared (toothed birds and flying reptiles), marine pelecypods became abundant.

Angiosperms appeared, modern flowering plants proliferated.

Dominance of dinosaurs, its spread between 208 and 44 Ma, many types of dinosaurssauropods, carnosaurs and stegosaurs dominated, great plant eating dinosaurs were in existence. Oceans were with full of fish, squids and coiled ammonites. Appearance of the first frogs, salamanders, crocodiles, flying reptiles and birds were noticed. The first birds and lizards appeared, mammals were common, bivalves, belemnites and ammonites were abundant. Sea urchins were common along with crinoids, starfish, sponges, terebratulid, rhynchonellid and brachiopods. Lush growth of ferns and palm-like cycads, gymnosperms also have grown much.

Triassic (245-208 Ma)

Permian (286$245 \mathrm{Ma})$. The Age of Amphibians
Continent emergent, seas marginal, climate arid, occurrence of terrestrial deposition, formation of salt, gypsum and red beds. Orogenic movements prevailed in some parts, Pangaea still in existence, altering global climate and ocean circulation happened.

World-wide continental uplift and orogenic movements, widespread aridity on one side and glaciation at the other side. Landmasses unite into the super-continent Pangaea, creating the Appalachians. This
Dominance of archosaurs on land as dinosaurs, ichthyosaurs, nothosaurs in oceans and pterosaurs in the air, appearance of primitive mammals, domination of reptiles and cycads, reduction of marine invertebrates, first mammals and crocodilian appeared, extreme abundance of ceratitic ammonoids were seen, modern corals appeared, first turtles, lizards, mammals and dinosaurs. Dicroidium flora were common on land, appearance of modern conifers, cycadeoids.

Extinction of Palaeozoic plants and invertebrates (251 $\mathrm{Ma})$, reduction in all types of life, almost $95 \%$ of life on the earth became extinct, primitive reptiles dominated in 
Table 1 Continued.

\begin{tabular}{|c|c|c|c|}
\hline Eras & Periods & Epochs & Significant events \\
\hline & & & $\begin{array}{l}\text { period records the end of Permo- } \\
\text { Carboniferous glaciations. }\end{array}$ \\
\hline & $\begin{array}{l}\text { Carboniferous } \\
(360-286 \mathrm{Ma})\end{array}$ & - & $\begin{array}{l}\text { It is known for its coal deposits, } \\
\text { limestones and gritstones, } \\
\text { Hercynian orogenic movements. } \\
\text { Highest ever atmospheric oxygen } \\
\text { levels seen on earth were in this } \\
\text { period. }\end{array}$ \\
\hline
\end{tabular}

Life on earth

places, extinction of all

trilobites, graptolites and

blastoids, beetles and flies got

evolved, marine life flourished

in warm shallow reefs,

abundance of spiriferid

brachiopods, bivalves,

foraminifers and ammonoids.

Cone-bearing gymnosperms

(the first true seed plants) and

the first true mosses appeared.

Abundant life on land and

water, first land vertebrates,

sea invertebrates, prevalence

of foraminifers, bryozoans,

brachiopods, cephalopods,

blastoids, crinoids and corals.

Brachiopods are the zone

fossils of Carboniferous

Period. Lamellibranchs and

winged insects were important

fauna, first Reptiles laid eggs

with shells in this period.

Large primitive trees, swamp

forests with ferns were

existing, Lepidodendron and

Sigillaria were prominent

flora.

Palaeozoic Devonian $\quad$ _ $\quad$ Violent volcanic eruptions and

crustal movements, folding, mountain-building activities

Age of fishes, sharks and rays, fishes move into the open seas, lunged fishes, amphibians appeared in sea covered most of the land, earth Devonian, mollusks were appeared to look green.

Silurian (438- $408 \mathrm{ma})$
Mild climate, stable and warm temperature, continents were generally flat and flooded, notable mountain building occurred in Europe.
Ordovician

(505-438 Ma).

The Age of

Graptolites
Mild climate-Adaptive Radiation (Ordovician radiation), shallow seas retreating from land and spreading back, first known marine abundant. Extinction of primitive vascular plants happened, origin of modern vascular plants with true leaves, roots and stems, some plants started to produce seeds rather than spores.

Rise of fishes and reef building corals, abundance of shell-forming sea animals, dominance of sea lilies, eurypterids and land scorpions, invasion of land by arthropods. Origin of the earliest vascular plants on earth, modern group of Algae and Fungi got evolved, $60 \%$ of marine species were wiped out at the base of the Silurian period, first period to see macrofossils of extensive terrestrial biota.

All plants and animals still restricted to water, first vertebrates originated as jawless fishes, invertebrates 
Table 1 Continued.

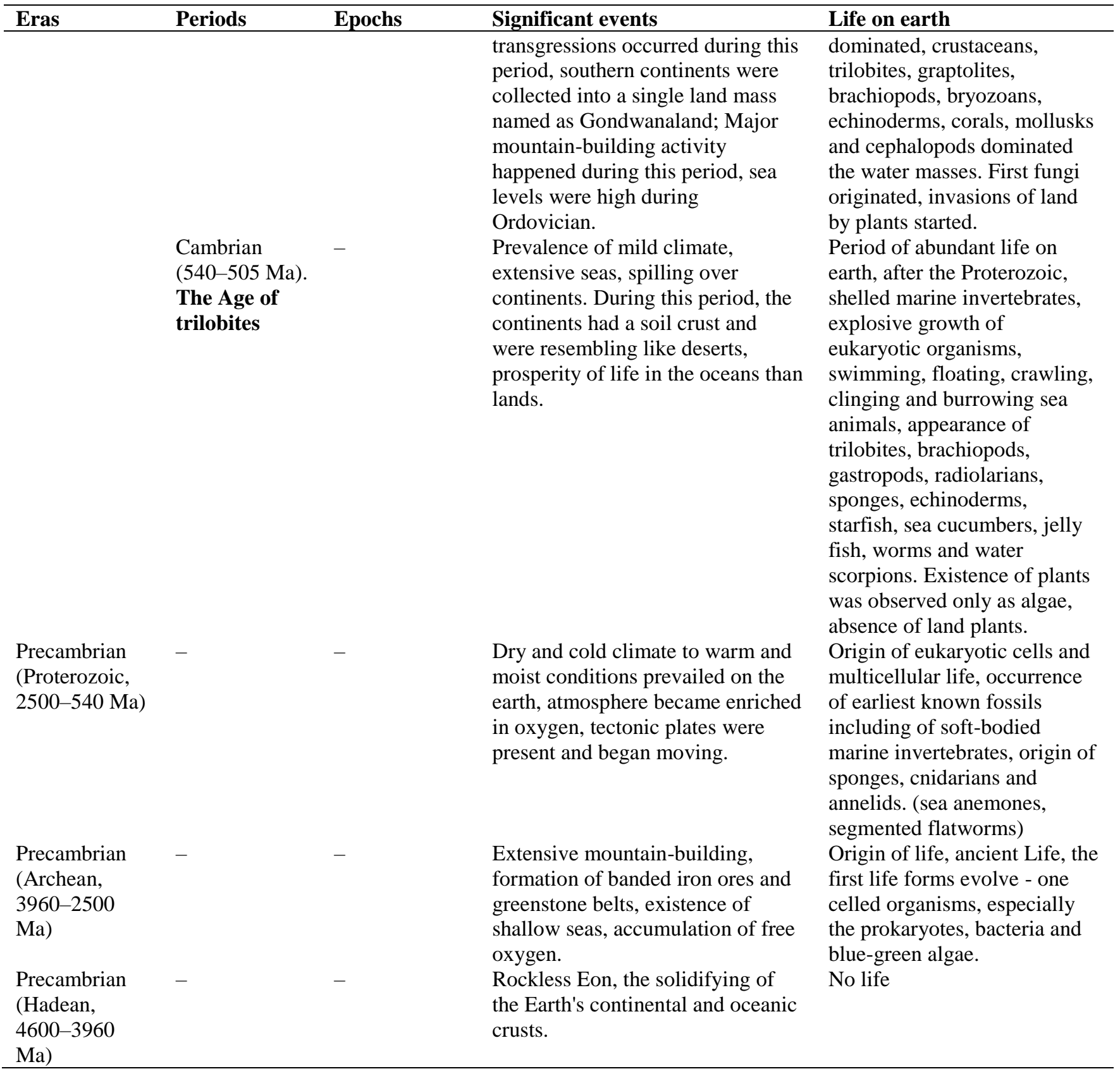

\section{Materials \& Methods}

This section contains:

1. Field investigation procedure;

2. Laboratory investigation procedure;

3. Source of information;

4. Method of data presentation.

\section{Field investigation procedure}

This includes observation on the exposed rock formations and collection of samples for microfossil studies. First of all, a reconnaissance survey is carried out in various directions for understanding the geological setting of the area and lateral persistence of various lithic types and their order of superposition. In most of the cases, the complete thickness of any rock formation is not exposed in any one section. A composite section is then compiled with the help of two or more 
sections. While collecting samples from exposures, utmost care is taken to avoid contamination.

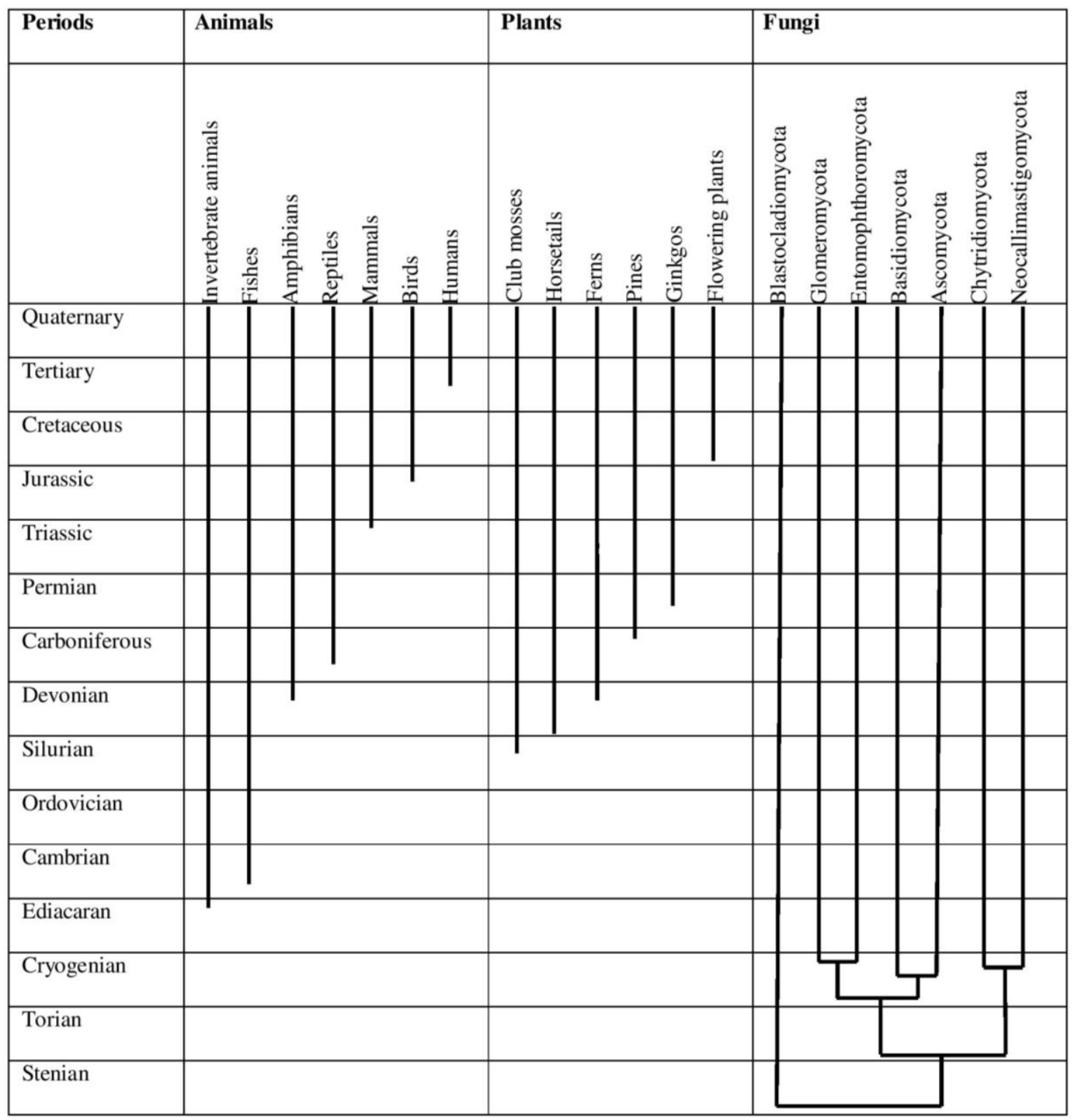

Figure 1 - Generalized diagram showing stratigraphic ranges and origins of some major groups of Animals, Plants and Fungi (Not to scale).

Precise geographic (including GPS readings) and stratigraphic locations along with geological details are noted in the field diary. Suitable lithologies are identified for collection of samples because recovery of microfossils, especially with regard to their abundance, depends on the rock types. Amongst the sedimentary rocks, limestone, carbonaceous shale, lignite, coal, and shaly siltstone are considered to be rich in microfossil contents whereas coarse textured rocks, weathered sediments and conglomerates are unlikely to yield microfossils. For collection of samples from exposed rocks, escarpments, ledges, river or stream cuttings (Fig. 2B), ridges, cliffs (Fig. 3A-C), are good natural sites. Usually, these sites contain large amounts of weathered rocks and vegetation or algal scum on its upper surface. Before collection, fresh rocks are exposed by removing the weathered rocks/ vegetation. Quarries, road cuttings (Fig. 2A, E-H), railway cuttings or open cast mine faces (Fig. 2C-D) are among the artificial, man-made sites for sample collection. Such sites are good for sample collection because these are easily accessible and here the rocks are generally 
not covered with weathered sediments and vegetation. Samples must be collected from measured stratigraphic sections only.

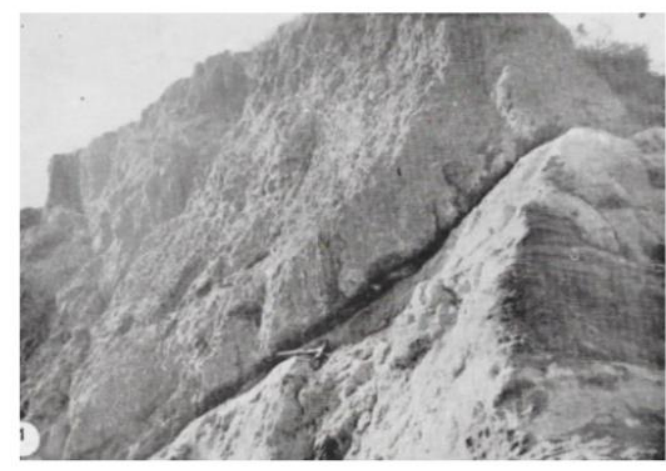

$\mathbf{A}$
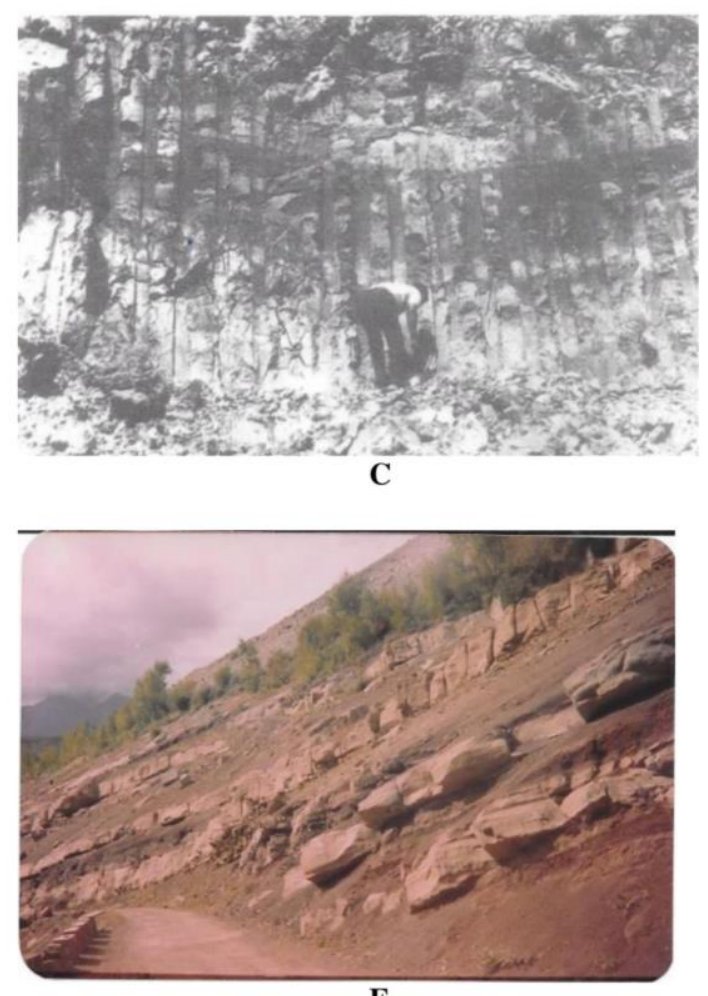

E

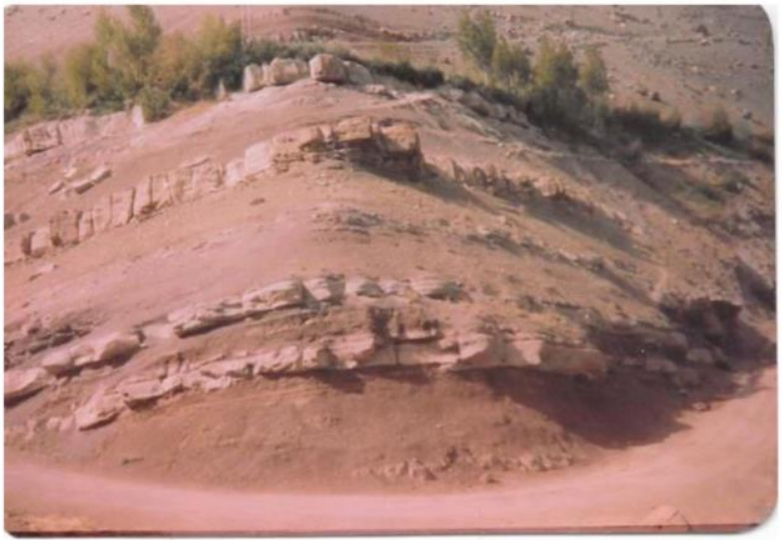

G

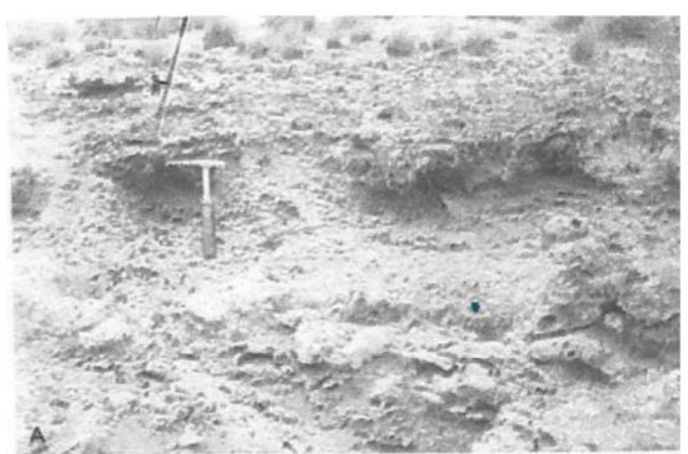

B

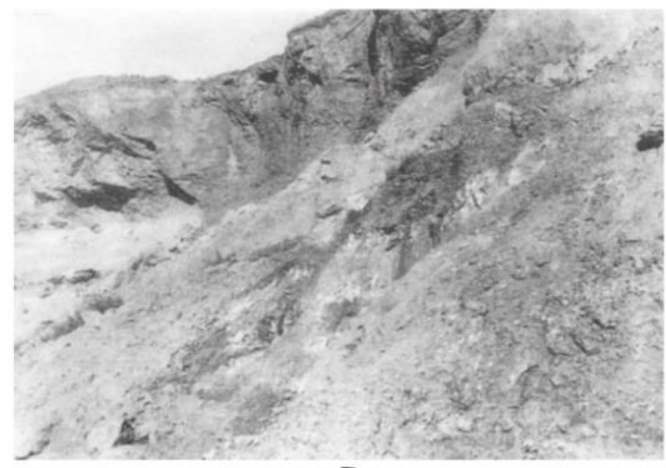

D
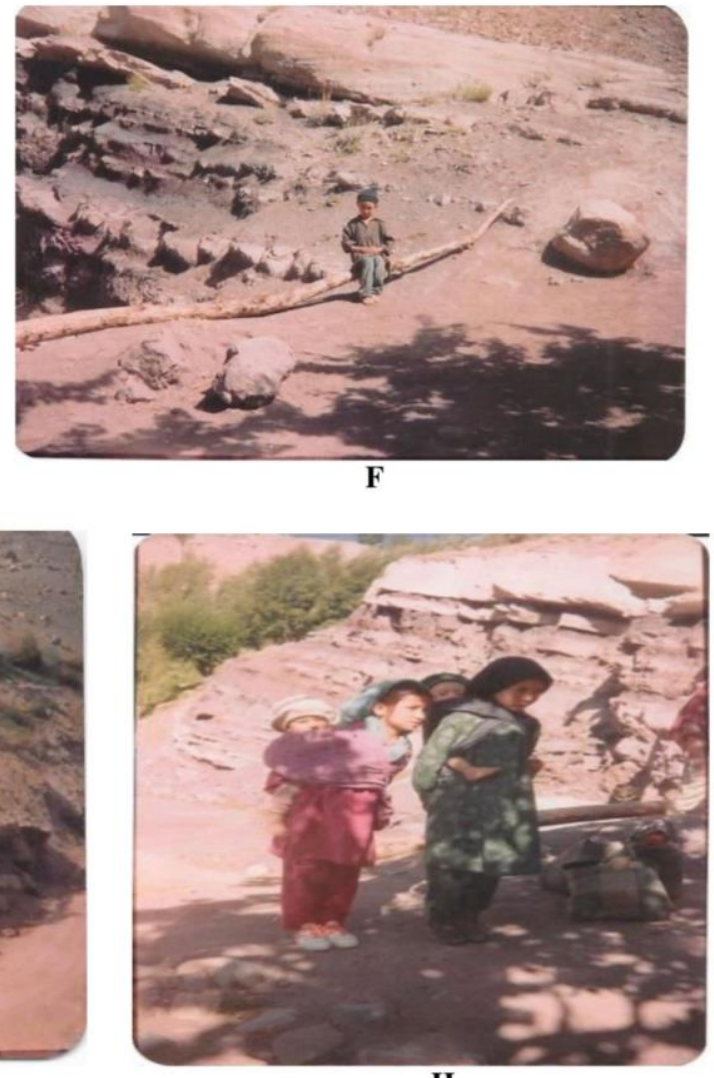

$\mathbf{H}$

Figure 2 - Stratigraphic sections. A, E-H Road cutting sections. B Stream cutting section. C-D Mine face sections. A Stratigraphic section exposing the contact of Matanomadh Formation with the overlying Naredi Formation, near Matanomadh Village, Kutch District, Gujarat, India (after 
Saxena 1981). B Intertrappean bed exposed at about $5 \mathrm{~km}$ from Naredi on Naliya-Narayan Sarovar Road, Kutch District, Gujarat, India (after Saxena \& Ranhotra 2009). C Mavli Mine section (NIMCO) at Redi showing Sindhudurg Formation (containing lignite) overlain by red ferruginous laterite (after Saxena et al. 1992). D Stratigraphic section of Pit no. 1 (Gogte Minerals) at Redi showing Sindhudurg Formation (containing lignite) overlain by pale red ferruginous laterite (after Saxena et al. 1992). E-H Road cutting sections showing Kuksho Formation at various locations along Kargil-Leh Road, Ladakh, India (unpublished photographs by R.K. Saxena).

Spot samples are taken at more or less uniform intervals along the thickness of the bed. The interval of sampling depends upon the thickness and lithology of the beds. For collection from coal/ lignite beds or from other beds of homogeneous lithology, channel sampling is done. In this method, samples are collected through the vertical thickness of any bed or specified thickness after making a $15 \mathrm{~cm}$ deep channel at right angle to the bedding plane. Vertical stratigraphic sections are shown in Fig. 3F-H. The deeply buried (subsurface) sediments are taken with the help of well drilling equipments by which a core, often hundreds of metres long, can be obtained. The bore cores are ideal material for microfossil analysis because they provide fresh samples from uninterrupted stratigraphic sequence without any chance of contamination or mixing (Fig. 3D). Stratigraphic sections of boreholes are shown in Fig. 3F, H.

\section{Laboratory investigation procedure}

For recovery of palynofossils and making slides, the following steps are taken: 1. Cleaning and desegregation, 2. Chemical processing, 3. Density separation, and 4. Mounting of slides and study of palynofossils (Fig. 4).

Cleaning and desegregation: Rock samples are cleaned thoroughly with water or alcohol to ensure removal of any kind of extraneous matter. Desegregation of rock samples is done by breaking them into small pieces with the help of pestle and mortar.

Chemical processing: Chemical processing is carried out in two steps: a. Removal of minerals (demineralization) and b. Alkali treatment.

a. Removal of minerals (demineralization): For removal of minerals, the rock samples are subjected to treatment with acids depending upon the kind of rock types. Carbonates, commonly calcites, are soluble in hydrochloric acid $(\mathrm{HCl})$; sulphates, sulphides and carbon contents are soluble in concentrated nitric acid (HNO3); and silicates, the most common content of the rocks, are removed by $40-60 \%$ hydrofluoric acid (HF). The steps adopted for processing of different lithologies are as follows. Shale and siltstone: Crushed samples with few drops of distilled water are kept in $40 \% \mathrm{HF}$ for 4-5 days or till the samples become completely pulverized. Containers having pulverized samples are filled with water; the material is allowed to settle for one hour and the supernatant water is decanted with the help of siphon tube. After repeating the process twice, samples are sieved with 400 mesh $(37 \mu \mathrm{m})$ and the residue left over the mesh is transferred to container. In carbonaceous shale samples little amount of commercial nitric acid is added and the container is kept inside the fume hood chamber (Fig. 3E) for 24 hours. After siphoning the supernatant water 45 times, samples are washed again with 400 mesh sieves. Limestone/mudstone: Crushed samples are first treated with concentrated hydrochloric acid for 24 hours and are then kept in $40 \%$ hydrofluoric acid for 2-3 days. Coal/lignite: Crushed samples are taken in glass containers and after adding a few drops of water, concentrated nitric acid is added drop by drop. Samples are constantly stirred and are placed inside the fume-hood chamber for 24-36 hours. The samples, when pulverized, are washed 2-3 times with water by siphoning the supernatant water. Each sample is sieved with 400 mesh sieve and the residue left over the mesh is transferred to the container.

b. Alkali treatment: After removal of minerals, samples are treated with solution of sodium carbonate or potassium hydroxide. The concentration of these solutions (10-20\%) and duration of treatment (2-5 minutes) are decided after checking the demineralized residue under the microscope. Alkali treatment is essential to remove the humic acids released during the process of 
demineralization. As a result of this treatment, the sample turns dark brown. After alkali treatment, samples are thoroughly washed with water to remove all traces of alkali.

Density separation: Sequel to the demineralization process, very fine mineral particles mixed with the macerated residue are generally observed. These are removed by density separation methods. These methods are also essential to separate and concentrate the microfossil fraction from the residue. Owing to their specific gravity, minerals and organic particles have different settling velocities. Spores and pollen, having much less density than the mineral particles, tend to float in water for a longer time and therefore can easily be separated. The commonly used density separation methods are: a. Swirling and b. Heavy liquid separation. Steps followed to achieve these methods are discussed below.

a. Swirling: The macerated residue is mixed with $10-15 \mathrm{ml}$ of water in a medium-sized watch glass. The watch glass is rotated in clock-wise direction. This action allows the mineral particles and larger cuticle pieces to settle at the bottom in the centre, whereas the lighter particles, including spores, pollen and fungi, remain suspended in the water. The upper layer of water is now transferred to another watch glass with the help of a dropper and is allowed to settle for about half an hour. The watch glass is again rotated allowing the organic matter to collect in the centre of watch glass. Water from the watch glass is removed with the help of a dropper. The collected material, containing spores, pollen and fungal remains, is mounted on slides for observation under the microscope.

b. Heavy liquid separation: This method is generally used to concentrate and separate the spore/pollen fraction from the macerated residue. In this method the chemically processed material is mixed with liquids whose specific gravity is higher than those of the organic particles. Heavy liquids, when thoroughly mixed with residue, allow the organic fraction to float at the upper part of it. Minerals being heavier, settle faster than the organic material. Centrifuging of the mixture leads to better results. Steps followed to separate the organic fraction from the macerated residue are as below: The residue is transferred to a centrifuge tube and is washed with $10 \% \mathrm{HCl}$. Washing with $\mathrm{HCl}$ at this stage prevents precipitation of insoluble impurities when the heavy liquid $(\mathrm{ZnCl} 2$ or $\mathrm{ZnBr} 2$ ) solution is added. The specific gravity of the solution should be about 2 . The solution is thoroughly mixed with residue and is centrifuged at $1500 \mathrm{rpm}$ for $10-20$ minutes. This action permits the settling of inorganic and organic components of the residue at the bottom and top layers respectively. The topmost layer, rich in spore/pollen contents, is sucked with the help of a dropper and is washed in sequence with $10 \% \mathrm{HCl}$ and water.

Mounting of slides and study of palynofossils: Water-free macerated residue is mixed with a few drops of polyvinyl alcohol solution and is spread uniformly over the cover glass with the help of a glass rod. The cover glasses are dried in oven for about 30 minutes and are then mounted in Canada balsam. To make the slides ready for study under microscope, slides are kept in oven at 50$60^{\circ} \mathrm{C}$ for 1 to 2 days. Slides prepared out of the productive samples are examined under the microscope for qualitative and quantitative assessment. Distinguishable morphotypes are identified and described under the artificial system of classification. Frequency of palynotaxa is determined by counting 200 palynofossil specimens in each sample. However, in case of poorly productive samples only 100 specimens may be counted.

\section{Source of information}

The data, presented here, have been obtained from the various studies on fossil fungi published during over one hundred years. Kalgutkar \& Jansonius (2000) published a synopsis of fossil fungi and tried to streamline taxonomic status of many fossil fungal genera and species. They provided descriptions for ca. 950 validly published species, attributed to approximately 300 genera and introduced twelve new genera and ca. 350 new combinations. Transfers of species to more appropriate genera resulted in 31 later homonyms, for which they provided new names. They also validated one genus and several species. In order to include all records of fossil fungal remains 
from the Indian Tertiary sediments, published till 2005, three catalogues were published (Lakhanpal et al. 1976, Saxena 1991, 2006). Besides, a monographic study was carried out by Saxena \& Tripathi (2011) with the objective to synthesize the available information on Indian fossil fungi. This incorporates description of 152 genera and 388 species of fossil fungi, including 15 new species and 12 new combinations, with comments wherever required. In addition to the above monographic studies, data have been gathered from scores of publications, containing information
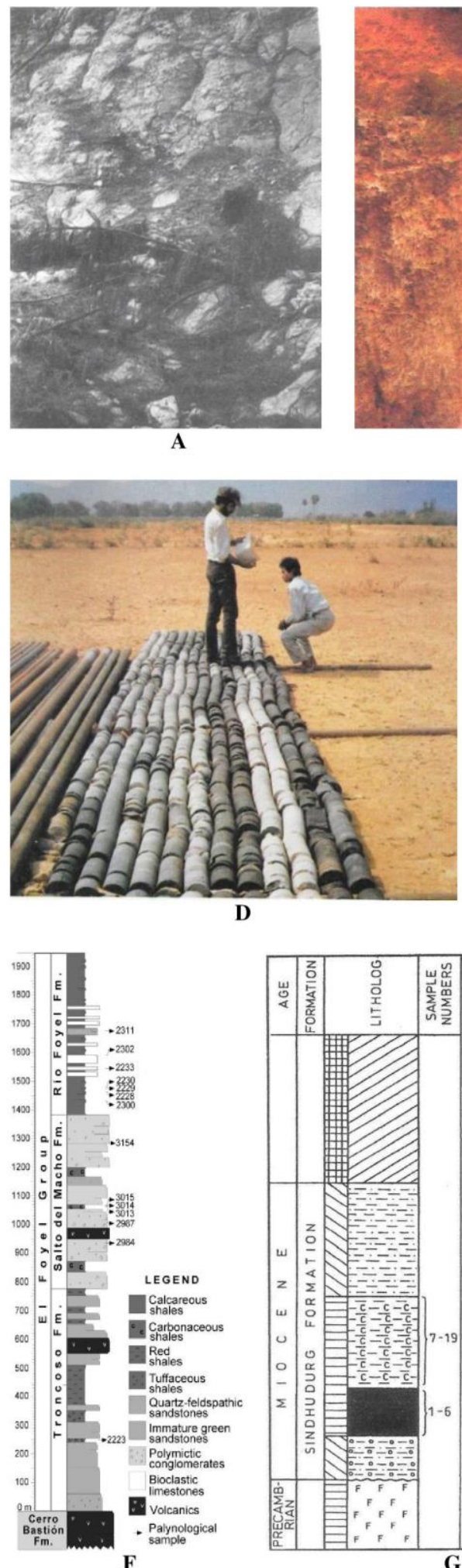
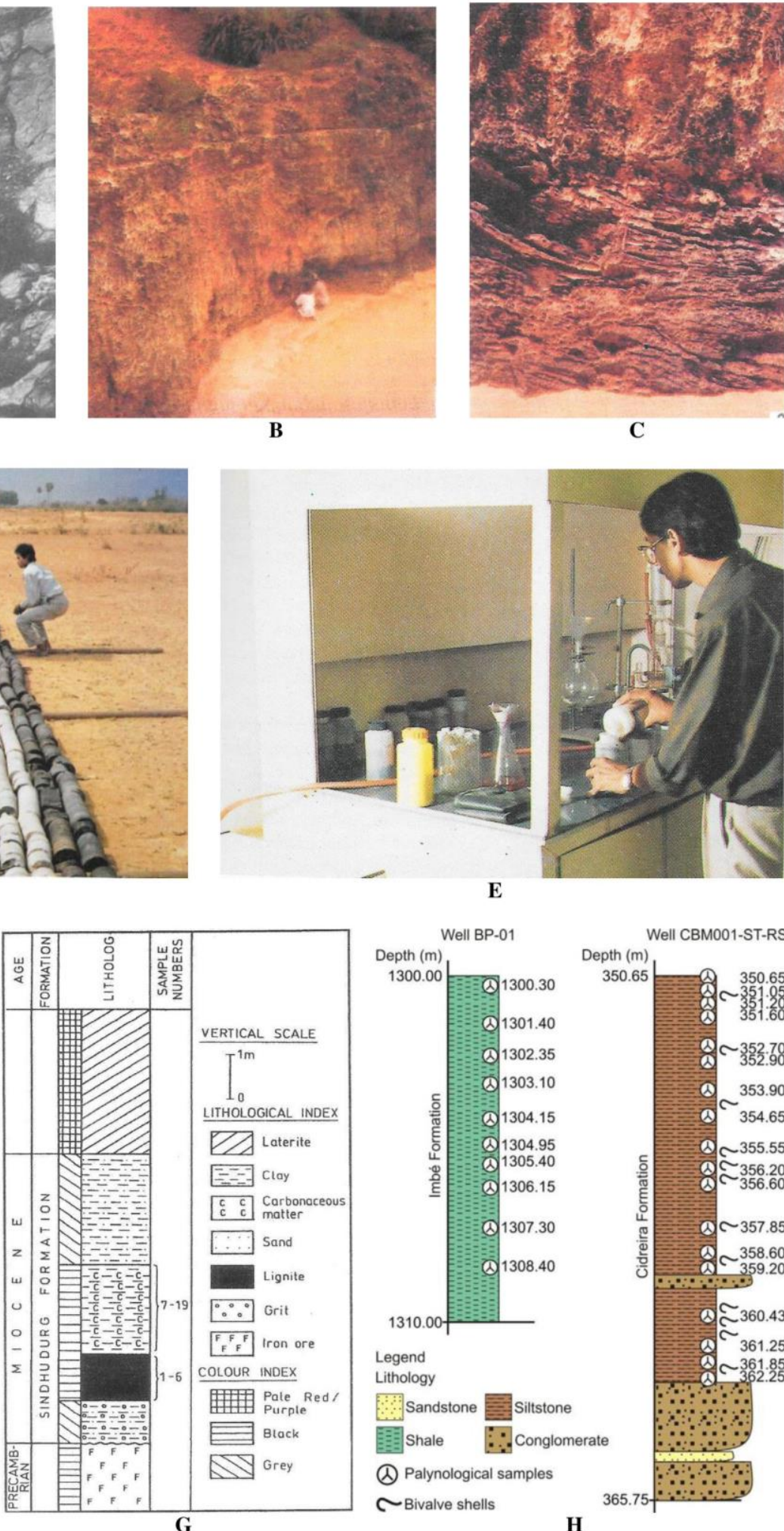

E

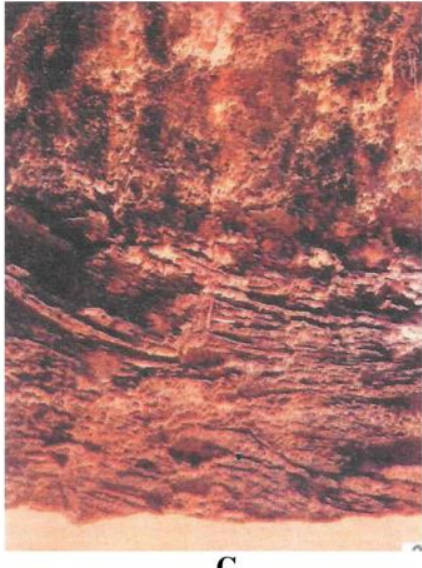

C

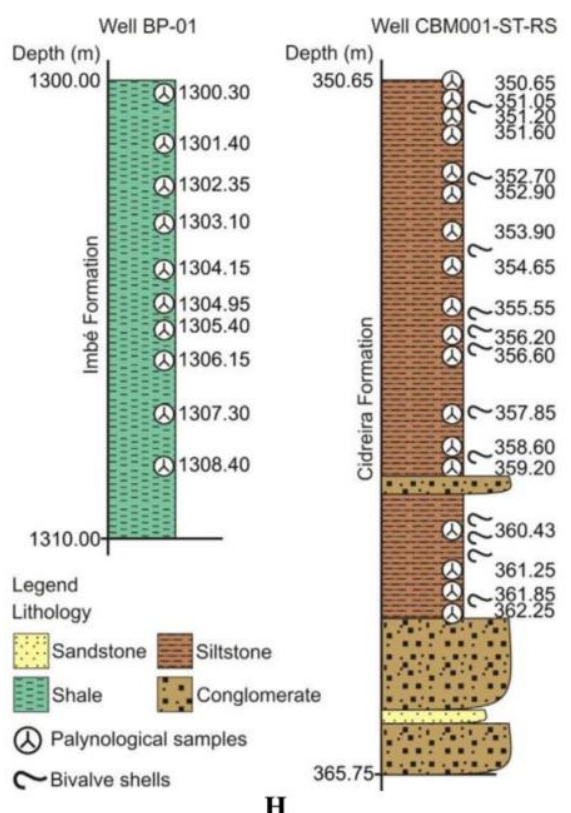

Figure 3 - A-C Cliff sections. D Bore cores. E Fume hood chamber. F, H Borehole sections. G Mine face section. A Sawai Bay Formation (mudstone) exposed in the type section, Car Nicobar 
Island, Andaman \& Nicobar Islands, India (after Chandra \& Saxena 1998). B Hard, arenaceous, greyish yellow limestone (Kakana Formation) exposed near Mus Jetty, Car Nicobar Island, Andaman \& Nicobar Islands, India (after Ghosh et al. 2004). C Bedded. arenaceous, shelly limestone (Kakana Formation) exposed near Kakana Village, Car Nicobar Island, Andaman \& Nicobar Islands, India (after Ghosh et al. 2004). D Sequential arrangement of rocks in bore-cores (after Tripathi 1995). E Fume hood chamber (after Tripathi 1995). F Rio Foyel Section, showing stratigraphic position of studied samples, El Foyel Group (Palaeogene) of Nirihuau Basin, Argentina (after Martínez et al. 2016). G Mavli Mine section at Redi, Sindhudurg District, Maharashtra, India (after Saxena 2000). H Lithological profile showing stratigraphic position of selected samples in the wells, Miocene deposits of the Pelotas Basin, Brazil (after Premaor et al. 2018).

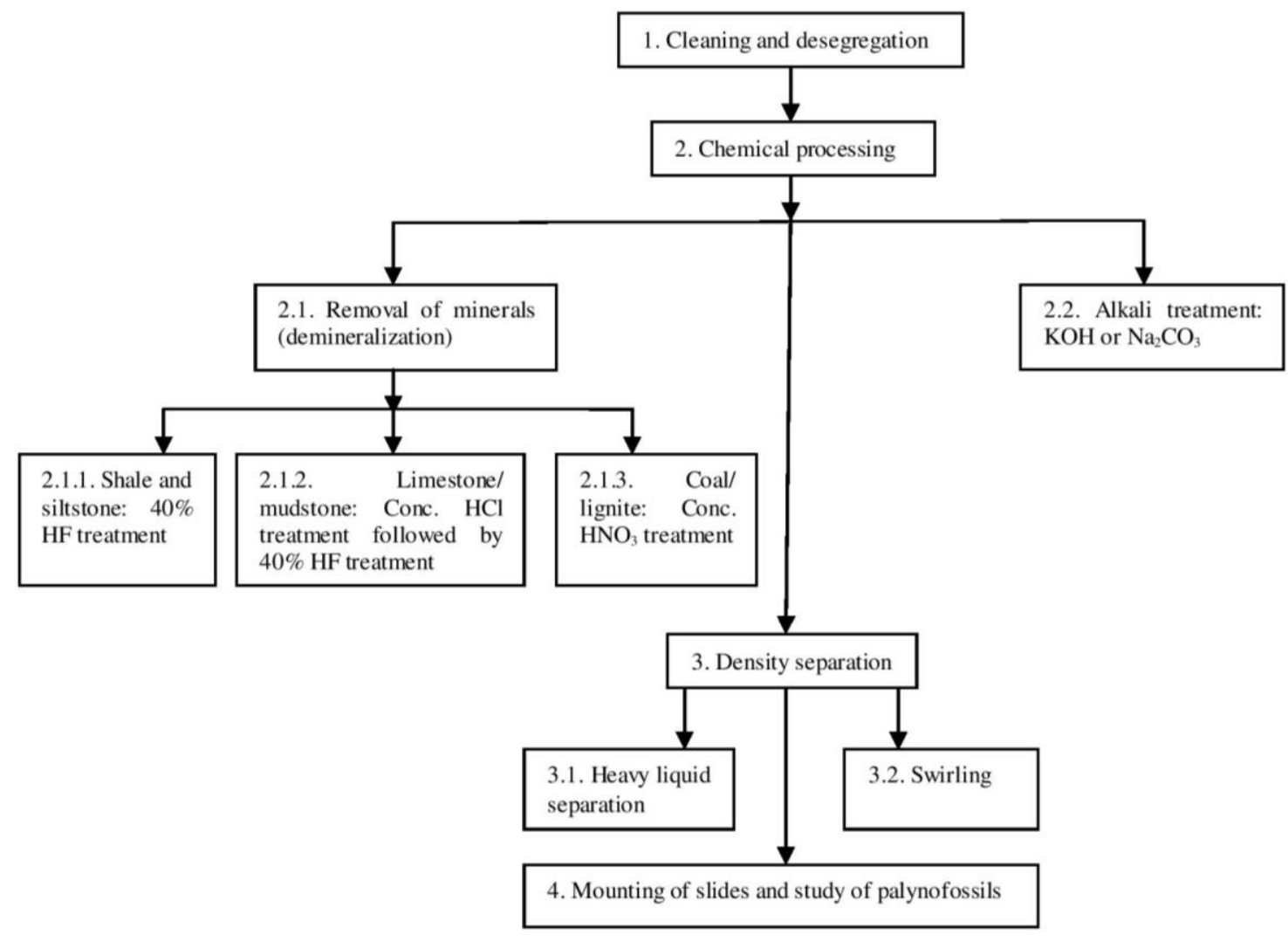

Figure 4 - Showing various steps taken for extraction of fossil fungi from the rock samples.

on fossil fungi from all parts of the globe, published in various journals and conference proceedings (Van der Hammen 1954, 1955, 1956, Rouse 1959, 1962, Potonié \& Sah 1960, Playford 1962, Varma \& Rawat 1963, Ramanujam \& Ramachar 1963 1980, Clarke 1965, Dilcher 1965, Mathur 1966, Srivastava 1968, Taugourdeau 1968, Elsik 1968, 1969, 1990a, b, 1992, 1999, Mathur \& Mathur 1969, Dutta \& Sah 1970, Jain \& Gupta 1970, Trivedi \& Verma 1970, Sheffy \& Dilcher 1971, Lange \& Smith 1971, 1975, Kar et al. 1972, Jain et al. 1973, Venkatachala \& Rawat 1973, Biradar \& Mahabale 1974, Elsik \& Dilcher 1974, Elsik \& Jansonius 1974, Sah \& Kar 1974, Salujha et al. 1974, Jansonius 1976, Kar \& Saxena 1976, Paradkar 1976, Chitaley \& Yawale 1978, Ke \& Shi 1978, Kemp 1978, Ramanujam \& Rao 1978, Smith 1978, Dueñas 1979, Jain \& Kar 1979, Pirozynski \& Weresub 1979, Kar 1979, 1990, Ramanujam \& Srisailam 1980, Salard-Cheboldaeff \& Locquin 1980, Zhang 1980, Ediger 1981, Huang 1981, Singh \& Saxena 1981, Barlinge \& Paradkar 1982, Saxena \& Singh 1983, Ambwani 1982, 1983, Chandra et al. 1984, Pathak \& Banerjee 1984, Gupta 1984, 1985, 2002, Song 1985, Stubblefield et al. 1985, Varma \& Patil 1985, Glass et al. 1986, Jarzen \& Elsik 1986, Saxena \& Sarkar 1986, Singh et al. 1986, Norris 1986, 
1997, Saxena \& Bhattacharyya 1987, 1990, Kalgutkar \& Sweet 1988, Saxena et al. 1988, Ediger \& Alisan 1989, Martínez-Hernández \& Tomasini-Ortiz 1989, Song et al. 1989, 1999, Elsik et al.

\section{Method of data presentation}

The taxa are placed into the following spore groups: 1. Amerosporae, 2. Didymosporae, 3. Phragmosporae, 4. Dictyosporae, 5. Helicosporae, 6. Staurosporae, and 7. Fossil fungal spore species assigned to modern genera. Under each of these, the genera are arranged in alphabetical order. The species are also arranged under each genus in alphabetical order, as follows.

The first paragraph includes i. Name of the genus followed by its author(s) and full bibliographical details, i.e. name of journal, volume number, page number and year of publication, ii. Index Fungorum Registration Identifier, iii. Type species followed by its author(s) and year of publication, and iv. Current name (if it is now different from the original name). The name of the legitimate genus is in bold capital letters whereas the same of the illegitimate one is in non-bold capital letters. In case of an illegitimate genus name, its current name is provided in bold capital letters.

The second paragraph presents Original Diagnosis (with reference to its author and year of publication in parenthesis). This is followed by Emended Diagnosis, if any (with reference to its author and year of publication in parenthesis). In case of more than one emended diagnosis, all are given in chronological order with similar details. The subsequent paragraphs pertain to Classification, Number of species known and Notes, if any.

Similarly, all the species described under each genus are arranged in alphabetical order. Each species is provided with the following information: i. Name of the species followed by its author(s) and year of publication, ii. Index Fungorum Registration Identifier, iii. Synonym(s), if any, iv. Location, v. Age, and vi. Notes, if any. The name of the legitimate species is in bold letters whereas the same of the illegitimate one is in non-bold letters. In case of illegitimate species name, its current name is provided in bold letters. Drawings of holotypes are provided for the type species of each genus, new species and new combinations and some commonly occurring fungal spore species.

\section{Genera and species of fossil fungal spores}

\section{Amerosporae}

1.1. Genus: AMEPIOSPORA Sal.-Cheb. \& Locq., C. r. Congr. natn. Socs. sav. Paris, sect. sci., fasc. 1. (Paleobotanique) 105: 185 (1980); Index Fungorum Registration Identifier: 25592; Type: A. ellipsoidea Sal.-Cheb. \& Locq. 1980; Current name: BASIDIOSPORITES Elsik 1968 fide Kalgutkar \& Jansonius (2000).

Original Diagnosis: Smooth, elliptical amerospores (Salard-Cheboldaeff \& Locquin 1980).

Classification: Fungi Imperfecti, Amerosporae.

Number of species known: Five (all the species, including type species, have been transferred to other genera).

Notes: The characters mentioned in the generic diagnosis are not sufficient to separate it from other unicellular inaperturate fungal spore genera (e.g. Basidiosporites Elsik, Lacrimasporonites R.T. Clarke, Monoporisporites Hammen). Hence, Kalgutkar \& Jansonius (2000) transferred Amepiospora ellipsoidea, the type species of Amepiospora, to Basidiosporites. This makes Amepiospora a later synonym of Basidiosporites. The other species of Amepiospora have been transferred to Monoporisporites and Lacrimasporonites, as given ahead.

1.1.1. Species: A. ellipsoidea Sal.-Cheb. \& Locq. 1980; Index Fungorum Registration Identifier: 107672; Current name: Basidiosporites ellipsoideus (Sal.-Cheb. \& Locq.) Kalgutkar \& Janson. 2000 fide Kalgutkar \& Jansonius (2000).

1.1.2. Species: A. fusoidis Sal.-Cheb. \& Locq. 1980; Index Fungorum Registration Identifier: 107718; Current name: Lacrimasporonites fusoides (Sal.-Cheb. \& Locq.) Kalgutkar \& 
Janson. 2000 fide Kalgutkar \& Jansonius (2000); Notes: Orthographic correction was made by Kalgutkar \& Jansonius 2000.

1.1.3. Species: A. globosa Sal.-Cheb. \& Locq. 1980; Index Fungorum Registration Identifier: 107719; Current name: Monoporisporites neoglobosus Kalgutkar \& Janson. 2000 fide Kalgutkar \& Jansonius (2000).

1.1.4. Species: A. macrospora Sal.-Cheb. \& Locq. 1980; Index Fungorum Registration Identifier: 107720; Current name: Monoporisporites macrosporus (Sal.-Cheb. \& Locq.) Kalgutkar \& Janson. 2000 fide Kalgutkar \& Jansonius (2000).

1.1.5. Species: A. triangularis Sal.-Cheb. \& Locq. 1980; Index Fungorum Registration Identifier: 107721; Current name: Monoporisporites triangularis (Sal.-Cheb. \& Locq.) Kalgutkar \& Janson. 2000 fide Kalgutkar \& Jansonius (2000).

1.2. Genus: ASYREGRAAMSPORA Sal.-Cheb. \& Locq., C. r. Congr. natn. Socs. sav. Paris, sect. sci., fasc. 1. (Paleobotanique) 105: 191 (1980); Index Fungorum Registration Identifier: 25593; Type: A. reticulata Sal.-Cheb. \& Locq. 1980.

Original Diagnosis: Amerospores, more or less reticulate, slightly asymmetrical, approximately $20 \times 15 \mu \mathrm{m}$ (Salard-Cheboldaeff \& Locquin 1980).

Classification: Fungi Imperfecti, Amerosporae.

Number of species known: One.

Notes: Jansonius \& Hills (1981) corrected spelling of the type species from "Asyreamspora reticulata" (as given in the protologue by Salard-Cheboldaeff \& Locquin 1980: 185) to Asyregraamspora reticulata (as per spelling of the generic name used by Salard-Cheboldaeff \& Locquin 1980: 191).

1.2.1. Species: A. reticulata Sal.-Cheb. \& Locq. 1980 (Fig. 5A); Index Fungorum Registration Identifier: 107752; Location: Coast of Equatorial Africa, Gulf of Guinea; Age: Early Miocene.

1.3. Genus: BASIDIOSPORITES Elsik, Pollen et Spores 10(2): 273 (1968); Index Fungorum Registration Identifier: 21028; Type: B. fournieri Elsik 1968.

Synonym: Amepiospora Sal.-Cheb. \& Locq. 1980 fide Kalgutkar \& Jansonius (2000), Index Fungorum Registration Identifier: 25592.

Original Diagnosis: Monoporate, unicellate, psilate fungal spores with the pore offset from one apex. No basal attachment area evident. Shape variable, generally elongate in some fashion (Elsik 1968).

Classification: Fungi Imperfecti, Amerosporae.

Number of species known: Four.

Notes: The spores of Basidiosporites are characterized by a pore offset from one apex. Since pore in Amepiospora ellipsoidea Sal.-Cheb. \& Locq. 1980 and Monoporisporites ovalis Sheffy \& Dilcher 1971 is offset from one apex, Kalgutkar \& Jansonius (2000) transferred them to Basidiosporites.

1.3.1. Species: B. ellipsoideus (Sal.-Cheb. \& Locq.) Kalgutkar \& Janson. 2000; Index Fungorum Registration Identifier: 483241; Basionym: Amepiospora ellipsoidea Sal.-Cheb. \& Locq. 1980; Location: Coast of Equatorial Africa, Gulf of Guinea, Cameroon, Africa; Age: Early Eocene-Early Miocene.

1.3.2. Species: B. fournieri Elsik 1968 (Fig. 5B); Index Fungorum Registration Identifier: 309461; Location: Strip mine approximately $11 \mathrm{~km}$ south-west of Rockdale, Milam County, Texas, U.S.A.; Age: Palaeocene (Rockdale lignite); Notes: Elsik (1968) suggested affinity of this genus with Basidiomycota.

1.3.3. Species: B. ovalis (Sheffy \& Dilcher) Kalgutkar \& Janson. 2000 (Fig. 5C); Index Fungorum Registration Identifier: 483267; Basionym: Monoporisporites ovalis Sheffy \& Dilcher 1971; Location: Puryear clay pit, 800 m south of Puryear, Tennessee, Henry County, U.S.A.; Age: 
Middle Eocene (Claiborne Formation); Notes: The specimen shows some darkening (thickening?) in median region of spore.

1.3.4. Species: B. sadasivanii Anil Chandra et al. 1984 (Fig. 5D); Index Fungorum Registration Identifier: 106626; Location: Sediment core no. 1 (Lat. 1757.9'N: Long. 70 $46.0^{\prime} \mathrm{E}$ ), Arabian Sea; Age: Late Quaternary; Notes: Chandra et al. (1984) differentiated this species from Basidiosporites fournieri Elsik 1968 by its larger size, placement of pore in the middle of the longer axis and thickened pore margin. The species epithet is in honour of T.S. Sadasivan, Department of Botany, Madras University, Chennai, India.

1.4. Genus: BIPORIPSILONITES Kalgutkar \& Janson., AASP Contributions Series (Dallas) 39: 37 (2000); Index Fungorum Registration Identifier: 28612; Type: B. belluloides (Z.C. Song) Kalgutkar \& Janson. 2000.

Original Diagnosis: Generally small to medium-sized unicellate fungal spores of more or less elongate fusiform to barrel-shaped outline; generally with a plane of symmetry through the equator; spore wall generally smooth, occasionally with some subdued sculpture, and of medium thickness; two terminal pores, forming pore chambers subtended by a basal septum, and enclosed by thin wall material that further thins centrifugally; septa, thin or thick, may show a central perforation and/or small septal folds; the terminal pore itself may be closed by very thin wall material, or ruptured to gaping and broad (Kalgutkar \& Jansonius 2000).

Classification: Fungi Imperfecti, Amerosporae.

Number of species known: Eleven.

Notes: Spores in this genus can be differentiated from Diporisporites Hammen by pore chambers. The name of the genus is derived from Latin $b i$-, or two, porate, and smooth (Greek psilos) character of the wall.

1.4.1. Species: B. anceps (G. Norris) Kalgutkar \& Janson. 2000; Index Fungorum Registration Identifier: 483269; Basionym: Striadiporites anceps Norris 1997; Location: Mackenzie River delta, Canada; Age: Palaeocene-Eocene; Notes: Kalgutkar \& Jansonius (2000) interpreted the annular thickenings as septa (or septal bases) and for that reason transferred the species to the new Biporipsilonites, which is characterized precisely by an oval shape, and one (or two) sets of septa underlying each of the terminal pores.

1.4.2. Species: B. belluloides (Z.C. Song) Kalgutkar \& Janson. 2000 (Fig. 5E); Index Fungorum Registration Identifier: 483268; Basionym: Diporicellaesporites belluloides Z.C. Song 1985; Location: Jiandingshan, Huangshi and Huatugou, Qaidam Basin, Qinghai Province, China; Age: Palaeocene-Late Eocene (Ke \& Shi 1978); Early Miocene-Late Miocene (Song 1985).

1.4.3. Species: B. bellulus (P. Ke \& Z.Y. Shi) ex Kalgutkar \& Janson. 2000; Index Fungorum Registration Identifier: 483270; Basionym: Diporicellaesporites bellulus P. Ke \& Z.Y. Shi 1978: 49, pl. 5, fig. 4 (nom. inval.), lectotype was designated by Kalgutkar \& Jansonius 2000; Location: Panshan, Liaoning Province; Laoshanggulin and Beidagang, Tianjin Municipality, Coastal region of Bohai, China; Age: Eocene-Oligocene.

1.4.4. Species: B. fusiformis (Anil Chandra et al.) Kalgutkar \& Janson. 2000 (Fig. 5F); Index Fungorum Registration Identifier: 483271; Basionym: Diporisporites fusiformis Anil Chandra et al. 1984; Location: Sediment core no. 1 (Lat. 1757.9'N: Long. $70^{\circ} 46.0^{\prime} \mathrm{E}$ ), Arabian Sea; Age: Late Quaternary.

1.4.5. Species: B. karii (Anil Chandra et al.) Kalgutkar \& Janson. 2000 (Fig. 5G); Index Fungorum Registration Identifier: 483272; Basionym: Multicellaesporites karii Anil Chandra et al.

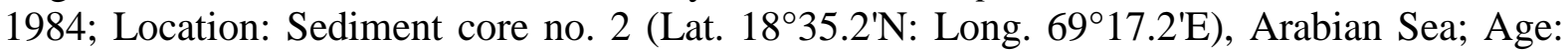
Late Quaternary; Notes: The species epithet is in honour of Dr. R.K. Kar, Birbal Sahni Institute of Palaeosciences, Lucknow, India.

1.4.6. Species: B. krempii (C.P. Varma \& Rawat) Kalgutkar \& Janson. 2000 (Fig. 5H); Index Fungorum Registration Identifier: 483273; Basionym: Psilodiporites krempii C.P. Varma \& Rawat 1963; Location: Western and eastern India, including oil exploration areas in West Bengal and Assam, India; Age: Early to Late Eocene. 
1.4.7. Species: B. maximus (Z.C. Song \& H.C. Luo in Z.C. Song et al.) Kalgutkar \& Janson. 2000; Index Fungorum Registration Identifier: 483274; Basionym: Diporisporites maximus Z.C. Song \& H.C. Luo in Z.C. Song et al. 1989; Location: Qingfeng County of Henan Province, China; Age: Late Eocene-Middle Oligocene (Shahejie Formation).

1.4.8. Species: B. mollis (P. Ke \& Z.Y. Shi) Kalgutkar \& Janson. 2000; Index Fungorum Registration Identifier: 483275; Basionym: Multicellaesporites mollis P. Ke \& Z.Y. Shi 1978; Location: Panshan, Liaoning Province, Coastal region of Bohai, China; Age: EoceneOligocene.

1.4.9. Species: B. mustus (P. Ke \& Z.Y. Shi) Kalgutkar \& Janson. 2000; Index Fungorum Registration Identifier: 483276; Basionym: Multicellaespoites mustus P. Ke \& Z.Y. Shi 1978; Location: Panshan, Liaoning Province, Coastal region of Bohai, China; Age: EoceneOligocene.

1.4.10. Species: B. padappakkarensis (P. Kumar) Kalgutkar \& Janson. 2000 (Fig. 5I); Index Fungorum Registration Identifier: 483277; Basionym: Diporicellaesporites padappakkarensis P. Kumar 1990; Location: Padappakkara, Kollam District, Kerala, India; Age: Early-Middle Miocene (Quilon Beds).

1.4.11. Species: B. verus (P. Ke \& Z.Y. Shi) Kalgutkar \& Janson. 2000; Index Fungorum Registration Identifier: 483278; Basionym: Multicellaesporites verus P. Ke \& Z.Y. Shi 1978; Location: Panshan, Liaoning Province, Coastal region of Bohai, China; Age: EoceneOligocene.

1.5. Genus: BIPORISPORITES P. Ke \& Z.Y. Shi, Early Tertiary Spores and Pollen Grains from the Coastal Region of Bohai (Beijing): 45 (1978); Index Fungorum Registration Identifier: 21029; Type: B. rotundus P. Ke \& Z.Y. Shi 1978.

Original Diagnosis: Spores one-celled, spherical. Diporate, pores situated at same end of spore. Spore wall of medium thickness, surface psilate or scabrate (Ke \& Shi 1978).

Emended Diagnosis: Fungal spore-like bodies, unicellate, equilateral, heteropolar, oblate, circular to oval in shape, one end (defined as apical) with a central boss-like thickening flanked by two pores at its proximal end and prominent lumina in the spore wall laterally adjacent to the constricted median part of the boss. Lateral arm-like thickenings arise from the distal end of the boss. Spore wall smooth, single layered, unornamented or bearing variable ornament in the form of concentric or reticulate thickenings that become subdued in the area immediately surrounding the central boss (Norris 1997).

Classification: Fungi Imperfecti, Amerosporae.

Number of species known: Two.

Notes: Ke \& Shi (1978) distinguished spores in this genus from those in Diporisporites Hammen 1954 by the two pores situated at the same end of the spore outline.

1.5.1. Species: B. praestigiatus G. Norris 1997; Index Fungorum Registration Identifier: 483787; Location: Mackenzie River delta, Canada; Age: Palaeocene-Eocene; Notes: The name of the species epithet is derived from Latin praestigiator = juggler, for the apparently outstretched arms and circling objects.

1.5.2. Species: B. rotundus P. Ke \& Z.Y. Shi 1978 (Fig. 5J); Index Fungorum Registration Identifier: 115624; Location: Panshan, Liaoning Province, Coastal region of Bohai, China; Age: Eocene-Oligocene.

1.6. Genus: CADYEXINIS Stach, Palaeontontographica 102(4-6): 86 (1957); Index Fungorum Registration Identifier: 21040; Type: C. vulgaris Stach 1957.

Original diagnosis: Spores 1-aperturate; elongated; exine psilate, smooth (Stach 1957, vide Huang 1981).

Classification: Fungi Imperfecti, Amerosporae.

Number of species known: Three. 
1.6.1. Species: C. taiwanensis T.C. Huang 1981; Index Fungorum Registration Identifier: 115726; Location: Taiwan; Age: Miocene.

1.6.2. Species: C. tenuis Stach 1957; Index Fungorum Registration Identifier: 114311; Location: Germany; Age: Carboniferous.

1.6.3. Species: C. vulgaris Stach 1957 (Fig. 5K); Index Fungorum Registration Identifier: 114312; Location: Germany; Age: Carboniferous.

1.7. Genus: CERVICHLAMYDOSPORA R. Kar et al., Review of Palaeobotany \& Palynology (Amsterdam) 158(3-4): 247 (2010); Index Fungorum Registration Identifier: 541645; Type: $\boldsymbol{C}$. nigra $\mathrm{R}$. Kar et al. 2010.

Original Diagnosis: Chlamydospores subcircular, dark brown-black, originate from neck of hyphae; solitary, 14-24 × 12-22 $\mu \mathrm{m}$, many hyphae adhere together at base, branch out laterally at tip; hyphae wall laevigate, granulose, grana up to $1 \mu \mathrm{m}$ thick, sparsely placed (Kar et al. 2010).

Classification: Fungi Imperfecti, Amerosporae.

Number of species known: One.

1.7.1. Species: C. nigra R. Kar et al. 2010 (Fig. 5L); Index Fungorum Registration Identifier: 542235; Location: Tlangsam, Mizoram, India; Age: Miocene (Bhuban Formation).

1.8. Genus: CUPULISPORONITES Z.C. Song \& Liu Cao, Monograph, State-Antarctic Committee, China (Beijing) 3: 38 (1994); Index Fungorum Registration Identifier: 28632; Type: C. megaporus Z.C. Song \& Liu Cao 1994; Current name: ANATOLINITES Elsik et al. 1990 fide Kalgutkar \& Jansonius (2000).

Original Diagnosis: One-celled spore, dolium- or cupula-shaped in outline, with a nearly equal width in the two terminal ends; one pore, the structure and form of pore variable; exine solid, laevigate or with weak ornamentation (Song \& Cao 1994).

Classification: Fungi Imperfecti, Amerosporae.

Number of species known: One (the single species has been transferred to Anatolinites Elsik et al. 1990).

1.8.1. Species: C. megaporus Z.C. Song \& Liu Cao 1994; Index Fungorum Registration Identifier: 483763; Current name: Anatolinites megaporus (Z.C. Song \& Liu Cao) Janson. et al. 1998 fide Jansonius et al. (1998).

1.9. Genus: DIPORISPORITES Hammen, Bol. Geol. (Bogota) 2(1): 83 (1954); Index Fungorum Registration Identifier: 21084; Type: D. elongatus Hammen 1954 (holotype was designated by Van der Hammen 1955).

Synonym: Scabradiporites Y.K. Mathur 1966 fide Kalgutkar \& Jansonius (2000), Index Fungorum Registration Identifier: 21292.

Original Diagnosis: Fungal spores "with two small pores" (Van der Hammen 1954).

Emended Diagnosis: Diporate fungal spore of one cell. Pores on opposite ends of the grains. Pores may be modified, i.e. with atrium, annulus or septum forming pore chamber. Shape variable. Ornamentation variable (Elsik 1968).

Classification: Fungi Imperfecti, Amerosporae.

Number of species known: 34 (but we accept only 17 species as legitimate because 16 species have been transferred to other genera and one species, viz. D. minutus Hammen 1954, was not validly published).

Notes: Potonié (1960: 113) formulated the following generic diagnosis: Shape approximately fusiform, with two opposite small pores at the tapered ends, smaller than in Diporites, in part with an annulus; exolamella more or less smooth.

1.9.1. Species: D. anklesvarensis (C.P. Varma \& Rawat) Elsik 1968 (comb. inval.); Index Fungorum Registration Identifier: 313250; Current name: Foveodiporites anklesvarensis C.P. Varma \& Rawat 1963 fide Kalgutkar \& Jansonius (2000). 
1.9.2. Species: D. barrelis A. Gupta 2002 (Fig. 5M); Index Fungorum Registration Identifier: 540470; Location: Dadahu Road Section, Sirmaur District, Himachal Pradesh, India; Age: Eocene (Subathu Formation).

1.9.3. Species: D. bhavnagarensis R.K. Saxena 2009 (Fig. 5N); Index Fungorum Registration Identifier: 515013; Basionym: Diporisporites granulatus B. Samant 2000; Location: Near Bhavnagar, Cambay Basin, Gujarat, India; Age: Early Eocene (Kharsalia Clay Formation).

1.9.4. Species: D. communis P. Ke \& Z.Y. Shi 1978; Index Fungorum Registration Identifier: 115643; Location: Panshan, Liaoning Province; Tanggu, Tianjin Municipality; Kenli, Shandong Province, Coastal region of Bohai, China; Age: Eocene-Oligocene; Notes: Elsik (1968) distinguished spores in this species from those in Diporisporites hammenii Elsik 1968 by their larger spore size and broadly rounded outline.

1.9.5. Species: D. conspicuus Ramanujam \& K.P. Rao 1978; Index Fungorum Registration Identifier: 115062; Current name: Foveodiporites conspicuus (Ramanujam \& K.P. Rao) Kalgutkar \& Janson. 2000 fide Kalgutkar \& Jansonius (2000).

1.9.6. Species: D. curvatus Ramanujam \& K.P. Rao 1978; Index Fungorum Registration Identifier: 115063; Current name: Hypoxylonites curvatus (Ramanujam \& K.P. Rao) Elsik 1990a fide Elsik (1990a).

1.9.7. Species: D. elegans P. Ke \& Z.Y. Shi 1978; Index Fungorum Registration Identifier: 115642; Current name: Foveodiporites elegans (P. Ke \& Z.Y. Shi) Kalgutkar \& Janson. 2000 fide Kalgutkar \& Jansonius (2000).

1.9.8. Species: D. ellipsoides (Sal.-Cheb. \& Locq.) Kalgutkar \& Janson. 2000; Index Fungorum Registration Identifier: 483322; Basionym: Psiammopomopiospora ellipsoides Sal.-Cheb. \& Locq. 1980; Location: Coast of Equatorial Africa, Gulf of Guinea, Cameroon, Africa; Age: Late Eocene-Oligocene; Notes: Elsik (1968) suggested affinity of this species with Basidiomycota.

1.9.9. Species: D. elongatus Hammen 1954 (Fig. 5O); Index Fungorum Registration Identifier: 330110; Location: Eastern Cordilleras, Colombia, South America; Age: Maastrichtian.

1.9.10. Species: D. elsikii R.K. Saxena 2000 (Fig. 5P); Index Fungorum Registration Identifier: 519769; Location: Mavli Mine at Redi, Sindhudurg District, Maharashtra, India; Age: Miocene (Sindhudurg Formation).

1.9.11. Species: D. fusiformis Anil Chandra et al. 1984; Index Fungorum Registration Identifier: 106781; Current name: Biporipsilonites fusiformis (Anil Chandra et al.) Kalgutkar \& Janson. 2000 fide Kalgutkar \& Jansonius (2000).

1.9.12. Species: D. giganticus R.K. Kar in R.K. Saxena 2012 (Fig. 5Q); Index Fungorum Registration Identifier: 519770; Basionym: Diporisporites giganticus R.K. Kar 1990 (nom. inval.); Location: Tripura-Assam, North-east India; Age: Miocene-Pliocene (Surma and Tipam groups).

1.9.13. Species: D. granulatus (Rouse) Elsik 1968 (comb. inval.) fide Kalgutkar \& Jansonius (2000); Index Fungorum Registration Identifier: 631277; Current name: Diporisporites pergranulatus Kalgutkar \& Janson. 2000 fide Kalgutkar \& Jansonius (2000).

1.9.14. Species: D. granulatus P. Ke \& Z.Y. Shi 1978; Index Fungorum Registration Identifier: 115641; Current name: Foveodiporites granulatus (P. Ke \& Z.Y. Shi) Kalgutkar \& Janson. 2000 fide Kalgutkar \& Jansonius (2000).

1.9.15. Species: D. granulatus B. Samant 2000; Index Fungorum Registration Identifier: 529671; Current name: Diporisporites bhavnagarensis R.K. Saxena 2009 fide Saxena (2009).

1.9.16. Species: D. gunniae (C.P. Varma \& Rawat) Elsik 1968 (comb. inval.) fide Kalgutkar \& Jansonius (2000); Index Fungorum Registration Identifier: 313253; Current name: Foveodiporites gunniae (C.P. Varma \& Rawat) Kalgutkar \& Janson. 2000 fide Kalgutkar \& Jansonius (2000).

1.9.17. Species: D. hammenii Elsik 1968 (Fig. 5R); Index Fungorum Registration Identifier: 313254; Location: Strip mine approximately $11 \mathrm{~km}$ south-west of Rockdale, Milam County, Texas, U.S.A.; Age: Palaeocene (Rockdale lignite). 
1.9.18. Species: D. harrisii (C.P. Varma \& Rawat) Elsik 1968 (comb. inval.); Index Fungorum Registration Identifier: 313255; Current name: Foveodiporites harrisii (C.P. Varma \& Rawat) Kalgutkar \& Janson. 2000 fide Kalgutkar \& Jansonius (2000).

1.9.19. Species: D. incurvus P. Ke \& Z.Y. Shi 1978; Index Fungorum Registration Identifier: 115640; Location: Cangxian, Hebei Province, Coastal region of Bohai, China; Age: EoceneOligocene.

1.9.20. Species: D. krempii (C.P. Varma \& Rawat) Elsik 1968 (comb. inval.); Index Fungorum Registration Identifier: 313256; Current name: Biporipsilonites krempii (C.P. Varma \& Rawat) Kalgutkar \& Janson. 2000 fide Kalgutkar \& Jansonius (2000).

1.9.21. Species: D. major Anil Chandra et al. 1984 (Fig. 5S); Index Fungorum Registration Identifier: 106782; Location: Sediment core no. 1 (Lat. $17^{\circ} 57.9^{\prime} \mathrm{N}$ : Long. $70^{\circ} 46.0^{\prime} \mathrm{E}$ ), Arabian Sea; Age: Late Quaternary.

1.9.22. Species: D. maximus Z.C. Song \& H.C. Luo in Z.C. Song et al. 1989; Index Fungorum Registration Identifier: 485270; Current name: Biporipsilonites maximus (Z.C. Song \& H.C. Luo in Z.C. Song et al.) Kalgutkar \& Janson. 2000 fide Kalgutkar \& Jansonius (2000); Notes: Kalgutkar \& Jansonius (2000) transferred D. maximus to Biporipsilonites because its holotype has pore chambers at both ends.

1.9.23. Species: D. minutiporatus Hammen 1954; Index Fungorum Registration Identifier: 330111; Current name: Foveodiporites minutiporatus (Hammen) Kalgutkar \& Janson. 2000 fide Kalgutkar \& Jansonius (2000); Notes: Kalgutkar \& Jansonius (2000) transferred D. maximus to Foveodiporites because its holotype has pore chambers at both ends and has foveolate spore wall.

1.9.24. Species: D. minutus Hammen 1954 (nom. inval.) fide Kalgutkar \& Jansonius (2000); Index Fungorum Registration Identifier: 330112; Location: Eastern Cordilleras, Colombia, South America; Age: Maastrichtian. Notes: Van der Hammen 1954 did not validly publish the species because he did not provide any figure of the type, though he published a brief description.

1.9.25. Species: D. naviculoides (Sal.-Cheb. \& Locq.) Kalgutkar \& Janson. 2000; Index Fungorum Registration Identifier: 483323; Basionym: Psiammopomopiospora naviculoides Sal.-Cheb. \& Locq. 1980; Location: Coast of Equatorial Africa, Gulf of Guinea, Cameroon, Africa; Age: Late Eocene-Oligocene; Notes: Salard-Cheboldaeff \& Locquin (1980) suggested affinity of this genus with Basidiomycota.

1.9.26 Species: D. oblongatus P. Ke \& Z.Y. Shi 1978; Index Fungorum Registration Identifier: 115639; Location: Tanggu, Tianjin Municipality; Kenli and Linyi, Shandong Province, Coastal Region of Bohai, China; Age: Eocene-Oligocene.

1.9.27. Species: D. pergranulatus Kalgutkar \& Janson. 2000; Index Fungorum Registration Identifier: 483324; Basionym: Diporites granulatus Rouse 1962; Location: Terminal Dock, the city of Vancouver, British Columbia; Age: Late Cretaceous-Middle Eocene (Burrard Formation).

1.9.28. Species: D. piercei (C.P. Varma \& Rawat) Elsik 1968 (comb. inval.); Index Fungorum Registration Identifier: 313257; Current name: Foveodiporites piercei (C.P. Varma \& Rawat) Kalgutkar \& Janson. 2000 fide Kalgutkar \& Jansonius (2000).

1.9.29. Species: D. pisciculatus G. Norris 1997; Index Fungorum Registration Identifier: 483788; Current name: Inapertisporites pisciculatus (G. Norris) Kalgutkar \& Janson. 2000 fide Kalgutkar \& Jansonius (2000).

1.9.30. Species: D. planus Mart.-Hern. \& Tom.-Ort. 1989 ex Kalgutkar \& Janson. 2000; Index Fungorum Registration Identifier: 483801; Basionym: Diporisporites planus Mart.-Hern. \& Tom.-Ort. 1989 (nom. inval.), lectotype designated by Kalgutkar \& Jansonius 2000; Location: Piedras Negras, Coahuila State, Mexico; Age: Maastrichtian; Notes: MartínezHernández \& Tomasini-Ortizin (1989) did not designate a type specimen thus Diporisporites planus Mart.-Hern. \& Tom.-Ort. 1989 was not validly published. Kalgutkar \& Jansonius (2000) designated the lectotype in order to validate the species. 
1.9.31. Species: D. psilatus P. Kumar 1990 (Fig. 5T); Index Fungorum Registration Identifier: 126555; Location: Padappakkara, Kollam District, Kerala, India; Age: Early-Middle Miocene (Quilon Beds).

1.9.32. Species: D. reticulatus (C.P. Varma \& Rawat) Elsik 1968 (comb. inval.); Index Fungorum Registration Identifier: 313258; Current name: Striadiporites reticulatus C.P. Varma \& Rawat 1963 fide Kalgutkar \& Jansonius (2000).

1.9.33. Species: D. sirmaurensis A. Gupta 2002 (Fig. 5U); Index Fungorum Registration Identifier: 540471; Location: Dadahu Road Section, Sirmaur District, Himachal Pradesh, India; Age: Eocene (Subathu Formation).

1.9.34. Species: D. varias (Y.K. Mathur) Kalgutkar \& Janson. 2000 (Fig. 5V); Index Fungorum Registration Identifier: 483325; Basionym: Scabradiporites varias Y.K. Mathur 1966; Location: Matanomadh, western Kutch, Gujarat, India; Age: Palaeocene (Supratrappeans); Notes: Kalgutkar \& Jansonius (2000) considered that Scabradiporites Y.K. Mathur 1966 (Mathur 1966) is superfluous thus the type species, Scabradiporites varias, was transferred to Diporisporites. This makes Scabradiporites a later synonym of Diporisporites.

1.10. Genus: DREMUSPORA Sal.-Cheb. \& Locq., C. r. Congr. natn. Socs. sav. Paris, sect. sci., fasc. 1. (Paleobotanique) 105: 191 (1980); Index Fungorum Registration Identifier: 25594; Type: D. cucurbitaria Sal.-Cheb. \& Locq. 1980.

Original Diagnosis: Spores with cells arranged as the parts in a mandarin orange (SalardCheboldaeff \& Locquin 1980).

Classification: Fungi Imperfecti, Amerosporae.

Number of species known: One.

Notes: Kalgutkar \& Jansonius (2000) remarked "The particular structure of the grouped spores makes the fungal nature of this taxon questionable. The summary diagnosis and description do not help to clarify its affinity; a reexamination of the holotype is needed to answer these questions". From the general organization, the holotype appears to be a fungal spore tetrad.

1.10.1. Species: D. cucurbitaria Sal.-Cheb. \& Locq. 1980 (Fig. 5W); Index Fungorum Registration Identifier: 107941; Location: Coast of Equatorial Africa, Gulf of Guinea, Cameroon, Africa; Age: Oligocene.

1.11. Genus: EXESISPORITES Elsik, Trans. Gulf Coast Assoc. Geol. Societies 19: 516 (1969); Index Fungorum Registration Identifier: 21100; Type: E. neogenicus Elsik 1969.

Original Diagnosis: Unicellular, aseptate, psilate, monoporate fungal spores of circular outline with lenticular to spherical? shape. The centrally located pore in most specimens is surrounded by a dark circular patch which is interpreted as a thickened wall. This polar area is occasionally found free of the spore (Elsik 1969).

Classification: Fungi Imperfecti, Amerosporae.

Number of species known: Four.

Notes: The centrally located pore in Exesisporites is generally surrounded by a dark circular patch which is interpreted as a thickened wall. Exesisporites is differentiated from Monoporisporites Hammen 1954, Basidiosporites Elsik 1968 and Lacrimasporonites R.T. Clarke 1965 on the character of the pore or hilum and the orientation of the spores in mounted residues. It is further differentiated from Reticulatisporonites Elsik 1968 by the lack of reticulate ornamentation. Glass et al. (1986) cited possible affinity of Exesisporites to the extant fungus Nigrospora Zimm.

1.11.1. Species: E. annulatus Kalgutkar 1993; Index Fungorum Registration Identifier: 483879; Location: Peel River, Yukon Territory, Canada; Age: Late Palaeocene-Early Eocene; Notes: Kalgutkar (1993) commented that "The spores resemble Exesisporites neogenicus Elsik 1969 in general morphology but show greater variation in size, are somewhat larger, and have a definite ring around the pore". The species is named after Latin, annulatus, ring, referring to the ring of thickening around the pore. 
1.11.2. Species: E. neogenicus Elsik 1969 (Fig. 5X); Index Fungorum Registration Identifier: 107966; Location: Northern Gulf of Mexico; Age: Miocene-Pleistocene; Notes: This species is characterized by the presence of somewhat thickened polar area around the minute pore.

1.11.3. Species: E. psilatus R.K. Saxena 2000 (Fig. 5Y); Index Fungorum Registration Identifier: 519806; Location: Mavli Mine at Redi, Sindhudurg District, Maharashtra, India; Age: Miocene (Sindhudurg Formation).

1.11.4. Species: E. verrucatus P. Kumar 1990 (Fig. 5Z); Index Fungorum Registration Identifier: 126559; Location: Padappakkara, Kollam District, Kerala, India; Age: Early-Middle Miocene (Quilon Beds); Notes: Exesisporites verrucatus differs from all the known species of this genus in having hyaline, hollow, rounded verruca-like sculptures at the peripheral margin of the spore. The species epithet is based on the peripheral verrucae.

1.12. Genus: FOLIOPOLLENITES Sierotin, Sporae dispersae im Rhat und Lias von Grossbellhofen (Mittelfranken). Inaugural-dissertation (Berlin): 55 (1961); Index Fungorum Registration Identifier: 25760; Type: $\boldsymbol{F}$. spinosus Sierotin 1961.

Original Diagnosis: Shaped like a tapered leaf; whole surface is covered with numerous spines of a little over $1 \mu \mathrm{m}$ long; exine two layered, a little more than $1 \mu \mathrm{m}$ thick; surface chagrinate; size $27 \times 21 \mu \mathrm{m}$ (Sierotin 1961).

Classification: Fungi Imperfecti, Amerosporae.

Number of species known: Four ((but we accept only three species as legitimate as $F$. elongates was not validly published).

Notes: Potonié (1966) quoted a letter from Sierotin that "possibly this is a microfossil that can be assigned elsewhere" (than in the flowering plants).

1.12.1. Species: F. elongatus Z.C. Song in Z.C. Song et al. 1999 (nom. inval.) fide Kalgutkar \& Jansonius (2000); Index Fungorum Registration Identifier: 483821; Location: China; Age: Late Cretaceous/Tertiary; Notes: The species name was not validly published because the author did not specify where the holotype was deposited, and did not provide a Latin description or English translation. The illustration is that of a smooth, fusiform amerosporae $(28 \times 11 \mu \mathrm{m})$ with one broadly rounded end, and the other one tapered to a point.

1.12.2. Species: $\boldsymbol{F}$. qaidamensis Z.C. Song 1985; Index Fungorum Registration Identifier: 637474; Location: Qigequan, Qaidam Basin, Qinghai Province, China; Age: Late Eocene-Late Oligocene; Notes: The peculiar echinate ornamentation distinguishes this species from the other known species of Foliopollenites.

1.12.3. Species: F. spinosus Sierotin 1961 (Fig. 5AA); Index Fungorum Registration Identifier: 114750; Location: Germany; Age: Early Jurassic.

1.12.4. Species: F. taiwanensis T.C. Huang 1981; Index Fungorum Registration Identifier: 115775; Location: Taiwan; Age: Miocene.

1.13. Genus: FOVEODIPORITES C.P. Varma \& Rawat, Grana Palynologica 4(1): 133 (1963); Index Fungorum Registration Identifier: 21105; Type: F. anklesvarensis C.P. Varma \& Rawat 1963.

Synonym: Punctodiporites C.P. Varma \& Rawat 1963 fide Kalgutkar \& Jansonius (2000), Index Fungorum Registration Identifier: 28617.

Original Diagnosis: Pollen grains diporate. Exine foveolate (Varma \& Rawat 1963).

Emended Diagnosis: Monocellate diporate fungal spores of mostly medium (ca 15-60 $\mu \mathrm{m}$ ) size; overall shape fusiform to elliptic, but characteristically somewhat lob-sided, with one side of the outline more convex than the other; spore wall relatively thin, externally essentially smooth, internally smooth, or with punctate, granulate, foveolate or similar sculpture; pores terminal, complex, consisting of a thin collar and separated from the spore interior by one or two septa (the latter forming a pore chamber); pore regions often with darker pigmentation (Kalgutkar \& Jansonius 2000).

Classification: Fungi Imperfecti, Amerosporae. 
Number of species known: Eleven.

Notes: Although originally described as pollen, these forms are now generally recognized as fungal spores.

1.13.1. Species: F. anklesvarensis C.P. Varma \& Rawat 1963 (Fig. 5AB); Index Fungorum Registration Identifier: 105891; Location: Western and eastern India, including oil exploration areas in West Bengal and Assam; Age: Early-Middle Eocene, Late EoceneOligocene, Early Miocene; Notes: Kalgutkar \& Jansonius (2000) observed that the presence of punctate or foveolate spore walls in this species is but a minor morphological variation. Specimens with either punctate or foveolate walls, and with walls showing both types of ornamentation, were seen (Kalgutkar 1993).

1.13.2. Species: F. bimucronatus (Sal.-Cheb. \& Locq.) Kalgutkar \& Janson. 2000; Index Fungorum Registration Identifier: 483363; Basionym: Diporites bimucronatus Sal.-Cheb. \& Locq. 1980; Location: Coast of Equatorial Africa, Gulf of Guinea, Cameroon, Africa; Age: Oligocene.

1.13.3. Species: F. conspicuus (Ramanujam \& K.P. Rao) Kalgutkar \& Janson. 2000 (Fig. 5AC); Index Fungorum Registration Identifier: 483364; Basionym: Diporisporites conspicuus Ramanujam \& K.P. Rao 1978; Location: Kannur, Kerala, India; Age: Miocene (Quilon and Warkalli beds); Notes: The conspicuous pores with atria and the thin, folded spore wall are the characteristic features of this species.

1.13.4. Species: F. elegans (P. Ke \& Z.Y. Shi) Kalgutkar \& Janson 2000; Index Fungorum Registration Identifier: 483365; Basionym: Diporisporites elegans P. Ke \& Z.Y. Shi 1978; Location: Panshan, Liaoning Province, Coastal region of Bohai, China; Age: EoceneOligocene.

1.13.5. Species: F. endogranulosus (Kemp) Kalgutkar \& Janson. 2000; Index Fungorum Registration Identifier: 483366; Basionym: Diporicellaesporites endogranulosus Kemp 1978; Location: Deep Sea Drilling Site 254, the Ninetyeast Ridge, Indian Ocean; Age: Late EoceneOligocene; Notes: This species shows close structural similarity to Foveodiporites anklesvarensis C.P. Varma \& Rawat, and for this reason Kalgutkar \& Jansonius (2000) transferred it to Foveodiporites.

1.13.6. Species: F. foedus (G. Norris) Kalgutkar \& Janson. 2000; Index Fungorum Registration Identifier: 483367; Basionym: Punctodiporites foedus G. Norris 1997; Location: Imperial ADGO F-28 Well, Mackenzie River delta, Canada; Age: Palaeocene-Eocene; Notes: This species is named after Latin foedus, foul, horrible.

1.13.7. Species: F. granulatus (P. Ke \& Z.Y. Shi) Kalgutkar \& Janson. 2000; Index Fungorum Registration Identifier: 483368; Basionym: Diporisporites granulatus P. Ke \& Z.Y. Shi 1978; Location: Panshan, Liaoning Province; Kenli, Shandong Province, Coastal region of Bohai, China; Age: Eocene-Oligocene; Notes: Ke \& Shi (1978) stated that further research is needed to determine whether these fossils are unicellular organisms or fungal spores.

1.13.8. Species: F. gunniae (C.P. Varma \& Rawat) Kalgutkar \& Janson. 2000 (Fig. 5AD); Index Fungorum Registration Identifier: 483369; Basionym: Psilodiporites gunniae C.P. Varma \& Rawat 1963; Location: Western and eastern India, including oil exploration areas in West Bengal and Assam; Age: Middle-Late Eocene; Notes: This species has been named after Mrs. Gunni Erdtman.

1.13.9. Species: F. harrisii (C.P. Varma \& Rawat) Kalgutkar \& Janson. 2000 (Fig. 5AE); Index Fungorum Registration Identifier: 483370; Basionym: Punctodiporites harrisii C.P. Varma \& Rawat 1963; Location: Western and eastern India, including oil exploration areas in West Bengal and Assam; Age: Early Eocene-Early Oligocene.

1.13.10. Species: F. minutiporatus (Hammen) Kalgutkar \& Janson. 2000; Index Fungorum Registration Identifier: 483371; Basionym: Diporisporites minutiporatus Hammen 1954; Location: Magdalena Valley, Eastern Cordellera, Colombia, South America. Age: Maastrichtian. 
1.13.11. Species: F. piercei (C.P. Varma \& Rawat) Kalgutkar \& Janson. 2000 (Fig. 5AF); Index Fungorum Registration Identifier: 483372; Basionym: Granodiporites piercei C.P. Varma \& Rawat 1963; Location: Western and eastern India, including oil exploration areas in West Bengal and Assam; Age: Middle-Late Eocene.

1.14. Genus: FUSIDIPOROSPORONITES Z.C. Song in Z.C. Song et al., Early Tertiary SporoPollen Assemblages from the Dongpu Region: 43, pl. 4, fig. 18, (1989); Index Fungorum Registration Identifier: 637475; Type: F. minutaestriatus Z.C. Song in Z.C. Song et al. 1989.

Original Diagnosis: One-celled spore, narrowly fusiform in outline, tapering to form a short tube at each terminal end; two pores, situated on the tips of the short tubes; pore simple, unstructured, exine (i.e. spore wall) moderately thick, ornamentation various, but commonly thin and weak (Song et al. 1989).

Classification: Fungi Imperfecti, Amerosporae.

Number of species known: One.

Notes: According to Song et al. (1989), ornamentation and shape of the type species, Fusidiporosporonites minutaestriatus, is similar to that in Lacrimasporonites minutaestriatus $\mathrm{P}$. Ke \& Z.Y. Shi 1978 [Current name: Monoporisporites minutaestriatus (P. Ke \& Z.Y. Shi) Kalgutkar \& Janson. 2000], but the latter has only one pore and one short terminal tube. Fusidiporosporonites minutaestriatus is characterized by numerous transverse, fine striae. This feature separates it from Striadiporites, which is characterized by longitudinal ridges (that may form a reticulum). This genus can also be distinguished from Fusiformisporites on the basis of the transverse striation, and the more elongated terminal tubes.

1.14.1. Species: F. minutaestriatus Z.C. Song in Z.C. Song et al. 1989 (Fig. 5AG); Index Fungorum Registration Identifier: 637476; Location: Shenxian county of Shandong Province, China; Age: Late Eocene-Middle Oligocene (Shahejie Formation).

1.15. Genus: GEOTRICHITES Stubblef. et al., Mycologia 77(1): 12 (1985); Index Fungorum Registration Identifier: 25685; Type: G. glaesarius Stubblef. et al. 1985.

Original Diagnosis: Hyphae aerial, erect or decumbent, septate, sometimes branching dichotomously. Conidiophores micronematous. Conidia holoarthric, aseptate, produced by schizolytic disarticulation, variable in size, oblong or truncate with obtuse ends (Stubblefield et al. 1985).

Classification: Fungi Imperfecti, Amerosporae.

Number of species known: One.

Notes: According to Stubblefield et al. (1985), Geotrichites conforms to the extant genus Geotrichum Link ex Pers. in most aspects, although it is impossible to determine whether the mycelium is dry or slimy in the fossilized state.

1.15.1. Species: G. glaesarius Stubblef. et al. 1985 (Fig. 5AH); Index Fungorum Registration Identifier: 105328; Location: Dominican Republic; Age: Late Oligocene or Early Miocene.

1.16. Genus: GRAAMSPORA Sal.-Cheb. \& Locq., C. r. Congr. natn. Socs. sav. Paris, sect. sci., fasc. 1. (Paleobotanique) 105: 191 (1980); Index Fungorum Registration Identifier: 25590; Type: G. pezizaffinis Sal.-Cheb. \& Locq. 1980; Current name: UNCINULITES Pampal. 1902 fide Kalgutkar \& Jansonius (2000).

Original Diagnosis: Amerospores, more or less verrucose-spinose; approximately $20 \times 15 \mu \mathrm{m}$ (Salard-Cheboldaeff \& Locquin 1980 fide Jansonius \& Hills 1981)

Classification: Fungi Imperfecti, Amerosporae.

Number of species known: One (the single species has been transferred to Uncinulites Pampl. 1902).

1.16.1. Species: G. pezizaffinis Sal.-Cheb. \& Locq. 1980, p. 184, pl. 1, fig. 3. Current name: Uncinulites pezizaffinis (Sal.-Cheb. \& Locq.) Kalgutkar \& Janson. 2000 fide Kalgutkar \& Jansonius (2000). 
1.17. Genus: GRANODIPORITES C.P. Varma \& Rawat, Grana Palynologica 4(1): 135 (1963); Type: G. erdtmanii C.P. Varma \& Rawat 1963, p. 135, fig. 13. Current name: BANKSIEAEIDITES Cookson 1950 (angiosperm pollen) fide Kalgutkar \& Jansonius (2000).

Original Diagnosis: Diporate pollen grains with granular exine (Varma \& Rawat 1963).

Classification: Fungi Imperfecti, Amerosporae.

Number of species known: Three (the type species, G. erdtmanii C.P. Varma \& Rawat 1963, belongs to angiospermous pollen whereas the remaining two species have been transferred to other fungal spore genera).

Notes: Since the type species (G. erdtmanii) has been transferred to Banksieaeidites Cookson (an angiospermous pollen) by Kalgutkar \& Jansonius (2000), Granodiporites became a later synonym of Banksieaeidites. The remaining two fungal species have been transferred to other genera.

1.17.1. Species: G. erdtmanii C.P. Varma \& Rawat 1963; Index Fungorum Registration Identifier: 519816; Current name: Banksieaeidites erdtmanii (C.P. Varma \& Rawat) Kalgutkar \& Janson. 2000 (angiospermous pollen) fide Kalgutkar \& Jansonius (2000).

1.17.2. Species: G. piercei C.P. Varma \& Rawat 1963; Index Fungorum Registration Identifier: 483374; Current name: Foveodiporites piercei (C.P. Varma \& Rawat) Kalgutkar \& Janson. 2000 fide Kalgutkar \& Jansonius (2000).

1.17.3. Species: G. sahnii C.P. Varma \& Rawat 1963; Index Fungorum Registration Identifier: 483375; Current name: Dyadosporites sahnii (C.P. Varma \& Rawat) Kalgutkar \& Janson. 2000 fide Kalgutkar \& Jansonius (2000).

1.18. Genus: GRAPHIOLITES Fritel, Mém. Soc. geol. Fr. Paleont. 40: 12 (1910); Index Fungorum Registration Identifier: 21122; Type: G. sabaleos Fritel 1910.

Original Diagnosis: In this genus are included fossil forms of which the external features and habitat agree with those of the extant Graphiola (Exobasidiales,Basidiomycota), i.e. fungi specialized in parasitizing palm fronds, where they form peridia consisting of deep, round or oval cupules; these cupules may occur dispersed, or be arranged in longitudinal series parallel to the nervature of the fronds on which they grow. When the peridia are oval, the longer axis is always aligned longitudinally (Fritel 1910).

Classification: Fungi Imperfecti, Amerosporae.

Number of species known: One.

Notes: Fritel (1910), for the first time, reported fossil spores of Graphiola and placed them in a new Graphiolites. Kalgutkar \& Jansonius (2000) stated that Graphiola was assigned to Fungi Imperfecti (hyphomycetes, Amerosporae) by Poiteau (1824). Hughes (1953) recognized that this genus currently is considered to be in the Basidiomycota (Graphiolaceae, Ustilaginales). However, he also stated that this position generally is regarded as dubious.

1.18.1. Species: G. sabaleos Fritel 1910 (Fig. 5AI); Index Fungorum Registration Identifier: 101378; Location: Cessoy, Seine-et-Marne, France; Age: Sparnacian (Early Eocene).

1.19. Genus: HAPLOGRAPHITES Félix, Zeitschr. Deutsche Geol. Gesell. 46: 275 (1894); Index Fungorum Registration Identifier: 21125; Type: H. cateniger Felix 1894 (lectotype was designated by Jansonius \& Hills 1976).

Original Diagnosis: Individual conidia average 15-17 $\mu \mathrm{m}$ in length, 9-11 (but up to 14) $\mu \mathrm{m}$ in width; colour mostly dark amber-brown, occasionally lighter; cell wall very thick (Felix 1894).

Classification: Fungi Imperfecti, Amerosporae.

Number of species known: Two.

Notes: Felix (1894) proposed Haplographites to accommodate fossil fungal spores showing similarity to spores of the living representatives of the grouping Haplographieae of Saccardo (particularly those of Haplographium Berk. \& Broome and Dematium Pers.) that their affinity to this grouping appears probable. 
1.19.1. Species: H. cateniger Félix 1894 (Fig. 6A); Index Fungorum Registration Identifier: 232186; Location: Perekeschkul, near Baku, Azerbaijan; Age: Eocene.

1.19.2. Species: H. xylophagus Félix 1894; Index Fungorum Registration Identifier: 218003; Location: Tarnow, Galicia; Age: Tertiary.

1.20. Genus: HYPOXYLONITES Elsik, Palaeontographica Abt. B 216(5-6): 143 (1990a), Index Fungorum Registration Identifier: 25556; Type: H. brazosensis Elsik 1990a.

Synonyms: Hypoxylonsporites P. Kumar 1990 fide Saxena 1992, Index Fungorum Registration Identifier: 25448; Xylariasporites Debi Mukh. 2012 fide hoc loco, Index Fungorum Registration Identifier: 588470.

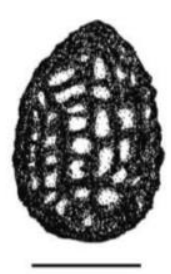

A

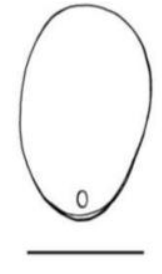

B

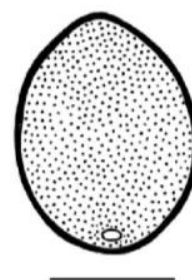

C

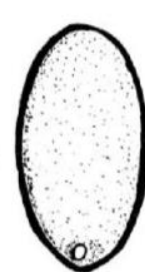

D

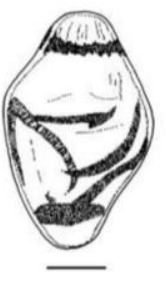

E
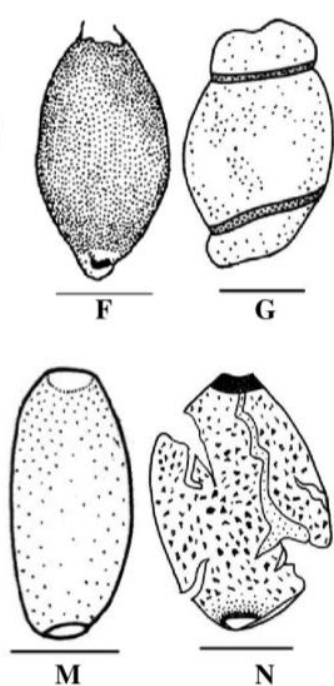

K
L

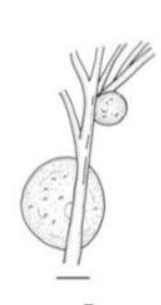

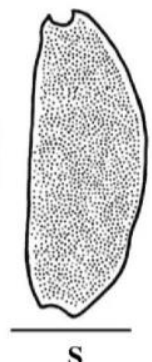
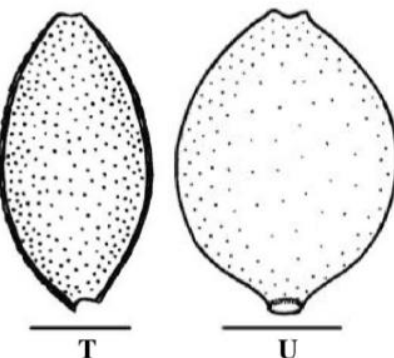
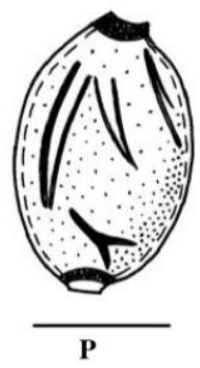
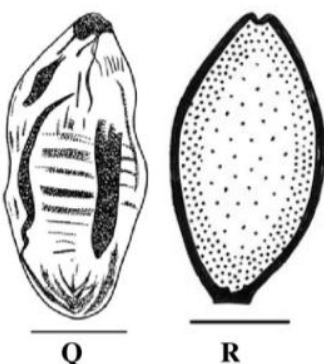

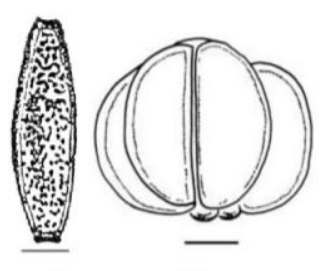

W

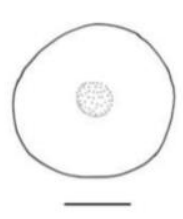

$\mathbf{X}$

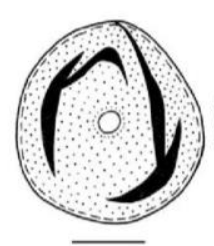

$\bar{Y}$
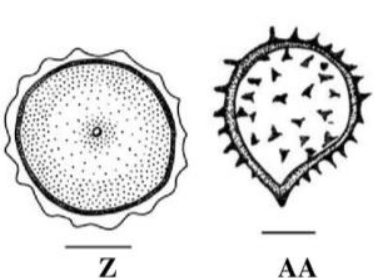

AA
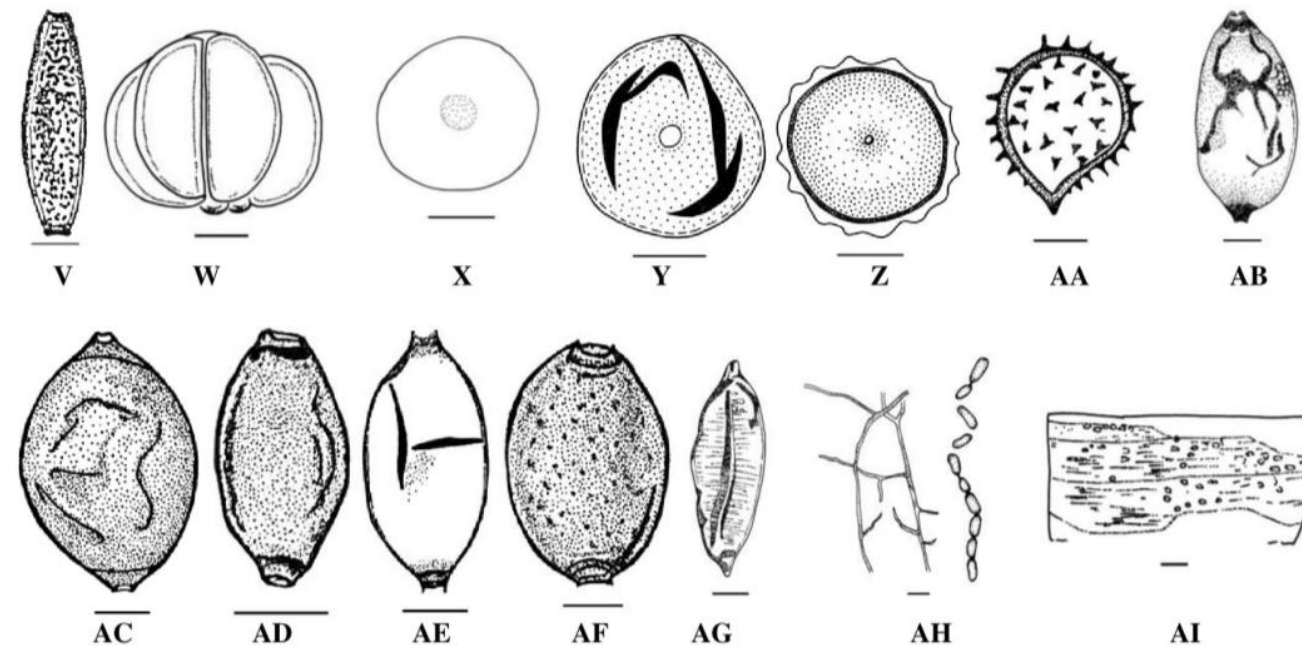

AH

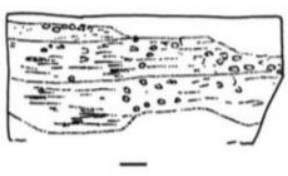

AI

Figure 5 - A-AI Amerosporae. A Asyregraamspora reticulata Sal.-Cheb. \& Locq. 1980, Bar = 8 $\mu \mathrm{m}$. B Basidiosporites fournieri Elsik 1968. 1980, Bar $=8 \mu \mathrm{m}$. C Basidiosporites ovalis (Sheffy \& 
Dilcher) Kalgutkar \& Janson. 2000. 1980, Bar $=10 \mu \mathrm{m}$. D Basidiosporites sadasivanii Anil Chandra et al. 1984, Bar $=10 \mu \mathrm{m}$. E Biporipsilonites belluloides (Z.C. Song) Kalgutkar \& Janson. 2000, Bar $=8 \mu \mathrm{m}$. F Biporipsilonites fusiformis (Anil Chandra et al.) Kalgutkar \& Janson. 2000, Bar $=20 \mu \mathrm{m}$. G Biporipsilonites karii (Anil Chandra et al.) Kalgutkar \& Janson. 2000, Bar $=5 \mu \mathrm{m}$. H Biporipsilonites krempii (C.P. Varma \& Rawat) Kalgutkar \& Janson. 2000, Bar $=20 \mu \mathrm{m}$. I Biporipsilonites padappakkarensis (P. Kumar) Kalgutkar \& Janson. 2000, Bar $=20 \mu \mathrm{m}$. J Biporisporites rotundus P. Ke \& Z.Y. Shi 1978, Bar $=8 \mu \mathrm{m}$. K Cadyexinis vulgaris Stach 1957, Bar $=40 \mu \mathrm{m}$. L Cervichlamydospora nigra R. Kar et al. 2010, Bar $=10 \mu \mathrm{m}$. M Diporisporites barrelis A. Gupta 2002, Bar $=10 \mu \mathrm{m}$. N Diporisporites bhavnagarensis R.K. Saxena 2009, Bar $=$ $20 \mu \mathrm{m}$. O Diporisporites elongatus Hammen 1954, Bar $=10 \mu \mathrm{m}$. P Diporisporites elsikii R.K. Saxena 2000, Bar $=30 \mu \mathrm{m}$. Q Diporisporites giganticus R.K. Kar 2012, Bar $=35 \mu \mathrm{m} . \mathrm{R}$ Diporisporites hammenii Elsik 1968, Bar $=5 \mu \mathrm{m}$. S Diporisporites major Anil Chandra et al. 1984, Bar $=10 \mu \mathrm{m}$. T Diporisporites psilatus P. Kumar 1990, Bar $=20 \mu \mathrm{m}$. U Diporisporites sirmaurensis A. Gupta 2002, Bar $=10 \mu \mathrm{m}$. V Diporisporites varias (Y.K. Mathur) Kalgutkar \& Janson. 2000, Bar $=7 \mu \mathrm{m}$. W Dremuspora cucurbitaria Sal.-Cheb. \& Locq. 1980, Bar $=8 \mu \mathrm{m} . \mathrm{X}$ Exesisporites neogenicus Elsik 1969, Bar $=12 \mu \mathrm{m}$. Y Exesisporites psilatus R.K. Saxena 2000, Bar $=20 \mu \mathrm{m} . \mathrm{Z}$ Exesisporites verrucatus P. Kumar 1990, Bar $=10 \mu \mathrm{m}$. AA Foliopollenites spinosus Sierotin 1961, Bar $=12 \mu \mathrm{m}$. AB Foveodiporites anklesvarensis C.P. Varma \& Rawat 1963, Bar $=$ $10 \mu \mathrm{m}$. AC Foveodiporites conspicuus (Ramanujam \& K.P. Rao) Kalgutkar \& Janson. 2000, Bar $=$ $10 \mu \mathrm{m}$. AD Foveodiporites gunniae (C.P. Varma \& Rawat) Kalgutkar \& Janson. 2000, Bar $=10$ $\mu \mathrm{m}$. AE Foveodiporites harrisii (C.P. Varma \& Rawat) Kalgutkar \& Janson. 2000, Bar $=10 \mu \mathrm{m}$. AF Foveodiporites piercei (C.P. Varma \& Rawat) Kalgutkar \& Janson. 2000, Bar $=10 \mu \mathrm{m}$. AG Fusidiporosporonites minutaestriatus Z.C. Song 1989, Bar $=12 \mu \mathrm{m}$. AH Geotrichites glaesarius Stubblef. et al. 1985, Bar $=5 \mu \mathrm{m}$. AI Graphiolites sabaleos Fritel 1910, Bar $=5 \mu \mathrm{m}$.

Original Diagnosis: Oval to elongate, aseptate, bilateral, psilate fungal spores bearing an elongate scar, slit or furrow. At the level of transmitted light microscopy, at least one species is faintly sculptured. The elongate furrow is parallel to the axis and can be of various lengths. Apices rounded to pointed; usually of similar shape but some species have an attachment scar at one end; apices can also be thickened or otherwise modified. The spore wall in most specimens is generally rigid (Elsik 1990a).

Classification: Fungi Imperfecti, Amerosporae.

Number of species known: 55 [but we accept only 53 species as legitimate because $H$. elongatus (Rouse) Elsik 1990a has been transferred to Inapertisporites Hammen 1954, and $H$. elongatus Sal.-Cheb. \& Locq. 1980 (nom. inval.) is considered to be a later taxonomic synonym of Hypoxylonites africanus Sal.-Cheb. \& Locq. ex Kalgutkar \& Janson. 2000]).

Notes: Hypoxylonites Elsik 1990a is characterized by one elongate scar or furrow which is straight and parallel to the long axis of the spore. The Hypoxylonites morphotype is possibly produced by many living fungi; most are in Xylariaceae (Ascomycota). The spore type is also produced by a few hyphomycetes. Elsik (1990a) cited a number of papers giving further details on possible affinities, and comparisons with similar spores produced by extant fungal species (Kalgutkar \& Jansonius 2000). Salard-Cheboldaeff \& Locquin (1980) assigned three species (viz. $H$. ellipsoideus, $H$. elongatus and $H$. xylarioides) to the generic name "Hypoxylonites", but did not provide a diagnosis for this genus. Thus, the generic name was not validly published in SalardCheboldaeff \& Locquin 1980, and neither were the species then assigned to it. Kumar (1990) proposed Hypoxylonsporites (Type: H. miocenicus) with the following diagnosis "Fungal spores unicellular, oval to ellipsoidal in shape with acutely rounded ends. A longitudinal slit like aperture may be running end to end. Spore wall single layered, smooth and may be differentially coloured." Hypoxylonites Elsik (March 1990) and Hypoxylonsporites Kumar (May 1990) are identical in all essential characters and therefore the latter is a later taxonomic synonym of Hypoxylonites. The above observation was made by Saxena (1992) who transferred the species described under Hypoxylonsporites Kumar to Hypoxylonites Elsik. Both of these genera have affinity with the 
extant Hypoxylon of the family Xylariaceae. The genus is named after its resemblance to the ascospores of extant Hypoxylon (Bull.) Fries.

1.20.1. Species: H. africanus Sal.-Cheb. ex Kalgutkar \& Janson. 2000; Index Fungorum Registration Identifier: 483399; Basionym: Hypoxylonites elongatus Sal.-Cheb. \& Locq. 1980 (nom. inval.); Location: Coast of Equatorial Africa, Gulf of Guinea, Cameroon, Africa; Age: Late Eocene-Oligocene-Early Miocene.

1.20.2. Species: H. armentroutii Elsik 1990a; Index Fungorum Registration Identifier: 130348; Location: The Green River Section, Washington, U.S.A.; Age: Late Eocene; Notes: The species epithet is in honour of John M. Armentrout, Mobil Technology Company, Dallas, Texas, U.S.A.

1.20.3. Species: H. asymetricus (Sal.-Cheb. \& Locq.) Elsik 1990a; Index Fungorum Registration Identifier: 130342; Basionym: Inapertisporites asymetricus Sal.-Cheb. \& Locq. 1980; Location: Coast of Equatorial Africa, Gulf of Guinea, Cameroon, Africa; Age: Early EoceneEarly Miocene (Salard-Cheboldaeff \& Locquin 1980); Early Eocene (Elsik 1990a); Notes: Salard-Cheboldaeff \& Locquin (1980) assigned its affinity with Ascomycota. Elsik (1990a) published an emended description, as follows: "Aseptate, psilate fungal spores ca. $12 \times 24$ $\mu \mathrm{m}$ overall. Outline reniform in side view, one side less convex and almost straight. Outline elliptical in top view, ends narrowly rounded. Spore wall ca. $0.5 \mu \mathrm{m}$ at the ends of the spore, ca. $0.5-1.0 \mu \mathrm{m}$ elsewhere except perhaps along the straighter side. The originally described spore wall of two layers is an expression of the overlapping edges of the furrow, which traverses most of the length of the more convex side of the spore".

1.20.4. Species: H. ater (P. Kumar) R.K. Saxena 1992 (Fig. 6B); Index Fungorum Registration Identifier: 483400; Basionym: Hypoxylonsporites ater P. Kumar 1990; Synonym: Hypoxylonites ater (P. Kumar) Kalgutkar \& Janson. 2000 fide Saxena \& Tripathi 2011; Location: Padappakkara, Kollam District, Kerala, India; Age: Early-Middle (Quilon Beds).

1.20.5. Species: H. bhubanensis Nandi \& Subhra Banerjee in R.K. Saxena 2012 (Fig. 6C); Index Fungorum Registration Identifier: 519748; Basionym: Hypoxylonites bhubanensis Nandi \& Subhra Banerjee in Nandi et al. 2003; Location: Renkte Kawn-Sherlui Road, Mizoram, India; Age: Neogene (Bhuban, Bokabil Tipam and Dupitila formations); Notes: Nandi \& Banerjee in Nandi et al. (2003) did not validly publish Hypoxylonites bhubanensis because they did not mention where the holotype was deposited. Saxena (2012) validated it by providing the missing validating information.

1.20.6. Species: H. brazosensis Elsik 1990a (Fig. 6D); Index Fungorum Registration Identifier: 130349; Location: Brazos County, Texas, U.S.A.; Age: Late Middle Eocene (Yegua Formation); Notes: Elsik (1990a) differentiated this species on the basis of slightly asymmetrical shape and the longitudinal furrow reaching the apices along the more convex side of the spore. The species epithet is derived from Brazos River, Brazos County, Texas.

1.20.7. Species: H. chaiffetzii Elsik 1990a (Fig. 6E); Index Fungorum Registration Identifier: 130350; Location: The Gulf Coast, U.S.A.; Age: Neogene; Notes: The species epithet is in honour of Michael Chaiffetz.

1.20.8. Species: H. chuittensis Elsik 1990a; Index Fungorum Registration Identifier: 130351; Location: Southern Alaska; Age: Neogene; Notes: The species epithet is derived from its occurrence in strata penetrated by the Superior No. 1, Chuitt River, Alaska.

1.20.9. Species: H. claibornensis Elsik 1990a; Index Fungorum Registration Identifier: 130352; Location: Claiborne Group, Henry County, Tennessee, U.S.A.; Age: Middle Eocene; Notes: The species epithet is derived from its occurrence in Claiborne Group.

1.20.10. Species: H. curvatus (Ramanujam \& K.P. Rao) Elsik 1990a (Fig. 6F); Index Fungorum Registration Identifier: 130343; Basionym: Diporisporites curvatus Ramanujam \& K.P. Rao 1978; Location: Alleppey, Alappuzha District, Kerala, India; Age: Miocene (Quilon and Warkalli beds). 
1.20.11. Species: H. disciformis (Sheffy \& Dilcher) R.K. Saxena, Wijayaw., D.Q. Dai, K.D. Hyde \& P.M. Kirk comb. nov. (Fig. 6G). This new combination is described under the section "New species and new combinations".

1.20.12. Species: H. edigeri Elsik 1990a; Index Fungorum Registration Identifier: 130353; Location: Turkey; Age: Late Eocene or Oligocene; Notes: The species epithet is in honour of V.S. Ediger. Turkish Petroleum Corporation, Research Center, Ankara, Turkey.

1.20.13. Species: H. ellipsoideus Sal.-Cheb. \& Locq. ex Kalgutkar \& Janson. 2000; Index Fungorum Registration Identifier: 108077; Location: Coast of Equatorial Africa, Gulf of Guinea, Cameroon, Africa; Age: Late Eocene-Oligocene-Early Miocene; Notes: SalardCheboldaeff \& Locquin (1980) assigned affinity of this species to Ascomycota.

1.20.14. Species: H. elongatioides Elsik 1990a; Index Fungorum Registration Identifier: 130354; Location: Tennessee, U.S.A.; Age: Middle Eocene; Notes: The species epithet is derived from its similarity to Hypoxylonites elongatus (Rouse) Kalgutkar \& Janson. 2000.

1.20.15. Species: H. elongatus (Rouse) Elsik 1990a; Index Fungorum Registration Identifier: 130344; Current name: Inapertisporites elongatus Rouse 1962 fide Kalgutkar \& Jansonius (2000).

1.20.16. Species: H. elongatus Sal.-Cheb. \& Locq. 1980 (nom. inval.) fide Kalgutkar \& Jansonius (2000); Index Fungorum Registration Identifier: 107682; Current name: Hypoxylonites africanus Sal.-Cheb. \& Locq. ex Kalgutkar \& Janson. 2000 fide Kalgutkar \& Jansonius (2000).

1.20.17. Species: H. elsikii Nandi \& Shubhra Banerjee in R.K. Saxena 2012 (Fig. 6H); Index Fungorum Registration Identifier: 519749; Synonym: Hypoxylonites elsikii Nandi \& Shubhra Banerjee in Nandi et al. 2003; Location: Renkte Kawn-Sherlui Road, Mizoram, India; Age: Tertiary (Siju, Kherapara, Bhuban, Bokabil and Dihing formations).

1.20.18. Species: H. eocenicus Elsik 1990a (Fig. 6I); Index Fungorum Registration Identifier: 130355; Location: The Green River Section, Washington, U.S.A.; Age: Late Eocene; Notes: The species epithet is after its occurrence in Eocene strata.

1.20.19. Species: H. eopleistocenicus Elsik 1990a; Index Fungorum Registration Identifier: 130356; Location: The Gulf Coast, U.S.A.; Age: Late Miocene; Notes: The species epithet is derived from its similarity to Hypoxylonites pleistocenicus.

1.20.20. Species: H. felixii Elsik 1990a (Fig. 6J); Index Fungorum Registration Identifier: 130357; Location: Mid Creek Section, Bristol Bay, Alaska; Age: Miocene; Notes: The species epithet is in memory of Johannes Felix.

1.20.21. Species: H. foldexinus Elsik 1990a; Index Fungorum Registration Identifier: 130358; Location: The Gulf Coast, U.S.A.; Age: Neogene; Notes: The species epithet is derived from the folds of the spore wall.

1.20.22. Species: H. foyelensis Bianchin., Alej. Martínez \& R.K. Saxena in Alej. Martínez et al. 2016; Index Fungorum Registration Identifier: 812333; Location: Rio Foyel section, Nirihuau Basin, Argentina; Age: Palaeogene (El Foyel Group); Notes: The specific epithet is after the El Foyel Group, from which samples were collected.

1.20.23. Species: H. fusiformis Elsik 1990a (Fig. 6K); Index Fungorum Registration Identifier: 130359; Location: The Gulf Coast, U.S.A.; Age: Neogene; Notes: The specific epithet is after its fusiform outline.

1.20.24. Species: H. gulfensis Elsik 1990a (Fig. 6L); Index Fungorum Registration Identifier: 130360; Location: The Gulf Coast, U.S.A.; Age: Neogene; Notes: The specific epithet is after the Gulf, i.e. Gulf of Mexico.

1.20.25. Species: H. horowitzii Elsik 1990a; Index Fungorum Registration Identifier: 130361; Location: Borehole Ashquelon 2, at the depth of 1685 m; Israel; Age: Neogene; Notes: The specific epithet is in honour of Aharon Horowitz.

1.20.26. Species: H. kumarii Kalgutkar \& Janson. 2000 (Fig. 6M); Index Fungorum Registration Identifier: 483402; Basionym: Hypoxylonsporites miocenicus Kumar 1990; Location: Padappakkara, Kollam District, Kerala, India; Age: Lower-Middle Miocene (Quilon Beds). 
1.20.27. Species: H. lammonsii Elsik 1990a; Index Fungorum Registration Identifier: 130362; Location: The Gulf Coast, U.S.A.; Age: Neogene; Notes: The specific epithet is in honour of J.M. Lammons.

1.20.28. Species: H. lanceolatus (Debi Mukh.) R.K. Saxena, Wijayaw., D.Q. Dai, K.D. Hyde \& P.M. Kirk comb. nov. (Fig. 6N). This new combination is described under the section "New species and new combinations".

1.20.29. Species: H. lineatus Elsik 1990a; Index Fungorum Registration Identifier: 130363; Location: The Gulf Coast, U.S.A.; Age: Neogene; Notes: The specific epithet is after the long straight furrow, i.e. like a line.

1.20.30. Species: H. magnus Elsik 1990a (Fig. 6O); Index Fungorum Registration Identifier: 130364; Location: Socony-Vacuum Borehole no. 2, Isla de Cubagua, Venezuela; Age: Middle Miocene; Notes: The specific epithet is for its large size.

1.20.31. Species: H. megaexinus Elsik 1990a; Index Fungorum Registration Identifier: 130365; Location: The Gulf Coast, U.S.A.; Age: Late Miocene; Notes: The specific epithet is after the relative thickness of the spore wall.

1.20.32. Species: H. minimus Nandi \& Subhra Banerjee in R.K. Saxena 2012 (Fig. 6P); Index Fungorum Registration Identifier: 519750; Basionym: Hypoxylonites minimus Nandi \& Subhra Banerjee in Nandi et al. 2003 (nom. inval.); Location: Renkte Kawn-Sherlui Road, Mizoram, India; Age: Tertiary (Siju, Bhuban, Bokabil, Tipam and Dupitila formations); Notes: The specific epithet indicates small size of spores.

1.20.33. Species: H. minutus Elsik 1990a; Index Fungorum Registration Identifier: 130366; Location: The Gulf Coast, U.S.A.; Age: Late Miocene.

1.20.34. Species: H. miocenicus Elsik 1990a (Fig. 6Q); Index Fungorum Registration Identifier: 130367; Location: The Gulf Coast, U.S.A.; Age: Late Miocene; Notes: The specific epithet indicates its occurrence in the Miocene.

1.20.35. Species: H. neogenicus Nandi \& Subhra Banerjee in R.K. Saxena 2012 (Fig. 6R); Index Fungorum Registration Identifier: 519753; Basionym: Hypoxylonites neogenicus Nandi \& Subhra Banerjee in Nandi et al. 2003; Location: Renkte Kawn-Sherlui Road, Mizoram, India; Age: Neogene (Bhuban, Bokabil, Tipam, Dupitila and Dihing formations).

1.20.36. Species: H. oblongus Elsik 1990a; Index Fungorum Registration Identifier: 130368; Location: The Sespe sand facies offshore California, U.S.A.; Age: Late Eocene; Notes: The specific epithet indicates its oblong shape.

1.20.37. Species: H. ovalis Elsik 1990a (Fig. 6S); Index Fungorum Registration Identifier: 130369; Location: The Green River Section, Washington, U.S.A.; Age: Eocene; Notes: The specific epithet indicates its oval shape.

1.20.38. Species: H. ovaloides Elsik 1990a; Index Fungorum Registration Identifier: 130370; Location: Strata in the Socony-Vacuum Borehole \# 2, Isla de Cubagua, Venezuela Age: Middle Eocene; Notes: The specific epithet indicates its similarity to Hypoxylonites ovalis.

1.20.39. Species: H. pirozynskii Elsik 1990a; Index Fungorum Registration Identifier: 130371; Location: The Gulf Coast, U.S.A.; Age: Neogene Notes: The specific epithet is in honour of Kris A. Pirozynski.

1.20.40. Species: H.pirozynskioides Elsik 1990a; Index Fungorum Registration Identifier: 130372; Location: Claiborne Group of Henry County, Tennessee, U.S.A., Also reworked into Neogene sediments offshore Louisiana, U.S.A.; Age: Middle Eocene; Notes: The specific epithet indicates its similarity to Hypoxylonites pirozynskii.

1.20.41. Species: H. pleistocenicus Elsik 1990a; Index Fungorum Registration Identifier: 130373; Location: Beaumont Clay, Harris County, Texas, U.S.A.; Age: Late Pleistocene; Notes: The specific epithet indicates its occurrence in Pleistocene sediments.

1.20.42. Species: H. pulvinatus (Sheffy \& Dilcher) Elsik 1990a; Index Fungorum Registration Identifier: 130345; Basionym: Inapertisporites pulvinatus Sheffy \& Dilcher 1971; Location: Puryear clay pit, $800 \mathrm{~m}$ south of Puryear, Henry County, Tennessee, U.S.A.(Sheffy \& Dilcher 1971); Northern Thrace Basin, Turkey (Ediger \& Alisan 1989); Age: Middle Eocene 
(Claiborne Formation) (Sheffy \& Dilcher 1971); Middle?-Late Eocene to Late Oligocene, Miocene-Pliocene (Ediger \& Alisan 1989); Notes: The diagnosis of this species was emended by Ediger \& Alisan (1989) and Elsik (1990a).

1.20.43. Species: H. ramanujamii Elsik 1990a; Index Fungorum Registration Identifier: 130374; Location: Possibly reworked in the Gulf Coast, U.S.A.; Green River section, Washington, U.S.A.; Age: Neogene of the Gulf Coast, U.S.A.; Late Eocene of the Green River section, U.S.A.; Notes: The specific epithet is in honour of C.G.K. Ramanujam, Department of Botany, University College of Science, Saifabad, Osmania University, Hyderabad, India

1.20.44. Species: H. subrotundus Nandi \& Subhra Banerjee in R.K. Saxena 2012 (Fig. 6T); Index Fungorum Registration Identifier: 519752; Basionym: Hypoxylonites subrotundus Nandi \& Subhra Banerjee in Nandi et al. 2003; Location: Renkte Kawn-Sherlui Road, Mizoram, India; Age: Tertiary (Siju, Bhuban, Bokabil, Tipam and Dupitila formations).

1.20.45. Species: H. subuliformis Elsik 1990a (Fig. 6U); Index Fungorum Registration Identifier: 130375; Location: Strata in the Socony-Vacuum Borehole No. 2, Isla de Cubagua, Venezuela; Age: Miocene; Notes: The specific epithet is after Latin subula = awl; and forma $=$ shape.

1.20.46. Species: H. sulekii Elsik 1990a (Fig. 6V); Index Fungorum Registration Identifier: 130376; Location: Socony-Vacuum Borehole no. 2, Isla de Cubagua, Venezuela; the Gulf Coast, U.S.A., The Pacific Coast, U.S.A.; Age: Middle Miocene strata in Venezuela; Neogene of the Gulf Coast, U.S.A.; Neogene of the Pacific Coast, from northern California to offshore Baja California, U.S.A.; Notes: The specific epithet is in honour of John A. Sulek.

1.20.47. Species: H. tennesseensis Elsik 1990a; Index Fungorum Registration Identifier: 130377; Location: The Gulf Coast and the Mississipi Embayment, U.S.A.; Age: Middle Eocene; Notes: The specific epithet indicates its occurrence in Tennessee.

1.20.48. Species: H. thindii Nandi \& A. Sinha in R.K. Saxena 2012 (Fig. 6W); Index Fungorum Registration Identifier: 519751; Basionym: Hypoxylonites thindii Nandi \& A. Sinha in Nandi et al. 2003; Location: Renkte Kawn-Sherlui Road, Mizoram, India; Age: Tertiary (Siju, Kherapara, Bhuban, Bokabil, Tipam, Dupitila and Dihing formations).

1.20.49. Species: H. truncatus Elsik 1990a; Index Fungorum Registration Identifier: 130378; Location: The Gulf Coast, U.S.A.; Age: Neogene; Notes: The specific epithet indicates its truncated outline.

1.20.50. Species: H. vicksburgensis Elsik 1990a; Index Fungorum Registration Identifier: 130379; Location: South Texas, U.S.A.; Age: Oligocene (Vicksburg Group); Notes: The specific epithet indicates its occurrence in the Vicksburg Group.

1.20.51. Species: H. vittatoides Elsik 1990a (Fig. 6X); Index Fungorum Registration Identifier: 130380; Location: Imperial Nuktak C-22 well, Mackenzie River delta, Mackenzie District, Northwest Territories, Canada; Age: Eocene; Notes: The holotype is Inapertisporites sp. cf. I. vittatus Sheffy \& Dilcher 1971 in Norris 1986: 18, pl. 1, fig. 1. The specific epithet indicates its resemblance to Hypoxylonites vittatus Sheffy \& Dilcher 1971.

1.20.52. Species: H. vittatus (Sheffy \& Dilcher) Elsik 1990a; Index Fungorum Registration Identifier: 130346; Basionym: Inapertisporites vittatus Sheffy \& Dilcher 1971; Location: Puryear clay pit, $800 \mathrm{~m}$ south of Puryear, Henry County, Tennessee, U.S.A.; Age: Middle Eocene (Claiborne Formation); Notes: Elsik (1990a) published an emended description of this species. The specific name refers to the opaque band formed by one layer of the cell wall.

1.20.53. Species: H. washingtonensis Elsik 1990a; Index Fungorum Registration Identifier: 130381; Location: The Green River section, Washington, U.S.A.; Age: Late Eocene; Notes: The specific epithet indicates its occurrence in Washington.

1.20.54. Species: H. wolfei Elsik 1990a; Index Fungorum Registration Identifier: 130382; Location: The Green River section, Washington, U.S.A.; Brazos County, Texas, U.S.A.; Age: Late Eocene of the Green River section; earliest Late Eocene of Caddell Formation of Texas, U.S.A.; Notes: The specific epithet is in honour of Jack A. Wolfe. 
1.20.55. Species: H. xylarioides Sal.-Cheb. \& Locq. ex Kalgutkar \& Janson. 2000; Index Fungorum Registration Identifier: 483403; Basionym: Hypoxylonites xylarioides Sal.-Cheb. \& Locq. 1980 (nom. inval.); Location: Coast of Equatorial Africa, Gulf of Guinea, Cameroon, Africa; Age: Late Eocene-Oligocene-Early Miocene; Notes: Salard-Cheboldaeff (1980) assigned its affinity with Ascomycota (Hypoxylon).

1.21. Genus: HYPOXYLONSPORITES P. Kumar, Review of Palaeobotany \& Palynology (Amsterdam) 63(1-2): 18 (1990); Index Fungorum Registration Identifier: 25448, Type: $H$. miocenicus Kumar 1990; Current name: HYPOXYLONITES Elsik 1990a fide Saxena (1992).

Original Diagnosis: Fungal spores unicellular, oval to elliptical in shape with acutely rounded ends. A longitudinal slit-like aperture may be running end to end. Spore wall single-layered, smooth, and may be differentially coloured (Kumar 1990).

Classification: Fungi Imperfecti, Amerosporae.

Number of species known: Two (since Hypoxylonsporites P. Kumar 1990 is a later synonym of Hypoxylonites Elsik 1990a, both the species have been transferred to Hypoxylonites Elsik 1990a).

Notes: Hypoxylonsporites shows close affinity with the extant Hypoxylon and Endocalyx. Similar specimens have been reported earlier from subsurface Tertiary sediments of Cauvery Basin, India (Venkatachala \& Rawat 1973), Neogene sediments of Rusizi Valley, Burundi (Sah 1967), Middle Eocene clay beds in the Lawrence Clay Pit, Henry County, Tennessee, U.S.A. (Elsik \& Dilcher 1974). Elsik (1969) figured similar spores from the Late Neogene deposits in the northern Gulf of Mexico and referred to them as Hypoxylon spp. Elsik's (March 1990) paper has priority over that of Kumar (May 1990), and hence Hypoxylonsporites is a later taxonomic synonym of Hypoxylonites fide Saxena 1992.

1.21.1. Species: H. ater P. Kumar 1990; Index Fungorum Registration Identifier: 126561; Current name: Hypoxylonites ater (P. Kumar) R.K. Saxena 1992 fide Saxena (1992).

1.21.2. Species: H. miocenicus P. Kumar 1990; Index Fungorum Registration Identifier: 126562; Current name: Hypoxylonites kumarii Kalgutkar \& Janson. 2000 fide Kalgutkar \& Jansonius (2000).

1.22. Genus: IMPRIMOSPORA G. Norris, Bull. geol. Suev. Can: 22 (1986); Index Fungorum Registration Identifier: 25449; Type: I. tankensis G. Norris 1986; Current name: PALAEOAMPHISPHAERELLA Ramanujam \& Srisailam 1980 fide Kalgutkar \& Jansonius (2000).

Original Diagnosis: Unicellate, ovoidal, equilateral, isopolar fungal spores with a central region of parallel striae or fissures parallel to the apical line. Pore or furrow present near one end of spore (Norris 1986).

Classification: Fungi Imperfecti, Amerosporae.

Number of species known: Two (both the species have been transferred to other genera).

Notes: Imprimospora is identical to Palaeoamphisphaerella Ramanujam \& Srisailam 1980 in diagnostic and general morphology and therefore is considered to be a later synonym of Palaeoamphisphaerella.

1.22.1. Species: I. ramanujamii P. Kumar 1990; Index Fungorum Registration Identifier: 126563; Current name: Kumarisporites ramanujamii (P. Kumar) Kalgutkar \& Janson. 2000 fide Kalgutkar \& Jansonius (2000).

1.22.2. Species: I. tankensis G. Norris 1986; Index Fungorum Registration Identifier: 126574; Current name: Palaeoamphisphaerella tankensis (G. Norris) Kalgutkar \& Janson. 2000 fide Kalgutkar \& Jansonius (2000).

1.23. Genus: INAPERTISPORITES Hammen, Bol. Geol. (Bogota) 2(1): 83 (1954); Index Fungorum Registration Identifier: 560987; Type: I. variabilis Hammen 1954 (lectotype was designated by Van der Hammen 1955). 
Synonyms: Inapertisporites Rouse 1959 (also a later homonym), Index Fungorum Registration Identifier: 21139; Triporisporonites Sheffy \& Dilcher 1971, Index Fungorum Registration Identifier: 21346.

Original Diagnosis: Fungal spores without performed aperture (Van der Hammen 1954).

Emended Diagnoses: Diagnosis of Inapertisporites was emended by Rouse (1959), Elsik (1968), Sheffy \& Dilcher (1971), Ediger (1981) and Saxena \& Bhattacharyya (1987), as follows: Spores free or grouped, anisopolar and inaperturate. Shape circular, oval or elliptical; outline often uneven because of wrinkles or folds. Ornamentation variable, ranging from laevigate to pseudoreticulate. Size-range 5-100 $\mu \mathrm{m}$ (Rouse 1959); Inaperturate, psilate, fungal spores. One cell, no septa. Shape variable (Elsik 1968); Fungal or algal spores unicellate, nonseptate, and inaperturate. Shape globular or non-globular; outline smooth or often uneven because of wrinkles or folds. Ornamentation variable. Size range 5-11 $\mu \mathrm{m}$ (Sheffy \& Dilcher 1971); Unicellular fungal spores without preformed aperture; shape variable, mostly irregularly rounded; one or more cells usually randomly clustered; exine not too thick, folded or cracked, scabrate or usually pitted (Ediger 1981); Inaperturate algal or fungal spores, unicellate, nonseptate. Shape and size variable, outline smooth or often uneven because of wrinkles or folds. Spore wall ornamentation variable (Saxena \& Bhattacharyya 1987).

Classification: Fungi Imperfecti, Amerosporae.

Number of species known: 71 (but we accept only 60 species as legitimate because eleven species have been transferred to other genera by various authors).

Notes: Rouse (1959) incorrectly considered the generic name Inapertisporites Hammen 1954 as not validly published. He stated that "Although a generic diagnosis and type species were not presented (i.e. by Van der Hammen 1954), the name is considered appropriate for reference to fossil spores that appear to be fungal, algal or possibly bryophytic in affiliation, and is therefore conserved." Actually, Van der Hammen (1954) had validly published the name of this genus with a diagnosis. A type species was not required for valid publication until 1958; Van der Hammen (1955) designated a type species, Inapertisporites variabilis. This is one of three species that Van der Hammen (1954) validly published. Consequently, Rouse (1959) created a later homonym and a taxonomic synonym of Inapertisporites Hammen 1954. Triporisporonites Sheffy \& Dilcher 1971 is a later taxonomic synonym of Inapertisporites. Ediger (1981) considered Microsporonites to be a later synonym and proposed to transfer its type species as "I. cacheutensis" (R.K. Jain) V.S. Ediger 1981. However, he did not validly publish this new combination because he did not provide full and direct reference of the basionym.

1.23.1. Species: I. argentinus (R.K. Jain) Kalgutkar \& Janson. 2000; Index Fungorum Registration Identifier: 483404; Basionym: Reticulatasporites argentinus R.K. Jain 1968; Location: Minas de Petroleo, about $32 \mathrm{~km}$ south-west of Mendoza, western Argentina; Age: Middle Triassic; Notes: Jain (1968) stated that this species is quite distinct from the others in this genus in having the fewest and largest brochi.

1.23.2. Species: I. asymetricus Sal.-Cheb. \& Locq. 1980; Index Fungorum Registration Identifier: 108084; Current name: Hypoxylonites asymetricus (Sal.-Cheb. \& Locq.) Elsik 1990a fide Elsik (1990a).

1.23.3. Species: I. cacheutensis (R.K. Jain) Kalgutkar \& Janson. 2000; Index Fungorum Registration Identifier: 483405; Basionym: Reticulatasporites cacheutensis R.K. Jain 1968; Location: Minas de Petroleo, about $32 \mathrm{~km}$ south-west of Mendoza, western Argentina; Age: Middle Triassic; Notes: Reticulatasporites cacheutensis broadly resembles other species of Reticulatasporites described earlier from various Permo-Carboniferous strata. However, it differs from them in having larger brochi with broader muri.

1.23.4. Species: I. cephalus Anil Chandra et al. 1984 (Fig. 6Y); Index Fungorum Registration Identifier: 106915; Location: Sediment core no. 1 (Lat. 1757.9'N: Long. 70 $46.0^{\prime} \mathrm{E}$ ), Arabian Sea; Age: Late Quaternary; Notes: The species epithet in the original publication is spelled as "cephalu" which has been corrected here. 
1.23.5. Species: I. chandrae R.K. Saxena \& S.K.M. Tripathi 2011 (Fig. 6Z); Index Fungorum Registration Identifier: 519898; Location: Sediment core no. 4 (Lat. $21^{\circ} 10.0^{\prime} \mathrm{N}$ : Long. 70²6.9'E), Arabian Sea; Age: Late Quaternary; Notes: The species epithet is in honour of Dr. Anil Chandra, Birbal Sahni Institute of Palaeosciences, Lucknow, India.

1.23.6. Species: I. circularis Sheffy \& Dilcher 1971 (Fig. 6AA); Index Fungorum Registration Identifier: 111543; Location: Puryear clay pit, Tennessee, Henry County, Texas, U.S.A.; Age: Middle Eocene (Claiborne Formation); Notes: The species epithet indicates its circular shape.

1.23.7. Species: I. clarkei Kalgutkar \& Janson. 2000; Index Fungorum Registration Identifier: 483406; Basionym: Monoporisporites globosus R.T. Clarke 1965; Location: Canon City coal field, Fremont County, Colorado, U.S.A.; Age: Late Cretaceous; Notes: The species epithet is in honour of Professor Robert T. Clarke.

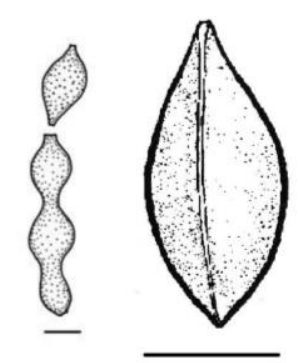

B
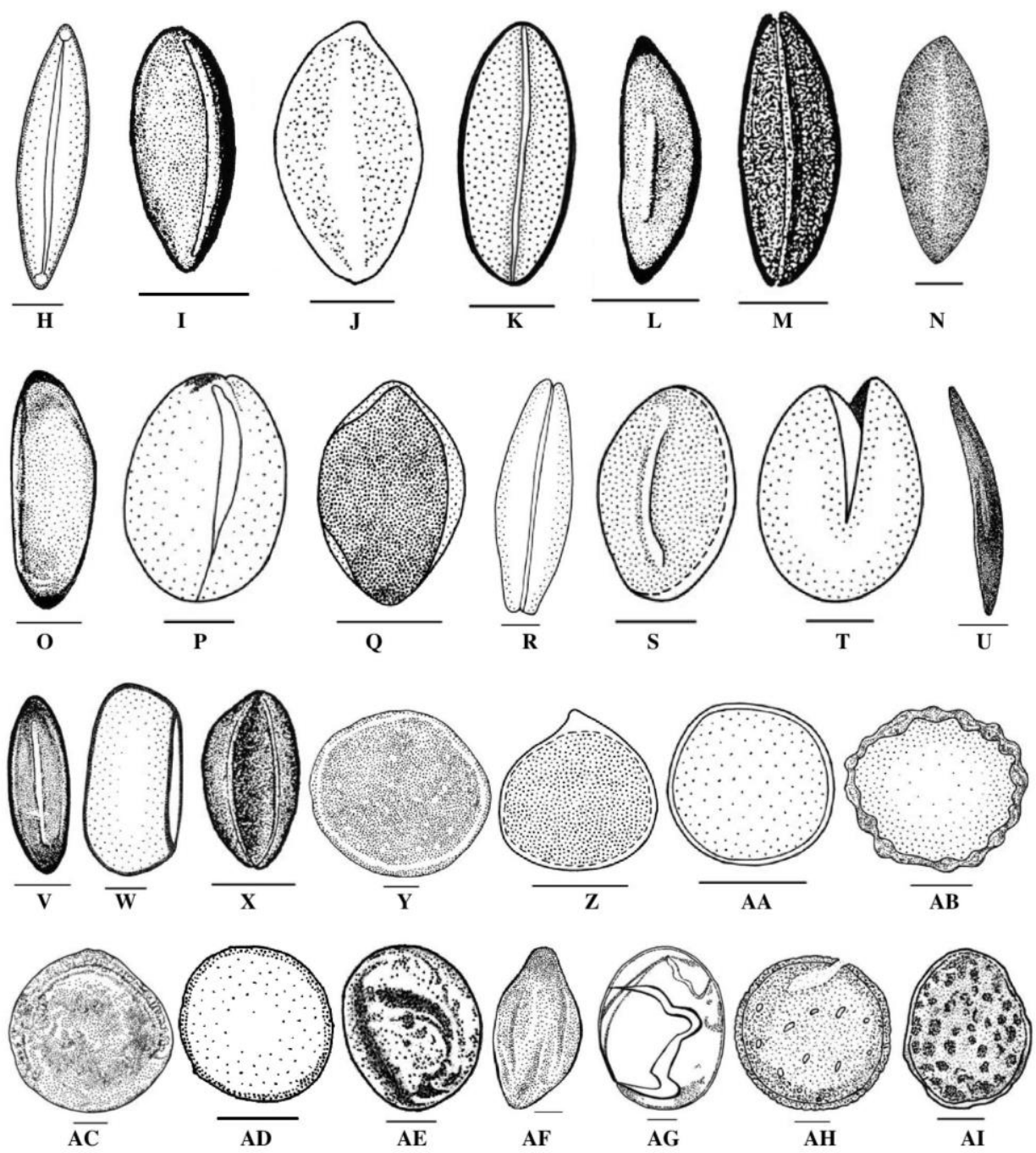

Figure 6 - A-AI Amerosporae. A Haplographites cateniger Félix 1894, Bar $=8 \mu \mathrm{m}$. B Hypoxylonites ater (P. Kumar) R.K. Saxena 1992, Bar $=10 \mu \mathrm{m}$. C Hypoxylonites bhubanensis 
Nandi \& Subhra Banerjee 2012, Bar $=5 \mu \mathrm{m}$. D Hypoxylonites brazosensis Elsik 1990a, Bar $=10$ $\mu \mathrm{m}$. E Hypoxylonites chaiffetzii Elsik 1990a, Bar $=10 \mu \mathrm{m}$. F Hypoxylonites curvatus (Ramanujam \& K.P. Rao) Elsik 1990a, Bar $=5 \mu \mathrm{m}$. G Hypoxylonites disciformis (Sheffy \& Dilcher) R.K. Saxena, Wijayaw., D.Q. Dai, K.D. Hyde \& P.M. Kirk comb. nov., Bar $=5 \mu \mathrm{m}$. H Hypoxylonites elsikii Nandi \& Shubhra Banerjee 2012, Bar $=5 \mu \mathrm{m}$. I Hypoxylonites eocenicus Elsik 1990a, Bar $=$ $10 \mu \mathrm{m}$. J Hypoxylonites felixii Elsik 1990a, Bar $=5 \mu \mathrm{m}$. K Hypoxylonites fusiformis Elsik 1990a, Bar $=5 \mu \mathrm{m}$. L Hypoxylonites gulfensis Elsik 1990a, Bar $=10 \mu \mathrm{m}$. M Hypoxylonites kumarii Kalgutkar \& Janson. 2000, Bar $=10 \mu \mathrm{m}$. N Hypoxylonites lanceolatus (Debi Mukh.) R.K. Saxena, Wijayaw., D.Q. Dai, K.D. Hyde \& P.M. Kirk comb. nov., Bar $=20 \mu \mathrm{m}$. O Hypoxylonites magnus Elsik 1990a, Bar $=10 \mu \mathrm{m}$. P Hypoxylonites minimus Nandi \& Subhra Banerjee 2012, Bar $=3 \mu \mathrm{m}$. $\mathrm{Q}$ Hypoxylonites miocenicus Elsik 1990a, Bar $=10 \mu \mathrm{m}$. R Hypoxylonites neogenicus Nandi \& Subhra Banerjee 2012, Bar $=5 \mu \mathrm{m}$. S Hypoxylonites ovalis Elsik 1990a, Bar $=5 \mu \mathrm{m} . \mathrm{T}$ Hypoxylonites subrotundus Nandi \& Subhra Banerjee 2012, Bar $=5 \mu \mathrm{m}$. U Hypoxylonites subuliformis Elsik 1990a, Bar $=10 \mu \mathrm{m}$. V Hypoxylonites sulekii Elsik 1990a, Bar $=10 \mu \mathrm{m} . \mathrm{W}$ Hypoxylonites thindii Nandi \& A. Sinha 2012, Bar $=5 \mu \mathrm{m}$. X Hypoxylonites vittatoides Elsik 1990a, Bar $=10 \mu \mathrm{m}$. Y Inapertisporites cephalus Anil Chandra et al. 1984, Bar $=10 \mu \mathrm{m} . \mathrm{Z}$ Inapertisporites chandrae R.K. Saxena \& S.K.M. Tripathi 2011, Bar $=5 \mu \mathrm{m}$. AA Inapertisporites circularis Sheffy \& Dilcher 1971, Bar $=7 \mu \mathrm{m}$. AB Inapertisporites crenulatus P. Kumar 1990, Bar $=10 \mu \mathrm{m}$. AC Inapertisporites cystoides Ambwani 1982, Bar $=10 \mu \mathrm{m}$. AD Inapertisporites deccanii (Chitaley \& Yawale) Kalgutkar \& Janson. 2000, Bar $=10 \mu \mathrm{m}$. AE Inapertisporites edigeri Kalgutkar \& Janson. 2000, Bar $=10 \mu \mathrm{m}$. AF Inapertisporites ellipticus Anil Chandra et al. 1984, $\mathrm{Bar}=20 \mu \mathrm{m}$. AG Inapertisporites giganteus Z.C. Song 1985, Bar $=10 \mu \mathrm{m}$. AH Inapertisporites globatus S.C.D. Sah \& R.K. Kar 1974, Bar $=10 \mu \mathrm{m}$. AI Inapertisporites granulosus Anil Chandra et al. 1984 , $\mathrm{Bar}=10 \mu \mathrm{m}$.

1.23.8. Species: I. communis Z.C. Song \& G.X. Li in Z.C. Song et al. 1989; Index Fungorum Registration Identifier: 637477; Location: Qingfeng county of Henan Province, China; Age: Late Eocene-Middle Oligocene (Shahejie Formation).

1.23.9. Species: I. conicus Z.C. Song \& G.X. Li in Z.C. Song et al. 1989; Index Fungorum Registration Identifier: 637478; Location: Qingfeng county of Henan Province, China; Age: Late Oligocene (Dongying Formation); Notes: This species can be distinguished from other species of Inapertisporites by its pointed protuberant end. The species epithet is after conical protuberance at one end of the spore.

1.23.10. Species: I. crenulatus P. Kumar 1990 (Fig. 6AB); Index Fungorum Registration Identifier: 126564; Location: Padappakkara, Kollam District, Kerala, India; Age: Early-Middle Miocene (Quilon Beds); Notes: Kumar (1990) stated that this species is comparable with fungal spores described as Geastrum-type (Jarzen \& Elsik 1986) from Recent sediments of Luangwa Valley, Zambia. The species epithet is after crenulated margin of the spore.

1.23.11. Species: I. cystoides Ambwani 1982 (Fig. 6AC); Index Fungorum Registration Identifier: 483900; Location: Kotta-Bommuru, near Rajamahendravaram, East Godavari District, Andhra Pradesh, India; Age: Early Eocene (Deccan Intertrappean Series).

1.23.12. Species: I. deccanii (Chitaley \& Yawale) Kalgutkar \& Janson. 2000 (Fig. 6AD); Index Fungorum Registration Identifier: 483407; Basionym: Ustilago deccanii Chitaley \& Yawale 1978; Location: Mohgaon Kalan, Chhindwara District, Madhya Pradesh, India; Age: Late Cretaceous, Maastrichtian (Deccan Intertrappean Series); Notes: Chitaley \& Yawale (1978) opined that the characters present in these spores lead to their placement under the smut family Ustilaginaceae. Comparison was made with Ustilago (Pers.) Roussel and Sphacelotheca de Bary because of some resemblances with them (Chitaley \& Yawale 1978). Kalgutkar \& Jansonius (2000) transferred this species to Inapertisporites, because they thought that, in a dispersed condition, individual spores could not possibly be associated with the smut fungi. 
1.23.13. Species: I. dilcheri Anil Chandra et al. 1984; Index Fungorum Registration Identifier: 106916; Current name: Diporicellaesporites dilcheri (Anil Chandra et al.) Kalgutkar \& Janson. 2000 fide Kalgutkar \& Jansonius (2000); Notes: The species epithet is in honour of Professor David L. Dilcher, Department of Botany, Indiana University, Bloomington, Indiana, U.S.A.

1.23.14. Species: I. disciformis Sheffy \& Dilcher 1971; Index Fungorum Registration Identifier: 111544; Current name: Hypoxylonites disciformis (Sheffy \& Dilcher) R.K. Saxena, Wijayaw., D.Q. Dai, K.D. Hyde \& P.M. Kirk comb. nov. This new combination is described under the section "New species and new combinations"

1.23.15. Species: I. edigeri Kalgutkar \& Janson. 2000 (Fig. 6AE); Index Fungorum Registration Identifier: 483408; Basionym: Inapertisporites rotundus V.S. Ediger 1981; Location: Thrace Basin, Turkey (Ediger 1981); Northern Thrace Basin, Turkey (Ediger \& Alisan 1989); Age: Late Eocene-Oligocene, Miocene-Pliocene (Ediger 1981); Middle?-Late Eocene to Late Oligocene, Miocene-Pliocene (Ediger \& Alisan 1989); Notes: Inapertisporites edigeri Kalgutkar \& Janson. 2000 is a replacement name of Inapertisporites rotundus V.S. Ediger 1981.

1.23.16. Species: I. elencantense Sepúlveda 1980; Index Fungorum Registration Identifier: 483916; Current name: Monoporisporites elencantensis (Sepúlveda) Kalgutkar \& Janson. 2000 fide Kalgutkar \& Jansonius (2000).

1.23.17. Species: I. ellipticus Anil Chandra et al. 1984 (Fig. 6AF); Index Fungorum Registration Identifier: 106917; Location: Sediment core no. 1 (Lat. 1757.9'N: Long. 70²6.0'E), Arabian Sea; Age: Late Quaternary.

1.23.18. Species: I. elongatus Rouse 1959; Index Fungorum Registration Identifier: 109864; Synonym: Hypoxylonites elongatus (Rouse) Elsik 1990a fide Kalgutkar \& Jansonius (2000); Location: Terminal Dock, British Columbia, Canada; Age: Late Cretaceous \& Middle Eocene (Burrard Formation).

1.23.19. Species: I. giganteus Z.C. Song 1985 (Fig. 6AG); Index Fungorum Registration Identifier: 519814; Location: Dafengshan, Qaidam Basin, Qinghai Province, China; Age: Middle-Late Miocene.

1.23.20. Species: I. globatus S.C.D. Sah \& R.K. Kar 1974 (Fig. 6AH); Index Fungorum Registration Identifier: 519813; Location: Palana, Bikaner District, Rajasthan, India; Age: Early Eocene (Palana lignite).

1.23.21. Species: I. globosus Sal.-Cheb. \& Locq. 1980; Index Fungorum Registration Identifier: 108086; Location: Coast of Equatorial Africa, Gulf of Guinea, Cameroon, Africa; Age: Early Eocene-Early Miocene.

1.23.22. Species: I. globulosus Rouse 1962; Index Fungorum Registration Identifier: 110211; Current name: Monoporisporites globulosus (Rouse) Kalgutkar \& Janson. 2000 fide Kalgutkar \& Jansonius (2000).

1.23.23. Species: I. granulatus P. Ke \& Z.Y. Shi 1978; Index Fungorum Registration Identifier: 115663; Location: Panshan, Liaoning Province; Kenli, Shandong Province, Coastal region of Bohai, China; Age: Eocene-Oligocene.

1.23.24. Species: I. granulosus Anil Chandra et al. 1984 (Fig. 6AI); Index Fungorum Registration Identifier: 106918; Location: Sediment core no. 5 (Lat. $24^{\circ} 04.5^{\prime} \mathrm{N}$ : Long. 69 $26.0^{\prime} \mathrm{E}$ ), Arabian Sea; Age: Late Quaternary.

1.23.25. Species: I. hammenii Anil Chandra et al. 1984 (Fig. 7A); Index Fungorum Registration Identifier: 106919; Location: Sediment core no. 4 (Lat. $21^{\circ} 10.0^{\prime} \mathrm{N}$ : Long. $70^{\circ} 26.9^{\prime} \mathrm{E}$ ), Arabian Sea; Age: Late Quaternary; Notes: The species epithet is in honour of Dr. T. Van der Hammen, who made commendable contributions to Tertiary palynology.

1.23.26. Species: I. ibrahimii V.S. Ediger \& Alisan 1989; Index Fungorum Registration Identifier: 125506; Location: Northern Thrace Basin, Turkey; Age: Middle?-Late Eocene to Late Oligocene, Miocene-Pliocene; Notes: The species epithet is in honour of Professor Ahmet Can Ibrahim. 
1.23.27. Species: I. indicus A. Gupta 2002 (Fig. 7B); Index Fungorum Registration Identifier: 540593; Location: Dadahu Road Section (left bank of Giri River), Sirmaur District, Himachal Pradesh, India; Age: Early Eocene (Subathu Formation).

1.23.28. Species: I. irregularis Sheffy \& Dilcher 1971; Index Fungorum Registration Identifier: 111545; Location: Puryear clay pit, $800 \mathrm{~m}$ south of Puryear, Henry County, Tennessee, U.S.A.; Age: Middle Eocene (Claiborne Formation).

1.23.29. Species: I. karii R.K. Saxena \& S.K.M. Tripathi 2011 (Fig. 7C); Index Fungorum Registration Identifier: 519943; Location: Sediment core no. 1 (Lat. 1757.9'N: Long. 7046.0'E), Arabian Sea; Age: Late Quaternary; Notes: The species epithet honours Dr. R.K. Kar, Birbal Sahni Institute of Palaeosciences, Lucknow, India.

1.23.30. Species: I. kedvesii Elsik 1968 (Fig. 7D); Index Fungorum Registration Identifier: 315797; Location: Strip mine $11 \mathrm{~km}$ south-west of Rockdale, Milam County, Texas, U.S.A.; Age: Palaeocene (Rockdale lignite).

1.23.31. Species: I. laevigatus Rouse 1959; Index Fungorum Registration Identifier: 106195; Location: South-eastern British Columbia, Canada; Age: Early Cretaceous (Kootenay Formation).

1.23.32. Species: I. longissimus Sheffy \& Dilcher 1971; Index Fungorum Registration Identifier: 111546; Location: Puryear clay pit, $800 \mathrm{~m}$ south of Puryear, Henry County, Tennessee, U.S.A.; Age: Middle Eocene (Claiborne Formation).

1.23.33. Species: I. major P. Ke \& Z.Y. Shi 1978; Index Fungorum Registration Identifier: 115676; Location: Kenli, Shandong Province, Coastal region of Bohai, China; Age: EoceneOligocene.

1.23.34. Species: I. maximus H.P. Singh \& R.K. Saxena 1981 (Fig. 7E); Index Fungorum Registration Identifier: 483889; Location: Gagret-Bharwain Road Section, Una District, Himachal Pradesh, India; Age: Pliocene-Pleistocene (Upper Siwalik).

1.23.35. Species: I. minutus Hammen 1954 (Fig. 7F); Index Fungorum Registration Identifier: 332523; Location: Magdalena Valley, Eastern Cordellera, Colombia, South America; Age: Maastrichtian.

1.23.36. Species: I. miocenicus H.P. Singh et al. 1986; Index Fungorum Registration Identifier: 131932; Current name: Quilonia miocenica (H.P. Singh et al.) Kalgutkar \& Janson. 2000 fide Kalgutkar \& Jansonius (2000).

1.23.37. Species: I. multiporus J.T.F. Guim. et al. 2013; Index Fungorum Registration Identifier: 637479; Location: BOP2 outcrop, central and coastal Amazon Region, North Brazil; Age: Miocene (Barreiras Formation); Notes: Guimarães et al. (2013) stated taxonomic affinity of this species with Ustilago (Ustilaginaceae). The so called pores on the spore wall are likely to be fungal scars, comparable to Fungal Scar Type 1 of Elsik (1968: 266, pl. 1, figs. 1-4). The species epithet indicates numbers of pores along the spore body.

1.23.38. Species: I. nodulus Sheffy \& Dilcher 1971; Index Fungorum Registration Identifier: 111547; Location: Puryear clay pit, $800 \mathrm{~m}$ south of Puryear, Henry County, Tennessee, U.S.A.; Age: Middle Eocene (Claiborne Formation).

1.23.39. Species: I. novus A. Gupta 2002 (Fig. 7G); Index Fungorum Registration Identifier: 540594; Location: Jamtah Road Section, Sirmaur District, Himachal Pradesh, India; Age: Early Eocene (Subathu Formation).

1.23.40. Species: I. obpyriformis Sheffy \& Dilcher 1971; Index Fungorum Registration Identifier: 111549; Location: Puryear clay pit, $800 \mathrm{~m}$ south of Puryear, Henry County, Tennessee, U.S.A.; Age: Middle Eocene (Claiborne Formation).

1.23.41. Species: I. obscurus Sheffy \& Dilcher 1971; Index Fungorum Registration Identifier: 111550; Location: Puryear clay pit, $800 \mathrm{~m}$ south of Puryear, Henry County, Tennessee, U.S.A.; Age: Middle Eocene (Claiborne Formation).

1.23.42. Species: I. ovalis Sheffy \& Dilcher 1971 (Fig. 7H); Index Fungorum Registration Identifier: 111548; Location: Puryear clay pit, Tennessee, Henry County, U.S.A.; Age: Middle Eocene (Claiborne Formation). 
1.23.43. Species: I. pisciculatus (G. Norris) Kalgutkar \& Janson. 2000; Index Fungorum Registration Identifier: 483409; Basionym: Diporisporites pisciculatus G. Norris 1997; Location: Mackenzie River delta, Canada; Age: Palaeocene-Eocene.

1.23.44. Species: I. plicatus Z.C. Song 1985; Index Fungorum Registration Identifier: 637480; Location: Dafengshan, Qaidam Basin, Qinghai Province, China; Age: Middle-Late Miocene.

1.23.45. Species: I. pseudoreticulatus Rouse 1959; Index Fungorum Registration Identifier: 106196; Location: South-eastern British Columbia, Canada; Age: Early Cretaceous (Kootenay Formation).

1.23.46. Species: I. pulvinatus Sheffy \& Dilcher 1971; Index Fungorum Registration Identifier: 111551; Current name: Hypoxylonites pulvinatus (Sheffy \& Dilcher) Elsik 1990a fide Elsik (1990a).

1.23.47. Species: I. punctatus Rouse 1959; Index Fungorum Registration Identifier: 106197; Location: South-eastern British Columbia, Canada; Age: Early Cretaceous (Kootenay Formation).

1.23.48. Species: I. punctatus Anil Chandra et al. 1984; Index Fungorum Registration Identifier: 106569; Current name: Inapertisporites udarii A. Gupta 1985 fide Gupta (1985).

1.23.49. Species: I. quadrangularis Anil Chandra et al. 1984 (Fig. 7I); Index Fungorum Registration Identifier: 106920; Location: Sediment core no. 4 (Lat. $21^{\circ} 10.0^{\prime} \mathrm{N}$ : Long. 70²6.9'E), Arabian Sea; Age: Late Quaternary.

1.23.50. Species: I. reniformis Sheffy \& Dilcher 1971; Index Fungorum Registration Identifier: 111552; Location: Puryear clay pit, $800 \mathrm{~m}$ south of Puryear, Henry County, Tennessee, U.S.A.; Age: Middle Eocene (Claiborne Formation).

1.23.51. Species: I. reticulatus Sheffy \& Dilcher 1971; Index Fungorum Registration Identifier: 111553; Location: Puryear clay pit, $800 \mathrm{~m}$ south of Puryear, Henry County, Tennessee, U.S.A.; Age: Middle Eocene (Claiborne Formation).

1.23.52. Species: I. rotundus P. Ke \& Z.Y. Shi 1978; Index Fungorum Registration Identifier: 115675; Location: Lijin and Kenli, Shandong Province, Coastal region of Bohai, China; Age: Eocene-Oligocene.

1.23.53. Species: I. rotundus V.S. Ediger 1981; Index Fungorum Registration Identifier: 108087; Current name: Inapertisporites edigeri Kalgutkar \& Janson. 2000 fide Kalgutkar \& Jansonius (2000).

1.23.54. Species: I. sahii R.K. Saxena \& S.K.M. Tripathi 2011 (Fig. 7J); Index Fungorum Registration Identifier: 519944; Location: Palana, Bikaner District, Rajasthan, India; Age: Early Eocene (Palana lignite); Notes: The species epithet is in honour of Dr. S.C.D. Sah, Wadia Institute of Himalayan Geology, Dehradun, India.

1.23.55. Species: I. sahnii Kalgutkar 1997; Index Fungorum Registration Identifier: 437912; Location: Kanguk Peninsula, Axel Heiberg Island, Northwest Territories, Canada; Age: Late Palaeocene-Early Eocene; Notes: The species epithet is in honour of Professor Birbal Sahni.

1.23.56. Species: I. scabridus Sheffy \& Dilcher 1971; Index Fungorum Registration Identifier: 111554; Location: Puryear clay pit, $800 \mathrm{~m}$ south of Puryear, Henry County, Tennessee, U.S.A.; Age: Middle Eocene (Claiborne Formation).

1.23.57. Species: I. sinhae A. Gupta 2002 (Fig. 7K); Index Fungorum Registration Identifier: 540595; Location: Dadahu Road Section, Sirmaur District, Himachal Pradesh, India; Age: Early Eocene (Subathu Formation); Notes: The species epithet is in honour of Dr. R.K. Kar, Birbal Sahni Institute of Palaeosciences, Lucknow, India.

1.23.58. Species: I. solidus Z.C. Song \& Liu Cao 1994; Index Fungorum Registration Identifier: 483760; Location: King George Island, Antarctica; Age: Late Cretaceous.

1.23.59. Species: I. subcapsularis Sheffy \& Dilcher 1971 (Fig. 7L); Index Fungorum Registration Identifier: 111555; Location: Puryear clay pit, Tennessee, Henry County, U.S.A.; Age: Middle Eocene (Claiborne Formation). 
1.23.60. Species: I. subcurvatus Sheffy \& Dilcher 1971; Index Fungorum Registration Identifier: 111556; Location: Puryear clay pit, $800 \mathrm{~m}$ south of Puryear, Henry County, Tennessee, U.S.A.; Age: Middle Eocene (Claiborne Formation).

1.23.61. Species: I. subovoides Sheffy \& Dilcher 1971 (Fig. 7M); Index Fungorum Registration Identifier: 111557; Location: Puryear clay pit, 800 m south of Puryear, Henry County, Tennessee, U.S.A.; Age: Middle Eocene (Claiborne Formation).

1.23.62. Species: I. subverrucatus A. Gupta 2002 (Fig. 7N); Index Fungorum Registration Identifier: 540596; Location: Jamtah Road Section, Sirmaur District, Himachal Pradesh, India; Age: Early Eocene (Subathu Formation).

1.23.63. Species: I. tetradus Rouse 1962; Index Fungorum Registration Identifier: 109865; Current name: Spegazzinites tetradus (Rouse) Kalgutkar \& Janson. 2000 fide Kalgutkar \& Jansonius (2000).

1.23.64. Species: I. tiwarii A. Gupta 2002 (Fig. 7O); Index Fungorum Registration Identifier: 540597; Location: Dadahu Road Section, Sirmaur District, Himachal Pradesh, India; Age: Early Eocene (Subathu Formation); Notes: The species epithet is in honour of Dr. R.K. Kar, Birbal Sahni Institute of Palaeosciences, Lucknow, India.

1.23.65. Species: I. triporatus Kalgutkar \& Janson. 2000; Index Fungorum Registration Identifier: 483413; Basionym: Triporisporites minutus Hammen 1954; Location: Magdalena Valley, Eastern Cordillera, Colombia, South America; Age: Maastrichtian.

1.23.66. Species: I. trivedii Ambwani 1982 (Fig. 7P); Index Fungorum Registration Identifier: 483899; Location: Kotta-Bommuru, near Rajamahendravaram, East Godavari District, Andhra Pradesh, India; Age: Early Eocene (Deccan Intertrappean Series); Notes: The species epithet is in honour of Professor B.S. Trivedi, Department of Botany, Lucknow University, Lucknow, India.

1.23.67. Species: I. typicus Hammen 1954; Index Fungorum Registration Identifier: 332524; Location: Magdalena Valley, Eastern Cordillera, Colombia, South America; Age: Maastrichtian.

1.23.68. Species: I. udarii A. Gupta 1985 (Fig. 7Q); Index Fungorum Registration Identifier: 133492; Basionym: Inapertisporites punctatus Anil Chandra et al. 1984; Location: Sediment core no. 3 (Lat. $19^{\circ} 32.8^{\prime} \mathrm{N}$ : Long. $71^{\circ} 21.5^{\prime} \mathrm{E}$ ), Arabian Sea; Age: Late Quaternary; Notes: The species epithet is in honour of Professor Ram Udar, Department of Botany, Lucknow University, Lucknow, India.

1.23.69. Species: I. variabilis Hammen 1954 (Fig. 7R); Index Fungorum Registration Identifier: 332525; Location: Magdalena Valley, Eastern Cordillera, Colombia, South America; Age: Maastrichtian.

1.23.70. Species: I. vittatus Sheffy \& Dilcher 1971; Index Fungorum Registration Identifier: 111558; Current name: Hypoxylonites vittatus (Sheffy \& Dilcher) Elsik 1990 fide Kalgutkar \& Jansonius (2000).

1.23.71. Species: I. vulgaris Sheffy \& Dilcher 1971 (Fig. 7S); Index Fungorum Registration Identifier: 111559; Location: Puryear clay pit, Tennessee, Henry County, U.S.A.; Age: Middle Eocene (Claiborne Formation).

1.24. Genus: INCERTISPORITES Hammen, Bol. Geol. (Bogota) 2(1): 83 (1954); Index Fungorum Registration Identifier: 21140; Type: I. polygranulatus Hammen 1954.

Original Diagnosis: Fungal spores of indefinite type. (Van der Hammen 1954).

Classification: Fungi Imperfecti, Amerosporae.

Number of species known: One.

1.24.1. Species: I. polygranulatus Hammen 1954 (Fig. 7T); Index Fungorum Registration Identifier: 332526; Location: Magdalena Valley, Eastern Cordillera, Colombia, South America; Age: Maastrichtian. 
1.25. Genus: LACRIMASPORONITES R.T. Clarke, Mountain Geologist 2(2): 87 (1965); Index Fungorum Registration Identifier: 21146; Type: L. levis R.T. Clarke 1965.

Original Diagnosis: Fungal spores unicellular (amerospores), elliptical (tear-shaped), hilate or monoporate, cell wall psilate (Clarke 1965).

Emended Diagnoses: Diagnosis of Lacrimasporonites was emended by Elsik (1968) and Kalgutkar \& Jansonius (2000), as follows: Monoporate, nonseptate, psilate fungal spores. Spatulate to elliptical. Pore apical (Elsik 1968); Unicellate, mostly medium-sized, spatulate to lacrimate, rarely approaching elliptical, smooth-walled fungal spores; with a flat hilar scar at one end, and a round pore at the opposite end of the spore (Kalgutkar \& Jansonius 2000).

Classification: Fungi Imperfecti, Amerosporae.

Number of species known: 31 (but we accept only six species as legitimate because 22 species have been transferred to other genera by Kalgutkar \& Jansonius 2000 and three species, viz. L. dolium Z.C. Song, Qian \& Y.H. Zheng in Z.C. Song et al. 1999, L. ovatus Z.C. Song, Qian \& Y.H. Zheng in Z.C. Song et al. 1999 and L. sondensis S. Soomro et al. 2010, have not been validly published).

Notes: Clarke (1965) opined that the shape is an important criterion in taxonomic identification of fungal spores. He restricted Monoporisporites for spherical and subspherical hilate or monoporate fungal spores and Lacrimasporonites for elliptical hilate or monoporate fungal spores. Kalgutkar \& Jansonius (2000) emended the diagnosis of Lacrimasporonites and proposed that unicellular spores with a real pore (or pore-shaped hilum), irrespective of their overall shape, be included in Monoporisporites. Consequently, a large number of species of Lacrimasporonites were transferred to Monoporisporites and to some other genera by Kalgutkar \& Jansonius (2000). The generic prefix is Latin for a tear, given in reference to the tear-drop shape of the spore.

1.25.1. Species: L. arcuatus Doub. \& D. Pons 1973; Index Fungorum Registration Identifier: 485259; Current name: Monoporisporites arcuatus (Doub. \& D. Pons) Kalgutkar \& Janson. 2000 fide Kalgutkar \& Jansonius (2000).

1.25.2. Species: L. basidii Elsik 1968; Index Fungorum Registration Identifier: 316200; Current name: Monoporisporites basidii (Elsik) Kalgutkar \& Janson. 2000 fide Kalgutkar \& Jansonius (2000).

1.25.3. Species: L. bellus Anil Chandra et al. 1984; Index Fungorum Registration Identifier: 106961; Current name: Monoporisporites bellus (Anil Chandra et al.) Kalgutkar \& Janson. 2000 fide Kalgutkar \& Jansonius (2000).

1.25.4. Species: L. buerglii (Hammen) Kalgutkar \& Janson. 2000; Index Fungorum Registration Identifier: 483415; Basionym: Monoporisporites buerglii Hammen 1954; Location: Magdalena Valley, Eastern Cordellera, Colombia, South America; Age: Maastrichtian.

1.25.5. Species: L. cupuliformis (Sheffy \& Dilcher) D.L.E. Glass et al. 1986; Index Fungorum Registration Identifier: 360322; Current name: Anatolinites cupuliformis (Sheffy \& Dilcher) Kalgutkar \& Janson. 2000 fide Kalgutkar \& Jansonius (2000).

1.25.6. Species: L. dolium Z.C. Song, Qian \& Y.H. Zheng in Z.C. Song et al. 1999 (nom. inval.) fide Kalgutkar \& Jansonius (2000); Index Fungorum Registration Identifier: 483842; Location: China; Age: Late Cretaceous/Tertiary; Notes: The species name was not validly published because the author did not specify where the holotype was deposited.

1.25.7. Species: L. fusoides (Sal.-Cheb. \& Locq.) Kalgutkar \& Janson. 2000; Index Fungorum Registration Identifier: 483242; Basionym: Amepiospora fusoides Sal.-Cheb. \& Locq. 1980; Location: Coast of Equatorial Africa, Gulf of Guinea, Cameroon, Africa; Age: Oligocene.

1.25.8. Species: L. globulosus (Rouse) G. Norris 1997; Index Fungorum Registration Identifier: 483785; Current name: Monoporisporites globulosus (Rouse) Kalgutkar \& Janson. 2000 fide Kalgutkar \& Jansonius (2000).

1.25.9. Species: L. hammenii (Mart.-Hern. \& Tom.-Ort.) Kalgutkar \& Janson. 2000; Index Fungorum Registration Identifier: 483416; Basionym: Monoporisporites hammenii Mart.Hern. \& Tom.-Ort. 1989; Location: Piedras Negras, Coahuila State, Mexico; Age: Maastrichtian. 
1.25.10. Species: L. levis R.T. Clarke 1965 (Fig. 7U); Index Fungorum Registration Identifier: 332866; Location: Canon City Coalfield, Fremont County, Colorado, U.S.A.; Age: Late Cretaceous.

1.25.11. Species: L. longus R.K. Kar 1979; Index Fungorum Registration Identifier: 112387; Current name: Didymoporisporonites longus (R.K. Kar) Kalgutkar \& Janson. 2000 fide Kalgutkar \& Jansonius (2000).

1.25.12. Species: L. magnus Haseld. 1973; Index Fungorum Registration Identifier: 483816; Current name: Monoporisporites nemagnus Kalgutkar \& Janson. 2000 fide Kalgutkar \& Jansonius (2000).

1.25.13. Species: L. magnus R.K. Saxena \& H.P. Singh 1983; Index Fungorum Registration Identifier: 485266; Current name: Didymoporisporonites gigas Kalgutkar \& Janson. 2000 fide Kalgutkar \& Jansonius (2000).

1.25.14. Species: L. major P. Ke \& Z.Y. Shi 1978; Index Fungorum Registration Identifier: 115683; Current name: Hilidicellites major (P. Ke \& Z.Y. Shi) Kalgutkar \& Janson. 2000 fide Kalgutkar \& Jansonius (2000).

1.25.15. Species: L. minutaestriatus P. Ke \& Z.Y. Shi 1978; Index Fungorum Registration Identifier: 115682; Current name: Monoporisporites minutaestriatus (P. Ke \& Z.Y. Shi) Kalgutkar \& Janson. 2000 fide Kalgutkar \& Jansonius (2000).

1.25.16. Species: L. niger P. Kumar 1990; Index Fungorum Registration Identifier: 126565; Current name: Monoporisporites niger (P. Kumar) Kalgutkar \& Janson. 2000 fide Kalgutkar \& Jansonius (2000).

1.25.17. Species: L. ovaliformis Anil Chandra et al. 1984; Index Fungorum Registration Identifier: 106962; Current name: Monoporisporites ovaliformis (Anil Chandra et al.) Kalgutkar \& Janson. 2000 fide Kalgutkar \& Jansonius (2000).

1.25.18. Species: L. ovalis Doub. \& D. Pons 1973; Index Fungorum Registration Identifier: 485260; Current name: Monoporisporites doubingerae Kalgutkar \& Janson. 2000 fide Kalgutkar \& Jansonius (2000).

1.25.19. Species: L. ovatus Z.C. Song, Qian \& Y.H. Zheng in Z.C. Song et al. 1999 (nom. inval.) fide Kalgutkar \& Jansonius (2000); Index Fungorum Registration Identifier: 483843; Notes: This species name was not validly published because the author did not specify where the holotype was deposited, and did not provide a Latin description or its English translation.

1.25.20. Species: L. oviformis V.S. Ediger 1981; Index Fungorum Registration Identifier: 108119; Current name: Monoporisporites oviformis (V.S. Ediger) Kalgutkar \& Janson. 2000 fide Kalgutkar \& Jansonius (2000).

1.25.21. Species: L. permagnus M.G. Parsons \& G. Norris 1999; Index Fungorum Registration Identifier: 483917; Location: Caribou Hills, Mackenzie River delta, Canada; Age: Eocene; Notes: The species epithet is derived from Latin permagnus $=$ very large.

1.25.22. Species: L. pseudoabruptus M.G. Parsons \& G. Norris 1999; Index Fungorum Registration Identifier: 483918; Location: Caribou Hills, Mackenzie River delta, Canada; Age: Eocene.

1.25.23. Species: L. psilatus Z.C. Song \& G.X. Li in Z.C. Song et al. 1989; Index Fungorum Registration Identifier: 485261; Current name: Monoporisporites perpsilatus Kalgutkar \& Janson. 2000 fide Kalgutkar \& Jansonius (2000).

1.25.24. Species: L. reniformis Sal.-Cheb. \& Locq. 1980; Index Fungorum Registration Identifier: 108120; Current name: Monoporisporites reniformis (Sal.-Cheb. \& Locq.) Kalgutkar \& Janson. 2000 fide Kalgutkar \& Jansonius (2000).

1.25.25. Species: L. scabratus Z.C. Song \& Liu Cao 1994; Index Fungorum Registration Identifier: 483761; Current name: Monoporisporites scabratus (Z.C. Song \& Liu Cao) Kalgutkar \& Janson. 2000 fide Kalgutkar \& Jansonius (2000).

1.25.26. Species: L. singularis Sheffy \& Dilcher 1971; Index Fungorum Registration Identifier: 111596; Current name: Monoporisporites singularovalis Kalgutkar \& Janson. 2000 fide Kalgutkar \& Jansonius (2000). 
1.25.27. Species: L. sondensis S. Soomro et al. 2010 (nom. inval.) fide hoc loco; Index Fungorum Registration Identifier: 637481; Location: Borehole Core DH No. 18 in the Sonda Coal field, Thatta District, Sindh, Pakistan; Age: Palaeocene; Notes: The species name was not validly published because the author did not specify where the holotype was deposited.

1.25.28. Species: L. stoughiae Elsik 1968; Index Fungorum Registration Identifier: 509432; Current name: Saccisporonites stoughiae (Elsik) Kalgutkar \& Janson. 2000 fide Kalgutkar \& Jansonius (2000).

1.25.29. Species: L. tenuis Z.C. Song \& Liu Cao 1994; Index Fungorum Registration Identifier: 483762; Current name: Anatolinites tenuis (Z.C. Song \& Liu Cao) Kalgutkar \& Janson. 2000 fide Kalgutkar \& Jansonius (2000).

1.25.30. Species: L. traversii V.S. Ediger \& Alisan 1989; Index Fungorum Registration Identifier: 125507; Current name: Monoporisporites traversii (V.S. Ediger \& Alisan) Kalgutkar \& Janson. 2000 fide Kalgutkar \& Jansonius (2000).

1.25.31. Species: L. westii Elsik 1968; Index Fungorum Registration Identifier: 316203; Current name: Monoporisporites westii (Elsik) Kalgutkar \& Janson. 2000 fide Kalgutkar \& Jansonius (2000).

1.26. Genus: LEPIOTASPORITES T.C. Huang, Taiwania 26: 47 (1981); Index Fungorum Registration Identifier: 21149; Type: L. taiwanensis T.C. Huang 1981

Original Diagnosis: Fungal spore with terminal hilum.

Classification: Fungi Imperfecti, Amerosporae.

Number of species known: One

1.26.1. Species: L. taiwanensis T.C. Huang 1981 (Fig. 7V); Index Fungorum Registration Identifier: 115785; Location: Taiwan; Age: Miocene (Talu Shale).

1.27. Genus: MAGNOSPORITES Rouse, Micropaleontology 8(2): 210 (1962); Index Fungorum Registration Identifier: 18487; Type: M. staplinii Rouse 1962.

Original Diagnosis: Spore-like bodies, circular to elliptical in outline and with a fairly thin wall (ca. $1.5 \mu \mathrm{m})$. The wall is a bright yellow and is always folded and contorted. There is no aperture apparent and no ornamentation on the smooth surface. Size-range 100-170 $\mu \mathrm{m}$ (Rouse 1962).

Classification: Fungi Imperfecti, Amerosporae.

Number of species known: One.

Notes: The fungal affinity of these forms is questionable. These structures are apparently associated with freshwater plants, as they are found only in freshwater deposits. Whether they are spores, sporangia, or remains of one-celled organisms is entirely open to question.

1.27.1. Species: M. staplinii Rouse 1962 (Fig. 7W); Index Fungorum Registration Identifier: 560989; Location: Terminal Dock, the city of Vancouver, British Columbia, Canada; Age: Late Cretaceous-Middle Eocene (Burrard Formation); Notes: The species is named in honour of Professor Frank L. Staplin.

1.28. Genus: MEDIAVERRUNITES Nandi \& A. Sinha, Palynology 31(1): 98 (2007); Index Fungorum Registration Identifier: 548478; Type: M. mulleri Nandi \& A. Sinha 2007; Current name: POTAMOMYCES K. D. Hyde 1995 fide Nuñez Otaño et al. (2017).

Original Diagnosis: Spores aseptate, oval to elliptical, monoaperturate (or sometimes inaperturate), pore situated at the basal end of the axis, equatorial region ornamented with flat or slightly elevated verrucae that remain arranged either freely around the equator or merge to form a shallow, thin to wide, dark to light, shadow-like rim or band, verrucae large or small, apex of verrucae rounded or slightly connate, spore wall psilate to sculptured (Nandi \& Sinha 2007).

Classification: Fungi Imperfecti, Amerosporae.

Number of species known: Seven (all the species, including type species, have been transferred to Potamomyces K. D. Hyde 1995). 
Notes: Muller (1959) recorded a characteristic unicellular fungal spore, having several verrucae at the equatorial region, from the Recent shelf sediments of the Orinoco Delta, Venezuela. He, however, did not assign it to any named taxon. Elsik (1976b) illustrated identical spores and informally named it Mediaverrusporonites. Jarzen \& Elsik (1986) informally used the name Mediaverrunites to accommodate these spores but they neither proposed it as a genus nor assigned any species to it. They described Mediaverrunites as follows: "Fungal spores one-celled, with a single aperture (some specimens appear inaperturate), outline oval to elliptical, pore situated at one end of axis, $7 \mu \mathrm{m}$ in diameter; spore colour medium brown; septum lacking, but with a shadow band, 10-12 $\mu \mathrm{m}$ wide; surface psilate except for shadow band which is ornamented with 8 (9?) large verrucae, $10-12 \mu \mathrm{m}$ in diameter; verrucae dark brown to black; spore wall thin $<1 \mu \mathrm{m}$ thick; spore length 62-65 $\mu \mathrm{m}$, spore width 33-35 $\mu \mathrm{m}$. " Nandi \& Sinha (2007) were the first to formally describe Mediaverrunites as a genus and designated Mediaverrunites mulleri Nandi \& A. Sinha 2007 as its type. Nandi \& Sinha (2007), however, considered Jarzen \& Elsik (1986) as the author of the genus and proposed an emended diagnosis. We interpret that Nandi \& Sinha (2007) were the original author (not the validating author) of Mediaverrunites because earlier authors had no intention of proposing it as a genus nor they assigned it any species. The genus is therefore solely ascribed to Nandi \& Sinha 2007 and cited as Mediaverrunites Nandi \& A. Sinha 2007 (not Jarzen \& Elsik ex Nandi \& A. Sinha 2007). The genus name is derived from the Latin media referring to the central position of the verrucae. Nuñez Otaño et al. 2017 considered Mediaverrunites Nandi \& A. Sinha 2007 to be a later synonym of Potamomyces K.D. Hyde 1995. They transferred all species Mediaverrunites, viz. M. batii Sancay 2014, M. elsikii Nandi \& A. Sinha 2007, M. fournieri Elsik \& Jarzen 2009, M. invaginatus Elsik \& Jarzen 2009, M. magnus Elsik \& Jarzen 2009, M. mulleri Nandi \& A. Sinha 2007 and M. pontidiensis Sancay 2014 to Potamomyces K.D. Hyde 1995.

1.28.1. Species: M. batii Sancay 2014; Index Fungorum Registration Identifier: 821044; Current name: Potamomyces batii (Sancay) ex Nuñez Otaño et al. 2017 fide Nuñez Otaño et al. (2017).

1.28.2. Species: M. elsikii Nandi \& A. Sinha 2007; Index Fungorum Registration Identifier: 568744; Current name: Potamomyces elsikii (Nandi \& A. Sinha) Nuñez Otaño et al. 2017 fide Nuñez Otaño et al. (2017).

1.28.3. Species: M. fournieri Elsik \& Jarzen 2009; Index Fungorum Registration Identifier: 568010; Current name: Potamomyces fournieri (Elsik \& Jarzen) Nuñez Otaño et al. 2017 fide Nuñez Otaño et al. (2017).

1.28.4. Species: M. invaginatus Elsik \& Jarzen 2009; Index Fungorum Registration Identifier: 568011; Current name: Potamomyces invaginatus (Elsik \& Jarzen) Nuñez Otaño et al. 2017 fide Nuñez Otaño et al. (2017).

1.28.5. Species: M. magnus Elsik \& Jarzen 2009; Index Fungorum Registration Identifier: 568012; Current name: Potamomyces magnus (Elsik \& Jarzen) Nuñez Otaño et al. 2017 fide Nuñez Otaño et al. (2017).

1.28.6. Species: M. mulleri Nandi \& A. Sinha 2007; Index Fungorum Registration Identifier: 568745; Current name: Potamomyces mulleri (Nandi \& A. Sinha) Nuñez Otaño et al. 2017 fide Nuñez Otaño et al. (2017).

1.28.7. Species: M. pontidiensis Sancay 2014; Index Fungorum Registration Identifier: 821045; Current name: Potamomyces pontidiensis (Sancay) ex Nuñez Otaño et al. 2017 fide Nuñez Otaño et al. (2017).

1.29. Genus: MICROSPORONITES R.K. Jain, Palaeontographica Abt. B 122(1-3): 8 (1968); Index Fungorum Registration Identifier: 21164; Type: M. cacheutensis R.K. Jain 1968.

Original Diagnosis: Fungal spores very small (10-20 $\mu \mathrm{m}$ in diameter), spherical, inaperturate, exine thin, psilate, smooth (Jain 1968).

Emended Diagnosis: Thin-walled single celled fungal spores of small diameter, that tend to occur in irregular clusters, but retain their individual spherical shape (not appressed into semipolyhedral shapes) (Kalgutkar \& Jansonius 2000). 
Classification: Fungi Imperfecti, Amerosporae.

Number of species known: Two.

Notes: Jain (1968) proposed this genus to accommodate very small, spherical, inaperturate, smooth walled fungal spores which were earlier referred to Sporonites.

1.29.1. Species: M. cacheutensis R.K. Jain 1968 (Fig. 7X); Index Fungorum Registration Identifier: 114325; Location: Minas de Petroleo, about $32 \mathrm{~km}$ south-west of Mendoza, western Argentina; Age: Middle Triassic.

1.29.2. Species: M. taiwanensis T.C. Huang 1981; Index Fungorum Registration Identifier: 115789; Location: Taiwan; Age: Miocene.

1.30. Genus: MONOPORISPORITES Hammen 1954, Bol. Geol. (Bogota) 2(2): 14 (1954); Index Fungorum Registration Identifier: 21174; Type: M. minutus Hammen 1954 (designated by Van der Hammen 1955).

Synonyms: Ornatisporites M.G. Parsons \& G. Norris 1999, Index Fungorum Registration Identifier: 28642; Polyporisporites Hammen 1954, Index Fungorum Registration Identifier: 21259; Psiammopomopiospora Sal.-Cheb. \& Locq. 1980, Index Fungorum Registration Identifier: 25597; Psiamspora Sal.-Cheb. \& Locq. 1980, Index Fungorum Registration Identifier: 25589; Reticulatisporonites Elsik 1968, Index Fungorum Registration Identifier: 21279.

Original Diagnosis: (Fungal) spore with one small, [(round) Van der Hammen 1955] pore. (Van der Hammen 1954).

Emended Diagnoses: Diagnosis of Monoporisporites was emended by Elsik (1968), Sheffy \& Dilcher (1971) and Kalgutkar \& Jansonius (2000), as follows: Monoporate, nonseptate, psilate fungal or algal spores. Shape spherical to subspherical (Elsik 1968); Monoporate, aseptate, psilate to finely punctate fungal or algal spores. Shapes spherical to subspherical, hilate or monoporate (Sheffy \& Dilcher 1971); Monohilate (or monoporate), unicellate, generally small to medium-sized, round, oval or elongate elliptical fungal spores. Wall generally smooth, but ornamented forms are included (Kalgutkar \& Jansonius 2000).

Classification: Fungi Imperfecti, Amerosporae.

Number of species known: 58 (but we accept only 47 species as legitimate because six species have been transferred to other genera by various authors and five species, viz. M. biformis Z.C. Song, Qian \& Y.H. Zheng in Z.C. Song et al. 1999, M. gigasus Z.C. Song in Z.C. Song et al. 1999, M. grymaeformis Z.C. Song in Z.C. Song et al. 1999, M. megaporus Z.C. Song in Z.C. Song et al. 1999 and M. operculatus Z.C. Song in Z.C. Song et al. 1999, have not been validly published).

Notes: Clarke (1965) provided the following restated (not emended) diagnosis: "Fungal spores unicellular (amerosporous), spherical to subspherical, hilate or monoporate, cell wall psilate to finely punctate." The emended diagnosis by Sheffy \& Dilcher (1971) provided combination of two previously published descriptions, i.e. restated description by Clarke (1965) and emended description by Elsik (1968). Moreover, the genus was expanded to include the punctate species as well, viz. Monoporisporites globosus R.T. Clarke 1965, M. buerglii Hammen 1954 and M. minutus Hammen 1954. Kalgutkar \& Jansonius (2000) included spherical and elongate spores in the genus, because both shapes may be produced by the same genus or species of modern fungi. Polyporisporites Hammen, Psiammopomopiospora Sal.-Cheb. \& Locq. and Reticulatisporonites Elsik are later taxonomic synonyms of Monoporisporites Hammen (Kalgutkar \& Jansonius 2000).

1.30.1. Species: M. abruptus Sheffy \& Dilcher 1971; Index Fungorum Registration Identifier:

111658; Location: Puryear clay pit, $800 \mathrm{~m}$ south of Puryear, Henry County, Tennessee, U.S.A.; Age: Middle Eocene (Claiborne Formation).

1.30.2. Species: M. annulatus Hammen 1954 (Fig. 7Y); Index Fungorum Registration Identifier: 334446; Location: Magdalena Valley, Eastern Cordellera, Colombia, South America; Age: Maastrichtian. 
1.30.3. Species: M. aquilus Kalgutkar 1997; Index Fungorum Registration Identifier: 437927; Location: Kanguk Peninsula, Axel Heiberg Island, Northwest Territories, Canada; Age: Late Palaeocene-Early Eocene.

1.30.4. Species: M. arcuatus (Doub. \& D. Pons) Kalgutkar \& Janson. 2000; Index Fungorum Registration Identifier: 483423; Basionym: Lacrimasporonites arcuatus Doub. \& D. Pons 1973; Location: Cerrejon basin, Colombia, South America; Age: Palaeocene-Eocene.

1.30.5. Species: M. basidii (Elsik) Kalgutkar \& Janson. 2000 (Fig. 7Z); Index Fungorum Registration Identifier: 483422; Basionym: Lacrimasporonites basidii Elsik 1968; Location: Strip mine approximately $11 \mathrm{~km}$ south-west of Rockdale, Milam County, Texas, U.S.A.; Age: Palaeocene.

1.30.6. Species: M. bellus (Anil Chandra et al.) Kalgutkar \& Janson. 2000 (Fig. 7AA); Index Fungorum Registration Identifier: 483424; Basionym: Lacrimasporonites bellus Anil Chandra et al. 1984; Location: Sediment core no. 1 (Lat. $17^{\circ} 57.9^{\prime} \mathrm{N}$ : Long. $70^{\circ} 46.0^{\prime} \mathrm{E}$ ), Arabian Sea; Age: Late Quaternary.

1.30.7. Species: M. biformis Z.C. Song, Qian \& Y.H. Zheng in Z.C. Song et al. 1999 (nom. inval.) fide Kalgutkar \& Jansonius (2000); Index Fungorum Registration Identifier: 483915; This species was not validly published because the author did not specify where the holotype is stored, and did not provide a Latin description or its English translation.

1.30.8. Species: M. buerglii Hammen 1954; Index Fungorum Registration Identifier: 334447; Current name: Lacrimasporonites buerglii (Hammen) Kalgutkar \& Janson. 2000 fide Kalgutkar \& Jansonius (2000).

1.30.9. Species: M. circularis R.K. Saxena 2009 (Fig. 7AB); Index Fungorum Registration Identifier: 515007; Basionym: Monoporisporites hammenii B. Samant \& Tapaswi 2000; Location: Cambay Basin, Surat District, Gujarat, India; Age: Early Eocene (Cambay Shale); Notes: Monoporisporites circularis R.K. Saxena 2009 is a replacement name of Monoporisporites hammenii B. Samant \& Tapaswi 2000.

1.30.10. Species: M. cupuliformis Sheffy \& Dilcher 1971; Index Fungorum Registration Identifier: 111659; Current name: Anatolinites cupuliformis (Sheffy \& Dilcher) Kalgutkar \& Janson. 2000 fide Kalgutkar \& Jansonius (2000).

1.30.11. Species: M. dilcheri Mart.-Hern. \& Tom.-Ort. 1989; Index Fungorum Registration Identifier: 483806; Location: Piedras Negras, Coahuila State, Mexico; Age: Maastrichtian.

1.30.12. Species: M. doubingerae Kalgutkar \& Janson. 2000; Index Fungorum Registration Identifier: 483425; Basionym: Lacrimasporonites ovalis Doub. \& D. Pons 1973; Location: Cerrejon basin, Colombia, South America; Age: Palaeocene-Eocene.

1.30.13. Species: M. elencantensis (Sepúlveda) Kalgutkar \& Janson. 2000; Index Fungorum Registration Identifier: 483426; Basionym: Inapertisporites elencantensis Sepúlveda 1980; Location: Northern Patagonian Cordillera, Chubut Province, Argentina; Age: Middle Eocene (Andean Andesitic Series).

1.30.14. Species: M. elongatus (Hammen) Kalgutkar \& Janson. 2000; Index Fungorum Registration Identifier: 483427; Basionym: Polyporisporites elongatus Hammen 1954; Location: Magdalena Valley, Eastern Cordillera, Colombia, South America; Age: Maastrichtian.

1.30.15. Species: M. gigasus Z.C. Song in Z.C. Song et al. 1999 (nom. inval.) fide Kalgutkar \& Jansonius (2000); Index Fungorum Registration Identifier: 483838; Notes: The species name was not validly published because the author did not specify where the holotype was deposited.

1.30.16. Species: M. globoides (Sal.-Cheb. \& Locq.) Kalgutkar \& Janson. 2000; Index Fungorum Registration Identifier: 483428; Basionym: Psiammopomopiospora globoides Sal.-Cheb. \& Locq. 1980; Location: Coast of Equatorial Africa, Gulf of Guinea, Cameroon, Africa; Age: Oligocene. 
1.30.17. Species: M. globosus R.T. Clarke 1965; Index Fungorum Registration Identifier: 334448; Current name: Inapertisporites clarkei Kalgutkar \& Janson. 2000 fide Kalgutkar \& Jansonius (2000).

1.30.18. Species: M. globulosus (Rouse) Kalgutkar \& Janson. 2000; Index Fungorum Registration Identifier: 483429; Basionym: Inapertisporites globulosus Rouse 1962; Location: Terminal Dock, the city of Vancouver, British Columbia, Canada; Age: Late Cretaceous-Middle Eocene (Burrard Formation).

1.30.19. Species: M. grandis Hammen 1954; Index Fungorum Registration Identifier: 334449; Location: Magdalena Valley, Eastern Cordellera, Colombia, South America; Age: Maastrichtian.

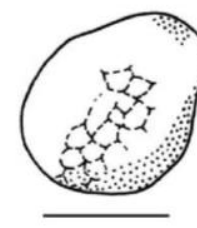

A

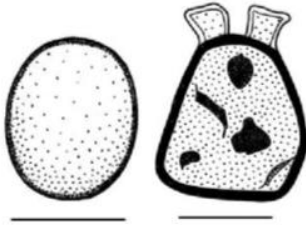

B

C

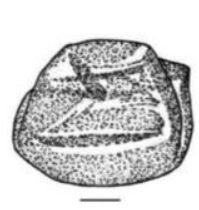

D

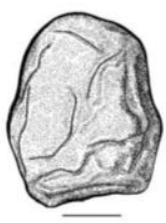

E

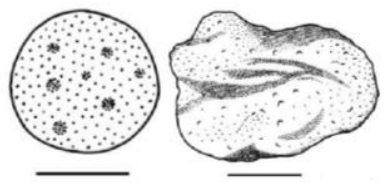

G
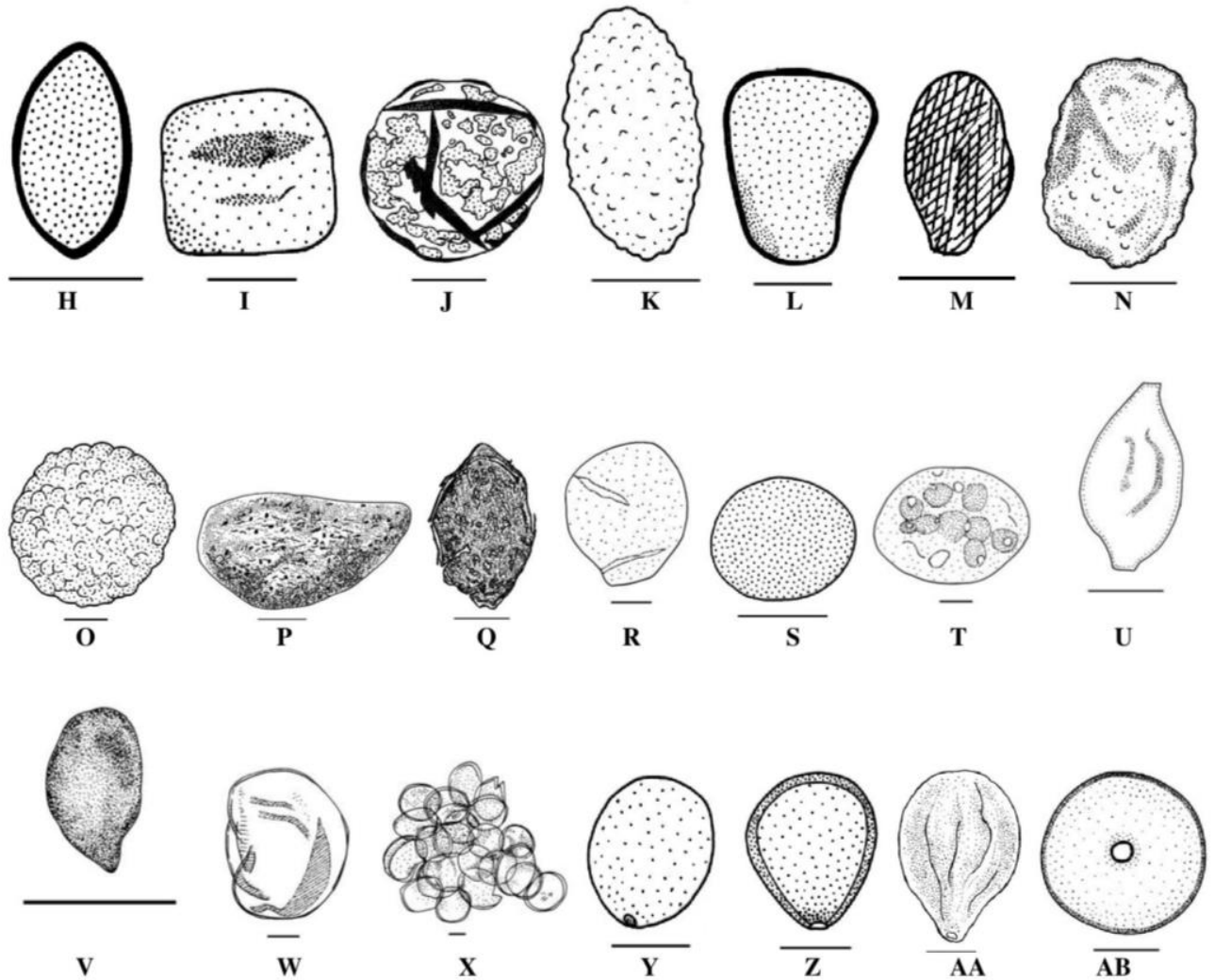

V

w
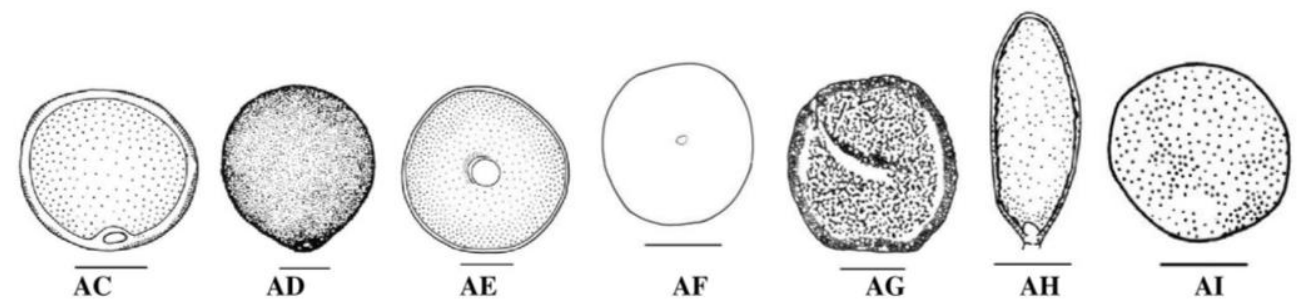

Figure 7 - A-AI Amerosporae. A Inapertisporites hammenii Anil Chandra et al. 1984, Bar $=20$ $\mu \mathrm{m}$. B Inapertisporites indicus A. Gupta 2002, Bar $=5 \mu \mathrm{m}$. C Inapertisporites karii R.K. Saxena \& S.K.M. Tripathi 2011, Bar $=20 \mu \mathrm{m}$. D Inapertisporites kedvesii Elsik 1968, Bar $=10 \mu \mathrm{m}$. E Inapertisporites maximus H.P. Singh \& R.K. Saxena 1981, Bar $=20 \mu \mathrm{m}$. F Inapertisporites 
minutus Hammen 1954, Bar $=5 \mu \mathrm{m}$. G Inapertisporites novus A. Gupta 2002, Bar $=25 \mu \mathrm{m} . \mathrm{H}$ Inapertisporites ovalis Sheffy \& Dilcher 1971, Bar $=7 \mu \mathrm{m}$. I Inapertisporites quadrangularis Anil Chandra et al. 1984, Bar $=5 \mu \mathrm{m}$. J Inapertisporites sahii R.K. Saxena \& S.K.M. Tripathi 2011, Bar $=30 \mu \mathrm{m}$. K Inapertisporites sinhae A. Gupta 2002, Bar $=5 \mu \mathrm{m}$. L Inapertisporites subcapsularis Sheffy \& Dilcher 1971, Bar $=5 \mu \mathrm{m}$. M Inapertisporites subovoides Sheffy \& Dilcher 1971, Bar $=5$ $\mu \mathrm{m}$. N Inapertisporites subverrucatus A. Gupta 2002, Bar $=10 \mu \mathrm{m}$. O Inapertisporites tiwarii A. Gupta 2002, Bar $=5 \mu \mathrm{m}$. P Inapertisporites trivedii Ambwani 1982, Bar $=20 \mu \mathrm{m}$. Q Inapertisporites udarii A. Gupta 1985, Bar $=20 \mu \mathrm{m}$. R Inapertisporites variabilis Hammen 1954, Bar $=8 \mu \mathrm{m}$. S Inapertisporites vulgaris Sheffy \& Dilcher 1971, Bar $=7 \mu \mathrm{m}$. T Incertisporites polygranulatus Hammen 1954, Bar $=20 \mu \mathrm{m}$. U Lacrimasporonites levis R.T. Clarke 1965, Bar $=8$ $\mu \mathrm{m} . \mathrm{V}$ Lepiotasporites taiwanensis T.C. Huang 1981, Bar $=10 \mu \mathrm{m} . \mathrm{W}$ Magnosporites staplinii Rouse 1962, Bar $=30 \mu \mathrm{m}$. X Microsporonites cacheutensis R.K. Jain 1968, Bar $=3 \mu \mathrm{m}$. Y Monoporisporites annulatus Hammen 1954, Bar $=5 \mu \mathrm{m}$. Z Monoporisporites basidii (Elsik) Kalgutkar \& Janson. 2000, Bar $=5 \mu \mathrm{m}$. AA Monoporisporites bellus (Anil Chandra et al.) Kalgutkar \& Janson. 2000, Bar $=20 \mu \mathrm{m}$. AB Monoporisporites circularis R.K. Saxena 2009, Bar $=$ $10 \mu \mathrm{m}$. AC Monoporisporites keralensis Ramanujam \& K.P. Rao 1978, Bar $=10 \mu \mathrm{m}$. AD Monoporisporites koenigii Elsik 1968, Bar $=10 \mu \mathrm{m}$. AE Monoporisporites meghalayaensis R.K. Saxena \& S.K.M. Tripathi 2011, Bar $=20 \mu \mathrm{m}$. AF Monoporisporites minutus Hammen 1954, Bar $=$ $8 \mu \mathrm{m}$. AG Monoporisporites neyveliensis Ramanujam \& Ramachar 1980, Bar $=5 \mu \mathrm{m}$. AH Monoporisporites niger (P. Kumar) Kalgutkar \& Janson. 2000, Bar $=10 \mu \mathrm{m}$. AI Monoporisporites novus Anil Chandra et al. 1984, Bar $=10 \mu \mathrm{m}$.

1.30.20. Species: M. grymaeformis Z.C. Song in Z.C. Song et al. 1999 (nom. inval.) fide Kalgutkar \& Jansonius (2000); Index Fungorum Registration Identifier: 483839; Notes: The species name was not validly published because the author did not specify where the holotype was deposited, and did not provide a Latin description or its English translation

1.30.21. Species: M. hammenii B. Samant \& Tapaswi 2000; Index Fungorum Registration Identifier: 515006; Current name: Monoporisporites circularis R.K. Saxena 2009 fide Saxena (2009).

1.30.22. Species: M. hammenii Mart.-Hern. \& Tom.-Ort. 1989; Index Fungorum Registration Identifier: 483805; Current name: Lacrimasporonites hammenii (Mart.-Hern. \& Tom.-Ort.) Kalgutkar \& Janson. 2000 fide Kalgutkar \& Jansonius (2000).

1.30.23. Species: M. keralensis Ramanujam \& K.P. Rao 1978 (Fig. 7AC); Index Fungorum Registration Identifier: 115076; Location: Padappakkara, Kollam District, Kerala, India; Age: Miocene (Quilon and Warkalli beds).

1.30.24. Species: M. koenigii Elsik 1968 (Fig. 7AD); Index Fungorum Registration Identifier: 317864; Location: Strip mine approximately $11 \mathrm{~km}$ south-west of Rockdale, Milam County, Texas, U.S.A.; Age: Palaeocene.

1.30.25. Species: M. macrosporus (Sal.-Cheb. \& Locq.) Kalgutkar \& Janson. 2000; Index Fungorum Registration Identifier: 483244; Basionym: Amepiospora macrospora Sal.-Cheb. \& Locq. 1980; Location: Coast of Equatorial Africa, Gulf of Guinea, Cameroon, Africa; Age: Oligocene.

1.30.26. Species: M. magnus Kalgutkar 1993; Index Fungorum Registration Identifier: 483882; Location: Peel River, Yukon Territory, Canada; Age: Late Palaeocene-Early Eocene.

1.30.27. Species: M. mathurii Kalgutkar \& Janson. 2000; Index Fungorum Registration Identifier: 483430; Basionym: Psilainaperturites ovalis Y.K. Mathur 1966; Location: Matanomadh, western Kutch, India; Age: Palaeocene.

1.30.28. Species: M. megaporus Z.C. Song in Z.C. Song et al. 1999 (nom. inval.) fide Kalgutkar \& Jansonius (2000); Index Fungorum Registration Identifier: 483840; Notes: The species name was not validly published because the author did not specify where the holotype is stored, and did not provide a Latin description or its English translation. 
1.30.29. Species: M. meghalayaensis R.K. Saxena \& S.K.M. Tripathi 2011 (Fig. 7AE); Index Fungorum Registration Identifier: 519946; Location: Sonapur-Badarpur Road Section, Jaintia Hills, Meghalaya and Cachar District, Assam, India; Age: Miocene (Bokabil Formation).

1.30.30. Species: M. minionoides O'Keefe 2017; Index Fungorum Registration Identifier: 821910; Location: Tumbes Province, Peru; Age: Miocene (Heath Formation); Notes: The species epithet refers to the ovoid form and single eye of the fictional cartoon characters known as 'minions'.

1.30.31. Species: M. minutaestriatus (P. Ke \& Z.Y. Shi) Kalgutkar \& Janson. 2000; Index Fungorum Registration Identifier: 483431; Basionym: Lacrimasporonites minutaestriatus $\mathrm{P}$. Ke \& Z.Y. Shi 1978; Location: Panshan, Liaoning Province, Coastal region of Bohai, China; Age: Eocene-Oligocene.

1.30.32. Species: M. minutus Hammen 1954 (Fig. 7AF); Index Fungorum Registration Identifier: 334450; Basionym: Monoporisporites minutus A Hammen 1954; left, top row of figures (lectotype selected by Jansonius \& Hills 1976); Location: Magdalena Valley, Eastern Cordillera, Colombia, South America; Age: Maastrichtian.

1.30.33. Species: M. nemagnus Kalgutkar \& Janson. 2000; Index Fungorum Registration Identifier: 483432; Basionym: Lacrimasporonites magnus Haseld. 1973; Location: San Martin (Graus), Esera Valley, Pyrenees, Spain; Age: Palaeocene-Late Eocene; Notes: Monoporisporites nemagnus Kalgutkar \& Janson. 2000 is a replacement name of Monoporisporites minutus A Hammen 1954.

1.30.34. Species: M. neoglobosus Kalgutkar \& Janson. 2000; Index Fungorum Registration Identifier: 483243; Basionym: Amepiospora globosa Sal.-Cheb. \& Locq. 1980; Location: Coast of Equatorial Africa, Gulf of Guinea, Cameroon, Africa; Age: Oligocene.

1.30.35. Species: M. neyveliensis Ramanujam \& Ramachar 1980 (Fig. 7AG); Index Fungorum Registration Identifier: 483756; Location: Neyveli, Cuddalore District, Tamil Nadu, India; Age: Miocene (Neyveli lignite).

1.30.36. Species: M. niger (P. Kumar) Kalgutkar \& Janson. 2000 (Fig. 7AH).; Index Fungorum Registration Identifier: 483433; Basionym: Lacrimasporonites niger Kumar 1990; Location: Padappakkara, Kollam District, Kerala, India; Age: Early-Middle Miocene; Notes: The species epithet is derived from its diagnostic dark wall (Latin niger = black).

1.30.37. Species: M. novus Anil Chandra et al. 1984 (Fig. 7AI); Index Fungorum Registration Identifier: 107032; Location: Sediment core no. 4 (Lat. $21^{\circ} 10.02 \mathrm{~N}$ : Long. $70^{\circ} 26.9^{\prime} \mathrm{E}$ ), Arabian Sea; Age: Late Quaternary.

1.30.38. Species: M. operculatus Z.C. Song in Z.C. Song et al. 1999 (nom. inval.) fide Kalgutkar \& Jansonius (2000); Index Fungorum Registration Identifier: 483841 Notes: The species name was not validly published because the author did not specify where the holotype was deposited, and did not provide a Latin description or its English translation

1.30.39. Species: M. ovaliformis (Anil Chandra et al.) Kalgutkar \& Janson. 2000 (Fig. 8A); Index Fungorum Registration Identifier: 483434; Basionym: Lacrimasporonites ovaliformis Anil Chandra et al. 1984; Location: Sediment core no. 1 (Lat. $17^{\circ} 57.9^{\prime} \mathrm{N}$ : Long. $70^{\circ} 46.0^{\prime} \mathrm{E}$ ), Arabian Sea; Age: Late Quaternary.

1.30.40. Species: M. ovalis Sheffy \& Dilcher 1971; Index Fungorum Registration Identifier: 111660; Current name: Basidiosporites ovalis (Sheffy \& Dilcher) Kalgutkar \& Janson. 2000 fide Kalgutkar \& Jansonius (2000).

1.30.41. Species: M. oviformis (V.S. Ediger) Kalgutkar \& Janson. 2000; Index Fungorum Registration Identifier: 483435; Basionym: Lacrimasporonites oviformis V.S. Ediger 1981; Location: Thrace Basin, Turkey; Age: Upper Eocene-Oligocene, Miocene-Pliocene.

1.30.42. Species: M. pannosus (M.G. Parsons \& G. Norris) Kalgutkar \& Janson. 2000; Index Fungorum Registration Identifier: 483436; Basionym: Ornatisporites pannosus M.G. Parsons \& G. Norris 1999; Location: Caribou Hills, Mackenzie River delta, Canada; Age: Late Palaeocene-Early Eocene. 
1.30.43. Species: M. perminutus Doub. \& D. Pons 1973; Index Fungorum Registration Identifier: 637482; Location: Cerrejon basin, Colombia, South America; Age: Palaeocene-Eocene.

1.30.44. Species: M. perpsilatus Kalgutkar \& Janson. 2000; Index Fungorum Registration Identifier: 83437; Basionym: Lacrimasporonites psilatus Z.C. Song \& G.X. Li in Z.C. Song et al. 1989; Qingteng county and Fanxian county of Henan Province, China; Age: Late Eocene-Middle Oligocene (Shahejie Formation).

1.30.45. Species: M. psilatus Anil Chandra et al. 1984 (Fig. 8B); Index Fungorum Registration Identifier: 107033; Location: Sediment core no. 1 (Lat. $17^{\circ} 57.9^{\prime} \mathrm{N}$ : Long. $70^{\circ} 46.0^{\prime} \mathrm{E}$ ), Arabian Sea; Age: Late Quaternary.

1.30.46. Species: M. reniformis (Sal.-Cheb. \& Locq.) Kalgutkar \& Janson. 2000; Index Fungorum Registration Identifier: 483438; Basionym: Lacrimasporonites reniformis Sal.-Cheb. \& Locq. 1980; Location: Coast of Equatorial Africa, Gulf of Guinea, Cameroon, Africa; Age: Early Eocene-Early Miocene.

1.30.47. Species: M. rigens Kalgutkar 1997; Index Fungorum Registration Identifier: 437928; Location: Kanguk Peninsula, Axel Heiberg Island, Northwest Territories, Canada; Age: Late Palaeocene-Early Eocene.

1.30.48. Species: M. scabratus (Z.C. Song \& Liu Cao) Kalgutkar \& Janson. 2000; Index Fungorum Registration Identifier: 483439; Basionym: Lacrimasporonites scabratus Z.C. Song \& Liu Cao 1994; Location: King George Island, Antarctica; Age: Late Cretaceous.

1.30.49. Species: M. sheffyi Anil Chandra et al. 1984 (Fig. 8C); Index Fungorum Registration Identifier: 107034; Location: Sediment core no. 5 (Lat. $24^{\circ} 04.5^{\prime} \mathrm{N}$ : Long. 69 $26.0^{\prime} \mathrm{E}$ ), Arabian Sea; Age: Late Quaternary; Notes: The species epithet is in honour of Dr. M.V. Sheffy.

1.30.50. Species: M. singhii A. Gupta 2002 (Fig. 8D); Index Fungorum Registration Identifier: 540671; Location: Jamtah Road Section, Sirmaur District, Himachal Pradesh, India; Age: Eocene (Subathu Formation); Notes: The species epithet honours Dr. H.P. Singh, Birbal Sahni Institute of Palaeosciences, Lucknow, India.

1.30.51. Species: M. singularis Sheffy \& Dilcher 1971; Index Fungorum Registration Identifier: 111661; Location: Puryear clay pit, $800 \mathrm{~m}$ south of Puryear, Henry County, Tennessee, U.S.A.; Age: Middle Eocene (Claiborne Formation).

1.30.52. Species: M. singularovalis Kalgutkar \& Janson. 2000; Index Fungorum Registration Identifier: 483440; Basionym: Lacrimasporonites singularis Sheffy \& Dilcher 1971; Location: Puryear clay pit, $800 \mathrm{~m}$ south of Puryear, Henry County, Tennessee, U.S.A.; Age: Middle Eocene.

1.30.53. Species: M. smithii Elsik 1968; Index Fungorum Registration Identifier: 317865; Location: Strip mine approximately $11 \mathrm{~km}$ south-west of Rockdale, Milam County, Texas, U.S.A.; Age: Palaeocene.

1.30.54. Species: M. sperryi (Elsik) Kalgutkar \& Janson. 2000; Index Fungorum Registration Identifier: 483441; Basionym: Reticulatisporonites sperryi Elsik 1968; Location: Strip mine approximately $11 \mathrm{~km}$ south-west of Rockdale, Milam County, Texas, U,S,A.; Age: Palaeocene.

1.30.55. Species: M. stoveri Elsik 1968 (Fig. 8E); Index Fungorum Registration Identifier: 317866; Location: Strip mine approximately $11 \mathrm{~km}$ south-west of Rockdale, Milam County, Texas, U.S.A.; Age: Palaeocene.

1.30.56. Species: M. traversei (V.S. Ediger \& Alisan) Kalgutkar \& Janson. 2000; Index Fungorum Registration Identifier: 483442; Basionym: Lacrimasporonites traversii V.S. Ediger \& Alisan 1989; Location: Northern Thrace Basin, Turkey; Age: Middle?-Late Eocene to Late Oligocene, Miocene-Pliocene.

1.30.57. Species: M. triangularis (Sal.-Cheb. \& Locq.) Kalgutkar \& Janson. 2000; Index Fungorum Registration Identifier: 483245; Basionym: Amepiospora triangularis Sal.-Cheb. \& Locq. 1980; Location: Coast of Equatorial Africa, Gulf of Guinea, Cameroon, Africa; Age: Oligocene. 
1.30.58. Species: M. westii (Elsik) Kalgutkar \& Janson. 2000; Index Fungorum Registration Identifier: 483443; Basionym: Lacrimasporonites westii Elsik 1968; Location: Strip mine approximately $11 \mathrm{~km}$ south-west of Rockdale, Milam County, Texas, U.S.A.; Age: Palaeocene.

1.31. Genus: NAILISPORITES T.C. Huang, Taiwania 26: 47 (1981); Index Fungorum Registration Identifier: 21190; Type: N. taiwanensis T.C. Huang 1981.

Original Diagnosis: Fungal spore with nail shape at one end.

Classification: Fungi Imperfecti, Amerosporae.

Number of species known: One.

1.31.1. Species: $\boldsymbol{N}$. taiwanensis T.C. Huang 1981 (Fig. 8F); Index Fungorum Registration Identifier: 115792; Location: Taiwan; Age: Miocene (Talu Shale).

1.32. Genus: NIGROSPORITES Debi Mukh., International Journal of Geology, Earth and Environmental Sciences 2(2): 9 (2012); Index Fungorum Registration Identifier: 588464; Type: $\boldsymbol{N}$. neyveliensis Debi Mukh. 2012.

Original Diagnosis: Dispersed conidia oval/ lanceolate, somewhat flattened, large, absolutely opaque, colour black, spore wall hyaline; size range 35-45 × 25-30 $\mu \mathrm{m}$ (Mukherjee 2012).

Classification: Fungi Imperfecti, Amerosporae.

Number of species known: One.

Notes: The genus name is derived from Nigrospora, a hyphomycete (Subramanian 1971).

1.32.1. Species: N. neyveliensis Debi Mukh. 2012 (Fig. 8G); Index Fungorum Registration Identifier: 588477; Location: Neyveli Lignite Mine-I, Cuddalore District, Tamil Nadu, India; Age: Miocene (Neyveli Lignite); Notes: Mukherjee (2012) opined that this species resembles Nigrospora (Hyphomycetes) for being black, opaque and lanceolate in shape. The specific epithet refers to its type locality Neyveli.

1.33. Genus: ORNATISPORITES M.G. Parsons \& G. Norris, Palaeontographica Abt. B 250(4-6): 117 (1999); Type: O. pannosus M.G. Parsons \& G. Norris 1999; Current name: MONOPORISPORITES Hammen 1954 fide Kalgutkar \& Jansonius (2000).

Original Diagnosis: Monoporate fungal (amero)spores subspherical in shape or with a somewhat elongate spore body - commonly elliptical, obovate or spatulate in outline. Spore wall ornamented with scabs (scabrate), verrucae or granula, or a combination of these types of ornament (Parsons \& Norris 1999).

Classification: Fungi Imperfecti, Amerosporae.

Number of species known: One (the single species has been transferred to Monoporisporites Hammen 1954).

Notes: The generic name is illegitimate, being a later homonym of Ornatisporites Nagy 1963 and Ornatisporites Górecka 1969.

1.33.1. Species: O. pannosus M.G. Parsons \& G. Norris 1999; Index Fungorum Registration Identifier: 483919; Current name: Monoporisporites pannosus (M.G. Parsons \& G. Norris) Kalgutkar \& Janson. 2000 fide Kalgutkar \& Jansonius (2000).

1.34. Genus: PALAEOAMPHISPHAERELLA Ramanujam \& Srisailam, Botanique, Nagpur 9(14): 128 (1980); Index Fungorum Registration Identifier: 21204; Type: P. pirozynskii Ramanujam \& Srisailam 1980.

Synonym: Imprimospora G. Norris 1986 fide Kalgutkar \& Jansonius (2000), Index Fungorum Registration Identifier: 25449.

Original Diagnosis: Spores brownish to dark brown, aseptate, elliptical, oblong or somewhat rhomboidal, with more or less rounded ends; with equatorial pores, placed equidistantly; surface psilate to scabrate (Ramanujam \& Srisailam 1980).

Classification: Fungi Imperfecti, Amerosporae. 
Number of species known: Three.

Notes: The equatorially disposed pores constitute a characteristic feature of this fungal spore genus. The fossil spores exhibit remarkable resemblances with the ascospores of Amphisphaerella included either under Xylariaceae or Amphisphaerellaceae of the pyrenomycetous Ascomycetes (Eriksson 1966). Palaeoamphisphaerella Ramanujam \& Srisailam (1980) appears indistinguishable from Imprimospora in general and diagnostic morphology. The equatorially disposed pores and transverse bands constitute the characteristic features of both genera. Imprimospora is therefore considered a later synonym of Palaeoamphisphaerella.

1.34.1. Species: P. keralensis Ramanujam \& Srisailam 1980 (Fig. 8H); Index Fungorum Registration Identifier: 109135; Location: Palayangadi, Kannur District and Cheruvattur, Kasaragod District, Kerala, India; Age: Miocene; Notes: The spore wall of this species is scabrate, unlike the psilate wall of the type species. According to Ramanujam \& Srisailam (1980), Palaeoamphisphaerella keralensis shows significant resemblance to the ascospores of Amphisphaerella dispersella (Nyl.) O.E. Erikss. 1966 [Current name: Rosellinia dispersella (Nyl.) P. Karst.].

1.34.2. Species: P. pirozynskii Ramanujam \& Srisailam 1980 (Fig. 8I); Index Fungorum Registration Identifier: 109136; Location: Palayangadi, Kannur District and Cheruvattur, Kasaragod District, Kerala, India; Age: Miocene.

1.34.3. Species: P. tankensis (G. Norris) Kalgutkar \& Janson. 2000; Index Fungorum Registration Identifier: 483485; Basionym: Imprimospora tankensis G. Norris 1986; Location: Imperial Nuktak C-22 Well, Mackenzie Delta Region, District of Mackenzie, North West Territory, Canada; Age: Eocene; Notes: Imprimospora tankensis, the type of Imprimospora G. Norris, appears to be similar in general and diagnostic morphology to Palaeoamphisphaerella pirozynskii described by Ramanujam and Srisailam (1980). The characteristic central part of the spore is described by Ramanujam and Srisailam (1980) as multiporate with 8-10 equatorial, equidistant pores with prominently thickened margin, whereas Norris (1986) described it as having 7 or 8 parallel fissures, extending longitudinally between two transverse, wide 'shadow bands'. Both the species are regarded as unicellular and aseptate. Kalgutkar \& Jansonius (2000), therefore, treated Imprimospora as a later synonym of Palaeoamphisphaerella, and transferred its type species to the latter genus.

1.35. Genus: PALAEOPERICONIA C.G. Ibáñez \& Zamuner, Mycotaxon 59: 138 (1996) (nom. inval.) fide Index Fungorum (2021); Index Fungorum Registration Identifier: 27673; Type: $P$. fritzschei C.G. Ibáñez \& Zamuner 1996.

Original Diagnosis (Combined description): Mycelium immersed, organized in layers (pl. 1, figs. 1-2); composed of brown hyphae, 4.3-9.6 $\mu \mathrm{m}$ wide, septa being infrequent, walls thin and delicate with sparse rounded ornamental elements (pl. 1, fig. 6). Conidiophores micronematous, mononematous. Conidiogenous cells blastic, terminal, with a blistered end. Blastoconidia globose, brown or dark brown, with verrucose walls (pl. 1, fig. 3), 6.7-14.4 $\mu \mathrm{m}$, formed singly or in basipetal chains of up to nine elements (pl. 1, fig. 2-5) from compact apical heads. Spherical terminal chlamydospore $37.4 \times 41.3 \mu \mathrm{m}$, with a thick wall $(2.4-3.4 \mu \mathrm{m}$ wide), and with contracted content, with a supporting hyphal end $8.2 \mu \mathrm{m}$ in diameter (pl. 1, fig. 6) (Ibañez \& Zamuner 1996).

Classification: Fungi Imperfecti, Amerosporae.

Number of species known: One (not validly published).

Notes: Ibáñez and Zamuner (1996) stated that the studied material was made up of only asexual structures represented by conidia produced on single conidiophores, not enclosed in pycnidia or acervuli (conidiomata). This allowed them to assign it within Hyphomycetes Moniliales. The presence of conidia and mycelium pigmented, rough-walled and conidial chains, would relate the sample studied to several Dematiaceae genera. The closely related genera would be Periconia Tode, Torula Pers., Stachybotrys Corda, Humicola Traaen, Thermomyces Tsikl. and Chlamydomyces Bainier. The studied material is the first fossil record related to Periconia Tode. The presence of Palaeopericonia suggests the existence of a warm temperate and very wet habitat. 
However, the genus was not validly published because its type species was not validly published and therefore no type was available.

1.35.1. Species: P. fritzschei C.G. Ibáñez \& Zamuner 1996 (nom. inval.) fide hoc loco; Index Fungorum Registration Identifier: 415737; Location: Jaramillo Petrified Forest, Santa Cruz Province, Argentina; Age: Middle Jurassic; Notes: The species was not validly published because no holotype was designated.

1.36. Genus: PARAPOTAMOMYCES O'Keefe, Palynology 41(S1): 319 (2017); Index Fungorum Registration Identifier: 821911; Type: P. maydiformis O'Keefe 2017.

Original Diagnosis: Spores biconical, dark brown, unicellular, with a germ pore at one end. Thickened verrucae are distributed in three roughly linear bands, one around the equator and one half-way up each pyramid, or a spiral pattern. Additional verrucae may occur between the upper bands and the apices (O'Keefe 2017).

Classification: Fungi Imperfecti, Amerosporae.

Number of species known: One.

Notes: According to O'Keefe (2017), this genus has many more verrucae than any recorded species of Potamomyces K.D. Hyde. A similar grain was reported as cf. Gliomastix by Jarzen \& Elsik (1986) from modern fluvial sediments from Zambia, Africa, but is clearly much too big to be Gliomastix. It is roughly the same size as this grain, but has less robust verrucae. The specimen of Jarzen \& Elsik (1986) looks much more like a Potamomyces with additional tubercles. The generic name is given because of its similarities to Potamomyces.

1.36.1. Species: P. maydiformis O'Keefe 2017 (Fig. 8J); Index Fungorum Registration Identifier: 821912; Location: Tumbes Province, Peru; Age: Miocene (Heath Formation); Notes: The species epithet refers to the verrucae looking like corn kernels stuck to the grain; thus, maydiformis after Zea mays L.

1.37. Genus: PEZIZASPORITES T.C. Huang, Taiwania 26: 47 (1981); Index Fungorum Registration Identifier: 21234; Type: P.taiwanensis T.C. Huang 1981

Original Diagnosis: Fungal spore with thin reticulate exine

Classification: Fungi Imperfecti, Amerosporae.

Number of species known: One.

1.37.1. Species: P. taiwanensis T.C. Huang 1981 (Fig. 8K); Index Fungorum Registration Identifier: 107941; Location: Taiwan; Age: Miocene (Peliao Sandstone).

1.38. Genus: POLYPORISPORITES Hammen, Bol. Geol. (Bogota) 2(1): 83 (1954); Index Fungorum Registration Identifier: 21259; Type: P. elongatus Hammen 1954; Current name: MONOPORISPORITES Hammen 1954 fide Kalgutkar \& Jansonius (2000).

Original Diagnosis: Fungal spores with more than three small pores. (Van der Hammen 1954).

Classification: Fungi Imperfecti, Amerosporae.

Number of species known: One (the single species has been transferred to Monoporisporites Hammen 1954).

Notes: Polyporisporites Hammen is a later taxonomic synonym of Monoporisporites Hammen 1954 sensu Kalgutkar \& Jansonius 2000.

1.38.1. Species: P. elongatus Hammen 1954; Index Fungorum Registration Identifier: 337477; Current name: Monoporisporites elongatus (Hammen) Kalgutkar \& Janson. 2000 fide Kalgutkar \& Jansonius (2000).

1.39. Genus: PORTALITES Hemer \& Nygreen, Micropaleontology 13: 187 (1967); Index Fungorum Registration Identifier: 25609; Type: P. confertus Hemer \& Nygreen 1967. 
Original Diagnosis: Amb circular to oval. Thick walled, with a portion of the wall thickened and containing a simple circular pore, from which a canal extends to the interior (Hemer \& Nygreen 1967).

Classification: Fungi Imperfecti, Amerosporae.

Number of species known: One.

Notes: Hemer \& Nygreen (1967) knew of no aplanospore of algae containing poratecanalicular structure of the type exhibited by this form, but did not eliminate possible relationship with the algae. Elsik (1992) included Portalites and the type species $P$. confertus in the group Amerosporae of fossil fungi, and gave an emended diagnosis and description of the one-celled, monoporate genus.

1.39.1. Species: P. confertus Hemer \& Nygreen 1967 (Fig. 8L); Index Fungorum Registration Identifier: 562009; Location: Borehole ST-8, Arabian American Oil Company's Stratigraphic Test No. 8 in Saudi Arabia; Age: Early Carboniferous.

1.40. Genus: PSIAMMOPOMOPIOSPORA Sal.-Cheb. \& Locq., C. r. Congr. natn. Socs. sav. Paris, sect. sci., fasc. 1. (Paleobotanique) 105: 191 (1980); Index Fungorum Registration Identifier: 25597; Type: P. globoides Sal.-Cheb. \& Locq. 1980; Current name: MONOPORISPORITES Hammen 1954 fide Kalgutkar \& Jansonius (2000).

Original Diagnosis: Smooth, monoporate, monoapiculate amerospore (Salard-Cheboldaeff \& Locquin 1980).

Classification: Fungi Imperfecti, Amerosporae.

Number of species known: Three (all the three species, including type species, have been transferred to other genera).

Notes: With the transfer of type species of Psiammopomopiospora to Monoporisporites Hammen 1954, the former became a later taxonomic synonym of the latter.

1.40.1. Species: P. ellipsoides Sal.-Cheb. \& Locq. 1980; Index Fungorum Registration Identifier: 108420; Current name: Diporisporites ellipsoides (Sal.-Cheb. \& Locq.) Kalgutkar \& Janson. 2000 fide Kalgutkar \& Jansonius (2000).

1.40.2. Species: P. globoides Sal.-Cheb. \& Locq. 1980; Index Fungorum Registration Identifier: 108421; Current name: Monoporisporites globoides (Sal.-Cheb. \& Locq.) Kalgutkar \& Janson. 2000 fide Kalgutkar \& Jansonius (2000).

1.40.3. Species: P. naviculoides Sal.-Cheb. \& Locq. 1980; Index Fungorum Registration Identifier: 108422; Current name: Diporisporites naviculoides (Sal.-Cheb. \& Locq.) Kalgutkar \& Janson. 2000 fide Kalgutkar \& Jansonius (2000).

1.41. Genus: PSIAMSPORA Sal.-Cheb. \& Locq., C. r. Congr. natn. Socs. sav. Paris, sect. sci., fasc. 1. (Paleobotanique) 105: 191 (1980); Index Fungorum Registration Identifier: 25589; Type: $\boldsymbol{P}$. fusiformis Sal.-Cheb. \& Locq. 1980.

Original Diagnosis: Smooth, fusiform amerospores (Salard-Cheboldaeff \& Locquin 1980).

Classification: Fungi Imperfecti, Amerosporae.

Number of species known: One.

Notes: The type species of Psiamspora, P. fusiformis, was described as inaperturate and fusiform. Inapertisporites Hammen 1954 is only diagnosed as "inaperturate" fungal spores. Hence, apparently, this genus appears to be similar to Inapertisporites. Kalgutkar \& Jansonius (2000), however, got on loan (from Salard-Cheboldaeff) negative of the photograph of Psiamspora fusiformis given in the original publication. They observed the negative and found that that there is no pore or hilum. The spore wall appears to be quite thick, somewhat thinning toward both ends, but with no more than a possible hint of a flat spot. On the basis of their observation of negative, they maintained Psiamspora as a genus for inaperturate, rather thick-walled, smooth amerospores of strictly elongate fusiform shape with narrowly rounded tapered ends.

1.41.1. Species: P. fusiformis Sal.-Cheb. \& Locq. 1980 (Fig. 8M); Index Fungorum Registration Identifier: 107693; Location: Coast of Equatorial Africa, Gulf of Guinea, Cameroon, Africa; 
Age: Early Eocene-Early Miocene.

1.42. Genus: PSILAINAPERTURITES Pierce, Bull. Minn. geol. Surv., Univ. Minn. 42: 44 (1961); Index Fungorum Registration Identifier: 581065; Type: P. psilatus Pierce 1961 (gymnosperm pollen).

Original Diagnosis: Psilate, inaperturate sporomorphs (Pierce 1961).

Classification: Fungi Imperfecti, Amerosporae.

Number of species known: Two [the type species, $P$. psilatus Pierce 1961, is a gymnospermous pollen whereas $P$. ovalis Mathur 1966 [Current name: Monoporisporites mathurii Kalgutkar \& Janson. 2000 fide Kalgutkar \& Jansonius (2000)] is a fungal spore species].

1.42.1. Species: P. ovalis Mathur 1966; Index Fungorum Registration Identifier: 30413; Current name: Monoporisporites mathurii Kalgutkar \& Janson. 2000 fide Kalgutkar \& Jansonius (2000).

1.42.2. Species: P. psilatus Pierce 1961; Botanical affinity: Pinaceae (cf. Laricoipollenites magnus Potonié 1951); Location: Minnesota, U.S.A.; Age: Early Upper Cretaceous (gymnospermous pollen).

1.43. Genus: PSILODIPORITES C.P. Varma \& Rawat, Grana Palynologica 4(1): 131 (1963); Index Fungorum Registration Identifier: 25664; Type: P. hammenii C.P. Varma \& Rawat 1963 (angiospermous pollen).

Original Diagnosis: Diporate pollen grains with psilate exine (which may sometimes appear finely scabrate under high power) (Varma \& Rawat 1963).

Classification: Angiospermae.

Number of species known: Seven (only four species, which are considered as fungal spores, have been included in this paper and all of them have been transferred to other genera).

Notes: Varma \& Rawat (1963) described their specimens as diporate pollen of angiospermous plants. Kalgutkar \& Jansonius (2000) stated that the type of Psilodiporites, P. hammenii, and also $P$. cooksoniae and P. elongatus, named in the same paper, are angiospermous pollen. However, Varma \& Rawat (1963) assigned three species, viz. P. bhardwaji, P. gunniae and P. krempii, to fungal spores which were later transferred by Kalgutkar \& Jansonius (2000) to other genera.

1.43.1. Species: P. bhardwaji C.P. Varma \& Rawat 1963; Index Fungorum Registration Identifier: 106421; Current name: Dyadosporites bhardwaji (C.P. Varma \& Rawat) Kalgutkar \& Janson. 2000 fide Kalgutkar \& Jansonius (2000).

1.43.2. Species: P. ellipsoideus Sal.-Cheb. \& Locq. 1980; Index Fungorum Registration Identifier: 108430; Current name: Dyadosporites ellipsoideus (Sal.-Cheb. \& Locq.) Kalgutkar \& Janson. 2000 fide Kalgutkar \& Jansonius (2000).

1.43.3. Species: P. gunniae C.P. Varma \& Rawat 1963; Index Fungorum Registration Identifier: 106426; Current name: Foveodiporites gunniae (C.P. Varma \& Rawat 1963) Kalgutkar \& Janson. 2000 fide Kalgutkar \& Jansonius (2000).

1.43.4. Species: P. krempii C.P. Varma \& Rawat 1963; Index Fungorum Registration Identifier: 106426; Current name: Biporipsilonites krempii (C.P. Varma \& Rawat) Kalgutkar \& Janson. 2000 fide Kalgutkar \& Jansonius (2000).

1.44. Genus: PUNCTODIPORITES C.P. Varma \& Rawat, Grana Palynologica 4(1): 136 (1963); Index Fungorum Registration Identifier: 28617; Type: P. harrisii C.P. Varma \& Rawat 1963; Current name: FOVEODIPORITES C.P. Varma \& Rawat 1963 fide Kalgutkar \& Jansonius (2000).

Original Diagnosis: Diporate grains with punctate exine (Varma \& Rawat 1963).

Classification: Fungi Imperfecti, Amerosporae.

Number of species known: Four (all the species, including type species, have been transferred to Foveodiporites C.P. Varma \& Rawat 1963). 
Notes: Punctodiporites C.P. Varma \& Rawat 1963 is considered to be a later synonym of Foveodiporites C.P. Varma \& Rawat 1963, as the type species has been transferred to the latter.

1.44.1. Species: P. foedus G. Norris 1997; Index Fungorum Registration Identifier: 483791; Current name: Foveodiporites foedus (G. Norris) Kalgutkar \& Janson. 2000 fide Kalgutkar \& Jansonius (2000).

1.44.2. Species: P. granulatus (Rouse) G. Norris 1997; Index Fungorum Registration Identifier: 483790; Current name: Diporisporites pergranulatus (Rouse) Kalgutkar \& Janson. 2000 fide Kalgutkar \& Jansonius (2000).

1.44.3. Species: P. harrisii C.P. Varma \& Rawat 1963; Index Fungorum Registration Identifier: 483373; Current name: Foveodiporites harrisii (C.P. Varma \& Rawat) Kalgutkar \& Janson. 2000 fide Kalgutkar \& Jansonius (2000).

1.44.4. Species: P. keshii G. Norris 1997 nom. illeg. fide Index Fungorum (2021).; Index Fungorum Registration Identifier: 646217; Notes: This is an illegitimate name as the competing synonym was not validly published.

1.45. Genus: RETICULATASPORITES Ibrahim, Sporenformen des Aegirhorizonts des RuhrReviers; Dissertation, Technische Hochschule zu Berlin 38 (1933); Type: R. facetus Ibrahim 1933 (Pteridophytic spore).

Original Diagnosis: Spores without trilete mark, and with a measurable reticulate sculpture on the spore wall; meshes up to $1 \mu \mathrm{m}$ (Ibrahim 1933).

Classification: Pteridophyta.

Number of species known: Three (the type species, $R$. facetus Ibrahim 1933, is a fossil pteridophytic spore and the other two fungal spore species have been transferred to Inapertisporites Hammen 1954).

1.45.1. Species: $R$. argentinus R.K. Jain 1968; Index Fungorum Registration Identifier: 486770; Current name: Inapertisporites argentinus (R.K. Jain) Kalgutkar \& Janson. 2000 fide Kalgutkar \& Jansonius (2000).

1.45.2. Species: R. cacheutensis R.K. Jain 1968; Index Fungorum Registration Identifier: 646218; Current name: Inapertisporites cacheutensis (R.K. Jain) Kalgutkar \& Janson. 2000 fide Kalgutkar \& Jansonius (2000).

1.45.3. Species: $R$. facetus Ibrahim 1933; Location: Germany; Age: Late Carboniferous (Pteridophytic spore).

1.46. Genus: RETICULATISPORONITES Elsik, Pollen et Spores 10(2): 274 (1968); Index Fungorum Registration Identifier: 21279; Type: $R$. sperryi Elsik 1968; Current name: MONOPORISPORITES Hammen 1954 fide Kalgutkar \& Jansonius (2000).

Original Diagnosis: Elliptical to spatulate, monoporate, reticulate, unicellate fungal spores.

Pore apical (Elsik 1968).

Classification: Fungi Imperfecti, Amerosporae.

Number of species known: One (the single species has been transferred to Monoporisporites Hammen 1954).

1.46.1. Species: $R$. sperryi Elsik 1968; Index Fungorum Registration Identifier: 322416; Current name: Monoporisporites sperryi (Elsik) Kalgutkar \& Janson. 2000 fide Kalgutkar \& Jansonius (2000).

1.47. Genus: RETIDIPORITES C.P. Varma \& Rawat, Grana Palynologica 4(1): 137 (1963); Index Fungorum Registration Identifier: 21280; Type: R. bengalensis C.P. Varma \& Rawat 1963. Original Diagnosis: Diporate grains with reticulate exine (Varma \& Rawat 1963).

Classification: Fungi Imperfecti, Amerosporae.

Number of species known: One.

1.47.1. Species: $\boldsymbol{R}$. bengalensis C.P. Varma \& Rawat 1963 (Fig. 8N); Index Fungorum Registration Identifier: 106439; Location: Western and eastern India, including oil exploration areas in 
West Bengal and Assam, India; Age: Early-Middle Eocene.

1.48. Genus: SACCISPORONITES Kalgutkar \& Janson., AASP Contributions Series (Dallas) 39: 266 (2000); Index Fungorum Registration Identifier: 28624; Type: S. stoughiae (Elsik) Kalgutkar \& Janson. 2000.

Original Diagnosis: One-celled fungal spores, spatulate in overall shape, with a distinct proximal hilum; spore proper with double wall layer, outer layer thicker than inner one, wall thickest at distal end; wall turned out at hilum, forming a lip with a characteristic $90^{\circ}$ angle at pore; whole spore loosely enveloped by a filmy perine, that may be lost in preservation or preparation (Kalgutkar \& Jansonius 2000).

Classification: Fungi Imperfecti, Amerosporae.

Number of species known: One.

Notes: The thin-walled perine is sufficiently persistent to serve as a basis for segregating this genus from other monocellate spore genera. The development of hilum is also diagnostic. Kalgutkar \& Jansonius (2000) opined that Lacrimasporonites stoughiae Elsik is a misfit in Lacrimasporonites Elsik and therefore they proposed Saccisporonites to accommodate it. The genus name was derived from the sac-like membranous perine enveloping the spore.

1.48.1. Species: S. stoughiae (Elsik) Kalgutkar \& Janson. 2000 (Fig. 8O); Index Fungorum Registration Identifier: 483546; Basionym: Lacrimasporonites stoughiae Elsik 1968, Location: Strip mine approximately $11 \mathrm{~km}$ south-west of Rockdale, Milam County, Texas, U.S.A.; Age: Palaeocene.

1.49. Genus: SCABRADIPORITES Y.K. Mathur, Quarterly Journal of the Geological, Mining \& Metallurgical Society of India 38: 43 (1966); Index Fungorum Registration Identifier: 21292; Type: S. varias Y.K. Mathur 1966; Current name: DIPORISPORITES Hammen 1954 fide Kalgutkar \& Jansonius (2000).

Original Diagnosis (Combined description): Amb elliptical, $42 \times 14 \mu \mathrm{m}$ in size, diporate, pores elliptical, larger axis $4 \mu \mathrm{m}$. Exine less than $1 \mu \mathrm{m}$ thick, scabrate, brown (Mathur 1966).

Classification: Fungi Imperfecti, Amerosporae.

Number of species known: One (the single species has been transferred to Diporisporites Hammen 1954).

Notes: The specific name is in reference to the variable nature of the spore wall, pore and size. Kalgutkar \& Jansonius (2000) considered this genus to be a later synonym of Diporisporites Hammen 1954

1.49.1. Species: S. varias Y.K. Mathur 1966; Index Fungorum Registration Identifier: 483818; Current name: Diporisporites varias (Y.K. Mathur) Kalgutkar \& Janson. 2000 fide Kalgutkar \& Jansonius (2000).

1.50. Genus: SENEGALOSPORITES Jardiné \& Magloire, Mémoires du Bureau de Recherches Géologiques et minières, Paris 32: 208 (1965); Index Fungorum Registration Identifier: 21298; Type: S. costatus Jardiné \& Magloire 1965 1965).

Original diagnosis: Spores 1-aperturate; lunate, with beak at one end (Jardiné \& Magloire

Classification: Fungi Imperfecti, Amerosporae.

Number of species known: Two.

1.50.1. Species: S. costatus Jardiné \& Magloire 1965; Index Fungorum Registration Identifier: 111026; Location: Senegal; Age: Cretaceous.

1.50.2. Species: S. taiwanensis T.C. Huang 1981; Index Fungorum Registration Identifier: 115817; Location: Taiwan; Age: Miocene (Talu Shale).

1.51. Genus: SPATULOSPORONITES Z.C. Song in Z.C. Song et al., Fossil Spores and Pollen of China (Beijing) 1: 825 (1999) (nom. inval.) fide Kalgutkar \& Jansonius (2000); Index Fungorum 
Registration Identifier: 28631; Type: S. minutus Z.C. Song, Qian \& Y.H. Zheng in Z.C. Song et al. 1999.

Original Diagnosis: Shape of spore subovate to broadly lanceolate ("spatulo-form"), with at both bottom and top (at poles of long axis) a finger-like cell projecting outward. Spore composed of numerous cells, cells arranged both in rows and columns, which produces a regular lattice-like pattern; all cells of roughly equal size. No pore(s) observed. Overall outline of spore gently undulate. Colour brown (Song, Qian \& Zheng in Song et al. 1999).

Classification: Fungi Imperfecti, Amerosporae.

Number of species known: One (not validly published).

Notes: The generic name was not validly published for lack of a statement where the type was deposited.

1.51.1. Species: S. minutus Z.C. Song, Qian \& Y.H. Zheng in Z.C. Song 1999 (nom. inval.) fide Kalgutkar \& Jansonius (2000); Index Fungorum Registration Identifier: 483853; Location: Eastern China, Northern Jiangsu Basin; Age: Early Tertiary (Third Formation of Funing Group); Notes: Kalgutkar \& Jansonius (2000) opined that the overall appearance of this spore resembles that of Dictyosporites morularis (Sal.-Cheb. \& Locq.) Kalgutkar \& Janson. 2000 or that of Dictyosporites symmetricus (V.S. Ediger) Kalgutkar \& Janson. 2000.

1.52. Genus: SPIROTREMESPORITES Dueñas, Caldasia 12(60): 539-571 (1979); Index Fungorum Registration Identifier: 21309; Type: S. simplex Dueñas 1979.

Synonym: Varisulcosporites Rouse \& Mustard 1997 fide Kalgutkar \& Jansonius (2000), Index Fungorum Registration Identifier: 28419.

Original Diagnosis: Ellipsoidal to elongate fungal spores possessing one or several spiraling furrows (Dueñas 1979).

Emended Diagnosis: Psilate, aseptate fungal spores. The aperture is a single furrow at an angle to the axis of the spore, straight or curved to S-shaped or sigmoidal in outline, or spiral around the spore axis. The furrow can be short and straight, entirely visible on one face of the spore; longer and curved; or long and spiral around the outside of the spore. The spore wall is generally rigid. The spore outline is elongate elliptical to oval, sometimes somewhat reniform in side view, i.e. with bilateral symmetry. The ends of the spore can be similar or dissimilar; one end can be truncated by an attachment scar (Elsik 1990a).

Classification: Fungi Imperfecti, Amerosporae.

Number of species known: 18 [but we accept only 17 species as legitimate because one species, viz. S. disciformis (Sheffy \& Dilcher) Elsik 1990a, has been transferred here to Hypoxylonites Elsik 1990a].

Notes: Dueñas (1979) gave the number of apertures as one or several spiraling furrows. Elsik (1990a) emended the diagnosis to include only spores with one furrow. As contrasted to the straight, longitudinally parallel furrow of Hypoxylonites, Spirotremesporites has a furrow that is set at an angle to the axis of the spore, at least for some part of the length of the furrow. This genus has affinity with Xylariaceae. Varisulcosporites Rouse \& Mustard is a later taxonomic synonym of Spirotremesporites.

1.52.1. Species: S. clinatus Elsik 1990a (Fig. 8P); Index Fungorum Registration Identifier: 130383; Location: The Gulf Coast, U.S.A.; Age: Neogene; Notes: The species epithet is derived from Latin clinatus, bent, sloping, slanted.

1.52.2. Species: S. disciformis (Sheffy \& Dilcher) Elsik 1990a; Index Fungorum Registration Identifier: 130347; Current name: Hypoxylonites disciformis (Sheffy \& Dilcher) R.K. Saxena, Wijayaw., D.Q. Dai, K.D. Hyde \& P.M. Kirk comb. nov. This new combination is described under the section "New species and new combinations"

1.52.3. Species: S. duenasii Elsik 1990a; Index Fungorum Registration Identifier: 130384; Location: Sabana de Bogota, Colombia, South America; Age: Pleistocene; Notes: The species epithet is in honour of Dr. Hernando Dueñas-Jimenez. 
1.52.4. Species: S. ecuatorialis Dueñas 1979; Index Fungorum Registration Identifier: 112635; Location: Sabana de Bogota, Colombia, South America; Age: Pleistocene.

1.52.5. Species: S. ellipticus Nandi \& Shubhra Banerjee in R.K. Saxena 2012 (Fig. 8Q); Index Fungorum Registration Identifier: 519758; Location: Renkte Kawn-Sherlui Road, Mizoram, India; Age: Cretaceous-Tertiary (Mahadeo, Langpar, Cherra Sandstone, Siju, Bhuban, Bokabil, Tipam and Dupitila formations).

1.52.6. Species: S. eminens (Rouse \& Mustard) Kalgutkar \& Janson. 2000 (Fig. 8R); Index Fungorum Registration Identifier: 483550; Basionym: Varisulcosporites eminens Rouse \& Mustard 1997; Location: Strait of Georgia, eastern Vancouver Island, the Fraser River lowlands of southwest British Columbia, Canada and the North-western Washington State, U.S.A.; Age: Late Eocene-Early Oligocene.

1.52.7. Species: S. longiletus Nandi \& Shubhra Banerjee in R.K. Saxena 2012 (Fig. 8S); Index Fungorum Registration Identifier: 519757; Location: Renkte Kawn-Sherlui Road, Mizoram, India; Age: Tertiary (Kherapara, Bhuban, Bokabil, Tipam and Dupitila formations).

1.52.8. Species: S. miocenicus Nandi \& Shubhra Banerjee in R.K. Saxena 2012 (Fig. 8T); Index Fungorum Registration Identifier: 519756; Location: Renkte Kawn-Sherlui Road, Mizoram, India; Age: Tertiary (Kherapara, Bhuban, Bokabil, Tipam, Dupitila and Dihing formations).

1.52.9. Species: S. multiplex Dueñas 1979; Index Fungorum Registration Identifier: 112636; Location: Sabana de Bogota, Colombia; Age: Pleistocene.

1.52.10. Species: S. neogenicus Elsik 1990a; Index Fungorum Registration Identifier: 130385; Location: The Gulf Coast, U.S.A.; Age: Neogene.

1.52.11. Species: S. obliquus Elsik 1990a; Index Fungorum Registration Identifier: 130386; Location: The Green River section, Washington, U.S.A.; Age: Late Eocene.

1.52.12. Species: S. reklawensis Elsik 1990a; Index Fungorum Registration Identifier: 130387; Location: Texas, U.S.A.; Age: Early Middle Eocene (Reklaw Formation of the Claiborne Group); Notes: The species epithet is derived from rock strata in which it occurs.

1.52.13. Species: S. reniformis Nandi \& Shubhra Banerjee in R.K. Saxena 2012 (Fig. 8U); Index Fungorum Registration Identifier: 519755; Location: Renkte Kawn-Sherlui Road, Mizoram, India; Age: Tertiary (Kherapara, Bhuban, Bokabil, Tipam and Dihing formations).

1.52.14. Species: S. shahejiensis Elsik 1990a; Index Fungorum Registration Identifier: 130388; Location: Leowning Province, China; Age: Eocene-Oligocene (Shahejie Formation); Notes: The species epithet is derived from rock strata in which it occurs.

1.52.15. Species: S. simplex Dueñas 1979 (Fig. 8V); Index Fungorum Registration Identifier: 112637; Location: Sabana de Bogota, Colombia, South America; Age: Pleistocene.

1.52.16. Species: S. subovoideus Sheffy \& Dilcher ex Elsik 1990a; Index Fungorum Registration Identifier: 130389; Basionym: Inapertisporites subovoideus Sheffy \& Dilcher 1971: 38, pl. 15, fig. 7 (only upper one of three specimens illustrated: holotype was designated by Elsik 1990a); Location: Henry County, Tennessee, U.S.A.; Age: Middle Eocene (Claiborne Group).

1.52.17. Species: S. tertiarus Nandi et al. in R.K. Saxena 2012 (Fig. 8W); Index Fungorum Registration Identifier: 519754; Location: Renkte Kawn-Sherlui Road, Mizoram, India; Age: Tertiary (Kherapara, Bhuban, Bokabil, Tipam and Dihing formations).

1.52.18. Species: S. yeguaensis Elsik 1990a; Index Fungorum Registration Identifier: 130390; Location: Central Texas, U.S.A.; Age: Late-Middle Eocene (Yegua Formation of the Claiborne Group); Notes: The species epithet is derived from rock strata in which it occurs.

1.53. Genus: STRIADIPORITES C.P. Varma \& Rawat, Grana Palynologica 4(1): 137 (1963); Index Fungorum Registration Identifier: 21324; Type: S. reticulatus C.P. Varma \& Rawat 1963.

Synonym: Stridiporosporites P. Ke \& Z.Y. Shi 1978 fide Norris (1986); Index Fungorum Registration Identifier: 21327.

Original Diagnosis: Diporate grains with striated exine (Varma \& Rawat 1963). 
Emended Diagnosis: Fungal spores of oval to fusiform ambitus and with longitudinally ribbed to broadly reticulate ornament. Two pores, one at each end of the spore on the long axis. One cell; no septa, except occasionally a very thin membrane across inner edge of apertures (Elsik \& Jansonius 1974)

Classification: Fungi Imperfecti, Amerosporae.

Number of species known: 15 (but we accept only 14 species as legitimate because one species, viz. S. anceps G. Norris 1997, has been transferred to Biporipsilonites Kalgutkar \& Janson. 2000).

Notes: This genus includes unicellular, diporate fungal spores with striated spore walls. Elsik \& Jansonius (1974) opined that the original diagnosis ("Diporate grains with striated exine") was too widely stated and was non-committal regarding the botanical affinity of these grains. The muri or longitudinal ridges are generally equal to or wider than the exine thickness. This differentiates the taxon from other diporate fungal spores of similar size and shape with microreticulate, alveolate or punctate exines. Some morphological similarity exists with the spores of Coelomomyces indicus Iyengar, as illustrated in Bland \& Couch (1973). Striadiporites has been recorded in sediments of Eocene-Recent, from areas as widely separated as India, Columbia, and Alaska. Norris (1986) considered that Stridiporosporites P. Ke \& Z.Y. Shi is the later synonym of Striadiporites and formally transferred its type, Stridiporosporites retistriatus, and other species to Striadiporites.

1.53.1. Species: S. anceps G. Norris 1997; Index Fungorum Registration Identifier: 483786; Current name: Biporipsilonites anceps (G. Norris) Kalgutkar \& Janson. 2000 fide Kalgutkar \& Jansonius (2000).

1.53.2. Species: S. asper (P. Ke \& Z.Y. Shi) Kalgutkar \& Janson. 2000; Index Fungorum Registration Identifier: 483558; Basionym: Stridiporosporites asper P. Ke \& Z.Y. Shi 1978; Location: Panshan, Liaoning Province; Beidagang, Tianjin Municipality, Coastal region of Bohai, China; Age: Eocene-Oligocene.

1.53.3. Species: S. bistriatus (P. Ke \& Z.Y. Shi) G. Norris 1986; Index Fungorum Registration Identifier: 126578; Basionym: Stridiporosporites bistriatus P. Ke \& Z.Y. Shi 1978; Location: Panshan, Liaoning Province; Tangjiahe and Beidagang, Tianjin Municipality, Coastal region of Bohai, China (Ke \& Shi 1978), Imperial Nuktak C-22 Well, Mackenzie Delta Region, District of Mackenzie, Northwest Territories, Canada (Norris 1986); Age: Eocene-Oligocene (Ke \& Shi 1978), Palaeogene (Norris 1986).

1.53.4. Species: S. boletelloides Sal.-Cheb. \& Locq. 1980; Index Fungorum Registration Identifier: 108575; Location: Gulf of Equatorial Africa, Gulf of Guinea, Cameroon, Africa; Age: Oligocene.

1.53.5. Species: S. californicus Elsik \& Janson. 1974; Index Fungorum Registration Identifier: 324237; Location: Santa Barbara Channel area, California, U.S.A.; Age: Early Miocene.

1.53.6. Species: S. dolium (P. Ke \& Z.Y. Shi) Kalgutkar \& Janson. 2000; Index Fungorum Registration Identifier: 483559; Basionym: Stridiporosporites dolium P. Ke \& Z.Y. Shi 1978; Location: Panshan, Liaoning Province, Coastal region of Bohai, China; Age: EoceneOligocene.

1.53.7. Species: S. inflexus (P. Ke \& Z.Y. Shi) G. Norris 1986; Index Fungorum Registration Identifier: 126579; Basionym: Stridiporosporites inflexus P. Ke \& Z.Y. Shi 1978, Location: Panshan, Liaoning Province; Tangjiahe and Beidagang, Tianjin Municipality, Coastal region of Bohai, China (Ke \& Shi 1978), Imperial Nuktak C-22 Well, Mackenzie Delta Region, District of Mackenzie, Northwest Territories, Canada (Norris 1986); Age: Eocene-Oligocene (Ke \& Shi 1978), Oligocene (Norris 1986).

1.53.8. Species: S. irregularis Kalgutkar 1993; Index Fungorum Registration Identifier: 483885; Location: Peel River, Yukon Territory, Canada; Age: Late Palaeocene-Early Eocene.

1.53.9. Species: S. minor (Z.C. Song \& Z.H. Sun in Z.C. Song et al.) Z.C. Song et al. 1999; Index Fungorum Registration Identifier: 483846; Basionym: Stridiporosporites minor Z.C. Song \& Z.H. Sun in Z.C. Song et al. 1989; Location: Qingfeng county and Fanxian county of Henan 
Province; Shenxian county of Shandong Province, China; Age: Late Eocene-Middle Oligocene (Shahejie Formation).

1.53.10. Species: S. multistriatus (P. Ke \& Z.Y. Shi) G. Norris 1986; Index Fungorum Registration Identifier: 126580; Basionym: Stridiporosporites multistriatus P. Ke \& Z.Y. Shi 1978; Location: Panshan, Liaoning Province; Coastal region of Bohai, China; Imperial Nuktak C22 Well, Mackenzie Delta Region, District of Mackenzie, Northwest Territories, Canada (Norris 1986); Age: Eocene-Oligocene.

1.53.11. Species: S. reticulatus C.P. Varma \& Rawat 1963 (Fig. 8X); Index Fungorum Registration Identifier: 111055; Location: Western and eastern India, including oil exploration areas in West Bengal and Assam; Age: Late Oligocene-Early Miocene.

1.53.12. Species: S. retistriatus (P. Ke \& Z.Y. Shi) Kalgutkar \& Janson. 2000; Index Fungorum Registration Identifier: 483560; Basionym: Stridiporosporites retistriatus P. Ke \& Z.Y. Shi 1978; Location: Panshan, Liaoning Province; Laoshanggulin and Beidagang, Tianjin Municipality, Coastal region of Bohai, China; Age: Eocene-Oligocene.

1.53.13. Species: S. sanctaebarbarae Elsik \& Janson. 1974; Index Fungorum Registration Identifier: 324238; Location: Santa Barbara Channel, California, U.S.A.; Age: Late Eocene and Oligocene.

1.53.14. Species: $\boldsymbol{S}$. spiralis Kalgutkar \& Janson. 2000; Index Fungorum Registration Identifier: 483561; Basionym: Stridiporosporites spiralis Z.C. Song \& G.X. Li in Z.C. Song et al. 1989; Location: Qingfeng county of Henan Province, China; Age: Late Eocene-Early Oligocene (Shahejie Formation).

1.53.15. Species: S. taiwanensis T.C. Huang 1981; Index Fungorum Registration Identifier: 115822; Location: Taiwan; Age: Miocene (Peliao Sandstone).

1.54. Genus: STRIDIPOROSPORITES P. Ke \& Z.Y. Shi, Early Tertiary Spores and Pollen Grains from the Coastal Region of Bohai (Beijing): 47 (1978); Index Fungorum Registration Identifier: 21327; Type: S. retistriatus P. Ke \& Z.Y. Shi 1978; Current name: STRIADIPORITES C.P. Varma \& Rawat 1963 fide Norris (1986).

Original Diagnosis: Spores one-celled and diporate, pores situated at opposite, acute ends of spore. Pores simple or compound, vestibulate or labiate, etc. Spore surface beset with ridges of various types, ridges regular or irregular, may anastomose to form reticulum (Ke \& Shi 1978).

Classification: Fungi Imperfecti, Amerosporae.

Number of species known: Eight (Since Stridiporosporites P. Ke \& Z.Y. Shi 1978 is a later synonym of Striadiporites C.P. Varma \& Rawat 1963, all its species were transferred to Striadiporites C.P. Varma \& Rawat 1963).

Notes: Song in Song et al. (1999) formulated an emended diagnosis, and simultaneously proposed the species Stridiporosporites dolium as the new type for the genus. This is contrary to the rules. In fact, Song in Song et al. (1999) introduced a heterotypic later homonym. Norris (1986) considered Stridiporosporites to be a later synonym of Striadiporites C.P. Varma \& Rawat 1963 and therefore all species of former were transferred to the latter, i.e. Striadiporites.

1.54.1. Species: S. asper P. Ke \& Z.Y. Shi 1978; Index Fungorum Registration Identifier: 115674; Current name: Striadiporites asper (P. Ke \& Z.Y. Shi) Kalgutkar \& Janson. 2000 fide Kalgutkar \& Jansonius (2000).

1.54.2. Species: S. bistriatus P. Ke \& Z.Y. Shi 1978; Index Fungorum Registration Identifier: 115673; Current name: Striadiporites bistriatus (P. Ke \& Z.Y. Shi) G. Norris 1986 fide Norris (1986).

1.54.3. Species: S. dolium P. Ke \& Z.Y. Shi 1978; Index Fungorum Registration Identifier: 115672; Current name: Striadiporites dolium (P. Ke \& Z.Y. Shi) Kalgutkar \& Janson. 2000 fide Kalgutkar \& Jansonius (2000).

1.54.4. Species: S. inflexus P. Ke \& Z.Y. Shi 1978; Index Fungorum Registration Identifier: 115689; Current name: Striadiporites inflexus (P. Ke \& Z.Y. Shi) G. Norris 1986 fide Norris (1978). 
1.54.5. Species: S. minor Z.C. Song \& Z.H. Sun in Z.C. Song et al. 1989; Index Fungorum Registration Identifier: 485248; Current name: Striadiporites minor (Z.C. Song \& Z.H. Sun in Z.C. Song et al.) Z.C. Song et al. 1999 fide Song et al. 1999.

1.54.6. Species: S. multistriatus P. Ke \& Z.Y. Shi 1978; Index Fungorum Registration Identifier: 115638; Current name: Striadiporites multistriatus (P. Ke \& Z.Y. Shi) G. Norris 1986 fide Norris (1986).

1.54.7. Species: S. retistriatus P. Ke \& Z.Y. Shi 1978; Index Fungorum Registration Identifier: 115637; Current name: Striadiporites retistriatus (P. Ke \& Z.Y. Shi) Kalgutkar \& Janson. 2000 fide Kalgutkar \& Jansonius (2000).

1.54.8. Species: S. spiralis Z.C. Song \& G.X. Li in Z.C. Song et al. 1989; Index Fungorum Registration Identifier: 485249; Current name: Striadiporites spiralis (Z.C. Song \& G.X. Li in Z.C. Song et al.) Kalgutkar \& Janson. 2000 fide Kalgutkar \& Jansonius (2000).

1.55. Genus: TRICHOSPORITES Félix, Zeitschr. Deutsche Geol. Gesell. 46: 273 (1894); Index Fungorum Registration Identifier: 21341; Type: T. conwentzii Félix 1984 (holotype: in Conwentz 1892).

Original Diagnosis: I designate...those fossil conidia as Trichosporites... that resemble the spores of the extant Trichosporium to such an extent that a natural affinity of the latter cannot be excluded (Felix 1894, adopted from Kalgutkar \& Jansonius 2000).

Classification: Fungi Imperfecti, Amerosporae.

Number of species known: One.

Notes: Felix (1894) commented that these conidia greatly resemble those of some Trichosporium species (e.g. T. fuscum Link). Several species of this genus do indeed live on decaying wood, such as T. fuscescens and T. splenicum, while T. fuscum is found on rotting fir branches. These fossil conidia were therefore described as Trichosporites.

1.55.1. Species: T. conwentzii Félix 1984 (Fig. 8Y); Index Fungorum Registration Identifier: 207941; Location: Near Ryedal, Sweden; Age: Late Cretaceous (Holma Sandstone); Notes: This species was named after H. Conwentz.

1.56. Genus: TRIPORISPORITES Hammen, Bol. Geol. (Bogota) 2(1): 83 (1954); Index Fungorum Registration Identifier: 21345; Type: T. minutus Hammen 1954; Current name: INAPERTISPORITES Hammen 1954 fide Kalgutkar \& Jansonius (2000).

Original Diagnosis: Fungal spores with three small pores. (Van der Hammen 1954).

Classification: Fungi Imperfecti, Amerosporae

Number of species known: One (the single species has been transferred to Inapertisporites Hammen 1954).

Notes: Kalgutkar \& Jansonius (2000) interpreted the three pores in the type specimen as being germinal or degradation pores, the number and placement of which have no taxonomic value. For that reason, they included the genus under Inapertisporites.

1.56.1. Species: T. minutus Hammen 1954; Index Fungorum Registration Identifier: 340461; Current name: Inapertisporites triporatus Kalgutkar \& Janson. 2000 fide Kalgutkar \& Jansonius (2000).

1.57. Genus: TRIPORISPORONITES Sheffy \& Dilcher, Palaeontographica Abt. B 133(1-3): 49 (1971); Index Fungorum Registration Identifier: 21346; Type: T. ovalis Sheffy \& Dilcher 1971; Current name: INAPERTISPORITES Hammen 1954 fide Kalgutkar \& Jansonius (2000).

Original Diagnosis: Unicellate fungal spore, psilate, aseptate, triporate. Shape variable (Sheffy \& Dilcher 1971).

Classification: Fungi Imperfecti, Amerosporae

Number of species known: Two (both the species have been transferred to other genera). 
1.57.1. Species: T. ovalis Sheffy \& Dilcher 1971; Index Fungorum Registration Identifier: 111989; Current name: Inapertisporites ovalis Sheffy \& Dilcher 1971 fide Kalgutkar \& Jansonius (2000).

1.57.2. Species: T. verus (P. Ke \& Z.Y. Shi) Norris 1986; Index Fungorum Registration Identifier: 126581; Current name: Biporipsilonites verus (P. Ke \& Z.Y. Shi) Kalgutkar \& Janson. 2000 fide Kalgutkar \& Jansonius (2000).

1.58. Genus: UNCINULITES Pampal., Pilzfunde aus der Augsburger Umgebung 8: 125 (1902); Index Fungorum Registration Identifier: 21350; Type: U. baccarinii Pampal. 1902.

Synonym: Graamspora Sal.-Cheb. \& Locq. 1980 fide Kalgutkar \& Jansonius (2000), Index Fungorum Registration Identifier: 25590.

Original Diagnosis (Combined description): Thin walled, dark, astomate, subglobose

perithecia 30-35 $\mu \mathrm{m}$; with 18-25 simple appendages with hooked tips; appendages nearly equal to perithecium, undivided, black at their base, dark-coloured at the tip (Pampaloni 1902).

Emended Diagnosis: These are small globose bodies measuring 20-22 $\mu \mathrm{m}$ in diameter, covered when ripe, on the outside with straight or curved filiform or spine-like projections - the socalled "appendages" - that attain sometimes to half the diameter of the globose body (Figs. 1-2). Both the central globose body and the projections are brownish in colour. These globose bodies, which are termed "perithecia" by Pampaloni (1902) in the as to be rendered opaque (Fig. 1); in a few cases, however, individuals - evidently in a younger stage of development, as is shown by the almost complete absence of projections - occur that are more transparent, and in these, under high power with a strong illumination, it can be seen that each globose body is not a compound mass of cells, but a single cell (Fig. 2). It seems clear, therefore, that each is to be regarded, not as a perithecium with appendages, but as a single spore with spinous epispore. On the precise determination of these spores I am not able at present to throw any light. It may be pointed out further that neither in the small size of the supposed "perithecium" nor in the nature of the "appendages" do the present objects bear the slightest resemblance to any of the species of Uncinula of the Erysiphaceae (Salmon 1903).

Classification: Fungi Imperfecti, Amerosporae.

Number of species known: Three.

Notes: Salmon (1903) ruled out slightest resemblance of Uncinulites to any of the species of Uncinula of the Erysiphaceae. Graamspora Sal.-Cheb. \& Locq. 1980 is similar to Uncinulites in having spinose or echinate spores, but in Uncinulites the spores are spherical whereas in Graamspora they are oval to elongate in outline (Elsik 1992). Spores in both Graamspora and Uncinulites are unicellular, aporate and typically spinose. The presence of spines on the spore walls is a consistent morphological character that makes them similar enough to group them in the same genus. Hence, Kalgutkar \& Jansonius (2000) considered Graamspora to be a later taxonomic synonym of Uncinulites.

1.58.1. Species: $\boldsymbol{U}$. artuziae V.S. Ediger \& Alisan 1989; Index Fungorum Registration Identifier: 125508; Location: Northern Thrace Basin, Turkey; Age: Middle-Late Eocene to Late Oligocene, Miocene-Pliocene; Notes: The species epithet honours Professor Samime Artüz.

1.58.2. Species: U. baccarinii Pampal. 1902 (Fig. 8Z); Index Fungorum Registration Identifier: 166879; Location: Italy; Age: Middle Miocene (Disodile beds).

1.58.3. Species: U. pezizaffinis (Sal.-Cheb. \& Locq.) Kalgutkar \& Janson. 2000; Index Fungorum Registration Identifier: 483571; Basionym: Graamspora pezizaffinis Sal.-Cheb. \& Locq. 1980; Location: Coast of Equatorial Africa, Gulf of Guinea, Cameroon, Africa; Age: Early Miocene.

1.59. Genus: VARISULCOSPORITES Rouse \& Mustard, Palynology 21: 208 (1997); Index Fungorum Registration Identifier: 28419; Type: V. eminens Rouse \& Mustard 1997; Current name: SPIROTREMESPORITES Dueñaz 1979 fide Kalgutkar \& Jansonius (2000). 
Original Diagnosis: Unicellate, elliptical to fusiform fungal spores, isopolar, with thickened polar caps consisting of polar walls (pl. 11, figs. 5, 6). Apertures single, in form of an elliptical [oblique] sulcus, or a sulcus plus 2 elongate grooves extending between sulcus and poles (Rouse \& Mustard 1997).

Classification: Fungi Imperfecti, Amerosporae.

Number of species known: One (the single species has been transferred to Spirotremesporites Dueñas 1979).

Notes: Spores of the type species, Varisulcosporites eminens, are characterized by the presence of an oblique furrow or groove. Elsik (1990a) emended Spirotremesporites Dueñas 1979, restricting it to spores with a single oblique furrow. Varisulcosporites is therefore considered to be a later taxonomic synonym of Spirotremesporites.

1.59.1. Species: V. eminens Rouse \& Mustard 1997; Index Fungorum Registration Identifier: 463994; Current name: Spirotremesporites eminens (Rouse \& Mustard) Kalgutkar \& Janson. 2000 fide Kalgutkar \& Jansonius (2000).

1.60. Genus: XYLARIASPORITES Debi Mukh., International Journal of Geology, Earth and Environmental Sciences 2(2): 9 (2012); Index Fungorum Registration Identifier: 588470; Type: $X$. lanceolatus Debi Mukh. 2012; Current name: HYPOXYLONITES Elsik 1990a fide hoc loco.

Original Diagnosis: Ascospore hyaline, brown in colour, one celled, dark colour with slit-like germ pore; size ranges 60-70 × 30-40 $\mu \mathrm{m}$ (generally $60 \times 40 \mu \mathrm{m}$ ); spores lanceolate, acute, pointed at the poles; germ pore up to $2 \mu \mathrm{m}$ wide (Mukherjee 2012).

Classification: Fungi Imperfecti, Amerosporae.

Number of species known: One (the single species is here transferred to Hypoxylonites Elsik 1990a).

Notes: The genus name is derived from Xylaria (Xylariaceae).

1.60.1. Species: X. lanceolatus Debi Mukh. 2012; Index Fungorum Registration Identifier: 588483;

Current name: Hypoxylonites lanceolatus (Debi Mukh.) R.K. Saxena, Wijayaw., D. Q. Dai,

K. D. Hyde \& P. M. Kirk comb. nov. This new combination is described under the section

"New species and new combinations".

1.61. Genus: XYLOHYPHITES Kalgutkar \& Sigler, Mycol. Res. 99(5): 514 (1995); Index Fungorum Registration Identifier: 13324; Type: X. verrucosus Kalgutkar \& Sigler 1995.

Original Diagnosis: Conidia in chains formed in acropetal succession, simple, ellipsoidal or cylindrical, pale brown, verrucose, aseptate, occasionally 1-septate; conidia tapering at each end but sometimes with slightly protuberant hilum (Kalgutkar \& Sigler 1995).

Classification: Fungi Imperfecti, Amerosporae.

Number of species known: One.

Notes: Kalgutkar \& Sigler (1995) suggested affinity of Xylohyphites to dematiaceous blastoconidial fungus. The genus is named after its affinity to Xylohypha (Fr.) E.W. Mason in Deighton 1960.

1.61.1. Species: X. verrucosus Kalgutkar \& Sigler 1995 (Fig. 8AA); Index Fungorum Registration Identifier: 414405; Location: Mohgaonkalan, Chhindwara District, Madhya Pradesh, India; Age: Maastrichtian (Deccan Intertrappean Beds); Notes: The species is named after verrucose nature of the conidia.

\section{Didymosporae}

2.1. Genus: AMPULLIFERINITES Kalgutkar \& Sigler, Mycol. Res. 99(5): 515 (1995); Index Fungorum Registration Identifier: 14288; Type: A. axelheibergii Kalgutkar \& Sigler 1995.

Original Diagnosis: Fungus filamentous; filaments in short or long, determinate chains of conidia; filaments traversed by thin and thick-walled septa which alternate along the chains; conidia in arthroconidial chains separated by dark, thick septa; didymosporous, not or slightly constricted at 
medium septum and with truncate ends except the terminal conidium which is rounded at the apex (Kalgutkar \& Sigler 1995).

Classification: Fungi Imperfecti, Didymosporae.

Number of species known: One.

Notes: Kalgutkar \& Sigler (1995) stated that Ampulliferinites appears to be similar to modern Ampulliferina B. Sutton 1969 which has didymosporous, catenate conidia that separate by fragmentation through the thick, dark brown septa along its length of arthroconidial chains. Ampulliferinites is also characterized by the presence of a basal cell with an attachment scar similar to one present in Ampulliferina. The genus name indicates its affinity to Ampulliferina B. Sutton.

2.1.1. Species: A. axelheibergi Kalgutkar \& Sigler 1995 (Fig. 8AB); Index Fungorum Registration Identifier: 412403; Location: Yukon Territory, North-western Canada; Age: Late Eocene or Early Oligocene (Amphitheatre Formation); Notes: The species epithet is after its type locality on Axel Heiberg Island.

2.2. Genus: CALDESITES Puri, Some plant-micro-fossils from the Cretaceous and Paleocene of Nigeria; University of Ibadan Botanical Studies 10: 16 (1963); Index Fungorum Registration Identifier: 92235; Type: C. nigerianus Puri 1963.

Original Diagnosis (combined description): These are two large ascospores of more or less the same size, lying partly one on the other. The larger measures $42 \times$ nearly $20 \mu \mathrm{m}$ (in the broadest part). The smaller spore is only a little smaller in dimensions. Both of these seem to be broken at the basal portion. They are thin-walled and are divided into more or less equal halves by the equatorial wall (Puri 1963).

Classification: Ascomycota, Microthyriales.

Number of species known: One.

2.2.1. Species: C. nigerianus Puri 1963; Index Fungorum Registration Identifier: 647741; Location: Nigeria; Age: Senonian?

2.3. Genus: CLADOSPORITES Félix, Zeitschr. Deutsche Geol. Gesell. 46: 276 (1894); Index Fungorum Registration Identifier: 21055; Type: C. bipartitus Felix 1894.

Original Diagnosis (Combined description): The conidia are elliptical or pear-shaped, smooth and of pale-brownish coloration. They are divided by a septum into two halves, one of which is invariably of roundish, the other of occasionally somewhat rounded three-sided shape. The length of the conidia is 10.2-11.9 $\mu \mathrm{m}$, the width 5.1-6.8 $\mu \mathrm{m}$. Special conidiophores are absent or rudimentary. In the vicinity of the conidia, brown, septate mycelial filaments occur. They are ramified, here and there of gnarled appearance. Clamp connections are absent (Félix 1894).

Classification: Fungi Imperfecti, Didymosporae.

Number of species known: Three.

Notes: According to Félix (1894), the conidia greatly resemble those of Cephalothecium Corda (Current name: Trichothecium Link fide Species Fungorum 2021) and Cladosporium Link. The former has water-clear conidia but the fossil conidia are partially coloured which may have been caused by the state of preservation of the organic substance in the conidial wall. The mycelium of Cephalothecium is very different, and an affiliation of the fossil conidia with the Cladosporieae is therefore more likely. For this reason, it was named Cladosporites.

2.3.1. Species: C. bipartitus Félix 1894 (Fig. 8AC); Index Fungorum Registration Identifier: 201043; Location: Perekeschkul, near Baku, Azerbaijan; Age: Eocene.

2.3.2. Species: C. fasciculatus E.W. Berry 1916; Index Fungorum Registration Identifier: 483913; Location: In silicified vessels of Laurinoxylon of Westmorland Bluff, Trinity River, Texas, U.S.A.; Age: Middle Eocene; Notes: According to Berry (1916), this species is found in abundance in silicified specimens of lauraceous wood from the Yegua Formation, Claiborne Group (Middle Eocene) of Texas and is entirely unlike any previously recorded fossil forms. 
2.3.3. Species: C. oligocaenicus E.W. Berry 1916; Index Fungorum Registration Identifier: 483912; Location: In petrified wood of Palmoxylon cellulosum Knowlton, Bayou Pierre, Mississippi, U.S.A.; Age: Early Oligocene.

2.4. Genus: DICELLAEPORISPORITES Kalgutkar, Review of Palaeobotany \& Palynology (Amsterdam) 97(1-2): 210 (1997); Index Fungorum Registration Identifier: 27773; Type: $\boldsymbol{D}$. poratus Kalgutkar 1997.

Original Diagnosis: Spores dicellate, broadly elliptic-fusiform or ellipsoidal, smooth, constricted or not at the central septum. Cells uniformly broad with rounded ends or broadest near the central septum and gradually tapering towards the apices. Apices of each cell thickened or not. Spores with symmetrically placed germinal pores or lateral germinal slits or furrows. Germinal pores axial or non-axial, one pore or lateral furrow in each cell (Kalgutkar 1997).

Classification: Fungi Imperfecti, Didymosporae.

Number of species known: Three.

Notes: Dicellaeporisporites can be distinguished from Dicellaesporites Elsik 1968 by the presence of a germinal pore in each cell.

2.4.1. Species: D. delitschiapites (Kalgutkar \& Sigler) Kalgutkar 1997; Index Fungorum Registration Identifier: 437901; Basionym: Dicellaesporites delitschiapites Kalgutkar \& Sigler 1995; Location: Kanguk Peninsula, Axel Heiberg Island, Northwest Territories, Canada; Age: Late Palaeocene-Early Eocene; Notes: Spores of this species are generally similar to the ascospores of the living loculoascomycetous and coprophilous Delitschia in the presence of furrows which appear similar to the distinctive germ slits.

2.4.2. Species: D. poratus Kalgutkar 1997 (Fig. 8AD); Index Fungorum Registration Identifier: 437900; Location: Kanguk Peninsula, Axel Heiberg Island, Northwest Territories, Canada; Age: Late Palaeocene-Early Eocene; Notes: The species epithet is derived from the porate cells.

2.4.3. Species: D. siglerae (Kalgutkar) Kalgutkar \& Janson. 2000; Index Fungorum Registration Identifier: 483291; Basionym: Fusiformisporites siglerae Kalgutkar 1997, Location: Kanguk Peninsula, Axel Heiberg Island, Northwest Territories, Canada; Age: Late Palaeocene-Early Eocene; Notes: The species epithet is in honour of Dr. Lynne Sigler.

2.5. Genus: DICELLAESPORITES Elsik, Pollen et Spores 10(2): 269 (1968); Index Fungorum Registration Identifier: 21074; Type: D. popovii Elsik 1968.

Original Diagnosis: Inaperturate, psilate fungal spores. Two cells, uniseptate. Shape variable (Elsik 1968).

Emended Diagnoses: Diagnosis of the genus Dicellaesporites was emended by Sheffy \& Dilcher (1971) and Norris (1986), as follows: Inaperturate fungal spores or algal bodies. Two cells, uniseptate, shape variable. Sculpture psilate to scabrate (Sheffy \& Dilcher 1971); Dicellate, inaperturate, isopolar, equilateral fungal spores. Spore wall laevigate to scabrate (Norris 1986).

Classification: Fungi Imperfecti, Didymosporae.

Number of species known: 68 (but we accept only 58 species as legitimate because eight species have been transferred to other genera and two species, viz. D. bolharensis Soomro et al. 2010 and D. lingulatus Z.C. Song in Z.C. Song et al. 1999 have not been validly published.

Notes: Both Elsik (1968) and Sheffy \& Dilcher (1971) mentioned the shape of Dicellaesporites as "variable". Norris (1986) did not accept it and emended the diagnosis to restrict this genus for dicellate aporate spores with isopolar, equilateral cells. Kalgutkar \& Jansonius (2000) stated that dicellate aporate spores may be isopolar with equilaterally exactly similar cells, but some have unequal cells as well (even on the same mycelium), e.g. in Dicellaesporites paradoxus $\mathrm{P}$. Ke \& Z.Y. Shi 1978 (pl. 1, figs. 10-11), D. inaequabilis Mart.-Hern. \& Tom.-Ort. 1989 (fig. 3c), D. keralaensis P. Kumar 1990 (pl. 1, fig. 12) and Dicellaesporites sp. 1 (Kalgutkar 1997). They, therefore, did not accept Norris' emendation. Elsik (1992) suggested an emended description of the type as having a pore in one of the cells that is not positioned on the axis of symmetry. 
2.5.1. Species: D. aculeolatus Sheffy \& Dilcher 1971 (Fig. 8AE); Index Fungorum Registration Identifier: 111404; Location: Puryear clay pit, $800 \mathrm{~m}$ south of Puryear, Henry County, Tennessee, U.S.A.; Age: Middle Eocene (Claiborne Formation); Notes: The species name refers to the somewhat pointed spore apices.

2.5.2. Species: D. africanus Sal.-Cheb. \& Locq. 1980; Index Fungorum Registration Identifier: 107909; Location: Coast of Equatorial Africa, Gulf of Guinea, Cameroon, Africa; Age: Oligocene-Early Miocene; Notes: Salard-Cheboldaeff \& Locquin (1980) assigned an affinity to Ascomycota.

2.5.3. Species: D. akoyolii V.S. Ediger \& Alisan 1989; Index Fungorum Registration Identifier: 125502; Location: Northern Thrace Basin, Turkey; Age: Middle?-Late Eocene to Late Oligocene, Miocene-Pliocene; Notes: The species epithet is in honour of Dr. Erol Akyol.

2.5.4. Species: D. antarcticus Z.C. Song \& Liu Cao 1994; Index Fungorum Registration Identifier: 483765; Location: King George Island, Antarctica; Age: Late Cretaceous; Notes: The species epithet is derived from the locality of type specimens.

2.5.5. Species: D. appendiculatus Sheffy \& Dilcher 1971; Index Fungorum Registration Identifier: 111405; Current name: Hilidicellites appendiculatus (Sheffy \& Dilcher) Kalgutkar \& Janson. 2000 fide Kalgutkar \& Jansonius (2000).

2.5.6. Species: D. arabimarinus Sat. K. Srivast. \& Al-Tayyar 2013; Index Fungorum Registration Identifier: 818887; Location: northern Arabian Gulf; Age: Aptian to late Albian; Notes: The species epithet is after Arabian Sea, Arabimarinus $=$ of the Arabian Sea.

2.5.7. Species: D. asymmetricus Sal.-Cheb. \& Locq. 1980; Index Fungorum Registration Identifier: 107910; Location: Coast of Equatorial Africa, Gulf of Guinea, Cameroon, Africa; Age: Oligocene-Early Miocene; Notes: Salard-Cheboldaeff \& Locquin (1980) assigned an affinity to Ascomycota.

2.5.8. Species: D. bellus K.F. Wang \& Y.L. Zhang 1986; Index Fungorum Registration Identifier: 646634; Location: China; Notes: Song et al. (1999) cited this name. Since its bibliographic details were not included in the list of references of Song et al. (1999), it is difficult to verify whether this species was validly published. Kalgutkar \& Jansonius (2000) opined that it is similar to Dicellaesporites camerounensis Sal.-Cheb. \& Locq. 1980, D. inaequabilis Mart.Hern. \& Tom.-Ort. 1989 and D. scaber Mart.-Hern. \& Tom.-Ort. 1989.

2.5.9. Species: D. bigeminatus (Sheffy \& Dilcher) Kalgutkar \& Janson. 2000; Index Fungorum Registration Identifier: 483292; Basionym: Multicellaesporites bigeminatus Sheffy \& Dilcher 1971; Location: Puryear clay pit, 800 m south of Puryear, Henry County, Tennessee, U.S.A.; Age: Middle Eocene (Claiborne Formation); Notes: According to Kalgutkar \& Jansonius (2000), the illustrated spores are clearly dicellate and catenate and therefore the species was assigned to Dicellaesporites Elsik 1968, as emended by Dilcher 1971.

2.5.10. Species: D. bolharensis Soomro et al. 2010 (nom. inval.) fide hoc loco; Index Fungorum Registration Identifier: 637483; Location: Borehole Core DH No. 18 in the Sonda Coalfield, Thatta District, Sindh, Pakistan; Age: Palaeocene; Notes: The species name was not validly published because the author did not specify where the holotype was deposited.

2.5.11. Species: D. camerounensis Sal.-Cheb. \& Locq. 1980; Index Fungorum Registration Identifier: 107911; Location: Coast of Equatorial Africa, Gulf of Guinea, Cameroon, Africa; Age: Oligocene; Notes: Salard-Cheboldaeff \& Locquin (1980) assigned an affinity to Ascomycota.

2.5.12. Species: D. campanulatus Ambwani 1983 (Fig. 8AF); Index Fungorum Registration Identifier: 106768; Location: Neyveli Lignite Mine, Cuddalore District, Tamil Nadu, India; Age: Late Miocene or Pliocene; Notes: The species epithet is derived from the campanulate upper cell.

2.5.13. Species: D. cartos P. Ke \& Z.Y. Shi 1978; Index Fungorum Registration Identifier: 115662; Location: Panshan, Liaoning Province, Coastal region of Bohai, China; Age: EoceneOligocene. 

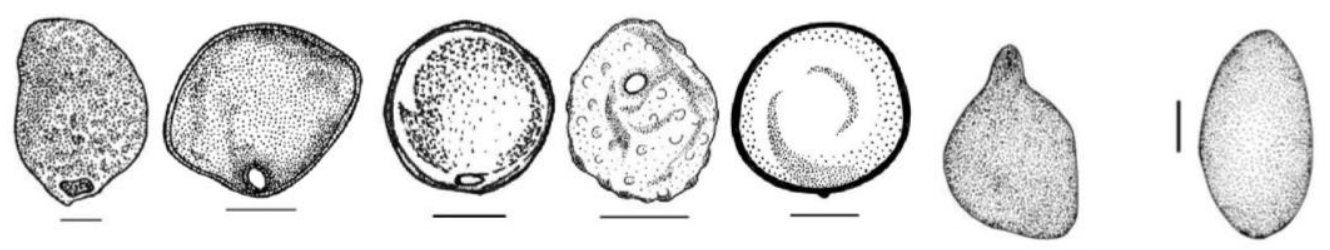

A

B

C

D

$\mathbf{E}$

F

G
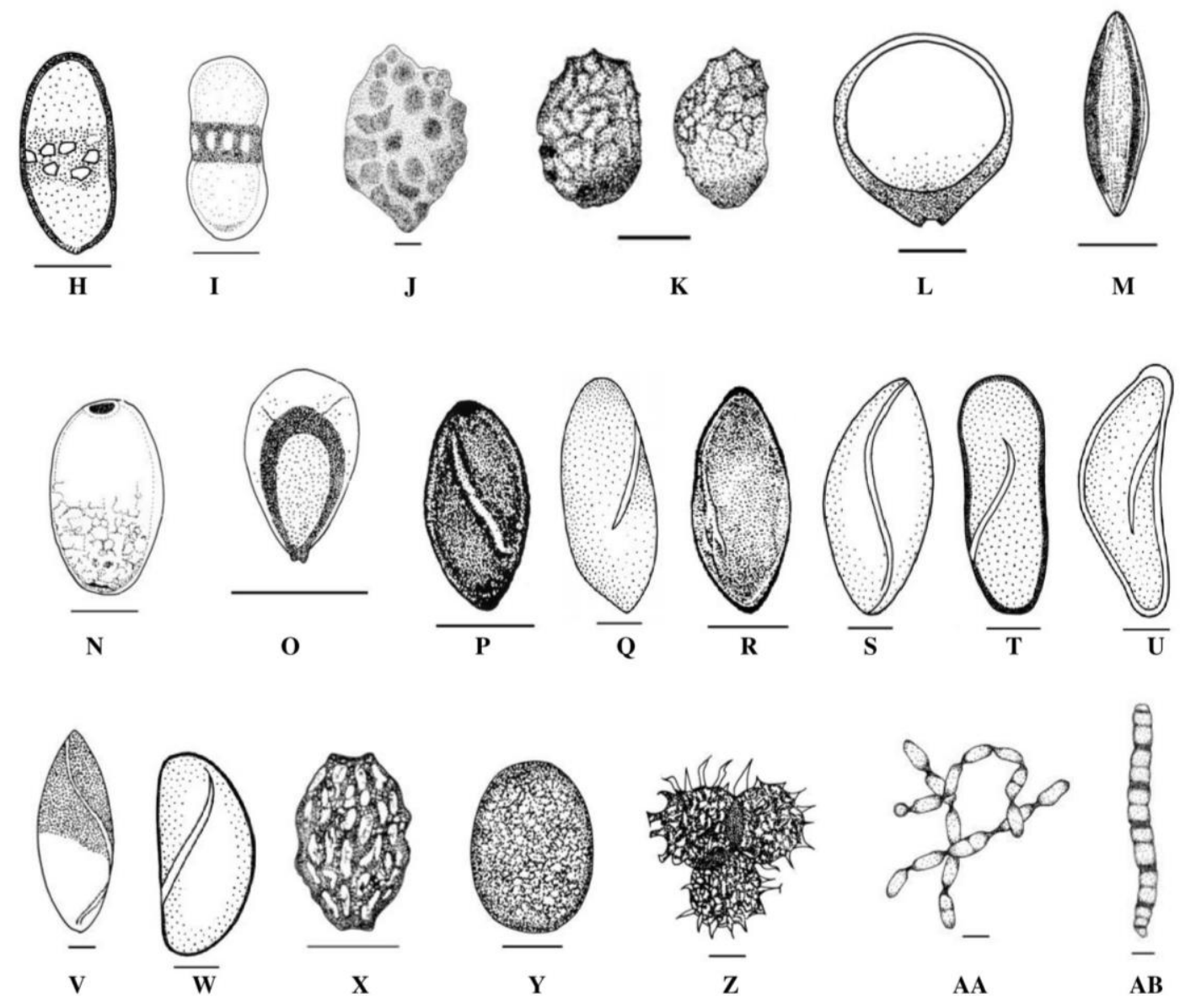

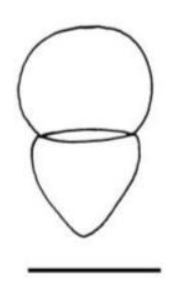

AC

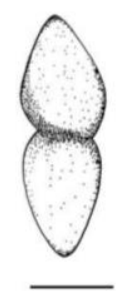

AD
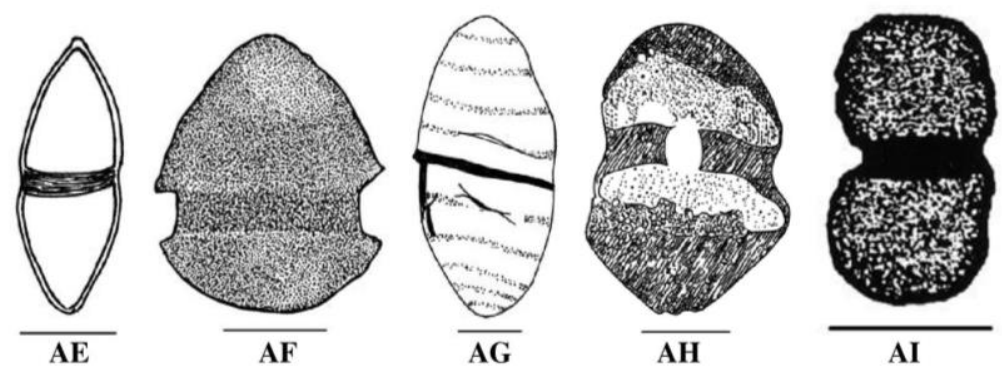

Figure 8 - A-AA Amerosporae. AB-AI Didymosporae. A Monoporisporites ovaliformis (Anil Chandra et al.) Kalgutkar \& Janson. 2000, Bar $=10 \mu \mathrm{m}$. B Monoporisporites psilatus Anil Chandra et al. 1984, Bar $=20 \mu \mathrm{m}$. C Monoporisporites sheffyi Anil Chandra et al. 1984, Bar $=10 \mu \mathrm{m}$. D Monoporisporites singhii A. Gupta 2002, Bar $=10 \mu \mathrm{m}$. E Monoporisporites stoveri Elsik 1968, Bar $=5 \mu \mathrm{m}$. F Nailisporites taiwanensis T.C. Huang 1981, Bar $=10 \mu \mathrm{m}$. G Nigrosporites neyveliensis Debi Mukh. 2012, Bar $=12 \mu \mathrm{m}$. H Palaeoamphisphaerella keralensis Ramanujam \& Srisailam 1980, Bar $=10 \mu \mathrm{m}$. I Palaeoamphisphaerella pirozynskii Ramanujam \& Srisailam 1980, Bar $=10$ $\mu \mathrm{m}$. J Parapotamomyces maydiformis O'Keefe 2017, Bar $=10 \mu \mathrm{m}$. K Pezizasporites taiwanensis T.C. Huang 1981, Bar $=10 \mu \mathrm{m}$. L Portalites confertus Hemer \& Nygreen 1967, Bar $=8 \mu \mathrm{m}$. M Psiamspora fusiformis Sal.-Cheb. \& Locq. 1980, Bar $=8 \mu \mathrm{m}$. N Retidiporites bengalensis C.P. 
Varma \& Rawat 1963, Bar $=15 \mu \mathrm{m}$. O Saccisporonites stoughiae (Elsik) Kalgutkar \& Janson. 2000, Bar $=10 \mu \mathrm{m}$. P Spirotremesporites clinatus Elsik 1990a, Bar $=10 \mu \mathrm{m}$. Q Spirotremesporites ellipticus Nandi \& Shubhra Banerjee 2012, Bar $=6 \mu \mathrm{m}$. R Spirotremesporites eminens (Rouse \& Mustard) Kalgutkar \& Janson. 2000, Bar $=10 \mu \mathrm{m}$. S Spirotremesporites longiletus Nandi \& Shubhra Banerjee 2012, Bar $=7 \mu \mathrm{m}$. T Spirotremesporites miocenicus Nandi \& Shubhra Banerjee 2012, Bar $=5 \mu \mathrm{m}$. U Spirotremesporites reniformis Nandi \& Shubhra Banerjee 2012, Bar $=6 \mu \mathrm{m}$. V Spirotremesporites simplex Dueñas 1979, Bar $=5 \mu \mathrm{m}$. W Spirotremesporites tertiarus Nandi et al. 2012, Bar $=5 \mu \mathrm{m}$. X Striadiporites reticulatus C.P. Varma \& Rawat 1963, Bar $=20 \mu \mathrm{m}$. Y Trichosporites conwentzii Félix 1984, Bar $=5 \mu \mathrm{m}$. Z Uncinulites baccarinii Pampal. 1902, Bar $=8$ $\mu \mathrm{m}$. AA Xylohyphites verrucosus Kalgutkar \& Sigler 1995, Bar $=5 \mu \mathrm{m}$. AB Ampulliferinites axelheibergi Kalgutkar \& Sigler 1995, Bar $=10 \mu \mathrm{m}$. AC Cladosporites bipartitus Félix 1894, Bar $=$ $7 \mu \mathrm{m}$. AD Dicellaeporisporites poratus Kalgutkar 1997, Bar $=10 \mu \mathrm{m}$. AE Dicellaesporites aculeolatus Sheffy \& Dilcher 1971, Bar $=5 \mu \mathrm{m}$. AF Dicellaesporites campanulatus Ambwani 1983, Bar $=20 \mu \mathrm{m}$. AG Dicellaesporites classicus R.K. Saxena \& S.K.M. Tripathi 2011, Bar $=25$ $\mu \mathrm{m}$. AH Dicellaesporites constrictus S.C.D. Sah \& R.K. Kar 1974, Bar $=20 \mu \mathrm{m}$. AI Dicellaesporites disphaericus Sheffy \& Dilcher 1971, Bar $=10 \mu \mathrm{m}$.

2.5.14. Species: D. cellaequalis Kalgutkar 1993; Index Fungorum Registration Identifier: 483862; Location: Peel River, Yukon Territory, Canada; Location: Peel River, Yukon Territory, Canada; Age: Late Palaeocene-Early Eocene; Notes: The species epithet is derived from the Latin, cella, cell; aequalis, equal, referring to the spores having both cells equal.

2.5.15. Species: D. classicus R.K. Saxena \& S.K.M. Tripathi 2011 (Fig. 8AG); Index Fungorum Registration Identifier: 561702; Location: Sonapur-Badarpur Road Section, Jaintia Hills, Meghalaya and Cachar District, Assam, India; Age: Early Miocene (Bhuban Formation)

2.5.16. Species: D. constrictus S.C.D. Sah \& R.K. Kar 1974 (Fig. 8AH); Index Fungorum Registration Identifier: 519767; Location: Palana, Bikaner District, Rajasthan, India; Age: Early Eocene (Palana lignite).

2.5.17. Species: D. crassiseptus Ramanujam \& Srisailam 1980; Index Fungorum Registration Identifier: 108842; Current name: Hilidicellites dubius (Ramanujam \& Srisailam) Kalgutkar \& Janson. 2000 fide Kalgutkar \& Jansonius (2000).

2.5.18. Species: D. delitschiapites Kalgutkar \& Sigler 1995; Index Fungorum Registration Identifier: 412946; Current name: Dicellaeporisporites delitschiapites (Kalgutkar \& Sigler) Kalgutkar 1997 fide Kalgutkar (1997).

2.5.19. Species: D. disphaericus Sheffy \& Dilcher 1971 (Fig. 8AI); Index Fungorum Registration Identifier: 111406; Location: Puryear clay pit, $800 \mathrm{~m}$ south of Puryear, Henry County, Tennessee, U.S.A.; Age: Middle Eocene (Claiborne Formation).

2.5.20. Species: D. dolium Z.C. Song 1985; Index Fungorum Registration Identifier: 637484; Location: Huangshi and Dafengshan, Qaidam Basin, Qinghai Province, China; Age: Palaeocene-Late Eocene; Early Miocene-Late Pliocene.

2.5.21. Species: D. ellipticus K.P. Jain \& R.K. Kar 1979 (Fig. 9A); Index Fungorum Registration Identifier: 112269; Location: Papanasam and Varkala, Thiruvananthapuram District, Kerala, India; Age: Miocene.

2.5.22. Species: D. elongatus Ramanujam \& K.P. Rao 1978 (Fig. 9B); Index Fungorum Registration Identifier: 115060; Location: Kannur, Kerala, India; Age: Miocene (Quilon and Warkalli beds); Notes: The elongate nature of the cells and the considerably thickened transverse septum are the important features of this species.

2.5.23. Species: D. elongatus P. Kumar 1990; Index Fungorum Registration Identifier: 126551; Current name: Dicellaesporites perelongatus Kalgutkar \& Janson. 2000 fide Kalgutkar \& Jansonius (2000).

2.5.24. Species: D. elongatus Z.C. Song 1985; Index Fungorum Registration Identifier: 485267; Current name: Dicellaesporites largelongatus Kalgutkar \& Janson. 2000 fide Kalgutkar \& Jansonius (2000). 
2.5.25. Species: D. elsikii B. Samant in R.K. Saxena 2009 (Fig. 9C); Index Fungorum Registration Identifier: 515018; Synonym: Dicellaesporites elsikii B. Samant 2000 (nom. inval.) fide Saxena (2009); Location: Near Bhavnagar, Cambay Basin, Gujarat, India; Age: Early Eocene (Kharsalia Clay Formation).

2.5.26. Species: D. foratus Zhong Y. Zhang 1980; Index Fungorum Registration Identifier: 485000; Location: Lunpola Basin, northern Xizang Plateau, Xizang, China; Age: Oligocene (Niubao Formation).

2.5.27. Species: D. fragilis Sheffy \& Dilcher 1971; Index Fungorum Registration Identifier: 111407; Location: Puryear clay pit, $800 \mathrm{~m}$ south of Puryear, Henry County, Tennessee, U.S.A.; Age: Middle Eocene (Claiborne Formation).

2.5.28. Species: D. fusiformis Sheffy \& Dilcher 1971 (Fig. 9D); Index Fungorum Registration Identifier: 111408; Location: Puryear clay pit, $800 \mathrm{~m}$ south of Puryear, Henry County, Tennessee, U.S.A.; Age: Middle Eocene (Claiborne Formation).

2.5.29. Species: D. granulatus Z.C. Song 1985; Index Fungorum Registration Identifier: 637485; Location: Dafengshan, Qaidam Basin, Qinghai Province, China; Age: Early Pliocene.

2.5.30. Species: D. granuliformis Sheffy \& Dilcher 1971; Index Fungorum Registration Identifier: 111409; Location: Puryear clay pit, 800 m south of Puryear, Henry County, Tennessee,

U.S.A.; Age: Middle Eocene (Claiborne Formation).

2.5.31. Species: D. guineensis Sal.-Cheb. \& Locq. 1980; Index Fungorum Registration Identifier: 107678; Location: Coast of Equatorial Africa, Gulf of Guinea, Cameroon, Africa; Age: Oligocene-Early Miocene; Notes: Salard-Cheboldaeff \& Locquin (1980) assigned an affinity to Ascomycota. Kalgutkar \& Jansonius (2000) stated that there is a suggestion in the photograph of (roughly) longitudinal striations running from one end of the spore to the other. Although these may represent foreign tissue under- or overlying the specimen, a similar feature was reported for $D$. striatus.

2.5.32. Species: D. himachalensis R.K. Saxena \& A.P. Bhattach. 1990 (Fig. 9E); Index Fungorum Registration Identifier: 519768; Location: Manjhi Khad section, Dharmsala, Kangra District, Himachal Pradesh, India; Age: Oligocene-Early Miocene.

2.5.33. Species: D. himalayaensis A. Gupta 2002 (Fig. 9F); Index Fungorum Registration Identifier: 540463; Location: Jamtah Road Section, Sirmaur District, Himachal Pradesh, India; Age: Eocene (Subathu Formation).

2.5.34. Species: D. inaequabilis Mart.-Hern. \& Tom.-Ort. 1989; Index Fungorum Registration Identifier: 483798; Location: Piedras Negras, Coahuila State, Mexico; Age: Maastrichtian; Notes: The species epithet indicates its cells are of different size.

2.5.35. Species: D. inaequalis (Y.N.R. Varma \& R.S. Patil) Kalgutkar \& Janson. 2000 (Fig. 9G); Index Fungorum Registration Identifier: 483293; Basionym: Dyadosporonites inaequalis Y.N.R. Varma \& R.S. Patil 1985; Location: Tonakkal area, Thiruvananthapuram District, Kerala, India; Age: Miocene; Notes: Dyadosporonites inaequalis is characterized by having unequal-sized dicellate condition. Kalgutkar \& Jansonius (2000) observed that the photograph of the type does not have axial pores at both ends as suggested by the original generic assignment. The two "pores" mentioned in the original description apparently refer to two cracks in the central septum. This form was therefore transferred to Dicellaesporites.

2.5.36. Species: D. indicus A. Gupta 2002 (Fig. 9H); Index Fungorum Registration Identifier: 540464; Location: Jamtah Road Section, Sirmaur District, Himachal Pradesh, India; Age: Eocene (Subathu Formation).

2.5.37. Species: D. jainii R.K. Saxena \& S.K.M. Tripathi 2011 (Fig. 9I); Index Fungorum Registration Identifier: 519938; Location: Barmer Hill, Barmer District, Rajasthan, India; Age: Palaeocene (Barmer Sandstone); Notes: The species epithet honours Dr. K.P. Jain, Birbal Sahni Institute of Palaeosciences, Lucknow, India.

2.5.38. Species: D. keralensis P. Kumar 1990 (Fig. 9J); Index Fungorum Registration Identifier: 126552; Location: Padappakkara, Kollam District, Kerala, India; Age: Early-Middle Miocene. 
2.5.39. Species: D. largelongatus Kalgutkar \& Janson. 2000; Index Fungorum Registration Identifier: 483294; Basionym: Dicellaesporites elongatus Z.C. Song 1985; Location: Huatugou and Dafengshan, Qaidam Basin, Qinghai Province, China; Age: Palaeocene - Late Eocene; Early-Late Miocene; Notes: Dicellaesporites elongatus Z.C. Song 1985 was a later homonym of Dicellaesporites elongatus Ramanujam \& K.P. Rao 1978. Hence, Kalgutkar \& Jansonius (2000) proposed a new name (D. largelongatus) for it. Spores of Dicellaesporites reniformis Zhong Y. Zhang 1980 are larger, and somewhat reniform.

2.5.40. Species: D. lenghuensis Z.C. Song 1985; Index Fungorum Registration Identifier: 637486; Location: Eboliang and Dafengshan, Qaidam Basin, Qinghai Province, China; Age: Palaeocene - Late Eocene; Early Miocene - Early Pliocene.

2.5.41. Species: D. levis Sheffy \& Dilcher 1971 (Fig. 9K); Index Fungorum Registration Identifier: 111410; Location: Puryear clay pit, $800 \mathrm{~m}$ south of Puryear, Henry, County, Tennessee, U.S.A.; Age: Middle Eocene (Claiborne Formation).

2.5.42. Species: D. lingulatus Z.C. Song in Z.C. Song et al. 1999 (nom. inval.) fide Kalgutkar \& Jansonius (2000); Index Fungorum Registration Identifier: 483822; Location: Coastal area of Bohai Sea, China; Age: Middle-Late Oligocene (Shahejie-Dongying formations); Notes: This name was not validly published because the author did not specify where the holotype is deposited, and did not provide a Latin description or its English translation.

2.5.43. Species: D. littoralis Sal.-Cheb. \& Locq. 1980; Index Fungorum Registration Identifier: 107912; Location: Coast of Equatorial Africa, Gulf of Guinea, Cameroon, Africa; Age: Oligocene-Early Miocene; Notes: Salard-Cheboldaeff \& Locquin (1980) assigned an affinity to Ascomycota.

2.5.44. Species: D. longus (Trivedi \& C.L. Verma) Kalgutkar \& Janson. 2000; Index Fungorum Registration Identifier: 483295; Basionym: Teleutosporites longus Trivedi \& C.L. Verma 1970 (nom. inval.); Location: Near Kuala Lumpur, Malaya; Age: Eocene; Notes: The species name was not validly published by Trivedi \& Verma (1970) because it was not assigned to a validly published generic name.

2.5.45. Species: D. magnus Doub. \& D. Pons 1973; Index Fungorum Registration Identifier: 485252; Current name: Reduviasporonites magnus (Doub. \& D. Pons) Kalgutkar \& Janson. 2000 fide Kalgutkar \& Jansonius (2000).

2.5.46. Species: D. major P. Ke \& Z.Y. Shi 1978; Index Fungorum Registration Identifier: 115661; Location: Beidagang, Trianjin Municipality, Coastal region of Bohai, China; Age: EoceneOligocene.

2.5.47. Species: D. megafusiformis Z.C. Song \& G.X. Li in Z.C. Song et al. 1989; Index Fungorum Registration Identifier: 637487; Location: Qingfeng county of Henan Province, China; Age: Late Eocene (Shahejie Formation).

2.5.48. Species: D. minutus R.K. Kar \& R.K. Saxena 1976 (Fig. 9L); Index Fungorum Registration Identifier: 112270; Location: Bhuj-Lakhpat Road, Matanomadh Village, District of Kutch, Gujarat, India; Age: Palaeocene.

2.5.49. Species: D. mollis P. Ke \& Z.Y. Shi 1978; Index Fungorum Registration Identifier: 115660; Location: Panshan, Liaoning Province, Coastal region of Bohai, China; Age: EoceneOligocene; Notes: Elsik et al. (1990) considered that Dicellaesporites mollis possibly is an aberrant form of Anatolinites dongyingensis.

2.5.50. Species: D. nakomanii V.S. Ediger \& Alisan 1989; Index Fungorum Registration Identifier: 125504; Location: Northern Thrace Basin, Turkey; Age: Middle?-Late Eocene to Late Oligocene, Miocene-Pliocene; Notes: The species epithet is in honour of Professor Eran Nakoman.

2.5.51. Species: D. navicularis K.F. Wang \& Y.L. Zhang 1986; Index Fungorum Registration Identifier: 637487; Location: China; Notes: Song et al. (1999) cited this name. Since its bibliographic details were not included in the list of references of Song et al. (1999), it is difficult to verify whether this species was validly published. Kalgutkar \& Jansonius (2000) 
opined that it is similar to Dicellaesporites obnixus G. Norris 1986 and D. perelongatus Kalgutkar \& Janson. 2000.

2.5.52. Species: D. nodusus V.S. Ediger 1981; Index Fungorum Registration Identifier: 107913; Location: Thrace Basin, Turkey; Age: Late Eocene-Oligocene, Miocene-Pliocene.

2.5.53. Species: D. oblongatus Z.C. Song \& Liu Cao 1994; Index Fungorum Registration Identifier: 483764; Location: King George Island, Antarctica; Age: Late Cretaceous; Notes: The species epithet is derived from ellipsoidal shape of spores.

2.5.54. Species: D. obnixus G. Norris 1986; Index Fungorum Registration Identifier: 126571; Location: Imperial Nuktak C-22 Well, Mackenzie Delta Region, District of Mackenzie, Northwest Territories, Canada; Age: Eocene; Notes: Kalgutkar \& Jansonius (2000) stated that although the holotype appears to be dicellate, other specimens appear to have (3?-) 4 cells. The latter also seem to have a curved longitudinal axis.

2.5.55. Species: D. ovatus Z.C. Song \& H.C. Luo in Z.C. Song et al. 1989; Index Fungorum Registration Identifier: 637489; Location: Shenxian county of Shandong Province, China; Age: Late Eocene-Middle Oligocene (Shahejie Formation).

2.5.56. Species: D. paradoxus P. Ke \& Z.Y. Shi 1978; Index Fungorum Registration Identifier: 115659; Current name: Disparidicellites paradoxus (P. Ke \& Z.Y. Shi) Kalgutkar \& Janson. 2000 fide Kalgutkar \& Jansonius (2000).

2.5.57. Species: D. perelongatus Kalgutkar \& Janson. 2000 (Fig. 9M); Index Fungorum Registration Identifier: 483296; Basionym: Dicellaesporites elongatus P. Kumar 1990; Location: Padappakkara, Kollam District, Kerala, India; Age: Early-Middle Miocene; Notes: Dicellaesporites elongatus P. Kumar 1990 was a later homonym of Dicellaesporites elongatus Ramanujam \& K.P. Rao 1978. Hence, Kalgutkar \& Jansonius (2000) proposed a new name (D. perelongatus) for it.

2.5.58. Species: D. popovii Elsik 1968 (Fig. 9N); Index Fungorum Registration Identifier: 312948; Location: Strip mine approximately $11 \mathrm{~km}$ southwest of Rockdale, Milam County, Texas, U.S.A.; Age: Palaeocene.

2.5.59. Species: D. reniformis Zhong Y. Zhang 1980; Index Fungorum Registration Identifier: 485001; Location: Lunpola Basin, northern Xizang Plateau, Xizang, China; Age: Oligocene (Niubao Formation).

2.5.60. Species: D. rinconii Doub. \& D. Pons 1973; Index Fungorum Registration Identifier: 637490; Location: Cerrejon basin, Colombia, South America; Age: Palaeocene-Eocene; The species is dedicated to M. Rincon, curator of the "Servicio Geológico Nacional" collection in Bogota.

2.5.61. Species: D. scaber Mart.-Hern. \& Tom.-Ort. 1989; Index Fungorum Registration Identifier: 483797; Location: Piedras Negras, Coahuila State, Mexico; Age: Maastrichtian; Notes: The species epithet indicates its rough ornamentation.

2.5.62. Species: D. septiconstrictus Kalgutkar 1993; Index Fungorum Registration Identifier: 483863; Location: Peel River, Yukon Territory, Canada; Age: Late Palaeocene-Early Eocene; Notes: The species epithet is derived from the Latin, septum, wall; constrictus, contracted, referring to the spores being constricted at the septum.

2.5.63. Species: D. singhii R.K. Saxena \& S.K.M. Tripathi 2011 (Fig. 9O); Index Fungorum Registration Identifier: 519939; Location: Hoshiarpur-Una Road Section, Hoshiarpur District, Punjab and Una District, Himachal Pradesh, India; Age: Pliocene (Upper Siwalik); Notes: The species epithet honours Dr. H.P. Singh, Birbal Sahni Institute of Palaeosciences, Lucknow, India.

2.5.64. Species: D. striatus P. Ke \& Z.Y. Shi 1978; Index Fungorum Registration Identifier: 115658; Current name: Fusiformisporites striatus (P. Ke \& Z.Y. Shi) Kalgutkar \& Janson. 2000 fide Kalgutkar \& Jansonius (2000).

2.5.65. Species: D. subaequatus Zhong Y. Zhang 1980; Index Fungorum Registration Identifier: 484999; Location: Lunpola Basin, northern Xizang Plateau, Xizang, China; Age: Oligocene (Niubao Formation). 
2.5.66. Species: D. suborbicularis Z.C. Song \& G.X. Li in Z.C. Song et al. 1989; Index Fungorum Registration Identifier: 637491; Location: Heze County of Shandong Province, China; Age: Late Oligocene (Dongying Formation).

2.5.67. Species: D. vermae R.K. Saxena, Wijayaw., D.Q. Dai, K.D. Hyde \& P.M. Kirk sp. nov. (Fig. 9P); This new species is described under the section "New species and new combinations".

2.5.68. Species: D. volubilis P. Ke \& Z.Y. Shi 1978; Index Fungorum Registration Identifier: 115657; Location: Panshan, Liaoning Province, Coastal region of Bohai, China; Age: Eocene-Oligocene.

2.6. Genus: DIDYMOPORISPORONITES Sheffy \& Dilcher Palaeontographica Abt. B 133(1-3): 42 (1971); Index Fungorum Registration Identifier: 21077; Type: D. psilatus Sheffy \& Dilcher 1971.

Original Diagnosis: Spores dicellate, uniseptate, pore at apex of one cell. Sculpture psilate to punctate, shape variable (Sheffy \& Dilcher 1971).

Emended Diagnosis: Generally small to medium dicellate conidia; the proximal cell much thinner walled and smaller than the distal one, with a distinct pore or hilum (Kalgutkar \& Jansonius 2000).

Classification: Fungi Imperfecti, Didymosporae.

Number of species known: 25 (but we accept only ten species as legitimate because fifteen species have been transferred to other genera).

Notes: Kalgutkar \& Jansonius (2000) emended the diagnosis of Didymoporisporonites to include dicellate spores with dissimilar cells only, of which only the smaller is porate. In the past, a number of spores (e.g. D. didymus, D. oblongatus) with equal or near-equal cells, of which one is porate, were also assigned to this genus. Elsik (1992) intended to propose a new "Poridicellites" to accommodate the latter type. Kalgutkar \& Jansonius (2000) considered that the "pore" in those forms actually is a hilum, and therefore transferred spores of this type to the new Hilidicellites.

2.6.1. Species: D. conicus Kalgutkar 1997; Index Fungorum Registration Identifier: 437904; Location: Kanguk Peninsula, Axel Heiberg Island, Northwest Territories, Canada; Age: Late Palaeocene-Early Eocene; Notes: The species epithet is derived from conical shape of small cell.

2.6.2. Species: D. crassiseptus Sal.-Cheb. \& Locq. 1980; Index Fungorum Registration Identifier: 107922; Current name: Hilidicellites crassiseptus (Sal.-Cheb. \& Locq.) Kalgutkar \& Janson. 2000 fide Kalgutkar \& Jansonius (2000).

2.6.3. Species: D. didymus Sal.-Cheb. \& Locq. 1980; Index Fungorum Registration Identifier: 107923; Current name: Dyadosporites hilatus Kalgutkar \& Janson. 2000 fide Kalgutkar \& Jansonius (2000).

2.6.4. Species: D. discitypicus (P. Ke \& Z.Y. Shi) Kalgutkar \& Janson. 2000; Index Fungorum Registration Identifier: 483309; Basionym: Multicellaesporites discitypicus P. Ke \& Z.Y. Shi 1978; Location: Panshan, Liaoning Province, Coastal region of Bohai, China; Age: EoceneOligocene; Notes: Kalgutkar \& Jansonius (2000) stated that the photograph of the type specimen shows a tear in the equatorial region of the spore, that apparently was interpreted as a septum; hence the spore was called "three-celled". They interpreted that the type is twocelled, one cell much smaller and thinner walled than the other. The small cell has subtle features suggesting the presence of a terminal pore.

2.6.5. Species: D. discors Kalgutkar 1993; Index Fungorum Registration Identifier: 483866; Location: Peel River, Yukon Territory, Canada; Age: Late Palaeocene-Early Eocene; Notes: Kalgutkar \& Jansonius (2000) adjusted the original spelling discordis of the specific epithet to discors, as grammatically the genitive case of an adjective is not applicable in the context used. The species epithet is derived from the Latin, discors, different, referring to the unequal cells. 
2.6.6. Species: D. elegans P. Ke \& Z.Y. Shi 1978; Index Fungorum Registration Identifier: 115654; Location: Panshan, Liaoning Province, Coastal region of Bohai, China; Age: EoceneOligocene.

2.6.7. Species: D. gigas Kalgutkar \& Janson. 2000 (Fig. 9Q); Index Fungorum Registration Identifier: 483310; Basionym: Lacrimasporonites magnus R.K. Saxena \& H.P. Singh 1983; Location: Hoshiarpur-Una Road section, near Bankhandi, Hoshiarpur District, Punjab, India; Age: Miocene-Pliocene; Notes: Kalgutkar \& Jansonius (2000) transferred it to Didymoporisporonites because of a septum at one end, as well as the apparent presence of a pore at the same end.

2.6.8. Species: D. henanensis Z.C. Song \& G.X. Li in Z.C. Song et al. 1989; Index Fungorum Registration Identifier: 485262; Current name: Hilidicellites henanensis (Z.C. Song \& G.X. Li in Z.C. Song et al.) Kalgutkar \& Janson. 2000 fide Kalgutkar \& Jansonius (2000).

2.6.9. Species: D. inaequalis Sheffy \& Dilcher 1971; Index Fungorum Registration Identifier: 111421; Locality: Puryear clay pit, $800 \mathrm{~m}$ south of Puryear, Henry County, Tennessee, U.S.A.; Age: Middle Eocene (Claiborne Formation); Notes: According to Sheffy \& Dilcher (1971), the spore is similar in shape and dimensions to Shortensis memorabilis [Current name: Vizella memorabilis (Dilcher) Selkirk 1972] (Dilcher (1965).

2.6.10. Species: D. indicus Anil Chandra et al. 1984; Index Fungorum Registration Identifier: 106776; Current name: Hilidicellites indicus (Anil Chandra et al.) Kalgutkar \& Janson. 2000 fide Kalgutkar \& Jansonius (2000).

2.6.11. Species: D. lacrymosus Sal.-Cheb. \& Locq. 1980; Index Fungorum Registration Identifier: 107924; Current name: Hilidicellites lacrymosus (Sal.-Cheb. \& Locq.) Kalgutkar \& Janson. 2000 fide Kalgutkar \& Jansonius (2000).

2.6.12. Species: D. longus (R.K. Kar) Kalgutkar \& Janson. 2000 (Fig. 9R); Index Fungorum Registration Identifier: 483311; Basionym: Lacrimasporonites longus R.K. Kar 1979; Location: Barkhana nala cutting near Sarangwara, Kutch District, Gujarat, India; Age: Oligocene.

2.6.13. Species: D. mucronatus Sal.-Cheb. \& Locq. 1980; Index Fungorum Registration Identifier: 107925; Current name: Dyadosporites mucronatus (Sal.-Cheb. \& Locq.) Kalgutkar \& Janson. 2000 fide Kalgutkar \& Jansonius (2000).

2.6.14. Species: D. normalis Sheffy \& Dilcher 1971; Index Fungorum Registration Identifier: 111422; Current name: Hilidicellites normalis (Sheffy \& Dilcher) Kalgutkar \& Janson. 2000 fide Kalgutkar \& Jansonius (2000).

2.6.15. Species: D. oblongatus P. Ke \& Z.Y. Shi 1978; Index Fungorum Registration Identifier: 115671; Current name: Hilidicellites oblongatus P. Ke \& Z.Y. Shi) Kalgutkar \& Janson. 2000 fide Kalgutkar \& Jansonius (2000).

2.6.16. Species: D. obtectus Sheffy \& Dilcher 1971; Index Fungorum Registration Identifier: 111423; Current name: Hilidicellites obtectus (Sheffy \& Dilcher) Kalgutkar \& Janson. 2000 fide Kalgutkar \& Jansonius (2000).

2.6.17. Species: D. ovatus P. Ke \& Z.Y. Shi 1978; Index Fungorum Registration Identifier: 115653; Current name: Hilidicellites ovatus (P. Ke \& Z.Y. Shi) Kalgutkar \& Janson. 2000 fide Kalgutkar \& Jansonius (2000).

2.6.18. Species: D. oviformis Mart.-Hern. \& Tom.-Ort. 1989; Index Fungorum Registration Identifier: 483799; 261072; Current name: Hilidicellites oviformis (Mart.-Hern. \& Tom.Ort.) Kalgutkar \& Janson. 2000 fide Kalgutkar \& Jansonius (2000).

2.6.19. Species: D. panshanensis P. Ke \& Z.Y. Shi 1978; Index Fungorum Registration Identifier: 115652; Location: Panshan, Liaoning Province, Coastal region of Bohai, China; Age: Eocene-Oligocene.

2.6.20. Species: D. psilatus Sheffy \& Dilcher 1971 (Fig. 9S); Index Fungorum Registration Identifier: 111424; Location: Puryear clay pit, $800 \mathrm{~m}$ south of Puryear, Henry County, Tennessee, U.S.A.; Age: Middle Eocene (Claiborne Formation). 
2.6.21. Species: D. siddiquiei Anil Chandra et al. 1984; Index Fungorum Registration Identifier: 106777; Current name: Hilidicellites siddiquiei (Anil Chandra et al.) Kalgutkar \& Janson. 2000 fide Kalgutkar \& Jansonius (2000).

2.6.22. Species: D. strangulatus Sal.-Cheb. \& Locq. 1980; Index Fungorum Registration Identifier: 107926; Current name: Hilidicellites strangulatus (Sal.-Cheb. \& Locq.) Kalgutkar \& Janson. 2000 fide Kalgutkar \& Jansonius (2000).

2.6.23. Species: D. teleutosporoides Sal.-Cheb. \& Locq. 1980; Index Fungorum Registration Identifier: 107927; Current name: Hilidicellites teleutosporoides (Sal.-Cheb. \& Locq.) Kalgutkar \& Janson. 2000 fide Kalgutkar \& Jansonius (2000).

2.6.24. Species: D. triangulus P. Ke \& Z.Y. Shi 1978; Index Fungorum Registration Identifier: 115702; Location: Panshan, Liaoning Province, Coastal region of Bohai, China; Age: Eocene-Oligocene.

2.6.25. Species: D. varius P. Ke \& Z.Y. Shi 1978; Index Fungorum Registration Identifier: 115688; Current name: Hilidicellites varius (P. Ke \& Z.Y. Shi) Kalgutkar \& Janson. 2000 fide Kalgutkar \& Jansonius (2000).

2.7. Genus: DIDYMOSPORONITES Sal.-Cheb. \& Locq., C. r. Congr. natn. Socs. sav. Paris, sect. sci., fasc. 1. (Paleobotanique) 105: 188 (1980); Index Fungorum Registration Identifier: 21079;

Type: D. saccatus Sal.-Cheb. \& Locq. 1980.

Original Diagnosis (Combined description): Spore 2-celled, septum thick; biconical, strongly constricted at the partition, surrounded by a loose smooth sac-like perine; $25 \times 17 \mu \mathrm{m}$ including the membrane, monohilate (monoporate) (Salard-Cheboldaeff \& Locquin 1980).

Classification: Fungi Imperfecti, Didymosporae.

Number of species known: One.

2.7.1. Species: D. saccatus Sal.-Cheb. \& Locq. 1980 (Fig. 9T); Index Fungorum Registration Identifier: 107928; Location: Coast of Equatorial Africa, Gulf of Guinea, Cameroon, Africa; Age: Oligocene-Early Miocene; Notes: This species was described as "Didymosporonites" saccatus which is probably an unintentional orthographical error for Didymoporisporonites. Kalgutkar \& Jansonius (2000) accepted the generic name in its original orthography as validly published with a combined description, because the unusual two-layered wall construction warrants the species to be recognized in a separate genus.

2.8. Genus: DIPLODITES Teterevn-Babajan \& Tasl. ex Kalgutkar et al., Review of Palaeobotany and Palynology (Amsterdam) 77(1-2): 111 (1993); Index Fungorum Registration Identifier: 532862; Type: D. sweetii Kalgutkar et al. 1993.

Synonym: Palaeodiplodites Kyoto Watan. et al. 1999, Index Fungorum Registration Identifier: 28342.

Original Diagnosis: Hyphae intercellular, in the pericarp, septate, branched, smooth, thickwalled. Pycnidia superficial or immersed, with no definite orientation; shape and size variable, globose to subglobose, ovate-oblong or pyriform; dark, thick-walled, wall tissue pseudoparenchymatous. Pycnidia generally ostiolate, astomous when immersed; solitary or aggregated in small groups; a subicle or stroma present. Stroma typically dark brown or black, composed of thick-walled cells, uniloculate. Immature pycnidia filled with thin-walled cells. Conidia 1-septate or aseptate, both kinds occurring in the same pycnidium, size variable, ellipsoidal-oblong to ovate, light to dark brown, septa twice as thick as spore walls; globose conidia 1-celled, lightly coloured; two-celled conidia brown, with striations occasionally present. Conidiophores or their remnants not present (Kalgutkar et al. 1993).

Classification: Fungi Imperfecti, Sphaeropsidales.

Number of species known: Five.

Notes: Kalgutkar (1993) validated the name Diplodites to encompass fossil taxa that are morphologically similar to the extant fungi Diplodia, Botryodiplodia, and other related genera such as Dothiorella and Macrophoma. 
2.8.1. Species: D. mohgaoensis (Barlinge \& Paradkar) Kalgutkar et al. 1993; Index Fungorum Registration Identifier: 532825; Basionym: Botryodiplodia mohgaoensis Barlinge \& Paradkar 1982; Location: Mohgaonkalan, Chhindwara District, Madhya Pradesh, India; Age: Late Cretaceous (Maastrichtian).

2.8.2. Species: D. rodei (Mahab.) Kalgutkar et al. 1993; Index Fungorum Registration Identifier: 532806; Basionym: Diplodia rodei Mahab. 1969; Location: Mohgaonkalan locality in Chhindwara District, Madhya Pradesh, India; Age: Late Cretaceous (Maastrichtian).

2.8.3. Species: D. sahnii (Singhai) Kalgutkar et al. 1993; Index Fungorum Registration Identifier: 532805; Basionym: Diplodia sahnii Singhai 1974; Location: Mohgaonkalan locality in Chhindwara District, Madhya Pradesh, India; Age: Late Cretaceous (Maastrichtian).

2.8.4. Species: D. sweetii Kalgutkar et al. 1993; Index Fungorum Registration Identifier: 533027; Location: Mohgaonkalan locality in Chhindwara District, Madhya Pradesh, India; Age: Late Cretaceous (Maastrichtian).

2.8.5. Species: D. yezoensis (Kyoto Watan. et al.) Kalgutkar \& Janson. 2000; Index Fungorum Registration Identifier: 483312; Basionym: Palaeodiplodites yezoensis Kyoto Watan. et al. 1999; Location: On bisexual cone of Cycadeoidella japonica Ogura, recovered from shales in the Middle Yezo Group, Kami-kinenbetsu River, Hokkaido, Japan; Age: Late Cretaceous Middle Turonian; Notes: The species epithet is derived from the ancient Japanese name for Hokkaido (Yezo).

2.9. Genus: DIPLONEUROSPORA K.P. Jain \& R.C. Gupta, Palaeobotanist 18(2): 180 (1970); Index Fungorum Registration Identifier: 21081; Type: D. tewarii K.P. Jain \& R.C. Gupta 1970.

Original Diagnosis: Ascospores two-celled, uniseriate, elliptical, margin uneven, cells unequal; upper cell prominent, dark brown, thick-walled, wall sculptured with longitudinal ribs. Lower cell hyaline, appendage-like, small in size, rib sculpture faint (Jain \& Gupta 1970).

Classification: Fungi Imperfecti, Didymosporae.

Number of species known: One.

Notes: Jain \& Gupta (1970) named the present two-celled fossil ascospore genus as Diploneurospora for its similarity to the single celled ascospores of extant Neurospora.

2.9.1. Species: D. tewarii K.P. Jain \& R.C. Gupta 1970 (Fig. 9U); Index Fungorum Registration Identifier: 313231; Location: Padappakkara, Kollam District, Kerala, India; Age: Miocene; Notes: The species epithet honours Dr. J.P. Tewari.

2.10. Genus: DISPARIDICELLITES Kalgutkar \& Janson., AASP Contributions Series (Dallas) 39: 94 (2000); Index Fungorum Registration Identifier: 28614; Type: D. paradoxus (P. Ke \& Z.Y. Shi) Kalgutkar \& Janson. 2000.

Original Diagnosis: Small to medium-sized, dicellate, inaperturate fungal spores; cells distinctly unequal, the proximal cell much smaller and thinner-walled than the distal cell; septum may show a perforation and/or septal folds (Kalgutkar \& Jansonius 2000).

Classification: Fungi Imperfecti, Didymosporae.

Number of species known: One.

Notes: In Didymoporisporites the smaller cell has a distinct terminal pore. Dicellaesporites has spores with two equal cells. The name of the genus is derived from Latin disparatus, dissimilar, and the dicellate structure of the spore.

2.10.1. Species: D. paradoxus (P. Ke \& Z.Y. Shi) Kalgutkar \& Janson. 2000 (Fig. 9V); Index Fungorum Registration Identifier: 483327; Basionym: Dicellaesporites paradoxus P. Ke \& Z.Y. Shi 1978, Location: Panshan, Liaoning Province, Coastal region of Bohai, China; Age: Eocene-Oligocene.

2.11. Genus: DYADOSPORITES R.T. Clarke, Mountain Geologist 2(2): 90, pl. 1, fig. 13-14. (1965); Index Fungorum Registration Identifier: 21091; Type: D. ellipsus R.T. Clarke 1965. 
Synonyms: Dyadosporites Hammen 1954 (nom. inval.) fide Kalgutkar \& Jansonius (2000), Index Fungorum Registration Identifier: 21091; Dyadosporonites Elsik 1968, Index Fungorum Registration Identifier: 21092; Psidimobipiospora Sal.-Cheb. \& Locq. 1980, Index Fungorum Registration Identifier: 25598.

Original Diagnosis: Fungal spores bilocular (didymosporous), elliptical, central septum simple, cell wall psilate to finely punctate, pore at apex of each cell (Clarke 1965).

Classification: Fungi Imperfecti, Didymosporae.

Number of species known: 43 (but we accept only 42 species as legitimate because one species, viz. D. umirensis Hammen 1955, was not validly published).

Notes: Van der Hammen (1955) did not validly publish Dyadosporites. He gave generic diagnosis and the name of the type species but the latter was never described or illustrated (Jansonius \& Hills 1976). Clarke (1965) treated Dyadosporites as having been validly published by Van der Hammen (1955). Kalgutkar \& Jansonius (2000) considered that Clarke (1965) was the first to validly publish the generic name and was the first to assign a species Dyadosporites ellipsus R.T. Clarke 1965 to it which became the type species through the principle of monotypy. Dyadosporonites Elsik 1968 and Psidimobipiospora Sal.-Cheb. \& Locq. 1980 are later taxonomic synonyms of Dyadosporites.

2.11.1. Species: D. acutus (Rouse \& Mustard) Kalgutkar \& Janson. 2000; Index Fungorum Registration Identifier: 483328; Basionym: Diporicellaesporites acutus Rouse \& Mustard 1997; Location: Strait of Georgia, eastern Vancouver Island, the Fraser River lowlands of southwest British Columbia, Canada and the North-western Washington State, U.S.A.; Age: Late mid-Eocene-Early late Eocene.

2.11.2. Species: D. annulatus (E.J. Romero \& M.T. Castro) Bianchin., Alej. Martínez \& R.K. Saxena in Alej. Martínez et al. 2016; Index Fungorum Registration Identifier: 812336; Basionym: Dyadosporonites annulatus E.J. Romero \& M.T. Castro 1986; Notes: These spores resemble Trichodelitschia (Phaeotrichaceae, Pleosporales) ascospores as illustrated in Cugny et al. (2010).

2.11.3. Species: D. antarcticus Kalgutkar \& Janson. 2000; Index Fungorum Registration Identifier: 483330; Basionym: Diporicellaesporites stenosus Z.C. Song \& Liu Cao 1994; Location: King George Island, Antarctica; Age: Late Cretaceous.

2.11.4. Species: D. bhardwaji (C.P. Varma \& Rawat) Kalgutkar \& Janson. 2000 (Fig. 9W); Index Fungorum Registration Identifier: 483331; Basionym: Psilodiporites bhardwaji C.P. Varma \& Rawat 1963; Location: Western and eastern India, including oil exploration areas in West Bengal and Assam; Age: Eocene-Miocene (Varma \& Rawat 1963).

2.11.5. Species: D. cannanorensis (Ramanujam \& K.P. Rao) Kalgutkar \& Janson. 2000 (Fig. 9X); Index Fungorum Registration Identifier: 483332; Basionym: Dyadosporonites cannanorensis Ramanujam \& K.P. Rao 1978; Location: Kannur, Kerala, India; Age: Miocene (Quilon and Warkalli beds).

2.11.6. Species: D. clarkii (Sal.-Cheb. \& Locq.) Kalgutkar \& Janson. 2000; Index Fungorum Registration Identifier: 483333; Basionym: Psidimobipiospora clarkii Sal.-Cheb. \& Locq. 1980; Location: Coast of Equatorial Africa, Gulf of Guinea, Cameroon, Africa; Age: Oligocene.

2.11.7. Species: D. denticulatus (Ramanujam \& K.P. Rao) Kalgutkar \& Janson. 2000 (Fig. 9Y); Index Fungorum Registration Identifier: 483334; Basionym: Dyadosporonites denticulatus Ramanujam \& K.P. Rao 1978; Location: Alleppey, Alappuzha District, Kerala, India; Age: Miocene (Quilon and Warkalli beds); Notes: Prominent pores with thickened rims and teethlike or wedge-shaped thickenings on one side of the septa are the diagnostic features of this species.

2.11.8. Species: D. didymus (Sheffy \& Dilcher) Kalgutkar \& Janson. 2000; Index Fungorum Registration Identifier: 483335; Basionym: Dyadosporonites didymus Sheffy \& Dilcher 1971; Location: Puryear clay pit, $800 \mathrm{~m}$ south of Puryear, Henry County, Tennessee, U.S.A.; Age: Middle Eocene (Claiborne Formation). 
2.11.9. Species: D. dubius P. Kumar 1990 (Fig. 9Z); Index Fungorum Registration Identifier: 126556; Location: Padappakkara, Kollam District, Kerala, India; Age: Early-Middle Miocene.

2.11.10. Species: D. dyadosporus (Sal.-Cheb. \& Locq.) Kalgutkar \& Janson. 2000; Index Fungorum Registration Identifier: 483336; Basionym: Psidimobipiospora dyadospora Sal.Cheb. \& Locq. 1980; Location: Coast of Equatorial Africa, Gulf of Guinea, Cameroon, Africa; Age: Oligocene.

2.11.11. Species: D. ellipsoideus (Sal.-Cheb. \& Locq.) Kalgutkar \& Janson. 2000; Index Fungorum Registration Identifier: 483337; Basionym: Psilodiporites ellipsoideus Sal.-Cheb. \& Locq. 1980; Location: Coast of Equatorial Africa, Gulf of Guinea, Cameroon, Africa; Age: Oligocene; Notes: Kalgutkar \& Jansonius (2000) stated that although the original description makes no mention of a septum, and although the authors grouped this species with the amerospores, there is no mistaking the central septum.

2.11.12. Species: D. ellipsus R.T. Clarke 1965 (Fig. 9AA); Index Fungorum Registration Identifier: 330252; Location: Canon City coal field, Fremont County, Colorado, U.S.A.; Age: Late Cretaceous; Notes: The species epithet indicates elliptical shape of the spore.

2.11.13. Species: D. elsikii (Sal.-Cheb. \& Locq.) Kalgutkar \& Janson. 2000; Index Fungorum Registration Identifier: 483338; Basionym: Psidimobipiospora elsikii Sal.-Cheb. \& Locq. 1980; Location: Coast of Equatorial Africa, Gulf of Guinea, Cameroon, Africa; Age: Late Eocene-Oligocene.

2.11.14. Species: D. grandiporus (H.P. Singh et al. 1986) Kalgutkar \& Janson. 2000 (Fig. 9AB); Index Fungorum Registration Identifier: 483339; Basionym: Dyadosporonites grandiporus H.P. Singh et al. 1986; Location: Surma group, Sonapur-Badarpur Road section, Jaintia Hills, Meghalaya and Cachar, Assam; Age: Early Miocene.

2.11.15. Species: D. hilatus Kalgutkar \& Janson. 2000; Index Fungorum Registration Identifier: 483340; Basionym: Didymoporisporonites didymus Sal.-Cheb. \& Locq. 1980; Location: Coast of Equatorial Africa, Gulf of Guinea, Cameroon, Africa; Age: Oligocene.

2.11.16. Species: D. inaequalis Kalgutkar 1993; Index Fungorum Registration Identifier: 483876; Location: Peel River, Yukon Territory, Canada; Age: Late Palaeocene-Early Eocene; Notes: The specific epithet is derived from the Latin, inaequalis, unequal, referring to the unequal size of the cells.

2.11.17. Species: D. incisus Kalgutkar 1993; Index Fungorum Registration Identifier: 483877; Location: Peel River, Yukon Territory, Canada; Age: Late Palaeocene-Early Eocene; Notes: The specific epithet is derived from the Latin, incisus, cut, referring to the pores pulling apart.

2.11.18. Species: D. inornatus (Mart.-Hern. \& Tom.-Ort.) Kalgutkar \& Janson. 2000; Index Fungorum Registration Identifier: 483341; Basionym: Dyadosporonites inornatus Mart.-Hern \& Tom.-Ort. 1989, Location: Piedras Negras, Coahuila State, Mexico; Age: Campanian; Notes: The specific epithet inornatus indicates lack of ornamentation.

2.11.19. Species: D. megaporus (Z.C. Song) Z.C. Song in Z.C. Song et al. 1999; Index Fungorum Registration Identifier: 483847; Basionym: Dyadosporonites megaporus Z.C. Song 1985; Location: Youshashan and Dafengshan, Qaidam Basin, Qinghai Province, China; Age: Palaeocene-Late Eocene; Middle Miocene-Late Miocene; Late Pliocene.

2.11.20. Species: D. minor Sal.-Cheb. \& Locq. 1980; Index Fungorum Registration Identifier: 107943; Location: Coast of Equatorial Africa, Gulf of Guinea, Cameroon, Africa; Age: Late Eocene-Oligocene; Notes: Salard-Cheboldaeff \& Locquin (1980) assigned an affinity to Ascomycota.

2.11.21. Species: D. mucronatus (Sal.-Cheb. \& Locq.) Kalgutkar \& Janson. 2000; Index Fungorum Registration Identifier: 483342; Basionym: Didymoporisporonites mucronatus Sal.-Cheb. \& Locq 1980; Location: Coast of Equatorial Africa, Gulf of Guinea, Cameroon, Africa; Age: Oligocene.

2.11.22. Species: D. novus P. Kumar 1990 (Fig. 9AC); Index Fungorum Registration Identifier: 126557; Location: Padappakkara, Kollam District, Kerala, India; Age: Early-Middle 
Miocene.

2.11.23. Species: D. oblongatus (P. Ke \& Z.Y. Shi) G. Norris 1986; Index Fungorum Registration Identifier: 126572; Basionym: Dyadosporonites oblongatus P. Ke \& Z.Y. Shi 1978; Location: Panshan, Liaoning Province, Coastal region of Bohai, China; (Norris): Imperial Nuktak C-22 Well, Mackenzie Delta Region, District of Mackenzie, Northwest Territories, Canada; Age: Eocene-Oligocene; (Norris): Eocene-Oligocene.

2.11.24. Species: D. obscurus Z.C. Song \& Liu Cao 1994; Index Fungorum Registration Identifier: 483766; Location: King George Island, Antarctica; Age: Late Cretaceous; Notes: The specific epithet obscurus is derived from the dark colour of spores.

2.11.25. Species: D. okayi (V.S. Ediger \& Alisan) Kalgutkar \& Janson. 2000; Index Fungorum Registration Identifier: 483343; Basionym: Dyadosporonites okayi V.S. Ediger \& Alisan 1989; Location: Northern Thrace Basin, Turkey; Age: Middle?-Late Eocene to Late Oligocene, Miocene-Pliocene, Notes: The specific epithet is in honour of Professor Hayrettin B. Okay.

2.11.26. Species: D. puryearensis (Sheffy \& Dilcher) Kalgutkar \& Janson. 2000; Index Fungorum Registration Identifier: 483344; Basionym: Diporicellaesporites puryearensis Sheffy \& Dilcher 1971; Location: Puryear clay pit, 800 m south of Puryear, Henry County, Tennessee, U.S.A.; Age: Middle Eocene (Claiborne Formation); Notes: The specific epithet is after the name of the pit from where the material was collected.

2.11.27. Species: D. quadratus (Rouse \& Mustard) Kalgutkar \& Janson. 2000; Index Fungorum Registration Identifier: 483345; Basionym: Diporicellaesporites quadratus Rouse \& Mustard 1997; Location: Strait of Georgia, eastern Vancouver Island, the Fraser River lowlands of southwest British Columbia, Canada, and North-western Washington State, U.S.A.; Age: Late mid-Eocene-Early Late Eocene.

2.11.28. Species: D. reticulatus (Ramanujam \& K.P. Rao) Kalgutkar \& Janson. 2000 (Fig. 9AD); Index Fungorum Registration Identifier: 483346; Basionym: Dyadosporonites reticulatus Ramanujam \& K.P. Rao 1978; Location: Kannur, Kerala, India; Age: Miocene (Quilon and Warkalli beds).

2.11.29. Species: D. sahnii (C.P. Varma \& Rawat) Kalgutkar \& Janson. 2000 (Fig. 9AE); Index Fungorum Registration Identifier: 483347; Basionym: Granodiporites sahnii C.P. Varma \& Rawat 1963; Location: Western and eastern India, including oil exploration areas in West Bengal and Assam; Age: Eocene-Miocene; The species epithet is in honour of Professor Birbal Sahni.

2.11.30. Species: D. scabratus (P. Kumar) Kalgutkar \& Janson. 2000 (Fig. 9AF); Index Fungorum Registration Identifier: 483348; Basionym: Psidimobipiospora scabrata Kumar 1990; Location: Padappakkara, Kollam District, Kerala, India; Age: Early-Middle Miocene.

2.11.31. Species: D. schwabii (Elsik) Kalgutkar \& Janson. 2000 (Fig. 9AG); Index Fungorum Registration Identifier: 126573; Basionym: Dyadosporonites schwabii Elsik 1968, Location: Strip mine approximately 7 miles southwest of Rockdale, Milam County, Texas, U.S.A.; Age: Palaeocene.

2.11.32. Species: D. singhii R.K. Saxena, Wijayaw., D.Q. Dai, K.D. Hyde \& P.M. Kirk sp. nov. (Fig. 9AH); This new species is described under the section "New species and new combinations".

2.11.33. Species: D. solidus (P. Ke \& Z.Y. Shi) Z.C. Song in Z.C. Song et al. 1999; Index Fungorum Registration Identifier: 483848; Basionym: Dyadosporonites solidus P. Ke \& Z.Y. Shi 1978, p. 49, pl. 5, fig. 10; Location: Kenli, Shandong Province, Coastal region of Bohai, China; Age: Eocene-Oligocene.

2.11.34. Species: D. stenosus (Z.C. Song \& G.X. Li in Z.C. Song et al.) Z.C. Song in Z.C. Song et al. 1999; Index Fungorum Registration Identifier: 483849; Basionym: Dyadosporonites stenosus Z.C. Song \& G.X. Li in Z.C. Song et al. 1989; Location: Shenxian county of Shandong Province, China; Age: Late Eocene-Middle Oligocene (Shahejie Formation). 

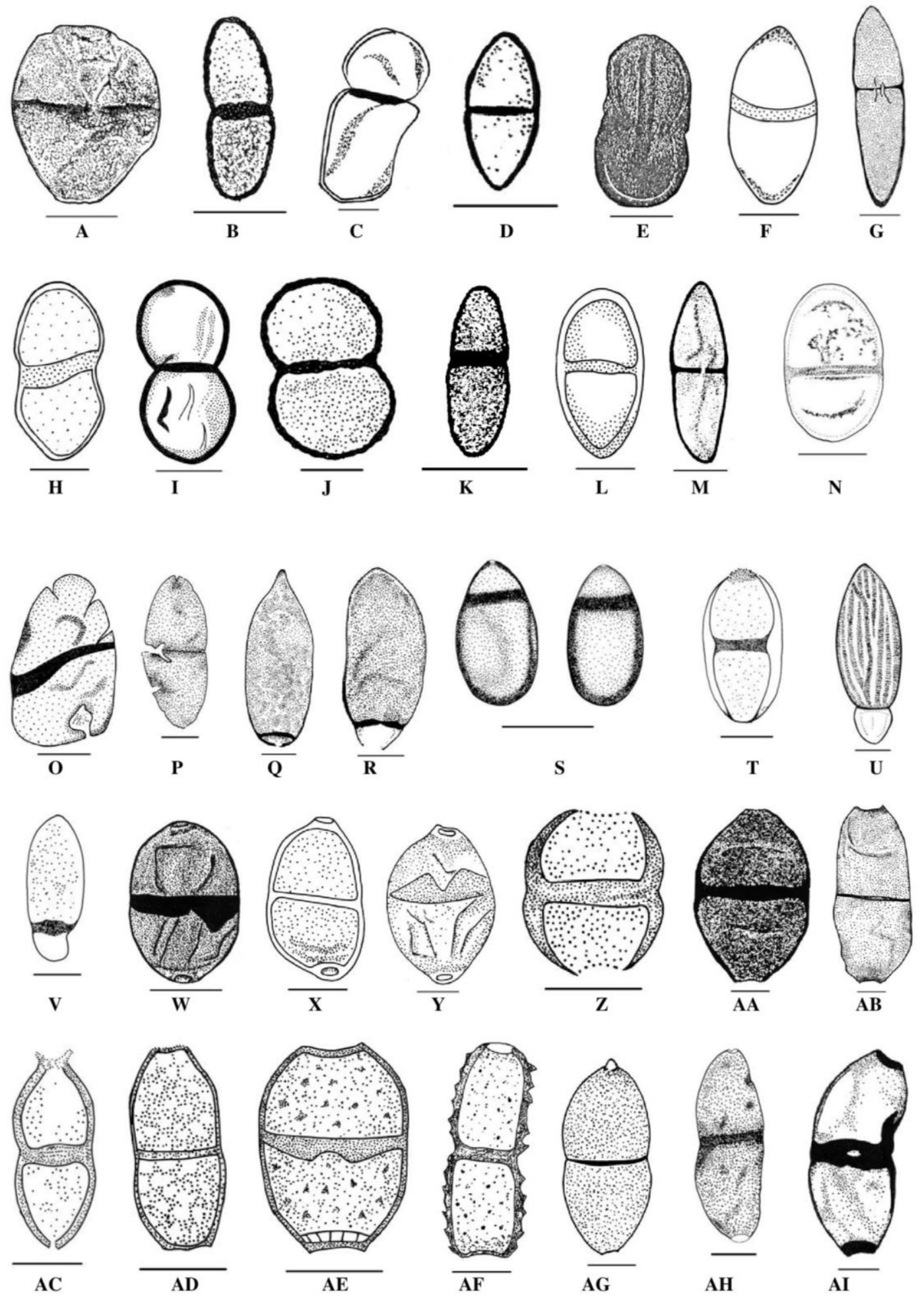

Figure 9 - A-AI Didymosporae. A Dicellaesporites ellipticus K.P. Jain \& R.K. Kar 1979, Bar = 20 $\mu \mathrm{m}$. B Dicellaesporites elongatus Ramanujam \& K.P. Rao 1978, Bar $=10 \mu \mathrm{m}$. C Dicellaesporites elsikii B. Samant in R.K. Saxena 2009, Bar $=10 \mu \mathrm{m}$. D Dicellaesporites fusiformis Sheffy \& Dilcher 1971, Bar $=10 \mu \mathrm{m}$. E Dicellaesporites himachalensis R.K. Saxena \& A.P. Bhattach. 1990, Bar $=20 \mu \mathrm{m}$. F Dicellaesporites himalayaensis A. Gupta 2002, Bar $=7 \mu \mathrm{m}$. G Dicellaesporites inaequalis (Y.N.R. Varma \& R.S. Patil) Kalgutkar \& Janson. 2000, Bar $=20 \mu \mathrm{m} . \mathrm{H}$ Dicellaesporites indicus A. Gupta 2002, Bar $=5 \mu \mathrm{m}$. I Dicellaesporites jainii R.K. Saxena \& S.K.M. Tripathi 2011, Bar $=10 \mu \mathrm{m}$. J Dicellaesporites keralensis P. Kumar 1990, Bar $=10 \mu \mathrm{m} . \mathrm{K}$ Dicellaesporites levis Sheffy \& Dilcher 1971, Bar $=10 \mu \mathrm{m}$. L Dicellaesporites minutus R.K. Kar \& R.K. Saxena 1976, Bar $=10 \mu \mathrm{m}$. M Dicellaesporites perelongatus Kalgutkar \& Janson. 2000, Bar = 
$10 \mu \mathrm{m}$. N Dicellaesporites popovii Elsik 1968, Bar $=12 \mu \mathrm{m}$. O Dicellaesporites singhii R.K. Saxena \& S.K.M. Tripathi 2011, Bar $=20 \mu \mathrm{m}$. P Dicellaesporites vermae R.K. Saxena, Wijayaw., D.Q. Dai, K.D. Hyde \& P.M. Kirk sp. nov., Bar $=17 \mu \mathrm{m}$. Q Didymoporisporonites gigas Kalgutkar \& Janson. 2000, Bar $=10 \mu \mathrm{m}$. R Didymoporisporonites longus (R.K. Kar) Kalgutkar \& Janson. 2000, Bar $=20 \mu \mathrm{m}$. S Didymoporisporonites psilatus Sheffy \& Dilcher 1971, Bar $=7 \mu \mathrm{m}$. T Didymosporonites saccatus Sal.-Cheb. \& Locq. 1980, Bar $=10 \mu \mathrm{m}$. U Diploneurospora tewarii K.P. Jain \& R.C. Gupta 1970, Bar $=8 \mu \mathrm{m}$. V Disparidicellites paradoxus (P. Ke \& Z.Y. Shi) Kalgutkar \& Janson. 2000, Bar $=10 \mu \mathrm{m}$. W Dyadosporites bhardwaji (C.P. Varma \& Rawat) Kalgutkar \& Janson. 2000, Bar $=20 \mu \mathrm{m}$. X Dyadosporites cannanorensis (Ramanujam \& K.P. Rao) Kalgutkar \& Janson. 2000, Bar $=10 \mu \mathrm{m}$. Y Dyadosporites denticulatus (Ramanujam \& K.P. Rao) Kalgutkar \& Janson. 2000, Bar $=10 \mu \mathrm{m}$. Z Dyadosporites dubius P. Kumar 1990, Bar $=10$ $\mu \mathrm{m}$. AA Dyadosporites ellipsus R.T. Clarke 1965, Bar $=15 \mu \mathrm{m}$. AB Dyadosporites grandiporus (H.P. Singh et al. 1986) Kalgutkar \& Janson. 2000, Bar $=10 \mu \mathrm{m}$. AC Dyadosporites novus P. Kumar 1990, Bar $=10 \mu \mathrm{m}$. AD Dyadosporites reticulatus (Ramanujam \& K.P. Rao) Kalgutkar \& Janson. 2000, Bar $=10 \mu \mathrm{m}$. AE Dyadosporites sahnii (C.P. Varma \& Rawat) Kalgutkar \& Janson. 2000, Bar $=10 \mu \mathrm{m}$. AF Dyadosporites scabratus (P. Kumar) Kalgutkar \& Janson. 2000, Bar $=10$ $\mu \mathrm{m}$. AG Dyadosporites schwabii (Elsik) Kalgutkar \& Janson. 2000, Bar $=5 \mu \mathrm{m}$. AH Dyadosporites singhii R.K. Saxena, Wijayaw., D.Q. Dai, K.D. Hyde \& P.M. Kirk sp. nov., Bar $=20 \mu \mathrm{m}$. AI Dyadosporites udarii (A. Gupta) Kalgutkar \& Janson. 2000, Bar $=10 \mu \mathrm{m}$.

2.11.35. Species: D. subovalis (Sheffy \& Dilcher) Kalgutkar \& Janson. 2000; Index Fungorum Registration Identifier: 483349; Basionym: Dyadosporonites subovalis Sheffy \& Dilcher 1971; Location: Puryear clay pit, 800 m south of Puryear, Henry County, Tennessee, U.S.A.; Age: Middle Eocene (Claiborne Formation).

2.11.36. Species: D. substrangulatus (Sal.-Cheb. \& Locq.) Kalgutkar \& Janson. 2000; Index Fungorum Registration Identifier: 483350; Basionym: Psidimobipiospora substrangulata Sal.-Cheb. \& Locq. 1980; Location: Coast of Equatorial Africa, Gulf of Guinea, Cameroon, Africa; Age: Late Eocene-Oligocene.

2.11.37. Species: D. taiwanensis T.C. Huang 1981; Index Fungorum Registration Identifier: 115746; Location: Taiwan; Age: Miocene.

2.11.38. Species: D. udarii (A. Gupta) Kalgutkar \& Janson. 2000 (Fig. 9AI); Index Fungorum Registration Identifier: 483351; Basionym: Dyadosporonites udarii A. Gupta 1984, Location: Barkhana nala cutting, near the village Sarangwara, District of Kutch, western India; Age: Oligocene Notes: The species epithet is in honour of Professor Ram Udar.

2.11.39. Species: D. umirensis Hammen 1955 (nom. inval.) fide Kalgutkar \& Jansonius (2000); Index Fungorum Registration Identifier: 509580.

2.11.40. Species: D. urniformis Kalgutkar 1993; Index Fungorum Registration Identifier: 483878; Location: Peel River, Yukon Territory, Canada; Age: Late Palaeocene-Early Eocene; Notes: The specific epithet is derived from the Latin, urniformis, urn-shaped, referring to the shape of the cells.

2.11.41. Species: D. verrucatus (Ramanujam \& Srisailam) Kalgutkar \& Janson. 2000 (Fig. 10A); Index Fungorum Registration Identifier: 483352; Basionym: Dyadosporonites verrucatus Ramanujam \& Srisailam 1980; Location: Kannur Beach area, Palayangadi and Cheruvattur (southern side of Karingottu River), Kerala, India; Location: Palayangadi; Age: Miocene.

2.11.42. Species: D. wilkinsonii (R.K. Saxena \& N.K. Misra) Kalgutkar \& Janson. 2000 (Fig. 10B); Index Fungorum Registration Identifier: 483353; Basionym: Diporicellaesporites wilkinsonii R.K. Saxena \& N.K. Misra 1990; Location: Ratnagiri beds, Amberiwadi section, Sindhudurg District, Maharashtra, India; Age: Neogene.

2.12. Genus: DYADOSPORONITES Elsik, Pollen Spores 10(2): 278 (1968); Index Fungorum Registration Identifier: 21092; Type: D. schwabii Elsik 1968; Current name: DYADOSPORITES R.T. Clarke 1965 fide Kalgutkar \& Jansonius (2000). 
Original Diagnosis: Diporate, uniseptate fungal spores. Shape and ornamentation variable. Single pore at each end of spore. Pores may be modified, i.e., atrium, annulus, or pore chamber formed by thin septum across end of spore (Elsik 1968).

Classification: Fungi Imperfecti, Didymosporae.

Number of species known: 22 (all the species have been transferred to Dyadosporites Clarke 1965 or to some other appropriate genera).

Notes: Kalgutkar \& Jansonius (2000) considered Dyadosporonites Elsik 1968 to be a later taxonomic synonym of Dyadosporites R.T. Clarke 1965.

2.12.1. Species: D. annulatus E.J. Romero \& M.T. Castro 1986; Index Fungorum Registration Identifier: 812335; Current name: Dyadosporites annulatus (E.J. Romero \& M.T. Castro) Bianchin., Alej. Martínez \& R.K. Saxena in Alej. Martínez et al. 2016 fide Martinez et al. (2016).

2.12.2. Species: D. bhardwaji (C.P. Varma \& Rawat) Elsik 1968 (nom. inval.); Index Fungorum Registration Identifier: 313433; Current name: Dyadosporites bhardwaji (C.P. Varma \& Rawat) Kalgutkar \& Janson. 2000 fide Kalgutkar \& Jansonius (2000).

2.12.3. Species: D. cannanorensis Ramanujam \& K.P. Rao 1978; Index Fungorum Registration Identifier: 124439, Current name: Dyadosporites cannanorensis (Ramanujam \& K.P. Rao) Kalgutkar \& Janson. 2000 fide Kalgutkar \& Jansonius (2000).

2.12.4. Species: D. constrictus Y.K. Mathur \& K. Mathur 1969; Index Fungorum Registration Identifier: 483857; Current name: Hilidicellites constrictus (Y.K. Mathur \& K. Mathur) Kalgutkar \& Janson. 2000 fide Kalgutkar \& Jansonius (2000).

2.12.5. Species: D. constrictus R.K. Kar $1979=$ Dyadosporonites udarii A. Gupta 1984 (nom. nov. pro Dyadosporonites constrictus R.K. Kar); Index Fungorum Registration Identifier: 112282; Current name: Dyadosporites udarii (A. Gupta) Kalgutkar \& Janson. 2000 fide Kalgutkar \& Jansonius (2000).

2.12.6. Species: D. denticulatus Ramanujam \& K.P. Rao 1978; Index Fungorum Registration Identifier: 115064; Current name: Dyadosporites denticulatus (Ramanujam \& K.P. Rao) Kalgutkar \& Janson. 2000 fide Kalgutkar \& Jansonius (2000).

2.12.7. Species: D. didymus Sheffy \& Dilcher 1971; Index Fungorum Registration Identifier: 111446; Current name: Dyadosporites didymus (Sheffy \& Dilcher) Kalgutkar \& Janson. 2000 fide Kalgutkar \& Jansonius (2000).

2.12.8. Species: D. ellipsus (R.T. Clarke) Elsik 1968 (nom. inval.); Index Fungorum Registration Identifier: 313434; Current name: Dyadosporites ellipsus Clarke 1965 fide Kalgutkar \& Jansonius (2000).

2.12.9. Species: D. grandiporus H.P. Singh et al. 1986; Index Fungorum Registration Identifier: 131931; Current name: Dyadosporites grandiporus (H.P. Singh et al.) Kalgutkar \& Janson. 2000 fide Kalgutkar \& Jansonius (2000).

2.12.10. Species: D. inaequalis Y.N.R. Varma \& R.S. Patil 1985; Index Fungorum Registration Identifier: 133494; Current name: Dicellaesporites inaequalis (Y.N.R. Varma \& R.S. Patil) Kalgutkar \& Janson. 2000 fide Kalgutkar \& Jansonius (2000).

2.12.11. Species: D. inornatus Mart.-Hern. \& Tom.-Ort. 1989; Index Fungorum Registration Identifier: 483802; Current name: Dyadosporites inornatus (Mart.-Hern. \& Tom.-Ort.) Kalgutkar \& Janson. 2000 fide Kalgutkar \& Jansonius (2000).

2.12.12. Species: D. megaporus Z.C. Song 1985; Index Fungorum Registration Identifier: 485263; Current name: Dyadosporites megaporus (Z.C. Song) Z.C. Song in Z.C. Song et al. 1999 fide Kalgutkar \& Jansonius (2000).

2.12.13. Species: D. oblongatus P. Ke \& Z.Y. Shi 1978; Index Fungorum Registration Identifier: 115636; Current name: Dyadosporites oblongatus (P. Ke \& Z.Y. Shi) G. Norris 1986 fide Norris (1986).

2.12.14. Species: D. okayi V.S. Ediger \& Alisan 1989; Index Fungorum Registration Identifier: 125505; Current name: Dyadosporites okayi (V.S. Ediger \& Alisan) Kalgutkar \& Janson. 2000 fide Kalgutkar \& Jansonius (2000). 
2.12.15. Species: D. reticulatus Ramanujam \& K.P. Rao 1978, p. 295, pl. 1, fig. 12. Index Fungorum Registration Identifier: Current name: Dyadosporites reticulatus (Ramanujam \& Rao) Kalgutkar \& Janson. 2000 fide Kalgutkar \& Jansonius (2000).

2.12.16. Species: D. sahnii (C.P. Varma \& Rawat) Elsik 1968 (nom. inval.) (= Granodiporites sahnii C.P. Varma \& Rawat 1963); Index Fungorum Registration Identifier: 115065; Current name: Dyadosporites sahnii (C.P. Varma \& Rawat) Kalgutkar \& Janson. 2000 fide Kalgutkar \& Jansonius (2000).

2.12.17. Species: D. schwabii Elsik 1968; Index Fungorum Registration Identifier: 313436; Current name: Dyadosporites schwabii (Elsik) Kalgutkar \& Janson. 2000 fide Kalgutkar \& Jansonius (2000).

2.12.18. Species: D. solidus P. Ke \& Z.Y. Shi 1978; Index Fungorum Registration Identifier: 115635; Current name: Dyadosporites solidus (P. Ke \& Z.Y. Shi) Z.C. Song in Z.C. Song et al. 1999 fide Kalgutkar \& Jansonius (2000).

2.12.19. Species: D. stenosus Z.C. Song \& G.X. Li in Z.C. Song et al. 1989; Index Fungorum Registration Identifier: 485264; Current name: Dyadosporites stenosus (Z.C. Song \& G.X. Li in Z.C. Song et al.) Z.C. Song in Z.C. Song et al. 1999 fide Kalgutkar \& Jansonius (2000).

2.12.20. Species: D. subovalis Sheffy \& Dilcher 1971; Index Fungorum Registration Identifier: 111447; Current name: Dyadosporites subovalis (Sheffy \& Dilcher) Kalgutkar \& Janson. 2000 fide Kalgutkar \& Jansonius (2000).

2.12.21. Species: D. udarii A. Gupta 1984; Index Fungorum Registration Identifier: 483858; Current name: Dyadosporites udarii (A. Gupta) Kalgutkar \& Janson. 2000 fide Kalgutkar \& Jansonius (2000).

2.12.22. Species: D. verrucatus Ramanujam \& Srisailam 1980; Index Fungorum Registration Identifier: 108852; Current name: Dyadosporites verrucatus (Ramanujam \& Srisailam) Kalgutkar \& Janson. 2000 fide Kalgutkar \& Jansonius (2000).

2.13. Genus: FELIXITES Elsik ex Janson. \& Hills, Pollen et Spores 31(1-2): 155 (1990b); Index Fungorum Registration Identifier: 25443; Type: $\boldsymbol{F}$. pollenisimilis (Horst) Elsik 1990b.

Original Diagnosis: Psilate, aporate, dicellate fungal spores with an elliptical outline. The spore outline occasionally can be slightly indented at the septum; individual dispersed cells can have an ovate outline. The septal area is generally very dark due to its excessive development; the septum can be several times the thickness of the cell wall. The septum typically is thick and darkly translucent to practically opaque. The septum is of two main layers, one continuing into the wall of each cell; in extreme cases the cells are found isolated as a dome-shaped cell truncated by the dark septal layer. The septal pore is distinct or not discernible. The spore wall is rigid at the septum, less rigid to folded away from the septum. Rarely a third cell is present; in those specimens the spore is oriented with a trilobate outline; the dark central septal area serves as a common junction for all three cells, but the exact nature of attachment and the septum of the third cell is generally obscured by the opacity of the attachment area (Elsik 1990b).

Classification: Fungi Imperfecti, Didymosporae.

Number of species known: Two.

Notes: Elsik (1990b) stated that Felixites was described for late Palaeozoic fungal didymospores that are aporate and characterized by a very thick medium septum. Chaetosphaerites Felix 1894 is tetracellate and the two end cells are more lightly pigmented than the two central cells. The genus is named in honour of Dr. Johannes Felix.

2.13.1. Species: F. playfordii Elsik 1990b; Index Fungorum Registration Identifier: 126549; Location: Spitsbergen; Age: Early Carboniferous; Notes: Felixites playfordii is characterized by its bicampanulate outline. The species epithet is in honour of Professor Geoffrey Playford.

2.13.2. Species: F. pollenisimilis (Horst) Elsik 1990b (Fig. 10C); Index Fungorum Registration Identifier: 126548; Basionym: Sporonites pollenisimilis Horst 1955; Synonym: Chaetosphaerites pollenisimilis (Horst) M.A. Butterworth \& R.W. Williams 1958 fide Elsik 1990a; Location: Concordia mine, Adit Andreas IV, Upper Silesia, S. Poland (Horst 1955), 
Lothians, Central and West Fife coalfields, Scotland (M.A. Butterworth \& R.W. Williams 1958), Billefjorden Sandstones, Spitsbergen, Norway (Playford 1962); Age: Carboniferous (Horst 1955, Playford 1962), Early Carboniferous (Butterworth \& Williams 1958).

2.14. Genus: FUSIFORMISPORITES Rouse, Micropaleontology 8(2): 210 (1962); Index Fungorum Registration Identifier: 21113; Type: F. crabbii Rouse 1962.

Synonym: Striadyadosporites Dueñas 1979 fide Kalgutkar \& Jansonius (2000), Index Fungorum Registration Identifier: 21325.

Original Diagnosis: Spores? very distinctly fusiform in outline. The unit is split into two equal halves by an equatorial wall that appears to be continuous, thus completely dividing the unit. Longitudinal grooves spread out along the wall from either pole like a spindle; some reach the equator, others stop short of it. Only occasionally is a groove continuous across the dividing wall. The wall is moderately thick, about $3 \mu \mathrm{m}$. Ornamentation laevigate. Size-range 20-100 $\mu \mathrm{m}$ (Rouse 1962).

Emended Diagnosis: Inaperturate, dicellate fungal spores bearing characteristic elongate striae, ribs, ridges or costae oriented parallel to the long axis of the spore. Wall of one or more layers. Inner surface of wall psilate to punctate or scabrate. Equatorial septum of two layers. Equatorial constriction of wall may or may not be present (Elsik 1968).

Classification: Fungi Imperfecti, Didymosporae.

Number of species known: 22 (but we accept only 20 species as legitimate because two species have been transferred to other genera).

Notes: Elsik (1968) emended the generic diagnosis to include forms with less obvious parallel ornamentational elements. Spores of Fusiformisporites have a close resemblance to the ascospores of the modern Cookeina (Wolf \& Cavaliere 1966). Wolf (1970) also reported non-petrified spores from Pleistocene and Eocene sediments that are similar in appearance to Cookeina. Although Fusiformisporites is generally known from the late Palaeocene to Recent (Elsik 1992), MartínezHernández \& Tomasini-Ortiz (1989) reported F. striaoctoformis from Maastrichtian strata.

2.14.1. Species: F. acutus P. Kumar 1990 (Fig. 10D); Index Fungorum Registration Identifier: 126560; Location: Padappakkara, Kollam District, Kerala, India; Age: Early-Middle Miocene.

2.14.2. Species: F. annafrancescae G. Norris 1997; Index Fungorum Registration Identifier: 483789; Location: Imperial ADGO F-28 Well, Mackenzie River delta, Canada; Age: Palaeocene-Eocene; Notes: Norris (1997) named this species in honour of his wife Mrs. Anne Frances Norris.

2.14.3. Species: F. barmerensis R.K. Saxena \& S.K.M. Tripathi 2011 (Fig. 10E); Index Fungorum Registration Identifier: 519942; Location: Barmer Hills, Barmer District, Rajasthan, India; Age: Palaeocene (Barmer Sandstone).

2.14.4. Species: F. crabbii Rouse 1962 (Fig. 10F); Index Fungorum Registration Identifier: 109769; Location: Terminal Dock, Vancouver, British Columbia, Canada; Age: Late Cretaceous-Middle Eocene (Burrard Formation).

2.14.5. Species: F. duenasii Kalgutkar \& Janson. 2000; Index Fungorum Registration Identifier: 483379; Basionym: Striadyadosporites elongatus Dueñas 1979; Location: Tarragona, Sabana de Bogota, Colombia, South America; Age: Pleistocene.

2.14.6. Species: F. elongatus Ramanujam \& K.P. Rao 1978 (Fig. 10G); Index Fungorum Registration Identifier: 115067; Location: Kannur, Kerala, India; Age: Miocene (Quilon and Warkalli beds).

2.14.7. Species: F. foedus S.K. Salujha et al. 1974 (Fig. 10H); Index Fungorum Registration Identifier: 519807; Location: Bali-Chara Nadi traverse, Khasi-Jaintia Hills, India; Age: Palaeogene (Disang Formation); Notes: A comparable specimen is illustrated by Baksi (1962) under Fungus striatus. 
2.14.8. Species: F. keralensis Ramanujam \& K.P. Rao 1978 (Fig. 10I); Index Fungorum Registration Identifier: 115068; Location: Kannur, Kerala, India; Age: Miocene (Quilon and Warkalli beds).

2.14.9. Species: F. lineatus Rouse \& Mustard 1997; Index Fungorum Registration Identifier: 463997; Location: Strait of Georgia, eastern Vancouver Island, the Fraser River lowlands of southwest British Columbia, Canada, and the North-western Washington State, U.S.A.; Age: Late Eocene-Early Oligocene; Notes: According to Rouse \& Mustard (1997), this species is a good index fossil for Late Eocene-Early Oligocene age of western coastal deposits in North America.

2.14.10. Species: F. lineolatus Sheffy \& Dilcher 1971 (Fig. 10J); Index Fungorum Registration Identifier: 111493; Location: Puryear clay pit, $800 \mathrm{~m}$ south of Puryear, Henry County, Tennessee, U.S.A.; Age: Middle Eocene (Claiborne Formation); Notes: The species epithet lineolatus refers to the continuous longitudinal lines.

2.14.11. Species: F. mackenziei M.G. Parsons \& G. Norris 1999; Index Fungorum Registration Identifier: 483920; Location: Caribou Hills, Mackenzie River delta, Canada; Age: Early Eocene; Notes: The species epithet is derived from the Mackenzie Delta.

2.14.12. Species: F. marii Elsik 1968; Index Fungorum Registration Identifier: 314247; Location: Strip mine approximately 7 miles southwest of Rockdale, Milam County, Texas, U.S.A.; Age: Palaeocene.

2.14.13. Species: F. microstriatus Hopkins 1969; Index Fungorum Registration Identifier: 637492; Location: Kitsilano outcrops and excavations of the Highbury Tunnel, southwestern British Columbia, Canada; Age: Late Eocene-Early Oligocene.

2.14.14. Species: $\boldsymbol{F}$. paucistriatus Rouse \& Mustard 1997; Index Fungorum Registration Identifier: 463996; Location: Strait of Georgia, eastern Vancouver Island, the Fraser River lowlands of southwest British Columbia, Canada, and the North-western Washington State, U.S.A.; Age: Late Palaeocene; Notes: Rouse \& Mustard (1997) stated that this species is distinguishable from others by generally low number of weak, thin, and often short striae concentrated in the mid-section of each hemisphere.

2.14.15. Species: $\boldsymbol{F}$. pseudocrabbii Elsik 1968 (Fig. 10K); Index Fungorum Registration Identifier: 314248; Location: Strip mine approximately 7 miles southwest of Rockdale, Milam County, Texas, U.S.A.; Age: Palaeocene.

2.14.16. Species: F. rugosus Sheffy \& Dilcher 1971; Index Fungorum Registration Identifier: 111494; Location: Puryear clay pit, $800 \mathrm{~m}$ south of Puryear, Henry County, Tennessee, U.S.A.; Age: Middle Eocene (Claiborne Formation); Notes: The species epithet refers to the irregular creases in the cell wall.

2.14.17. Species: $\boldsymbol{F}$. sahii R.K. Saxena, Wijayaw., D.Q. Dai, K.D. Hyde \& P.M. Kirk sp. nov. (Fig. 10L); This new species is described under the section "New species and new combinations".

2.14.18. Species: F siglerae Kalgutkar 1997; Index Fungorum Registration Identifier: 437392; Current name: Dicellaeporisporites siglerae (Kalgutkar) Kalgutkar \& Janson. 2000 fide Kalgutkar \& Jansonius (2000).

2.14.19. Species: F. striaoctoformis Mart.-Hern. \& Tom.-Ort. 1989; Index Fungorum Registration Identifier: 263516; Location: Piedras Negras, Coahuila State, Mexico; Age: Maastrichtian; Notes: The species epithet is derived from its figure-eight shape and its striation.

2.14.20. Species: $\boldsymbol{F}$. striatus (P. Ke \& Z.Y. Shi) Kalgutkar \& Janson. 2000; Index Fungorum Registration Identifier: 483380; Basionym: Dicellaesporites striatus P. Ke \& Z.Y. Shi 1978; Location: Tangjiahe, Tianjin Municipality, Coastal region of Bohai, China; Age: EoceneOligocene.

2.14.21. Species: F. taiwanensis T.C. Huang 1981; Index Fungorum Registration Identifier: 115777; Location: Taiwan; Age: Miocene.

2.14.22. Species: F. tonakkalensis Y.N.R. Varma \& R.S. Patil 1985; Index Fungorum Registration Identifier: 133495; Current name: Varmasporites tonakkalensis (Y.N.R. Varma \& R.S. Patil) Kalgutkar \& Janson. 2000 fide Kalgutkar \& Jansonius (2000). 
2.15. Genus: HILIDICELLITES Kalgutkar \& Janson., AASP Contributions Series (Dallas) 39: 133 (2000); Index Fungorum Registration Identifier: 28618; Type: H. appendiculatus (Sheffy \& Dilcher) Kalgutkar \& Janson. 2000.

Original Diagnosis: Small to medium-sized dicellate fungal spores, with the proximal end flattened or truncate, due to the presence of a hilum or pore-like structure; the two cells generally of comparable size; spore wall thin or of medium thickness, smooth or with subdued sculpture, generally thinner than the septal base (Kalgutkar \& Jansonius 2000).

Classification: Fungi Imperfecti, Didymosporae.

Number of species known: 18.

Notes: In Didymoporisporonites, the proximal cell is much smaller than the distal cell. Dicellaesporites lacks a hilum or pore. The genus name is derived from Latin hilum, scar, and the dicellate structure of these spores.

2.15.1. Species: H. appendiculatus (Sheffy \& Dilcher) Kalgutkar \& Janson. 2000 (Fig. 10M); Index Fungorum Registration Identifier: 483381; Basionym: Dicellaesporites appendiculatus Sheffy \& Dilcher 1971; Location: Puryear clay pit, 800 m south of Puryear, Henry County, Tennessee, U.S.A.; Age: Middle Eocene (Claiborne Formation).

2.15.2. Species: H. constrictus (Y.K. Mathur \& K. Mathur) Kalgutkar \& Janson. 2000 (Fig. 10N); Index Fungorum Registration Identifier: 519810; Basionym: Dyadosporonites constrictus Y.K. Mathur \& K. Mathur 1969; Location: Naera and Baraia area of Kutch, Gujarat, India; Age: Pliocene; Notes: Mathur \& Mathur (1969) incorrectly cited the generic name as "Dyadosporonites Hammen 1954". Kalgutkar \& Jansonius (2000) stated that this error in bibliographic citation does not invalidate the publication of the species name. The specific epithet is derived from the strong constriction at the septum.

2.15.3. Species: H. crassiseptus (Sal.-Cheb. \& Locq.) Kalgutkar \& Janson. 2000; Index Fungorum Registration Identifier: 483383; Basionym: Didymoporisporonites crassiseptus Sal.-Cheb. \& Locq. 1980; Location: Coast of Equatorial Africa, Gulf of Guinea, Cameroon, Africa; Age: Oligocene.

2.15.4. Species: H. dubius Kalgutkar \& Janson. 2000 (Fig. 10O); Index Fungorum Registration Identifier: 483384; Basionym: Dicellaesporites crassiseptus Ramanujam \& Srisailam 1980; Location: Kannur Beach area, Palayangadi and Cheruvattur (southern side of Karingottu River), Kerala, India; Age: Miocene.

2.15.5. Species: H. henanensis (Z.C. Song \& G.X. Li in Z.C. Song et al.) Kalgutkar \& Janson. 2000; Index Fungorum Registration Identifier: 483385; Basionym: Didymoporisporonites henanensis Z.C. Song \& G.X. Li in Z.C. Song et al. 1989, Location: Qingteng county of Henan Province, China; Age: Late Eocene-Early Oligocene (Shahejie Formation); Notes: This species can be distinguished from other species of Didymoporisporonites by its large size, and having folds on the surface.

2.15.6. Species: H. indicus (Anil Chandra et al.) Kalgutkar \& Janson. 2000 (Fig. 10P); Index Fungorum Registration Identifier: 483386; Basionym: Didymoporisporonites indicus Anil Chandra et al. 1984; Location: Cores from the Arabian Sea, type locality Core no. 1; Age: Late Quaternary.

2.15.7. Species: H. lacrymosus (Sal.-Cheb. \& Locq.) Kalgutkar \& Janson. 2000; Index Fungorum Registration Identifier: 483387; Basionym: Didymoporisporonites lacrymosus Sal.-Cheb. \& Locq. 1980; Location: Coast of Equatorial Africa, Gulf of Guinea, Cameroon, Africa; Age: Oligocene.

2.15.8. Species: H. major (P. Ke \& Z.Y. Shi) Kalgutkar \& Janson. 2000; Index Fungorum Registration Identifier: 483388; Basionym: Lacrimasporonites major P. Ke \& Z.Y. Shi 1978; Location: Panshan, Liaoning Province, Coastal region of Bohai, China; Age: EoceneOligocene.

2.15.9. Species: H. normalis (Sheffy \& Dilcher) Kalgutkar \& Janson. 2000; Index Fungorum Registration Identifier: 483389; Basionym: Didymoporisporonites normalis Sheffy \& Dilcher 
1971, Location: Puryear clay pit, 800 m south of Puryear, Henry County, Tennessee, U.S.A.; Age: Middle Eocene (Claiborne Formation).

2.15.10. Species: H. oblongatus (P. Ke \& Z.Y. Shi) Kalgutkar \& Janson. 2000; Index Fungorum Registration Identifier: 483390; Basionym: Didymoporisporonites oblongatus P. Ke \& Z.Y. Shi 1978, Location: Panshan, Liaoning Province, Coastal region of Bohai, China; Age: Eocene-Oligocene.

2.15.11. Species: H. obtectus (Sheffy \& Dilcher) Kalgutkar \& Janson. 2000; Index Fungorum Registration Identifier: 483391; Basionym: Didymoporisporonites obtectus Sheffy \& Dilcher 1971; Location: Puryear clay pit, 800 m south of Puryear, Henry County, Tennessee, U.S.A.; Age: Middle Eocene (Claiborne Formation); Notes: The species epithet refers to the presence of an external psilate sheath.

2.15.12. Species: H. ovatus (P. Ke \& Z.Y. Shi) Kalgutkar \& Janson. 2000; Index Fungorum Registration Identifier: 483392; Basionym: Didymoporisporonites ovatus P. Ke \& Z.Y. Shi 1978; Location: Tanggu, Tianjin Municipality; Kenli, Shandong Province, Coastal region of Bohai, China; Age: Eocene-Oligocene.

2.15.13. Species: H. oviformis (Mart.-Hern. \& Tom.-Ort.) Kalgutkar \& Janson. 2000; Index Fungorum Registration Identifier: 483393; Basionym: Didymoporisporonites oviformis Mart.-Hern. \& Tom.-Ort. 1989; Location: Piedras Negras, Coahuila State, Mexico; Age: Maastrichtian; Notes: The genus name was incorrectly spelled "Dydimoporisporites Sheffy \& Dilcher" in Martínez-Hernández \& Tomasini-Ortiz. (1989). The epithet is derived from its oval shape.

2.15.14. Species: H. siddiquiei (Anil Chandra et al.) Kalgutkar \& Janson. 2000 (Fig. 10Q); Index Fungorum Registration Identifier: 483394; Basionym: Didymoporisporonites siddiquiei Anil Chandra et al. 1984; Location: Cores from the Arabian Sea, type locality Core no. 2; Age: Late Quaternary; Notes: The present species epithet is in honour of Dr. H.N. Siddiquie, National Institute of Oceanography, Dona Paula, Goa, India.

2.15.15. Species: H. strangulatus (Sal.-Cheb. \& Locq.) Kalgutkar \& Janson. 2000; Index Fungorum Registration Identifier: 483395; Basionym: Didymoporisporonites strangulatus Sal.-Cheb. \& Locq. 1980; Location: Coast of Equatorial Africa, Gulf of Guinea, Cameroon, Africa; Age: Oligocene.

2.15.16. Species: H. teleutosporoides (Sal.-Cheb. \& Locq.) Kalgutkar \& Janson. 2000; Index Fungorum Registration Identifier: 483396; Basionym: Didymoporisporonites teleutosporoides Sal.-Cheb. \& Locq. 1980, Location: Coast of Equatorial Africa, Gulf of Guinea, Cameroon, Africa; Age: Oligocene-Early Miocene.

2.15.17. Species: H. trivedii Kalgutkar \& Janson. 2000; Index Fungorum Registration Identifier: 483397; Basionym: Teleutosporites ovatus Trivedi \& C.L. Verma 1970 (nom. inval.) fide Kalgutkar \& Jansonius (2000); Location: Near Kuala Lumpur, Malaya; Age: Eocene; Notes: Trivedi \& Verma (1970) stated that these spores come closest to the teleutospores of rusts. The specific epithet is derived from the oval shape of the spores. Kalgutkar \& Jansonius (2000) stated that the species name $T$. ovatus was not validly published by Trivedi \& Verma (1970) because it was not assigned to a validly published generic name. They validated the species name and transferred it to Hilidicellites. The name Hilidicellites ovatus was preoccupied, necessitating a new specific epithet. The species epithet is in honour of Professor B.S. Trivedi, Department of Botany, Lucknow University, Lucknow, India.

2.15.18. Species: H. varius (P. Ke \& Z.Y. Shi) Kalgutkar \& Janson. 2000; Index Fungorum Registration Identifier: 483398; Basionym: Didymoporisporonites varius P. Ke \& Z.Y. Shi 1978; Location: Nanjiao, Tianjin Municipality, Coastal region of Bohai, China; Age: EoceneOligocene.

2.16. Genus: PALAEODIPLODITES Kyoto Watan. et al., Int. J. Plant Sci. 160(2): 440 (1999); Index Fungorum Registration Identifier: 28342, Type: P. yezoensis Kyoto Watan. et al. 1999; Current name: DIPLODITES Kalgutkar et al. 1993. 
Original Diagnosis: Fossil pycnidia and acervuli; semi-immersed, globose, composed of thick-walled cells, textura angularis, and producing numerous conidia; conidia dark, ellipsoidal with dark medial septum and truncate base; conidial wall ornamented with angularly reticulate ridges (Watanabe et al. 1999).

Classification: Fungi Imperfecti, Sphaeropsidales.

Number of species known: One (the single species has been transferred to Diplodites Kalgutkar et al. 1993).

Notes: The genus name is derived from Greek Palaeo and modern genus Diplodia.

2.16.1. Species: P. yezoensis Kyoto Watan. et al. 1999; Fungorum Registration Identifier: 460927;

Current name: Diplodites yezoensis (Kyoto Watan. et al.) Kalgutkar \& Janson. 2000 fide

Kalgutkar \& Jansonius (2000).

2.17. Genus: PSIDIMOBIPIOSPORA Sal.-Cheb. \& Locquin, C. r. Congr. natn. Socs. sav. Paris, sect. sci., fasc. 1. (Paleobotanique) 105: 191 (1980); Index Fungorum Registration Identifier: 25598; Type: P. dyadospora Sal.-Cheb. \& Locq. 1980; Current name: DYADOSPORITES Clarke 1965 fide Kalgutkar \& Jansonius (2000).

Original Diagnosis: Smooth dihilate didymospores (Salard-Cheboldaeff \& Locquin 1980).

Classification: Fungi Imperfecti, Didymosporae.

Number of species known: Five (all the species have been transferred to Dyadosporites Clarke 1965).

2.17.1. Species: P. clarkii Sal.-Cheb. \& Locq. 1980; Index Fungorum Registration Identifier: 108423; Current name: Dyadosporites clarkii (Sal.-Cheb. \& Locq.) Kalgutkar \& Janson. 2000 fide Kalgutkar \& Jansonius (2000).

2.17.2. Species: P. dyadospora Sal.-Cheb. \& Locq. 1980; Index Fungorum Registration Identifier: 108424; Current name: Dyadosporites dyadosporus (Sal.-Cheb. \& Locq.) Kalgutkar \& Janson. 2000 fide Kalgutkar \& Jansonius (2000).

2.17.3. Species: P. elsikii Sal.-Cheb. \& Locq. 1980; Index Fungorum Registration Identifier: 108425; Current name: Dyadosporites elsikii (Sal.-Cheb. \& Locq.) Kalgutkar \& Janson. 2000 fide Kalgutkar \& Jansonius (2000).

2.17.4. Species: P. scabrata P. Kumar 1990; Index Fungorum Registration Identifier: 126568; Current name: Dyadosporites scabratus (P. Kumar) Kalgutkar \& Janson. 2000 fide Kalgutkar \& Jansonius (2000).

2.17.5. Species: P. substrangulata Sal.-Cheb. \& Locq. 1980; Index Fungorum Registration Identifier: 108426; Current name: Dyadosporites substrangulatus (Sal.-Cheb. \& Locq.) Kalgutkar \& Janson. 2000 fide Kalgutkar \& Jansonius (2000).

2.18. Genus: PUCCINIASPORONITES Ramanujam \& Ramachar, Records of the Geological Survey of India 113(5): 82 (1980); Index Fungorum Registration Identifier: 28628; Type: $\boldsymbol{P}$. arcotensis Ramanujam \& Ramachar 1980.

Original Diagnosis: Teliospores borne singly on pedicels, two-celled by prominent horizontal septum; wall thick, pigmented; one germ pore in each cell, more or less terminal in upper [distal] cell, and lateral in lower [proximal] cell (Ramanujam \& Ramachar 1980).

Classification: Basidiomycota, Pucciniomycotina, Pucciniomycetes, Pucciniales, Pucciniaceae.

Number of species known: One.

2.18.1. Species: P. arcotensis Ramanujam \& Ramachar 1980 (Fig. 10R); Index Fungorum Registration Identifier: 483757; Location: Neyveli Lignite Mine, Cuddalore District, Tamil Nadu, India; Age: Miocene. Notes: According to Ramanujam \& Ramachar (1980), the fossil spores are quite similar to spores of modern Puccinia, which parasitizes members of the family Poaceae. 
2.19. Genus: STRIADYADOSPORITES Dueñas, Caldasia 12(60): 564 (1979); Index Fungorum Registration Identifier: 21325; Type: S. elongatus Dueñas 1979; Current name: FUSIFORMISPORITES Rouse 1962 fide Kalgutkar \& Jansonius (2000).

Original Diagnosis: Elongate two-celled fungal spores with striate surface. [Jansonius \& Hills 1980, card no. 3770.]

Classification: Fungi Imperfecti, Didymosporae.

Number of species known: One (the single species has been transferred to Fusiformisporites Rouse 1962).

2.19.1. Species: S. elongatus Dueñas 1979; Index Fungorum Registration Identifier: 112651; Current name: Fusiformisporites duenasii Kalgutkar \& Janson. 2000 fide Kalgutkar \& Jansonius (2000).

2.20. Genus: VALSARITES Puri, Some Plant-micro-fossils from the Cretaceous and Palaeocene of Nigeria; University of Ibadan Botanical Studies 10: 14 (1963); Index Fungorum Registration Identifier: 646215; Type: V. senonianus Puri 1963.

Original Diagnosis (Combined description): This is an ascospore of some Ascomycota, measuring $21 \times 12 \mu \mathrm{m}$ in the middle of the broader segment. It is divided into two halves by an equatorial wall that is continuous. The lower half is narrower, about $10 \mu \mathrm{m}$ or so. There seems to be some sort of irregular and faint reticulation. The wall of the spore is not thickened.

Classification: Ascomycota, Sphaeriales.

Number of species known: One.

Notes: According to Puri (1963), spores of this genus resemble ascospores of Endothia Fr., Didymosphaeria Fuckel, and Valsaria Ces. \& De Not. Spores of Valsaria insitiva (Tode) Ces. \& De Not. are closest in size.

2.20.1. Species: V. senonianus Puri 1963 (Fig. 10S); Index Fungorum Registration Identifier: IF646216; Location: Nigeria; Age: Senonian.

2.21. Genus: VERRUDISPORONITES O'Keefe, Palynology 41(S1): 322 (2017); Index Fungorum Registration Identifier: 821913; Type: V. elsikianus O'Keefe 2017.

Original Diagnosis: Dicellate, diporate fungal spores with broadly fusiform to oval outlines which may or may not be indented at the median septum. Median septum annulate. Spore axis is straight or nearly so. Typically, 18-24 $\mu \mathrm{m}$ wide $\times 25-33 \mu \mathrm{m}$ long. Pores may or may not be surrounded by protruding collars and are typically annulate, the annulus being formed by a thickening of the wall. Pores may be modified by a basal septum into pore chambers, which may be obscured in some species by very thick, dark spore walls. Surface has scattered to abundant verrucae (O’Keefe 2017).

Classification: Fungi Imperfecti, Didymosporae.

Number of species known: One.

Notes: The name of the genus is derived from the verrucate spore wall and two cells of this spore.

2.21.1. Species: V. elsikianus O'Keefe 2017 (Fig. 10T); Index Fungorum Registration Identifier: 821914; Location: Tumbes Province, Peru; Age: Miocene (Heath Formation); Notes: The specific epithet was chosen to honour Dr. William C. Elsik.

\section{Phragmosporae}

3.1. Genus: ALLEPPEYSPORONITES Ramanujam \& K.P. Rao, Proc. IV International Palynology Conference, Lucknow 1976-1977 1: 299 (1978); Index Fungorum Registration Identifier: 21008; Type: A. scabratus Ramanujam \& K.P. Rao 1978.

Original Diagnosis: Spores branched, brownish in colour, multicellular, nonaperturate, septa only transverse, branches one or two per spore, gently curved. Basal and terminal cells each with a conspicuous appendage. Spore wall psilate to scabrate (Ramanujam \& Rao 1978). 
Classification: Fungi Imperfecti, Phragmosporae.

Number of species known: One.

Notes: Ramanujam \& Rao (1978) commented that the branched nature and the presence of appendages are the important features of this spore type and that the fossil taxon shows striking similarity to the dematiaceous fungus Grallomyces F. Stevens (Barnett 1956, Ellis 1971, Subramanian 1971). The spore wall in Grallomyces is minutely verrucate whereas in the fossil spores it is essentially scabrate. Grallomyces is common in moist tropics. Ramanujam and Rao (1978) illustrated two specimens of this species. Of these, the holotype (pl. 3, fig. 40) complies with the specific diagnosis whereas the other specimen (pl. 3, fig. 41) appears to be different.

3.1.1. Species: A. scabratus Ramanujam \& K.P. Rao 1978 (Fig. 10U); Index Fungorum Registration Identifier: 115028; Location: Alleppey, Alappuzha District, Kerala, India; Age: Miocene (Warkalli Beds).

3.2. Genus: ANATOLINITES Elsik et al., Palynology 14: 92 (1990); Index Fungorum Registration Identifier: 21010; Type: A. dongyingensis (P. Ke \& Z.Y. Shi) Elsik et al. 1990.

Synonym: Cupulisporonites Z.C. Song \& Liu Cao 1994 fide Kalgutkar \& Jansonius (2000), Index Fungorum Registration Identifier: 28632.

Original Diagnosis: Diporate, tricellate to tetracellate, generally psilate to vaguely sculptured fungal spores with a straight to practically straight axis. The pores are centered on the ends of the spore axis. The pore at the distal (wider) end of the spore is simple, with the spore wall thinning from the inside of the cell into the pore; or slightly thickened, sometimes with a faint suggestion of an attachment scar. The pore at the proximal (smaller) end of the spore is in a relatively thinner wall, and is simple, with the wall thickness unchanged or annulate. The overall spore outline is broadly to narrowly obovate. The spore outline is straight to slightly indented over the ends of the septa. The cells are arranged in a graded series of distally increasing size. The ends of the spore are generally rounded, as the pores are simple; if not, the former presence and subsequent loss of a cell can be inferred. The spore wall is generally of uniform to variable thickness, and is predominantly psilate, although the sculpture can be scabrate to pitted at optimum magnifications. A subdued infrasculpture is also possible. Variable spore wall thickness can be suggested by the variable development of the brown pigmentation; the cell(s) at the distal end of the spore is/are generally of darker colour. The septa are of variable thickness. The septal pore is generally distinct (Elsik et al. 1990).

Classification: Fungi Imperfecti, Phragmosporae.

Number of species known: 14.

Notes: Anatolinites Elsik et al. 1990 and Brachysporisporites R.T. Lange \& P.H. Sm. 1971 have similar shapes and spore outlines. Anatolinites has two simple pores, upon which the genus can be differentiated from Brachysporisporites and similar brachysporid fungal spores that have a single pore. In addition, the pore of Brachysporisporites can be a compound pore chamber.

3.2.1. Species: A. alaskaensis Elsik et al. 1990; Index Fungorum Registration Identifier: 412404; Location: Coal Bay, Port Moller Quadrangle, Alaska Peninsula; Age: ?Eocene (undifferentiated); Notes: The species epithet is after its occurrence in Alaska.

3.2.2. Species: A. alternarioides Elsik et al. 1990; Index Fungorum Registration Identifier: 412405; Location: Kerala, India; Age: Early to Middle Miocene (Quilon and Warkalli beds); Notes: The species epithet is after its similarity to extant Alternaria.

3.2.3. Species: A. antarcticus (Z.C. Song \& Liu Cao) Kalgutkar \& Janson. 2000; Index Fungorum Registration Identifier: 483246; Basionym: Pluricellaesporites antarcticus Z.C. Song \& Liu Cao 1994; Location: King George Island, Antarctica; Age: Late Cretaceous; Notes: The species epithet is derived from the locality of the type specimens.

3.2.4. Species: A. chubutensis Elsik et al. 1990; Index Fungorum Registration Identifier: 412406; Location: Northern Patagonian Cordillera, Chubut Province, Argentina; Age: Late Palaeocene (Andean, Andesitic Series); Notes: The species epithet is derived from Chubut Province, the place of its occurrence. 
3.2.5. Species: A. claibornensis Elsik et al. 1990; Index Fungorum Registration Identifier: 412407; Location: Central Texas, U.S.A.; Age: Middle Eocene (Stone City Formation of the Claiborne Group); Notes: The species epithet indicates its occurrence in the Claiborne Group.

3.2.6. Species: A. cupuliformis (Sheffy \& Dilcher) Kalgutkar \& Janson. 2000; Index Fungorum Registration Identifier: 483247; Basionym: Monoporisporites cupuliformis Sheffy \& Dilcher 1971; Synonym: Lacrimasporonites cupuliformis (Sheffy \& Dilcher) D.L.E. Glass et al. 1986 fide Kalgutkar \& Jansonius (2000); Location: East and south-central Texas, U.S.A.; Age: Late Eocene (Manning Formation); Notes: The species epithet refers to the cup shape of the spore.

3.2.7. Species: A. dongyingensis (P. Ke \& Z.Y. Shi) Elsik et al. 1990 (Fig. 10V); Index Fungorum Registration Identifier: 412408; Basionym: Multicellaesporites dongyingensis P. Ke \& Z.Y. Shi 1978; Location: Panshan, Liaoning Province, Coastal region of Bohai, China; Age: Oligocene; Notes: Elsik et al. (1990) stated that Anatolinites dongyingensis appears to be endemic to some Turkish Tertiary basins, such as the Thrace Basin in North-western Turkey and the Tekman Basin in eastern Turkey. The species occurs from the Late Eocene to the Early? Miocene in the northern Thrace Basin, where it can be considered as an index fossil for the Late Oligocene, based on its abundance in those strata (Ediger 1981, Ediger \& Alisan 1989). The overall range of Anatolinites dongyingensis apparently is Late Palaeocene to Early? Miocene.

3.2.8. Species: A. holocenicus Elsik et al. ex Kalgutkar \& Janson. 2000; Index Fungorum Registration Identifier: 412409; Location: Alblasserwaard, province of Zuid-Holland, The Netherlands; Age: Holocene; Notes: Anatolinites holocenicus was not validly published by Elsik et al. (1990) because the author did not specify where the holotype was deposited. Kalgutkar \& Jansonius (2000) validated the species name by citing information on where the type is deposited, i.e. Hugo de Vries Laboratorium, University of Amsterdam. The species epithet indicates its occurrence in the Holocene sediments.

3.2.9. Species: A. megaporus (Z.C. Song \& Liu Cao) Janson. et al. 1998, card no. 5071; Index Fungorum Registration Identifier: 637493; Basionym: Cupulisporonites megaporus Z.C. Song \& Liu Cao 1994; Location: King George Island, Antarctica; Age: Late Cretaceous; Notes: The species epithet refers to the large size of the pore.

3.2.10. Species: A. reklawensis Elsik et al. 1990; Index Fungorum Registration Identifier: 412410; Location: Central Texas, U.S.A.; Age: Early Middle Eocene (Reklaw Formation, lower Claiborne Group); Notes: The species epithet indicates its occurrence in the Reklaw Formation.

3.2.11. Species: A. spinatus M.G. Parsons \& G. Norris 1999; Index Fungorum Registration Identifier: 483921; Location: Caribou Hills, Mackenzie Delta, northern Canada; Age: Late Palaeocene-Early to Middle Eocene.

3.2.12. Species: A. subcapsilaris (Sheffy \& Dilcher) Elsik et al. 1990; Index Fungorum Registration Identifier: 412411; Basionym: Pluricellaesporites subcapsilaris Sheffy \& Dilcher 1971; Location: Puryear clay pit, 800 m south of Puryear, Henry County, Tennessee, U.S.A.; Age: Middle Eocene (Claiborne Formation); Notes: The holotype was selected by Kalgutkar \& Jansonius (2000).

3.2.13. Species: A. tenuis (Z.C. Song \& Liu Cao) Kalgutkar \& Janson. 2000; Index Fungorum Registration Identifier: 483248; Basionym: Lacrimasporonites tenuis Z.C. Song \& Liu Cao 1994; Location: King George Island, Antarctica; Age: Late Cretaceous; Notes: The species epithet indicates thinning of spore wall.

3.2.14. Species: A. thraceus (V.S. Ediger) Kalgutkar \& Janson. 2000; Index Fungorum Registration Identifier: 483249; Basionym: Brachysporisporites thraceus V.S. Ediger 1981, Orth. corr. pro Brachysporisporites thraceous; Location: Thrace Basin, Turkey; Age: Late Eocene-Oligocene, Miocene-Pliocene; Notes: Kalgutkar \& Jansonius (2000) assigned Brachysporisporites thraceus to Anatolinites. It may be a taxonomic synonym of Anatolinites dongyingensis (V.S. Ediger) Elsik et al. 1990 (Kalgutkar \& Jansonius 2000). The specific 
epithet originally was spelled "thraceous", an obvious typographic or orthographic error. Kalgutkar and Jansonius (2000) corrected it as "thraceus" (= from Thrace).

3.3. Genus: ASPERGILLITES Trivedi \& C.L. Verma, J. Palynology 5(2): 68 (1970) ex Janson. et al. 1998; Index Fungorum Registration Identifier: 21023; Type: A. torulosus Trivedi \& C.L. Verma ex Janson. et al., 1998; Current name: CERCOSPORITES Salmon 1903.

Synonym: Aspergillites Trivedi \& C.L. Verma 1970 (nom. inval.).

Original Diagnosis: (combined description): Fungal spores in chains consisting of five to many conidial spores, spore outline almost circular, spores without connective wall, smooth, dark brown, [wall] about $1 \mu \mathrm{m}$ thick, basal part of the chain where conidia are formed from conidiophore clearly seen. Length of individual chains varies, depending on the number of conidia present in it; terminal spore $13 \times 13 \mu \mathrm{m}$, middle spore $17 \times 17 \mu \mathrm{m}$ (Trivedi \& Verma 1970).

Classification: Ascomycota, Eurotiales.

Number of species known: One (the single species has been transferred to Cercosporites Salmon 1903).

3.3.1. Species: A. torulosus Trivedi \& C.L. Verma ex Janson. et al. 1998; Index Fungorum Registration Identifier: 309200; Current name: Cercosporites torulosus (Janson. et al.)

Kalgutkar \& Janson. 2000.

3.4. Genus: AXISPORONITES Kalgutkar \& Janson., AASP Contributions Series (Dallas) 39: 36 (2000); Index Fungorum Registration Identifier: 28611; Type: A. indicus (Kumar) Kalgutkar \& Janson. 2000.

Original Diagnosis: Medium sized, inaperturate, tricellate fungal spores; overall shape more or less elliptical; two polar cells smaller, triangular, with dark pigmentation and thicker wall than large, hyaline central cell; septa thicker than wall of central cell (Kalgutkar \& Jansonius 2000).

Classification: Fungi Imperfecti, Phragmosporae.

Number of species known: One.

Notes: The genus name is derived from the Latin word axis = (geographic) pole.

3.4.1. Species: A. indicus (P. Kumar) Kalgutkar \& Janson. 2000 (Fig. 10W); Index Fungorum Registration Identifier: 483266; Basionym: Multicellaesporites indicus Kumar 1990; Location: Clay mine section near Kanjantheria House, Padappakkara, Kollam District, Kerala, India; Age: Early-Middle Miocene (Quilon Beds); Notes: The species epithet is after its occurrence in India.

3.5. Genus: BRACHYSPORISPORITES R.T. Lange \& P.H. Sm., Neues Jb. für Geologie und Paläontologie 11: 677 (1971); Index Fungorum Registration Identifier: 21037; Type: B. pyriformis R.T. Lange \& P.H. Sm. 1971.

Synonym: Granatisporites Elsik \& Janson. 1974 fide Kalgutkar \& Jansonius (2000), Index Fungorum Registration Identifier: 21121.

Original Diagnosis: Obovate, turbinate or pyriform, phaeophragmospores of several cells, the cells much broader than long in a sharply graded series of diminishing size from a large domed apical cell to a small hyaline attachment cell, with extremely dark thick bands of septa, similarly graded towards the attachment cell (Lange \& Smith 1971).

Emended Diagnosis: Fungal spores of three or more cells and two or more septa, symmetrical along the long axis; clavate, obovate, pyriform or ovoid shape; cells are arranged in a graded series of diminishing size from a large domed apical cell to a relatively small hyaline or so attachment cell; one or two cells at aporate end usually bigger [and making up the bulk of the spore]; monoporate, pore is situated on the long axis at the narrower end of the spore; exine thickest on the biggest cell, psilate or scabrate; there may be some pits especially on the biggest cell; thickness of septa variable, there may be at least one opening on septa (Ediger 1981).

Classification: Fungi Imperfecti, Phragmosporae. 
Number of species known: 24 (but we accept only fifteen species as legitimate because six species have been transferred to other genera and three species, viz. B. communis Z.C. Song in Z.C. Song et al. 1999, B. elongatus Z.C. Song in Z.C. Song et al. 1999 and B. lageniformis Z.C. Song in Z.C. Song et al. 1999, have not been validly published).

Notes: Spores of Brachysporisporites are usually compared to the conidia of the modern Brachysporium Sacc.

3.5.1. Species: B. antarcticus Z.C. Song \& Liu Cao 1994; Index Fungorum Registration Identifier: 483767; Location: King George Island, Antarctica; Age: Late Cretaceous; Notes: The species is derived from the provenance of the type specimens.

3.5.2. Species: B. atratus Kalgutkar 1993; Index Fungorum Registration Identifier: 483860; Location: Peel River, Yukon Territory, Canada; Age: Late Palaeocene-Early Eocene; Notes: The species epithet refers to the dark colour of the spores, Latin, atratus, dressed in black.

3.5.3. Species: B. bullatus Kalgutkar 1993; Index Fungorum Registration Identifier: 483861; Location: Peel River, Yukon Territory, Canada; Age: Late Palaeocene-Early Eocene; Notes: The species epithet is derived from the Latin, bullatus, inflated, referring to the bulged cell.

3.5.4. Species: B. catinus (Elsik \& Janson.) Kalgutkar \& Janson. 2000 (Fig. 10X); Index Fungorum Registration Identifier: 483795; Basionym: Granatisporites catinus Elsik \& Janson. 1974; Location: Mackenzie River Delta, Northwest Territories, Canada; Age: Palaeogene.

3.5.5. Species: B. communis Z.C. Song in Z.C. Song et al. 1999 (nom. inval.) fide Kalgutkar \& Jansonius (2000); Index Fungorum Registration Identifier: 483834; Notes: Song (1999) did not validly publish the name, as he did not cite where the type is stored and did not provide a Latin description or its English translation.

3.5.6. Species: B. conicus (P. Ke \& Z.Y. Shi) Norris 1997, Current name: Paragranatisporites conicus (P. Ke \& Z.Y. Shi) Kalgutkar \& Janson. 2000 fide Kalgutkar \& Jansonius (2000).

3.5.7. Species: B. cotalis (Elsik \& Janson.) Norris 1986; Index Fungorum Registration Identifier: 126569; Basionym: Granatisporites cotalis Elsik \& Janson. 1974; Location: Mackenzie Delta, Northwest Territories, Canada (Elsik \& Jansonius 1974), Imperial Nuktak C-22 Well, Mackenzie Delta Region, District of Mackenzie, Northwest Territories, Canada (Norris 1986); Age: Palaeogene (Elsik \& Jansonius 1974), Eocene (Norris 1986); Notes: The species epithet is derived from the Greek kotalis, pestle.

3.5.8. Species: B. elongatus Z.C. Song in Z.C. Song et al. 1999 (nom. inval.) fide Kalgutkar \& Jansonius (2000); Index Fungorum Registration Identifier: 483835; Notes: Song (1999) did not validly publish the name, as he did not cite where the holotype is deposited and did not provide a Latin description or its English translation.

3.5.9. Species: B. endophragmia Kalgutkar \& Sigler 1995; Index Fungorum Registration Identifier: 412616; Current name: Jansoniisporites endophragmia (Kalgutkar \& Sigler) Kalgutkar 1997 fide Kalgutkar (1997).

3.5.10. Species: B. fustitudinus G. Norris 1997; Index Fungorum Registration Identifier: 483793; Location: Imperial ADGO F-28 Well, Mackenzie River delta, Canada; Age: PalaeoceneEocene; Notes: The species epithet is derived from the Latin fustitudinus: cudgel-walloping.

3.5.11. Species: B. grandus Z.C. Song \& Liu Cao 1994; Index Fungorum Registration Identifier: 483768; Orthogr. corr. pro Brachysporisporites grandus Z.C. Song \& Liu Cao 1994; Location: King George Island, Antarctica; Age: Late Cretaceous; Notes: The species epithet is derived from the from large bulk of spore.

3.5.12. Species: B. incurvus (P. Ke \& Z.Y. Shi) Z.C. Song in Z.C. Song et al. 1999; Index Fungorum Registration Identifier: 483836; Current name: Paragranatisporites incurvus (P. Ke \& Z.Y. Shi) Kalgutkar \& Janson. 2000 fide Kalgutkar \& Jansonius (2000).

3.5.13. Species: B. infacetus Kalgutkar 1997; Index Fungorum Registration Identifier: 437390; Current name: Pluricellaesporites infacetus (Kalgutkar) Kalgutkar \& Janson. 2000 fide Kalgutkar \& Jansonius (2000).

3.5.14. Species: B. inuvikensis M.G. Parsons \& G. Norris 1999; Index Fungorum Registration Identifier: 483922; Location: Caribou Hills, Mackenzie River delta, northern Canada; Age: 
Late Palaeocene - Early to Middle Eocene; The species epithet is derived from the community of Inuvik.

3.5.15. Species: B. lageniformis Z.C. Song in Z.C. Song et al. 1999 (nom. inval.) fide Kalgutkar \& Jansonius (2000); Index Fungorum Registration Identifier: 483837; Notes: The name of the species was not validly published by Song (1999) because the author did not specify where the holotype is stored, and did not provide a Latin description or its English translation.

3.5.16. Species: B. longovatus Z.C. Song \& Liu Cao 1994 (Fig. 10Y); Index Fungorum Registration Identifier: 483770; Location: King George Island, Antarctica; Age: Late Cretaceous; Notes: The species epithet refers to elongated egg-shaped spore.

3.5.17. Species: B. lunpolaensis (Zhong Y. Zhang) Z.C. Song in Z.C. Song et al. 1999; Index Fungorum Registration Identifier: 483914; Current name: Paragranatisporites lunpolaensis Zhong Y. Zhang 1980 fide Kalgutkar \& Jansonius (2000).

3.5.18. Species: B. magnus B. Samant in R.K. Saxena 2009 (Fig. 10Z); Index Fungorum Registration Identifier: 515015; Synonym: Brachysporisporites magnus B. Samant 2000, (nom. inval.) fide Kalgutkar \& Jansonius (2000); Location: Near Bhavnagar, Cambay Basin, Gujarat, India; Age: Early Eocene (Kharsalia Clay Formation).

3.5.19. Species: B. maximus (P. Ke \& Z.Y. Shi) Kalgutkar \& Janson. 2000; Index Fungorum Registration Identifier: 483282; Basionym: Multicellaesporites maximus P. Ke \& Z.Y. Shi 1978; Location: Panshan, Liaoning Province, Coastal region of Bohai, China; Age: EoceneOligocene.

3.5.20. Species: B. opimus (Elsik \& Janson.) G. Norris 1986; Index Fungorum Registration Identifier: 126570; Basionym: Granatisporites opimus Elsik \& Janson. 1974; Location: Mackenzie Delta Region, District of Mackenzie, Northwest Territories, Canada; Age: Palaeogene (Elsik \& Jansonius 1974), Eocene (Norris 1986); Notes: The species epithet is derived from the Latin opimus, fat.

3.5.21. Species: B. ovoidus Z.C. Song \& Liu Cao 1994; Index Fungorum Registration Identifier: 483769; Location: King George Island. Antarctica; Age: Late Cretaceous; Notes: The species epithet indicates its almost ovate shape.

3.5.22. Species: B. pyriformis R.T. Lange \& P.H. Sm. 1971 (Fig. 10AA); Index Fungorum Registration Identifier: 309928; Location: Maslin Bay, South Australia; Age: Early-Middle Eocene; Notes: Spore Type B described by Ramanujam \& Rao (1978) from Quilon and Warkalli beds (Miocene) of Kerala resembles Brachysporisporites pyriformis in possessing similar shape and nature of cells, septa and spore wall.

3.5.23. Species: B. tenuis P. Kumar 1990 (Fig. 10AB); Index Fungorum Registration Identifier: 126550; Location: Padappakkara, Kollam District, Kerala, India; Age: Early-Middle Miocene (Quilon Beds); Notes: Didymoporisporonites sp. described by Varma \& Patil (1985) from the Miocene sediments of Tonakkal area in Thiruvanthapuram District, Kerala resembles Brachysporisporites tenuis Kumar (1990) in all morphological features, hence merged to it.

3.5.24. Species: B. thraceous V.S. Ediger 1981; Index Fungorum Registration Identifier: 107761; Current name: Anatolinites thraceus (V.S. Ediger) Kalgutkar \& Janson. 2000 fide Kalgutkar \& Jansonius (2000).

3.6. Genus: CANNANOROSPORONITES Ramanujam \& K.P. Rao 1978; Index Fungorum Registration Identifier: 21044; Type: C. raoi Ramanujam \& K.P. Rao 1978; Current name: CHAETOSPHAERITES Felix 1894 fide Kalgutkar \& Jansonius (2000).

Original Diagnosis: Spores melanin-coloured, tetracellate, barell-shaped, cells unequal in size, basal and terminal cells smaller than central cells. Cells exhibit differential pigmentation, two central cells dark coloured, basal and terminal cells sub-hyaline to hyaline. Central cells with buldging lateral walls. Septa considerably thickened. Spore wall psilate. Apical cell conidiogenous, bearing a large simple pore (Ramanujam \& Rao 1978).

Classification: Fungi Imperfecti, Phragmosporae. 
Number of species known: One (the single species has been transferred to Chaetosphaerites Felix 1894).

3.6.1. Species: C. raoi Ramanujam \& K.P. Rao 1978; Index Fungorum Registration Identifier: 115037; Current name: Chaetosphaerites raoi (Ramanujam \& K.P. Rao) Kalgutkar \& Janson. 2000 fide Kalgutkar \& Jansonius (2000).

3.7. Genus: CERATOHIRUDISPORA R. Kar et al., Review of Palaeobotany \& Palynology (Amsterdam) 158(3-4): 246 (2010); Index Fungorum Registration Identifier: 541644; Type: $\boldsymbol{C}$. miocenica $\mathrm{R}$. Kar et al. 2010.

Original Diagnosis: Hyphomycetaceous fungi, conidiophore small, growth terminated by production of apical conidium; conidium enlarges laterally in opposite direction to produce twothree arms, conidia 5-10 celled, septa up to $2 \mu \mathrm{m}$ thick, with broad base and narrow tip (Kar et al. 2010).

Classification: Fungi Imperfecti, Phragmosporae.

Number of species known: Two.

Notes: Ceratosporium Schwein. and Hirudinaria Ces. produce same type of conidia. The two conidia that are generally developed by the conidiophore are placed opposite to each other laterally. In the dispersed state it is not possible to distinguish one from the other (Subramanian 1971). The genus name is after the genera Ceratosporium and Hirudinaria of the Hyphomycetes.

3.7.1. Species: C. miocenica R. Kar et al. 2010 (Fig. 10AC); Index Fungorum Registration Identifier: 542233; Location: Tlangsam, Mizoram, India; Age: Miocene (Bhuban Formation); Notes: The species epithet is after its occurrence in Miocene sediments.

3.7.2. Species: C. triradiata R. Kar et al. 2010 (Fig. 10AD); Index Fungorum Registration Identifier: 542234; Notes: The species epithet is after its three armed conidia.

3.8. Genus: CERCOSPORITES E.S. Salmon, J. Bot., Lond. 41: 127 (1903); Index Fungorum Registration Identifier: 21048; Type: C. salmonii Kalgutkar 1997.

Synonym: Aspergillites Trivedi \& C.L. Verma ex Janson. et al. 1998 fide Kalgutkar \& Jansonius (2000), Index Fungorum Registration Identifier: 21023.

Original Diagnosis: Mycelium consisting of pale brown, septate, filamentous hyphae that grow individually and have a diameter of 5-8 $\mu \mathrm{m}$; at more or less irregular intervals the hyphae may suddenly inflate into larger, more or less globose cells of 15-23 $\mu \mathrm{m}$ diameter which, when mature, are opaque dark brown and aligned into chains of 3 to 6 cells or rarely into biseriate aggregates, and which probably function as sclerotia (Salmon 1903).

Classification: Fungi Imperfecti, Phragmosporae.

Number of species known: Three.

3.8.1. Species: C. catenatus (Ramanujam \& K.P. Rao) Kalgutkar \& Janson. 2000 (Fig. 10AE); Index Fungorum Registration Identifier: 483287; Basionym: Pluricellaesporites catenatus Ramanujam \& K.P. Rao; Location: Varkala, Thiruvananthapuram District, Kerala, India; Age: Miocene (Quilon and Warkalli beds).

3.8.2. Species: C. salmonii Kalgutkar 1997 (Fig. 10AF); Index Fungorum Registration Identifier: 437391; Location: Kanguk Peninsula, Axel Heiberg Island, Northwest Territories, Canada; Age: Late Palaeocene-Early Eocene (Iceberg Bay Formation); Notes: The species epithet is in honour of Dr. Ernest Salmon, author of the generic name.

3.8.3. Species: C. torulosus (Trivedi \& C.L. Verma) Kalgutkar \& Janson. 2000; Index Fungorum Registration Identifier: 483288; Basionym: Aspergillites torulosus Trivedi \& C.L. Verma ex Janson. et al. 1998; Argillites torulosus Trivedi \& C.L. Verma 1970 (nom. inval.); Location: Near Kuala Lumpur, Malaya; Age: Eocene; Notes: The name Aspergillites torulosus was not validly published by Trivedi \& Verma (1970) because two different specimens, on two different slides, were listed under "Holotype Preparation". 
3.9. Genus: CHAETOSPHAERITES Félix, Zeitschr. Deutsche Geol. Gesell. 46: 272 (1894); Index Fungorum Registration Identifier: 21053; Type: C. bilychnis Felix 1894.

Synonym: Cannanorosporonites Ramanujam \& K.P. Rao 1978 fide Kalgutkar \& Jansonius (2000), Index Fungorum Registration Identifier: 21044.

Original Diagnosis: Some of the silicified spores are characterized particularly by the two middle cells being dark brown, the two end cells pale brown. Since the boundaries of the respective colours coincide exactly with the sharp delimitations of the individual segments, it is probably not justified to assume that the differences in shade only resulted from the state of preservation. It is unlikely, particularly in view of the minute size of the objects, for differences to occur in the state of preservation of the individual parts; in addition, within the genera Chaetosphaeria, Lophiostoma, Massaria and Melanomma there occur many species in which only the middle cells are of darker colour - generally dark brown or blackish-than the end cells which often appear almost colourless. The shape of the sporidia is strongly obtuse spindle-shaped, almost like that of a cylinder with rounded ends. They probably consist of 4 segments, but the midmost septum is not clearly visible on account of the dark coloration of this area. The length is $0.0238 \mathrm{~mm}$ [23.8 $\mu \mathrm{m}]$, the width 0.0085 $\mathrm{mm}[8.5 \mu \mathrm{m}]$. The two median, dark coloured cells are larger than the two others; their combined length is $0.0148 \mathrm{~mm}[14.8 \mu \mathrm{m}]$ (Felix 1894).

Classification: Fungi Imperfecti, Phragmosporae.

Number of species known: Five (but we accept only three species as legitimate because two species have been transferred to other genera).

Notes: This genus is characterized by spores having two middle cells being dark brown and two end cells pale brown. The shape of the sporidia is strongly obtuse spindle-shaped, almost like that of a cylinder with rounded ends. Cannanorosporonites Ramanujam \& K.P. Rao is a later taxonomic synonym of Chaetosphaerites.

3.9.1. Species: C. bilychnis Félix 1894 (Fig. 10AG); Index Fungorum Registration Identifier: 246518; Location: Perekeschkul, near Baku, Azerbaijan; Age: Eocene.

3.9.2. Species: C. camerounensis Sal.-Cheb. \& Locq. 1980; Index Fungorum Registration Identifier: 107812; Current name: Multicellites camerounensis (Sal.-Cheb. \& Locq.) Kalgutkar \& Janson. 2000 fide Kalgutkar \& Jansonius (2000).

3.9.3. Species: C. obscurus (P. Ke \& Z.Y. Shi) Kalgutkar \& Janson. 2000; Index Fungorum Registration Identifier: 483289; Basionym: Multicellaesporites obscurus P. Ke \& Z.Y. Shi 1978; Location: Panshan, Liaoning Province, Coastal region of Bohai, China; Age: EoceneOligocene.

3.9.4. Species: C. pollenisimilis (Horst) M.A. Butterworth \& R.W. Williams 1958; Index Fungorum Registration Identifier: 637472; Current name: Felixites pollenisimilis (Horst) Elsik 1990b fide Elsik (1990b).

3.9.5. Species: C. raoi (Ramanujam \& K.P. Rao) Kalgutkar \& Janson. 2000 (Fig. 10AH); Index Fungorum Registration Identifier: 483286; Basionym: Cannanorosporonites raoi Ramanujam \& K.P. Rao 1978; Location: Kannur, Kerala, India; Age: Miocene (Quilon and Warkalli beds); Notes: The species epithet is in honour of Professor A.R. Rao, one of the pioneer workers in the field of palaeomycology in India.

3.10. Genus: CHORDECYSTIA C.B. Foster, Jitsuyo Sakumotsu Byorigaku 372: 109 (1979); Index Fungorum Registration Identifier: 27204; Type: C. chalasta C.B. Foster 1979.

Original Diagnosis: Microfossils occurring in chains of two or more individuals, or as discrete, disarticulated cells. Median members of chain originally cylindrical, terminal members ellipsoidal or club-shaped. Termini of cells intact; invaginated or convex, depending upon position in chain; often constricted and slightly thicker (folded?) at points of interconnection. Wall apparently onelayered, without obvious structure. One or two narrow clefts or grooves may extend \pm diagonally between the ends of the cell, or from one end to approximately midway along opposite wall of cell. When chain is intact, grooves appear to spiral along its length. The grooves may delimit dehiscence area (Foster 1979). 
Classification: Fungi Imperfecti, Phragmosporae.

Number of species known: One.

3.10.1. Species: C. chalasta C.B. Foster 1979 (Fig. 10AI); Index Fungorum Registration Identifier: 560974; Location: Australia; Age: Late? Permian; Notes: Elsik (1992) treated the name of this genus as a later synonym of Reduviasporonites. Kalgutkar \& Jansonius (2000) did not accept the synonymy proposed by Elsik (1999).

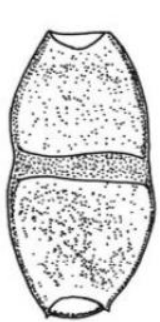

$\overline{\mathbf{A}}$
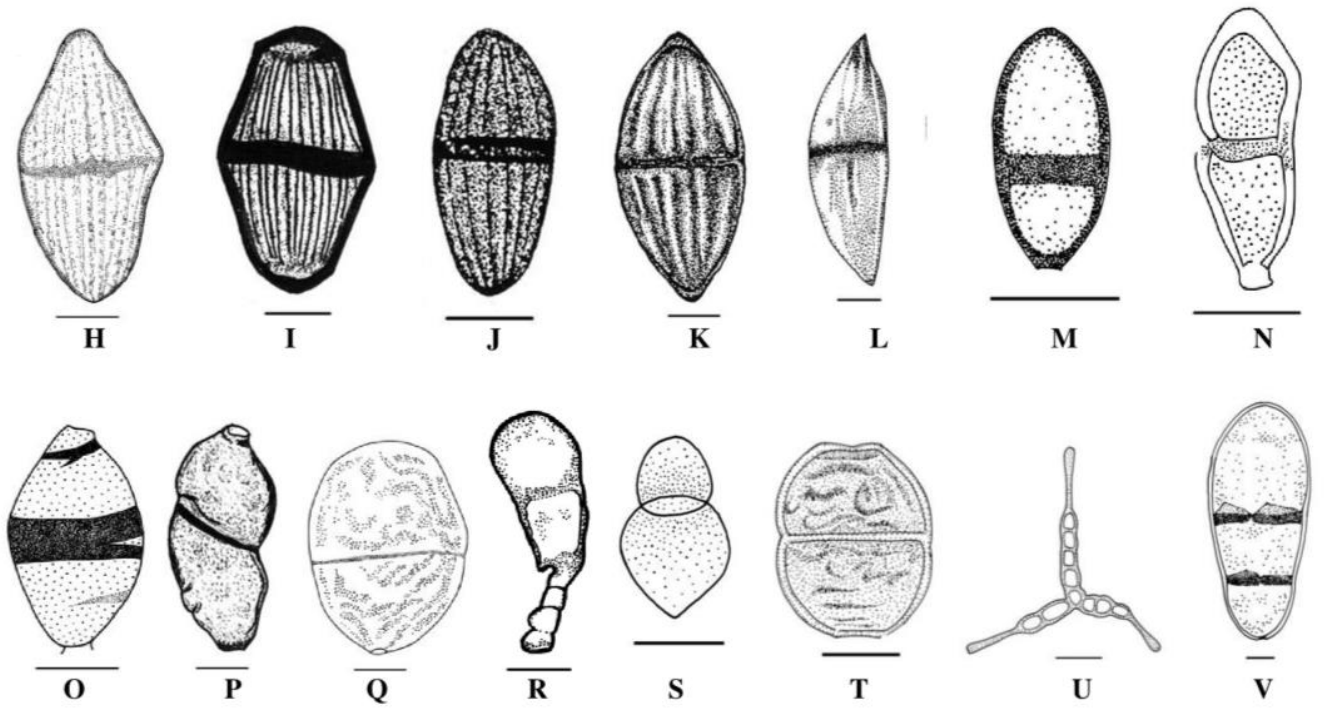

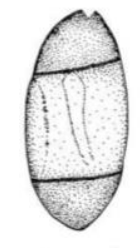

$\mathbf{W}$
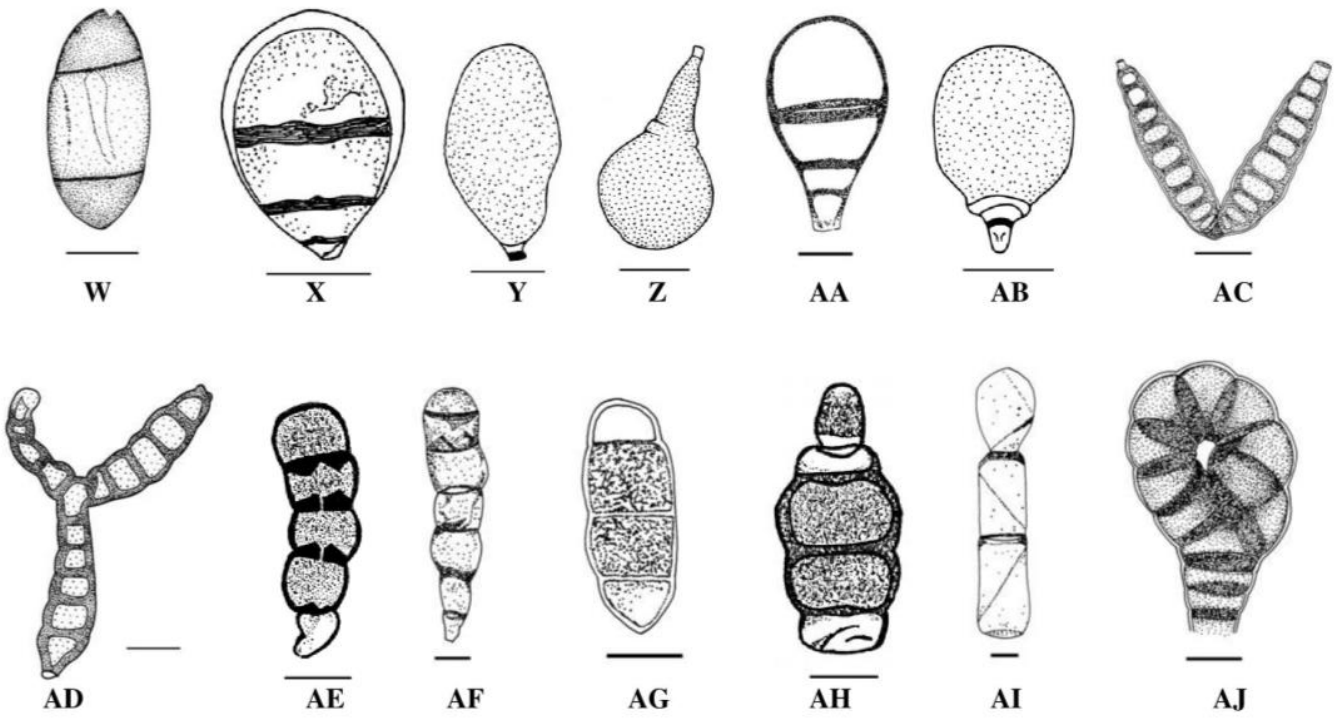

Figure 10 - A-S Didymosporae. T-AI Phragmosporae. A Dyadosporites verrucatus (Ramanujam \& Srisailam) Kalgutkar \& Janson. 2000, Bar $=10 \mu \mathrm{m}$. B Dyadosporites wilkinsonii (R.K. Saxena \& N.K. Misra) Kalgutkar \& Janson. 2000, Bar $=10 \mu \mathrm{m}$. C Felixites pollenisimilis (Horst) Elsik 
1990b, Bar $=20 \mu \mathrm{m}$. D Fusiformisporites acutus P. Kumar 1990, Bar $=10 \mu \mathrm{m}$. E Fusiformisporites barmerensis R.K. Saxena \& S.K.M. Tripathi 2011, Bar $=20 \mu \mathrm{m}$. F Fusiformisporites crabbii Rouse 1962, Bar $=12 \mu \mathrm{m} . \mathrm{G}$ Fusiformisporites elongatus Ramanujam \& K.P. Rao 1978, Bar $=10 \mu \mathrm{m} . \mathrm{H}$ Fusiformisporites foedus S.K. Salujha et al. 1974, Bar $=10 \mu \mathrm{m}$. I Fusiformisporites keralensis Ramanujam \& K.P. Rao 1978, Bar $=10 \mu \mathrm{m}$. J Fusiformisporites lineolatus Sheffy \& Dilcher 1971, Bar $=10 \mu \mathrm{m}$. K Fusiformisporites pseudocrabbii Elsik 1968, Bar $=10 \mu \mathrm{m}$. L Fusiformisporites sahii R.K. Saxena, Wijayaw., D.Q. Dai, K.D. Hyde \& P.M. Kirk sp. nov., Bar $=15 \mu \mathrm{m}$. M Hilidicellites appendiculatus (Sheffy \& Dilcher) Kalgutkar \& Janson. 2000, Bar $=20 \mu \mathrm{m} . \mathrm{N}$ Hilidicellites constrictus (Y.K. Mathur \& K. Mathur) Kalgutkar \& Janson. 2000, Bar $=10 \mu \mathrm{m} . \mathrm{O}$ Hilidicellites dubius Kalgutkar \& Janson. 2000, Bar $=20 \mu \mathrm{m}$. P Hilidicellites indicus (Anil Chandra et al.) Kalgutkar \& Janson. 2000, Bar $=10 \mu \mathrm{m}$. Q Hilidicellites siddiquiei (Anil Chandra et al.) Kalgutkar \& Janson. 2000, Bar $=10 \mu \mathrm{m}$. R Pucciniasporonites arcotensis Ramanujam \& Ramachar 2000, Bar $=10 \mu \mathrm{m}$. S Valsarites senonianus Puri 1963, Bar $=10 \mu \mathrm{m}$. T Verrudisporonites elsikianus O'Keefe 2017, Bar $=10 \mu \mathrm{m}$. U Alleppeysporonites scabratus Ramanujam \& K.P. Rao 1978, Bar $=20 \mu \mathrm{m}$. V Anatolinites dongyingensis (P. Ke \& Z.Y. Shi) Elsik et al. 1990, Bar $=10$ $\mu \mathrm{m}$. W Axisporonites indicus (P. Kumar) Kalgutkar \& Janson. 2000, Bar $=10 \mu \mathrm{m}$. X Brachysporisporites catinus (Elsik \& Janson.) Kalgutkar \& Janson. 2000, Bar $=20 \mu \mathrm{m}$. Y Brachysporisporites longovatus Z.C. Song \& Liu Cao 1994, Bar $=20 \mu \mathrm{m}$. Z Brachysporisporites magnus B. Samant in R.K. Saxena 2009, Bar $=30 \mu \mathrm{m}$. AA Brachysporisporites pyriformis R.T. Lange \& P.H. Sm. 1971, Bar $=10 \mu \mathrm{m}$. AB Brachysporisporites tenuis P. Kumar 1990, Bar $=20$ $\mu \mathrm{m}$. AC Ceratohirudispora miocenica R. Kar et al. 2010, Bar $=10 \mu \mathrm{m}$. AD Ceratohirudispora triradiata R. Kar et al. 2010, Bar $=10 \mu \mathrm{m}$. AE Cercosporites catenatus (Ramanujam \& K.P. Rao) Kalgutkar \& Janson. 2000, Bar $=10 \mu \mathrm{m}$. AF Cercosporites salmonii Kalgutkar 1997, Bar $=10 \mu \mathrm{m}$. AG Chaetosphaerites bilychnis Félix 1894, Bar $=5 \mu \mathrm{m}$. AH Chaetosphaerites raoi (Ramanujam \& K.P. Rao) Kalgutkar \& Janson. 2000, Bar $=12 \mu \mathrm{m}$. AI Chordecystia chalasta C.B. Foster 1979, Bar $=10 \mu \mathrm{m}$. AJ Circinoconites arthrus R. Kar et al. 2010, Bar $=8 \mu \mathrm{m}$.

3.11. Genus: CIRCINOCONITES R. Kar et al., Review of Palaeobotany \& Palynology (Amsterdam) 158(3-4): 246 (2010); Index Fungorum Registration Identifier: 541647; Type: $\boldsymbol{C}$. arthrus $\mathrm{R}$. Kar et al. 2010.

Original Diagnosis: Fungal conidia, conidia acrogenous, strongly spiraled, spirals 30-39 $\times$ 25-31 $\mu \mathrm{m}$; solitary, coiled, not in chains or slime, 8-14 septate, fist-shaped, dark brown, constricted at septa, cells increasing in diameter from base to apex, dissimilar, spirally arranged (Kar et al. 2010).

Classification: Fungi Imperfecti, Phragmosporae.

Number of species known: One.

Notes: Kar et al. (2010) stated that the coiled conidia generally occur amongst the aquatic fungi. Besides, there are also aeroaquatic or helicosporous fungi which also produce helicoid conidia (van Beverwijk 1953). The name of the genus is derived from Greek arthron (Gr.) = joint.

3.11.1. Species: $\boldsymbol{C}$. arthrus R. Kar et al. 2010 (Fig. 10AJ); Index Fungorum Registration Identifier: 542238; Location: Tlangsam, Mizoram, India; Age: Miocene (Bhuban Formation).

3.12. Genus: CLADOSPORIUMSPORINITES Debi Mukh., International Journal of Geology, Earth and Environmental Sciences 2(2): 8 (2012); Index Fungorum Registration Identifier: 588468; Type: C. cylindricus Debi Mukh. 2012.

Original Diagnosis: Conidia cylindrical, oblong, rounded at both the ends, 3-4 septate, fuliginous (dark soot colour); size 80-100 × 15-30 $\mu \mathrm{m}$; septa slightly constricted (Mukherjee 2012).

Classification: Fungi Imperfecti, Phragmosporae.

Number of species known: One. 
Notes: Mukherjee (2012) opined that these conidia are borne on the apical part of the conidiophores but are found detached in dispersed condition. They resemble to the conidia of extant Cladosporium (growing on leaves of Dianthus barbatus and other Caryophyllaceae plants).

3.12.1. Species: C. cylindricus Debi Mukh. 2012 (Fig. 11A); Index Fungorum Registration Identifier: 588481; Location: Neyveli Lignite Mine-I, Cuddalore District, Tamil Nadu, India; Age: Miocene (Neyveli Lignite); Notes: The specific epithet refers to the cylindrical shape.

3.13. Genus: DIPORICELLAESPORITES Elsik, Mikol. Fitopatol. 7(3): 181 (1968); Index Fungorum Registration Identifier: 21083; Type: D. stacyi Elsik 1968.

Original Diagnosis: Elongate, diporate, multicellate fungal or algal spores. One pore at each end of the spore. Shape and ornamentation variable except never coiled. Two or more septae (Elsik 1968).

Classification: Fungi Imperfecti, Phragmosporae.

Number of species known: 68 (but we accept only 50 species as legitimate because 18 species have been transferred to other genera).

3.13.1. Species: D. acuminatus Sheffy \& Dilcher 1971; Index Fungorum Registration Identifier: 111432; Location: Puryear clay pit, $800 \mathrm{~m}$ south of Puryear, Henry County, Tennessee, U.S.A.; Age: Middle Eocene (Claiborne Formation); Notes: The specific epithet indicates pointed spore apex.

3.13.2. Species: D. acutus Rouse \& Mustard 1997; Index Fungorum Registration Identifier: 464001; Current name: Dyadosporites acutus (Rouse \& Mustard) Kalgutkar \& Janson. 2000 fide Kalgutkar \& Jansonius (2000).

3.13.3. Species: D. aequalibus Kalgutkar 1993; Index Fungorum Registration Identifier: 483867; Location: Peel River, Yukon Territory, Canada; Age: Late Palaeocene-Early Eocene; Notes: The specific epithet is derived from the Latin, aequabilis, equal, referring to spores with symmetrical cells.

3.13.4. Species: D. anisosporus Sal.-Cheb. \& Locq. 1980; Index Fungorum Registration Identifier: 107929; Location: Coast of Equatorial Africa, Gulf of Guinea, Cameroon, Africa; Age: Late Eocene-Oligocene.

3.13.5. Species: D. antarcticus Z.C. Song \& Liu Cao 1994; Index Fungorum Registration Identifier: 483773; Location: King George Island, Antarctica; Age: Late Cretaceous; Notes: The species epithet is after the locality of type specimens.

3.13.6. Species: D. attenuatus Ramanujam \& Srisailam 1980; Index Fungorum Registration Identifier: 108846; Current name: Quilonia attenuata (Ramanujam \& Srisailam) Kalgutkar \& Janson. 2000 fide Kalgutkar \& Jansonius (2000).

3.13.7. Species: D. belluloides Z.C. Song 1985; Index Fungorum Registration Identifier: 374794; Current name: Biporipsilonites belluloides (Z.C. Song) Kalgutkar \& Janson. 2000 fide Kalgutkar \& Jansonius (2000).

3.13.8. Species: D. bellulus P. Ke \& Z.Y. Shi (nom. inval.); Index Fungorum Registration Identifier: 115648, Current name: Biporipsilonites bellulus ex Kalgutkar \& Janson. 2000 fide Kalgutkar \& Jansonius (2000).

3.13.9. Species: D. chitaleyae Kalgutkar 1993; Index Fungorum Registration Identifier: 483868; Location: Peel River, Yukon Territory, Canada; AGE: Late Palaeocene-Early Eocene; Notes: The species epithet is in honour of Dr. Shya Chitaley.

3.13.10. Species: D. concavus P. Kumar 1990 (Fig. 11B); Index Fungorum Registration Identifier: 126553; Location: Padappakkara, Kollam District, Kerala, India; Age: Early-Middle Miocene (Quilon Beds).

3.13.11. Species: D. dilcheri (Anil Chandra et al.) Kalgutkar \& Janson. 2000 (Fig. 11C); Index Fungorum Registration Identifier: 483313; Basionym: Inapertisporites dilcheri Anil Chandra 1984; Location: Sediment core no. 1 (Lat. $17^{\circ} 57.9^{\prime} \mathrm{N}$ : Long. $70^{\circ} 46.0^{\prime} \mathrm{E}$ ), Arabian Sea; Age: Late Quaternary; Notes: The species epithet is in honour of Professor D.L. Dilcher. 
3.13.12. Species: D. doliiformis Kalgutkar 1997; Index Fungorum Registration Identifier: 437905; Location: Kanguk Peninsula, Axel Heiberg Island, Northwest Territories, Canada; Age: Late Palaeocene-Early Eocene; Notes: The species is named for barrel-shape of spores.

3.13.13. Species: D. dolium P. Ke \& Z.Y. Shi 1978; Index Fungorum Registration Identifier: 115647; Location: Panshan, Liaoning Province, Coastal region of Bohai, China; Age: Eocene-Oligocene.

3.13.14. Species: D. elegans Z.C. Song \& H.C. Luo in Z.C. Song et al. 1989; Index Fungorum Registration Identifier: 637494; Location: Shenxian county of Shandong Province, China; Age: Late Eocene-Middle Oligocene (Shahejie Formation); Notes: According to Kalgutkar \& Jansonius (2000), the single figure illustrated appears to have some longitudinal septa, subdividing the central three cells (that themselves are separated by two transverse septa).

3.13.15. Species: D. ellipticus Zhong Y. Zhang 1980; Index Fungorum Registration Identifier: 485003; Location: Lunpola Basin, northern Xizang Plateau, Xizang, China; Age: Oligocene (Niubao Formation).

3.13.16. Species: D. elongatus (Sheffy \& Dilcher) Kalgutkar \& Janson. 2000; Index Fungorum Registration Identifier: 483314; Basionym: Multicellaesporites elongatus Sheffy \& Dilcher 1971; Location: Puryear clay pit, 800 m south of Puryear, Henry County, Tennessee, U.S.A.; Age: Middle Eocene (Claiborne Formation); Notes: According to Sheffy \& Dilcher (1971), this spore resembles the shape of teliospores of Xenodochus Schlect, in Ramanujam \& Ramachar (1963).

3.13.17. Species: D. elsikii Mart.-Hern. \& Tom.-Ort. 1989; Index Fungorum Registration Identifier: 483800; Location: Piedras Negras, Coahuila State, Mexico; Age: Maastrichtian; Notes: The species epithet is in honour of Dr. William C. Elsik.

3.13.18. Species: D. elsikii B. Samant \& Tapaswi 2000; Index Fungorum Registration Identifier: 515004; Current name: Diporicellaesporites samantiae R.K. Saxena 2009 fide Saxena (2009); Notes: Diporicellaesporites elsikii B. Samant \& Tapaswi 2000 is illegitimate, being later homonym of Diporicellaesporites elsikii Mart.-Hern. \& Tom.-Ort. 1989. For this reason, Saxena (2009) replaced it with a new name.

3.13.19. Species: D. endogranulosus Kemp 1978; Index Fungorum Registration Identifier: 111433; Current name: Foveodiporites endogranulosus (Kemp) Kalgutkar \& Janson. 2000 fide Kalgutkar \& Jansonius (2000).

3.13.20. Species: D. extensus Rouse \& Mustard 1997; Index Fungorum Registration Identifier: 464000; Location: Strait of Georgia, eastern Vancouver Island, the Fraser River lowlands of southwest British Columbia, Canada, and northwestern Washington State, U.S.A.; Age: Late Paleocene.

3.13.21. Species: D. fusiformis Ramanujam \& Srisailam 1980 (Fig. 11D); Index Fungorum Registration Identifier: 108847; Location: Kannur Beach area, Palayangadi and Cheruvattur (southern side of Karingottu River), Kerala, India; Age: Miocene (Warkalli Beds).

3.13.22. Species: D. fusiformis Z.C. Song \& H.C. Luo in Z.C. Song et al. 1989; Index Fungorum Registration Identifier: 485265; Current name: Diporicellaesporites minifusiformis Kalgutkar \& Janson. 2000 fide Kalgutkar \& Jansonius (2000).

3.13.23 Species: D. fusoides Sal.-Cheb. \& Locq. 1980; Index Fungorum Registration Identifier: 107930; Location: Coast of Equatorial Africa, Gulf of Guinea, Cameroon, Africa; Age: Early Miocene.

3.13.24. Species: D. giganteus P. Ke \& Z.Y. Shi 1978; Index Fungorum Registration Identifier: 115646; Location: Huanghua, Hebei Province, Coastal region of Bohai, China; Age: EoceneOligocene.

3.13.25. Species: D. hillsii Kalgutkar 1993; Index Fungorum Registration Identifier: 483869, Current name: Quilonia hillsii (Kalgutkar) Kalgutkar \& Janson. 2000 fide Kalgutkar \& Jansonius (2000).

3.13.26. Species: D. icebergi Kalgutkar \& Sigler 1995; Index Fungorum Registration Identifier: 412959; Location: Kanguk Peninsula, Axel Heiberg Island, Northwest Territories, Canada; 
Age: Late Palaeocene or Early Eocene (Iceberg Bay Formation); Notes: The species epithet is after its occurrence in Iceberg Bay Formation.

3.13.27. Species: D. incurviusculus Kalgutkar 1997; Index Fungorum Registration Identifier: 437906; Location: Kanguk Peninsula, Axel Heiberg Island, Northwest Territories, Canada; Age: Late Palaeocene-Early Eocene; Notes: The species epithet is after the incurved pores found the spores of this species.

3.13.28. Species: D. intrastriatus H.P. Fan in X.T. Guan et al. 1989; Index Fungorum Registration Identifier: 637495; Location: Southern Bohai Sea region, China; Age: Neogene (Guantao Formation).

3.13.29. Species: D. jansonii Kalgutkar 1993; Index Fungorum Registration Identifier: 483870; Location: Peel River, Yukon Territory, Canada; Age: Late Palaeocene-Early Eocene; Notes: Kalgutkar (1993) opined that the tendency of these spores to form in succession and their morphological similarity are comparable to conidia encountered in species of modern Annellophora, a dematiaceous hyphomycetous fungus. The species epithet is honour of Dr. Jan Jansonius.

3.13.30. Species: D. laevigataeformis P. Ke \& Z.Y. Shi 1978; Index Fungorum Registration Identifier: 261342; Location: Panshan, Liaoning Province, Coastal region of Bohai, China; Age: Eocene-Oligocene.

3.13.31. Species: D. lageniformis Zhong Y. Zhang 1980; Index Fungorum Registration Identifier: 485005; Current name: Quilonia lageniformis (Zhong Y. Zhang) Kalgutkar \& Janson. 2000 fide Kalgutkar \& Jansonius (2000).

3.13.32. Species: D. lanceolatus Z.C. Song 1985; Index Fungorum Registration Identifier: 485257; Current name: Multicellaesporites songii Kalgutkar \& Janson. 2000 fide Kalgutkar \& Jansonius (2000).

3.13.33. Species: D. liaoningensis P. Ke \& Z.Y. Shi 1978; Index Fungorum Registration Identifier: 115622; Location: Panshan, Liaoning Province; Kenli, Shandong Province, Coastal region of Bohai, China; Age: Eocene-Oligocene.

3.13.34. Species: D. macellus Kalgutkar \& Janson. 2000; Index Fungorum Registration Identifier: 483315; Basionym: Multicellaesporites attenuatus Sheffy \& Dilcher 1971; Location: Puryear clay pit, $800 \mathrm{~m}$ south of Puryear, Henry County, Tennessee, U.S.A.; Age: Middle Eocene (Claiborne Formation); Notes: The species epithet is derived from Latin macellus = rather slender, thin.

3.13.35. Species: D. mediocoloratus Kalgutkar 1993; Index Fungorum Registration Identifier: 483871; Location: Peel River, Yukon Territory, Canada; Age: Late Palaeocene-Early Eocene; Notes: The species epithet is derived from the Latin, medius, middle; coloratus, coloured, referring to the middle cell pigment.

3.13.36. Species: D. minifusiformis Kalgutkar \& Janson. 2000; Index Fungorum Registration Identifier: 483316; Basionym: Diporicellaesporites fusiformis Z.C. Song \& H.C. Luo in Z.C. Song et al. 1989; Location: Shenxian county of Shandong Province, China; Age: Late Eocene-Middle Oligocene (Shahejie Formation); Notes: Diporicellaesporites minifusiformis Kalgutkar \& Janson. 2000 is a replacement name of Diporicellaesporites fusiformis Z.C. Song \& H.C. Luo in Z.C. Song et al. 1989.

3.13.37. Species: D. minusculus (Sheffy \& Dilcher) Kalgutkar \& Janson. 2000; Index Fungorum Registration Identifier: 483317; Basionym: Pluricellaesporites minusculus Sheffy \& Dilcher 1971; Location: Puryear clay pit, 800 m south of Puryear, Henry County, Tennessee, U.S.A.; Age: Middle Eocene (Claiborne Formation).

3.13.38. Species: D. minutigranulatus (Hammen) Kalgutkar \& Janson. 2000; Index Fungorum Registration Identifier: 483318; Basionym: Pluricellaesporites minutigranulatus Hammen 1954, p. 104, Location: Magdalena Valley, Eastern Cordellera, Colombia, South America; Age: Maastrichtian. 
3.13.39. Species: D. minutus Zhong Y. Zhang 1980; Index Fungorum Registration Identifier: 485004; Location: Lunpola Basin, northern Xizang Plateau, Xizang, China; Age: Oligocene (Niubao Formation).

3.13.40. Species: D. multicellatus R.K. Saxena \& S. Khare 1992; Index Fungorum Registration Identifier: 483893; Current name: Quilonia multicellata (R.K. Saxena \& S. Khare) Kalgutkar \& Janson. 2000 fide Kalgutkar \& Jansonius (2000).

3.13.41. Species: D. navicularis Kalgutkar 1993; Index Fungorum Registration Identifier: 483872; Location: Peel River, Yukon Territory, Canada; Age: Late Palaeocene-Early Eocene; Notes: The species epithet is derived from the Latin, navicularis, boat-shaped, referring to the shape of the spores.

3.13.42. Species: D. oblongatus P. Ke \& Z.Y. Shi 1978; Index Fungorum Registration Identifier: 115644; Location: Coastal region of Bohai, China; Age: Early Tertiary.

3.13.43. Species: D. oculinus M.G. Parsons \& G. Norris 1999; Index Fungorum Registration Identifier: 483923; Location: Caribou Hills, Mackenzie Delta, northern Canada; Age: Late Palaeocene-Early to Middle Eocene; Notes: The species epithet is derived from Latin oculus, eye, and -inus, like, referring to the eye-like shape of this spore.

3.13.44. Species: D. ordinatus (Sheffy \& Dilcher) Kalgutkar \& Janson. 2000; Index Fungorum Registration Identifier: 483319; Basionym: Fractisporonites ordinatus Sheffy \& Dilcher 1971; Location: Puryear clay pit, 800 m south of Puryear, Henry County, Tennessee, U.S.A.; AGE: Middle Eocene (Claiborne Formation).

3.13.45. Species: D. padappakkarensis P. Kumar 1990; Index Fungorum Registration Identifier: 126554; Current name: Biporipsilonites padappakkarensis (P. Kumar) Kalgutkar \& Janson. 2000 fide Kalgutkar \& Jansonius (2000).

3.13.46. Species: D. papillatus Kalgutkar 1997; Index Fungorum Registration Identifier: 437907; Location: Kanguk Peninsula, Axel Heiberg Island, Northwest Territories, Canada; Age: Late Palaeocene-Early Eocene; Notes: The species epithet is after papillate spores.

3.13.47. Species: D. pluricellus R.K. Kar \& R.K. Saxena 1976 (Fig. 11E); Index Fungorum Registration Identifier: 112280; Location: Matanomadh, Bhuj-Lakhpat Road, Kutch District, Gujarat, India; Age: Palaeocene (Matanomadh Formation).

3.13.48. Species: D. prakashii Anil Chandra et al. 1984; Index Fungorum Registration Identifier: 106780; Current name: Quilonia prakashii (Anil Chandra et al.) Kalgutkar \& Janson. 2000 fide Kalgutkar \& Jansonius (2000).

3.13.49. Species: D. psilatus Elsik \& Dilcher 1974; Index Fungorum Registration Identifier: 637496; Location: Lawrence Clay Pit, Henry County, Tennessee, U.S.A.; Age: Middle Eocene.

3.13.50. Species: D. puryearensis Sheffy \& Dilcher 1971; Index Fungorum Registration Identifier: 111434; Current name: Dyadosporites puryearensis (Sheffy \& Dilcher) Kalgutkar \& Janson. 2000 fide Kalgutkar \& Jansonius (2000).

3.13.51. Species: D. quadratus Rouse \& Mustard 1997; Index Fungorum Registration Identifier: 464002; Current name: Dyadosporites quadratus (Rouse \& Mustard) Kalgutkar \& Janson. 2000 fide Kalgutkar \& Jansonius (2000).

3.13.52. Species: D. quaternarius Kalgutkar 1993; Index Fungorum Registration Identifier: 483873; Location: Peel River, Yukon Territory, Canada; Age: Late Palaeocene-Early Eocene; Notes: The species epithet is derived from the Latin, quaternarius, consisting of four, referring to the spores being typically four-celled.

3.13.53. Species: D. ramanujamii Kalgutkar 1997; Index Fungorum Registration Identifier: 437908; Location: Kanguk Peninsula, Axel Heiberg Island, Northwest Territories, Canada; Age: Late Palaeocene-Early Eocene; Notes: The species epithet is in honour of Professor C.G.K. Ramanujam.

3.13.54. Species: D. reticulatus Elsik \& Dilcher 1974; Index Fungorum Registration Identifier: 637497; Location: Lawrence Clay Pit, Henry County, Tennessee; Age: Middle Eocene. 
3.13.55. Species: D. samantiae R.K. Saxena 2009 (Fig. 11F); Index Fungorum Registration Identifier: 515005; Basionym: Diporicellaesporites elsikii B. Samant \& Tapaswi 2000; Location: Near Bhavnagar, Cambay Basin, Gujarat, India; Age: Early Eocene (Kharsalia Clay Formation); Notes: Diporicellaesporites samantiae R.K. Saxena 2009 is a replacement name of Diporicellaesporites elsikii B. Samant \& Tapaswi 2000.

3.13.56. Species: D. scalaris Kalgutkar 1993; Index Fungorum Registration Identifier: 483874, Current name: Scolecosporites scalaris (Kalgutkar 1993) Kalgutkar \& Janson. 2000 fide Kalgutkar \& Jansonius (2000).

3.13.57. Species: D. segmentatus Rouse \& Mustard 1997; Index Fungorum Registration Identifier: 464003; Location: Strait of Georgia, eastern Vancouver Island, the Fraser River lowlands of southwest British Columbia, Canada, and North-western Washington State, U.S.A.; Age: Late Eocene-Early Oligocene.

3.13.58. Species: D. serratulus Traverse \& Ash 1994; Index Fungorum Registration Identifier: 313249; Location: Wallowa terrane in Hells Canyon, Idaho, U.S.A.; Age: Early Jurassic to early Middle Jurassic; Notes: The species epithet is derived from the Latin for toothed.

3.13.59. Species: D. stacyi Elsik 1968 (Fig. 11G); Index Fungorum Registration Identifier: 313249; Location: Strip mine approximately $11 \mathrm{~km}$ south-west of Rockdale, Milam County, Texas, U.S.A.; Age: Palaeocene (Rockdale lignite).

3.13.60. Species: D. stenosus Z.C. Song \& Liu Cao 1994; Index Fungorum Registration Identifier: 483774, Current name: Dyadosporites antarcticus Kalgutkar \& Janson. 2000 fide Kalgutkar \& Jansonius (2000).

3.13.61. Species: D. suboblongatus (Sheffy \& Dilcher) Kalgutkar \& Janson. 2000; Index Fungorum Registration Identifier: 483320; Basionym: Pluricellaesporites suboblongatus Sheffy \& Dilcher 1971; Location: Puryear clay pit, 800 m south of Puryear, Henry County, Tennessee, U.S.A.; Age: Middle Eocene (Claiborne Formation).

3.13.62. Species: D. taeniolelloides Kalgutkar 1997; Index Fungorum Registration Identifier: 437902; Location: Kanguk Peninsula, Axel Heiberg Island, Northwest Territories, Canada; Age: Late Palaeocene-Early Eocene; Notes: According to Kalgutkar (1997), the present species resembles the catenate conidia of species of the modern Taeniolella S. Hughes, particularly Taeniolella rudis (Sacc.) S. Hughes. In species of Taeniolella, the conidia are generally smooth whereas in Diporicellaesporites taeniolelloides, the spores are larger and broader, and generally coarsely rough. The species epithet is derived from the presumed affinity to Taeniolella.

3.13.63. Species: D. taiwanensis T.C. Huang 1981; Index Fungorum Registration Identifier: 115742; Location: Taiwan; Age: Miocene.

3.13.64. Species: D. tetralocularis Sheffy \& Dilcher 1971; Index Fungorum Registration Identifier: 111435; Location: Puryear clay pit, $800 \mathrm{~m}$ south of Puryear, Henry County, Tennessee, U.S.A.; Age: Middle Eocene (Claiborne Formation).

3.13.65. Species: D. tiruchirappalliensis R.K. Saxena, Wijayaw., D.Q. Dai, K.D. Hyde \& P.M. Kirk sp. nov. (Fig. 11H); This new species is described under the section "New species and new combinations".

3.13.66. Species: D. vermiculatus Kalgutkar 1993; Index Fungorum Registration Identifier: 483875; Location: Peel River, Yukon Territory, Canada; Age: Late Palaeocene-Early Eocene; Notes: The species epithet is derived from the Latin, vermiculus, little worm (grub), referring to the worm-like shape of the spores.

3.13.67. Species: D. verrucatus H.P. Singh et al. 1986 (Fig. 11I); Index Fungorum Registration Identifier: 131930; Location: Sonapur-Badarpur road Section, Jaintia Hills, Meghalaya and Cachar, Assam, India; Age: Early Miocene (Bhuban Formation, Surma group); Notes: The species epithet refers to the verrucate spore wall.

3.13.68. Species: D. wilkinsonii R.K. Saxena \& N.K. Misra 1990; Index Fungorum Registration Identifier: 483360; Current name: Dyadosporites wilkinsonii (R.K. Saxena \& N.K. Misra) Kalgutkar \& Janson. 2000 fide Kalgutkar \& Jansonius (2000). 

1970.

Original Diagnosis: Diporate; amb more or less globular to sub-spheroidal; small to medium in size; pores placed one over the other, circular in shape, and encircled by one or more thickened rims; exine thin, surface sculpture psilate to scabrate or finely granulate (Dutta \& Sah 1970).

Emended Diagnosis: Small to medium sized, tri- to tetracellate conidia, of which the distal cell is very much larger than the other cells. Although the basic structure can be compared to that of Brachysporisporites, here the distal cell is so inflated, that it is spherical, or its width even larger than its length, commonly causing the spores to be (proximo-distally) compressed in the equatorial plane. This in turn causes the two or three proximalmost cells to collapse into each other. Spore wall thin to very thin, and prone to concentric folding, in the distal cell; septa thin, with distinct rimmed pores, anchored by thick, opaque septal bases, that in proximo-distal compression form concentric rings. When the compression is somewhat oblique, the proximal cells show that they are forming a short, more or less tapering tube, the end of which has a small, imperceptible pore, indicating that it is functionally a hilum (Kalgutkar \& Jansonius 2000).

Classification: Fungi Imperfecti, Phragmosporae.

Number of species known: Two.

Notes: Dutta \& Sah (1970), though proposed Diporipollis as a pollen genus, compared it with fungal spore genera, viz. Diporisporites Hammen (1954), Diporites Hammen (1954). Kalgutkar \& Jansonius (2000), on the basis of personal communication with William C. Elsik, recognized its fungal affinity and considered it as 'Fungi Imperfecti, Phragmosporae'.

3.14.1. Species: D. assamicus S.K. Dutta \& S.C.D. Sah 1970 (Fig. 11J); Index Fungorum Registration Identifier: 519812; Location: Umstew, South Shillong Plateau, Meghalaya, India; Age: Early Eocene (Cherra Formation); Notes: Dutta \& Sah (1970) mentioned that "pollen grains of Diporipollis assamicus are not comparable to any of the fossil species known so far. Although the present pollen grains from Assam show a striking resemblance to pollen within the family Gramineae, their affinity with the family Gramineae remains questionable owing to number, position and nature of the apertures". According to Kalgutkar \& Jansonius (2000), William C. Elsik (personal communication with Jan Jansonius) recognized this grain as a fungal spore: the "thickened rims" mark the septal boundaries, the largest of which located where the proximal cylinder of cells is attached to the distal-most cell (Jansonius \& Hills 1976).

3.14.2. Species: D. melanii (Elsik) Kalgutkar \& Janson. 2000; Index Fungorum Registration Identifier: 483321; Basionym: Pluricellaesporites melanii Elsik 1968; Synonym: Granatisporites melanii (Elsik) Elsik \& Janson. 1974 fide Kalgutkar \& Jansonius (2000); Location: Strip mine approximately 7 miles southwest of Rockdale, Milam County, Texas, U.S.A.; Age: Palaeocene.

3.15. Genus: DWAYABEEJAESPORONITES Debi Mukh., International Journal of Geology, Earth and Environmental Sciences 2(2): 4 (2012); Index Fungorum Registration Identifier: 588462; Type: D. undulatus Debi Mukh. 2012.

Original Diagnosis: Conidiophores with 14-15 cells arranged in acropetal order, thick walled, enclosed in an undulating conidiophores wall; conidiophores up to $200 \mu \mathrm{m}$ size, apical cell mostly smaller; scoliospores range 12-25 × 25-32 $\mu \mathrm{m}$ (Mukherjee 2012).

Classification: Fungi Imperfecti, Phragmosporae.

Number of species known: One.

Notes: The name of the genus is after extant Dwayabeeja Subramanian 1971.

3.15.1. Species: D. undulatus Debi Mukh. 2012 (Fig. 11K); Index Fungorum Registration Identifier: 588475; Location: Neyveli Lignite Mine-I, Cuddalore District, Tamil Nadu, India; Age: Miocene (Neyveli Lignite); Notes: The specific epithet refers to its undulate nature. 
3.16. Genus: EDMUNDMASONAESPORITES Debi Mukh., International Journal of Geology, Earth and Environmental Sciences 2(2): 4 (2012); Index Fungorum Registration Identifier: 588463; Type: E. globulatus Debi Mukh. 2012.

Generic Diagnosis: Spore multicelled, septate, dark in colour; 5 celled, apical cell enlarged, globular, vacuolated; spores $100-120 \times 18-30 \mu \mathrm{m}$, apical cell large measures $33 \mu \mathrm{m}$, basal one 18 $\mu \mathrm{m}$; spore wall laevigate (Mukherjee 2012).

Classification: Fungi Imperfecti, Phragmosporae.

Number of species known: One.

Notes: The present fossil spore shows resemblance with the extant Edmundmasonia Subram. under Hyphomycetes.

3.16.1. Species: E. globulatus Debi Mukh. 2012 (Fig. 11L); Index Fungorum Registration Identifier: 588476; Location: Neyveli Lignite Mine-I, Cuddalore District, Tamil Nadu, India; Age: Miocene (Neyveli Lignite); Notes: The specific epithet refers to globular apical cell.

3.17. Genus: FOVEOLETISPORONITES Ramanujam \& K.P. Rao, Proc. IV International Palynology Conference, Lucknow 1976-1977 1: 299 (1978); Index Fungorum Registration Identifier: 21102; Type: $\boldsymbol{F}$. miocenicus Ramanujam \& K.P. Rao 1978.

Original Diagnosis: Spores simple, light to dark brown, multicellate, inaperturate. Spore wall two-layered, inner layer forming transverse septa, surface conspicuously foveolate (Ramanujam \& Rao 1978).

Classification: Fungi Imperfecti, Phragmosporae.

Number of species known: Three.

Notes: The diagnostic features of this genus are the simple, multiseptate nature and the conspicuously foveolate sculpturing of the spore wall.

3.17.1. Species: F. indicus Ramanujam \& Srisailam 1980 (Fig. 11M); Index Fungorum Registration Identifier: 108883; Location: Kannur Beach area, Palayangadi and Cheruvattur (southern side of Karingottu River), Kerala, India; Age: Miocene (Warkalli Beds).

3.17.2. Species: F. keralensis R.K. Saxena \& S.K.M. Tripathi 2011 (Fig. 11N); Index Fungorum Registration Identifier: 519940; Location: Around Kollam and Varkala, Kerala, India; Age: Miocene.

3.17.3. Species: F. miocenicus Ramanujam \& K.P. Rao 1978 (Fig. 11O); Index Fungorum Registration Identifier: 115066; Location: Varkala, Kerala, India; Age: Miocene (Quilon and Warkalli Beds).

3.18. Genus: FRACTISPORONITES R.T. Clarke, Mountain Geologist 2(2): 91 (1965); Index Fungorum Registration Identifier: 21106, Type: $\boldsymbol{F}$. canalis R.T. Clarke 1965.

Original Diagnosis: Fungal spores uniseriate, fragments consist of four to many rectangular to square cells, sides generally parallel (Clarke 1965).

Classification: Fungi Imperfecti, Phragmosporae.

Number of species known: Nine (but we accept only eight species as legitimate because $F$. ordinatus Sheffy \& Dilcher 1971 has been transferred to Diporicellaesporites Elsik 1968).

Notes: The prefix of the generic name is derived from the Latin word fractus meaning broken. Fractisporonites is for fragments of very long fungal spores that generally has breaks at both ends, which differentiates it from all other psilate scalariform species.

3.18.1. Species: F. canalis R.T. Clarke 1965 (Fig. 11P); Index Fungorum Registration Identifier: 330975; Location: Canon City coal field, Fremont County, Colorado, U.S.A.; Age: Late Cretaceous; Notes: The species epithet is derived from Latin canalis for channel, or canal, and is given in reference to the tubular structure extending the length of the spore.

3.18.2. Species: F. doliiformis Kalgutkar 1993; Index Fungorum Registration Identifier: 483880; Location: Peel River, Yukon Territory, Canada; Age: Late Palaeocene-Early Eocene; Notes: The species epithet is derived from Latin, doliiformis, vessel-shaped, referring to the cells being barrel-shaped. 
3.18.3. Species: F. elongatus (Sat. K. Srivast.) Kalgutkar \& Janson. 2000; Index Fungorum Registration Identifier: 483376; Basionym: Pluricellaesporites elongatus Sat. K. Srivast. 1968, Location: East Coulee locality, sec. 27, twp. 27, rge. 18, W. 4th mer., Alberta, Canada; Age: Maastrichtian; Notes: The species epithet is derived from the elongated cells of the species.

3.18.4. Species: F. filiformis (Hammen) Kalgutkar \& Janson. 2000; Index Fungorum Registration Identifier: 483377; Basionym: Pluricellaesporites filiformis Hammen 1954; Location: Magdalena Valley, Eastern Cordellera, Colombia, South America; Age: Maastrichtian.

3.18.5. Species: F. lucibiliporus Sat. K. Srivast. \& H. Al. -Tayyar 2013; Index Fungorum Registration Identifier: 818888; Location: Northern Arabian Gulf; Age: Late middle Albian; Notes: Fusiform conidia of Scolicosporium macrosporium (Berk.) Sutton of Coelomycetes has a pore on the wall of each cell (Ellis \& Ellis 1985). The species epithet is derived from the Latin lucibilis = bright.

3.18.6. Species: F. moniliformis R.T. Clarke 1965; Index Fungorum Registration Identifier: 330976; Location: Canon City coal field, Fremont County, Colorado; Age: Late Cretaceous; Notes: The species epithet is derived from the regularly constricted intervals at the septa (Latin monile is beaded necklace). Fractisporonites moniliformis differs from $F$. canalis by its septal constrictions.

3.18.7. Species: F. nodosus (Sat. K. Srivast.) Kalgutkar \& Janson. 2000; Index Fungorum Registration Identifier: 483378; Basionym: Pluricellaesporites nodosus Sat. K. Srivast. 1968; Location: Morrin Bridge locality, sec. 16, twp. 31, rge. 21, W. 4th mer., Alberta, Canada; Age: Maastrichtian; Notes: The species epithet is derived from the Latin nodosus $=$ having knots.

3.18.8. Species: F. ordinatus Sheffy \& Dilcher 1971; Index Fungorum Registration Identifier: 111492; Current name: Diporicellaesporites ordinatus (Sheffy \& Dilcher) Kalgutkar \& Janson. 2000 fide Kalgutkar \& Jansonius (2000).

3.18.9. Species: F. pittsburgensis Traverse \& Ash 1994; Index Fungorum Registration Identifier: 363118; Location: Wallowa terrane in Hells Canyon, Idaho, U.S.A.; Age: Early Jurassic to early Middle Jurassic.

3.19. Genus: GRANATISPORITES Elsik \& Janson., Can. J. Bot. 52(5): 953 (1974); Index Fungorum Registration Identifier: 21121; Type: G. cotalis Elsik \& Janson. 1974; Current name: BRACHYSPORISPORITES R.T. Lange \& P.H. Sm. 1971 fide Kalgutkar \& Jansonius (2000).

Original Diagnosis: Fungal spores of three or more cells and two or more septa, symmetrical or nearly so around the long axis. Ambitus oval to clavate; widest towards aporate end. One aperture, pore, hilum or exitus, generally situated on the long axis at the narrower end of the spore. Exine psilate, or has ornament of low relief. One or two (rarely three) cells at aporate end always much larger and constituting the bulk of the spore (Elsik \& Jansonius 1974).

Classification: Fungi Imperfecti, Phragmosporae.

Number of species known: Five (all the species have been transferred to other genera).

Notes: Lange \& Smith (1975) stated that the type species of Granatisporites should be assigned to Brachysporisporites R.T. Lange \& P.H. Sm. 1971, the correct name for this formgeneric concept. This makes Granatisporites a later synonym of Brachysporisporites. Therefore, $G$. cotalis Elsik \& Janson. 1974 (type species) and two other species, described by the same authors, have been transferred to Brachysporisporites R.T. Lange \& P.H. Sm. 1971. However, the remaining two species have been transferred to other genera.

3.19.1. Species: G. catinus Elsik \& Janson. 1974; Index Fungorum Registration Identifier: 314702; Current name: Brachysporisporites catinus (Elsik \& Janson.) Kalgutkar \& Janson. 2000 fide Kalgutkar \& Jansonius (2000).

3.19.2. Species: G. coahuilensis Mart-Hern. \& Tom.-Ort. 1989; Index Fungorum Registration Identifier: 483804; Current name: Pluricellaesporites coahuilensis (Mart-Hern. \& Tom.-Ort.) Kalgutkar \& Janson. 2000 fide Kalgutkar \& Jansonius (2000). 
3.19.3. Species: G. cotalis Elsik \& Janson. 1974; Index Fungorum Registration Identifier: 314703; Current name: Brachysporisporites cotalis (Elsik \& Janson.) G. Norris 1986 fide Norris (1986).

3.19.4. Species: G. melanii (Elsik) Elsik \& Janson. 1974; Index Fungorum Registration Identifier: 314704; Current name: Diporipollis melanii (Elsik) Kalgutkar \& Janson. 2000 fide Kalgutkar \& Jansonius (2000).

3.19.5. Species: G. opimus Elsik \& Janson. 1974; Index Fungorum Registration Identifier: 314705; Current name: Brachysporisporites opimus (Elsik \& Janson.) G. Norris 1986 fide Norris (1986).

3.20. Genus: HAPALOPHRAGMITES Ramanujam \& Ramachar, Records of the geological Survey of India 113(5): 82 (1980); Index Fungorum Registration Identifier: 28629; Type: $\boldsymbol{H}$. cumminsii Ramanujam \& Ramachar 1980, p. 82, pl. 1, fig. 7.

Original Diagnosis: Teliospores triquetrously three-celled, pedicellate, odd cell terminal, the two basal cells borne on a common stalk; wall cinnamon-brown; one germ pore in each cell (Ramanujam \& Ramachar 1980).

Classification: Basidiomycota, Uredinales.

Number of species known: One.

3.20.1. Species: H. cumminsii Ramanujam \& Ramachar 1980 (Fig. 11Q); Index Fungorum Registration Identifier: 483758; Location: Neyveli Lignite Mine, Cuddalore District, Tamil Nadu, India; Age: Miocene (Neyveli lignite); Notes: Named for G.B. Cummins, famed uredinologist of Arizona University, U.S.A.

3.21. Genus: HETEROCYSTINELLA Cookson \& Eisenack, Neues Jahrbuch für Geologie und Paläontologie, Monatshefte 2: 79 (1979); Index Fungorum Registration Identifier: 637498; Type: H. bulbosa Cookson \& Eisenack 1979.

Original Diagnosis: The coenobium consists of several approximately spherical cells of widely different size, arranged in a straight row in order of decreasing size (Cookson \& Eisenack 1979).

Classification: Fungi Imperfecti, Phragmosporae.

Number of species known: One.

3.21.1. Species: H. bulbosa Cookson \& Eisenack 1979 (Fig. 11R); Index Fungorum Registration Identifier: 637499; Location: Eucla basin, Western Australia; Age: Middle Cretaceous; Notes: Eisenack (1979) suggested affinity to the Algae. Kalgutkar \& Jansonius (2000) considered this form a possible multicelled fungal spore (Jansonius \& Hills 1982).

3.22. Genus: JANSONIISPORITES Kalgutkar, Review of Palaeobotany \& Palynology (Amsterdam) 97(1-2): 216 (1997); Index Fungorum Registration Identifier: 27774; Type: J. endophragmia (Kalgutkar \& Sigler) Kalgutkar 1997.

Original Diagnosis: Spores obovoid to clavate, smooth, light brown to brown, not dark, 2-4 septate; septa slightly notched. Cells often unequally coloured. Spores truncated at the base. Spore wall consisting of two layers that commonly are not appressed, and that may be somewhat separated between the septa; characterized by distinct presence of folds along the internal cell wall and encircling the septa (Kalgutkar 1997).

Classification: Fungi Imperfecti, Phragmosporae.

Number of species known: One.

3.22.1. Species: J. endophragmia (Kalgutkar \& Sigler) Kalgutkar 1997 (Fig. 11S); Index Fungorum Registration Identifier: 437914; Location: Kanguk Peninsula, Axel Heiberg Island, Northwest Territories, Canada; Age: Late Palaeocene-Early Eocene. 
3.23. Genus: KUMARISPORITES Kalgutkar \& Janson., AASP Contributions Series (Dallas) 39: 157 (2000); Index Fungorum Registration Identifier: 28619; Type: K. ramanujamii (P. Kumar.) Kalgutkar \& Janson. 2000.

Original Diagnosis: Small to medium-sized tricellate, inaperturate fungal spores; central cell may be larger than the tapering terminal cells; septa (or septal bases) thicker than spore wall; spore wall ornamented by longitudinal ribs running full length of the spore, tapering towards the poles (Kalgutkar \& Jansonius 2000).

Classification: Fungi Imperfecti, Phragmosporae.

Number of species known: One.

Notes: Imprimospora ramanujamii P. Kumar 1990 is a misfit in Imprimospora and therefore Kalgutkar \& Jansonius (2000) proposed Kumarisporites to accommodate it.

3.23.1. Species: K. ramanujamii (P. Kumar) Kalgutkar \& Janson. 2000 (Fig. 11T); Index Fungorum Registration Identifier: 483411; Basionym: Imprimospora ramanujamii P. Kumar 1990; Location: Clay mine section near Kanjantheria House, Padappakkara, Kollam District, Kerala, India; Age: Early-Middle Miocene (Quilon Beds).

3.24. Genus: MATHURISPORITES Kalgutkar \& Janson., AASP Contributions Series (Dallas) 39: 166 (2000); Index Fungorum Registration Identifier: 28620; Type: M. ellipticus (Y.K. Mathur \& K. Mathur) Kalgutkar \& Janson. 2000.

Original Diagnosis: Medium-sized hilate spores, generally consisting of a darker central part with 2-4(-6) cells, and proximal and distal parts of a single to few hyaline cells. No distal pore. Septa distinct, as thick as, or thicker than, the spore wall. Differs from Pluricellaesporites in the swollen dark central cells (Kalgutkar \& Jansonius 2000).

Classification: Fungi Imperfecti, Phragmosporae.

Number of species known: Two.

Notes: Kalgutkar \& Jansonius (2000) opined that Pluricellaesporites ellipticus Y.K. Mathur \& K. Mathur is a misfit in Pluricellaesporites Hammen and therefore they proposed Mathurisporites to accommodate it.

3.24.1. Species: M. ellipticus (Y.K. Mathur \& K. Mathur) Kalgutkar \& Janson. 2000 (Fig. 11U); Index Fungorum Registration Identifier: 483417; Basionym: Pluricellaesporites ellipticus Y.K. Mathur \& K. Mathur 1969; Location: Naera and Baraia, Kutch District, Gujarat, India; Age: Pliocene.

3.24.2. Species: M. glomeratus (Sat. K. Srivast.) Kalgutkar \& Janson. 2000; Index Fungorum Registration Identifier: 483418; Basionym: Pluricellaesporites glomeratus Sat. K. Srivast. 1968; Location: East Coulee, Alberta, Canada; Age: Maastrichtian (Horseshoe Canyon Formation).

3.25. Genus: MONILITES Pampal., Pilzfunde aus der Augsburger Umgebung 8: 128 (1902); Index Fungorum Registration Identifier: 21171; Type: M. albidus Pampal. 1902.

Original Diagnosis: Hyphae septate, hyaline, loosely but copiously branching. Conidia globose, elliptical, hyaline, smooth, 18-21 $\mu \mathrm{m}$, obtuse on both sides, in short chains that occasionally branch. (Pampaloni 1902).

Classification: Fungi Imperfecti, Phragmosporae.

Number of species known: One.

3.25.1. Species: M. albidus Pampal. 1902 (Fig. 11V); Index Fungorum Registration Identifier: 141284; Location: "Disodile" beds, Italy; Age: Middle Miocene.

3.26. Genus: MULTICELLAESPORITES Elsik, Pollen et Spores 10(2): 269 (1968); Index Fungorum Registration Identifier: 21181; Type: M. nortonii Elsik 1968.

Synonym: Warkallisporonites Ramanujam \& K.P. Rao 1978 fide Kalgutkar \& Jansonius (2000), Index Fungorum Registration Identifier: 21361. 
Original Diagnosis: Inaperturate, psilate fungal spores of three or more cells; two or more septa. Shape variable around a long axis (Elsik 1968).

Emended Diagnoses: Diagnosis of Multicellaesporites was emended by Sheffy \& Dilcher (1971) and Kumar (1990), as follows: Inaperturate, psilate to scabrate fungal spores or algal bodies of three or more cells; two or more septa. Shape variable around a long axis (Sheffy \& Dilcher 1971); Fungal spores multicellate, elongate. A longitudinal slit or furrow present. Spore wall smooth or ornamented or differentially coloured or thickened (Kumar 1990).

Classification: Fungi Imperfecti, Phragmosporae.

Number of species known: 91 (but we accept only thirteen species as legitimate because 71 species have been transferred to other genera by various authors and seven species, viz. M. biconicus Z.C. Song in Z.C. Song et al. 1999, M. leguminosus Z.C. Song in Z.C. Song et al. 1999, M. longiovatus Z.C. Song, Qian \& Y.H. Zheng in Z.C. Song et al. 1999, M. margarodes Z.C. Song in Z.C. Song et al. 1999, M. megafusus Z.C. Song, Qian \& Y.H. Zheng in Z.C. Song et al. 1999, M. spatulatus Z.C. Song, Qian \& Y.H. Zheng in Z.C. Song et al. 1999 and M. spindlus Z.C. Song, Qian \& Y.H. Zheng in Z.C. Song et al. 1999 have not been validly published).

Notes: Sheffy \& Dilcher (1971) emended the generic diagnosis to include a wider range of ornamentation than found in the type species. Kumar (1990) also emended the generic diagnosis. Kalgutkar \& Jansonius (2000) adopted the emended diagnosis of Kumar (1990) and paraphrased the same as follows: "Fungal spores, generally of three to five cells; overall shape fusiform to elliptical, commonly with a slight curvature in the long axis; generally, the equatorial section is a plane of symmetry; commonly with a subtle, but distinct, longitudinal furrow, crease, thinning or rupture of the wall on the concave side of the spore, that may be expressed in only the terminal cells, or along the whole spore; spore wall smooth or with minute sculpturing; septa distinct or thin, commonly with a perforation or septal folds." Warkallisporonites Ramanujam \& K.P. Rao 1978 is the later taxonomic synonym of Multicellaesporites Elsik 1968.

3.26.1. Species: M. acuminatus Rouse \& Mustard 1997; Index Fungorum Registration Identifier: 463998; Synonym: Piriurella acuminata (Rouse \& Mustard) M.G. Parsons \& G. Norris 1999 fide Kalgutkar \& Jansonius (2000); Current name: Polycellaesporonites acuminatus (Rouse \& Mustard) Kalgutkar \& Janson. 2000 fide Kalgutkar \& Jansonius (2000).

3.26.2. Species: M. allomorphus Sheffy \& Dilcher 1971; Index Fungorum Registration Identifier: 111662; Current name: Multicellites allomorphus (Sheffy \& Dilcher) Kalgutkar \& Janson. 2000 fide Kalgutkar \& Jansonius (2000).

3.26.3. Species: M. articulatus Sat. K. Srivast. \& Al-Tayyar 2013; Index Fungorum Registration Identifier: 818889; Location: northern Arabian Gulf; Age: Aptian; Notes: Srivastava and AlTayyar (2013) stated that similar conidiophores occur in Lobatopedis foliicola P.M. Kirk of Hyphomycetes (Ellis \& Ellis 1985). The species epithet is derived from Latin articulus = joint

3.26.4. Species: M. attenuatus Sheffy \& Dilcher 1971; Index Fungorum Registration Identifier: 111663; Current name: Diporicellaesporites macellus Kalgutkar \& Janson. 2000, fide Kalgutkar \& Jansonius (2000).

3.26.5. Species: M. bellus P. Ke \& Z.Y. Shi 1978; Index Fungorum Registration Identifier: 115677; Current name: Multicellites bellus (P. Ke \& Z.Y. Shi) Kalgutkar \& Janson. 2000 fide Kalgutkar \& Jansonius (2000).

3.26.6. Species: M. biconicus Z.C. Song in Z.C. Song et al. 1999 (nom. inval.) fide Kalgutkar \& Jansonius (2000); Index Fungorum Registration Identifier: 483823; Notes: This species name was not validly published because the author did not specify where the holotype is stored, and did not provide a Latin description or its English translation.

3.26.7. Species: M. bigeminatus Sheffy \& Dilcher 1971; Index Fungorum Registration Identifier: 111664; Current name: Dicellaesporites bigeminatus (Sheffy \& Dilcher) Kalgutkar \& Janson. 2000 fide Kalgutkar \& Jansonius (2000).

3.26.8. Species: M. bilobus Rouse \& Mustard 1997; Index Fungorum Registration Identifier: 463999; Location: Strait of Georgia, eastern Vancouver Island, the Fraser River lowlands of 
southwest British Columbia, Canada and the North-western Washington State, U.S.A.; Age: Late Palaeocene.

3.26.9. Species: M. capsularis Sheffy \& Dilcher 1971; Index Fungorum Registration Identifier: 111665; Current name: Pluricellaesporites capsularis (Sheffy \& Dilcher) Kalgutkar \& Janson. 2000 fide Kalgutkar \& Jansonius (2000).

3.26.10. Species: M. cerrejonensis Doub. \& D. Pons 1973; Index Fungorum Registration Identifier: 485250; Current name: Reduviasporonites cerrejonensis (Doub. \& D. Pons) Kalgutkar \& Janson. 2000 fide Kalgutkar \& Jansonius (2000).

3.26.11. Species: M. cingulatus P. Ke \& Z.Y. Shi 1978; Index Fungorum Registration Identifier: 115691; Current name: Multicellites cingulatus (P. Ke \& Z.Y. Shi) Kalgutkar \& Janson. 2000 fide Kalgutkar \& Jansonius (2000).

3.26.12. Species: M. circularis B. Samant \& Tapaswi 2000; Index Fungorum Registration Identifier: 519787; Current name: Multicellites circularis (B. Samant \& Tapaswi) R.K. Saxena \& S.K.M. Tripathi 2011 fide Saxena \& Tripathi (2011); Notes: This species does not possess a longitudinal furrow, an essential character of Multicellaesporites (sensu Kalgutkar \& Jansonius 2000) and therefore Saxena \& Tripathi (2011) transferred it to Multicellites Kalgutkar \& Janson. 2000.

3.26.13. Species: M. compactilis P. Ke \& Z.Y. Shi 1978; Index Fungorum Registration Identifier: 115690; Current name: Multicellites compactilis (P. Ke \& Z.Y. Shi) Kalgutkar \& Janson. 2000 fide Kalgutkar \& Jansonius (2000).

3.26.14. Species: M. confusus Anil Chandra et al. 1984; Index Fungorum Registration Identifier: 107038; Current name: Multicellites confusus (Anil Chandra et al.) Kalgutkar \& Janson. 2000 fide Kalgutkar \& Jansonius (2000).

3.26.15. Species: M. conicus P. Ke \& Z.Y. Shi 1978; Index Fungorum Registration Identifier: 115656; Current name: Paragranatisporites conicus (P. Ke \& Z.Y. Shi) Kalgutkar \& Janson. 2000 fide Kalgutkar \& Jansonius (2000).

3.26.16. Species: M. conspicuus P. Ke \& Z.Y. Shi 1978; Index Fungorum Registration Identifier: 115655; Current name: Multicellites conspicuus (P. Ke \& Z.Y. Shi) Kalgutkar \& Janson. 2000 fide Kalgutkar \& Jansonius (2000).

3.26.17. Species: M. crassisporus Sal.-Cheb. \& Locq. 1980; Index Fungorum Registration Identifier: 108235; Current name: Multicellites crassisporus (Sal.-Cheb. \& Locq.) Kalgutkar \& Janson. 2000 fide Kalgutkar \& Jansonius (2000).

3.26.18. Species: M. curvatus Ambwani 1983; Index Fungorum Registration Identifier: 107039; Current name: Reduviasporonites curvatus (Ambwani) Kalgutkar \& Janson. 2000 fide Kalgutkar \& Jansonius (2000).

3.26.19. Species: M. dawaensis Wang \& Leng 1982; Index Fungorum Registration Identifier: 637500; Location: China; Notes: This species was cited in Song et al. (1999). Since its bibliographic details were not included in the list of references of Song et al. (1999), it is difficult to verify whether this species was validly published. Kalgutkar \& Jansonius (2000) opined that it has close similarity with Dyadosporites clarkii (Sal.-Cheb. \& Locq.) Kalgutkar \& Janson. 2000.

3.26.20. Species: M. denticulatus (Ramanujam \& K.P. Rao) Kalgutkar \& Janson. 2000 (Fig. 11W); Index Fungorum Registration Identifier: 483445; Basionym: Warkallisporonites denticulatus Ramanujam \& K.P. Rao 1978; Location: Kannur, Kerala, India; Age: Miocene (Quilon and Warkalli beds).

3.26.21. Species: M. desmodes P. Ke \& Z.Y. Shi 1978; Index Fungorum Registration Identifier: 115687; Current name: Multicellites desmodes (P. Ke \& Z.Y. Shi) Kalgutkar \& Janson. 2000 fide Kalgutkar \& Jansonius (2000).

3.26.22. Species: M. didymus Sheffy \& Dilcher 1971; Index Fungorum Registration Identifier: 111666; Current name: Multicellites didymus (Sheffy \& Dilcher) Kalgutkar \& Janson. 2000 fide Kalgutkar \& Jansonius (2000). 
3.26.23. Species: M. differentialis Ramanujam \& Srisailam 1980; Index Fungorum Registration Identifier: 109089; Current name: Ramasricellites differentialis (Ramanujam \& Srisailam) Kalgutkar \& Janson. 2000 fide Kalgutkar \& Jansonius (2000)

3.26.24. Species: M. dilcheri B. Samant in R.K. Saxena 2009 (Fig. 11X); Index Fungorum Registration Identifier: 515016; Synonym: Multicellaesporites dilcheri B. Samant 2000 (nom. inval.); Location: Bhavnagar, Cambay Basin, Gujarat, India; Age: Early Eocene (Kharsalia Clay Formation); Notes: Samant (2000) described the new species "Multicellaesporites dilcheri" but did not validly publish the name, as she did not cite where the type was deposited. The species was validated by Saxena (2009) by providing holotype location.

3.26.25. Species: M. discitypicus P. Ke \& Z.Y. Shi 1978; Index Fungorum Registration Identifier: 115686; Current name: Didymoporisporonites discitypicus (P. Ke \& Z.Y. Shi) Kalgutkar \& Janson. 2000 fide Kalgutkar \& Jansonius (2000).

3.26.26. Species: M. dongyingensis P. Ke \& Z.Y. Shi 1978; Index Fungorum Registration Identifier: 115670; Current name: Anatolinites dongyingensis (P. Ke \& Z.Y. Shi) Elsik et al. 1990 fide Elsik et al. (1990).

3.26.27. Species: M. doualae Sal.-Cheb. \& Locq. 1980; Index Fungorum Registration Identifier: 108236; Current name: Multicellites doualae (Sal.-Cheb. \& Locq.) Kalgutkar \& Janson. 2000 fide Kalgutkar \& Jansonius (2000).

3.26.28. Species: M. ellipticus Sheffy \& Dilcher 1971; Index Fungorum Registration Identifier: 111667; Current name: Multicellites ellipticus (Sheffy \& Dilcher) Kalgutkar \& Janson. 2000 fide Kalgutkar \& Jansonius (2000).

3.26.29. Species: M. elongatus Sheffy \& Dilcher 1971; Index Fungorum Registration Identifier: 111668; Current name: Diporicellaesporites elongatus (Sheffy \& Dilcher) Kalgutkar \& Janson. 2000 fide Kalgutkar \& Jansonius (2000).

3.26.30. Species: M. elongatus B. Samant 2000; Index Fungorum Registration Identifier: 529875; Current name: Multicellites psilatus (R.K. Saxena) R.K. Saxena \& S.K.M. Tripathi 2011 fide Saxena \& Tripathi (2011); Notes: Samant (2000) described the new species "Multicellaesporites elongatus" but did not validly publish the name, as she did not cite where the type was deposited. The species was validated by Saxena (2009) by providing holotype location, obtained from personal communication with Dr. Bandana Samant. Further, the epithet "elongatus" cannot be used because of the existence of Multicellaesporites elongatus Sheffy \& Dilcher 1971. Saxena (2009) therefore proposed a new name Multicellaesporites psilatus Saxena 2009. Kalgutkar \& Jansonius (2000), however, redefined Multicellaesporites and restricted this genus only for spores having a distinct longitudinal furrow. They transferred all the species of this genus, which lack longitudinal furrow, under Multicellites. This species also was therefore transferred to Multicellites Kalgutkar \& Janson. 2000 by Saxena \& Tripathi (2011).

3.26.31. Species: M. elsikii R.K. Kar \& R.K. Saxena 1976; Index Fungorum Registration Identifier: 112453; Current name: Multicellites elsikii (R.K. Kar \& R.K. Saxena) Kalgutkar \& Janson. 2000 fide Kalgutkar \& Jansonius (2000).

3.26.32. Species: M. elsikii V.S. Ediger \& Alisan 1989; Index Fungorum Registration Identifier: 125503; Current name: Pluricellaesporites edigeri Kalgutkar \& Janson. 2000 fide Kalgutkar \& Jansonius (2000).

3.26.33. Species: M. elsikii (Ramanujam \& Srisailam) P. Kumar 1990; Index Fungorum Registration Identifier: 126566; Current name: Staphlosporonites elsikii Ramanujam \& Srisailam 1980 fide Kalgutkar \& Jansonius (2000).

3.26.34. Species: M. evidens P. Ke \& Z.Y. Shi 1978; Index Fungorum Registration Identifier: 115684; Current name: Multicellites evidens (P. Ke \& Z.Y. Shi) Kalgutkar \& Janson. 2000 fide Kalgutkar \& Jansonius (2000).

3.26.35. Species: M. evidens Zhong Y. Zhang 1980 (=Multicellaesporites lunpolaensis Z.C. Song in Z.C. Song et al. 1999); Index Fungorum Registration Identifier: 484271; Current name: 
Ramasricellites lunpolaensis (Z.C. Song in Z.C. Song et al. 1999) Kalgutkar \& Janson. 2000 fide Kalgutkar \& Jansonius (2000).

3.26.36. Species: M. fusiformis Sheffy \& Dilcher 1971; Index Fungorum Registration Identifier: 111669; Current name: Pluricellaesporites malevisus Kalgutkar \& Janson. 2000 fide Kalgutkar \& Jansonius (2000).

3.26.37. Species: M. fusus V.S. Ediger 1981; Index Fungorum Registration Identifier: 108237; Current name: Multicellites fusus (V.S. Ediger) Kalgutkar \& Janson. 2000 fide Kalgutkar \& Jansonius (2000).

3.26.38. Species: M. grandiusculus Sheffy \& Dilcher 1971; Index Fungorum Registration Identifier: 111670; Current name: Multicellites grandiusculus (Sheffy \& Dilcher) Kalgutkar \& Janson. 2000 fide Kalgutkar \& Jansonius (2000).

3.26.39. Species: M. granulatus P. Ke \& Z.Y. Shi 1978; Index Fungorum Registration Identifier: 115701; Current name: Multicellites granulatus (P. Ke \& Z.Y. Shi) Kalgutkar \& Janson. 2000 fide Kalgutkar \& Jansonius (2000).

3.26.40. Species: M. himalayaensis A. Gupta 2002; Index Fungorum Registration Identifier: 540672; Current name: Multicellites himalayaensis (A. Gupta) R.K. Saxena \& S.K.M. Tripathi 2011 fide Saxena \& Tripathi (2011); Notes: This species does not possess a longitudinal furrow, an essential character of Multicellaesporites (sensu Kalgutkar \& Jansonius 2000) and therefore has been transferred to Multicellites Kalgutkar \& Janson. 2000 by Saxena \& Tripathi (2011).

3.26.41. Species: M. incurvus P. Ke \& Z.Y. Shi 1978; Index Fungorum Registration Identifier: 115649; Current name: Paragranatisporites incurvus (P. Ke \& Z.Y. Shi) Kalgutkar \& Janson. 2000 fide Kalgutkar \& Jansonius (2000).

3.26.42. Species: M. indicus P. Kumar 1990; Index Fungorum Registration Identifier: 126567; Current name: Axisporonites indicus (Kumar) Kalgutkar \& Janson. 2000 fide Kalgutkar \& Jansonius (2000).

3.26.43. Species: M. irregularis Sheffy \& Dilcher 1971; Index Fungorum Registration Identifier: 111671; Current name: Pluricellaesporites irregularis (Sheffy \& Dilcher) Kalgutkar \& Janson. 2000 fide Kalgutkar \& Jansonius (2000).

3.26.44. Species: M. jainii A. Gupta 2002; Index Fungorum Registration Identifier: 540673; Current name: Multicellites jainii (A. Gupta) R.K. Saxena \& S.K.M. Tripathi 2011 fide Saxena \& Tripathi (2011); Notes: This species does not possess a longitudinal furrow, an essential character of Multicellaesporites [sensu Kalgutkar \& Jansonius 2000) and therefore Saxena \& Tripathi (2011) transferred it to Multicellites Kalgutkar \& Janson. 2000].

3.26.45. Species: M. karii Anil Chandra et al. 1984; Index Fungorum Registration Identifier: 106573; Current name: Biporipsilonites karii (Anil Chandra et al.) Kalgutkar \& Janson. 2000 fide Kalgutkar \& Jansonius (2000).

3.26.46. Species: M. kumarii R.K. Saxena 2009; Index Fungorum Registration Identifier: 515008; Basionym: Multicellaesporites elsikii (Ramanujam \& Srisailam) P. Kumar 1990; Notes: Multicellaesporites kumarii R.K. Saxena 2009 is a replacement name of Multicellaesporites elsikii (Ramanujam \& Srisailam) Kumar 1990.

3.26.47. Species: M. laevigataeformis Wang \& Leng, 1982; Index Fungorum Registration Identifier: 637501; Location: China; Notes: This species was cited in Song et al. (1999). Since its bibliographic details were not included in the list of references of Song et al. (1999), it is difficult to verify whether this species was validly published. Kalgutkar \& Jansonius (2000) opined that it resembles Dyadosporites verrucatus (Ramanujam \& Srisailam) Kalgutkar \& Janson. 2000.

3.26.48. Species: M. lanceolatus P. Ke \& Z.Y. Shi 1978; Index Fungorum Registration Identifier: 483467; Current name: Multicellites lanceolatus (P. Ke \& Z.Y. Shi) Kalgutkar \& Janson. 2000 fide Kalgutkar \& Jansonius (2000).

3.26.49. Species: M. leguminosus Z.C. Song in Z.C. Song et al. Z.C. Song 1999 (nom. inval.) fide Kalgutkar \& Jansonius (2000); Index Fungorum Registration Identifier: 483824; Notes: Song 
(1999) did not validly publish the name, as he did not cite where the type was deposited and did not provide a Latin description or its English translation.

3.26.50. Species: M. leptaleus P. Ke \& Z.Y. Shi 1978; Index Fungorum Registration Identifier: 115666; Current name: Multicellites leptaleus (P. Ke \& Z.Y. Shi) Kalgutkar \& Janson. 2000 fide Kalgutkar \& Jansonius (2000).

3.26.51. Species: M. littoralis Sal.-Cheb. \& Locq. 1980; Index Fungorum Registration Identifier: 108238; Current name: Multicellites littoralis (Sal.-Cheb. \& Locq.) Kalgutkar \& Janson. 2000 fide Kalgutkar \& Jansonius (2000).

3.26.52. Species: M. longiovatus Z.C. Song, Qian \& Y.H. Zheng in Z.C. Song et al. 1999 (nom. inval.) fide Kalgutkar \& Jansonius (2000); Index Fungorum Registration Identifier: 483825; Location: China; Age: Late Cretaceous/Tertiary; Notes: This name was not validly published because the author did not specify where the holotype is stored, and did not provide a Latin description or its English translation.

3.26.53. Species: M. lunpolaensis Z.C. Song in Z.C. Song et al. 1999; Index Fungorum Registration Identifier: 483826; Current name: Multicellites evidens P. Ke \& Z.Y. Shi 1978 fide Kalgutkar \& Jansonius (2000).

3.26.54. Species: M. margaritus P. Ke \& Z.Y. Shi 1978; Index Fungorum Registration Identifier: 115665; Current name: Multicellites margaritus (P. Ke \& Z.Y. Shi) Kalgutkar \& Janson. 2000 fide Kalgutkar \& Jansonius (2000).

3.26.55. Species: M. margarodes Z.C. Song in Z.C. Song et al. 1999 (nom. inval.) fide Kalgutkar \& Jansonius (2000); Index Fungorum Registration Identifier: 483827; Notes: This name was not validly published because the author did not specify where the holotype was deposited, and did not provide a Latin description or its English translation.

3.26.56. Species: M. maximus P. Ke \& Z.Y. Shi 1978; Index Fungorum Registration Identifier: 115664; Current name: Brachysporisporites maximus (P. Ke \& Z.Y. Shi) Kalgutkar \& Janson. 2000 fide Kalgutkar \& Jansonius (2000).

3.26.57. Species: M. megafusus Z.C. Song, Qian \& Y.H. Zheng in Z.C. Song et al. 1999 (nom. inval.) fide Kalgutkar \& Jansonius (2000); Index Fungorum Registration Identifier: 483828; Notes: This name was not validly published because the author did not specify where the holotype was deposited, and did not provide a Latin description or its English translation.

3.26.58. Species: M. megareniformis (Zhong Y. Zhang) Z.C. Song in Z.C. Song et al. 1999; Index Fungorum Registration Identifier: 483829; Current name: Dicellaesporites reniformis Zhong Y. Zhang 1980 fide Kalgutkar \& Jansonius (2000).

3.26.59 Species: M. mollis P. Ke \& Z.Y. Shi 1978; Index Fungorum Registration Identifier: 115680; Current name: Biporipsilonites mollis (P. Ke \& Z.Y. Shi) Kalgutkar \& Janson. 2000 fide Kalgutkar \& Jansonius (2000).

3.26.60. Species: M. mustus P. Ke \& Z.Y. Shi 1978; Index Fungorum Registration Identifier: 115694; Current name: Biporipsilonites mustus (P. Ke \& Z.Y. Shi) Kalgutkar \& Janson. 2000 fide Kalgutkar \& Jansonius (2000).

3.26.61. Species: M. nortonii Elsik 1968 (Fig. 11Y); Index Fungorum Registration Identifier: 317946; Location: Strip mine approximately 7 miles southwest of Rockdale, Milam County, Texas, U.S.A.; Age: Palaeocene (Rockdale Lignite).

3.26.62. Species: M. obscurus P. Ke \& Z.Y. Shi 1978; Index Fungorum Registration Identifier: 115693; Current name: Chaetosphaerites obscurus (P. Ke \& Z.Y. Shi) Kalgutkar \& Janson. 2000 fide Kalgutkar \& Jansonius (2000).

3.26.63. Species: M. oculeus P. Ke \& Z.Y. Shi 1978; Index Fungorum Registration Identifier: 115698; Current name: Multicellites oculeus (P. Ke \& Z.Y. Shi) Kalgutkar \& Janson. 2000 fide Kalgutkar \& Jansonius (2000).

3.26.64. Species: M. ornatus Wang \& Leng 1982; Index Fungorum Registration Identifier: 637502; Location: China; Notes: This species was cited in Song et al. (1999). Since its bibliographic details were not included in the list of references of Song et al. (1999), it is difficult to verify whether this species was validly published. Kalgutkar \& Jansonius (2000) opined that it is 
similar to Diporicellaesporites antarcticus Z.C. Song \& Liu Cao 1994 or possibly Hilidicellites indicus (Anil Chandra et al.) Kalgutkar \& Janson. 2000.

3.26.65. Species: M. ovatoides Z.C. Song \& G.X. Li in Z.C. Song et al. 1989; Index Fungorum Registration Identifier: 485256; Current name: Mulicellites ovatoides (Z.C. Song \& G.X. Li in Z.C. Song et al.) Kalgutkar \& Janson. 2000 fide Kalgutkar \& Jansonius (2000).

3.26.66. Species: M. ovatus Sheffy \& Dilcher 1971; Index Fungorum Registration Identifier: 111672; Current name: Multicellites ovatus (Sheffy \& Dilcher) Kalgutkar \& Janson. 2000 fide Kalgutkar \& Jansonius (2000).

3.26.67. Species: M. pachydermus P. Ke \& Z.Y. Shi 1978; Index Fungorum Registration Identifier: 115697; Current name: Multicellites pachydermus (P. Ke \& Z.Y. Shi) Kalgutkar \& Janson. 2000 fide Kalgutkar \& Jansonius (2000).

3.26.68. Species: M. pachysporus Sal.-Cheb. \& Locq. 1980; Index Fungorum Registration Identifier: 108239; Current name: Multicellites pachysporus (Sal.-Cheb. \& Locq.) Kalgutkar \& Janson. 2000 fide Kalgutkar \& Jansonius (2000).

3.26.69. Species: M. pandus Sheffy \& Dilcher 1971; Index Fungorum Registration Identifier: 111673; Current name: Multicellites pandus (Sheffy \& Dilcher) Kalgutkar \& Janson. 2000 fide Kalgutkar \& Jansonius (2000).

3.26.70. Species: M. prakashii Ambwani 1982; Index Fungorum Registration Identifier: 483901; Current name: Reduviasporonites prakashii (Ambwani) Kalgutkar \& Janson. 2000 fide Kalgutkar \& Jansonius (2000).

3.26.71. Species: M. psilatus R.K. Saxena 2009; Index Fungorum Registration Identifier: 515014; Basionym: Multicellaesporites elongatus Samant 2000 (nom. inval.) fide Saxena 2009; Current name: Multicellites psilatus (R.K. Saxena) R.K. Saxena \& S.K.M. Tripathi 2011 fide Saxena \& Tripathi (2011).

3.26.72. Species: M. pulvinus Debi Mukh. 2012; Index Fungorum Registration Identifier: 565665; Location: Neyveli Lignite Mine-I, Cuddalore District, Tamil Nadu, India; Age: Miocene (Neyveli Lignite).

3.26.73. Species: M. qingfengensis Z.C. Song \& H.C. Luo in Z.C. Song et al. 1989; Index Fungorum Registration Identifier: 485251; Current name: Reduviasporonites qingfengensis (Z.C. Song \& H.C. Luo in Z.C. Song et al.) Kalgutkar \& Janson. 2000 fide Kalgutkar \& Jansonius (2000).

3.26.74. Species: M. quattorodecimcellus Mart.-Hern. \& Tom.-Ortiz; Index Fungorum Registration Identifier: 271930; Current name: Multicellites quattorodecimcellus (Mart.-Hern. \& Tom.Ortiz) Kalgutkar \& Janson. 2000 fide Kalgutkar \& Jansonius (2000).

3.26.75. Species: M. ramanujamii A. Gupta 2002; Index Fungorum Registration Identifier: 540674; Current name: Multicellites ramanujamii (A. Gupta 2002) R.K. Saxena \& S.K.M. Tripathi 2011 fide Saxena \& Tripathi (2011); Notes: This species does not possess a longitudinal furrow, an essential character of Multicellaesporites (sensu Kalgutkar \& Jansonius 2000) and therefore was transferred to Multicellites Kalgutkar \& Janson. 2000.

3.26.76. Species: M. reniformis P. Ke \& Z.Y. Shi 1978; Index Fungorum Registration Identifier: 115704; Current name: Multicellites reniformis (P. Ke \& Z.Y. Shi) Kalgutkar \& Janson. 2000 fide Kalgutkar \& Jansonius (2000).

3.26.77. Species: M. reticulatus B. Samant \& Tapaswi 2000; Index Fungorum Registration Identifier: 519788; Current name: Multicellites reticulatus (B. Samant \& Tapaswi) R.K. Saxena \& S.K.M. Tripathi 2011 fide Saxena \& Tripathi (2011); Notes: This species does not possess a longitudinal furrow, an essential character of Multicellaesporites (sensu Kalgutkar \& Jansonius 2000) and therefore Saxena \& Tripathi (2011) transferred this species to Multicellites Kalgutkar \& Janson. 2000.

3.26.78. Species: M. sacciformis Sheffy \& Dilcher 1971; Index Fungorum Registration Identifier: 111674; Current name: Pluricellaesporites sacciformis (Sheffy \& Dilcher) Kalgutkar \& Janson. 2000 fide Kalgutkar \& Jansonius (2000). 
3.26.79. Species: M. serpentinus Debi Mukh. 2012; Index Fungorum Registration Identifier: 565666; Location: Neyveli Lignite Mine-I, Cuddalore District, Tamil Nadu, India; Age: Miocene (Neyveli Lignite).

3.26.80. Species: M. simplicissimus Sheffy \& Dilcher 1971; Index Fungorum Registration Identifier: 111675; Current name: Multicellites simplicissimus (Sheffy \& Dilcher) Kalgutkar \& Janson. 2000 fide Kalgutkar \& Jansonius (2000).

3.26.81. Species: M. songii Kalgutkar \& Janson. 2000; Index Fungorum Registration Identifier: 483446; Basionym: Diporicellaesporites lanceolatus Z.C. Song 1985; Location: Jiandingshan, Qaidam Basin, Qinghai Province, China; Age: Early-Middle Miocene; Notes: Song (1985) assigned this form to Diporicellaesporites. Kalgutkar \& Jansonius (2000) could not observe pore at any of the terminal poles. They, rather, saw a small incision at the lower end that lines up with the longitudinal furrow that is well expressed near the left margin. They therefore placed this species under Multicellaesporites (with a question mark). We hereby confirm, with certainty, the transfer of this species to Multicellaesporites.

3.26.82. Species: M. spatulatus Z.C. Song, Qian \& Y.H. Zheng in Z.C. Song et al. 1999 (nom. inval.) fide Kalgutkar \& Jansonius (2000); Index Fungorum Registration Identifier: 483830; Notes: This name was not validly published because the author did not specify where the holotype was deposited, and did not provide a Latin description or its English translation.

3.26.83. Species: M. spindlus Z.C. Song, Qian \& Y.H. Zheng in Z.C. Song et al. 1999 (nom. inval.) fide Kalgutkar \& Jansonius (2000); Index Fungorum Registration Identifier: 483831; Notes: This name was not validly published because the author did not specify where the holotype is stored, and did not provide a Latin description or its English translation.

3.26.84. Species: M. squamosus Debi Mukh. 2012; Index Fungorum Registration Identifier: 565667; Location: Neyveli Lignite Mine-I, Cuddalore District, Tamil Nadu, India; Age: Miocene (Neyveli Lignite); Notes: Mukherjee (2012) placed this species in Ascomycota.

3.26.85. Species: M. subglobosus Zhong Y. Zhang 1980; Index Fungorum Registration Identifier: 485002; Current name: Pluricellaesporites subglobosus (Zhong Y. Zhang) Kalgutkar \& Janson. 2000 fide Kalgutkar \& Jansonius (2000).

3.26.86. Species: M. tener P. Ke \& Z.Y. Shi 1978, Orth. corr. pro Multicellaesporites tenerus P. Ke \& Z.Y. Shi 1978; Current name: Multicellites tener (P. Ke \& Z.Y. Shi) Kalgutkar \& Janson. 2000 fide Kalgutkar \& Jansonius (2000).

3.26.87. Species: M. tricellatus Anil Chandra et al. 1984; Index Fungorum Registration Identifier: 107040; Current name: Pluricellaesporites tricellatus (Anil Chandra et al.) Kalgutkar \& Janson. 2000 fide Kalgutkar \& Jansonius (2000).

3.26.88. Species: M. tricyclosus P. Ke \& Z.Y. Shi 1978; Index Fungorum Registration Identifier: 115692; Current name: Multicellites tricyclosus (P. Ke \& Z.Y. Shi) Kalgutkar \& Janson. 2000 fide Kalgutkar \& Jansonius (2000).

3.26.89. Species: M. vermiculatus P. Ke \& Z.Y. Shi 1978; Index Fungorum Registration Identifier: 115703; Current name: Multicellites vermiculatus (P. Ke \& Z.Y. Shi) Kalgutkar \& Janson. 2000 fide Kalgutkar \& Jansonius (2000).

3.26.90. Species: M. verus P. Ke \& Z.Y. Shi 1978; Index Fungorum Registration Identifier: 115669; Current name: Biporipsilonites verus (P. Ke \& Z.Y. Shi) Kalgutkar \& Janson. 2000 fide Kalgutkar \& Jansonius (2000).

3.26.91. Species: M. volubilis P. Ke \& Z.Y. Shi 1978; Index Fungorum Registration Identifier: 115633; Current name: Multicellites volubilis (P. Ke \& Z.Y. Shi) Kalgutkar \& Janson. 2000 fide Kalgutkar \& Jansonius (2000).

3.27. Genus: MULTICELLITES Kalgutkar \& Janson. 2000, AASP Contributions Series (Dallas) 39: 189 (2000); Index Fungorum Registration Identifier: 28622; Type: M. tener (P. Ke \& Z.Y. Shi) Kalgutkar \& Janson. 2000.

Original Diagnosis: Multicellate, uniserial, inaperturate fungal spores; number of cells three to many, terminal cells usually rounded; spore wall usually smooth, of medium thickness, usually 
thinner than the septa (or septal bases); septa generally perforate, or with septal folds (Kalgutkar \& Jansonius 2000).

Classification: Fungi Imperfecti, Phragmosporae.

Number of species known: 46.

Notes: The generic name is derived from the main diagnostic character, which is the presence of many (Latin multus) cells in each linear spore.

3.27.1. Species: M. allomorphus (Sheffy \& Dilcher) Kalgutkar \& Janson. 2000; Index Fungorum Registration Identifier: 483447; Basionym: Multicellaesporites allomorphus Sheffy \& Dilcher 1971; Location: Puryear clay pit, 800 m south of Puryear, Henry County, Tennessee, U.S.A.; Age: Middle Eocene (Claiborne Formation); Notes: The specific epithet allomorphus refers to the strange shape of the spore.

3.27.2. Species: M. bellus (P. Ke \& Z.Y. Shi) Kalgutkar \& Janson. 2000; Index Fungorum Registration Identifier: 483448; Basionym: Multicellaesporites bellus P. Ke \& Z.Y. Shi 1978; Location: Kenli, Shandong Province, Coastal region of Bohai, China; Age: EoceneOligocene.

3.27.3. Species: M. camerounensis (Sal.-Cheb. \& Locq.) Kalgutkar \& Janson. 2000; Index Fungorum Registration Identifier: 483449; Basionym: Chaetosphaerites camerounensis Sal.Cheb. \& Locq. 1980; Location: Coast of Equatorial Africa, Gulf of Guinea, Cameroon, Africa; Age: Oligocene; Notes: Salard-Cheboldaeff \& Locquin (1980) suggested affinity of this species Ascomycota.

3.27.4. Species: M. chandrae R.K. Saxena \& S.K.M. Tripathi 2011 (Fig. 11Z); Index Fungorum Registration Identifier: 519947; Location: Sediment core no. 2 (Lat. $18^{\circ} 35.2^{\prime} \mathrm{N}$ : Long. 69 17.2'E), Arabian Sea; Age: Late Quaternary; Notes: The species epithet is in honour of Dr. Anil Chandra, Birbal Sahni Institute of Palaeosciences, Lucknow, India.

3.27.5. Species: M. cingulatus (P. Ke \& Z.Y. Shi) Kalgutkar \& Janson. 2000; Index Fungorum Registration Identifier: 483450; Basionym: Multicellaesporites cingulatus P. Ke \& Z.Y. Shi 1978; Location: Panshan, Liaoning Province, Coastal region of Bohai, China; Age: EoceneOligocene.

3.27.6. Species: M. circularis (B. Samant \& Tapaswi) R.K. Saxena \& S.K.M. Tripathi 2011 (Fig. 11AA); Index Fungorum Registration Identifier: 519935; Basionym: Multicellaesporites circularis B. Samant \& Tapaswi 2000; Location: Cambay Basin Gujarat, India; Age: Early Eocene (Cambay Shale).

3.27.7. Species: M. clarkei (Sat. K. Srivast.) Kalgutkar \& Janson. 2000; Index Fungorum Registration Identifier: 483451; Basionym: Pluricellaesporites clarkei Sat. K. Srivast. 1968; Location: East Coulee locality, sec. 27, twp. 27, rge. 18, W. 4th mer., Alberta, Canada; Age: Maastrichtian; Notes: The specific epithet is given in honour of Professor Robert T. Clarke.

3.27.8. Species: M. compactilis (P. Ke \& Z.Y. Shi) Kalgutkar \& Janson. 2000; Index Fungorum Registration Identifier: 483452; Basionym: Multicellaesporites compactilis P. Ke \& Z.Y. Shi 1978; Location: Guangrao, Shandong Province, Coastal region of Bohai, China; Age: Eocene-Oligocene.

3.27.9. Species: M. confusus (Anil Chandra et al.) Kalgutkar \& Janson. 2000 (Fig. 11AB); Index Fungorum Registration Identifier: 483453; Basionym: Multicellaesporites confusus Anil Chandra et al. 1984; Location: Sediment core no. 4 (Lat. $21^{\circ} 10.0^{\prime} \mathrm{N}$ : Long. $70^{\circ} 26.9^{\prime} \mathrm{E}$ ), Arabian Sea; Age: Late Quaternary.

3.27.10. Species: M. conspicuus (P. Ke \& Z.Y. Shi) Kalgutkar \& Janson. 2000; Index Fungorum Registration Identifier: 483454; Basionym: Multicellaesporites conspicuus P. Ke \& Z.Y. Shi 1978; Location: Panshan, Liaoning Province, Coastal region of Bohai, China; Age: EoceneOligocene.

3.27.11. Species: M. crassisporus (Sal.-Cheb. \& Locq.) Kalgutkar \& Janson. 2000 (Fig. 11AC); Index Fungorum Registration Identifier: 483455; Basionym: Multicellaesporites crassisporus Sal.-Cheb. \& Locq. 1980; Location: Coast of Equatorial Africa, Gulf of Guinea, Cameroon, 
Africa; Age: Late Eocene-Oligocene; Notes: Salard-Cheboldaeff \& Locquin (1980) suggested affinity of this species with Ascomycota.

3.27.12. Species: M. desmodes (P. Ke \& Z.Y. Shi) Kalgutkar \& Janson. 2000; Index Fungorum Registration Identifier: 483456; Basionym: Multicellaesporites desmodes P. Ke \& Z.Y. Shi 1978; Location: Panshan, Liaoning Province, Coastal region of Bohai, China; Age: EoceneOligocene.

3.27.13. Species: M. didymus (Sheffy \& Dilcher) Kalgutkar \& Janson. 2000; Index Fungorum Registration Identifier: 483457; Basionym: Multicellaesporites didymus Sheffy \& Dilcher 1971; Location: Puryear clay pit, 800 m south of Puryear, Henry County, Tennessee, U.S.A.; Age: Middle Eocene (Claiborne Formation); Notes: The specific epithet didymus means twin or similar pairs, referring to the two pairs of cells separated by the equatorial constriction.

3.27.14. Species: M. doualae (Sal.-Cheb. \& Locq.) Kalgutkar \& Janson. 2000; Index Fungorum Registration Identifier: 483458; Basionym: Multicellaesporites doualae Sal.-Cheb. \& Locq. 1980; Location: Coast of Equatorial Africa, Gulf of Guinea, Cameroon, Africa; Age: Early Miocene; Notes: Salard-Cheboldaeff and Locquin (1980) suggested affinity of this species with Ascomycota.

3.27.15. Species: M. ellipticus (Sheffy \& Dilcher) Kalgutkar \& Janson. 2000; Index Fungorum Registration Identifier: 483459; Basionym: Multicellaesporites ellipticus Sheffy \& Dilcher 1971; Location: Puryear clay pit, 800 m south of Puryear, Henry County, Tennessee, U.S.A.; Age: Middle Eocene (Claiborne Formation).

3.27.16. Species: M. elsikii (R.K. Kar \& R.K. Saxena) Kalgutkar \& Janson. 2000 (Fig. 11AD); Index Fungorum Registration Identifier: 483460; Basionym: Multicellaesporites elsikii R.K. Kar \& R.K. Saxena 1976; Location: Bhuj-Lakhpat Road, Matanomadh, Kutch District, Gujarat, India; Age: Palaeocene (Matanomadh Formation).

3.27.17. Species: M. erdtmanii (Hammen) Kalgutkar \& Janson. 2000; Index Fungorum Registration Identifier: 483461; Basionym: Pluricellaesporites erdtmanii Hammen 1954; Location: Magdalena Valley, Eastern Cordellera, Colombia, South America; Age: Maastrichtian.

3.27.18. Species: M. evidens (P. Ke \& Z.Y. Shi) Kalgutkar \& Janson. 2000; Index Fungorum Registration Identifier: 483462; Basionym: Multicellaesporites evidens P. Ke \& Z.Y. Shi 1978; Location: Panshan, Liaoning Province, Coastal region of Bohai, China; Age: EoceneOligocene.

3.27.19. Species: M. fusus (V.S. Ediger) Kalgutkar \& Janson. 2000; Index Fungorum Registration Identifier: 483463; Basionym: Multicellaesporites fusus V.S. Ediger 1981; Location: Thrace Basin, Turkey; Age: Upper Eocene-Oligocene, Miocene-Pliocene.

3.27.20. Species: M. grandiusculus (Sheffy \& Dilcher) Kalgutkar \& Janson. 2000; Index Fungorum Registration Identifier: 483464; Basionym: Multicellaesporites grandiusculus Sheffy \& Dilcher 1971; Location: Puryear clay pit, 800 m south of Puryear, Henry County, Tennessee, U.S.A.; Age: Middle Eocene (Claiborne Formation); Notes: The specific epithet indicates that the spore is somewhat large in size.

3.27.21. Species: M. granulatus (P. Ke \& Z.Y. Shi) Kalgutkar \& Janson. 2000; Index Fungorum Registration Identifier: 483465; Basionym: Multicellaesporites granulatus P. Ke \& Z.Y. Shi 1978; Location: Panshan, Liaoning Province, Coastal region of Bohai, China; Age: EoceneOligocene.

3.27.22. Species: M. himalayaensis (A. Gupta) R.K. Saxena \& S.K.M. Tripathi 2011 (Fig. 11AE); Index Fungorum Registration Identifier: 519900; Basionym: Multicellaesporites himalayaensis A. Gupta 2002; Location: Dadahu Road Section, Sirmaur District, Himachal Pradesh, India; Age: Late Palaeocene to Late Eocene (Subathu Formation).

3.27.23. Species: M. jainii (A. Gupta) R.K. Saxena \& S.K.M. Tripathi 2011 (Fig. 11AF); Index Fungorum Registration Identifier: 519901; Basionym: Multicellaesporites jainii A. Gupta 2002; Location: Dadahu Road Section, Sirmaur District, Himachal Pradesh, India; Age: Late 
Palaeocene to Late Eocene (Subathu Formation); Notes: The species epithet honours Dr. K.P. Jain, Birbal Sahni Institute of Palaeosciences, Lucknow, India.

3.27.24. Species: M. krauselii (Hammen) Kalgutkar \& Janson. 2000; Index Fungorum Registration Identifier: 483466; Basionym: Pluricellaesporites krauselii Hammen 1954; Location: Magdalena Valley, Eastern Cordellera, Colombia, South America; Age: Maastrichtian.

3.27.25. Species: M. lanceolatus (P. Ke \& Z.Y. Shi) Kalgutkar \& Janson. 2000; Index Fungorum Registration Identifier: 483467; Basionym: Multicellaesporites lanceolatus P. Ke \& Z.Y. Shi 1978; Location: Huangxian, Shandong Province, Coastal region of Bohai, China; Age: Eocene-Oligocene.

3.27.26. Species: M. leptaleus (P. Ke \& Z.Y. Shi) Kalgutkar \& Janson. 2000; Index Fungorum Registration Identifier: 483468; Basionym: Multicellaesporites leptaleus Ke \&Shi 1978; Location: Panshan, Liaoning Province, Coastal region of Bohai, China; Age: EoceneOligocene.

3.27.27. Species: M. ligeae (Félix) Kalgutkar \& Janson. 2000; Index Fungorum Registration Identifier: 483469; Basionym: Leptosphaerites ligeae Felix 1894; Location: Perekeschkul, near Baku, Azerbaijan; Age: Eocene.

3.27.28. Species: M. littoralis (Sal.-Cheb. \& Locq.) Kalgutkar \& Janson. 2000; Index Fungorum Registration Identifier: 483470; Basionym: Multicellaesporites littoralis Sal.-Cheb. \& Locq. 1980; Location: Coast of Equatorial Africa, Gulf of Guinea, Cameroon, Africa; Age: Oligocene; Notes: Salard-Cheboldaeff \& Locquin (1980) suggested affinity of this species to Ascomycota.

3.27.29. Species: M. margaritus (P. Ke \& Z.Y. Shi) Kalgutkar \& Janson. 2000; Index Fungorum Registration Identifier: 483471; Basionym: Multicellaesporites margaritus P. Ke \& Z.Y. Shi 1978; Location: Panshan, Liaoning Province; Beidagang, Tianjin Municipality, Coastal region of Bohai, China; Age: Eocene-Oligocene.

3.27.30. Species: M. oculeus (P. Ke \& Z.Y. Shi) Kalgutkar \& Janson. 2000; Index Fungorum Registration Identifier: 483472; Basionym: Multicellaesporites oculeus P. Ke \& Z.Y. Shi 1978; Location: Kenli, Shandong Province, Coastal region of Bohai, China; Age: EoceneOligocene.

3.27.31. Species: M. ovatoides (Z.C. Song \& G.X. Li in Z.C. Song et al.) Kalgutkar \& Janson. 2000; Index Fungorum Registration Identifier: 483473; Basionym: Multicellaesporites ovatoides Z.C. Song \& G.X. Li in Z.C. Song et al. 1989; Location: Qingfeng county of Henan Province, China; Age: Late Oligocene (Dongying Formation).

3.27.32. Species: M. ovatus (Sheffy \& Dilcher) Kalgutkar \& Janson. 2000; Index Fungorum Registration Identifier: 483474; Basionym: Multicellaesporites ovatus Sheffy \& Dilcher 1971; Location: Puryear clay pit, 800 m south of Puryear, Henry County, Tennessee, U.S.A.; Age: Middle Eocene (Claiborne Formation).

3.27.33. Species: M. pachydermus (P. Ke \& Z.Y. Shi) Kalgutkar \& Janson. 2000; Index Fungorum Registration Identifier: 483475; Basionym: Multicellaesporites pachydermus P. Ke \& Z.Y. Shi 1978; Location: Kenli, Shandong Province, Coastal region of Bohai, China; Age: EoceneOligocene; Notes: The species epithet refers to the indicates thicker spore wall.

3.27.34. Species: M. pachysporus (Sal.-Cheb. \& Locq.) Kalgutkar \& Janson. 2000; Index Fungorum Registration Identifier: 483476; Basionym: Multicellaesporites pachysporus Sal.Cheb. \& Locq. 1980; Location: Coast of Equatorial Africa, Gulf of Guinea, Cameroon, Africa; Age: Late Eocene-Oligocene; Notes: Salard-Cheboldaeff \& Locquin (1980) suggested affinity of this species Ascomycota.

3.27.35. Species: M. pandus (Sheffy \& Dilcher) Kalgutkar \& Janson. 2000; Index Fungorum Registration Identifier: 483477; Basionym: Multicellaesporites pandus Sheffy \& Dilcher 1971; Location: Puryear clay pit, 800 m south of Puryear, Henry County, Tennessee, U.S.A.; Age: Middle Eocene (Claiborne Formation); Notes: The specific name pandus means bent, crooked, or curved, which describes the shape of the spore. 


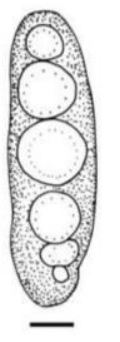

$\mathbf{A}$

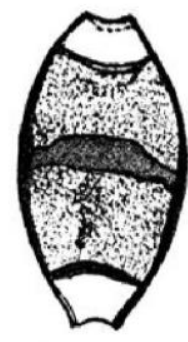

B
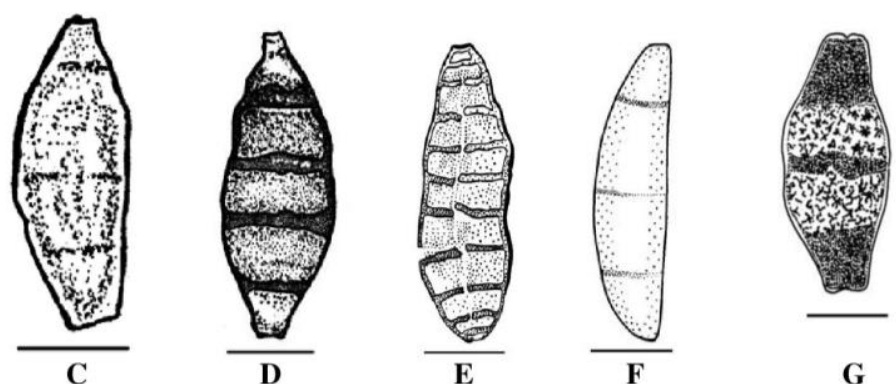

G

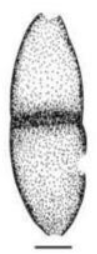

H
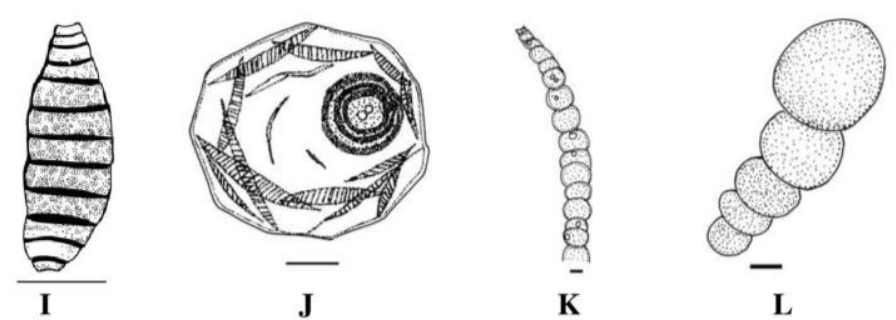

L
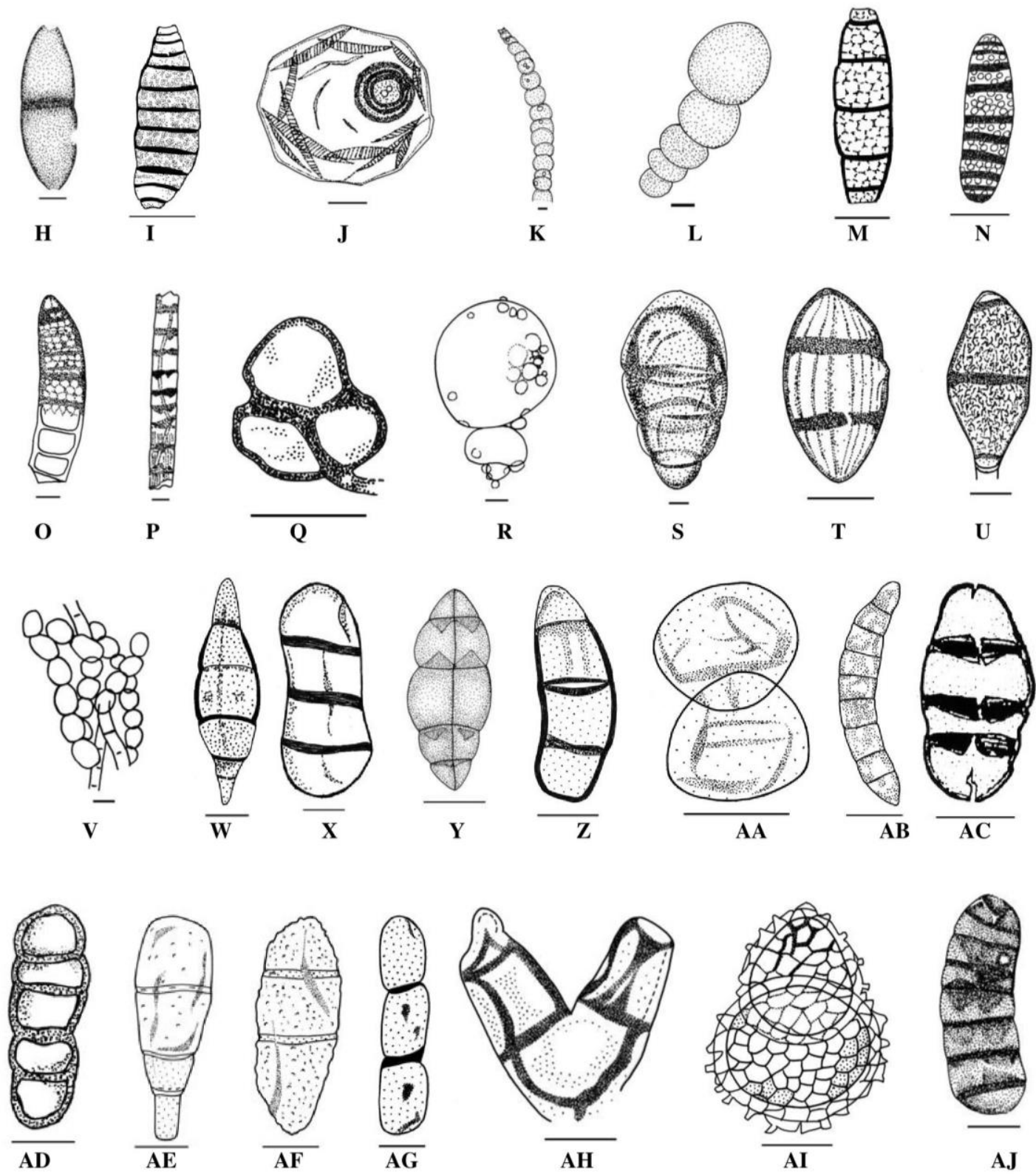

Figure 11 - A-AI Phragmosporae. A Cladosporiumsporinites cylindricus Debi Mukh. 2012, Bar = $15 \mu \mathrm{m}$. B Diporicellaesporites concavus P. Kumar 1990, Bar $=10 \mu \mathrm{m}$. C Diporicellaesporites dilcheri (Anil Chandra et al.) Kalgutkar \& Janson. 2000, Bar $=20 \mu \mathrm{m}$. D Diporicellaesporites fusiformis Ramanujam \& Srisailam 1980, Bar $=10 \mu \mathrm{m}$. E Diporicellaesporites pluricellus R.K. Kar \& R.K. Saxena 1976, Bar $=20 \mu \mathrm{m}$. F Diporicellaesporites samantiae R.K. Saxena 2009, Bar $=10$ $\mu \mathrm{m} . \mathrm{G}$ Diporicellaesporites stacyi Elsik 1968, Bar $=10 \mu \mathrm{m} . \mathrm{H}$ Diporicellaesporites tiruchirappalliensis R.K. Saxena, Wijayaw., D.Q. Dai, K.D. Hyde \& P.M. Kirk sp. nov., Bar = 8 $\mu \mathrm{m}$. I Diporicellaesporites verrucatus H.P. Singh et al. 1986, Bar $=50 \mu \mathrm{m}$. J Diporipollis 
assamicus S.K. Dutta \& S.C.D. Sah 1970, Bar $=10 \mu \mathrm{m}$. K Dwayabeejaesporonites undulatus Debi Mukh. 2012, Bar $=8 \mu \mathrm{m}$. L Edmundmasonaesporites globulatus Debi Mukh. 2012, Bar $=12 \mu \mathrm{m}$. M Foveoletisporonites indicus Ramanujam \& Srisailam 1980, Bar $=20 \mu \mathrm{m}$. N Foveoletisporonites keralensis R.K. Saxena \& S.K.M. Tripathi 2011, Bar $=30 \mu \mathrm{m}$. O Foveoletisporonites miocenicus Ramanujam \& K.P. Rao 1978, Bar $=12 \mu \mathrm{m}$. P Fractisporonites canalis R.T. Clarke 1965, Bar $=15$ $\mu \mathrm{m}$. Q Hapalophragmites cumminsii Ramanujam \& Ramachar 1980, Bar $=20 \mu \mathrm{m}$. R Heterocystinella bulbosa Cookson \& Eisenack 1979, Bar $=10 \mu \mathrm{m}$. S Jansoniisporites endophragmia (Kalgutkar \& Sigler) Kalgutkar 1997, Bar $=4 \mu \mathrm{m}$. T Kumarisporites ramanujamii (P. Kumar) Kalgutkar \& Janson. 2000, Bar $=12 \mu \mathrm{m}$. U Mathurisporites ellipticus (Y.K. Mathur \& K. Mathur) Kalgutkar \& Janson. 2000, Bar $=10 \mu \mathrm{m}$. V Monilites albidus Pampal. 1902, Bar $=12$ $\mu \mathrm{m}$. W Multicellaesporites denticulatus (Ramanujam \& K.P. Rao) Kalgutkar \& Janson. 2000, Bar $=20 \mu \mathrm{m}$. X Multicellaesporites dilcheri B. Samant in R.K. Saxena 2009, Bar $=5 \mu \mathrm{m}$. Y Multicellaesporites nortonii Elsik 1968, Bar $=12 \mu \mathrm{m}$. Z Multicellites chandrae R.K. Saxena \& S.K.M. Tripathi 2011, Bar $=10 \mu \mathrm{m}$. AA Multicellites circularis (B. Samant \& Tapaswi) R.K. Saxena \& S.K.M. Tripathi 2011, Bar $=10 \mu \mathrm{m}$. AB Multicellites confusus (Anil Chandra et al.) Kalgutkar \& Janson. 2000, Bar $=20 \mu \mathrm{m}$. AC Multicellites crassisporus (Sal.-Cheb. \& Locq.) Kalgutkar \& Janson. 2000, Bar $=20 \mu \mathrm{m}$. AD Multicellites elsikii (R.K. Kar \& R.K. Saxena) Kalgutkar \& Janson. 2000, Bar $=15 \mu \mathrm{m}$. AE Multicellites himalayaensis (A. Gupta) R.K. Saxena \& S.K.M. Tripathi 2011, Bar $=10 \mu \mathrm{m}$. AF Multicellites jainii (A. Gupta) R.K. Saxena \& S.K.M. Tripathi 2011, Bar $=5 \mu \mathrm{m}$. AG Multicellites psilatus (R.K. Saxena) R.K. Saxena \& S.K.M. Tripathi 2011, Bar $=5 \mu \mathrm{m}$. AH Multicellites ramanujamii (A. Gupta) R.K. Saxena \& S.K.M. Tripathi 2011, Bar $=10 \mu \mathrm{m}$. AI Multicellites reticulatus (B. Samant \& Tapaswi) R.K. Saxena \& S.K.M. Tripathi 2011, Bar $=5 \mu \mathrm{m}$. AJ Multicellites tamilensis R.K. Saxena, Wijayaw., D.Q. Dai, K.D. Hyde \& P.M. Kirk sp. nov., Bar $=20 \mu \mathrm{m}$.

3.27.36. Species: M. psilatus (R.K. Saxena) R.K. Saxena \& S.K.M. Tripathi 2011 (Fig. 11AG); Index Fungorum Registration Identifier: 519903; Basionym: Multicellaesporites psilatus R.K. Saxena 2009 (= Multicellaesporites elongatus B. Samant 2000, nom. inval. fide Saxena 2009); Location: Bhavnagar, Cambay Basin, Gujarat, India; Age: Early Eocene (Kharsalia Clay Formation).

3.27.37. Species: M. quattorodecimcellus (Mart.-Hern. \& Tom.-Ort.) Kalgutkar \& Janson. 2000; Index Fungorum Registration Identifier: 271940; Basionym: Multicellaesporites quattorodecimcellus Mart.-Hern. \& Tom.-Ort. 1989; Location: Piedras Negras, Coahuila State, Mexico; Age: Maastrichtian; Notes: The species epithet quattorodecimcellus refers to the spore having 14 cells.

3.27.38. Species: M. ramanujamii (A. Gupta) R.K. Saxena \& S.K.M. Tripathi 2011 (Fig. 11AH); Index Fungorum Registration Identifier: 519902; Basionym: Multicellaesporites ramanujamii A. Gupta 2002; Location: Jamath Road Section, Sirmaur District, Himachal Pradesh, India; Age: Late Palaeocene to Late Eocene (Subathu Formation).

3.27.39. Species: M. reniformis (P. Ke \& Z.Y. Shi) Kalgutkar \& Janson. 2000; Index Fungorum Registration Identifier: 483479; Basionym: Multicellaesporites reniformis P. Ke \& Z.Y. Shi 1978; Location: Panshan, Liaoning Province, Coastal region of Bohai, China; Age: EoceneOligocene.

3.27.40. Species: M. reticulatus (B. Samant \& Tapaswi) R.K. Saxena \& S.K.M. Tripathi 2011 (Fig. 11AI); Index Fungorum Registration Identifier: 519936; Basionym: Multicellaesporites B. Samant \& Tapaswi 2000; Location: Surat District, Gujarat, India; Age: Early Eocene.

3.27.41. Species: M. simplicissimus (Sheffy \& Dilcher) Kalgutkar \& Janson. 2000; Index Fungorum Registration Identifier: 483480; Basionym: Multicellaesporites simplicissimus Sheffy \& Dilcher 1971; Location: Puryear clay pit, 800 m south of Puryear, Henry County, Tennessee, U.S.A.; Age: Middle Eocene (Claiborne Formation). 
3.27.42. Species: M. tamilensis R.K. Saxena, Wijayaw., D.Q. Dai, K.D. Hyde \& P.M. Kirk sp. nov. (Fig. 11AJ); This new species is described under the section "New species and new combinations".

3.27.43. Species: M. tener (P. Ke \& Z.Y. Shi) Kalgutkar \& Janson. 2000 (Fig. 12A); Index Fungorum Registration Identifier: 483481; Basionym: Multicellaesporites tener P. Ke \& Z.Y. Shi 1978; Location: Panshan, Liaoning Province, Coastal region of Bohai, China; Age: Eocene-Oligocene; Notes: The species epithet refers to the comparative thinness and fragility of the spore wall.

3.27.44. Species: M. tricyclosus (P. Ke \& Z.Y. Shi) Kalgutkar \& Janson. 2000; Index Fungorum Registration Identifier: 483482; Basionym: Multicellaesporites tricyclosus P. Ke \& Z.Y. Shi 1978; Location: Panshan, Liaoning Province, Coastal region of Bohai, China; Age: EoceneOligocene.

3.27.45 Species: M. vermiculatus (P. Ke \& Z.Y. Shi) Kalgutkar \& Janson. 2000; Index Fungorum Registration Identifier: 483483; Basionym: Multicellaesporites vermiculatus P. Ke \& Z.Y. Shi 1978; Location: Huangxian, Shandong Province, Coastal region of Bohai, China; Age: Eocene-Oligocene.

3.27.46. Species: M. volubilis (P. Ke \& Z.Y. Shi) Kalgutkar \& Janson. 2000; Index Fungorum Registration Identifier: 483484; Basionym: Multicellaesporites volubilis P. Ke \& Z.Y. Shi 1978; Location: Panshan, Liaoning Province, Coastal region of Bohai, China; Age: EoceneOligocene.

3.28. Genus: ORNASPORONITES Proc. IV International Palynology Conference, Lucknow 1976-1977 1: 298 (1978); Index Fungorum Registration Identifier: 21200; Type: O. inaequalis Ramanujam \& K.P. Rao 1978.

Original Diagnosis: Spores brownish yellow to pale yellow, 4-celled, fusiform, diporate, cells unequal in size, basal and apical cells much smaller than two central cells; transverse septa three, central septum straight, other two septa curved. One simple pore at each end of spore along its long axis. Spore wall rugulate-reticuloid (Ramanujam \& Rao 1978).

Classification: Fungi Imperfecti, Phragmosporae.

Number of species known: One.

Notes: This monotypic genus differs from Fusiformisporites because the latter possesses only a single septum and is longitudinally ribbed and inaperturate.

3.28.1. Species: O. inaequalis Ramanujam \& K.P. Rao 1978 (Fig. 12B); Index Fungorum Registration Identifier: 115078; Location: Alleppey, Alappuzha District, Kerala, India; Age: Miocene (Quilon and Warkalli beds).

3.29. Genus: PALAEOCURVULARIA Dörfelt \& A.R. Schmidt in A.R. Schmidt et al., Palaeontographica Abt. B 283(4-6): 161 (2010); Index Fungorum Registration Identifier: 622339; Type: $\boldsymbol{P}$. variabilis Dörfelt \& A.R. Schmidt in A.R. Schmidt et al. 2010.

Original Diagnosis: Conidiogenous fungus having characters of extant genera Helminthosporium, Drechslera, Curvularia, Bipolaris and Exserohilum. Conidia pigmented, one to eight celled, 1-7 transverse septa present, rarely unicellular. Rarely occurring single-celled spores possess a basal hilar appendix, while the multicellular spores possess a basal hilar cell (Schmidt et al. 2010).

Classification: Pleosporaceae, Pleosporales, Pleosporomycetidae, Dothideomycetes, Pezizomycotina, Ascomycota.

Number of species known: One.

3.29.1. Species: P. variabilis Dörfelt \& A.R. Schmidt in A.R. Schmidt et al. 2010 (Fig. 12C); Index Fungorum Registration Identifier: 622340; Location: Ethiopia; Age: Cretaceous; Notes: The fungus was recorded from the faecal pellets of insect embedded in amber, collected from the Cretaceous sediments of Ethiopia. 
3.30. Genus: PARAGRANATISPORITES Zhong Y. Zhang, Acta palaeont. sin. 19(4): 298 (1980); Index Fungorum Registration Identifier: 28685; Type: P. lunpolaensis Zhong Y. Zhang 1980.

Original Diagnosis: Fungal spores consisting of three or more cells, with a single germinal aperture, and noticeably asymmetrical around their long axis. One or two cells at the inaperturate end of the spore are commonly quite large, giving the spore a swollen appearance in that area. The germinal aperture at the narrow end of the spore, offset from its long axis. Spore wall psilate to scabrate. Two or more transverse septa are observed (Zhang 1980).

Classification: Fungi Imperfecti, Phragmosporae.

Number of species known: Five.

Notes: Zhang (1980) distinguished Paragranatisporites from Granatisporites Elsik \& Janson. 1974 by the fact that its spores are conspicuously asymmetrical about their long axis, whereas those of Granatisporites are symmetrical or nearly symmetrical around the long axis. Kalgutkar \& Jansonius (2000) considered that Granatisporites Elsik \& Janson. 1974 is a later synonym of Brachysporisporites R.T. Lange \& P.H. Sm. 1971. In Palaeocirrenalia Ramanujam \& Srisailam 1980, the long axis of the spore is more curved to helicoidal; also, it has a more than hemispherical, darkly pigmented distal cell.

3.30.1. Species: P. conicus (P. Ke \& Z.Y. Shi) Kalgutkar \& Janson. 2000; Index Fungorum Registration Identifier: 483279; Basionym: Multicellaesporites conicus P. Ke \& Z.Y. Shi 1978; Synonym: Brachysporisporites conicus (P. Ke \& Z.Y. Shi) Norris 1997 fide Kalgutkar \& Jansonius (2000); Location: Panshan, Liaoning Province, Coastal region of Bohai, China; Age: Eocene-Oligocene.

3.30.2. Species: P. incurvus (P. Ke \& Z.Y. Shi) Kalgutkar \& Janson. 2000; Index Fungorum Registration Identifier: 483280; Basionym: Multicellaesporites incurvus P. Ke \& Z.Y. Shi 1978; Location: Kenli, Shandong Province, Coastal region of Bohai, China; Age: EoceneOligocene.

3.30.3. Species: P. lunpolaensis Zhong Y. Zhang 1980 (Fig. 12D); Index Fungorum Registration Identifier: 484998; Location: Lunpola Basin, northern Xizang Plateau, Xizang, China; Age: Oligocene (Niubao Formation).

3.30.4. Species: P. putus (P. Ke \& Z.Y. Shi) Kalgutkar \& Janson. 2000; Index Fungorum Registration Identifier: 483508; Basionym: Involutisporonites putus P. Ke \& Z.Y. Shi 1978; Location: Panshan, Liaoning Province, Coastal region of Bohai, China; Age: EoceneOligocene.

3.30.5. Species: P. vermiculus (V.S. Ediger) Kalgutkar \& Janson. 2000; Index Fungorum Registration Identifier: 483509; Basionym: Pluricellaesporites vermiculus V.S. Ediger 1981; Location: Thrace Basin, Turkey; Age: Late Eocene-Oligocene, Miocene-Pliocene.

3.31. Genus: PHIALOPHORONITES Debi Mukh., International Journal of Geology, Earth and Environmental Sciences 2(2): 5 (2012); Index Fungorum Registration Identifier: 588465; Type: $\boldsymbol{P}$. magnus Debi Mukh. 2012.

Original Diagnosis: Phialophores in a vesicle (head-like structure), generally solitary, colour light brown; circular to subcircular shape; size 600-700 $\times 350-400 \mu \mathrm{m} ; 30-40$ microspores per phialophore; size of the microspores 40-80 $\mu \mathrm{m}$, spore exine laevigate (Mukherjee 2012).

Classification: Fungi Imperfecti, Phragmosporae.

Number of species known: One.

Notes: Similar spore bearing bodies of Phialophora, a hyphomycetous taxon, are known to occur generally on humic matters (Subramanian 1971). The name of the genus is based on extant Phialophora.

3.31.1. Species: P. magnus Debi Mukh. 2012 (Fig. 12E); Index Fungorum Registration Identifier: 588478; Location: Neyveli Lignite Mine-I, Cuddalore District, Tamil Nadu, India; Age: Miocene (Neyveli Lignite); Notes: The species epithet refers to the large size of the spores. 
3.32. Genus: PIRIURELLA Cookson \& Eisenack, Neues Jb. für Geologie und Paläontologie (2): 78 (1979); Index Fungorum Registration Identifier: 21250; Type: P. elongata Cookson \& Eisenack 1979; Current name: PLURICELLAESPORITES Hammen 1954 fide Kalgutkar \& Jansonius (2000).

Original Diagnosis: Coenobium elongate pear-shaped, flat, in its broader parts with paired cells, in the narrower parts with a row of single cells. In immature forms with only a few cells lined up in a row (Jansonius \& Hills 1982).

Classification: Fungi Imperfecti, Phragmosporae.

Number of species known: Three (all the species have been transferred to other genera).

Notes: Smith \& Chaloner (1979) opined that Piriurella is a conidium of an Alternaria-like taxon. Elsik (1992) accepted similarity of Piriurella to Alternaria and commented that the name has priority only if a form genus was created, i.e. if it is a fossil form and not a modern contaminant. As Piriurella is considered to include fossil fungal spores with an affinity to modern Alternaria, Kalgutkar \& Sigler (1995) described their Alternaria-type conidia under Piriurella. Kalgutkar \& Jansonius (2000) transferred the type species, P. elongatus, to Pluricellaesporites (as P. cooksoniae Kalgutkar \& Janson. 2000) making Piriurella a later synonym of Pluricellaesporites Hammen 1954.

3.32.1. Species: P. acuminata (Rouse \& Mustard) Parsons \& G. Norris 1999; Index Fungorum Registration Identifier: 483924; Current name: Polycellaesporonites acuminatus (Rouse \& Mustard) Kalgutkar \& Janson. 2000 fide Kalgutkar \& Jansonius (2000).

3.32.2. Species: P. alternariata Kalgutkar \& Sigler 1995; Index Fungorum Registration Identifier: 413840; Current name: Polycellaesporonites alternariatus (Kalgutkar \& Sigler) Kalgutkar \& Janson. 2000 fide Kalgutkar \& Jansonius (2000).

3.32.3. Species: P. elongata Cookson \& Eisenack 1979; Index Fungorum Registration Identifier: 483892; Current name: Pluricellaesporites cooksoniae Kalgutkar \& Janson. 2000 fide Kalgutkar \& Jansonius (2000).

3.33. Genus: PLURICELLAESPORITES Hammen, Bol. Geol. (Bogota) 2(1): 83 (1954); Index Fungorum Registration Identifier: 21255; Type: P. typicus Hammen 1954 (designated by Van der Hammen 1955: 14).

Synonym: Piriurella Cookson \& Eisenack 1979 fide Kalgutkar \& Jansonius (2000), Index Fungorum Registration Identifier: 21250.

Original Diagnosis: Fungal spores composed of several [grains or] cells aligned along a single axis (Van der Hammen 1954).

Restated diagnosis: Fungal spores uniseriate, individuals consisting of five to many cells, cells flattened at common boundary, convex on sides, each cell connected by a slit-like opening through the septa (Clarke 1965).

Emended Diagnoses: Diagnosis of Pluricellaesporites was emended by Elsik (1968), Sheffy \& Dilcher (1971) and Elsik \& Jansonius (1974), as follows: Monoporate, psilate fungal or algal spores of three or more cells. Symmetrical or nearly symmetrical around one long axis. Two or more septa (Elsik 1968); Monoporate, psilate to scabrate fungal or algal spores of three or more cells; two or more septa. Cells linear along one long axis (Sheffy \& Dilcher 1971); Fungal spores of three or more cells, two or more septa, symmetrical or very nearly so around the long axis. There is a single aperture, pore, hilum or exitus, at one end. Septa may be entire, perforate or split. Cells are short to long in relation to overall spore length. Spore outline is lenticular, oval or cylindrical. One or two cells at aporate end never constitute the bulk of the spore. Exine is psilate to variously ornamented; if ornament is present it is subdued, i.e. of low relief (Elsik \& Jansonius 1974).

Classification: Fungi Imperfecti, Phragmosporae.

Number of species known: 84 (but we accept only 56 species as legitimate because 26 species have been transferred to other genera and two species, viz. P. collaris Z.C. Song, Qian \& Y.H. Zheng in Z.C. Song et al. 1999 and P. lagenosus Z.C. Song, Qian \& Y.H. Zheng in Z.C. Song et al., have not been validly published). 
Notes: Lange \& Smith (1971) considered the generic circumscription of Pluricellaesporites, as provided by Van der Hammen (1954), unacceptably broad. Later, Lange \& Smith (1975), in their paper on Ctenosporites and other Palaeogene fungal spores, stated that "Pluricellaesporites is at risk of becoming a terminological catchall for few-celled linear phragmospores, unless an effective revision of this group is accomplished soon". However, in the mean time, Elsik \& Jansonius (1974) emended the diagnosis of Pluricellaesporites to include monoporate/ monohilate, symmetrical or nearly symmetrical fungal spores of three or more cells showing different characteristics of shape, size, ornamentation and septation, and made its description more complete and generally acceptable. Kalgutkar \& Jansonius (2000) followed the generic diagnosis, as emended by Elsik \& Jansonius (1974).

3.33.1. Species: P. alleppeyensis Ramanujam \& K.P. Rao 1978; Index Fungorum Registration Identifier: 115085; Current name: Quilonia alleppeyensis (Ramanujam \& K.P. Rao) Kalgutkar \& Janson. 2000 fide Kalgutkar \& Jansonius (2000).

3.33.2. Species: P. annulatus Anil Chandra et al. 1984 (Fig. 12F); Index Fungorum Registration Identifier: 107177; Location: Sediment core no. 1 (Lat. $17^{\circ} 57.9^{\prime} \mathrm{N}$ : Long. $70^{\circ} 46.0^{\prime} \mathrm{E}$ ), Arabian Sea; Age: Late Quaternary; Notes: Chandra et al. (1984) suggested a possible affinity with Curvularia sp.

3.33.3. Species: P. antarcticus Z.C. Song \& Liu Cao 1994; Index Fungorum Registration Identifier: 483771; Current name: Anatolinites antarcticus (Z.C. Song \& Liu Cao) Kalgutkar \& Janson. 2000 fide Kalgutkar \& Jansonius (2000).

3.33.4. Species: P. apiculatus Kalgutkar 1993; Index Fungorum Registration Identifier: 483883; Location: Peel River, Yukon Territory, Canada; Age: Late Palaeocene-Early Eocene; Notes: According to Kalgutkar (1993), this species shows a close affinity to the conidia of the extant dematiaceous fungus Phaeodactylium alpiniae in general morphology. The species epithet is derived From the Latin apiculatus, with a point, referring to the spores being pointed at their base.

3.33.5. Species: P. beaufortensis M.G. Parsons \& G. Norris 1999; Index Fungorum Registration Identifier: 483925; Location: Caribou Hills, Mackenzie River delta, northern Canada; Age: Late Palaeocene - Early to Middle Eocene; Notes: The species epithet is after the Beaufort Sea.

3.33.6. Species: P. capsularis (Sheffy \& Dilcher) Kalgutkar \& Janson. 2000; Index Fungorum Registration Identifier: 483515; Basionym: Multicellaesporites capsularis Sheffy \& Dilcher 1971; Location: Puryear clay pit, 800 m south of Puryear, Henry County, Tennessee, U.S.A.; Age: Middle Eocene (Claiborne Formation).

3.33.7. Species: P. catenatus Ramanujam \& K.P. Rao 1978; Index Fungorum Registration Identifier: 115086; Current name: Cercosporites catenatus (Ramanujam \& K.P. Rao) Kalgutkar \& Janson. 2000 fide Kalgutkar \& Jansonius (2000).

3.33.8. Species: P. clarkei Sat. K. Srivast. 1968; Index Fungorum Registration Identifier: 337277; Current name: Multicellites clarkei (Sat. K. Srivast.) Kalgutkar \& Janson. 2000 fide Kalgutkar \& Jansonius (2000).

3.33.9. Species: P. clavellatus Z.C. Song \& G.X. Li in Z.C. Song et al. 1989; Index Fungorum Registration Identifier: 485254; Current name: Polycellaesporonites clavellatus (Z.C. Song \& G.X. Li in Z.C. Song et al.) Kalgutkar \& Janson. 2000 fide Kalgutkar \& Jansonius (2000).

3.33.10. Species: P. coahuilensis (Mart.-Hern. \& Tom.-Ort.) Kalgutkar \& Janson. 2000; Index Fungorum Registration Identifier: 483516; Basionym: Granatisporites coahuilensis Mart.Hern. \& Tom.-Ort. 1989; Location: Piedras Negras, Coahuila State, Mexico; Age: Maastrichtian; Notes: The species epithet indicates its occurrence in the state of Coahuila.

3.33.11. Species: P. collaris Z.C. Song, Qian \& Y.H. Zheng in Z.C. Song et al. 1999 (nom. inval.) fide Kalgutkar \& Jansonius (2000); Index Fungorum Registration Identifier: 483844; Notes: This name was not validly published because the author did not specify where the holotype is stored, and did not provide a Latin description or its English translation. 
3.33.12. Species: P. conspicuus (P. Ke \& Z.Y. Shi) G. Norris 1997; Index Fungorum Registration Identifier: 483792; Basionym: Multicellaesporites conspicuus P. Ke \& Z.Y. Shi 1978; Current name: Multicellites conspicuus (P. Ke \& Z.Y. Shi) Kalgutkar \& Janson. 2000 fide Kalgutkar \& Jansonius (2000).

3.33.13. Species: P. cooksoniae Kalgutkar \& Janson. 2000; Index Fungorum Registration Identifier: 483517; Basionym: Piriurella elongata Cookson \& Eisenack 1979; Location: Eucla basin, Western Australia; Age: Middle Cretaceous.

3.33.14. Species: P. delicatus P. Ke \& Z.Y. Shi 1978; Index Fungorum Registration Identifier: 115678; Location: Panshan, Liaoning Province, Coastal region of Bohai, China; Age: Eocene-Oligocene.

3.33.15. Species: P. dentatus Trivedi \& C.L. Verma 1970 ex Kalgutkar \& Janson. 2000; Index Fungorum Registration Identifier: 320739; Basionym: Pluricellaesporites dentatus Trivedi \& C.L. Verma 1970 (nom. inval.), lectotype was designated by Kalgutkar and Jansonius 2000; Location: Near Kuala Lumpur, Malaya; Age: Eocene; Notes: Trivedi \& Verma (1970) did not validly publish the name of species because they included two, entirely different, specimens under the heading "Holotype". Kalgutkar \& Jansonius (2000) validated the species name by designating the lectotype.

3.33.16. Species: P. edigeri Kalgutkar \& Janson. 2000; Index Fungorum Registration Identifier: 483518; Basionym: Multicellaesporites elsikii V.S. Ediger \& Alisan 1989; Location: Northern Thrace Basin, Turkey; Age: Middle?-Late Eocene to Late Oligocene, MiocenePliocene; Notes: The species epithet of the basionym honours Dr. William C. Elsik and the new name honours Dr. V.S. Ediger, author of the homonym.

3.33.17. Species: P. ellipticus Y.K. Mathur \& K. Mathur 1969; Index Fungorum Registration Identifier: 483856; Current name: Mathurisporites ellipticus (Y.K. Mathur \& K. Mathur) Kalgutkar \& Janson. 2000 fide Kalgutkar \& Jansonius (2000).

3.33.18. Species: P. ellipticus Mart.-Hern. \& Tom.-Ort. 1989; Index Fungorum Registration Identifier: 483808; Current name: Pluricellaesporites mexicanus Kalgutkar \& Janson. 2000 fide Kalgutkar \& Jansonius (2000).

3.33.19. Species: P. elongatus Sat. K. Srivast. 1968; Index Fungorum Registration Identifier: 337278; Current name: Fractisporonites elongatus (Sat. K. Srivast.) Kalgutkar \& Janson. 2000 fide Kalgutkar \& Jansonius (2000).

3.33.20. Species: P. elsikii B. Samant \& Tapaswi 2000; Index Fungorum Registration Identifier: 515011; Current name: Pluricellaesporites suratensis R.K. Saxena 2009 fide Saxena (2009); Notes: Pluricellaesporites elsikii B. Samant \& Tapaswi 2000 is illegitimate, being later homonym of Pluricellaesporites elsikii Kalgutkar 1997. Hence, Saxena (2009) replaced it with a new name Pluricellaesporites suratensis R.K. Saxena 2009.

3.33.21. Species: P. elsikii Kalgutkar 1997; Index Fungorum Registration Identifier: 437932; Location: Kanguk Peninsula, Axel Heiberg Island, Northwest Teritories, Canada; Age: Late Palaeocene-Early Eocene; Notes: According to Kalgutkar (1997), this species strikingly resembles the conidia of modern dematiaceous hyphomycetous fungus Clasterosporium cocoicola M.B. Ellis (Shaw \& Ellis 1959). The species epithet honours Dr. William C. Elsik.

3.33.22. Species: P. eocenicus B. Samant \& Tapaswi 2000 (Fig. 12G); Index Fungorum Registration Identifier: 519789; Location: Surat District, Gujarat, India; Age: Early Eocene (Cambay Shale).

3.33.23. Species: P. erdtmanii Hammen 1954; Index Fungorum Registration Identifier: 337279; Current name: Multicellites erdtmanii (Hammen) Kalgutkar \& Janson. 2000 fide Kalgutkar \& Jansonius (2000).

3.33.24. Species: P. excipularis Kalgutkar \& Sigler 1995; Index Fungorum Registration Identifier: 413859; Location: Kanguk Peninsula, Axel Heiberg Island, Northwest Territories, Canada; Age: Late Palaeocene or Early Eocene (Iceberg Bay Formation); Notes: According to Kalgutkar \& Sigler (1995), the conidia of Pluricellaesporites excipularis morphologically resemble modern Excipularia Sacc. 1884 (Ascomycota genera incertae sedis fide 
Wijayawardene et al. 2020a). The species epithet is derived from its apparent affinity to Excipularia Sacc.

3.33.25. Species: P. filiformis Hammen 1954; Index Fungorum Registration Identifier: 337280; Current name: Fractisporonites filiformis (Hammen) Kalgutkar \& Janson. 2000 fide Kalgutkar \& Jansonius (2000).

3.33.26. Species: P. fusiformis P. Ke \& Z.Y. Shi 1978; Index Fungorum Registration Identifier: 115679; Location: Panshan, Liaoning Province, Coastal region of Bohai, China; Age: Eocene-Oligocene.

3.33.27. Species: P. globatus B. Samant in R.K. Saxena 2009 (Fig. 12H); Index Fungorum Registration Identifier: 515002; Basionym: Pluricellaesporites globatus B. Samant 2000 (nom. inval.); Location: Bhavnagar, Cambay Basin, Gujarat, India; Age: Early Eocene (Kharsalia Clay Formation).

3.33.28. Species: P. glomeratus Sat. K. Srivast. 1968; Index Fungorum Registration Identifier: 337281; Current name: Mathurisporites glomeratus (Sat. K. Srivast.) Kalgutkar \& Janson. 2000 fide Kalgutkar \& Jansonius (2000).

3.33.29. Species: P. grahamii Mart.-Hern. \& Tom.-Ort. 1989; Index Fungorum Registration Identifier: 483809; Location: Piedras Negras, Coahuila State, Mexico; Age: Maastrichtian; Notes: The species epithet honours Dr. A. Graham.

3.33.30. Species: P. guptae R.K. Saxena 2009 (Fig. 12I); Index Fungorum Registration Identifier: 515010; Basionym: Pluricellaesporites minutus A. Gupta 2002; Location: Dadahu Road Section, Sirmaur District, Himachal Pradesh, India; Age: Late Palaeocene to Late Eocene (Subathu Formation); Notes: Pluricellaesporites guptae R.K. Saxena 2009 is a replacement name of Pluricellaesporites minutus A. Gupta 2002.

3.33.31. Species: P. heterosporus (Sal.-Cheb. \& Locq.) Kalgutkar \& Janson. 2000; Index Fungorum Registration Identifier: 483519; Basionym: Dictyosporites heterosporus Sal.Cheb. \& Locq. 1980; Location: Coast of Equatorial Africa, Gulf of Guinea, Cameroon, Africa; Age: Oligocene.

3.33.32. Species: P. hillsii Elsik 1968 (Fig. 12J); Index Fungorum Registration Identifier: 519795; Location: Strip mine approximately 7 miles southwest of Rockdale, Milam County, Texas, U.S.A.; Age: Palaeocene.

3.33.33. Species: P. himachalensis R.K. Saxena \& S.K.M. Tripathi 2011 (Fig. 12K); Index Fungorum Registration Identifier: 519948; Location: Bhakra-Nangal Section, Bilaspur District, Himachal Pradesh, India; Age: Early Pliocene (Middle Siwalik).

3.33.34. Species: P. idahoensis Traverse \& Ash 1994; Index Fungorum Registration Identifier: 363119; Location: Wallowa terrane in Hells Canyon, Idaho, U.S.A.; Age: Early Jurassic to early Middle Jurassic; Notes: The species epithet idahoensis refers to the state of Idaho.

3.33.35. Species: P. infacetus (Kalgutkar) Kalgutkar \& Janson. 2000; Index Fungorum Registration Identifier: 483281; Basionym: Brachysporisporites infacetus Kalgutkar 1997; Location: Kanguk Peninsula, Axel Heiberg Island, Northwest Territories, Canada; Age: Late Palaeocene-Early Eocene; Notes: The spores of Pluricellaesporites infacetus are similar to the conidia of Brachysporium bloxami (Cooke) Sacc. 1886 in general appearance, although the latter are smooth and distally narrow (Kalgutkar 1997). The species epithet indicates coarse spore surface.

3.33.36. Species: P. informis P. Ke \& Z.Y. Shi 1978; Index Fungorum Registration Identifier: 115696; Current name: Quilonia informis (P. Ke \& Z.Y. Shi) Kalgutkar \& Janson. 2000 fide Kalgutkar \& Jansonius (2000).

3.33.37. Species: P. irregularis (Sheffy \& Dilcher) Kalgutkar \& Janson. 2000; Index Fungorum Registration Identifier: 483520; Basionym: Multicellaesporites irregularis Sheffy \& Dilcher 1971; Location: Puryear clay pit, 800 m south of Puryear, Henry County, Tennessee, U.S.A.; Age: Middle Eocene (Claiborne Formation).

3.33.38. Species: P. karii A. Gupta 2002 (Fig. 12L); Index Fungorum Registration Identifier: 540757; Location: Jamtah Road Section, Sirmaur District, Himachal Pradesh, India; Age: 
Eocene (Subathu Formation); Notes: The species epithet honours Dr. R.K. Kar, Birbal Sahni Institute of Palaeosciences, Lucknow, India.

3.33.39. Species: P. keralensis R.K. Saxena \& S.K.M. Tripathi 2011 (Fig. 12M); Index Fungorum Registration Identifier: 519950; Location: Around Kollam and Varkala, Kerala, India; Age: Miocene.

3.33.40. Species: P. krauselii Hammen 1954; Index Fungorum Registration Identifier: 337282; Current name: Multicellites krauselii (Hammen) Kalgutkar \& Janson. 2000 fide Kalgutkar \& Jansonius (2000).

3.33.41. Species: P. lagenosus Z.C. Song, Qian \& Y.H. Zheng in Z.C. Song et al. 1999 (nom. inval.) fide Kalgutkar \& Jansonius (2000); Index Fungorum Registration Identifier: 483845; Notes: Song et al. (1999) did not validly publish this name because they did not specify where the holotype was deposited, and did not provide a Latin description or its English translation.

3.33.42. Species: P. lanceolatus Z.C. Song \& G.X. Li in Z.C. Song et al. 1989; Index Fungorum Registration Identifier: 485247; Current name: Quilonia lanceolata (Z.C. Song \& G.X. Li in Z.C. Song et al.) Kalgutkar \& Janson. 2000 fide Kalgutkar \& Jansonius (2000).

3.33.43. Species: P. longicollus Sheffy \& Dilcher 1971 (Fig. 12N); Index Fungorum Registration Identifier: 111833; Location: Puryear clay pit, $800 \mathrm{~m}$ south of Puryear, Henry County, Tennessee, U.S.A.; Age: Middle Eocene (Claiborne Formation); Notes: The specific epithet refers to the presence of a long terminal neck.

3.33.44. Species: P. magnus Rouse \& Mustard 1997; Index Fungorum Registration Identifier: 464004; Location: Strait of Georgia, eastern Vancouver Island, the Fraser River lowlands of southwest British Columbia, Canada, and North-western Washington State, U.S.A.; Age: Late Eocene-Early Oligocene.

3.33.45. Species: P. malayensis (Trivedi \& C.L. Verma) Kalgutkar \& Janson. 2000; Index Fungorum Registration Identifier: 483240.; Basionym: Alternaria malayensis Trivedi \& C.L. Verma 1970; Location: Near Kuala Lumpur, Malaya; Age: Eocene; Notes: According to Trivedi \& Verma (1970), spores described in this species resemble the conidia of Alternaria Nees (Pleosporaceae, Pleosporales, Dothideomycetes fide Wijayawardene et al. 2020a), where conidia divide transversely into two or more by transverse septa, forming two- or more celled conidial spores. Fossil spore resembles the living spore of Alternaria in all respect except that they are smaller in size.

3.33.46. Species: P. malevisus Kalgutkar \& Janson. 2000; Index Fungorum Registration Identifier: 483521; Basionym: Multicellaesporites fusiformis Sheffy \& Dilcher 1971; Location: Puryear clay pit, $800 \mathrm{~m}$ south of Puryear, Henry County, Tennessee, U.S.A.; Age: Middle Eocene (Claiborne Formation); Notes: According to Sheffy \& Dilcher (1971), this spore resembles the material which Bradley (1931) identified as Leptosphaeria Ces. \& De Not. (Leptosphaeriaceae, Pleosporales, Dothideomycetes fide Wijayawardene et al. 2020a). The new species epithet is from Latin male $=$ poorly, and visus $=$ observed.

3.33.47. Species: P. maximus P. Ke \& Z.Y. Shi 1978; Index Fungorum Registration Identifier: 115695; Current name: Quilonia maximus (P. Ke \& Z.Y. Shi) Kalgutkar \& Janson. 2000 fide Kalgutkar \& Jansonius (2000).

3.33.48. Species: P. mehrotrae R.K. Saxena \& S.K.M. Tripathi 2011 (Fig. 12O); Index Fungorum Registration Identifier: 519951; Location: Sonapur-Badarpur Road Section, Jaintia Hills, Meghalaya and Cachar District, Assam, India; Age: Early Miocene (Bhuban Formation).

3.33.49. Species: P. melanii Elsik 1968; Index Fungorum Registration Identifier: 320740; Synonym: Granatisporites melanii (Elsik) Elsik \& Janson. 1974 fide Kalgutkar \& Jansonius (2000); Current name: Diporipollis melanii (Elsik) Kalgutkar \& Janson. 2000 fide Kalgutkar \& Jansonius (2000).

3.33.50. Species: P. mexicanus Kalgutkar \& Janson. 2000; Index Fungorum Registration Identifier: 483522; Basionym: Pluricellaesporites ellipticus Mart.-Hern. \& Tom.-Ortiz 1989; Location: Piedras Negras, Coahuila State, Mexico; Age: Maastrichtian; Notes: Pluricellaesporites 
mexicanus Kalgutkar \& Janson. 2000 is a replacement name of Pluricellaesporites ellipticus Mart.-Hern. \& Tom.-Ortiz 1989.

3.33.51. Species: P. minusculus Sheffy \& Dilcher 1971; Index Fungorum Registration Identifier: 111834; Current name: Diporicellaesporites minusculus (Sheffy \& Dilcher) Kalgutkar \& Janson. 2000 fide Kalgutkar \& Jansonius (2000).

3.33.52. Species: P. minutigranulatus Hammen 1954; Index Fungorum Registration Identifier: 337283; Current name: Diporicellaesporites minutigranulatus (Hammen) Kalgutkar \& Janson. 2000 fide Kalgutkar \& Jansonius (2000).

3.33.53. Species: P. minutus (Trivedi \& Verma) ex Kalgutkar \& Janson. 2000; Index Fungorum Registration Identifier: 483523; Basionym: Brachysporium minutum Trivedi \& C.L. Verma 1970 (nom. inval.), lectotype was designated by Kalgutkar \& Jansonius 2000); Location: Near Kuala Lumpur, Malaya; Age: Eocene; Notes: Trivedi \& Verma (1970) did not validly publish Brachysporium minutum because they included two elements under the designation "Holotype". Kalgutkar \& Jansonius (2000) designated Fig. 4 of Trivedi \& Verma (1970) as lectotype, and assigned the species to Pluricellaesporites.

3.33.54. Species: P. minutus A. Gupta 2002; Index Fungorum Registration Identifier: 515009; Current name: Pluricellaesporites guptae R.K. Saxena 2009 fide Saxena (2009); Notes: Pluricellaesporites minutus A. Gupta 2002 is illegitimate, being later homonym of Pluricellaesporites minutus Kalgutkar \& Janson. 2000. Hence, Saxena (2009) replaced it with a new name, Pluricellaesporites guptae R.K. Saxena 2009.

3.33.55. Species: P. mirus P. Ke \& Z.Y. Shi 1978; Index Fungorum Registration Identifier: 115700; Location: Panshan, Liaoning Province, Coastal region of Bohai, China; Age: Eocene-Oligocene.

3.33.56. Species: P. misrae Anil Chandra et al. 1984 (Fig. 12P); Index Fungorum Registration Identifier: 107178; Location: Sediment core no. 4 (Lat. $21^{\circ} 10.0^{\prime} \mathrm{N}$ : Long. $70^{\circ} 26.9^{\prime} \mathrm{E}$ ), Arabian Sea; Age: Late Quaternary; Notes: The species epithet honours Professor Ramesh C. Misra.

3.33.57. Species: P. nodosus Sat. K. Srivast. 1968; Index Fungorum Registration Identifier: 337284; Current name: Fractisporonites nodosus (Sat. K. Srivast.) Kalgutkar \& Janson. 2000 fide Kalgutkar \& Jansonius (2000).

3.33.58. Species: P. ocellatus Z.C. Song \& Liu Cao 1994; Index Fungorum Registration Identifier: 483772; Location: King George Island, Antarctica; Age: Late Cretaceous; Notes: The species epithet refers to the shape of small pore.

3.33.59. Species: P. ovatus Sheffy \& Dilcher 1971; Index Fungorum Registration Identifier: 111835; Location: Puryear clay pit, $800 \mathrm{~m}$ south of Puryear, Henry County, Tennessee, U.S.A.; Age: Middle Eocene (Claiborne Formation).

3.33.60. Species: P. patagonicus Bianchin., Alej. Martınez \& R.K. Saxena in Alej. Martınez et al. 2016; Index Fungorum Registration Identifier: 812334; Location: Rio Foyel section, Nirihuau Basin, Argentina; Age: Palaeogene (El Foyel Group); Notes: These spores resemble those of Bactrodesmium Cooke. The species epithet refers to the zone from which the material was collected.

3.33.61. Species: P. planus Trivedi \& C.L. Verma ex Kalgutkar \& Janson. 2000 (Fig. 12Q); Index Fungorum Registration Identifier: 320741; Basionym: Pluricellaesporites planus Trivedi \& C.L. Verma 1970 (nom. inval.), lectotype was designated by Kalgutkar \& Jansonius (2000); Location: Near Kuala Lumpur, Malaya; Age: Eocene; Notes: Trivedi \& Verma (1970) did not validly publish the name of species as they did not designate the holotype. Kalgutkar \& Jansonius (2000) validated the species name by designating the lectotype.

3.33.62. Species: P. psilatus R.T. Clarke 1965 (Fig. 12R); Index Fungorum Registration Identifier: 337285; Location: Canon City Coalfield, Fremont County, Colorado, U.S.A.; Age: Late Cretaceous; Notes: The species epithet psilatus indicates smooth cell walls of the spore.

3.33.63. Species: P. rectangulatus Y.K. Mathur \& K. Mathur 1969 (Fig. 12S); Index Fungorum Registration Identifier: 483855; Location: Naera and Baraia area of Kutch District, Gujarat, India; Age: Pliocene; Notes: According to Mathur \& Mathur (1969), the spores of this species 
are teliospore of Uredinales. The specific epithet is in reference to the rectangular shape of the cells.

3.33.64. Species: P. regularis J.T.F. Guim. et al. 2013; Index Fungorum Registration Identifier: 637503; Location: BOP2 outcrop, central and coastal Amazon Region, North Brazil; Age: Miocene (Barreiras Formation); Notes: Guimarães et al. (2013) stated taxonomic affinity of this species with Curvularia, Pleosporaceae. The species epithet indicates regular size of the cells.

3.33.65. Species: P. sacciformis (Sheffy \& Dilcher) M.G. Parsons \& G. Norris 1999; Index Fungorum Registration Identifier: 483926; Basionym: Multicellaesporites sacciformis Sheffy \& Dilcher 1971; Location: Puryear clay pit, $800 \mathrm{~m}$ south of Puryear, Henry County, Tennessee, U.S.A.; Age: Middle Eocene (Claiborne Formation).

3.33.66. Species: P. scabiosus R.T. Clarke 1965; Index Fungorum Registration Identifier: 337286; Location: Canon City coal field, Fremont County, Colorado, U.S.A.; Age: Late Cretaceous; Notes: The specific epithet is Latin for rough and is given in reference to the appearance of the cell wall.

3.33.67. Species: P. scalaris Kalgutkar 1997; Index Fungorum Registration Identifier: 437933; Current name: Scolecosporites modicus Kalgutkar \& Janson. 2000 fide Kalgutkar \& Jansonius (2000).

3.33.68. Species: P. semicircularis Debi Mukh. 2012; Index Fungorum Registration Identifier: 565672; Location: Neyveli Lignite Mine-I, Cuddalore District, Tamil Nadu, India; Age: Miocene (Neyveli Lignite).

3.33.69. Species: P. serratus Sheffy \& Dilcher 1971; Index Fungorum Registration Identifier: 111836; Location: Puryear clay pit, $800 \mathrm{~m}$ south of Puryear, Henry County, Tennessee, U.S.A.; Age: Middle Eocene (Claiborne Formation); Notes: The specific epithet serratus means jagged, and refers to the appearance of the septa.

3.33.70. Species: P. sheffyi Mart.-Hern. \& Tom.-Ort. 1989; Index Fungorum Registration Identifier: 483810; Location: Piedras Negras, Coahuila State, Mexico; Age: Maastrichtian; Notes: The species epithet is in honour of Dr. M.V. Sheffy.

3.33.71. Species: P. simplicissimus Sheffy \& Dilcher 1971; Index Fungorum Registration Identifier: 111837; Location: Puryear clay pit, $800 \mathrm{~m}$ south of Puryear, Henry County, Tennessee, U.S.A.; Age: Middle Eocene (Claiborne Formation).

3.33.72. Species: P. sirmaurensis A. Gupta 2002 (Fig. 12T); Index Fungorum Registration Identifier: 540758; Location: Dadahu Road Section, Sirmaur District, Himachal Pradesh, India; Age: Eocene (Subathu Formation).

3.33.73. Species: P. subcapsilaris Sheffy \& Dilcher 1971; Index Fungorum Registration Identifier: 111838; Current name: Anatolinites subcapsilaris (Sheffy \& Dilcher) Elsik et al. 1990 fide Elsik et al. (1990); Notes: Elsik et al. (1990) transferred the species to Anatolinites. They emended the description of the species, and drew attention to the tendency of the individual cells of the spore to break loose by splitting along the septa.

3.33.74. Species: P. subglobosus (Zhong Y. Zhang) Kalgutkar \& Janson. 2000; Index Fungorum Registration Identifier: 483524; Basionym: Multicellaesporites subglobosus Zhong Y. Zhang 1980; Location: Lunpola Basin, northern Xizang Plateau, Xizang, China; Age: Oligocene (Niubao Formation); Notes: Kalgutkar \& Jansonius (2000) transferred the species to Pluricellaesporites on the basis of the presence of a flat spot at one end of the type specimen which they considered a hilum.

3.33.75. Species: P. suboblongatus Sheffy \& Dilcher 1971; Index Fungorum Registration Identifier: 111839; Current name: Diporicellaesporites suboblongatus (Sheffy \& Dilcher) Kalgutkar \& Janson. 2000 fide Kalgutkar \& Jansonius (2000).

3.33.76. Species: P. suratensis R.K. Saxena 2009 (Fig. 12U); Index Fungorum Registration Identifier: 515012; Basionym: Pluricellaesporites elsikii B. Samant \& Tapaswi 2000; Location: Surat District, Gujarat, India; Age: Early Eocene (Surat lignite, Cambay Shale); 
Notes: Pluricellaesporites suratensis R.K. Saxena 2009 is a replacement name of Pluricellaesporites elsikii B. Samant \& Tapaswi 2000.

3.33.77. Species: P. tamilensis R.K. Saxena \& S. Khare 1992 (Fig. 12V); Index Fungorum Registration Identifier: 483894; Location: Borehole - JC-12, Jayamkondacholapuram, 45 km south of Neyveli, Tiruchirappalli District, Tamil Nadu, India; Age: Miocene.

3.33.78. Species: P. tenuis Sheffy \& Dilcher 1971; Index Fungorum Registration Identifier: 111840; Location: Puryear clay pit, $800 \mathrm{~m}$ south of Puryear, Henry County, Tennessee, U.S.A.; Age: Middle Eocene (Claiborne Formation); Notes: The species epithet indicates the long slender shape of the spore.

3.33.79. Species: P. tricellatus (Anil Chandra et al.) Kalgutkar \& Janson. 2000 (Fig. 12W); Index Fungorum Registration Identifier: 483525; Basionym: Multicellaesporites tricellatus Anil Chandra et al. 1984; Location: Sediment core no. 5 (Lat. $24^{\circ} 04.5^{\prime} \mathrm{N}$ : Long. $69^{\circ} 26.0^{\prime} \mathrm{E}$ ), Arabian Sea; Age: Late Quaternary.

3.33.80. Species: P. trichocladites Kalgutkar 1997; Index Fungorum Registration Identifier: 437934; Location: Kanguk Peninsula, Axel Heiberg Island, Northwest Teritories, Canada; Age: Late Palaeocene-Early Eocene. Etymology: Similarity to dematiaceous fungus Trichocladium Harz.; Notes: According to Kalgutkar (1997), Pluricellaesporites trichocladites shows resemblance to conidia of extant dematiaceous fungus Trichocladium opacum (Corda) S. Hughes in general morphology and in having spores ranging from 2 to many cells. Conidia of extant Pithomyces griminicolus Roy \& Rai described by Matsushima (1989) also appear similar to spores of Pluricellaesporites trichocladites, but are verrucose.

3.33.81. Species: P. typicus Hammen 1954 (Fig. 12X); Index Fungorum Registration Identifier: 337287; Location: Magdalena Valley, Eastern Cordillera, Colombia, South America; Age: Maastrichtian.

3.33.82. Species: P. vermiculus V.S. Ediger 1981; Index Fungorum Registration Identifier: 108390; Current name: Paragranatisporonites vermiculus (V.S. Ediger 1981) Kalgutkar \& Janson. 2000 fide Kalgutkar \& Jansonius (2000).

3.33.83. Species: P. verrucatus H.P. Singh et al. 1986 (Fig. 12Y); Index Fungorum Registration Identifier: 131934; Location: Sonapur-Badarpur Road section, Jaintia Hills, Meghalaya and Cachar, Assam, India; Age: Early Miocene (Bhuban Formation).

3.33.84. Species: P. woodianus O'Keefe 2017; Index Fungorum Registration Identifier: 821915; Location: Tumbes Province, Peru; Age: Miocene (Heath Formation); Notes: The species epithet honours Dr. Gordon Wood.

3.34. Genus: QUILONIA K.P. Jain \& R.C. Gupta, Palaeobotanist 18(2): 180 (1970); Index Fungorum Registration Identifier: 21272; Type: Q. typica K.P. Jain \& R.C. Gupta 1970.

Original Diagnosis: Body multicellular, filamentous. Exine thick, margin undulated. Apical and basal portions narrow, central [section] wide. Basal stalk prominent with one or two rectangular thick-walled cells; apical cell mostly incomplete, curved, central portion broad, elongate with irregularly shaped furrow-like suture, inside the filament at different places occur one to four small circular, ostiolate bodies (Jain \& Gupta 1970).

Emended Diagnosis: Pluricellate hilate fungal spores, with an oval to elongate obpyriform pigmented central section, the greatest width of which tends to be near the proximal end; spore distally extended into a (very) elongated multiseptate narrow stalk that terminates in a closed cell, although the tip of the stalk is commonly lacking; proximally, there is a short tapering stalk with a hilate scar. Both stalks tend to be thin-walled or hyaline (Kalgutkar \& Jansonius 2000).

Classification: Fungi Imperfecti, Phragmosporae.

Number of species known: Eleven.

3.34.1. Species: Q. alleppeyensis (Ramanujam \& K.P. Rao) Kalgutkar \& Janson. 2000 (Fig. 12Z); Index Fungorum Registration Identifier: 483529; Basionym: Pluricellaesporites alleppeyensis Ramanujam \& K.P. Rao 1978; Location: Alleppey, Alappuzha District, Kerala, India; Age: Miocene (Quilon and Warkalli beds); Notes: Ramanujam \& Rao (1978) stated 
that this species shows significant similarity to conidia of the dematiaceous hyphomycetous taxon Sporidesmium tropicale (Ellis 1974). Sporidesmium is commonly encountered in moist tropical regions.

3.34.2. Species: Q. attenuata (Ramanujam \& Srisailam) Kalgutkar \& Janson. 2000 (Fig. 12AA); Index Fungorum Registration Identifier: 483530; Basionym: Diporicellaesporites attenuatus Ramanujam \& Srisailam 1980; Location: Kannur Beach area, Palayangadi and Cheruvattur, Kerala, India; Age: Miocene (Warkalli Beds).

3.34.3. Species: Q. hillsii (Kalgutkar) Kalgutkar \& Janson. 2000; Index Fungorum Registration Identifier: 483531; Basionym: Diporicellaesporites hillsii Kalgutkar 1993; Location: Peel River, Yukon Territory, Canada; Age: Late Palaeocene-Early Eocene; Notes: The species epithet is in honour of Dr. L.V. Hills.

3.34.4. Species: Q. informis (P. Ke \& Z.Y. Shi) Kalgutkar \& Janson. 2000; Index Fungorum Registration Identifier: 483532; Basionym: Pluricellaesporites informis P. Ke \& Z.Y. Shi 1978; Location: Panshan, Liaoning Province, Coastal region of Bohai, China; Age: EoceneOligocene.

3.34.5. Species: Q. lageniformis (Zhong Y. Zhang) Kalgutkar \& Janson. 2000; Index Fungorum Registration Identifier: 483533; Basionym: Diporicellaesporites lageniformis Zhong Y. Zhang 1980; Location: Lunpola Basin, northern Xizang Plateau, Xizang, China; Age: Oligocene (Niubao Formation).

3.34.6. Species: Q. lanceolata (Z.C. Song \& G.X. Li in Z.C. Song et al.) Kalgutkar \& Janson. 2000; Index Fungorum Registration Identifier: 483534; Basionym: Pluricellaesporites lanceolatus Z.C. Song \& G.X. Li in Z.C. Song et al. 1989; Location: Qingfeng county of Henan Province, China; Age: Late Eocene-Early Oligocene (Shahejie Formation).

3.34.7. Species: Q. maxima (P. Ke \& Z.Y. Shi) Kalgutkar \& Janson. 2000; Index Fungorum Registration Identifier: 483535; Basionym: Pluricellaesporites maximus P. Ke \& Z.Y. Shi 1978; Location: Laoshanggulin, Tianjin Municipality, Coastal region of Bohai, China; Age: Eocene-Oligocene.

3.34.8. Species: Q. miocenica (H.P. Singh et al.) Kalgutkar \& Janson. 2000 (Fig. 12AB); Index Fungorum Registration Identifier: 483536; Basionym: Inapertisporites miocenicus H.P. Singh et al. 1986; Location: 173 km stone, Sonapur-Badarpur Road Section, Jaintia Hills, Meghalaya, India; Age: Early Miocene (Bhuban Formation).

3.34.9. Species: Q. multicellata (R.K. Saxena \& S. Khare) Kalgutkar \& Janson. 2000 (Fig. 12AC); Index Fungorum Registration Identifier: 483537; Basionym: Diporicellaesporites multicellatus R.K. Saxena \& S. Khare 1992; Location: Jayamkondacholapurum Well-12, 45 km south of Neyveli, Tiruchirappalli District, Tamil Nadu, India; Age: Eocene (Neyveli Formation).

3.34.10. Species: Q. prakashii (Anil Chandra et al.) Kalgutkar \& Janson. 2000 (Fig. 12AD); Index Fungorum Registration Identifier: 483538; Basionym: Diporicellaesporites prakashii Anil Chandra et al. 1984; Location: Sediment core no. 1 (Lat. $17^{\circ} 57.9^{\prime} \mathrm{N}$ : Long. $70^{\circ} 46.0^{\prime} \mathrm{E}$ ), Arabian Sea; Age: Late Quaternary; Notes: The species epithet is in honour of Dr. Uttam Prakash, Birbal Sahni Institute of Palaeosciences, Lucknow, India.

3.34.11. Species: Q. typica K.P. Jain \& R.C. Gupta 1970 (Fig. 12AE); Index Fungorum Registration Identifier: 322212; Location: Padappakkara, Kollam District, Kerala, India; Age: Miocene; Notes: According to Jain \& Gupta (1970), this species most closely resembles the extant Annellophora (S. Hughes) Ellis 1958.

3.35. Genus: RAMASRICELLITES Kalgutkar \& Janson., AASP Contributions Series (Dallas) 39: 259 (2000); Index Fungorum Registration Identifier: 28623; Type: R. differentialis (Ramanujam \& Srisailam) Kalgutkar \& Janson 2000.

Original Diagnosis: Fungal spores inaperturate, tetracellate, ellipsoidal, with central cells broader, thicker walled and more pigmented than the terminal cells; terminal cells thin-walled to 
hyaline, with rounded ends; septa (or septal bases) thick and dark, evenly spaced (Kalgutkar \& Jansonius 2000).

Classification: Fungi Imperfecti, Phragmosporae.

Number of species known: Two.

Notes: Kalgutkar \& Jansonius (2000) opined that Multicellaesporites differentialis Ramanujam \& Srisailam is a misfit in Multicellaesporites and therefore they proposed Ramasricellites to accommodate it. The sharp differentiation between the dark, broad central cells and the narrower, elongate hyaline terminal cells, as well as the lack of constriction at the median septum, differentiate this form from species in Multicellites. The name of the genus is a composite of the beginnings of the surnames Ramanujam and Srisailam, the authors of the type species.

3.35.1. Species: R. differentialis (Ramanujam \& Srisailam) Kalgutkar \& Janson. 2000 (Fig. 12AF); Index Fungorum Registration Identifier: 483539; Basionym: Multicellaesporites differentialis Ramanujam \& Srisailam 1980; Location: Kannur Beach area, Palayangadi and Cheruvattur (southern side of Karingottu River), Kerala, India; Age: Miocene (Warkalli Beds); Notes: The differences in the pigmentation, shape and wall thickness of the terminal two cells from the central two cells, constitute the diagnostic features of this species. The fossil spore shows striking resemblances with the conidia of some species of the modern dematiaceous genus Spiropes Cif., viz. S. clavatus (Ellis \& G. Martin) M.B. Ellis and S. effusus (Pat.) M.B. Ellis.

3.35.2. Species: R. lunpolaensis (Z.C. Song in Z.C. Song et al. 1999) Kalgutkar \& Janson. 2000; Index Fungorum Registration Identifier: 483540; Basionym: Multicellaesporites lunpolaensis Z.C. Song in Z.C. Song et al. 1999; Synonym: Multicellaesporites evidens Zhong Y. Zhang 1980 fide Kalgutkar \& Jansonius (2000); Location: Lunpola Basin, Xizang, China; Age: Middle-Late Oligocene.

3.36. Genus: REDUVIASPORONITES L.R. Wilson, Okla. Geol. Notes 22(4): 91-92 (1962); Index Fungorum Registration Identifier: 21278; Type: R. catenulatus L.R. Wilson 1962.

Original Diagnosis: Conidia-like spores occurring in uniseriate chains (phragmospores?) of several or more individuals; subspherical, slightly flattened at the contacts with adjacent spores, all approximately same diameter, walls $1-2 \mu \mathrm{m}$ thick, uniform, smooth or slightly rough, yellow or brown, translucent (Wilson 1962).

Classification: Fungi imperfecti, Phragmosporae.

Number of species known: Nine.

Notes: Wilson (1962) stated that these fossils differ from Penicillites curtipes Berk. 1848 (Eocene), as illustrated in Hirmer (1927), in having spores of subspherical rather than elliptical shape and walls that are relatively thinner than those in Penicillites. According to him, another fossil fungus with which Reduviasporonites should be compared is the Eocene Torulites moniliformis Menge (Casp. 1907). This form is illustrated as having spores that are progressively smaller towards the apex (Hirmer 1927). The shape of the spores and mycelium of Torulites resembles more closely the modern Hormiscum Kunze ex Wallr. than with Torula Persoon ex Fr. The first part of the generic name Reduviasporonites has been derived from the Latin reduvia (fragment) and suffix -sporonites indicates that the specimens are fossil fungus spores not organically attached to other structures. Sporonites is used in preference to -sporites to indicate that the spore is of fungal affinity.

3.36.1. Species: R. anangus G. Norris 1986; Index Fungorum Registration Identifier: 126575; Location: Imperial Nuktak C-22 Well, Mackenzie Delta Region, District of Mackenzie, N. W. T., Canada; Age: Oligocene.

3.36.2. Species: R. catenarius (G. Playford) Kalgutkar \& Janson. 2000; Index Fungorum Registration Identifier: 483541; Basionym: Synsphaeridium catenarium G. Playford in Playford \& Dring 1981; Location: Carnarvon Basin, Western Australia; Age: Late Devonian (Late? Frasnian).

3.36.3. Species: R. catenulatus L.R. Wilson 1962 (Fig. 12AG); Index Fungorum Registration Identifier: 338248; Location: North bank of Salt Fork of the Red River, Greer County, 
Oklahoma, U.S.A.; Age: Late Permian; Notes: Wilson (1962) observed several hundred specimens of this species during an examination of 150 microscope-slide preparations of the Flowerpot Shale. This abundance may indicate that the fungus was of a marine type and thrived in the shallow waters of the sea; however, no account of modern marine fungus comparable to Reduviasporonites catenulatus has been found during a search of the literature. The specific epithet is derived from the Latin catena (chain) and is given in reference to the occurrence of the spores in chain-like units.

3.36.4. Species: R. cerrejonensis (Doub. \& D. Pons) Kalgutkar \& Janson. 2000; Index Fungorum Registration Identifier: 483542; Basionym: Multicellaesporites cerrejonensis Doub. \& D. Pons 1973; Location: Cerrejon basin, Colombia, South America; Age: Palaeocene-Eocene.

3.36.5. Species: R. curvatus (Ambwani) Kalgutkar \& Janson. 2000; Index Fungorum Registration Identifier: 483543; Basionym: Multicellaesporites curvatus Ambwani 1983; Location: Neyveli Lignite Mine, Cuddalore District, Tamil Nadu, India; Age: Late Miocene or Pliocene (Neyveli Lignite).

3.36.6. Species: R. magnus (Doub. \& D. Pons) Kalgutkar \& Janson. 2000; Index Fungorum Registration Identifier: 483544; Basionym: Dicellaesporites magnus Doub. \& D. Pons 1973; Location: Cerrejon basin, Colombia, South America; Age: Palaeocene-Eocene.

3.36.7. Species: R. prakashii (Ambwani) Kalgutkar \& Janson. 2000 (Fig. 12AH); Index Fungorum Registration Identifier: 483545; Basionym: Multicellaesporites prakashii Ambwani 1982; Location: Kotta-Bommuru Village, Rajamahendravaram, East Godavari District, Andhra Pradesh, India; Age: Early Eocene; Notes: The species epithet is in honour of Dr. Uttam Prakash, Birbal Sahni Institute of Palaeosciences, Lucknow, India.

3.36.8. Species: R. qingfengensis (Z.C. Song \& H.C. Luo in Z.C. Song et al.) Z.C. Song in Z.C. Song et al. 1999; Index Fungorum Registration Identifier: 483832; Basionym: Multicellaesporites qingfengensis Z.C. Song \& H.C. Luo in Z.C. Song et al. 1989; Location: Qingfeng county of Henan Province, China; Age: Late Eocene-Middle Oligocene (Shahejie Formation).

3.36.9. Species: $R$. ramosus Kalgutkar 1993; Index Fungorum Registration Identifier: 483884; Location: Peel River, Yukon Territory, Canada; Age: Late Palaeocene-Early Eocene; Notes: The species epithet is derived from the Latin, ramosus, branched.

3.37. Genus: RETICELLITES D.L.E. Glass et al., Pollen et Spores 28: 414 (1986); Index Fungorum Registration Identifier: 11439; Type: $\boldsymbol{R}$. houstonii D.L.E. Glass et al. 1986.

Original Diagnosis: Fungal spores of 3 or more cells, rarely 2, generally of unequal size, with sculpture of indistinct to distinct reticulum. Spore outline lanceolate, spatulate or ovate, indented or not across the septa. Axis appears to be straight, but when a pore is present the axis is occasionally curved through the smaller cell to the pore. Pore present or not, often very obscure. Spore wall of one or two layers; layers tightly appressed or, less commonly, separated. Spores with melanin pigment; the outer wall layer over the larger cells and both layers over the smaller cell can be yellow with practically no brownish component. Septa of two layers; layering not always evident. Septal pores are obscure in the type species (Glass et al. 1986).

Classification: Fungi Imperfecti, Phragmosporae.

Number of species known: One.

Notes: The combination of overall shape and the reticulate spore wall is unique for these spores. The name of the genus denotes sculpture and the multiple number of cells.

3.37.1. Species: R. houstonii D.L.E. Glass et al. 1986 (Fig. 12AI); Index Fungorum Registration Identifier: 360321; Location: South-central Texas, U.S.A.; Age: Late Eocene (Manning Formation); Notes: The species epithet is in memory of Sam Houston, on the occasion of the Texas sesquicentennial.

3.38. Genus: SCOLECOSPORITES R.T. Lange \& P.H. Sm., Neues Jb. für Geologie und Paläontologie 11: 674 (1971); Index Fungorum Registration Identifier: 21296; Type: 
S. maslinensis R.T. Lange \& P.H. Sm. 1971.

Original Diagnosis: Scoleco-phragmospores of lengths 15-30 times of the breadth, the outline of walls and septa ladder-like (Lange \& Smith 1971).

Emended Diagnosis: Long to very long, linear filamentous phragmospores, hilate, with or without distal pore; length many times width of spore. Spores scalariform, commonly broken and lacking proximal and/ or distal portions; wall and septa commonly thin; septa often with septal folds. Not or barely indented at septa (Kalgutkar \& Jansonius 2000).

Classification: Fungi Imperfecti, Phragmosporae.

Number of species known: Five [but we accept only four species as legitimate because one species, viz. S. vermiculatus (P. Ke \& Z.Y. Shi) Z.C. Song 1999, has been transferred to Multicellites Kalgutkar \& Janson. 2000].

Notes: According to Lange \& Smith (1971) this species has phragmospores typically of more than 10 cells and typically with length greater than 4 times breadth. Kalgutkar \& Jansonius (2000) emended the generic diagnosis.

3.38.1. Species: S. longus Z.C. Song \& Z.H. Sun in Z.C. Song et al. 1989; Index Fungorum Registration Identifier: 637504; Location: Qingfeng county of Henan Province, China; Age: Late Eocene-Middle Oligocene (Shahejie Formation).

3.38.2. Species: S. maslinensis R.T. Lange \& P.H. Sm. 1971 (Fig. 12AJ); Index Fungorum Registration Identifier: 323295; Location: Maslin Bay, South Australia; Age: Early-Middle Eocene.

3.38.3. Species: S. modicus Kalgutkar \& Janson. 2000; Index Fungorum Registration Identifier: 483547; Basionym: Pluricellaesporites scalaris Kalgutkar 1997; Location: Kanguk Peninsula, Axel Heiberg Island, Northwest Territories, Canada; Age: Late Palaeocene-Early Eocene; Notes: The species epithet is derived from Latin modicus $=$ modest, moderate, for its modest length compared to other species in this genus.

3.38.4. Species: S. scalaris (Kalgutkar) Kalgutkar \& Janson. 2000 (Fig. 12AK); Index Fungorum Registration Identifier: 483548; Basionym: Diporicellaesporites scalaris Kalgutkar 1993; Location: Peel River, Yukon Territory, Canada; Age: Late Palaeocene-Early Eocene; Notes: The species epithet is derived from the Latin, scalaris, scalariform, referring to the ladder-like appearance of the spores.

3.38.5. Species: S. vermiculatus (P. Ke \& Z.Y. Shi) Z.C. Song in Z.C. Song et al. 1999; Index Fungorum Registration Identifier: 483833; Basionym: Multicellaesporites vermiculatus $\mathrm{P} . \mathrm{Ke}$ \& Z.Y. Shi 1978; Current name: Multicellites vermiculatus (P. Ke \& Z.Y. Shi) Kalgutkar \& Janson. 2000 fide Kalgutkar \& Jansonius (2000).

3.39. Genus: TRIPITHONITES Sat. K. Srivast. \& Al-Tayyar, Savitriana 3: 180 (2013); Index Fungorum Registration Identifier: 817993; Type: T. amoenus Sat. K. Srivast. \& Al-Tayyar 2013.

Original Diagnosis: Tricellate fungal spore, middle cell dark coloured, end-cells hyaline; middle cell oval to elliptical, middle cell generally with a longitudinal furrow; exine surface smooth, middle cell with two wall-layers, inner wall layer dark, smooth to striate (Srivastava \& AlTayyar 2013).

Classification: Fungi Imperfecti, Phragmosporae.

Number of species known: Two.

Notes: Tripithonites is distinct from Dicellaesporites Elsik 1968 and Tricellaesporonites Sheffy \& Dilcher 1971, in having two hyaline cells attached at the extremities of a large black cell. The name of the genus is derived from the Greek tri $-=$ three; pithon $=$ cellar.

3.39.1. Species: T. amoenus Sat. K. Srivast. \& Al-Tayyar 2013 (Fig. 12AL); Index Fungorum Registration Identifier: 818890; Location: Northern Arabian Gulf; Age: Late middle Albian; Notes: Tripithonites amoenus consists of tricellate fungal spores having a large dark elliptical cells and two hyaline end-cells. The species epithet is derived from the Latin amoenus = delightful, lovely. 
3.39.2. Species: T. argoperatus Sat. K. Srivast. \& Al-Tayyar 2013; Index Fungorum Registration Identifier: 818891; Location: Northern Arabian Gulf; Age: Late middle Albian; Notes: The species epithet is derived from the Greek argos $=$ white; peratos $=$ end, extremity.

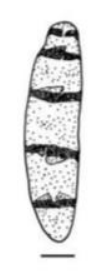

A

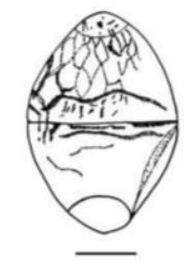

B

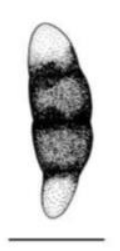

C

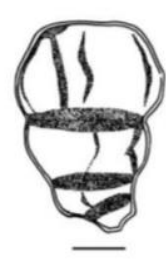

D

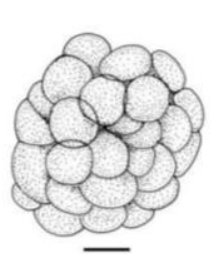

E

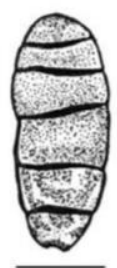

$\mathbf{F}$

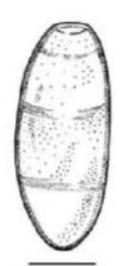

G

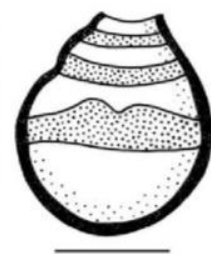

H
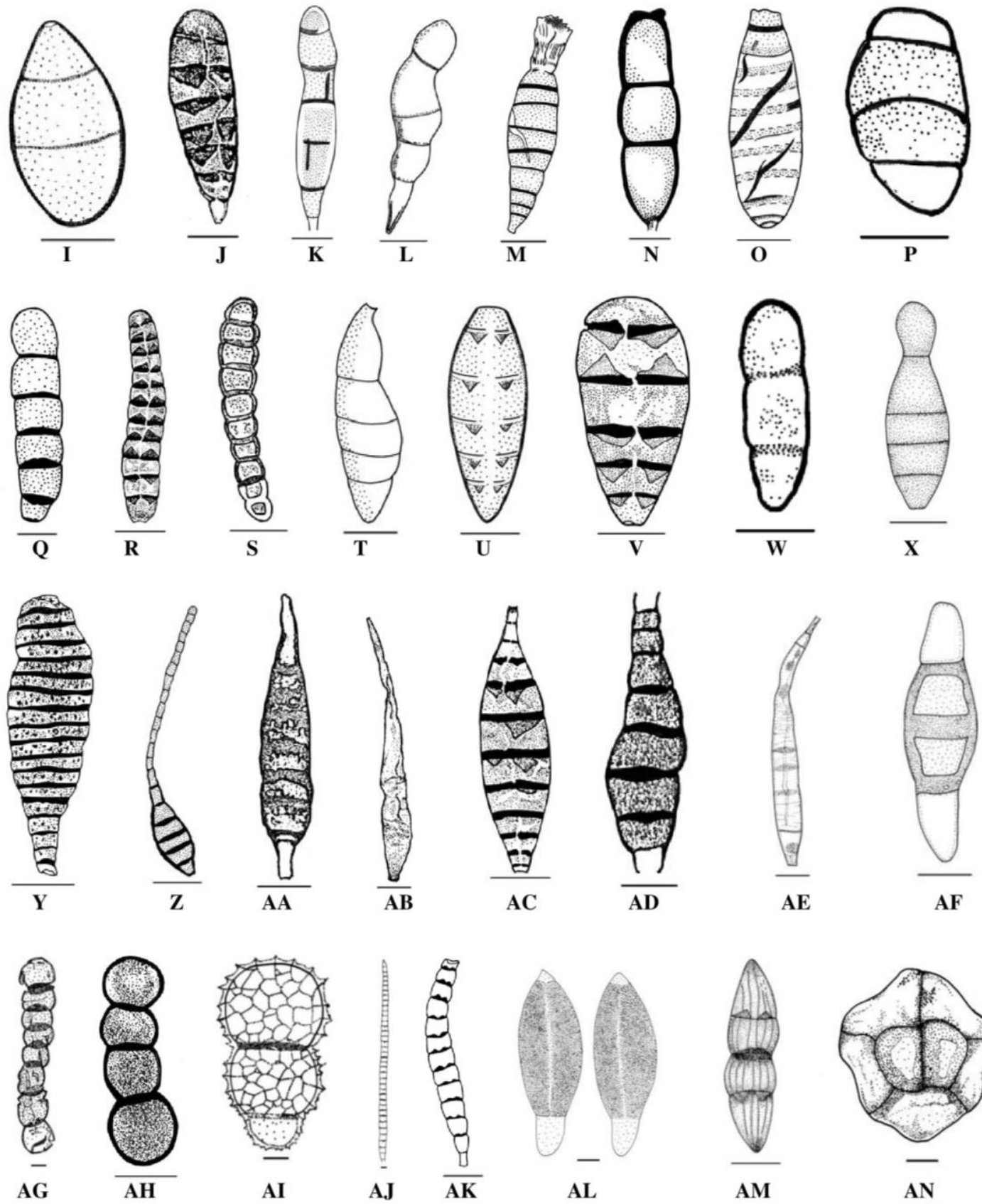

AL
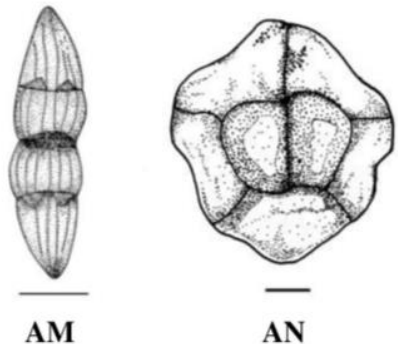

AN

Figure 12 - A-AM Phragmosporae. AN Dictyosporae. A Multicellites tener (P. Ke \& Z.Y. Shi) Kalgutkar \& Janson. 2000, Bar $=8 \mu \mathrm{m}$. B Ornasporonites inaequalis Ramanujam \& K.P. Rao 1978, Bar $=15 \mu \mathrm{m}$. C Palaeocurvularia variabilis Dörfelt \& A.R. Schmidt 2010, Bar $=10 \mu \mathrm{m} . \mathrm{D}$ 
Paragranatisporites lunpolaensis Zhong Y. Zhang 1980, Bar $=8 \mu \mathrm{m}$. E Phialophoronites magnus Debi Mukh. 2012, Bar $=120 \mu \mathrm{m}$. F Pluricellaesporites annulatus Anil Chandra et al. 1984, Bar = $10 \mu \mathrm{m}$. G Pluricellaesporites eocenicus B. Samant \& Tapaswi 2000, Bar $=10 \mu \mathrm{m}$. H Pluricellaesporites globatus B. Samant in R.K. Saxena 2009, Bar $=40 \mu \mathrm{m}$. I Pluricellaesporites guptae R.K. Saxena 2009, Bar $=8 \mu \mathrm{m}$. J Pluricellaesporites hillsii Elsik 1968, Bar $=10 \mu \mathrm{m} . \mathrm{K}$ Pluricellaesporites himachalensis R.K. Saxena \& S.K.M. Tripathi 2011, Bar $=15 \mu \mathrm{m}$. L Pluricellaesporites karii A. Gupta 2002, Bar $=10 \mu \mathrm{m}$. M Pluricellaesporites keralensis R.K. Saxena \& S.K.M. Tripathi 2011, Bar $=30 \mu \mathrm{m}$. N Pluricellaesporites longicollus Sheffy \& Dilcher 1971, Bar $=5 \mu \mathrm{m}$. O Pluricellaesporites mehrotrae R.K. Saxena \& S.K.M. Tripathi 2011, Bar $=20$ $\mu \mathrm{m}$. P Pluricellaesporites misrae Anil Chandra et al. 1984, Bar $=10 \mu \mathrm{m}$. Q Pluricellaesporites planus Trivedi \& C.L. Verma ex Kalgutkar \& Janson. 2000, Bar $=10 \mu \mathrm{m}$. R Pluricellaesporites psilatus R.T. Clarke 1965, Bar $=20 \mu \mathrm{m}$. S Pluricellaesporites rectangulatus Y.K. Mathur \& K. Mathur 1969, Bar $=10 \mu \mathrm{m}$. T Pluricellaesporites sirmaurensis A. Gupta 2002, Bar $=10 \mu \mathrm{m}$. U Pluricellaesporites suratensis R.K. Saxena 2009, Bar $=10 \mu \mathrm{m}$. V Pluricellaesporites tamilensis R.K. Saxena \& S. Khare 1992, Bar $=20 \mu \mathrm{m}$. W Pluricellaesporites tricellatus (Anil Chandra et al.) Kalgutkar \& Janson. 2000, Bar $=10 \mu \mathrm{m}$. X Pluricellaesporites typicus Hammen 1954, Bar $=20$ $\mu \mathrm{m}$. Y Pluricellaesporites verrucatus H.P. Singh et al. 1986, Bar $=20 \mu \mathrm{m}$. Z Quilonia alleppeyensis (Ramanujam \& K.P. Rao) Kalgutkar \& Janson. 2000, Bar $=20 \mu \mathrm{m}$. AA Quilonia attenuata (Ramanujam \& Srisailam) Kalgutkar \& Janson. 2000, Bar $=5 \mu \mathrm{m}$. AB Quilonia miocenica (H.P. Singh et al.) Kalgutkar \& Janson. 2000, Bar $=10 \mu \mathrm{m}$. AC Quilonia multicellata (R.K. Saxena \& S. Khare) Kalgutkar \& Janson. 2000, Bar $=10 \mu \mathrm{m}$. AD Quilonia prakashii (Anil Chandra et al.) Kalgutkar \& Janson. 2000, Bar $=10 \mu \mathrm{m}$. AE Quilonia typica K.P. Jain \& R.C. Gupta 1970, Bar $=20 \mu \mathrm{m}$. AF Ramasricellites differentialis (Ramanujam \& Srisailam) Kalgutkar \& Janson. 2000, Bar $=7 \mu \mathrm{m}$. AG Reduviasporonites catenulatus L.R. Wilson 1962, Bar $=8 \mu \mathrm{m}$. AH Reduviasporonites prakashii (Ambwani) Kalgutkar \& Janson. 2000, Bar $=8 \mu \mathrm{m}$. AI Reticellites houstonii D.L.E. Glass et al. 1986, Bar $=6 \mu \mathrm{m}$. AJ Scolecosporites maslinensis R.T. Lange \& P.H. Sm. 1971, Bar $=8 \mu \mathrm{m}$. AK Scolecosporites scalaris (Kalgutkar) Kalgutkar \& Janson. 2000, Bar $=$ $20 \mu \mathrm{m}$. AL Tripithonites amoenus Sat. K. Srivast. \& Al-Tayyar 2013, Bar $=6 \mu \mathrm{m}$. AM Varmasporites tonakkalensis (Y.N.R. Varma \& R.S. Patil) Kalgutkar \& Janson. 2000, Bar $=10 \mu \mathrm{m}$. AN Centonites symmetricus Peppers 1964, Bar $=12 \mu \mathrm{m}$.

3.40. Genus: VARMASPORITES Kalgutkar \& Janson., AASP Contributions Series (Dallas) 39: 309 (2000); Index Fungorum Registration Identifier: 28626; Type: V. tonakkalensis (Y.N.R. Varma \& R.S. Patil) Kalgutkar \& Janson. 2000.

Original Diagnosis: Fusiform, four-celled, inaperturate fungal spores, with a pronounced constriction at the thick median septum, and with a distinct ribbed or striate sculpture parallel to the long axis. The two centrifugal septa may be less strongly developed (Kalgutkar \& Jansonius 2000).

Classification: Fungi Imperfecti, Phragmosporae.

Number of species known: One.

Notes: Kalgutkar \& Jansonius (2000) opined that Fusiformisporites tonakkalensis Y.N.R. Varma \& R.S. Patil is a misfit in Fusiformisporites Rouse and therefore they proposed Varmasporites to accommodate it.

3.40.1. Species: V. tonakkalensis (Y.N.R. Varma \& R.S. Patil) Kalgutkar \& Janson. 2000 (Fig. 12AM); Index Fungorum Registration Identifier: 483572; Basionym: Fusiformisporites tonakkalensis Y.N.R. Varma \& R.S. Patil 1985; Location: Tonakkal area, Thiruvananthapuram District, Kerala, India; Age: Miocene.

3.41. Genus: WARKALLISPORONITES Ramanujam \& K.P. Rao, Proc. IV International Palynology Conference, Lucknow 1976-1977 1: 298 (1978); Index Fungorum Registration Identifier: 21361; Type: W. denticulatus Ramanujam \& K.P. Rao 1978; Current name: MULTICELLAESPORITES Elsik 1968 fide Kalgutkar \& Jansonius (2000). 
Original Diagnosis: Spores simple, melanin-coloured, multicellular, uniseriate, fusiform, multiporate. Spores distinctly constricted in the central region. Denticulate or wedge-shaped thickenings on some septa, pore slit-like in each septum. Spore wall granular to scabrate (Ramanujam \& Rao 1978).

Classification: Fungi Imperfecti, Phragmosporae.

Number of species known: One (the single species has been transferred to Multicellaesporites Elsik 1968).

Notes: Since Kalgutkar \& Jansonius (2000) transferred the type species to Multicellaesporites Elsik 1968, Warkallisporonites Ramanujam \& K.P. Rao 1978 became a later taxonomic synonym of Multicellaesporites Elsik 1968.

3.41.1. Species: W. denticulatus Ramanujam \& K.P. Rao 1978; Index Fungorum Registration Identifier: 115097; Current name: Multicellaesporites denticulatus (Ramanujam \& K.P. Rao) Kalgutkar \& Janson. 2000 fide Kalgutkar \& Jansonius (2000).

\section{Dictyosporae}

4.1. Genus: ARBUSCULITES Paradkar, Journal of Palynology 10(2): 120 (1976); Index Fungorum Registration Identifier: 21013; Type: A. dicotylophylli Paradkar 1976; Current name: DICTYOSPORITES Felix 1894 fide Kalgutkar \& Jansonius (2000).

Original Diagnosis: Saprophytic [saprobic] fungus, septate mycelium, dictyospores formed on a conidial head (Paradkar 1976).

Classification: Fungi Imperfecti, Dictyosporae.

Number of species known: One (the single species has been transferred to Dictyosporites Felix 1894).

4.1.1. Species: A. dicotylophylli Paradkar 1976; Index Fungorum Registration Identifier: 483814; Current name: Dictyosporites dicotylophylli (Paradkar) Kalgutkar \& Janson. 2000 fide Kalgutkar \& Jansonius (2000).

4.2. Genus: CENTONITES Peppers, Bull. Ill. St. geol. Surv. 90: 47 (1964); Index Fungorum Registration Identifier: 21032; Type: C. symmetricus Peppers 1964.

Original Diagnosis: The microfossils are composed of 5 to approximately 15 polygonal segments joined to form radially or bilaterally symmetrical bodies, their symmetry depending upon their number and arrangement. Most of the microfossils are flatly compressed, but many are folded. Straight grooves are present on one side of the body where the segments are joined. Elevated, flattened ridges or folds occur adjacent to and along both sides of the grooves but are absent along the smooth outer margin of the microfossils. The microfossils usually are made up of an odd number of segments. The most common variation consists of five segments arranged in a boatshaped pattern with two small, pointed segments at one end, two larger segments in the middle, and one pointed segment at the opposite end. In the largest specimens two to four segments in the center are almost completely bordered by other segments. Along the margins of the largest specimens three small indentations may occur, almost equal distances apart, where segments are absent. These indentations either have smooth edges and look almost like pores or they have uneven edges as if segments had been torn out. The microfossils are revealed under oil immersion objective as laevigate. They are 1 to $2 \mu \mathrm{m}$ thick. The known size range is 50.2 to $123.2 \mu \mathrm{m}$ in maximum diameter (Peppers 1964).

Classification: Fungi Imperfecti, Dictyosporae.

Number of species known: One.

Notes: Elsik (1992) indicated that the spore wall of Centonites appears to be not exclusively fungal; thus, an algal affinity cannot be ruled out.

4.2.1. Species: C. symmetricus Peppers 1964 (Fig. 12AN); Index Fungorum Registration Identifier: 560969; Location: Illinois, U.S.A.; Age: Late Pennsylvanian; Notes: The species epithet is in reference to the symmetrical arrangement of the segments. 
4.3. Genus: CTENOSPORITES Elsik \& Janson., Can. J. Bot. 52(5): 956 (1974); Index Fungorum Registration Identifier: 21066; Type: C. eskerensis Elsik \& Janson. 1974.

Original Diagnosis: Multicellular structures of fungal origin; one main stem of a few to several (commonly seven-nine) cells and lateral or secondary septate branches (cf. filaments) along one side of the main stem. Main stem and lateral branches are straight to slightly curved; apex of the main stem may be curved towards the side of the lateral branches; lateral branches are curved concave to the apex of the main stem. Basal cell of the stem is generally torn and may be thinnerwalled than that portion of the stem bearing branches. Branches are of a few to several (commonly five-seven) cells. Branches may have incomplete septa but in all cases the apical branch has fewer septa (i.e., in most cases none) than the basal branches; the progression (with occasional exception) is one more septum with each additional branch counting from the apex to the base of the stem. Apical cell(s) of the stem may mimic the most apical branch or may be lacking altogether (Elsik \& Jansonius 1974).

Classification: Fungi Imperfecti, Dictyosporae.

Number of species known: Three (but we accept only two species as legitimate because one species, C. wolfei Elsik \& Janson. 1974, has been considered to be a synonym of Ctenosporites eskerensis Elsik \& Janson. 1974).

Notes: The species epithet is derived from Greek kteis, ktenos $=$ comb.

4.3.1. Species: C. eskerensis Elsik \& Janson. 1974 (Fig. 13A); Index Fungorum Registration Identifier: 312369; Synonym: Ctenosporites wolfei Elsik \& Janson. 1974 (named in honour of Dr. J.A. Wolfe); Location Gulf of Alaska, Alaska (Elsik \& Jansonius 1974), Lower Headon deposits, Hordle Cliff, Hampshire, England (Smith 1978); Age: Late Eocene-Early Oligocene; Notes: Smith (1978) considered differences in Ctenosporites eskerensis and C. wolfei as morphological variations produced by the same mycelium and placed Ctenosporites wolfei in synonymy with Ctenosporites eskerensis.

4.3.2. Species: C. sherwoodiae Kalgutkar \& Janson. 2000; Index Fungorum Registration Identifier: 483290; Location: Fremount County, Colorado, U.S.A.; Age: Late Cretaceous (Vermejo Formation coal beds); Notes: Kalgutkar \& Jansonius (2000) formally named Fungal Spore sp. A (in Clarke 1965) after Martha Sherwood, in recognition of her important contributions to the knowledge of fossil fungal spores.

4.3.3. Species: C. wolfei Elsik \& Janson. 1974; Index Fungorum Registration Identifier: 312370; Current name: Ctenosporites eskerensis Elsik \& Janson. 1974 fide Kalgutkar \& Jansonius (2000).

4.4. Genus: DACTYLOSPORITES Paradkar 1976; Index Fungorum Registration Identifier: 21070; Type: D. dicotylophylli Paradkar 1976; Current name: DICTYOSPORITES Felix 1894 fide Kalgutkar \& Jansonius (2000).

Original Diagnosis: Fungus saprophytic [saprobic], mycelium septate, phragmospores smooth (Paradkar 1976).

Classification: Fungi Imperfecti, Dictyosporae.

Number of species known: One (the single species has been transferred to Dictyosporites Felix 1894).

Notes: Dactylosporites Paradkar (1976) is a later synonym of Dictyosporites Felix (1894).

4.4.1. Species: D. dicotylophylli Paradkar 1976; Index Fungorum Registration Identifier: 483815; Current name: Dictyosporites paradkariae Kalgutkar \& Janson. 2000 fide Kalgutkar \& Jansonius (2000).

4.5. Genus: DICTYOSPORITES Félix 1894, Zeitschr. Deutsche Geol. Gesell. 46: 277 (1894); Index Fungorum Registration Identifier: 21075; Type: D. loculatus Felix 1894 (type selected by Jansonius \& Hills 1976).

Synonyms: Arbusculites Paradkar 1976, Index Fungorum Registration Identifier: 21013; Dactylosporites Paradkar 1976, Index Fungorum Registration Identifier: 21070; Pleosporonites 
R.T. Lange \& P.H. Sm. 1971, Index Fungorum Registration Identifier: 21253; Ravenelites Ramanujam \& Ramachar 1980, Index Fungorum Registration Identifier: 28630.

Original Diagnosis: The so-called wall-shaped conidia become multicellular by repeated transverse and longitudinal divisions. In addition to large conidia, whose growth can probably be regarded as complete, uni- and bicellular conidia representing the initial developmental stages also occur. They are all of brownish coloration. Their outlines are rather variable, depending on the position of the conidium to the plane of section. Viewed from the top or bottom, they often appear spherical with flatly indented outlines; longitudinal sections are of rather irregular shape; elliptical, pear-shaped or resembling short, corpulent snails (e.g. Turbo). The maximum length is $0.0204 \mathrm{~mm}$ [20.4 $\mu \mathrm{m}]$, the maximum diameter $0.0153 \mathrm{~mm}[15.3 \mu \mathrm{m}]$; the respective dimensions of an only bicellular conidium are 0.0102 and $0.0085 \mathrm{~mm}$ [10.2 and $8.5 \mu \mathrm{m}]$ (Felix 1894).

Emended Diagnosis: Inaperturate, multicellate (apparently by internal septation, of irregular pattern), muriform fungal spores, cells rounded to rounded polygonal. Overall shape rounded, oval/ovoid to elongate; indentations may occur where septa intersect the amb. A hilum cannot be discerned. Staphlosporonites differs in showing a distinct hilum, or proximal hilar cell. Papulosporonites consists of spore clusters or aggregates, in which there is no suggestion of linear or planar symmetry (Kalgutkar \& Jansonius 2000).

Classification: Fungi Imperfecti, Dictyosporae.

Number of species known: 20 (but we accept only 15 species as legitimate because five species have been transferred to other genera).

Notes: According to Kalgutkar \& Jansonius (2000), different species of Dictyosporites are comparable to the conidia of some modern genera like Alternaria, Dictyosporium, Septosporium and Stemphylium, all belonging to dematiaceous hyphomycetes, and the ascospores of Pleospora.

4.5.1. Species: D. dicotylophylli (Paradkar) Kalgutkar \& Janson. 2000 (Fig. 13B); Index Fungorum Registration Identifier: 483297; Basionym: Arbusculites dicotylophylli Paradkar 1976; Location: Mohgaonkalan, Chhindwara District, Madhya Pradesh, India; Age: Late Cretaceous (Maastrichtian); Notes: According to Paradkar (1976), this species can be compared with the Arbuscula Bat. \& Peres (Batista \& Peres 1965) (Current name: Neoarbuscula B. Sutton 1983 fide Species Fungorum 2021). Arbuscula is recorded on fallen Eugenia leaves. The specific name is after its occurrence on a dicotyledonous leaf.

4.5.2. Species: D. dictyosus (Sal.-Cheb. \& Locq.) Kalgutkar \& Janson. 2000; Index Fungorum Registration Identifier: 483298; Basionym: Pleosporonites dictyosus Sal.-Cheb. \& Locq. 1980; Location: Coast of Equatorial Africa, Gulf of Guinea, Cameroon, Africa; Age: Oligocene.

4.5.3. Species: D. eccentricus Kalgutkar 1993; Index Fungorum Registration Identifier: 483865; Current name: Kutchiathyrites canadensis Kalgutkar \& Janson. 2000 fide Kalgutkar \& Jansonius (2000).

4.5.4. Species: D. elsikii Kalgutkar 1993; Index Fungorum Registration Identifier: 483864; Current name: Staphlosporonites billelsikii Kalgutkar \& Janson. 2000 fide Kalgutkar \& Jansonius (2000).

4.5.5. Species: D. felixii R.T. Lange \& P.H. Sm. 1971; Index Fungorum Registration Identifier: 312993; Current name: Staphlosporonites felixii (R.T. Lange \& P.H. Sm.) Kalgutkar \& Janson. 2000 fide Kalgutkar \& Jansonius (2000).

4.5.6. Species: D. firbasii (Hammen) Kalgutkar \& Janson. 2000; Index Fungorum Registration Identifier: 483299; Basionym: Polyadosporites firbasii Hammen 1954; Location: Magdalena Valley, Eastern Cordellera, Colombia, South America; Age: Maastrichtian.

4.5.7. Species: D. garciabarrigae (Hammen) Kalgutkar \& Janson. 2000; Index Fungorum Registration Identifier: 483300; Basionym: Polyadosporites garciabarrigae Hammen 1954; Location: Magdalena Valley, Eastern Cordellera, Colombia, South America; Age: Maastrichtian.

4.5.8. Species: D. globimuriformis Kalgutkar 1997; Index Fungorum Registration Identifier: 437903; Location: Kanguk Peninsula, Axel Heiberg Island, Northwest Territories, Canada; 
Age: Late Palaeocene-Early Eocene; Notes: The species epithet refers to the rounded and muriform nature of spores.

4.5.9. Species: D. heterosporus Sal.-Cheb. \& Locq. 1980; Index Fungorum Registration Identifier: 107915; Current name: Pluricellaesporites heterosporus (Sal.-Cheb. \& Locq.) Kalgutkar \& Janson. 2000 fide Kalgutkar \& Jansonius (2000).

4.5.10. Species: D. hyalinus (R.T. Lange \& P.H. Sm. 1971) Kalgutkar \& Janson. 2000; Index Fungorum Registration Identifier: 483301; Basionym: Pleosporonites hyalinus R.T. Lange \& P.H. Sm. 1971; Location: Maslin Bay, South Australia; Age: Early-Middle Eocene; Notes: The transfer of this species, the type of Pleosporonites, makes Pleosporonites a later taxonomic synonym of Dictyosporites.

4.5.11. Species: D. loculatus Félix 1894 (Fig. 13C); Index Fungorum Registration Identifier: 189946; Location: Perekeschkul, near Baku, Azerbaijan; Age: Eocene; Notes: Félix (1894) stated that as compared with the conidia of recent forms, the fossils show the closest resemblance to those of the genera Macrosporium Bon., Septosporium Zopf., Stemphylium Wallr. and Stigmella Lév.

4.5.12. Species: D. morularis (Sal.-Cheb. \& Locq.) Kalgutkar \& Janson. 2000; Index Fungorum Registration Identifier: 483302; Basionym: Pleosporonites morularis Sal.-Cheb. \& Locq. 1980; Location: Coast of Equatorial Africa, Gulf of Guinea, Cameroon, Africa; Age: Oligocene.

4.5.13. Species: D. moruloides (Sal.-Cheb. \& Locq.) Kalgutkar \& Janson. 2000; Index Fungorum Registration Identifier: 483303; Basionym: Pleosporonites moruloides Sal.-Cheb. \& Locq. 1980; Location: Coast of Equatorial Africa, Gulf of Guinea, Cameroon, Africa; Age: Early Miocene.

4.5.14. Species: D. ovalis (Sheffy \& Dilcher) Kalgutkar \& Janson. 2000; Index Fungorum Registration Identifier: 483304; Basionym: Staphlosporonites ovalis Sheffy \& Dilcher 1971; Location: Puryear clay pit, $800 \mathrm{~m}$ south of Puryear, Henry County, Tennessee, U.S.A.; Age: Middle Eocene (Claiborne Formation).

4.5.15. Species: D. ovoideus Sal.-Cheb. \& Locq. 1980; Index Fungorum Registration Identifier: 107916; Basionym: Pleosporonites ovoideus Sal.-Cheb. \& Locq. 1980; Location: Coast of Equatorial Africa, Gulf of Guinea, Cameroon, Africa; Age: Oligocene.

4.5.16. Species: D. pachycellularis Sal.-Cheb. \& Locq. 1980; Index Fungorum Registration Identifier: 107917; Current name: Staphlosporonites pachycellularis (Sal.-Cheb. \& Locq.) Kalgutkar \& Janson. 2000 fide Kalgutkar \& Jansonius 2000.

4.5.17. Species: D. paradkariae Kalgutkar \& Janson. 2000 (Fig. 13D); Index Fungorum Registration Identifier: 483305; Basionym: Dactylosporites dicotylophylli Paradkar 1976; Location: Mohgaon Kalan, Chhindwara District, Madhya Pradesh, India; Age: Late Cretaceous (Maastrichtian); Notes: Paradkar (1976) stated that such spores are found in the genera Alternaria and Dactylosporium (Barnett 1965). More resemblance is seen, however, with Dactylosporium in the shape, size and number of cells in the compound spores, than with Alternaria. Kalgutkar \& Jansonius (2000) transferred this species to Dictyosporites Felix 1894 with a new name (Dictyosporites paradkariae Kalgutkar \& Janson. 2000, 'paradkarii') because the name Dictyosporites dicotylophylli (Paradkar) Kalgutkar \& Janson. 2000 was preoccupied, The species epithet is in honour of Professor B.S. Trivedi, Department of Botany, Lucknow University, Lucknow, India.

4.5.18. Species: D. symmetricus (V.S. Ediger) Kalgutkar \& Janson. 2000; Index Fungorum Registration Identifier: 483306; Basionym: Transeptaesporites symmetricus V.S. Ediger 1981; Location: Thrace Basin, Turkey; Age: Late Eocene-Oligocene, Miocene-Pliocene; Notes: Ediger (1981) opined that this species has probable affinity with Alternaria.

4.5.19. Species: D. tirumalacharii (Ramanujam \& Ramachar) Kalgutkar \& Janson. 2000 (Fig. 13E); Index Fungorum Registration Identifier: 483307; Basionym: Ravenelites tirumalacharii Ramanujam \& Ramachar 1980; Location: Neyveli Lignite Mine, Cuddalore District, Tamil Nadu, India; Age: Miocene (Neyveli lignite). 
4.5.20. Species: D. tristratosus (Sheffy \& Dilcher) Kalgutkar \& Janson. 2000 (Fig. 13F); Index Fungorum Registration Identifier: 483308; Basionym: Staphlosporonites tristratosus Sheffy \& Dilcher 1971; Location: Puryear clay pit, $800 \mathrm{~m}$ south of Puryear, Henry County, Tennessee, U.S.A.; Age: Middle Eocene (Claiborne Formation); Notes: The specific name refers to the arrangement of the cells into three layers.

4.6. Genus: DICTYOSPORIUMINITES Debi Mukh., International Journal of Geology, Earth and Environmental Sciences 2(2): 5 (2012); Index Fungorum Registration Identifier: 588466; Type: D. intermedius Debi Mukh. 2012.

Original Diagnosis: Conidiophore compact in sporodochium-like structure, clustered, dark in colour; size mediumly large, 400-450 × 125-150 $\mu \mathrm{m}$; conidia produced singly, acrogenous; branches multiseptate, 5-8 septa observed; 4-5 branches present (Mukherjee 2012).

Classification: Fungi Imperfecti, Dictyosporae.

Number of species known: One.

Notes: The genus is named after extant Dictyosporium (Hyphomycetes).

4.6.1. Species: D. intermedius Debi Mukh. 2012 (Fig. 13G); Index Fungorum Registration Identifier: 588479; Location: Neyveli Lignite Mine-I, Cuddalore District, Tamil Nadu, India; Age: Miocene (Neyveli Lignite); Notes: Dictyosporiminites intermedium can be compared with the extant Dictyosporium in having sporodochium-like structure with multiseptate conidiophores (united together).

4.7. Genus: DICTYOSTROMA R. Kar et al., Review of Palaeobotany \& Palynology (Amsterdam) 158(3-4): 247 (2010); Index Fungorum Registration Identifier: 622180; Type: D. perfectum R. Kar et al. 2010; Current name: KUTCHIATHYRITES R.K. Kar 1979 fide Saxena \& Tripathi (2011).

Original Diagnosis: Stromata fan-shaped except attachment zone; attachment slightly pointed, haustorium hyaline, nonseptate, tubular, 32-49 × 22-38 $\mu \mathrm{m}$, lateral arms more or less equal, hyphae radially and transversely anastomose to form pseudoreticulation on both sides (Kar et al. 2010).

Classification: Fungi Imperfecti, Dictyosporae.

Number of species known: One (the single species has been transferred to Kutchiathyrites R.K. Kar 1979).

Notes: Kar et al. (2010) proposed Dictyostroma ("Dictyostromata"), which is identical to Kutchiathyrites R.K. Kar 1979 and therefore the former is considered here as later synonym of the latter.

4.7.1. Species: D. perfectum R. Kar et al. 2010; Index Fungorum Registration Identifier: 622214; Current name: Kutchiathyrites perfectus (R. Kar et al.) R.K. Saxena \& S.K.M. Tripathi 2011 fide Saxena \& Tripathi (2011).

4.8. Genus: KUTCHIATHYRITES R.K. Kar, Palaeobotanist 26(1): 32 (1979); Index Fungorum Registration Identifier: 21145; Type: K. eccentricus R.K. Kar 1979.

Synonym: Dictyostroma R. Kar et al. 2010 fide Saxena \& Tripathi 2011, Index Fungorum Registration Identifier: 622180.

Original Diagnosis: Microthyriaceous asco-stromata eccentric in development, no free hyphae present, dimidiate, nonostiolate, radially arranged hyphae thick, dark, diverging from one another, transverse hyphae comparatively thinner, \pm translucent, interconnecting radial ones to form squarish, pseudoparenchymatous cells without any pore; Description: Microthyriaceous ascostromata of approximately semicircular shape in most specimens, in others they look like fish scales, size range 64-110 $\times 41-73 \mu \mathrm{m}$. Upper surface of ascostromata darker than inner one; radial hyphae also well pronounced in former. Radial hyphae look like dark strands; transverse hyphae illdeveloped, sometimes hardly discernable at places (Kar 1979).

Emended Diagnosis: Hilate conidia, fan-shaped, formed by numerous linear filaments radiating out from the hilum; conidia may be flattened (i.e. two-) or three dimensional; filaments 
may be joined to their neighbours, or partially free, and may branch towards the periphery; hilum may or may not show the stipe from which it developed (Kalgutkar \& Jansonius 2000).

Classification: Fungi Imperfecti, Dictyosporae.

Number of species known: Five.

Notes: Kalgutkar \& Jansonius (2000) opined that Kutchiathyrites is not a microthyriaceous fructification, as stated by Kar (1979), but a multicellular spore/conidium showing a clear attachment area, scar or pore. Kutchiathyrites eccentricus, as described by Kar (1979), demonstrates a close similarity to the conidia of the hyphomycetous fungus Mycoenterolobium platysporum Goos 1970. This similarity was also pointed out by Jain \& Kar (1979), who referred to Kendrick \& Carmichael (1973), where such eccentric structures are shown as conidia of the hyphomycetous Mycoenterolobium platysporum.

4.8.1. Species: K. canadensis Kalgutkar \& Janson. 2000; Index Fungorum Registration Identifier: 483412; Basionym: Dictyosporites eccentricus Kalgutkar 1993; Location: Peel River, Yukon Territory, Canada; Age: Late Palaeocene-Early Eocene; Notes: The species epithet refers to the place of its occurrence in Canada.

4.8.2. Species: K. eccentricus R.K. Kar 1979 (Fig. 13H); Index Fungorum Registration Identifier: 112385; Location: Barkhana nala cutting, near Sarangwara village, Kutch District, Gujarat, India; Age: Oligocene (Maniyara Fort Formation); Notes: The species epithet refers to fan like shape of the conidia.

4.8.3. Species: K. mehrotrae R.K. Saxena \& S.K.M. Tripathi 2011 (Fig. 13I); Index Fungorum Registration Identifier: 519945; Basionym: Kutchiathyrites sp. in Singh et al. 1986; Location: Sonapur-Badarpur Road Section, Jaintia Hills, Meghalaya and Cachar District, Assam, India; Age: Early Miocene (Bhuban Formation).

4.8.4. Species: K. palmatus (P. Ke \& Z.Y. Shi) Kalgutkar \& Janson. 2000; Index Fungorum Registration Identifier: 483414; Basionym: Microthyriacites palmatus P. Ke \& Z.Y. Shi 1978; Location: Kenlixian and Bingxian, Shandong Province, Coastal region of Bohai, China; Age: Eocene-Oligocene.

4.8.5. Species: K. perfectus (R. Kar et al.) R.K. Saxena \& S.K.M. Tripathi 2011 (Fig. 13J); Index Fungorum Registration Identifier: 519897; Basionym: Dictyostromata perfecta R. Kar et al. 2010; Location: Tlangsam, Mizoram, India; Age: Miocene (Bhuban Formation).

4.9. Genus: LIRASPORIS R. Potonié \& S.C.D. Sah, Palaeobotanist 7(2): 132 (1960); Index Fungorum Registration Identifier: 21154; Type: L. intergranifer R. Potonié \& S.C.D. Sah 1960.

Original Diagnosis: Size varies from $69 \times 103 \mu \mathrm{m}$ to $116 \times 134 \mu \mathrm{m}$; outline oval, longitudinal ends of oval broadly rounded or somewhat tapering, sometimes showing irregular protuberances which form a jumbled mass; extrema lineamenta somewhat smooth except the longitudinal ends which are always nearly notched; following the longer axis exist perhaps 20-30 parallel but narrow ribs showing between them spaced grana (Potonié \& Sah 1960).

Emended Diagnosis: Fungal bodies oval-elliptical with equal or unequal, broad, generally notched ends. Mycelia, long, septate, \pm parallel to one another, extending from one end to other; wall generally laevigate, sometimes granulose (Jain \& Kar 1979).

Classification: Fungi Imperfecti, Dictyosporae.

Number of species known: Three (but we accept only two species as legitimate because $L$. dongpuensis is not validly published).

Notes: Jain \& Kar (1979) opined that the parallel ribs seem to be septate fungal mycelia arranged in longitudinal direction and transferred from Polyplicates to Fungi. Kalgutkar \& Jansonius (2000) had reservations about the fungal nature these forms.

4.9.1. Species: L. dongpuensis Z.C. Song in Z.C. Song et al. 1999 (nom. inval.) fide Kalgutkar \& Jansonius (2000); Index Fungorum Registration Identifier: 483854; Notes: Lirasporis dongpuensis was not validly published by Song (1999) because the author did not specify where the holotype is deposited and also did not provide a Latin or English translation. 
4.9.2. Species: L. elongatus R.K. Kar in R.K. Saxena 2012 (Fig. 13K); Index Fungorum Registration Identifier: 519798; Location: Rokhia borehole; Tripura, north-east India; Age: Early-Middle Miocene; Notes: Kar (1990) did not validly publish Lirasporis elongatus as he did not cite information on where its type is stored. Saxena (2012) validated the name of this species and ascribed it to Kar, because its description and illustrations published by Kar (1990) are the validating ones. The holotype of this species name is that designated by Kar (1990).

4.9.3. Species: L. intergranifer R. Potonié \& S.C.D. Sah 1960 (Fig. 13L); Index Fungorum Registration Identifier: 519797; Location: European Club, Kannur Beach, (Potonié \& Sah 1960); Padappakkara, Edvai and Varkala, Kerala, India (Jain \& Kar 1979); Age: Late Miocene or Pliocene (Potonié \& Sah 1960); Early Miocene-Early Pliocene (Jain \& Kar 1979).

4.10. Genus: OCTOSPORITES Sal.-Cheb. \& Locq., C. r. Congr. natn. Socs. sav. Paris, sect. sci., fasc. 1. (Paleobotanique) 105: 191 (1980); Index Fungorum Registration Identifier: 25608; Type: O. stauroides Sal.-Cheb. \& Locq. 1980.

Original Diagnosis: Monohilate, octocellate murospores, globular, the middle partitions forming a cross; $15 \mu \mathrm{m}$ (Salard-Cheboldaeff \& Locquin 1980).

Classification: Fungi Imperfecti, Dictyosporae.

Number of species known: One.

4.10.1. Species: O. stauroides Sal.-Cheb. \& Locq. 1980 (Fig. 13M); Index Fungorum Registration Identifier: 108279; Location: Coast of Equatorial Africa, Gulf of Guinea, Cameroon, Africa; Age: Early Miocene.

4.11. Genus: PALAMBAGES Wetzel, Micropaleontology 7(3): 338 (1961); Index Fungorum Registration Identifier: 21217; Type: P. morulosa Wetzel 1961.

Original Diagnosis: Spheroidal bodies, composed of many (8-18?) oval membranous cells, sometimes with a flat peripheral portion (with aperture?) (Wetzel 1961).

Classification: Fungi Imperfecti, Dictyosporae.

Number of species known: Three.

Notes: Kalgutkar \& Jansonius (2000) opined that Palambages is characterized by cells or spores arranged in clusters of varying sizes, similar to groups of spores that occur in Polyadosporites. In Palambages, the colonies are membranous and consist of thin-walled, hyaline cells; in Polyadosporites, the spores in colonies are thicker-walled and pigmented. Colonies of Palambages are similar in appearance to coenobial of colonial algae. The genus name is derived from Latin palaeo $=$ old; ambages $=$ going round, winding, ambiguous.

4.11.1. Species: P. canadiana Sat. K. Srivast. 1968; Index Fungorum Registration Identifier: 335542; Location: Drumheller locality, sec. 30, twp. 29, rge. 20, W. 4th mer., Alberta, Canada; Age: Maastrichtian;

4.11.2. Species: P. colonicus Trivedi \& C.L. Verma 1970 ex Kalgutkar \& Janson. 2000; Index Fungorum Registration Identifier: 319134; Basionym: Palambages colonica Trivedi \& C.L. Verma 1970 (nom. inval.), holotype designated by Kalgutkar \& Jansonius 2000; Location: Near Kuala Lumpur, Malaysia ('Malaya'); Age: Eocene; Notes: Trivedi \& Verma (1970) did not validly publish the name of this species because two different specimens were included under the designation "Holotype". Kalgutkar \& Jansonius (2000) selected fig. 5 as holotype and validated the species name.

4.11.3. Species: P. morulosa Wetzel 1961 (Fig. 13N); Index Fungorum Registration Identifier: 319135; Location: Baltic Cretaceous flintstones; Age: Cretaceous; Notes: The species epithet is derived from Latin morula $=$ diminutive of morum, a mulberry. 
4.12. Genus: PAPULOSPORONITES Schmied. \& A. J. Schwab, Deutsche Akademie der Wissenschaften zu Berlin, 6: 686 (1964); Index Fungorum Registration Identifier: 21220; Type: $\boldsymbol{P}$. sphaeromorphus Schmied. \& A. J. Schwab 1964.

Original Diagnosis: Fungal remains of globular to elongate shape, consisting of numerous more or less polygonal cells that are firmly fused into mulberry-shaped aggregates. Cells without any regular order, or concentrically arranged. No differentiation of an outer wall layer; however, one to three of the innermost cells commonly much larger. Occasionally individual aggregates fused together (Schmiedeknecht \& Schwab 1964).

Classification: Fungi Imperfecti, Dictyosporae.

Number of species known: Eight (but we accept only 7 species as legitimate because one species, viz. P. mohgaoensis (Chitaley \& Yawale) Kalgutkar \& Janson. 2000, is here transferred to Thecaphora Fingerh 1836).

Notes: Kalgutkar \& Jansonius (2000) opined that Palambages appears to represent thinnerwalled vesicles, which are less tightly aggregated into spherical units.

4.12.1. Species: P. enormis (V.S. Ediger) Kalgutkar \& Janson. 2000; Index Fungorum Registration Identifier: 483501; Basionym: Polyadosporites enormis V.S. Ediger 1981; Location: Thrace Basin, Turkey; Age: Late Eocene-Oligocene, Miocene-Pliocene.

4.12.2. Species: P. hammenii (Haseld.) Kalgutkar \& Janson. 2000; Index Fungorum Registration Identifier: 483502; Basionym: Polyadosporites hammenii Haseld. 1973; Location: Arén, Ribagorzana Valley, Pyrenees, Spain; Age: Early Palaeocene-Late Eocene.

4.12.3. Species: P. mohgaoensis (Chitaley \& Yawale) Kalgutkar \& Janson. 2000; Index Fungorum Registration Identifier: 483503; Synonym: Sorosporium mohgaoense Chitaley \& Yawale 1978 fide Kalgutkar \& Jansonius (2000), Index Fungorum Registration Identifier: 111035; Current name: Thecaphora mohgaoensis (Chitaley \& Yawale) R.K. Saxena, Wijayaw., D.Q. Dai, K.D. Hyde \& P.M. Kirk comb. nov. This new combination is described under the section "New species and new combinations"

4.12.4. Species: P. multicellatus (R.K. Saxena \& H.P. Singh) Kalgutkar \& Janson. 2000 (Fig. 13O); Index Fungorum Registration Identifier: 483504; Basionym: Staphlosporonites multicellatus R.K. Saxena \& H.P. Singh 1983; Location: Hoshiarpur-Una Road section, near Bankhandi, Hoshiarpur District, Punjab, India; Age: Miocene-Pliocene.

4.12.5. Species: P. orbis (V.S. Ediger) Kalgutkar \& Janson. 2000; Index Fungorum Registration Identifier: 483505; Basionym: Polyadosporites orbis V.S. Ediger 1981; Location: Thrace Basin, Turkey; Age: Late Eocene-Oligocene, Miocene-Pliocene.

4.12.6. Species: P. siwalikus (R.K. Saxena \& A.P. Bhattach.) Kalgutkar \& Janson. 2000 (Fig. 13P); Index Fungorum Registration Identifier: 483506; Basionym: Staphlosporonites siwalikus R.K. Saxena \& A.P. Bhattach. 1987, Location: Kala Amb-Nahan area, Sirmaur District, Himachal Pradesh, India; Age: Miocene.

4.12.7. Species: P. sphaeromorphus Schmied. \& A.J. Schwab 1964 (Fig. 13Q); Index Fungorum Registration Identifier: 637505; Location: Zwischenflöz, Tagebau des Braunkohlenwerkes Nachterstedt, Germany; Age: Middle Eocene.

4.12.8. Species: P. subcircularis (Anil Chandra et al.) Kalgutkar \& Janson. 2000 (Fig. 13R); Index Fungorum Registration Identifier: 483507; Basionym: Staphlosporonites subcircularis Anil Chandra et al. 1984; Location: Sediment core no. 2 (Lat. $18^{\circ} 35.2^{\prime} \mathrm{N}$ : Long. $69^{\circ} 17.2^{\prime} \mathrm{E}$ ), Arabian Sea; Age: Late Quaternary.

4.13. Genus: PLEOSPORONITES R.T. Lange \& P.H. Sm., Neues Jb. für Geologie und Paläontologie 11: 672 (1971); Index Fungorum Registration Identifier: 21253; Type: P. hyalinus R.T. Lange \& P.H. Sm. 1971; Current name: DICTYOSPORITES Felix 1894 fide Kalgutkar \& Jansonius (2000).

Original Diagnosis: Hyaline muriform fungal spores, ellipsoid to ovoid in outline, and manycelled, apparently by internal septation of irregular pattern (Lange \& Smith 1971).

Classification: Fungi Imperfecti, Dictyosporae. 
Number of species known: Five (all the species have been transferred to Dictyosporites Felix 1894).

Notes: According to Kalgutkar \& Jansonius (2000), Pleosporonites appears to be closely related to Dictyosporites Felix 1894. Different species of Dictyosporites are comparable to modern genera, such as the conidia of Alternaria Nees, Dictyosporium Corda, Septosporium Corda and Stemphylium Wallr. and the ascospores of Pleospora Rabenh. ex Ces. \& De Not.

4.13.1. Species: P. dictyosus Sal.-Cheb. \& Locq. 1980; Index Fungorum Registration Identifier: 108376; Current name: Dictyosporites dictyosus (Sal.-Cheb. \& Locq.) Kalgutkar \& Janson. 2000 fide Kalgutkar \& Jansonius (2000).

4.13.2. Species: P. hyalinus R.T. Lange \& P.H. Sm. 1971; Index Fungorum Registration Identifier: 320665; Current name: Dictyosporites hyalinus (R.T. Lange \& P.H. Sm.) Kalgutkar \& Janson. 2000 fide Kalgutkar \& Jansonius (2000).

4.13.3. Species: P. morularis Sal.-Cheb. \& Locq. 1980; Index Fungorum Registration Identifier: 108377; Current name: Dictyosporites morularis (Sal.-Cheb. \& Locq.) Kalgutkar \& Janson. 2000 fide Kalgutkar \& Jansonius (2000).

4.13.4. Species: P. moruloides Sal.-Cheb. \& Locq. 1980; Index Fungorum Registration Identifier: 108378; Current name: Dictyosporites moruloides (Sal.-Cheb. \& Locq.) Kalgutkar \& Janson. 2000 fide Kalgutkar \& Jansonius (2000).

4.13.5. Species: P. ovoideus Sal.-Cheb. \& Locq. 1980; Index Fungorum Registration Identifier: 108379; Current name: Dictyosporites ovoideus (Sal.-Cheb. \& Locq.) Kalgutkar \& Janson. 2000 fide Kalgutkar \& Jansonius (2000).

4.14. Genus: POLYADOSPORITES Hammen 1954, Boletín Geológico (Bogota) 2(1): 82 (1954); Index Fungorum Registration Identifier: 21256; Type: P. suescae Hammen 1954.

Original Diagnosis: Fungal spores composed of several grains or cells that are united along several axes or in a more or less irregular manner (Van der Hammen 1954).

Emended Diagnosis: Spores (sub) spherical, loosely aggregated in clusters, with individual cells not connected to others by shared walls; clusters (colonies?) more or less regularly spherical to subspherical (Kalgutkar \& Jansonius 2000).

Classification: Fungi Imperfecti, Dictyosporae.

Number of species known: Nine (but we accept only three species as legitimate because six species have been transferred to other genera).

4.14.1. Species: P. conoideus (Sheffy \& Dilcher) V.S. Ediger 1981; Index Fungorum Registration Identifier: 108394; Current name: Staphlosporonites conoideus Sheffy \& Dilcher 1971 fide Kalgutkar \& Jansonius (2000).

4.14.2. Species: P. enormis V.S. Ediger 1981; Index Fungorum Registration Identifier: 108395; Current name: Papulosporonites enormis (V.S. Ediger) Kalgutkar \& Janson. 2000 fide Kalgutkar \& Jansonius (2000).

4.14.3. Species: P. firbasii Hammen 1954; Index Fungorum Registration Identifier: 337454; Current name: Dictyosporites firbasii (Hammen) Kalgutkar \& Janson. 2000 fide Kalgutkar \& Jansonius (2000).

4.14.4. Species: P. garciabarrigae Hammen 1954; Index Fungorum Registration Identifier: 337455; Current name: Dictyosporites garciabarrigae (Hammen) Kalgutkar \& Janson. 2000 fide Kalgutkar \& Jansonius (2000).

4.14.5. Species: P. hammenii Haseld. 1973; Index Fungorum Registration Identifier: 483817; Current name: Papulosporonites hammenii (Haseld.) Kalgutkar \& Janson. 2000 fide Kalgutkar \& Jansonius (2000).

4.14.6. Species: P. nadahensis M.R. Rao \& R. Patnaik 2001 (Fig. 13S); Index Fungorum Registration Identifier: 519784; Location: Nadah, Panchkula, Haryana, India; Age: Late Pliocene (Pinjor Formation). 
4.14.7. Species: P. orbis V.S. Ediger 1981; Index Fungorum Registration Identifier: 108396; Current name: Papulosporonites orbis (V.S. Ediger) Kalgutkar \& Janson. 2000 fide Kalgutkar \& Jansonius (2000).

4.14.8. Species: P. siwalikus M.R. Rao \& R. Patnaik 2001 (Fig. 13T); Index Fungorum Registration Identifier: 519785; Location: Nadah, Panchkula, Haryana, India; Age: Late Pliocene (Pinjor Formation).

4.14.9. Species: P. suescae Hammen 1954 (Fig. 13U); Index Fungorum Registration Identifier: 337456; Location: Magdalena Valley, Eastern Cordillera, Colombia, South America; Age: Maastrichtian.

4.15. Genus: POLYCELLAESPORONITES Anil Chandra et al. 1984, Biovigyanam 10: 49 (1984); Index Fungorum Registration Identifier: 25604; Type: P. bellus Anil Chandra et al. 1984.

Original Diagnosis: Capsular fungal spores; inaperturate; one end of the spore is rounded while the other gives rise to a tube-like projection; multicellate; cells arranged in clusters, and not in a row or along a single axis; spore wall laevigate (Chandra et al. 1984).

Emended Diagnoses: The diagnosis of Polycellaesporonites was emended by Kalgutkar \& Jansonius (2000) and Gupta (2002), as follows: Muriform spores with a hilum, and distally with an elongated, knob-like or beaked, extension; overall structure as that in the modern Alternaria (Kalgutkar \& Jansonius 2000); Capsular spore, one end of the spore gives rise to tube like projection, multicellate, inaperturate, cells arranged in clusters and not in a row or along a single axis, spore wall laevigate to ornamented (Gupta 2002).

Classification: Fungi Imperfecti, Dictyosporae.

Number of species known: Seven.

Notes: Kalgutkar \& Jansonius (2000) opined that the type resembles to Staphlosporonites Sheffy \& Dilcher 1971, but differs in that the elongate projection is distal, rather than being a (proximal) hold-fast or hilum.

4.15.1. Species: P. acuminatus (Rouse \& Mustard) Kalgutkar \& Janson. 2000; Index Fungorum Registration Identifier: 483526; Basionym: Multicellaesporites acuminatus Rouse \& Mustard 1997; Synonym: Piriurella acuminata (Rouse \& Mustard) M.G. Parsons \& G. Norris 1999 fide Kalgutkar \& Jansonius (2000); Location: Strait of Georgia, eastern Vancouver Island, the Fraser River lowlands of southwest British Columbia, Canada and the North-western Washington State, U.S.A.; Age: Late Palaeocene.

4.15.2. Species: P. alternariatus (Kalgutkar \& Sigler) Kalgutkar \& Janson. 2000 (Fig. 13V); Index Fungorum Registration Identifier: 483527; Basionym: Piriurella alternariata Kalgutkar \& Sigler 1995; Location: Kanguk Peninsula, Axel Heiberg Island, Northwest Territories, Canada; Age: Late Palaeocene or Early Eocene (Iceberg Bay Formation).

4.15.3. Species: P. bellus Anil Chandra et al. 1984 (Fig. 13W); Index Fungorum Registration

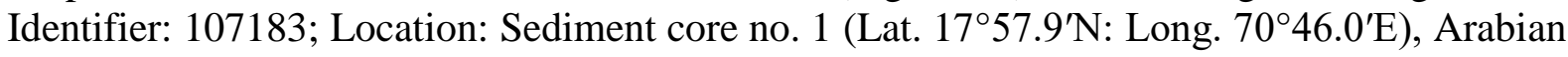
Sea; Age: Late Quaternary; Notes: Chandra et al. (1984) suggested possible affinity of this species to Alternaria sp.

4.15.4. Species: P. clavellatus (Z.C. Song \& G.X. Li in Z.C. Song et al.) Kalgutkar \& Janson. 2000; Index Fungorum Registration Identifier: 483528; Basionym: Pluricellaesporites clavellatus Z.C. Song \& G.X. Li in Z.C. Song et al. 1989; Location: Heze County and Shenxian County of Shandong Province, China; Age: Middle-Late Oligocene (Shahejie and Dongying formations).

4.15.5. Species: P. psilatus A. Gupta 2002 (Fig. 13X); Index Fungorum Registration Identifier: 540760; Location: Dadahu Road Section, Sirmaur District, Himachal Pradesh, India; Age: Eocene (Subathu Formation).

4.15.6. Species: P. saxenae A. Gupta 2002 (Fig. 13Y); Index Fungorum Registration Identifier: 540761; Location: Jamtah Road Section, Sirmaur District, Himachal Pradesh, India; Age: Eocene (Subathu Formation); Notes: The species epithet honours Dr. Ramesh K. Saxena, Birbal Sahni Institute of Palaeosciences, Lucknow, India. 
4.15.7. Species: P. sirmaurensis A. Gupta 2002 (Fig. 13Z); Index Fungorum Registration Identifier: 540762; Location: Dadahu Road Section, Sirmaur District, Himachal Pradesh, India; Age: Eocene (Subathu Formation).

4.16. Genus: RAVENELITES Ramanujam \& Ramachar, Records of the Geological Survey of India 113(5): 83 (1980); Index Fungorum Registration Identifier: 28630; Type: $R$. tirumalacharii Ramanujam \& Ramachar 1980; Current name: DICTYOSPORITES Felix 1894 fide Kalgutkar \& Jansonius (2000).

Original Diagnosis: Teliospores one-celled but strongly adherent, forming discoid heads. Number of spores in each telial head variable; outer walls of peripheral cells (spores) of each head smooth or ornamented; wall pigmented; one germ pore in each cell (spore) of discoid head (Ramanujam \& Ramachar 1980).

Classification: Fungi Imperfecti, Dictyosporae.

Number of species known: One (the single species has been transferred to Dictyosporites Felix 1894).

Notes: Kalgutkar \& Jansonius (2000) considered this genus as a later synonym of Dictyosporites Felix 1894.

4.16.1. Species: R. tirumalacharii Ramanujam \& Ramachar 1980; Index Fungorum Registration Identifier: 483759; Current name: Dictyosporites tirumalacharii (Ramanujam \& Ramachar) Kalgutkar \& Janson. 2000 fide Kalgutkar \& Jansonius (2000).

4.17. Genus: STAPHLOSPORONITES Sheffy \& Dilcher 1971, Palaeontographica Abt. B 133 (13): 48 (1971); Index Fungorum Registration Identifier: 21316; Type: S. conoideus Sheffy \& Dilcher 1971.

Synonym: Transeptaesporites V.S. Ediger 1981 fide Kalgutkar \& Jansonius (2000), Index Fungorum Registration Identifier: 25599.

Original Diagnosis: Inaperturate, psilate to punctuate fungal or algal bodies of four or more irregular cells. Cells in clusters, shape variable along more than one axis (Sheffy \& Dilcher 1971).

Emended Diagnosis: Inaperturate multicellate fungal spores, with muriform architecture (cells internally dividing without a regular pattern), lacking a plane or axis of symmetry. Cells rounded or rounded polygonal, septa may be depressed where they intersect the amb. Overall shape generally more or less elongate; sometimes oval to ellipsoidal, rarely subspherical. Always with a distinct proximal hold-fast cell and/or a hilar scar (Kalgutkar \& Jansonius 2000).

Classification: Fungi Imperfecti, Dictyosporae.

Number of species known: 23 (but we accept only 18 species as legitimate because five species have been transferred to other genera).

Notes: Presence of a hilate scar differentiates this genus from Dictyosporites.

4.17.1. Species: S. allomorphus Sheffy \& Dilcher 1971; Index Fungorum Registration Identifier: 111945; Location: Puryear clay pit, $800 \mathrm{~m}$ south of Puryear, Henry County, Tennessee, U.S.A.; Age: Middle Eocene (Claiborne Formation); Notes: The specific name refers to the strange shape of the spore. According to Kalgutkar \& Jansonius (2000), the narrow end appears to be hilate, possibly with a hyphal fragment attached.

4.17.2. Species: S. billelsikii Kalgutkar \& Janson. 2000; Index Fungorum Registration Identifier: 483554; Basionym: Dictyosporites elsikii Kalgutkar 1993; Location: Peel River, Yukon Territory, Canada; Age: Late Palaeocene-Early Eocene; Notes: The species epithet honours Dr. William C. Elsik.

4.17.3. Species: S. chandrae A. Gupta 2002 (Fig. 13AA); Index Fungorum Registration Identifier: 540809; Location: Jamtah Road Section, Sirmaur District, Himachal Pradesh, India; Age: Eocene (Subathu Formation); Notes: The species epithet is in honours of Dr. Anil Chandra, Birbal Sahni Institute of Palaeosciences, Lucknow, India. 
4.17.4. Species: S. conoideus Sheffy \& Dilcher 1971 (Fig. 13AB); Index Fungorum Registration Identifier: 111946; Location: Puryear clay pit, $800 \mathrm{~m}$ south of Puryear, Henry County, Tennessee, U.S.A.; Age: Middle Eocene (Claiborne Formation).

4.17.5. Species: S. delumbus Norris 1986; Index Fungorum Registration Identifier: 126577; Location: Imperial Nuktak C-22 Well. Mackenzie Delta Region, District of Mackenzie, Northwest Territories, Canada; Age: Eocene to Oligocene.

4.17.6. Species: S. dichotomus A. Gupta 2002 (Fig. 13AC); Index Fungorum Registration Identifier: 540810; Location: Jamtah Road Section, Sirmaur District, Himachal Pradesh, India; Age: Eocene (Subathu Formation).

4.17.7. Species: S. discitypicus P. Ke \& Z.Y. Shi 1978; Index Fungorum Registration Identifier: 115634; Location: Panshan, Liaoning Province, Coastal region of Bohai, China; Age: Eocene-Oligocene.

4.17.8. Species: S. elongatus A. Gupta 2002 (Fig. 13AD); Index Fungorum Registration Identifier: 540811; Location: Jamtah Road Section, Sirmaur District, Himachal Pradesh, India; Age: Eocene (Subathu Formation).

4.17.9. Species: S. elsikii Ramanujam \& Srisailam 1980 (Fig. 13AE); Index Fungorum Registration Identifier: 109551; Location: Kannur Beach area, Palayangadi and Cheruvattur (southern side of Karingottu River), Kerala, India; Age: Miocene; Notes: Kumar (1990) transferred this species to Multicellaesporites, as Multicellaesporites elsikii (Ramanujam \& Srisailam) Kumar 1990. However, Kalgutkar \& Jansonius (2000) did not accept this transfer.

4.17.10. Species: S. felixii (R.T. Lange \& P.H. Sm.) Kalgutkar \& Janson. 2000; Index Fungorum Registration Identifier: 282643; Basionym: Dictyosporites felixii R.T. Lange \& P.H. Sm. 1971; Location: Maslin Bay, South Australia; Age: Early-Middle Eocene.

4.17.11. Species: S. irregularis (V.S. Ediger) Kalgutkar \& Janson. 2000; Index Fungorum Registration Identifier: 483556; Basionym: Transeptaesporites irregularis V.S. Ediger 1981; Location: Thrace Basin, Turkey; Age: Upper Eocene-Oligocene, Miocene-Pliocene; Notes: Ediger (1981) suggested possible affinity of this species to Alternaria sp.

4.17.12. Species: S. laetevirens K.F. Wang \& Y.L. Zhang 1986; Index Fungorum Registration Identifier: 637506; Location: China; Notes: This species was cited in Song et al. (1999). Since its bibliographic details were not included in the list of references of Song et al. (1999), it is difficult to verify whether this species was validly published. Kalgutkar \& Jansonius (2000) opined that it is similar to Staphlosporonites irregularis (Ediger) Kalgutkar \& Janson. 2000.

4.17.13. Species: S. lanceolatus K.F. Wang \& Y.L. Zhang 1986; Index Fungorum Registration Identifier: 637507; Location: China; Notes: This species was cited in Song et al. (1999). Since its bibliographic details were not included in the list of references of Song et al. (1999), it is difficult to verify whether this species was validly published. Kalgutkar \& Jansonius (2000) opined that it is similar to Staphlosporonites allomorphus Sheffy \& Dilcher 1971.

4.17.14. Species: S. multicellatus R.K. Saxena \& H.P. Singh 1983; Index Fungorum Registration Identifier: 485255; Current name: Papulosporonites multicellatus (R.K. Saxena \& H.P. Singh) Kalgutkar \& Janson. 2000 fide Kalgutkar \& Jansonius (2000).

4.17.15. Species: S. neyveliensis Ambwani 1983 (Fig. 13AF); Index Fungorum Registration Identifier: 107315; Location: Neyveli Lignite Mine, Cuddalore District, Tamil Nadu, India; Age: Late Miocene or Pliocene; Notes: According to Ambwani (1983), this species appears similar to the spore type illustrated by Graham (1962) as Alternaria but differs in having larger number of cells and considerably bigger size.

4.17.16. Species: S. ovalis Sheffy \& Dilcher 1971; Index Fungorum Registration Identifier: 111947; Current name: Dictyosporites ovalis (Sheffy \& Dilcher) Kalgutkar \& Janson. 2000 fide Kalgutkar \& Jansonius (2000).

4.17.17. Species: S. pachycellularis (Sal.-Cheb. \& Locq.) Kalgutkar \& Janson. 2000; Index Fungorum Registration Identifier: 637508; Basionym: Dictyosporites pachycellularis Sal.- 
Cheb. \& Locq. 1980; Location: Coast of Equatorial Africa, Gulf of Guinea, Cameroon, Africa; Age: Oligocene.
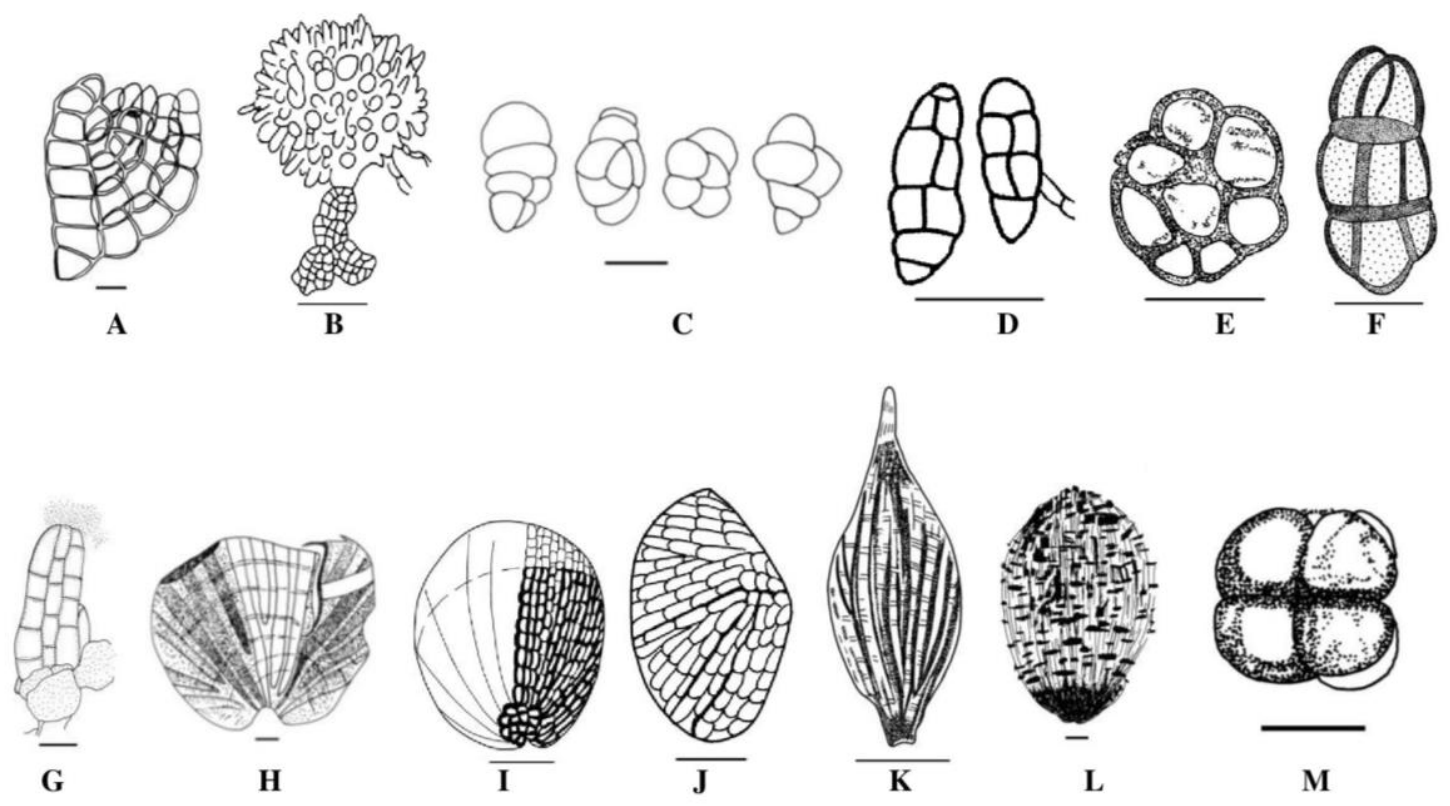

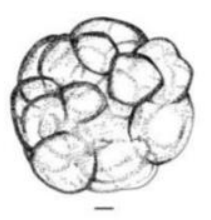

$\mathbf{N}$

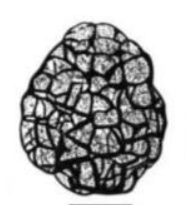

o
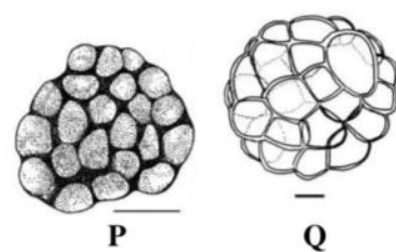

Q
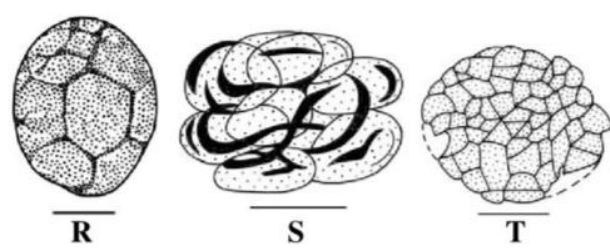

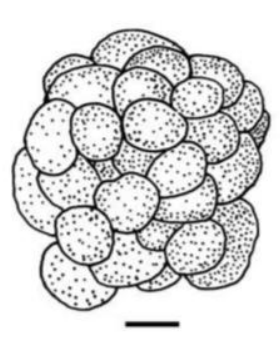

$\mathbf{U}$

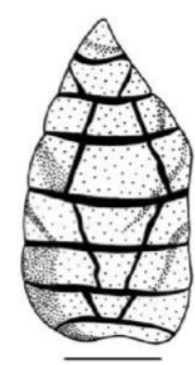

V

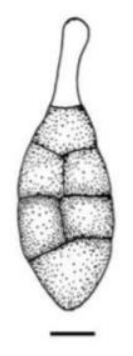

W
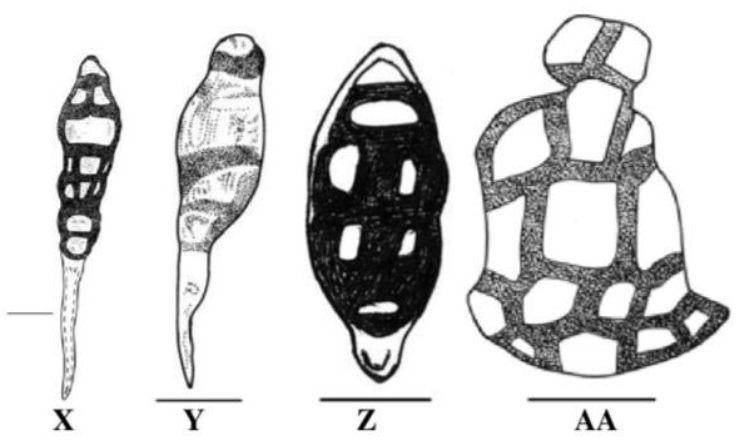

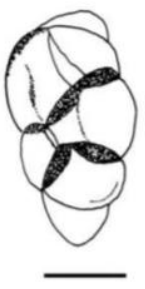

$\mathbf{A B}$
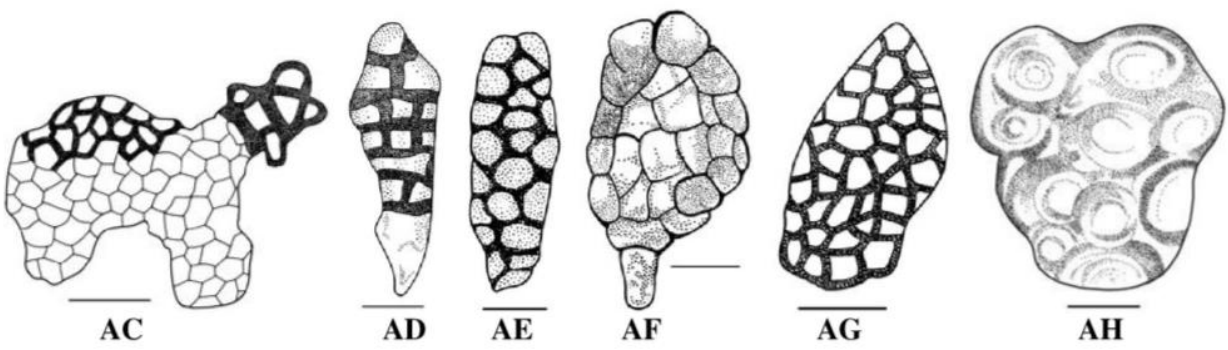

Figure 13 - A-AH Dictyosporae.A Ctenosporites eskerensis Elsik \& Janson. 1974, Bar $=5 \mu \mathrm{m}$. B Dictyosporites dicotylophylli (Paradkar) Kalgutkar \& Janson. 2000, Bar $=20 \mu \mathrm{m}$. C Dictyosporites loculatus Félix 1894, Bar $=5 \mu \mathrm{m}$. D Dictyosporites paradkariae Kalgutkar \& Janson. 2000, Bar $=$ $20 \mu \mathrm{m}$. E Dictyosporites tirumalacharii (Ramanujam \& Ramachar) Kalgutkar \& Janson. 2000, Bar $=20 \mu \mathrm{m}$. F Dictyosporites tristratosus (Sheffy \& Dilcher) Kalgutkar \& Janson. 2000, Bar $=5 \mu \mathrm{m}$. G Dictyosporiuminites intermedius Debi Mukh. 2012, Bar $=20 \mu \mathrm{m}$. H Kutchiathyrites eccentricus R.K. Kar 1979, Bar $=10 \mu$ m. I Kutchiathyrites mehrotrae R.K. Saxena \& S.K.M. Tripathi 2011, 
Bar $=40 \mu \mathrm{m}$. J Kutchiathyrites perfectus (R. Kar et al.) R.K. Saxena \& S.K.M. Tripathi 2011, Bar $=$ $10 \mu \mathrm{m}$. K Lirasporis elongatus R.K. Kar 2012, Bar $=10 \mu \mathrm{m}$. L Lirasporis intergranifer R. Potonié \& S.C.D. Sah 1960, Bar $=12 \mu \mathrm{m}$. M Octosporites stauroides Sal.-Cheb. \& Locq. 1980, Bar $=12$ $\mu \mathrm{m}$. N Palambages morulosa Wetzel 1961, Bar $=12 \mu \mathrm{m}$. O Papulosporonites multicellatus (R.K. Saxena \& H.P. Singh) Kalgutkar \& Janson. 2000, Bar $=20 \mu \mathrm{m}$. P Papulosporonites siwalikus (R.K. Saxena \& A.P. Bhattach.) Kalgutkar \& Janson. 2000, Bar $=20 \mu \mathrm{m}$. Q Papulosporonites sphaeromorphus Schmied. \& A. J. Schwab 1964, Bar $=10 \mu \mathrm{m}$. R Papulosporonites subcircularis (Anil Chandra et al.) Kalgutkar \& Janson. 2000, Bar $=10 \mu \mathrm{m}$. S Polyadosporites nadahensis M.R. Rao \& R. Patnaik 2001, Bar $=40 \mu \mathrm{m}$. T Polyadosporites siwalikus M.R. Rao \& R. Patnaik 2001, Bar $=10 \mu \mathrm{m}$. U Polyadosporites suescae Hammen 1954, Bar $=10 \mu \mathrm{m}$. V Polycellaesporonites alternariatus (Kalgutkar \& Sigler) Kalgutkar \& Janson. 2000, Bar $=15 \mu \mathrm{m}$. W Polycellaesporonites bellus Anil Chandra et al. 1984, Bar $=10 \mu \mathrm{m}$. X Polycellaesporonites psilatus A. Gupta 2002, Bar $=10 \mu \mathrm{m}$. Y Polycellaesporonites saxenae A. Gupta 2002, Bar $=5 \mu \mathrm{m} . \mathrm{Z}$ Polycellaesporonites sirmaurensis A. Gupta 2002, Bar $=15 \mu \mathrm{m}$. AA Staphlosporonites chandrae A. Gupta 2002, Bar $=20 \mu \mathrm{m}$. AB Staphlosporonites conoideus Sheffy \& Dilcher 1971, Bar $=8 \mu \mathrm{m}$. AC Staphlosporonites dichotomus A. Gupta 2002, Bar $=20 \mu \mathrm{m}$. AD Staphlosporonites elongatus A. Gupta 2002, Bar $=8 \mu \mathrm{m}$. AE Staphlosporonites elsikii Ramanujam \& Srisailam 1980, Bar $=10$ $\mu \mathrm{m}$. AF Staphlosporonites neyveliensis Ambwani 1983, Bar $=20 \mu \mathrm{m}$. AG Staphlosporonites raoi A. Gupta 2002, Bar $=10 \mu \mathrm{m}$. AH Staphlosporonites settyi A. Gupta 2002, Bar $=10 \mu \mathrm{m}$.

4.17.18. Species: S. raoi A. Gupta 2002 (Fig. 13AG); Index Fungorum Registration Identifier: 540812; Location: Jamtah Road Section, Sirmaur District, Himachal Pradesh, India; Age: ?Eocene (Dagshai Formation).

4.17.19. Species: S. settyi A. Gupta 2002 (Fig. 13AH); Index Fungorum Registration Identifier: 540813; Location: Jamtah Road Section, Sirmaur District, Himachal Pradesh, India; Age: Eocene (Subathu Formation).

4.17.20. Species: S. siwalikus R.K. Saxena \& A.P. Bhattach. 1987; Index Fungorum Registration Identifier: 483890; Current name: Papulosporonites siwalikus (R.K. Saxena \& A.P. Bhattach.) Kalgutkar \& Janson. 2000 fide Kalgutkar \& Jansonius (2000).

4.17.21. Species: S. subcircularis Anil Chandra et al. 1984; Index Fungorum Registration Identifier: 107316; Current name: Papulosporonites subcircularis (Anil Chandra et al.) Kalgutkar \& Janson. 2000 fide Kalgutkar \& Jansonius (2000).

4.17.22. Species: S. tetracellatus A. Gupta 2002 (Fig. 14A); Index Fungorum Registration Identifier: 540814; Location: Jamtah Road Section, Sirmaur District, Himachal Pradesh, India; Age: Eocene (Subathu Formation).

4.17.23. Species: S. tristratosus Sheffy \& Dilcher 1971; Index Fungorum Registration Identifier: 111948; Current name: Dictyosporites tristratosus (Sheffy \& Dilcher) Kalgutkar \& Janson. 2000 fide Kalgutkar \& Jansonius (2000).

4.18. Genus: TRANSEPTAESPORITES V.S. Ediger 1981; Index Fungorum Registration Identifier: 25599; Type: T. irregularis V.S. Ediger 1981; Current name: STAPHLOSPORONITES Sheffy \& Dilcher 1971 fide Kalgutkar \& Jansonius (2000).

Original Diagnosis: Fungal spores of five or more cells, four or more septa; shape is oval to irregularly elongated; septa thicker than exine, imperforate, at least one of them transverse to the others; individual cells variable in shape and size, usually rounded, lighter, a weak area is always present at the middle of the cells, cells are light coloured to hyaline (Ediger 1981).

Classification: Fungi Imperfecti, Dictyosporae.

Number of species known: Five (all the species have been transferred to other genera).

Notes: According to Ediger (1981), these fossil fungal spores resemble the conidia of the modern Alternaria, however, the new genus is proposed because of inadequate knowledge about the relationship between the fossil and modern genera. Kalgutkar \& Jansonius (2000) opined that the illustrated specimens assigned to Transeptaesporites irregularis by Ediger (1981) appear so 
variable that they may not all be conspecific. Ediger (1981) cited Staphlosporonites as a synonym of the new Transeptaesporites, but transferred its type species $S$. conoideus to Polyadosporites. Jansonius \& Hills (1982) argued that Ediger (1981) did not provide bibliographic reference of basionyms in sufficient detail to validly publish the new combinations. Three other species of Staphlosporonites, named by Sheffy \& Dilcher (1971), were also invalidly transferred to Transeptaesporites by Ediger (1981).

4.18.1. Species: T. allomorphus (Sheffy \& Dilcher) V.S. Ediger 1981; Index Fungorum Registration Identifier: 107699; Current name: Staphlosporonites allomorphus Sheffy \& Dilcher 1971 fide Kalgutkar \& Jansonius (2000).

4.18.2. Species: T. irregularis V.S. Ediger 1981; Index Fungorum Registration Identifier: 108586; Current name: Staphlosporonites irregularis (V.S. Ediger) Kalgutkar \& Janson. 2000 fide Kalgutkar \& Jansonius (2000).

4.18.3. Species: T. ovalis (Sheffy \& Dilcher) V.S. Ediger 1981; Index Fungorum Registration Identifier: 108587; Current name: Dictyosporites ovalis (Sheffy \& Dilcher) Kalgutkar \& Janson. 2000 fide Kalgutkar \& Jansonius (2000).

4.18.4. Species: T. symmetricus V.S. Ediger 1981; Index Fungorum Registration Identifier: 108588; Current name: Dictyosporites symmetricus (V.S. Ediger) Kalgutkar \& Janson. 2000 fide Kalgutkar \& Jansonius (2000).

4.18.5. Species: T. tristratosus (Sheffy \& Dilcher) V.S. Ediger 1981; Index Fungorum Registration Identifier: 108589; Current name: Dictyosporites tristratosus (Sheffy \& Dilcher) Kalgutkar \& Janson. 2000 fide Kalgutkar \& Jansonius (2000).

\section{Helicosporae}

5.1. Genus: COLLIGERITES K.P. Jain \& R.K. Kar, Palaeobotanist 26(2): 110 (1979); Index Fungorum Registration Identifier: 21058; Type: C. kutchensis (R.K. Kar \& R.K. Saxena) K.P. Jain \& R.K. Kar 1979.

Original Diagnosis: Spores multicellular, coiled, cells generally smaller, rounded in central region and bigger, rectangular in outer region. Spore wall mostly laevigate, sometimes granulose. Pore may be present or absent in each cell (Jain \& Kar 1979).

Classification: Fungi Imperfecti, Helicosporae.

Number of species known: Three (but we accept only two species as legitimate because one species, C. chowdhryi K.P. Jain \& R.K. Kar 1979, has been transferred to Involutisporonites R.T. Clarke 1965).

5.1.1. Species: C. chowdhryi K.P. Jain \& R.K. Kar 1979; Index Fungorum Registration Identifier: 112034; Current name: Involutisporonites chowdhryi (K.P. Jain \& R.K. Kar) Kalgutkar \& Janson. 2000 fide Kalgutkar \& Jansonius (2000).

5.1.2. Species: C. kutchensis (R.K. Kar \& R.K. Saxena) K.P. Jain \& R.K. Kar 1979 (Fig. 14B); Index Fungorum Registration Identifier: 112205; Basionym: Involutisporonites kutchensis R.K. Kar \& R.K. Saxena 1976; Location: Bhuj-Lakhpat Road, Matanomadh Village, Kutch District, Gujarat, India (Kar \& Saxena 1976); Papanasam and Varkala, Kerala, India (Jain \& Kar 1979); Age: Palaeocene (Kar \& Saxena 1976); Miocene (Jain \& Kar 1979).

5.1.3. Species: C. trochus B. Samant in R.K. Saxena 2009 (Fig. 14C); Index Fungorum Registration Identifier: 515017; Synonym: Colligerites trochus B. Samant 2000 (nom. inval.) fide Saxena (2009).; Location: Near Bhavnagar, Cambay Basin, Gujarat, India; Age: Early Eocene (Kharsalia Clay Formation).

5.2. Genus: ELSIKISPORONITES P. Kumar, Review of Palaeobotany \& Palynology (Amsterdam) 63(1-2): 18 (1990); Index Fungorum Registration Identifier: 25441; Type: $\boldsymbol{E}$. tubulatus Kumar 1990.

Original Diagnosis: Fungal spores monoporate, aseptate, tubular and coiled. Pore at outer end, nozzle-like. Spore wall smooth and pale (Kumar 1990). 
Classification: Fungi Imperfecti, Helicosporae.

Number of species known: One.

Notes: The generic name honours Dr. William C. Elsik.

5.2.1. Species: E. tubulatus P. Kumar 1990 (Fig. 14D); Index Fungorum Registration Identifier: 126558; Location: Padappakkara, Kollam District, Kerala, India; Age: Early-Middle Miocene.

5.3. Genus: HELICOMINITES Barlinge \& Paradkar, Botanique, Nagpur 10(1-4): 167 (1982); Index Fungorum Registration Identifier: 21126; Type: H. salvinites Barlinge \& Paradkar 1982.

Original Diagnosis: Fungus saprophytic [saprobic]; mycelium septate, branched, hyphae faint in colour; pycnidium and acervulus absent; conidia coiled in loose spirals and narrow at both ends (Barlinge \& Paradkar 1982).

Classification: Fungi Imperfecti, Helicosporae.

Number of species known: One.

5.3.1. Species: H. salvinites Barlinge \& Paradkar 1982 (Fig. 14E); Index Fungorum Registration Identifier: 108905; Location: Mohgaon Kalan, Chhindwara District, Madhya Pradesh, India; Age: Cretaceous - Maastrichtian (Deccan Intertrappean Series).

5.4. Genus: HELICOONITES Kalgutkar \& Sigler (as 'Helicoönites'), Mycol. Res. 99(5): 519 (1995); Index Fungorum Registration Identifier: 622357; Type: H. goosii Kalgutkar \& Sigler 1995

Original Diagnosis: Conidia simple, tightly coiled or twisted in three planes to form an ovoid, ellipsoidal (doliiform) to cylindrical or beehive to barrel-shaped spiral; spirals made up of variable numbers of ascending coils or gyres, with each successive gyre usually of smaller diameter; filaments multiseptate, fuscous; cells rectangular (Kalgutkar \& Sigler 1995).

Classification: Fungi Imperfecti, Helicosporae.

Number of species known: One.

5.4.1. Species: H. goosii Kalgutkar \& Sigler 1995 (Fig. 14F); Index Fungorum Registration Identifier: 627571; Location: Strand Fiord, Axel Heiberg Island, Northwest Territories, Canada; Age: Early Eocene (Iceberg Bay Formation); Notes: According to Kalgutkar \& Sigler (1995), Helicoonites goosii appears more closely allied to species of Helicoon (Goos et al. 1986) such as H. richonis than to species of Helicodendron (Goos et al. 1985). The species epithet honours Dr. R.D. Goos.

5.5. Genus: HELICOSPORIATES Kalgutkar \& Sigler, Mycol. Res. 99(5): 520 (1995); Index Fungorum Registration Identifier: 15012; Type: H. pirozynskii Kalgutkar \& Sigler 1995.

Original Diagnosis: Conidia simple, pale brown to brown, helicoid; spirals of loose to tightly coiled filaments; filaments slender, multicellular. Conidia usually helically coiled in one plane or somewhat cochleate (Kalgutkar \& Sigler 1995).

Classification: Fungi Imperfecti, Helicosporae.

Number of species known: One.

5.5.1. Species: H. pirozynskii Kalgutkar \& Sigler 1995 (Fig. 14G); Index Fungorum Registration Identifier: 413166; Location: Strand Fiord, Axel Heiberg Island, Northwest Territories, Canada; Age: Early Eocene (Iceberg Bay Formation); Notes: The species epithet honours Dr. Kris A. Pirozynski.

5.6. Genus: INVOLUTISPORONITES R.T. Clarke, Mountain Geologist 2(2): 90 (1965); Index Fungorum Registration Identifier: 21142; Type: I. foraminus R.T. Clarke 1965.

Original Diagnosis: Fungal spores planispiral, individual cells lobate, septa simple with an opening through each septum (Clarke 1965).

Emended Diagnosis: Monoporate, psilate, multiseptate, coiled fungal spores (Elsik 1968).

Classification: Fungi Imperfecti, Helicosporae. 
Number of species known: Eight (but we accept only four species as legitimate because four species have been transferred to other genera).

Notes: Clarke (1965) named the genus in reference to the involute arrangement of the cells.

5.6.1. Species: I. chowdhryi (K.P. Jain \& R.K. Kar) Kalgutkar \& Janson. 2000 (Fig. 14H); Index Fungorum Registration Identifier: 483410; Basionym: Colligerites chowdhryi K.P. Jain \& R.K. Kar 1979; Location: Papanasam and Varkala, Kerala, India; Age: Miocene; Notes: Jain \& Kar (1979) opined that Colligerites chowdhryi resembles closely the spores of Helicominopsis fici (illustrated by Subramanian 1971). The spores of Helicomina caperoniae are also helicoid but the coilings are not as prominent as in the present species. The species epithet honours Dr. Harsh Chowdhry.

5.6.2. Species: I. crassus Z.C. Song \& Liu Cao 1994; Index Fungorum Registration Identifier: 483775; Location: Antarctica; Age: Late Cretaceous.

5.6.3. Species: I. foraminus R.T. Clarke 1965 (Fig. 14I); Index Fungorum Registration Identifier: 332602; Location: Canon City coal field, Fremont County, Colorado, U.S.A.; Age: Late Cretaceous; Notes: The species epithet refers to the resemblance of the species to planispiral foraminifera.

5.6.4. Species: I. kutchensis R.K. Kar \& R.K. Saxena 1976; Index Fungorum Registration Identifier: 112379; Current name: Colligerites kutchensis (R.K. Kar \& R.K. Saxena) Jain \& Kar 1979 fide Jain \& Kar (1979).

5.6.5. Species: I. minutus Rouse \& Mustard 1997; Index Fungorum Registration Identifier: 463995; Current name: Palaeoslimacomyces minutus (Rouse \& Mustard) Kalgutkar \& Janson. 2000 fide Kalgutkar \& Jansonius (2000).

5.6.6. Species: I. putus P. Ke \& Z.Y. 1978; Index Fungorum Registration Identifier: 115668; Current name: Paragranatisporites putus (P. Ke \& Z.Y. Shi) Kalgutkar \& Janson. 2000 fide Kalgutkar \& Jansonius (2000).

5.6.7. Species: I. trapezoides Kalgutkar 1993; Index Fungorum Registration Identifier: 483881; Location: Peel River, Yukon Territory, Canada; Age: Late Palaeocene-Early Eocene; Notes: The species epithet is derived from the Latin, trapezoideus, irregularly four-sided.

5.6.8. Species: I. wilcoxii Elsik 1968; Index Fungorum Registration Identifier: 315918; Current name: Paleoslimacomyces wilcoxii (Elsik) Kalgutkar \& Janson. 2000 fide Kalgutkar \& Jansonius (2000).

5.7. Genus: PALAEOCIRRENALIA Ramanujam \& Srisailam, Botanique, Nagpur 9(1-4): 124 (1980); Index Fungorum Registration Identifier: 21205; Type: P elegans Ramanujam \& Srisailam 1980.

Original Diagnosis: Spores light brown to reddish brown, inaperturate, helicoid, 1 to $11 / 4$ times loosely coiled, multicellular, 2- to 6-septate, septa transverse, prominent, as thick and dark bands, cells of unequal size, terminal cell dome-shaped and broader, basal cell usually cuneate, pale-coloured, surface psilate (Ramanujam \& Srisailam 1980).

Classification: Fungi Imperfecti, Helicosporae.

Number of species known: Two

Notes: Ramanujam \& Srisailam (1980) stated that "In their loosely coiled 2- to 6-septate nature with the terminal cell dome-shaped, these spores are remarkably similar to the conidia of the modern dematiaceous hyphomycete Cirrenalia (Ellis 1976). The species of Cirrenalia are characteristic of brackish to marine habitats and hence are environmentally significant. They are generally found on driftwood. No information is available with regard to the nature of the conidiophores of the fossil specimens, i.e. whether they are simple or branched." Kalgutkar \& Jansonius (2000) opined that the characteristics of a more than hemispherical to globular dark distal cell, the curved longitudinal axis, and an indistinct proximal hilum, define this genus.

5.7.1. Species: P. elegans Ramanujam \& Srisailam 1980 (Fig. 14J); Index Fungorum Registration Identifier: 109520; Location: Kannur Beach area, Palayangadi and Cheruvattur (southern side of Karingottu River), Kerala, India; Age: Miocene; Notes: According to Ramanujam \& 
Srisailam (1980), these spores exhibit remarkable similarity with the conidia of Cirrenalia macrocephala (Kohlm.) Meyers \& R.T. Moore 1960 (Ellis 1976).

5.7.2. Species: P. oligoseptata Ramanujam \& Srisailam 1980 (Fig. 14K); Index Fungorum Registration Identifier: 109521; Location: Kannur Beach area, Palayangadi and Cheruvattur (southern side of Karingottu River), Kerala, India; Age: Miocene.

5.8. Genus: PALEOSLIMACOMYCES Kalgutkar \& Sigler, Mycol. Res. 99(5): 521 (1995); Index Fungorum Registration Identifier: 27617; Type: P. canadensis Kalgutkar \& Sigler 1995.

Original Diagnosis: Conidia simple, solitary, helicoid, curved to hemi-circinate, brown to fuscous, smooth. Conidia 2-3-septate; septa dark, often thick; conidial filaments short, made up of 3-4 broadly curved cells; cells, except the apical cell, darkly-pigmented; apical cell hyaline to pale brown (Kalgutkar \& Sigler 1995).

Classification: Fungi Imperfecti, Helicosporae.

Number of species known: Three.

Notes: According to Kalgutkar \& Sigler (1995), conidia of Paleoslimacomyces show some similarity to the conidia of extant Slimacomyces monospora (W.B. Kendr.) Minter, which was originally described by Kendrick (1958) in Helicoma Corda.

5.8.1. Species: P. canadensis Kalgutkar \& Sigler 1995 (Fig. 14L); Index Fungorum Registration Identifier: 413657; Location: Kanguk Peninsula, Axel Heiberg Island, Northwest Territories, Canada; Age: Late Palaeocene or Early Eocene (Iceberg Bay Formation); Notes: The species epithet is derived from the place of its occurrence in Canada.

5.8.2. Species: P. minutus (Rouse \& Mustard) Kalgutkar \& Janson. 2000; Index Fungorum Registration Identifier: 483499; Basionym: Involutisporonites minutus Rouse \& Mustard 1997; Location: Strait of Georgia, eastern Vancouver Island, the Fraser River lowlands of southwest British Columbia, Canada, and the North-western Washington State, U.S.A.; Age: Late Palaeocene.

5.8.3. Species: P. wilcoxii (Elsik) Kalgutkar \& Janson. 2000 (Fig. 14M); Index Fungorum Registration Identifier: 483500; Basionym: Involutisporonites wilcoxii Elsik 1968; Location: Strip mine approximately $11 \mathrm{~km}$ southwest of Rockdale, Milam County, Texas, U.S.A.; Age: Palaeocene.

5.9. Genus: RETIHELICOSPORONITES Ramanujam \& K.P. Rao, Proc. IV International Palynology Conference, Lucknow 1976-1977 1: 3 (1978); Index Fungorum Registration Identifier: 21281; Type: R. elsikii Ramanujam \& K.P. Rao 1978.

Original Diagnosis: Spores simple, uniseriate, multicellular, inaperturate, basal cell cuneate, other cells rectangular; apical part of spore helical. Spore wall reticulate (Ramanujam \& Rao 1978).

Classification: Fungi Imperfecti, Helicosporae.

Number of species known: One.

Notes: Ramanujam \& Rao (1978) opined that Involutisporonites Elsik 1968, although multiseptate and helical, is distinguishable by its monoporate and psilate nature. Helical spores (conidia) are found in various genera of Hyphomycetes, viz. Helicoma, Helicomina, Helicoon, Helicodendron, Hiospira and Xenosporella (Barnett 1956, Ellis 1971, Ainsworth et al. 1973). In possessing a reticulate cell wall, the fossil spores show remarkable resemblance to the conidia of the Hiospira state of Brooksia tropicalis. Hiospira is commonly encountered in moist tropical regions. Elsik (1992) considered spores of Retihelicosporonites to be monoporate and differentiated them from other multicellate monoporate form genera on their combination of reticulate sculpture and their tendency to be loosely coiled.

5.9.1. Species: R. elsikii Ramanujam \& K.P. Rao 1979 (Fig. 14N); Index Fungorum Registration Identifier: 115089; Location: Alleppey, Alappuzha District, Kerala, India, locality: Age: Miocene (Quilon and Warkalli beds); Notes: The species epithet honours of Dr. William C. Elsik. 


\section{Staurosporae}

6.1. Genus: EOGLOBELLA W.H. Bradley, U.S. Geological Survey Professional Paper 168: 1-58 (1931); Index Fungorum Registration Identifier: 637509; Type: E. longipes W.H. Bradley 1931.

Original Diagnosis: Thallus of definite shape, radially symmetrical, consisting of a single spherical cell to which are attached four equally spaced, greatly elongated, cylindrical appendages. These are apparently single cells that are enlarged and flattened where they join the globular cell and tapered to a rather blunt conical point at the distal end. They arise from the globular cell a little below the equator and diverge slightly downward. The globular cell is about $38 \mu \mathrm{m}$ in diameter; the appendages are about $6 \mu \mathrm{m}$ in diameter and range in length from 115 to about $145 \mu \mathrm{m}$. The characters of the genus will also serve to define the species (Bradley 1931).

Classification: Fungi Imperfecti, Staurosporae.

Number of species known: One.

Notes: According to Kalgutkar \& Jansonius (2000), Eoglobella has four appendices that grow from one corner or side whereas Tribolites W.H. Bradley 1964 has four (or three) well developed filaments, each coming from opposite corners (and one of which, according to Bradley (1931), tends to be truncated, and possibly served as an attachment). Frasnacritetrus is similar to Eoglobella, but is larger, and lacks a distinct hilate scar.

6.1.1. Species: E. longipes W.H. Bradley 1931 (Fig. 14O); Index Fungorum Registration Identifier: 637510; Location: Garfield County, Colorado, U.S.A.; Age: Middle Eocene.

6.2. Genus: FRASNACRITETRUS Taug., Cahiers de Micropaléontologie 10: 3 (1968); Index Fungorum Registration Identifier: 519771; Type: F.josettae Taug. 1968.

Original Diagnosis: Organic-walled microorganisms, generally of subcylindrical shape tending to a rounded or slightly bell-shaped parallelepiped, in transversal section nearly circular at one pole, becoming rectangular with rounded corners at the opposite pole which carries four hollow horns (or "processes") that extend the ribs of the body (Taugourdeau 1968).

Emended Diagnosis: Microfossils having two to four processes. Body subrectangular, unicellular or divided into chambers by septa, smooth or variously sculptured. Processes mostly smooth but may also be sculptured, unicellular or septate. Main body of the microfossils generally rectangular-subrectangular but variously shaped; either unicellular or divided into longitudinal chambers by vertical septa or multichambered, being divided by both vertical and transverse septa; septa may be complete or incomplete, sometimes septa faintly developed; body either smooth or ornamented with grana, verrucae or coni, etc., sculpturing elements may be closely or sparsely or evenly distributed. Two to four processes arising from one end of the body (although in Frasnacritetrus sp. 4, three processes are attached at the end of the body while the fourth one comes out from the middle of the body); generally broader at the base and tapering towards the apices; cylindrical or ribbon-like; either aseptate-unicellular or septate, septa one to many in each process; apex of processes pointed or blunt. Frasnacritetrus is not comparable to any of the known fossil palynogenera (Saxena \& Sarkar 1986).

Classification: Fungi Imperfecti, Staurosporae.

Number of species known: Seven.

Notes: Taugourdeau (1968) stated that this single specimen does not resemble any microfossil already described. He also did not rule out possibility of contamination. He speculated possibility of this specimen being either a broken Diacrodian or half an organism of some Conjugales (Desmidiales) or linear colony such as certain Desmochitina or hydrozoans. But he rejected all the above possibilities and could not reach to any conclusion. Saxena \& Sarkar (1986) emended the generic diagnosis, to allow inclusion of a number of fungal conidia that show a general similarity to the morphology of Tetraploa. This fungus generally grows on Poaceae, and the fossil species occur in association with grass pollen. Saxena \& Sarkar (1986) adduced this to support their suggestion that Frasnacritetrus should not be considered an acritarch but a fossil genus with affinity to Tetraploa. The generic diagnosis of Frasnacritetrus as originally proposed by Taugourdeau, only 
accommodates microfossils with four processes, whereas Saxena \& Sarkar (1986) also recovered specimens with three processes. Specimens with only two processes have also been recorded by Sharma (1976). Except for the difference in number of processes, there is no major morphological difference between the specimens which could justify the erection of a new genus. Saccardo (1880, 1886) classified similar forms under the Staurosporae, which include spores having a forked or starshaped appearance (Subramanian 1971). Kendrick \& Carmichael (1973) published a list of staurosporous genera and their illustrations. A comparison of the present microfossils with these genera reveals a close resemblance with Tetraploa, a genus belonging to the dematiaceous hyphomycetes, and in all probability they belong to it; hence their placement under Acritarcha incertae sedis by Taugourdeau (1968) does not seem justified.

6.2.1. Species: F. conatus R.K. Saxena \& S. Sarkar 1986 (Fig. 14P); Index Fungorum Registration Identifier: 519773; Location: Lower Siwalik, Nalagarh-Ramshahr Road section, Solan District, Himachal Pradesh, India; Age: Middle-Late Miocene.

6.2.2. Species: F. indicus R.K. Saxena \& S. Khare 1991 (Fig. 14Q); Index Fungorum Registration Identifier: 483898; Location: Jayamkondacholapuram well-12 (JC-12), $45 \mathrm{~km}$ south of Neyveli, Tiruchirappalli District, Tamil Nadu, India; Age: Tertiary.

6.2.3. Species: F. jamtahensis A. Gupta 2002 (Fig. 14R); Index Fungorum Registration Identifier: 540509; Location: Jamtah Road Section, Sirmaur District, Himachal Pradesh, India; Age: Late Palaeocene-Early Oligocene (Subathu and Dagshai formations).

6.2.4. Species: $\boldsymbol{F}$. josettae Taug. 1968 (Fig. 14S); Index Fungorum Registration Identifier: 519772; Location: France; Age: Late Devonian.

6.2.5. Species: F. masolensis R.K. Saxena \& S.K.M. Tripathi 2011 (Fig. 14T); Index Fungorum Registration Identifier: 519941; Location: Masol-Kiratpur Section, Ambala District, Haryana, India; Age: Pliocene (Tatrot and Pinjor formations).

6.2.6. Species: F. siwalikus R.K. Saxena et al. 1987 (Fig. 14U); Index Fungorum Registration Identifier: 519774; Location: Upper Siwalik exposed between Masol and Kiratpur in Ambala District, Haryana, India; Age: Miocene-Pliocene (Tatrot and Pinjor formations).

6.2.7. Species: F. taugourdeaui R.K. Saxena \& S. Sarkar 1986 (Fig. 14V); Index Fungorum Registration Identifier: 519775; Location: Near Banethi, Sirmaur District, Himachal Pradesh, India; Age: Early Miocene (Kasauli Formation).

6.3. Genus: MOSSOPISPORITES Kalgutkar \& Janson., AASP Contributions Series (Dallas) 39: 183 (2000); Index Fungorum Registration Identifier: 28621; Type: M. multicellulus (P. Ke \& Z.Y. Shi) Kalgutkar \& Janson. 2000.

Original Diagnosis: Multicellate medium-sized triporate fungal spores with a (concave) triangular outline. The pores occur at the distal ends of three radial extensions of the outline, where a series of squat transverse cells are stacked to form short, broad arms. The interior of the spore is filled with similar cells, that are interlocking to form a kind of mosaic. One of the arms may be more strongly developed than the other two (Kalgutkar \& Jansonius 2000).

Classification: Fungi Imperfecti, Staurosporae.

Number of species known: One.

Notes: The overall shape of Trihyphites Kalgutkar \& Janson. 2000 is triradiate, rather than triangular; this genus also has a single (large) central cell. Tribolites is inaperturate, and has a very large central cell. The genus name honours Dr. G. D. Mossop.

6.3.1. Species: M. multicellulus (P. Ke \& Z.Y. Shi) Kalgutkar \& Janson. 2000 (Fig. 14W); Index Fungorum Registration Identifier: 483444; Basionym: Triporicellaesporites multicellulus $\mathrm{P}$. Ke \& Z.Y. Shi 1978; Location: Gangzhou, Hebei Province, Coastal region of Bohai, China; Age: Eocene-Oligocene.

6.4. Genus: PESAVIS Elsik \& Janson., Can. J. Bot. 52(5): 955 (1974); Index Fungorum Registration Identifier: 21231; Type: P. tagluensis Elsik \& Janson. 1974. 
Original Diagnosis: Multicellular fungal fruiting body consisting of a stalked central cell and two lateral arms consisting of some 5-10 cells each. Lateral arms may be straight or curved, widely spread or closely appressed. Two planes of symmetry present. Cells of the primary structure may or may not have secondary septate hyphae-like filaments (Elsik \& Jansonius 1974).

Classification: Fungi Imperfecti, Staurosporae.

Number of species known: Four (but we accept only two species as legitimate because two species have been transferred to other genera).

6.4.1. Species: P. elongatus (P. Ke \& Z.Y. Shi) Z.C. Song in Z.C. Song et al. 1999; Index Fungorum Registration Identifier: 483850; Current name: Triporicellaesporites elongatus $\mathrm{P}$. Ke \& Z.Y. Shi 1978 fide Kalgutkar \& Jansonius (2000).

6.4.2. Species: P. parvus Kalgutkar \& Sweet 1988; Index Fungorum Registration Identifier: 637511; Location: Big Fish River area on the Yukon Coastal Plain, the Bonnet Plume Basin in Central Yukon, the central Alberta Foothills and southwestern Saskatchewan, Canada; Age: Maastrichtian.

6.4.3. Species: P. simplex Elsik \& Janson. 1974; Index Fungorum Registration Identifier: 319408; Current name: Triporicellaesporites simplex (Elsik \& Janson.) Kalgutkar \& Janson. 2000 fide Kalgutkar \& Jansonius (2000).

6.4.4. Species: P. tagluensis Elsik \& Janson. 1974 (Fig. 14X); Index Fungorum Registration Identifier: 319409; Location: Washington state, British Columbia, Alaska, U.S.A., and the Mackenzie delta, Northwest Territorries, Canada; Age: Palaeocene-Eocene.

6.5. Genus: SPEGAZZINITES Félix, Zeitschr. Deutsche Geol. Gesell. 46: 279 (1894); Index Fungorum Registration Identifier: 21303; Type: S. cruciformis Felix 1894 (lectotype was designated by Jansonius \& Hills 1976).

Original Diagnosis (Combined description): The remains are the conidia of a hyphomycete. Their shape and size varies more than is usually the case with such structures. However, the morphology is the same in all of them as far as the somewhat thick polished sections disclose: they consist of 4 partial cells. In the smaller conidia, these partial cells are of a slightly elongated shape, and their narrow sides are oriented towards a point in such a way that together they form a regular, equal-armed cross (figs. 8a-c). In the larger specimens, the individual cells are more roundish, the arms of the cross therefore shortened, so that the entire structure approaches the shape of a tightly tied, cube-shaped parcel, a shape found, for instance, in the body of the genus Sarcina. The size of the smaller conidia is $0.012-0.015 \mathrm{~mm}[12-15 \mu \mathrm{m}]$, that of the larger ones $0.021-0.024 \mathrm{~mm}$ [21-24 $\mu \mathrm{m}]$; in between occur numerous transitional forms. Some of the conidia are spinose, and not only the larger ones as was claimed by Hoffmann, but rather small conidia as well. The spines are of various length, in the larger conidia they are generally shorter than in the smaller specimens. The dimensions specified above refer to asetose specimens. In addition to conidia, the respective polished sections also contain numerous mycelial remains. A connection between them and the conidia could not be definitely established, but there is one case where a conidium appears to sit at the end of a hyphal branch. The mycelium is sparsely ramified, septa were not observed. The thicker filaments are 0.003-0.006 mm $(3-6 \mu \mathrm{m})$ in diameter (Felix 1894, translated English version in Kalgutkar \& Jansonius 2000).

Classification: Fungi Imperfecti, Staurosporae.

Number of species known: Three.

6.5.1. Species: S. cruciformis Félix 1894 (Fig. 14Y); Index Fungorum Registration Identifier: 197021; Location: Germany; Age: Tertiary; Notes: Félix (1894) stated that the fossil conidia resemble very closely to those of a hyphomycete described by Saccardo as Spegazzinia ornata which belongs to the family Tubercularieae. Spegazzinia also displays partly parcelshaped and partly cruciform conidia which consist of 4 cells and are partly covered with spines. Jansonius \& Hills (1976) designated the lectotype. 
6.5.2. Species: S. indicus Ramanujam \& Srisailam 1980 (Fig. 14Z); Index Fungorum Registration Identifier: 109246; Location: Kannur Beach area, Palayangadi and Cheruvattur (southern side of Karingottu River), Kerala, India; Age: Miocene.

6.5.3. Species: S. tetradus (Rouse) Kalgutkar \& Janson. 2000; Index Fungorum Registration Identifier: 483549; Basionym: Inapertisporites tetradus Rouse 1962; Location: Terminal Dock, the city of Vancouver, British Columbia, Canada; Age: Late Cretaceous-Middle Eocene (Burrard Formation).

6.6. Genus: TRIBOLITES W.H. Bradley, Amer. J. Sci. Arts, Ser. 2 262: 413 (1964); Index Fungorum Registration Identifier: 21338; Type: T. tetrastonyx W.H. Bradley 1964.

Synonym: Trihyphaecites Peppers 1970 fide Kalgutkar \& Jansonius (2000), Index Fungorum Registration Identifier: 21343.

Original Diagnosis: Conidia consisting of four tapered arms that end in an abruptly tapered sharp point and that radiate from a large central, polyhedral cell; apices of the arms corresponding to the apices of a more or less regular tetrahedron; arms subdivided by thick septa into three to five nearly equidimensional cells; one arm tip generally flattened, which presumably represents the point of attachment to the conidiophore; overall dimensions 60-90 $\mu \mathrm{m}$ (Bradley 1964).

Emended Diagnosis: Inaperturate, medium to large-sized conidia consisting of a large, inflated polyhedral (generally triangular or tetrahedral) central cell, the corners of which are extended into tapered arms consisting of some two to six nearly equidimensional cells; the radial arms closed terminally, rounded to pointed, but one arm generally with a flat (hilar?) end (Kalgutkar \& Jansonius 2000).

Classification: Fungi Imperfecti, Staurosporae.

Number of species known: Two.

Notes: According to Bradley (1964), the conidia resemble in structure and general form the conidia of extant genera Tetrachaetum and Lemonniera.

6.6.1. Species: T. tetrastonyx W.H. Bradley 1964 (Fig. 14AA); Index Fungorum Registration Identifier: 340260; Location: Wyoming, Colorado, U.S.A.; Age: Eocene; Notes: According to Bradley (1964), the conidia resemble in structure and general form the conidia of extant Tetrachaetum elegans and Lemonniera aquatica, but the arms are much shorter, stockier, and the cell walls much thicker.

6.6.2. Species: T. triangulatus (Peppers) Kalgutkar \& Janson. 2000; Index Fungorum Registration Identifier: 483562; Basionym: Trihyphaecites triangulatus Peppers 1970; Location: North eastern part of the Illinois Basin, Illinois. U.S.A.; Age: Carboniferous-Pennsylvanian (Carbondale and Spoon formations).

6.7. Genus: TRIHYPHAECITES Peppers, Bull. Ill. St. geol. Surv. 93: 135 (1970); Index Fungorum Registration Identifier: 21343; Type: T. triangulatus Peppers 1970; Current name: TRIBOLITES W.H. Bradley 1964 fide Kalgutkar \& Jansonius (2000).

Original Diagnosis: The fossils are composed of radially symmetrical, triangular to roundly triangular bodies that give rise to septate hyphae from each of the corners. Septa are also present at the corners where the hyphae are joined to the body. The hyphae may consist of one segment with a well rounded terminal end or may be of several segments in which the terminal end is either well rounded or broken. The fossils generally possess minor folds and are slightly torn. They are laevigate and about $1 \mu \mathrm{m}$ thick. The triangular central body is generally thicker than the hyphae. Known size range from one corner to the opposite side of the triangular body is 32.2 to $48.8 \mu \mathrm{m}$ (Peppers 1970).

Classification: Fungi Imperfecti, Staurosporae.

Number of species known: Two (both the species have been transferred to other genera).

Notes: According to Peppers (1970), Trihyphaecites is characterized by its triangular body with septate hyphae at each of the corners. 
6.7.1. Species: T. fractus Z.C. Song \& Liu Cao in Z.C. Song et al. 1989; Index Fungorum Registration Identifier: 485274; Current name: Trihyphites fractus (Z.C. Song \& Liu Cao in Z.C. Song et al.) Kalgutkar \& Janson. 2000 fide Kalgutkar \& Jansonius (2000).

6.7.2. Species: T. triangulatus Peppers 1970; Index Fungorum Registration Identifier: 325019; Current name: Tribolites triangulatus (Peppers) Kalgutkar \& Janson. 2000 fide Kalgutkar \& Jansonius (2000).

6.8. Genus: TRIHYPHITES Kalgutkar \& Janson., AASP Contributions Series (Dallas) 39: 305 (2000); Index Fungorum Registration Identifier: 28625; Type: T. fractus (Z.C. Song \& Liu Cao) Kalgutkar \& Janson. 2000

Synonym: Trihyphaecites fractus Z.C. Song \& Liu Cao in Z.C. Song et al. 1989 fide Kalgutkar \& Jansonius (2000), Index Fungorum Registration Identifier: 485274.

Original Diagnosis: Fungal spores triradiate; from a small triangular central cell, three arms radiate out, each consisting of up to a dozen cells, and each terminating with a wide pore-like structure (Kalgutkar \& Jansonius 2000).

Classification: Fungi Imperfecti, Staurosporae.

Number of species known: One.

Notes: The generic name is a contraction of Trihyphaecites, of which the type species, $T$. triangulatus, was transferred to Tribolites.

6.8.1. Species: T. fractus (Z.C. Song \& Liu Cao) Kalgutkar \& Janson. 2000 (Fig. 14AB); Index Fungorum Registration Identifier: 483569; Basionym: Trihyphaecites fractus Z.C. Song \& Liu Cao in Z.C. Song et al. 1989; Location: Shenxian county of Shandong Province, China; Age: Late Eocene-Middle Oligocene (Shahejie Formation).

6.9. Genus: TRIPORICELLAESPORITES P. Ke \& Z.Y. Shi, Early Tertiary spores and pollen grains from the coastal region of Bohai: 51 (1978); Index Fungorum Registration Identifier: 21344; Type: T. triangulus P. Ke \& Z.Y. Shi 1978.

Original Diagnosis: Spores triangular-lenticular in shape, outline triangular in polar view. Triporate, pores situated at corners of triangle, prominent, might be vestibulate. Multicellular, cells in triangulate [triaxial?] arrangement. Spore wall of medium thickness, surface psilate or provided with granulate to indistinct finely reticulate sculpturing (Ke \& Shi 1978).

Emended Diagnosis: Pluricellate fungal spores with triangular to inverted V-shaped outline, with a central (stalked) hilum; the two lateral wings or appendages may be closed terminally, but commonly are preserved with the distalmost cells lacking; spore wall smooth (Kalgutkar \& Jansonius 2000).

Classification: Fungi Imperfecti, Staurosporae.

Number of species known: Four (but we accept only three species as legitimate because one species has been transferred to Mossopisporites Kalgutkar \& Janson. 2000).

Notes: This genus can be distinguished from all other genera of fossil fungal spores by the fact that its members are both multicellular and triporate and exhibit a triangular to chevron-shaped outline.

6.9.1. Species: T. elongatus P. Ke \& Z.Y. Shi 1978; Index Fungorum Registration Identifier: 115699; Synonym: Pesavis elongatus (P. Ke \& Z.Y. Shi) Z.C. Song in Z,C, Song et al. 1999 fide Kalgutkar \& Jansonius (2000); Location: Cangxian, Hebei Province, Coastal region of Bohai, China; Age: Eocene-Oligocene.

6.9.2. Species: T. multicellulus P. Ke \& Z.Y. Shi 1978; Index Fungorum Registration Identifier: 115651; Current name: Mossopisporites multicellulus (P. Ke \& Z.Y. Shi) Kalgutkar \& Janson. 2000 fide Kalgutkar \& Jansonius (2000).

6.9.3. Species: T. simplex (Elsik \& Janson.) Kalgutkar \& Janson. 2000; Index Fungorum Registration Identifier: 483570; Basionym: Pesavis simplex Elsik \& Janson. 1974; Location: Mackenzie Delta, Northwest Territories, Canada; Age: Palaeogene. 
6.9.4. Species: T. triangulus P. Ke \& Z.Y. Shi 1978 (Fig. 14AC); Index Fungorum Registration Identifier: 115650; Location: Panshan, Liaoning Province, Coastal region of Bohai, China; Age: Eocene-Oligocene.

\section{Fossil fungal spore species assigned to modern genera}

7.1. Genus: ACREMONIUM Link, Mag. Gesell. naturf. Freunde, Berlin 3(1-20: 15 (1809); Index Fungorum Registration Identifier: 7028; Type: A. alternarium Link 1809.

Classification: Bionectriaceae, Hypocreales, Hypocreomycetidae, Sordariomycetes, Pezizomycotina, Ascomycota.

Number of fossil species known: One.

7.1.1. Species: A. succineum Casp. 1907; Index Fungorum Registration Identifier: 107444; Location: Baltic area, Poland; Age: Tertiary (Oligocene?).

7.2. Genus: ALTERNARIA Nees, Syst. Pilze (Würzburg): 72 (1816); Index Fungorum Registration Identifier: 7106; Type: A. tenuis Nees 1816.

Classification: Pleosporaceae, Pleosporales, Pleosporomycetidae, Dothideomycetes, Pezizomycotina, Ascomycota.

Number of fossil species known: One (the single fossil species has been transferred to Pluricellaesporites Hammen 1954).

7.2.1. Species: A. malayensis Trivedi \& C.L. Verma 1970; Index Fungorum Registration Identifier: 308511; Current name: Pluricellaesporites malayensis (Trivedi \& Verma) Kalgutkar \& Janson. 2000 fide Kalgutkar \& Jansonius (2000).

7.3. Genus: BOTRYODIPLODIA Sacc., Syll. fung. (Abellini) 3: 377 (1884); Index Fungorum Registration Identifier: 7420; Type: As per Index Fungorum, Saccardo accepted the type of Diplodia b Botryodiplodia as Diplodia juglandis (Fr.) Fr. 1849.

Classification: Diporthales, Diaporthomycetidae, Sordariomycetes, Pezizomycotina, Ascomycota.

Number of fossil species known: One (the single fossil species has been transferred to Diplodites).

7.3.1. Species: B. mohgaoensis Barlinge \& Paradkar 1982; Index Fungorum Registration Identifier: 108725; Current Name: Diplodites mohgaoensis (Barlinge \& Paradkar) Kalgutkar et al. 1993 fide Kalgutkar et al. 1993.

7.4. Genus: BRACHYSPORIUM Sacc., Syll. fung. (Abellini) 4: 423 (1886); Index Fungorum Registration Identifier: 7444; Type: B. obovatum (Berk.) Sacc. 1886.

Classification: Trichosphaeriaceae, Trichosphaeriales, Diaporthomycetidae, Sordariomycetes, Pezizomycotina, Ascomycota.

Number of fossil species known: One (the single fossil species has been transferred to Pluricellaesporites Hammen 1954).

7.4.1. Species: B. minutum Trivedi \& C.L. Verma 1970; Index Fungorum Registration Identifier: 7444 (nom. inval.); Current name: Pluricellaesporites minutus (Trivedi \& Verma) ex Kalgutkar \& Janson. 2000 fide Kalgutkar \& Jansonius (2000).

7.5. Genus: CHAETOSPHAERIA Tul. \& C. Tul., Select. fung. corpol. (Paris) 2: 252 (1863); Index Fungorum Registration Identifier: 970; Type: C. innumera Berk. \& Broome ex Tul. \& C. Tul. 1863.

Classification: Chaetosphaeriaceae, Chaetosphaeriales, Sordariomycetidae, Sordariomycetes, Pezizomycotina, Ascomycota.

Number of fossil species known: One. 
7.5.1. Species: C. elsikii M.J. Pound et al. 2018; Index Fungorum Registration Identifier: 821981; Location: Bees Nest Pit, Brassington, Derbyshire, U.K.; Age: Miocene.

7.6. Genus: CLASTEROSPORIUM Schwein., Trans. Am. phil. Soc., New Series 4(2): 300 (1834); Index Fungorum Registration Identifier: 7685; Type: C. caricinum Schwein. 1834.

Classification: Magnaporthaceae, Magnaporthales, Diaporthomycetidae, Sordariomycetes, Pezizomycotina, Ascomycota.

Number of fossil species known: One.

7.6.1. Species: C. eocenicum Fritel \& R. Vig. 1909; Index Fungorum Registration Identifier: 198755; Location: Brétigny et Muirancourt (Oise), France; as calcareous pseudomorphs in marls underlying lignites; Age: Sparnacian (Early Eocene).

7.7. Genus: DESMIDIOSPORA Thaxt., Bot. Gaz. 16: 203 (1891); Index Fungorum Registration Identifier: 7964; Type: D. myrmecophila Thaxt. 1891.

Classification: Ascomycota genera incertae sedis.

Number of fossil species known: Two.

Notes: Desmidiospora Thaxt. 1891 comprises three species. The type species $D$. myrmecophila Thaxt. 1891 represents living fungi, whereas the other two, viz. D. willoughbyi (W.H. Bradley) D.L.E. Glass et al. 1986 and D. marginiconvoluta Kalgutkar 1997, represent fossil fungi.

7.7.1 Species: D. marginiconvoluta Kalgutkar 1997; Index Fungorum Registration Identifier: 437899; Location: Kanguk Peninsula, Axel Heiberg Island, Northwest Territories, Canada; Age: Late Palaeocene-Early Eocene (Iceberg Bay Formation, Eureka Sound Group); Notes: The species epithet indicates convoluted spore margin.

7.7.2. Species: D. willoughbyi (W.H. Bradley) D.L.E. Glass et al. 1986 (Fig. 14AD); Index Fungorum Registration Identifier: 357741; Basionym: Entophlyctis willoughbyi Bradley 1967; Location: Wyoming, Colorado (Bradley 1967), East and south-central Texas, U.S.A. (D.L.E. Glass et al. 1986); Age: Eocene (Bradley 1967), Late Eocene (Manning Formation, Jackson group) (Glass et al. 1986).

7.8. Genus: DIPLODIA Fr., in Montagne, Annls Sci. Nat. Bot., ser. 2 1: 302 (1934); Index Fungorum Registration Identifier: 8047; Type: D. mutila (Fr.) Mont. 1834.

Classification: Botryosphaeoriaceae, Botryosphaeriales, Dothideomycetes, Pezizomycotina, Ascomycota.

Number of fossil species known: Two (both the fossil species have been transferred to Diplodites).

7.8.1. Species: D. rodei Mahab. 1969; Index Fungorum Registration Identifier: 313187; Current Name: Diplodites rodei (Mahab.) Kalgutkar et al. 1993 fide Kalgutkar et al. 1993.

7.8.2. Species: D. sahnii Singhai 1974; Index Fungorum Registration Identifier: 313191; Current Name: Diplodites sahnii (Singhai) Kalgutkar et al. 1993 fide Kalgutkar et al. 1993.

7.9. Genus: DIPOROTHECA C.C. Gordon \& C.G. Shaw, Mycologia 52(2): 331 (1961); Index Fungorum Registration Identifier: 1635; Type: D. rhizophila C.C. Gordon \& C.G. Shaw 1961.

Classification: Diporothecaceae, Pezizomycotina, Ascomycota.

Number of fossil species known: Two.

7.9.1. Species: D. doniana O'Keefe 2017; Index Fungorum Registration Identifier: 821917; Location: Tumbes Province, Peru; Age: Miocene (Heath Formation); Notes: The specific epithet is a feminization of 'Don' in honour of Donald W. Engelhardt, Earth Sciences Resources Institute, University of South Carolina, Columbia, South Carolina, U.S.A.

7.9.2. Species: D. gorda O'Keefe 2017; Index Fungorum Registration Identifier: 821918; Location: Tumbes Province, Peru; Age: Miocene (Heath Formation); Notes: The specific epithet is 
Spanish for 'fat woman', given the very boxy, fat shape of the grain relative to other spores of Diporotheca.

7.10. Genus: ENTOPHLYCTIS A. Fisch. in Winter, Rabenh. Krypt.-Fl., Edn. 2 (Leipzig) 1(4): 114 (1892); Index Fungorum Registration Identifier: 20222; Type: E. cienkowskiana (Zopf) A. Fisch. 1892 (Basionym: Rhizidium cienkowskianum Zopf 1885)

Classification: Chytriomycetaceae, Chytridiales, Chytridiomycetidae, Chytridiomycetes, Chytridiomycota.

Number of fossil species known: One (the single fossil species has been transferred to Desmidiospora Thaxt.).

7.10.1. Species: E. willoughbyi W.H. Bradley 1967; Index Fungorum Registration Identifier: 330609; Current name: Desmidiospora willoughbyi (W.H. Bradley) D.L.E. Glass et al. 1986 fide D.L.E. Glass et al. 1986.

7.11. Genus: EPICOCCUM Link, Mag. Gesell. naturf. Freunde, Berlin 7: 32 (1816); Index Fungorum Registration Identifier: 8188; Type: E. nigrum Link 1816.

Classification: Didymellaceae, Pleosporales, Pleosporomycetidae, Dothideomycetes, Pezizomycotina, Ascomycota.

Number of fossil species known: One.

7.11.1. Species: E. deccanense R. Srivast. et al. 2009 (Fig. 14AE); Index Fungorum Registration Identifier: 561524; Location: Jhargad, near Jhadgaon village, Yavatmal District, Maharashtra, India; Age: Late Maastrichtian-Danian (Deccan Intertrappean Beds).

7.12. Genus: GONATOBOTRYS Corda, Pracht-Fl. Eur. Schimmelbiled.: 9 (1839); Index Fungorum Registration Identifier: 8374; Type: G. simplex Corda 1839; Current name: MELANOSPORA Corda 1837 fide Wijayawardene et al. (2020a).

Classification: Ceratostomataceae, Coronophorales, Hypocreomycetidae, Sordariomycetes, Pezizomycotina, Ascomycota.

Number of fossil species known: One (the single fossil species is here transferred to Melanospora Corda 1837).

7.12.1. Species: G. primigenius Casp. 1907; Index Fungorum Registration Identifier: 8374; Current name: Melanospora primigenia (Casp.) R.K. Saxena, Wijayaw., D.Q. Dai, K.D. Hyde \& P.M. Kirk comb. nov. This new combination is described under the section "New species and new combinations".

7.13. Genus: MELANOSPORA Corda, Icon fung. (Prague) (1837); Index Fungorum Registration Identifier: 3085; Type: M. zamiae Corda 1837.

Synonym: Gonatobotrys Corda 1839 fide Wijayawardene et al. 2020a, Index Fungorum Registration Identifier: 8374.

Classification: Ceratostomataceae, Melanosporales, Hypocreomycetidae, Sordariomycetes, Pezizomycotina, Ascomycota.

Number of fossil species known: One.

7.13.1. Species: M. primigenia (Casp.) R.K. Saxena, Wijayaw., D.Q. Dai, K.D. Hyde \& P.M. Kirk comb. nov. (Fig. 14AF). This new combination is described under the section "New species and new combinations".

7.14. Genus: POTAMOMYCES K.D. Hyde, Nova Hedwigia 61(1-2): 132 (1995); Index Fungorum Registration Identifier: 27626; Type: P. armatisporus K.D. Hyde 1995.

Synonym: Mediaverrunites Nandi \& A. Sinha 2007 fide Nuñez Otaño et al. 2017, Index Fungorum Registration Identifier: 548478.

Classification: Ascomycota genera incertae sedis.

Number of fossil species known: Seven. 
7.14.1. Species: $\boldsymbol{P}$. batii (Sancay) ex Nuñez Otaño et al. 2017; Index Fungorum Registration Identifier: 814793; Basionym. Mediaverrunites batii Sancay 2014; Location: Turkey; Age: Late Miocene.

7.14.2. Species: P. elsikii (Nandi \& A. Sinha) Nuñez Otaño et al. 2017; Index Fungorum Registration Identifier: 814695; Basionym. Mediaverrunites elsikii Nandi \& A. Sinha 2007; Location: Rengtekawn-Sherlui Road Traverse, Mizoram, India; Age: Neogene.

7.14.3. Species: P. fournieri (Elsik \& Jarzen) Nuñez Otaño et al. 2017; Index Fungorum Registration Identifier: 814696; Basionym: Mediaverrunites fournierii Elsik \& Jarzen 2009; Location: Colombia, South America; Age: Early Miocene.

7.14.4. Species: P. invaginatus (Elsik \& Jarzen) Nuñez Otaño et al. 2017; Index Fungorum Registration Identifier: 814698; Basionym: Mediaverrunites invaginatus Elsik \& Jarzen 2009; Location: Colombia, South America; Age: Early Miocene.

7.14.5. Species: P. magnus (Elsik \& Jarzen) Nuñez Otaño et al. 2017; Index Fungorum Registration Identifier: 814697; Basionym: Mediaverrunites magnus Elsik \& Jarzen 2009; Location: Colombia, South America; Age: Early Miocene.

7.14.6. Species: P. mulleri (Nandi \& A. Sinha) Nuñez Otaño et al. 2017; Index Fungorum Registration Identifier: 814692; Basionym: Mediaverrunites mulleri Nandi \& A. Sinha 2007; Location: Rengtekawn-Sherlui Road Traverse, Mizoram, India; Age: Neogene.

7.14.7. Species: P. pontidiensis (Sancay) ex Nuñez Otaño et al. 2017; Index Fungorum Registration Identifier: 814794; Basionym: Mediaverrunites pontidiensis Sancay 2014; Location: Turkey; Age: Late Miocene.

7.15 Genus: RAMULARIA Unger, Exanth. Pflanzen (Wein): 119 (1833); Index Fungorum Registration Identifier: 9691; Type: $R$. pusilla Unger 1833.

Classification: Mycosphaerellaceae, Capnodiales, Dothideomycetidae, Dothideomycetes, Pezizomycotina, Ascomycota.

Number of fossil species known: One

7.15.1. Species: R. oblongispora Casp. 1907; Index Fungorum Registration Identifier: 107582; Location: Baltic area, Poland; Age: Tertiary (Oligocene?).

7.16. Genus: RHEXOAMPULLIFERA P.M. Kirk, Trans. Br. mycol. Soc. 78(2): 299 (1982); Index Fungorum Registration Identifier: 9717; Type: R. fagi (M.B. Ellis) P.M. Kirk \& C.M. Kirk 1982.

Classification: Ascomycota genera incertae sedis.

Number of fossil species known: Two.

7.16.1. Species: R. stogieana M.J. Pound et al. 2018; Index Fungorum Registration Identifier: 821979; Location: Bees Nest Pit, Brassington, Derbyshire, U.K.; Age: Miocene.

7.16.2. Species: R. sufflata M.J. Pound et al. 2018; Index Fungorum Registration Identifier: 821980; Location: Bees Nest Pit, Brassington, Derbyshire, U.K.; Age: Miocene.

7.17. Genus: SCLERODERMA Pers., Syn. meth. fung. (Göttingen) 1: xiv, 150 (1801); Index Fungorum Registration Identifier: 19309; Type: S. verrucosum (Bull.) ex Pers. 1801.

Classification: Sclerodermataceae, Boletales, Agaricomycetidae, Agaricomycetes, Agaricomycotina, Basidiomycota.

Number of fossil species known: One.

7.17.1. Species: S. echinosporites Rouse 1962; Index Fungorum Registration Identifier: 110078; Location: South shore of Burrard Inlet, British Columbia, Canada; Age: (Middle?) Eocene (but possibly as old as Late Cetaceous?).

7.18. Genus: SOROSPORIUM F. Rudolphi, Linnaea 4: 116 (1829); Index Fungorum Registration Identifier: 16318; Type: S. saponariae F. Rudolphi 1829; Current name: THECAPHORA Fingerh 1836 fide Wijayawardene et al. (2020a). 
Classification: Glomosporiaceae, Urocystidales, Ustilaginomycetes, Ustilaginomycotina, Basidiomycota.

Number of fossil species known: One (the single fossil species is here transferred to Melanospora Corda 1837).

Notes: Sorosporium F. Rudolphi was rejected against the conserved name Thecaphora Fingerh and its type species S. saponariae F. Rudolphi, was transferred to Thecaphora Fingerh by Vánky 1998.

7.18.1. Species: S. mohgaoense Chitaley \& Yawale 1978; Index Fungorum Registration Identifier: 111035; Current Name: Thecaphora mohgaoensis (Chitaley \& Yawale) R.K. Saxena, Wijayaw., D.Q. Dai, K.D. Hyde \& P.M. Kirk comb. nov. This new combination is described under the section "New species and new combinations".

7.19. Genus: SPHAEROPHORUS Pers., Ann. Bot. (Usteri) 7: 23 (1794); Index Fungorum Registration Identifier: 5112; Type: S. coralloides Pers. 1794.

Classification: Sphaerophoraceae, Lecanorales, Lecanoromycetidae, Lecanoromycetes, Pezizomycotina, Ascomycota.

Number of fossil species known: One.

7.19.1. Species: S. moniliformis Menge 1858; Index Fungorum Registration Identifier: 628321; Location: Baltic area; Age: Early Tertiary (Oligocene?).

7.20. Genus: SPORIDESMIUM Link, Mag. Gesell. naturf. Freunde. Berlin 3(1-2): 41 (1809); Index Fungorum Registration Identifier: 10024; Type: S. atrum Link 1809.

Classification: Sporidesmiaceae, Sporidesmiales, Diaporthomycetidae, Sordariomycetes, Pezizomycotina, Ascomycota.

Number of fossil species known: One.

7.20.1. Species: S. henryense Dilcher 1965; Index Fungorum Registration Identifier: 339523; Location: Western Tennessee, U.S.A.; Age: Early Eocene.

7.21. Genus: STILBUM Tode, Fung. mecklenb. sel. (Luneburg) 1: 10 (1790); Index Fungorum Registration Identifier: 18601; Type: S. vulgare Tode 1790.

Classification: Chionosphaeraceae, Agaricostilbales, Agaricostilbomycetes,

Pucciniomycotina, Basidiomycota.

Number of fossil species known: One.

7.21.1. Species: S. succini Casp. 1907; Index Fungorum Registration Identifier: 107596; Location: Baltic area, Poland; Age: Tertiary (Oligocene); Notes: The species epithet is derived from Latin succinum $=$ amber.

7.22. Genus: TETRACOCCOSPORIUM Szabó, Hedwigia 44: 77 (1905); Index Fungorum Registration Identifier: 10192; Type: T. paxianum Szabó 1905

Classification: Ascomycota genera incertae sedis.

Number of fossil species known: One.

7.22.1. Species: T. eocenum Biradar \& Mahab. 1974 (Fig. 14AG); Index Fungorum Registration Identifier: 519781; Location: Mohgaon Kalan, Chhindwara District, Madhya Pradesh, India; Age: Maastrichtian (Deccan Intertrappean Series).

7.23. Genus: THECAPHORA Fingerh, Linnaea 10: 230 (1836); Index Fungorum Registration Identifier: 16347; Type: T. hyalina Fingerh 1836.

Synonym: Sorosporium F. Rudolphi 1829 fide Index Fungorum, Index Fungorum Registration Identifier: 16318.

Classification: Glomosporiaceae, Urocystidales, Ustilaginomycetes, Ustilaginomycotina, Basidiomycota.

Number of fossil species known: One. 
7.23.1. Species: T. mohgaoensis (Chitaley \& Yawale) R.K. Saxena, Wijayaw., D.Q. Dai, K.D. Hyde \& P.M. Kirk comb. nov. (Fig. 14AH). This new combination is described under the section "New species and new combinations". Notes: Kalgutkar \& Jansonius 2000 transferred Sorosporium mohgaoense to fossil fungal spore genus Papulosporonites [as Papulosporonites mohgaoensis (Chitaley \& Yawale) Kalgutkar \& Janson. 2000] without providing any convincing reason for the same. We, therefore, do not accept this transfer.

7.24. Genus: TORULA Pers., Ann. Bot. (Usteri) 15: 25 (1795); Index Fungorum Registration Identifier: 10248; Type: T. monilis Pers. 1795.

Classification: Torulaceae, Pleosporales, Pleosporomycetidae, Dothideomycetes, Pezizomycotina, Ascomycota.

Number of fossil species known: Three.

7.24.1. Species: T. globulifera Casp. 1907; Index Fungorum Registration Identifier: 107604; Location: Baltic area, Poland; Age: Tertiary (Oligocene?).

7.24.2. Species: T. heteromorpha Casp. 1907; Index Fungorum Registration Identifier: 105832; Location: Baltic area, Poland; Age: Tertiary (Oligocene?).

7.24.3. Species: T. mengeana Casp. \& R. Klebs in Casp. 1907; Index Fungorum Registration Identifier: 634247; Location: Baltic area, Poland; Age: Tertiary (Oligocene?).

7.25. Genus: USTILAGO (Pers.) Roussel, Fl. Calvados, Edn 2: 47 (1806), Index Fungorum Registration Identifier: 16391; Type: $\boldsymbol{U}$. hordei (Pers.) Lagerh. 1889.

Classification: Ustilaginaceae, Ustilaginales, Ustilaginomycetidae, Ustilaginomycetes, Ustilaginomycotina, Basidiomycota.

Number of fossil species known: One (the single species has been transferred to Inapertisporites Hammen 1954).

7.25.1. Species: U. deccanii Chitaley \& Yawale 1978; Index Fungorum Registration Identifier: 111080; Current Name: Inapertisporites deccanii (Chitaley \& Yawale) Kalgutkar \& Janson. 2000 fide Kalgutkar \& Jansonius (2000).

7.26. Genus: ZOPFIELLA G. Winter, Rabenh. Krypt. -Fl., Edn 2 (Leipzig) 1.2: 56 (1884); Index Fungorum Registration Identifier: 5876; Type: Z. tabulata Zopf ex G. Winter 1884.

Classification: Lasiosphaeriaceae, Sordariales, Sordariomycetidae, Sordariomycetes, Pezizomycotina, Ascomycota.

Number of fossil species known: One.

7.26.1. Species: Z. neogenica O'Keefe 2017; Index Fungorum Registration Identifier: 821916; Location: Tumbes Province, Peru; Age: Miocene (Heath Formation); Notes: The specific epithet refers to the age of the specimen.

\section{New species and new combinations}

Hypoxylonites disciformis (Sheffy \& Dilcher) R.K. Saxena, Wijayaw., D.Q. Dai, K.D. Hyde \& P.M. Kirk comb. nov. Index Fungorum Registration Identifier: 554345.

Fig. 6G

Basionym - Inapertisporites disciformis Sheffy \& Dilcher, Palaeontographica Abt. B 133: 39, pl. 13, fig. 8, pl. 15, fig. 8, 1971; Index Fungorum Registration Identifier: 111544.

Synonym - Spirotremesporonites disciformis (Sheffy \& Dilcher) Elsik 1990a.

Holotype - Sheffy \& Dilcher 1971: 39, pl. 13, fig. 8, pl. 15, fig. 8; PPS (1) 17.6 × 101.2.

Diagnosis - Disk-shaped spore, size $6.8 \times 16.4 \mu \mathrm{m}$, a narrow, straight slit present from one end to the other, spore wall $1 \mu \mathrm{m}$ thick, psilate, medium pigment

Location - Puryear clay pit, $800 \mathrm{~m}$ south of Puryear, Henry County, Tennessee, U.S.A.

Age - Middle Eocene (Claiborne Formation). 
Notes - Kalgutkar \& Jansonius (2000) stated that the line drawing of Inapertisporites disciformis given by Sheffy \& Dilcher (1971) appears to show similarity to Hypoxylonites, based on the pattern of the furrow, which is straight and not oblique, wavy or spiral. However, they tentatively followed synonymy in Elsik (1990a) and described it as Spirotremesporites disciformis. We interpret the longitudinal slit, from one end to the other, as straight and transfer it to Hypoxylonites.

Hypoxylonites lanceolatus (Debi Mukh.) R.K. Saxena, Wijayaw., D.Q. Dai, K.D. Hyde \& P.M. Kirk comb. nov. Fig. $6 \mathrm{~N}$ Index Fungorum Registration Identifier: 554568.

Basionym - Xylariasporites lanceolatus Debi Mukh., International Journal of Geology, Earth and Environmental Sciences 2(2): 9, fig. 3.13, 2012; Index Fungorum Registration Identifier: 588483.

Holotype - Mukherjee 2012: 9, fig. 3.13; size $60 \times 40 \mu \mathrm{m}$, slide no. LU-D/6, co-ordinates (K7/4), Museum, Department of Geology, Lucknow University, Lucknow, India.

Diagnosis - Aeciospore hyaline, brown, one celled, dark brown in colour, germ pore slit-like, size range 60-70 × 30-40 $\mu \mathrm{m}$ (usually $60 \times 40 \mu \mathrm{m}$ ); lanceolate, biconvex, tapering at the poles, aperture fine, $2 \mu \mathrm{m}$ wide.

Location - Neyveli Lignite Mine-I, Cuddalore District, Tamil Nadu, India.

Age - Miocene (Neyveli Lignite).

Notes - Mukherjee (2012) stated that this species belongs to family Xylariaceae of Ascomycota. The present spore having one cell with fine germ pore, shows affinity with Xylaria spores (as mentioned by Ainsworth et al. 1973). Xylariasporites lanceolatus Debi Mukh. (Type of Xylariasporites) conforms to Hypoxylonites Elsik 1990a in all the essential characters, hence transferred to Hypoxylonites. The specific epithet refers to its lens-like shape, lanceolatus = lenslike.

Melanospora primigenia (Casp.) R.K. Saxena, Wijayaw., D.Q. Dai, K.D. Hyde \& P.M. Kirk comb. nov.

Fig. $14 \mathrm{AF}$ Index Fungorum Registration Identifier: IF556982.

Basionym - Gonatobotrys primigenius Casp. (as "primigenia"), in Klebs, Abh.. preuss. geol. Landesanst. 4(1): 11, taf. 1, fig. 6. 1907, Index Fungorum Registration Identifier: 626875.

Synonym - Gonatobotrytites primigenius (Casp.) Pia 1927; Index Fungorum Registration Identifier: 115070.

Holotype - Gonatobotrys primigenius Casp. 1907: 11, taf. 1, fig. 6, collected from Tertiary sediments of Austria.

Location - Location: Baltic area, Poland.

Age - Tertiary (Oligocene?).

Thecaphora mohgaoensis (Chitaley \& Yawale) R.K. Saxena, Wijayaw., D.Q. Dai, K.D. Hyde \& P.M. Kirk comb. nov.

Fig. 14AH

Index Fungorum Registration Identifier: 556983.

Basionym - Sorosporium mohgaoense Chitaley \& Yawale, Botanique 7(4): 190, pl. 1, fig. 1. 1978; Index Fungorum Registration Identifier: 111035.

Synonym: Papulosporonites mohgaoensis (Chitaley \& Yawale) Kalgutkar \& Janson. 2000: 217, pl. 18, fig. 6; Index Fungorum Registration Identifier: 483503.

Holotype - Chitaley \& Yawale 1978: 190; pl. 1, fig. 1; I Fu/NRY deposited with SRII, Nagpur (designated by Kalgutkar \& Jansonius 2000).

Diagnosis - The spore balls are deeply buried in the host tissue and look reddish brown to pale yellow. They are egg-shaped consisting of 5 to 25 spores. The spores are more or less permanently united and the balls are not covered by a sterile sheath or any pseudomembrane. No sterile cells are present inside the spore balls. Size of spore balls varies from 17-21 $\times 35-46 \mu \mathrm{m}$. 
Individual spores are globose in shape but because of compression they look polyhedral. Germ pores are observed in many of them. However, the mycelium is not seen. Spores are 5.3 to $10.6 \mu \mathrm{m}$ with an average of $8 \mu \mathrm{m}$ in diameter, globose to ovoid, polyhedral in balls, without any contents, epispore smooth, $0.3-0.7 \mu \mathrm{m}$.

Location - Mohgaonkalan, Chhindwara District, Madhya Pradesh, India.

Age - Late Cretaceous-Maastrichtian.

Dicellaesporites vermae R.K. Saxena, Wijayaw., D.Q. Dai, K.D. Hyde \& P.M. Kirk sp. nov.

Index Fungorum Registration Identifier: 555416.

Fig. 9P

Etymology - The species is named in honour of late Professor C.L. Verma of the Department of Botany, Lucknow University, Lucknow, India.

Holotype - Dicellaesporites sp. A in H.P. Singh, R.K. Saxena \& M.R. Rao 1986, Palaeobotanist 35(1): 98, pl. 2, fig. 18, BSIP slide no. 8123 , coordinates $62.4 \times 106.5$, Museum, Birbal Sahni Institute of Palaeosciences, Lucknow, India.

Diagnosis - Fungal spores elliptical in shape, size $79-87 \times 31-35 \mu \mathrm{m}$, dicellate, inaperturate, uniseptate, septa $1 \mu \mathrm{m}$ thick, spore wall psilate, hyaline, sometimes with minor folds. India.

Location - Sonapur-Badarpur Road section, Jaintia Hills, Meghalaya and Cachar, Assam,

Age - Early Miocene (Dona Member, Bhuban Formation, Surma group).

Dyadosporites singhii R.K. Saxena, Wijayaw., D.Q. Dai, K.D. Hyde \& P.M. Kirk sp. nov.

Index Fungorum Registration Identifier: 555425.

Fig. 9AH

Etymology - The species is named in honour of late Dr. H.P. Singh of the Birbal Sahni Institute of Palaeosciences, Lucknow, India.

Holotype - Diporicellaesporites sp. in R.Y. Singh, Dogra \& Vimal 1985, Journal of Palynology 21: 53, pl. 3, fig. 54, slide no. LUGM 44/10/20, Museum, Department of Geology, Lucknow University, Lucknow, India.

Diagnosis - Fungal spores brown coloured, fusiform with tapering ends, size 78-90 $\times 23-28$ $\mu \mathrm{m}$, diporate, pores terminal, distinct, large, 6-10 $\mu \mathrm{m}$ in diameter, dicellate, uniseptate, septum 4 $\mu \mathrm{m}$ thick, spore wall $1.5 \mu \mathrm{m}$ thick, psilate.

Location - Assam and Meghalaya, India.

Age - Oligocene (Barail Group).

Fusiformisporites sahii R.K. Saxena, Wijayaw., D.Q. Dai, K.D. Hyde \& P.M. Kirk sp. nov.

Fig. 10L

Index Fungorum Registration Identifier: 555491.

Etymology - The species is named in honour of late Dr. S.C.D. Sah of the Wadia Institute of Himalayan Geology, Dehradun, India.

Holotype - Fusiformisporites sp. in R.K. Saxena \& S. Khare 1992, Geophytology 21: 38, pl. 1, fig. 8, BSIP slide no. 10384, coordinates $40.2 \times 107.9$, Museum, Birbal Sahni Institute of Palaeosciences, Lucknow, India.

Diagnosis - Spores fusiform with pointed ends, size 103-110 $\times 35-38 \mu \mathrm{m}$, inaperturate, dicellate, septum 3-4 $\mu \mathrm{m}$ thick, each cell having longitudinal ribs, spore wall $1 \mu \mathrm{m}$ thick, psilate.

Location - Jayamkondacholapuram Well 12, Tiruchirappalli District, Tamil Nadu, India.

Age - Late Palaeocene-Middle Eocene.

Diporicellaesporites tiruchirappalliensis R.K. Saxena, Wijayaw., D.Q. Dai, K.D. Hyde \& P.M. Kirk sp. nov.

Fig. $11 \mathrm{H}$

Index Fungorum Registration Identifier: 555593.

Etymology - The species is named after Tiruchirappalli District of Tamil Nadu, India where the type locality is situated. 


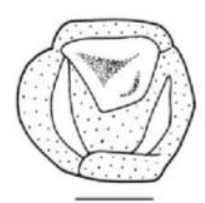

A

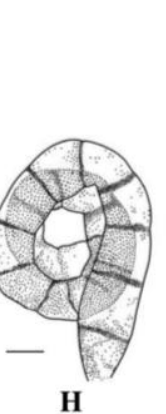

H
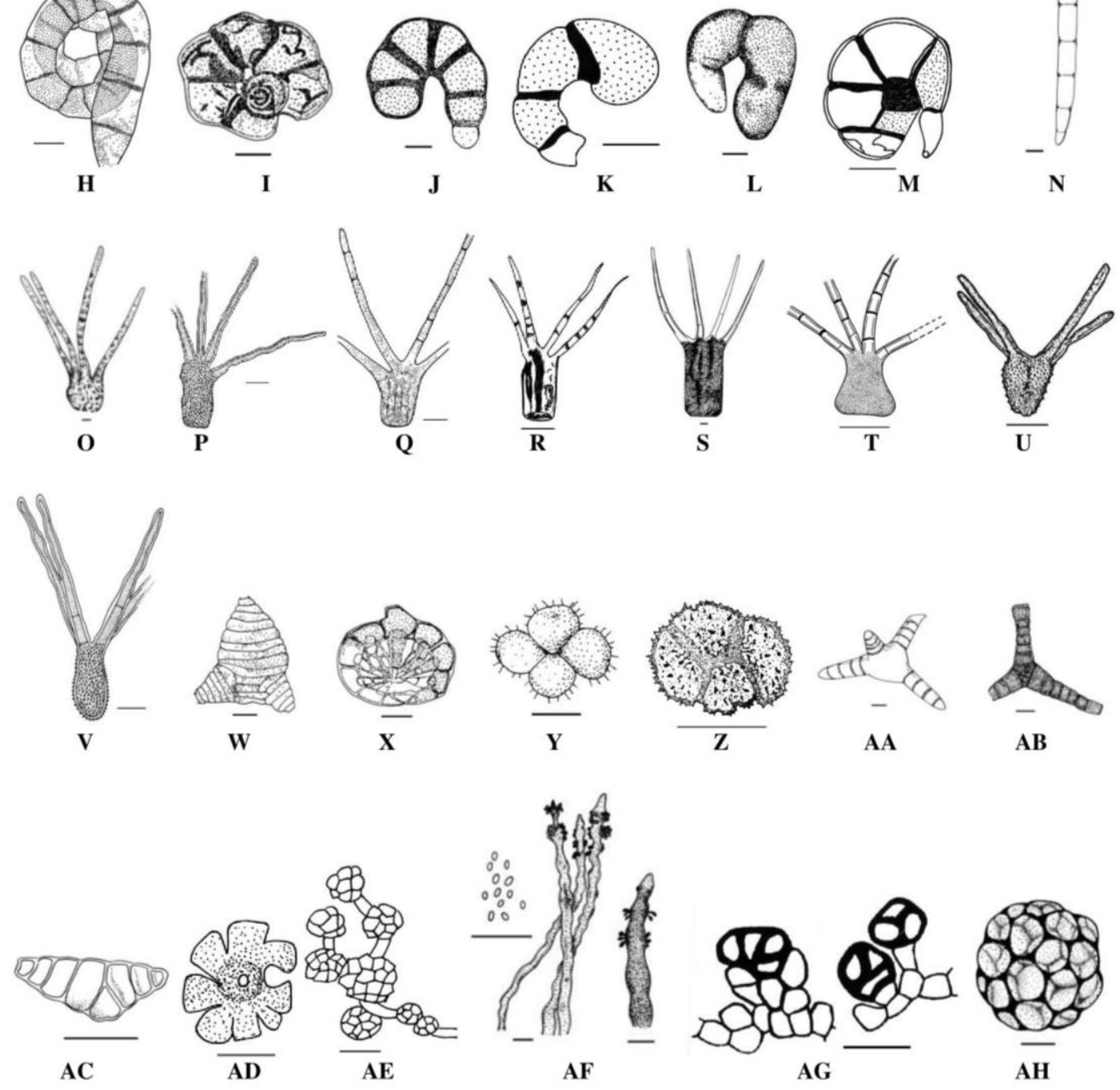

Figure 14 - A Dictyosporae. B-N Helicosporae. O-AC Staurosporae. AD-AH Fossil fungal spore species assigned to modern genera. A Staphlosporonites tetracellatus A. Gupta 2002, Bar $=10 \mu \mathrm{m}$. B Colligerites kutchensis (R.K. Kar \& R.K. Saxena) K.P. Jain \& R.K. Kar 1979, Bar $=8 \mu \mathrm{m}$. C Colligerites trochus B. Samant in R.K. Saxena 2009, Bar $=30 \mu \mathrm{m}$. D Elsikisporonites tubulatus P. Kumar 1990, Bar $=12 \mu \mathrm{m}$. E Helicominites salvinites Barlinge \& Paradkar 1982, Bar $=10 \mu \mathrm{m} . \mathrm{F}$ Helicoonites goosii Kalgutkar \& Sigler 1995, Bar $=10 \mu \mathrm{m}$. G Helicosporiates pirozynskii Kalgutkar \& Sigler 1995, Bar $=8 \mu \mathrm{m}$. H Involutisporonites chowdhryi (K.P. Jain \& R.K. Kar) Kalgutkar \& Janson. 2000, Bar $=10 \mu \mathrm{m}$. I Involutisporonites foraminus R.T. Clarke 1965, Bar $=10$ $\mu \mathrm{m}$. J Palaeocirrenalia elegans Ramanujam \& Srisailam 1980, Bar $=8 \mu \mathrm{m} . \mathrm{K}$ Palaeocirrenalia oligoseptata Ramanujam \& Srisailam 1980, Bar $=20 \mu \mathrm{m}$. L Paleoslimacomyces canadensis 
Kalgutkar \& Sigler 1995, Bar $=5 \mu \mathrm{m}$. M Paleoslimacomyces wilcoxii (Elsik.) Kalgutkar \& Janson. 2000, Bar $=8 \mu \mathrm{m}$. N Retihelicosporonites elsikii Ramanujam \& K.P. Rao 1979, Bar $=20 \mu \mathrm{m} . \mathrm{O}$ Eoglobella longipes W.H. Bradley 1931, Bar $=8 \mu \mathrm{m}$. P Frasnacritetrus conatus R.K. Saxena \& S. Sarkar 1986, Bar $=10 \mu \mathrm{m}$. Q Frasnacritetrus indicus R.K. Saxena \& S. Khare 1991, Bar $=10 \mu \mathrm{m}$. $\mathrm{R}$ Frasnacritetrus jamtahensis A. Gupta 2002, Bar $=15 \mu \mathrm{m}$. S Frasnacritetrus josettae Taug. 1968, Bar $=5 \mu \mathrm{m}$. T Frasnacritetrus masolensis R.K. Saxena \& S.K.M. Tripathi 2011, Bar $=20 \mu \mathrm{m}$. U Frasnacritetrus siwalikus R.K. Saxena et al. 1987, Bar $=10 \mu \mathrm{m}$. V Frasnacritetrus taugourdeaui R.K. Saxena \& S. Sarkar 1986, Bar $=10 \mu \mathrm{m}$. W Mossopisporites multicellulus (P. Ke \& Z.Y. Shi) Kalgutkar \& Janson. 2000, Bar $=10 \mu \mathrm{m}$. X Pesavis tagluensis Elsik \& Janson. 1974, Bar $=10 \mu \mathrm{m}$. Y Spegazzinites cruciformis Félix 1894, Bar $=10 \mu \mathrm{m}$. Z Spegazzinites indicus Ramanujam \& Srisailam 1980, Bar $=10 \mu \mathrm{m}$. AA Tribolites tetrastonyx W.H. Bradley 1964, Bar $=15 \mu \mathrm{m}$. AB Trihyphites fractus (Z.C. Song \& Liu Cao) Kalgutkar \& Janson. 2000, Bar $=10 \mu \mathrm{m}$. AC Triporicellaesporites triangulus Ke \& Shi 1978, Bar $=15 \mu \mathrm{m}$. AD Desmidiospora willoughbyi (W.H. Bradley) D.L.E. Glass, et al. 1986, Bar $=8 \mu \mathrm{m}$. AE Epicoccum deccanense R. Srivast. et al. 2009, Bar $=10 \mu \mathrm{m}$. AF Melanospora primigenia (Casp.) R.K. Saxena, Wijayaw., D.Q. Dai, K.D. Hyde \& P.M. Kirk comb. nov., Bar $=5 \mu \mathrm{m}$. AG Tetracoccosporium eocenum Biradar \& Mahab. 1974, Bar $=20 \mu \mathrm{m}$. AH Thecaphora mohgaoensis (Chitaley \& Yawale) R.K. Saxena, Wijayaw., D.Q. Dai, K.D. Hyde \& P.M. Kirk comb. nov., Bar $=10 \mu \mathrm{m}$.

Holotype - Diporicellaesporites sp. in R.K. Saxena \& S. Khare 1992, Geophytology 21: 39, pl. 1, fig. 6, BSIP slide no. 10381, coordinates $69.2 \times 93.2$, Museum, Birbal Sahni Institute of Palaeosciences, Lucknow, India.

Diagnosis - Spores elongated, size 58-68 $\times 20-22 \mu \mathrm{m}$, tetracellate, terminal cells smaller than the middle ones, septum between two bigger cells $4 \mu \mathrm{m}$ thick, other septa less than $1 \mu \mathrm{m}$ thick, diporate, pores terminal, distinct, $c a .4 \mu \mathrm{m}$ in diameter, spore wall $1.5 \mu \mathrm{m}$ thick, psilate.

Location - Jayamkondacholapuram Well 12, Tiruchirappalli District, Tamil Nadu, India.

Age - Late Palaeocene-Middle Eocene.

Multicellites tamilensis R.K. Saxena, Wijayaw., D.Q. Dai, K.D. Hyde \& P.M. Kirk sp. nov.

Index Fungorum Registration Identifier: 555609.

Fig. 11AJ

Etymology - The species is named after Tamil Nadu State of India where the type locality is situated.

Holotype - Multicellaesporites sp. 1 in R.K. Saxena \& S. Khare 1992, Geophytology 21: 38, pl. 1, fig. 9, BSIP slide no. 10381, coordinates $30.1 \times 100.0$, Museum, Birbal Sahni Institute of Palaeosciences, Lucknow, India.

Diagnosis - Spores elliptical with rounded ends; size 82-90 × 27-29 $\mu \mathrm{m}$, octacellate, septa distinct, 1.5-2 $\mu \mathrm{m}$ thick, no longitudinal slit or furrow present, spore wall $1.5 \mu \mathrm{m}$ thick, psilate.

Location - Jayamkondacholapuram Well 12, Tiruchirappalli District, Tamil Nadu.

Age - Late Palaeocene-Middle Eocene.

\section{Discussion}

It is evident from the fungal spore records that they exhibit a broad range of morphological variations. Since their assignment to modern fungal taxa is seldom possible, these are placed into artificial supra-generic taxa based on morphological characters, e.g. number and nature of cells and characters associated with apertures, septa and spore wall. These may be unicellate, dicellate, tricellate, tetracellate, multicellate, muriform, filiform, spirally coiled and star-like. Similarly, these may be inaperturate, monoaperturate, diaperturate, triaperturate and multiaperturate. These artificial supra-generic taxa are: Amerosporae, Didymosporae, Phragmosporae, Dictyosporae, Helicosporae and Staurosporae. Under each of these, genera are arranged in alphabetical order. Similarly, species are also arranged under each genus in alphabetical order. Five new species, viz. Dicellaesporites vermae, Dyadosporites singhii, Fusiformisporites sahii, Diporicellaesporites tiruchirappalliensis 
and Multicellites tamilensis, and four new combinations, viz. Hypoxylonites disciformis (Sheffy \& Dilcher), Hypoxylonites lanceolatus (Debi Mukh.), Melanospora primigenia (Casp.) and Thecaphora mohgaoensis (Chitaley \& Yawale) are also proposed. The dominant genera, both in number and variety, having more than twenty species are: Dicellaesporites (66 species), Diporicellaesporites (43 species), Diporisporites (35 species), Dyadosporites (43 species), Hypoxylonites (55 species), Inapertisporites (71 species), Monoporisporites (58 species), Multicellaesporites (91 species), Multicellites (46 species), Pluricellaesporites (83 species) and Staphlosporonites (23 species). The diagnostic characters of the most important and commonly occurring fossil fungal spore genera are summarized in Table 2.

Table 2 Summary of diagnostic characters of important, commonly occurring, fossil fungal spores

\begin{tabular}{|c|c|c|}
\hline $\begin{array}{l}\text { Supra-generic } \\
\text { taxa }\end{array}$ & Fungal spore genera & Diagnostic features \\
\hline \multirow[t]{14}{*}{$\begin{array}{l}\text { Amerosporae } \\
\text { Unicellate }\end{array}$} & Basidiosporites Elsik & $\begin{array}{l}\text { Elongate-variable shaped spores with a single pore offset from } \\
\text { one apex, spore wall psilate. }\end{array}$ \\
\hline & $\begin{array}{l}\text { Biporipsilonites Kalgutkar } \\
\text { \& Janson. }\end{array}$ & $\begin{array}{l}\text { Elongate, fusiform to barrel-shaped spores, generally with a } \\
\text { plane of symmetry through the equator, spore wall generally } \\
\text { smooth, occasionally with some subdued sculpture, two terminal } \\
\text { pores, forming pore chambers subtended by a basal septum and } \\
\text { enclosed by thin wall material that further thins centrifugally, } \\
\text { septa thin or thick, may have a central perforation and/or small } \\
\text { septal folds. }\end{array}$ \\
\hline & $\begin{array}{l}\text { Cervichlamydospora } \mathrm{R} . \\
\text { Kar et al. }\end{array}$ & $\begin{array}{l}\text { Chlamydospores sub-circular, dark brown-black, originate from } \\
\text { neck of hyphae; solitary, many hyphae adhere together at base, } \\
\text { branch out laterally at tip; hyphae wall laevigate-granulose, grana } \\
\text { up to } 1 \mu \mathrm{m} \text { thick, sparsely placed. }\end{array}$ \\
\hline & Diporisporites Hammen & Elongate, diporate spores, pores on opposite ends. \\
\hline & Exesisporites Elsik & $\begin{array}{l}\text { Lenticular, monoporate, pore small, pore surrounded by } \\
\text { thickening. }\end{array}$ \\
\hline & $\begin{array}{l}\text { Foveodiporites C.P. Varma } \\
\text { \& Rawat }\end{array}$ & $\begin{array}{l}\text { Diporate, fusiform to elliptic, spore wall relatively thin, } \\
\text { externally smooth, internally smooth, or with punctate, granulate, } \\
\text { foveolate or similar sculpture; pores terminal, complex, } \\
\text { consisting of a thin collar and separated from the spore interior } \\
\text { by one or two septa. }\end{array}$ \\
\hline & Hypoxylonites Elsik & $\begin{array}{l}\text { Oval to elongate, bilateral, psilate spores, provided with elongate } \\
\text { scar, slit or furrow. }\end{array}$ \\
\hline & Inapertisporites Hammen & $\begin{array}{l}\text { Inaperturate, shape and size variable, spore wall psilate to } \\
\text { variously ornamented. }\end{array}$ \\
\hline & $\begin{array}{l}\text { Lacrimasporonites R.T. } \\
\text { Clarke }\end{array}$ & $\begin{array}{l}\text { Spatulate to elliptical spores, spore wall psilate, monoporate, } \\
\text { pore apical. }\end{array}$ \\
\hline & Monoporisporites Hammen & $\begin{array}{l}\text { Monoporate, spherical to sub-spherical spores, spore wall psilate } \\
\text { to finely punctuate. }\end{array}$ \\
\hline & Palaeoamphisphaerella & Elliptical, oblong or rhomboidal spores with rounded ends, \\
\hline & $\begin{array}{l}\text { Ramanujam \& Srisailam } \\
\text { Retidiporites C.P. Varma \& } \\
\text { Rawat }\end{array}$ & $\begin{array}{l}\text { provided with equatorial pore. } \\
\text { Diporate spores with reticulate exine. }\end{array}$ \\
\hline & Spirotremesporites Dueñas & $\begin{array}{l}\text { Psilate, aseptate, elongate-elliptical to oval spores, aperture in the } \\
\text { form of single furrow at an angle to the axis of the spore, straight } \\
\text { or curved to S-shaped or sigmoidal in outline, or spiral around } \\
\text { the spore axis. }\end{array}$ \\
\hline & $\begin{array}{l}\text { Striadiporites C.P. Varma } \\
\text { \& Rawat }\end{array}$ & $\begin{array}{l}\text { Oval to fusiform spores, wall longitudinally ribbed to broadly } \\
\text { reticulate. Two pores, one at each end of the spore on the long } \\
\text { axis. }\end{array}$ \\
\hline \multirow[t]{3}{*}{ Didymosporae } & Dicellaesporites Elsik & $\begin{array}{l}\text { Two-celled, uniseptate spores with variable shapes, inaperturate, } \\
\text { spore wall psilate. }\end{array}$ \\
\hline & $\begin{array}{l}\text { Didymoporisporonites } \\
\text { Sheffy \& Dilcher }\end{array}$ & $\begin{array}{l}\text { Dicellate, uniseptate spores, apex of one cell provided with pore, } \\
\text { spore wall psilate to punctuate. }\end{array}$ \\
\hline & Dyadosporites R.T. Clarke & $\begin{array}{l}\text { Diporate spores, with a single pore at each end, spore wall psilate } \\
\text { to variously sculptured. }\end{array}$ \\
\hline
\end{tabular}


Table 2 Continued.

\begin{tabular}{|c|c|c|}
\hline $\begin{array}{l}\text { Supra-generic } \\
\text { taxa }\end{array}$ & Fungal spore genera & Diagnostic features \\
\hline \multirow{20}{*}{ Phragmosporae } & Fusiformisporites Rouse & $\begin{array}{l}\text { Fusiform, inaperturate spores, split into two equal halves by } \\
\text { equatorial wall, bearing characteristic elongate striae, ribs, } \\
\text { ridges or costae oriented parallel to longer axis. }\end{array}$ \\
\hline & $\begin{array}{l}\text { Hilidicellites Kalgutkar \& } \\
\text { Janson. }\end{array}$ & $\begin{array}{l}\text { Small to medium-sized dicellate spores, with the proximal } \\
\text { end flattened or truncate, due to the presence of a hilum or } \\
\text { pore-like structure, the two cells generally of comparable size; } \\
\text { spore wall thin, smooth or with subdued sculpture. }\end{array}$ \\
\hline & Alleppeysporonites & Spores branched, multicellate, septate, individual cell \\
\hline & Ramanujam \& K.P. Rao & $\begin{array}{l}\text { rectangular, basal and terminal cells provided with a } \\
\text { conspicuous appendage. }\end{array}$ \\
\hline & $\begin{array}{l}\text { Axisporonites Kalgutkar \& } \\
\text { Janson. }\end{array}$ & $\begin{array}{l}\text { Inaperturate, tricellate spores, elliptical in shape, two polar } \\
\text { cells smaller, thicker, triangular, with dark pigmentation, } \\
\text { central cell large, hyaline; septa thick. }\end{array}$ \\
\hline & $\begin{array}{l}\text { Brachysporisporites R.T. } \\
\text { Lange \& P.H. Sm. }\end{array}$ & $\begin{array}{l}\text { Obovate, turbinate or pyriform, multi-celled spores, cells } \\
\text { broader than long, gradually diminishing in size towards the } \\
\text { attachment cell which is the smallest, with very dark, thick } \\
\text { bands of septa similarly reducing in size. }\end{array}$ \\
\hline & $\begin{array}{l}\text { Cannanorosporonites } \\
\text { Ramanujam \& K.P. Rao }\end{array}$ & $\begin{array}{l}\text { Tetracellate, barrel-shaped spores, basal and terminal cells } \\
\text { smaller than central cells. }\end{array}$ \\
\hline & $\begin{array}{l}\text { Ceratohirudispora R. Kar } \\
\text { et al. }\end{array}$ & $\begin{array}{l}\text { Conidiophore small, growth terminated by production of } \\
\text { apical conidium; conidium enlarges laterally in opposite } \\
\text { direction to produce two-three arms, conidia 5-10 celled, } \\
\text { septa with broad base and narrow tip. }\end{array}$ \\
\hline & Chaetosphaerites Felix & $\begin{array}{l}\text { Sporidia strongly obtuse spindle-shaped, almost like that of a } \\
\text { cylinder with rounded ends, consist of } 4 \text { segments, two } \\
\text { median, dark coloured cells larger than the two others. }\end{array}$ \\
\hline & Circinoconites R. Kar et al. & $\begin{array}{l}\text { Conidia acrogenous, strongly spiraled, solitary, coiled, not in } \\
\text { chains or slime, } 8-14 \text { septate, fist-shaped, dark brown, } \\
\text { constricted at septa, cells increasing in diameter from base to } \\
\text { apex, dissimilar, spirally arranged. }\end{array}$ \\
\hline & $\begin{array}{l}\text { Cladosporiumsporinites } \\
\text { Debi Mukh. }\end{array}$ & $\begin{array}{l}\text { Conidia cylindrical, oblong, rounded at both the ends, 3-4 } \\
\text { septate, fuliginous (dark soot colour), septa slightly } \\
\text { constricted. }\end{array}$ \\
\hline & Diporicellaesporites Elsik & $\begin{array}{l}\text { Elongate, diporate spores, one pore at each end of the spore, } \\
\text { wall psilate to finely structured. }\end{array}$ \\
\hline & $\begin{array}{l}\text { Diporipollis S.K. Dutta \& } \\
\text { S.C.D. Sah }\end{array}$ & $\begin{array}{l}\text { Diporate; globular to sub-spheroidal; pores placed one over } \\
\text { the other, circular in shape, and encircled by one or more } \\
\text { thickened rims; exine thin, surface sculpture psilate to } \\
\text { scabrate or finely granulate. }\end{array}$ \\
\hline & $\begin{array}{l}\text { Dwayabeejaesporonites } \\
\text { Debi Mukh. }\end{array}$ & $\begin{array}{l}\text { Conidiophores with } 14-15 \text { cells arranged in acropetal order, } \\
\text { thick walled, enclosed in an undulating conidiophores wall; } \\
\text { conidiophores up to } 200 \mu \mathrm{m} \text { size, apical cell mostly smaller. }\end{array}$ \\
\hline & $\begin{array}{l}\text { Edmundmasonaesporites } \\
\text { Debi Mukh. }\end{array}$ & $\begin{array}{l}\text { Spore multicellular, septate, dark in colour; } 5 \text { celled, apical } \\
\text { cell enlarged, globular, vacuolated, apical cell larger than the } \\
\text { basal one, spore wall psilate. }\end{array}$ \\
\hline & Foveoletisporonites & Four or more celled, elongate spores, spore wall foveolate, \\
\hline & & foveolae irregularly aligned. \\
\hline & $\begin{array}{l}\text { Kumarisporites Kalgutkar } \\
\text { \& Janson. }\end{array}$ & $\begin{array}{l}\text { Tricellate, inaperturate spores, central cell may be larger than } \\
\text { the tapering terminal cells; septa thicker than spore wall; } \\
\text { spore wall ornamented by longitudinal ribs running full length } \\
\text { of the spore, tapering towards the poles. }\end{array}$ \\
\hline & $\begin{array}{l}\text { Mathurisporites Kalgutkar } \\
\text { \& Janson. }\end{array}$ & $\begin{array}{l}\text { Hilate spores, generally consisting of a darker central part } \\
\text { with } 2-4 \text { cells, and proximal and distal parts of a single to few } \\
\text { hyaline cells. No distal pore. }\end{array}$ \\
\hline & Multicellaesporites Elsik & $\begin{array}{l}\text { Three or more celled spores, shape variable, a longitudinal slit } \\
\text { or furrow present, inaperturate, spore wall psilate or } \\
\text { ornamented or differentially coloured or thickened. }\end{array}$ \\
\hline
\end{tabular}


Table 2 Continued.

\begin{tabular}{|c|c|c|}
\hline $\begin{array}{l}\text { Supra-generic } \\
\text { taxa }\end{array}$ & Fungal spore genera & Diagnostic features \\
\hline & $\begin{array}{l}\text { Multicellites Kalgutkar \& } \\
\text { Janson. }\end{array}$ & $\begin{array}{l}\text { Multicellate, uniseriate, inaperturate, number of cells three to } \\
\text { many, terminal cells usually rounded; spore wall usually } \\
\text { smooth, of medium thickness, septa generally perforate, or } \\
\text { with septal folds. }\end{array}$ \\
\hline & Nigrosporites Debi Mukh. & $\begin{array}{l}\text { Conidia oval/ lanceolate, somewhat flattened, large, } \\
\text { absolutely opaque, colour black, spore wall hyaline. }\end{array}$ \\
\hline & Ornasporonites & Fusiform, four-celled, diporate spores, basal and apical cells \\
\hline & Ramanujam \& K.P. Rao & much small, one pore at each end. \\
\hline & Pluricellaesporites & Three or more celled spores, long, monoporate, psilate to \\
\hline & Hammen & scabrate. \\
\hline & $\begin{array}{l}\text { Quilonia K.P. Jain \& R.C. } \\
\text { Gupta }\end{array}$ & $\begin{array}{l}\text { Filamentous, multicellular spores, apical and basal portions } \\
\text { narrow, central wide. Basal stalk prominent with one or two } \\
\text { rectangular thick-walled cells; apical cell mostly incomplete, } \\
\text { curved, central portion broad, elongate with irregularly } \\
\text { shaped furrow-like suture, inside the filament at different } \\
\text { places occur one to four small circular, ostiolate bodies. Exine } \\
\text { thick, margin undulated. }\end{array}$ \\
\hline & $\begin{array}{l}\text { Ramasricellites Kalgutkar } \\
\text { \& Janson. }\end{array}$ & $\begin{array}{l}\text { Inaperturate, tetracellate spores, ellipsoidal, with central cells } \\
\text { broader, thicker walled and more pigmented than the terminal } \\
\text { cells; terminal cells thin-walled to hyaline, with rounded } \\
\text { ends;septa (or septal bases) thick and dark, evenly spaced. }\end{array}$ \\
\hline & $\begin{array}{l}\text { Reduviasporonites L.R. } \\
\text { Wilson }\end{array}$ & $\begin{array}{l}\text { Conidia-like spores occurring in uniseriate chains, } \\
\text { subspherical, slightly flattened at the contacts with adjacent } \\
\text { spores, all approximately same diameter, walls } 1-2 \mu \mathrm{m} \text { thick, } \\
\text { uniform, smooth or slightly rough, yellow or brown, } \\
\text { translucent. }\end{array}$ \\
\hline & $\begin{array}{l}\text { Scolecosporites R.T. Lange } \\
\text { \& P.H. Sm. }\end{array}$ & $\begin{array}{l}\text { Long to very long, linear filamentous phragmospores, hilate, } \\
\text { with or without distal pore, length many times width of spore. } \\
\text { Spores scalariform, commonly broken and lacking proximal } \\
\text { and/or distal portions; wall and septa commonly thin; septa } \\
\text { often with septal folds. Not or barely indented at septa. }\end{array}$ \\
\hline & $\begin{array}{l}\text { Varmasporites Kalgutkar } \\
\text { \& Janson. }\end{array}$ & $\begin{array}{l}\text { Fusiform, four-celled spores, inaperturate, with a pronounced } \\
\text { constriction at the thick median septum, and with a distinct } \\
\text { ribbed or striate sculpture parallel to the long axis. }\end{array}$ \\
\hline \multirow[t]{6}{*}{ Dictyosporae } & Dictyosporites Felix & $\begin{array}{l}\text { Inaperturate, multicellate, muriform spores, cells rounded to } \\
\text { rounded polygonal. Overall shape rounded, oval/ovoid to } \\
\text { elongate. }\end{array}$ \\
\hline & Kutchiathyrites R.K. Kar & $\begin{array}{l}\text { Hilate conidia, fan shaped, formed by numerous linear } \\
\text { filaments radiating out from the hilum, conidia may be } \\
\text { flattened, filaments may be joined to their neighbours, or } \\
\text { partially free, and may branch towards the periphery. }\end{array}$ \\
\hline & $\begin{array}{l}\text { Lirasporis R. Potonié \& } \\
\text { S.C.D. Sah }\end{array}$ & $\begin{array}{l}\text { Fungal bodies oval-elliptical with equal or unequal, broad, } \\
\text { generally notched ends. Mycelia, long, septate, } \pm \text { parallel to } \\
\text { one another, extending from one end to other; wall generally } \\
\text { laevigate, sometimes granulose. }\end{array}$ \\
\hline & $\begin{array}{l}\text { Papulosporonites } \\
\text { Schmied. \& A.J. Schwab }\end{array}$ & $\begin{array}{l}\text { Fungal remains of globular to elongate shape, consisting of } \\
\text { numerous more or less polygonal cells that are firmly fused } \\
\text { into mulberry-shaped aggregates. Cells without any regular } \\
\text { order, or concentrically arranged; one to three of the } \\
\text { innermost cells commonly much larger. Occasionally } \\
\text { individual aggregates fused together. }\end{array}$ \\
\hline & Polyadosporites Hammen & $\begin{array}{l}\text { Spores subspherical, loosely aggregated in clusters, with } \\
\text { individual cells not connected to others by shared walls; } \\
\text { clusters (colonies?) more or less regularly spherical to } \\
\text { subspherical. }\end{array}$ \\
\hline & $\begin{array}{l}\text { Polycellaesporonites Anil } \\
\text { Chandra et al. }\end{array}$ & $\begin{array}{l}\text { Elongate, multicellate, inaperturate, psilate, one end rounded, } \\
\text { other end giving rise to a tube-like projection, cells arranged } \\
\text { in clusters. }\end{array}$ \\
\hline
\end{tabular}


Table 2 Continued.

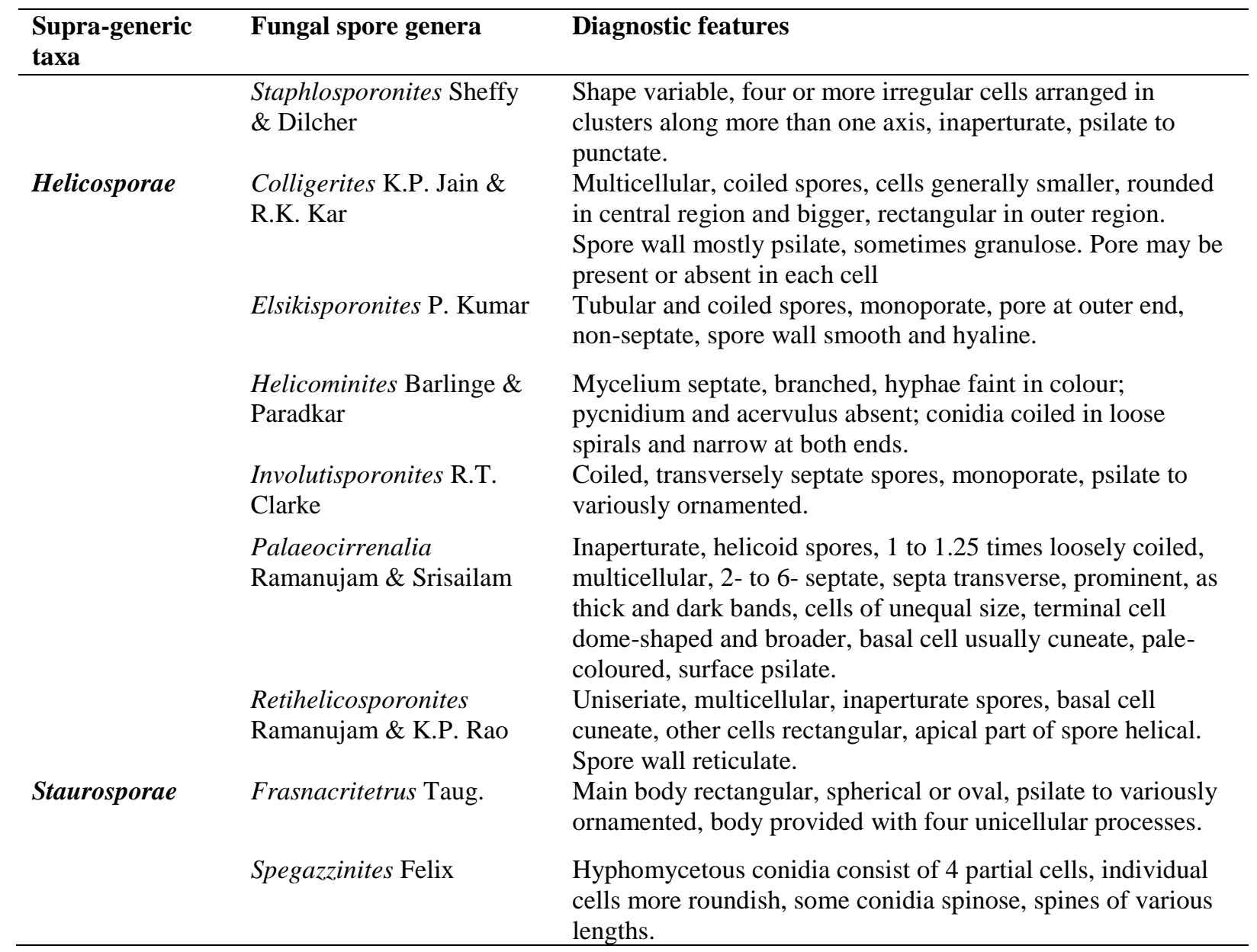

\section{Relationship of fossil fungal spore genera with extant fungal taxa}

The major applications of any kind of fossil study are in biostratigraphic zonation, correlation and dating of the sedimentary rock successions and in determination of palaeoclimate, palaeoecology and environment of deposition. For palaeoclimatic and palaeoecological interpretations, "Uniformitarian Principle" (Uniformitarianism) is applied. This principle is based on the assumption that the same natural laws and processes that operate in our present-day scientific observations have always operated in the universe in the past and apply everywhere in the universe. This principle is largely accepted by earth scientists the world over and is simplified as "The Present is the key to the Past".

The primary prerequisite for applying this principle is to relate fossils with their modern counterparts. Since habitats, climate and ecology of present day organisms is known, it can easily be suggested to be the same for their ancient fossil relatives. This prompts fossil workers, including palaeomycologists, to trace affinity of fossil taxa to their present day representatives. An attempt has been made here to trace relationship of fossil fungal spore taxa with extant fungi. This also helps in interpreting evolutionary trend of a taxon or group of taxa.

Palaeomycologists and fungal taxonomists have been using molecular clock methods and fossil records for 'dating evolutionary divergences in the fungal tree of life' (Lücking et al. 2009). However, some studies suggested that the early fungi could have existed as lichens (Eriksson 2005). Taylor et al. (2015) accepted fossil fungal genera in six different phyla (viz. Chytridiomycota, Blastocladiomycota, Glomeromycota, Ascomycota, Basidiomycota, Zygomycota), according to the modern classification in the tree of life. Even though fossil fungal genera have been reported in six different phyla, fungal spores are mainly restricted to Ascomycota and Basidiomycota. Moreover, in many cases, the spores have been compared with hyphomycetous or 
coelomycetous taxa, the two main artificial groups in traditional mycology (i.e. only morphological characters have been considered in taxonomy).

Among the linked modern genera, hyphomycetous taxa which have separate conidiophores or rarely synnemata are more important than other morphological groups. For examples, Alternaria Nees, Dictyosporium Corda, Macrosporium Bon., Septosporium Corda and Stemphylium Wallr. have been repeatedly compared with fossil fungal genera. Moreover, Helicoma Corda, Helicomina L.S. Olive, Slimacomyces Minter and Trochophora R.T. Moore have also been compared with fossil genera which have 'helicoid' conidia. Recent DNA based phylogenetic studies showed that Tubeufia Penz. \& Sacc., a sexually typified genus, has helicoma-like asexual morphs thus we can assume some of these helicoma-like fossil asexual genera might have links with other sexual morphs.

Fossil fungal spore taxa and their counterparts according to modern taxonomy are summarized in Tables 3, 4. Table 3 presents fungal spore species assigned to extant fungal genera. Altogether, 24 genera have been recorded, 19 belonging to Ascomycota, four to Basidiomycota and one to Chytridiomycota. Table 4 presents fossil fungal spore genera and species and their probable relationship with extant taxa. Here also, Ascomycota constitute the bulk of assemblage, with more dominant classes being Dothideomycetes and Sordariomycetes.

\section{Palaeoenvironmental Implications}

Fungi, being heterotrophic in nature, are found in close association with specific plants and animals, and when found in fossil state are indicative of similar kind of situations during the geological past. Fossil fungi, therefore, may provide useful information about the palaeoenvironment, past habitats and their hosts. In this regard, fossil epiphyllous fungi can be more reliable and advantageous. Fossil spororocarps of microthyriaceous taxa are generally considered to be reliable palaeoenvironmental indicators. Their occurrences are, generally, correlated with moist, humid climates and tropical to subtropical temperatures. The role of fossil fungi in interpreting past environment is now receiving increased attention (Kar \& Saxena 1976, Ramanujam \& Rao 1978, van Geel et al. 1981, Pirozynski et al. 1988, Stubblefield \& Taylor 1988, Saxena \& Tripathi 2011). Wolf (1966a, b, 1967a, b, 1968) interpreted the fluctuating abundance of fungal spores in lakes as reflecting environmental perturbations and vegetation changes caused by changes in climate. Wolf (1967a), in particular, restated the importance of fungal spore analyses complement in pollen analyses in interpreting floristic changes and the sequence of vegetational modifications in ancient times. The fossil peltate fungi are generally identified to the extant Microthyriaceae which are ectoparasites on leaves of higher plants of tropical to subtropical zones growing particularly in areas with high humidity. Edwards (1922) reported the occurrence of this group on conifer needles. Microthyriaceous fungi grow best in rain forests, rain forest margins and along creek banks (Ramanujam 1982). Hence their presence is generally indicative of a wet tropical climate with heavy precipitation.

The palaeohabitat interpretations based on fossil epiphyllous microthyriaceous fungi and their germlings is well established through the studies on their modern equivalents growing on leaf litter from various Australian regions. These studies have shown the occurrence of microthyriaceous germlings in greater number on the plants growing in moist tropical habitats. Such studies have great potential in interpreting the palaeoclimate and should be undertaken for other geographical areas. However, the ecological interpretations based on epiphyllous fungi should be made with caution because some of these are reported to occur in wider latitudinal ranges (Dilcher 1965, Selkirk 1975). It is therefore, advisable to take into consideration the complete palynological assemblage for palaeoenvironmental interpretations. In most of the cases, coordinated studies on megafossils in association with palynological assemblages may provide more accurate information about the palaeoenvironmental conditions. Dilcher (1965) published an account of epiphyllous fungi from Microthyriales, Erysiphales and Meliolales, thriving on leaves of different plants, from the middle Eocene of Tennessee, U.S.A. Such studies bear great potential for determining the regional palaeoclimate by comparing the fossils with extant taxa of known habitats. Environmental 
interpretations based on the presence of Microthyriaceae may, however, sometimes be hampered due to the incorrect identification of the material. Their presence in dispersed fossil assemblages should, therefore, be ascertained before deciphering the past climate. The red alga Caloglossa leprieurii, generally found on grasses of brackish water marshes may be confused with Trichopeltinites due to morphological resemblance. Similarly, marine green alga Ulvella lens also resembles the fructifications of Microthyriaceae.

Studies, particularly focusing on host-fungus relationship, are also of great significance in attempting the palaeoenvironmental interpretations. Chitaley (1978) and Chitaley and Yawale (1978) provided valuable palaeoecological information based on the presence of fossil fungal spores in petrified plant materials from the Deccan Intertrappean beds of Central India.

Similar kinds of interpretations were published by Kar et al. (2003, 2004a, b, 2005, 2006) and Sharma et al. (2005). These studies emphasize the importance of some fungal spores in evaluation of palaeoenvironment. Kar et al. (2003) reported a sporocarp assignable to Polyporaceae (Basidiomycota) from the Lameta Formation (Late Cretaceous) exposed in Madhya Pradesh, India. This fossil, called Lithopolyporales zeerabadensis, resembles the modern Fomes which are saprobes on dead wood of various trees. Kar et al. (2004a) described a fossil fungus showing affinity to Colletotrichum Corda (Melanconiaceae), from an Intertrappean bed exposed at Mohgaon-Kalan Village, Chhindwara District, Madhya Pradesh, India. The modern species of this genus causes red rot in the economically important plants. The fossil of this fungus shows setae on the margins of the acervuli and was found to be preserved on a leaf cuticle. It was called Protocolletotrichum deccanensis. Kar et al. (2004b) described fossil parasitic fungi and epiphyllous fruiting bodies from the coprolite of dinosaurs. The coprolite yielding these fossils was collected from the Lameta Formation (Maastrichtian) of Central India. Occurrence of these fungi indicates that the plant leaves infected by the recovered fungi were part of dinosaurs' diet. Kar et al. (2006) reported two types of fossil Ingoldian aquatic fungi from the Miocene sediments of Mizoram, India. The first type, comparable to the extant Tetrachaetum, is needle-shaped and belongs to the scolicospores whereas the other type, comparable to the extant Ceratosporella, possesses globular to triangular body belongs to staurospores.

On the basis of fossil fungi, Kar \& Saxena (1976) interpreted a warm and humid, tropical climate during the Palaeocene (Matanomadh Formation) of Kutch, western India with the support from spores and pollen of vascular plants. Ramanujam \& Srisailam (1980) recorded a prevalence of Palaeocirrenalia, the helicoid spore, in Neogene sediments of Kerala, India and interpreted brackish to marine conditions by comparing them to the similar modern dematiaceous hyphomycete, Cirrenalia, which is commonly found in such an environment. The presence of other spores in the same strata, affiliated to Grallomyces, Sporidesmium, Spegazzinia, Amphisphaerella and Isthmospora, also supports this interpretation of a tropical climate. This conclusion was corroborated by pteridophytic spores and angiospermous pollen from the same strata and a tropical climate was concluded (Ramanujam \& Rao 1978, Ramanujam \& Srisailam 1980). A warm and humid environment has been interpreted by Kalgutkar \& McIntyre (1991) in the Canadian Arctic due to the presence of helicosporous fungal types. Studies on certain fungal assemblages, sporomorphs and sporocarps, in coordination with micro- and megafossils of other groups, are used to infer the palaeoenvironment (Dilcher 1973). Pirozynski (1976a, b) and Ramanujam (1982) stressed the importance of coordinating the study of fossil fungi with their modern counterparts, in order to realize the full potential of fossil fungal spores as indicators of ancient environment. Ramanujam (1982) further urged that only those types, clearly related to modern taxa of which the environmental requirements are known, are relevant in such studies. These assessments are based on the assumption that the palaeoclimatic sensitivity of fossil taxa was similar to that of the comparable modern counterparts. In this regard special stress was laid to explore the possibility of relating fossil fungal spores with those of modern fungi so as to realize their full potential in determining the ancient environment. However, only those types that could be related to the modern forms with certainty should be taken into account for this specific purpose. Jarzen \& Elsik 
(1986) showed how the habitat and host preference of fungal spores recovered from recent deposits along the Luangwa River in Zambia, conceivably can be used to deduce the environment of Neogene sediments with similar fossil fungal spores.

Table 3 Fossil fungal spore species assigned to extant fungal genera

\begin{tabular}{|c|c|c|c|c|c|}
\hline Phylum & Class & Order & Family & Extant genera & Fossil species \\
\hline \multirow[t]{14}{*}{$\begin{array}{l}\text { Ascomycota Caval.- } \\
\text { Sm. }\end{array}$} & $\begin{array}{l}\text { Dothideomycetes } \\
\text { O.E. Erikss. \& Winka }\end{array}$ & $\begin{array}{l}\text { Botryosphaeriales } \\
\text { C.L. Schoch }\end{array}$ & $\begin{array}{l}\text { Botryosphaeriaceae Theiss. } \\
\text { \& P. Syd. }\end{array}$ & Diplodia Fr. & $\begin{array}{l}\text { D. rodei Mahab. [Current name: Diplodites } \\
\text { rodei (Mahab.) Kalgutkar et al.]; D. sahnii } \\
\text { Singhai [Current name: Diplodites sahnii } \\
\text { (Singhai) Kalgutkar et al.] }\end{array}$ \\
\hline & & $\begin{array}{l}\text { Capnodiales } \\
\text { Woron. }\end{array}$ & Mycosphaerellaceae Lindau & Ramularia Sacc. & R. oblongispora Casp. \\
\hline & & $\begin{array}{l}\text { Pleosporales Luttr. } \\
\text { ex M.E, Barr }\end{array}$ & Didymellaceae Gruyter & Epicoccum Link. & E. deccanense R. Srivast. et al. \\
\hline & & & Pleosporaceae Nitschke & Alternaria Nees ex Fr. & $\begin{array}{l}\text { A. malayensis Trivedi \& C.L. Verma [Current } \\
\text { name: Pluricellaesporites malayensis (Trivedi } \\
\text { \& C.L. Verma) Kalgutkar \& Janson.] }\end{array}$ \\
\hline & & & Torulaceae Corda & Torula Pers. ex Fr. & $\begin{array}{l}\text { T. globulifera Casp., T. heteromorpha Casp., } \\
\text { T. mengeana Casp. \& R. Klebs }\end{array}$ \\
\hline & & $\begin{array}{l}\text { Sporidesmiales } \\
\text { Crous }\end{array}$ & Sporidesmiaceae Fr. & $\begin{array}{l}\text { Sporidesmium Link ex } \\
\text { Fr. }\end{array}$ & S. henryense Dilcher \\
\hline & $\begin{array}{l}\text { Lecanoromycetes } \\
\text { O.E. Erikss. \& Winka }\end{array}$ & Lecanorales Nannf. & Sphaerophoraceae Fr. & Sphaerophorus Pers. & S. moniliformis Menge \\
\hline & $\begin{array}{l}\text { Sordariomycetes O.E. } \\
\text { Erikss. \& Winka }\end{array}$ & $\begin{array}{l}\text { Chaetosphaeriales } \\
\text { Huhndorf. et al. }\end{array}$ & $\begin{array}{l}\text { Chaetosphaeriaceae Réblová } \\
\text { et al. }\end{array}$ & $\begin{array}{l}\text { Chaetosphaeria Tul. \& } \\
\text { C. Tul. }\end{array}$ & C. elsikii M.J. Pound et al. \\
\hline & & $\begin{array}{l}\text { Coronophorales } \\
\text { Nannf. }\end{array}$ & $\begin{array}{l}\text { Ceratostomataceae G. } \\
\text { Winter }\end{array}$ & Melanospora Corda & G. primigenius Casp. \\
\hline & & $\begin{array}{l}\text { Diaporthales } \\
\text { Nannf. }\end{array}$ & $\begin{array}{l}\text { Botryosphaeriaceae Theiss. } \\
\& \text { P. Syd. }\end{array}$ & Botryodiplodia Sacc. & $\begin{array}{l}\text { B. mohgaoensis Barlinge \& Paradkar [Current } \\
\text { name: Diplodites mohgaoensis (Barlinge \& } \\
\text { Paradkar) Kalgutkar et al.] }\end{array}$ \\
\hline & & $\begin{array}{l}\text { Hypocreales Nannf. } \\
\text { ex Korf \& Lizon }\end{array}$ & $\begin{array}{l}\text { Bionectriaceae Samuels \& } \\
\text { Rossman }\end{array}$ & $\begin{array}{l}\text { Acremonium Link ex } \\
\text { Fries. }\end{array}$ & A. succineum Casp. \\
\hline & & $\begin{array}{l}\text { Magnaporthales } \\
\text { Thongk. et al. }\end{array}$ & $\begin{array}{l}\text { Magnaporthaceae P.F. } \\
\text { Cannon }\end{array}$ & $\begin{array}{l}\text { Clasterosporium } \\
\text { Schwein. }\end{array}$ & C. eocenicum Fritel \& R. Vig. \\
\hline & & $\begin{array}{l}\text { Sordariales Chadef. } \\
\text { ex D. Hawksw. \& } \\
\text { O.E. Erikss. }\end{array}$ & Lasiosphaeriaceae Nannf. & Zopfiella $\mathrm{G}$. Winter & Z. neogenica O'Keefe \\
\hline & & $\begin{array}{l}\text { Trichosphaeriales } \\
\text { M.E, Barr }\end{array}$ & $\begin{array}{l}\text { Trichosphaeriaceae } \mathrm{G} . \\
\text { Winter }\end{array}$ & Brachysporium Sacc. & $\begin{array}{l}\text { B. minutum Trivedi \& C.L. Verma [Current } \\
\text { name: Pluricellaesporites minutus }\end{array}$ \\
\hline
\end{tabular}


Table 3 Continued.

\begin{tabular}{|c|c|c|c|c|c|}
\hline Phylum & Class & Order & Family & Extant genera & Fossil species \\
\hline & & & & & $\begin{array}{l}\text { (Trivedi \& C.L. Verma) ex Kalgutkar \& } \\
\text { Janson.] }\end{array}$ \\
\hline & Incertae sedis & Incertae sedis & $\begin{array}{l}\text { Diporothecaceae Mibey \& } \\
\text { D. Hawksw. }\end{array}$ & $\begin{array}{l}\text { Diporotheca C.C. } \\
\text { Gordon \& C.G. Shaw }\end{array}$ & D. doniana O'Keefe, D. gorda O'Keefe \\
\hline & Incertae sedis & Incertae sedis & Incertae sedis & Desmidiospora Thaxt. & $\begin{array}{l}\text { D. marginiconvoluta Kalgutkar, D. } \\
\text { willoughbyi (W.H. Bradley) D.L.E. Glass, et } \\
\text { al. }\end{array}$ \\
\hline & Incertae sedis & Incertae sedis & Incertae sedis & Potamomyces K.D. Hyde & $\begin{array}{l}P . \text { batii (Sancay) ex Nuñez Otaño et al.; } P \text {. } \\
\text { elsikii (Nandi \& A. Sinha) Nuñez Otaño et } \\
\text { al.; } \\
P . \text { fournieri (Elsik \& Jarzen) Nuñez Otaño et } \\
\text { al.; } P \text {. invaginatus (Elsik \& Jarzen) Nuñez } \\
\text { Otaño et al.; } P \text {. magnus (Elsik \& Jarzen) } \\
\text { Nuñez Otaño et al.; } P \text {. mulleri (Nandi \& A. } \\
\text { Sinha) Nuñez Otaño et al.; } P \text {. pontidiensis } \\
\text { (Sancay) ex Nuñez Otaño et al. }\end{array}$ \\
\hline & Incertae sedis & Incertae sedis & Incertae sedis & $\begin{array}{l}\text { Rhexoampullifera P.M. } \\
\text { Kirk }\end{array}$ & $\begin{array}{l}\text { R. stogieana M.J. Pound et al., R. sufflata } \\
\text { M.J. Pound et al. }\end{array}$ \\
\hline & Incertae sedis & Incertae sedis & Incertae sedis & $\begin{array}{l}\text { Tetracoccosporium } \\
\text { Szabó. }\end{array}$ & T. eоcenum Biradar \& Mahab. \\
\hline \multirow{4}{*}{$\begin{array}{l}\text { Basidiomycota } \\
\text { Whittaker ex R.T. } \\
\text { Moore }\end{array}$} & $\begin{array}{l}\text { Agaricomycetes } \\
\text { Doweld }\end{array}$ & $\begin{array}{l}\text { Boletales E.-J. } \\
\text { Gilbert }\end{array}$ & Sclerodermataceae Corda & Scleroderma Pers. & S. echinosporites Rouse \\
\hline & $\begin{array}{l}\text { Agaricostilbomycetes } \\
\text { R. Bauer et al. }\end{array}$ & $\begin{array}{l}\text { Agaricostilbales } \\
\text { Oberw. \& R. Bauer }\end{array}$ & $\begin{array}{l}\text { Chionosphaeraceae Oberw. \& } \\
\text { Bandoni }\end{array}$ & Stilbum Tode ex Fr. & S. succini Casp. \\
\hline & $\begin{array}{l}\text { Ustilaginomycetes } \\
\text { Warm. }\end{array}$ & $\begin{array}{l}\text { Urocystidales R. } \\
\text { Bauer \& Oberw. }\end{array}$ & Glomosporiaceae Cif. & Thecaphora Fingerh. & $\begin{array}{l}\text { T. mohgaoensis (Chitaley \& Yawale) R.K. } \\
\text { Saxena, Wijayaw., D.Q. Dai, K.D. Hyde \& } \\
\text { P.M. Kirk comb. nov. } \\
\text { [Synonyms: Sorosporium mohgaoense } \\
\text { Chitaley \& Yawale; Papulosporonites } \\
\text { mohgaoensis (Chitaley \& Yawale) Kalgutkar } \\
\text { \& Janson.] }\end{array}$ \\
\hline & & & Ustilaginaceae Tul. \& C. Tul. & Ustilago (Pers.) Roussel. & $\begin{array}{l}\text { U. deccani Chitaley \& Yawale [Current } \\
\text { name: Inapertisporites deccani (Chitaley \& } \\
\text { Yawale) Kalgutkar \& Janson.] }\end{array}$ \\
\hline $\begin{array}{l}\text { Chytridiomycota } \\
\text { Doweld }\end{array}$ & $\begin{array}{l}\text { Chytridiomycetes M. } \\
\text { Möbius }\end{array}$ & Chytridiales Cohn & Chytriomycetaceae Letcher & Entophlyctis A. Fisch. & $\begin{array}{l}\text { E. willoughbyi W.H. Bradley [Current name: } \\
\text { Desmidiospora willoughbyi (W.H. Bradley) } \\
\text { D.L.E. Glass et al.] }\end{array}$ \\
\hline
\end{tabular}


Table 4 Fossil fungal spore genera and species and their probable relationship with extant taxa $\left({ }^{*}\right.$ when the equivalent extant genus name is not available, higher rank taxon name is given)

\begin{tabular}{|c|c|c|c|c|c|c|}
\hline Phylum & Class & Order & Family & Modern genus & Fossil genus & Fossil species \\
\hline $\begin{array}{l}\text { Ascomycota Caval.- } \\
\text { Sm. }\end{array}$ & $\begin{array}{l}\text { Dothideomycetes } \\
\text { O.E. Erikss. \& } \\
\text { Winka }\end{array}$ & $\begin{array}{l}\text { Microthyriales G. } \\
\text { Arnaud } \\
\text { Pleosporales } \\
\text { Luttr. ex M.E, } \\
\text { Barr }\end{array}$ & $\begin{array}{l}\text { Mycosphaerellaceae } \\
\text { Lindau } \\
\text { Piedraiaceae Viégas } \\
\text { ex Cif. et al. } \\
- \\
\text { Dictyosporiaceae } \\
\text { Boonmee \& K.D. Hyde }\end{array}$ & $\begin{array}{l}\text { Helicomina L.S. } \\
\text { Olive } \\
\text { Trichosporium P. } \\
\text { Karst. } \\
- \\
\text { Dictyosporium } \\
\text { Corda }\end{array}$ & $\begin{array}{l}\text { Cladosporiumsporinite } \\
\text { s Debi Mukh. } \\
\text { Involutisporonites R.T. } \\
\text { Clarke } \\
\text { Trichosporites Félix } \\
\text { *Mariusia D. Pons \& } \\
\text { Boureau } \\
\text { Dictyosporites Félix } \\
\end{array}$ & 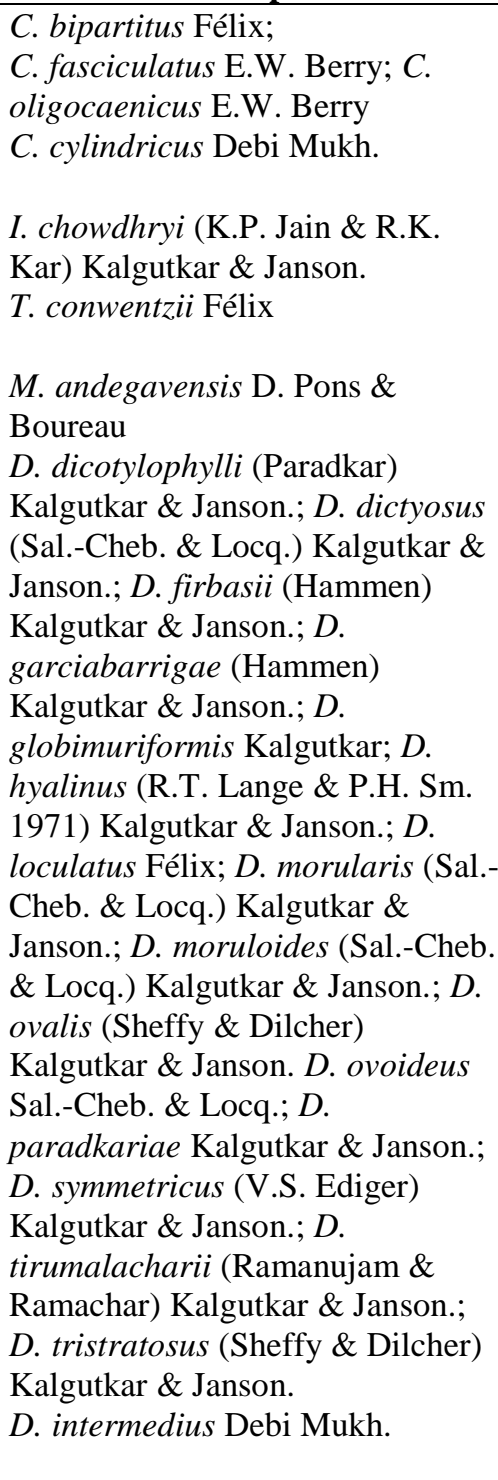 \\
\hline
\end{tabular}


Table 4 Continued.

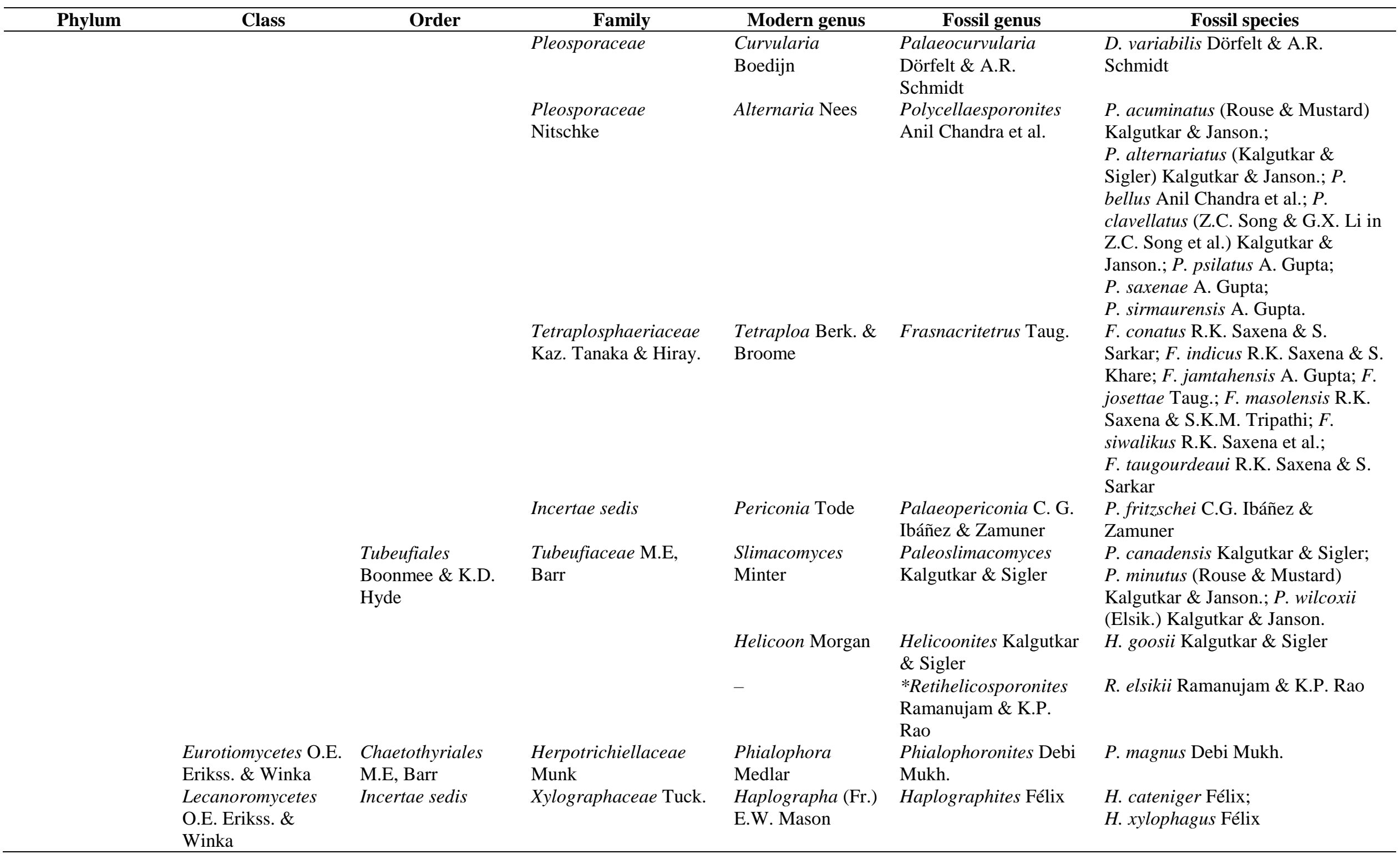


Table 4 Continued.

\begin{tabular}{|c|c|c|c|c|c|c|}
\hline Phylum & Class & Order & Family & Modern genus & Fossil genus & Fossil species \\
\hline & Leotiomycetes O.E. & Helotiales Nannf. & Discinellaceae & Tetrachaetum & Tribolites W.H. & T. triangulatus (Peppers) Kalgutkar \\
\hline & Erikss. \& Winka & ex Korf \& Lizoň & $\begin{array}{l}\text { Ekanayaka \& K.D. } \\
\text { Hyde }\end{array}$ & $\begin{array}{l}\text { Ingold/Lemonnier } \\
a \text { De Wild. }\end{array}$ & Bradley & $\begin{array}{l}\text { \& Janson.; T. tetrastonyx W.H. } \\
\text { Bradley }\end{array}$ \\
\hline & \multirow[t]{2}{*}{ Pezizomycetes } & \multirow[t]{2}{*}{ Pezizales J. Schrot. } & Pezizaceae Dumort. & - & $\begin{array}{l}\text { *Pezizasporites T.C. } \\
\text { Huang }\end{array}$ & P. taiwanensis T.C. Huang \\
\hline & & & $\begin{array}{l}\text { Sarcoscyphaceae Le } \\
\text { Gal ex Eckblad }\end{array}$ & Cookeina Kuntze & $\begin{array}{l}\text { Fusiformisporites } \\
\text { Rouse }\end{array}$ & $\begin{array}{l}F . \text { acutus } \text { P. Kumar; } F \text {, Barmerensis } \\
\text { R.K. Saxena \& S.K.M. Tripathi; } F \text {. } \\
\text { elongatus Ramanujam \& K.P. Rao; } \\
\text { F. striaoctoformis Mart.-Hern. \& } \\
\text { Tom.-Ort. }\end{array}$ \\
\hline & \multirow{11}{*}{$\begin{array}{l}\text { Saccharomycetes } \mathrm{G} . \\
\text { Winter } \\
\text { Sordariomycetes } \\
\text { O.E. Erikss. \& } \\
\text { Winka }\end{array}$} & $\begin{array}{l}\text { Saccharomycetales } \\
\text { Luerss. }\end{array}$ & $\begin{array}{l}\text { Dipodascaceae Engl. } \\
\& \text { E. Gilg }\end{array}$ & Geotrichum Link & $\begin{array}{l}\text { Geotrichites Stubblef. } \\
\text { et al. }\end{array}$ & G. glaesarius Stubblef. et al. \\
\hline & & $\begin{array}{l}\text { Amphisphaeriales } \\
\text { D. Hawksw. \& } \\
\text { O.E. Erikss. }\end{array}$ & $\begin{array}{l}\text { Amphisphaeriaceae G. } \\
\text { Winter }\end{array}$ & $\begin{array}{l}\text { Ceratosporium } \\
\text { Schwein. }\end{array}$ & $\begin{array}{l}\text { Ceratohirudispora } \mathrm{R} . \\
\text { Kar et al. }\end{array}$ & C. miocenica $\mathrm{R}$. Kar et al. \\
\hline & & & & $\begin{array}{l}\text { Amphisphaerella } \\
\text { (Sacc.) Kirschst. }\end{array}$ & $\begin{array}{l}\text { Palaeoamphisphaerell } \\
\text { a Ramanujam \& } \\
\text { Srisailam }\end{array}$ & $\begin{array}{l}P . \text { keralensis Ramanujam \& } \\
\text { Srisailam; } P \text {. pirozynskii } \\
\text { Ramanujam \& Srisailam; } P . \\
\text { tankensis (G. Norris) Kalgutkar \& } \\
\text { Janson. }\end{array}$ \\
\hline & & $\begin{array}{l}\text { Hypocreales } \\
\text { Lindau }\end{array}$ & Incertae sedis & Gliomastix Guég. & $\begin{array}{l}\text { Parapotamomyces } \\
\text { O'Keefe }\end{array}$ & P. maydiformis O'Keefe \\
\hline & & Microascales & Halosphaeriaceae E. & Cirrenalia Meyers & Palaeocirrenalia & P. elegans Ramanujam \& \\
\hline & & Luttr. ex Benny \& & Müll. \& Arx ex & \& R.T. Moore & Ramanujam \& & Srisailam; \\
\hline & & R.K. Benj. & Kohlm. & & Srisailam & $\begin{array}{l}\text { P. oligoseptata } \text { Ramanujam \& } \\
\text { Srisailam }\end{array}$ \\
\hline & & $\begin{array}{l}\text { Sordariales Chad. } \\
\text { ex D. Hawksw. \& } \\
\text { O.E. Erikss. }\end{array}$ & $\begin{array}{l}\text { Sordariaceae G. } \\
\text { Winter }\end{array}$ & $\begin{array}{l}\text { Neurospora Shear } \\
\& \text { B.O. Dodge }\end{array}$ & $\begin{array}{l}\text { Diploneurospora K.P. } \\
\text { Jain \& R.C. Gupta }\end{array}$ & D. tewarii K.P. Jain \& R.C. Gupta \\
\hline & & & Incertae sedis & $\begin{array}{l}\text { Edmundmasonia } \\
\text { Subram. }\end{array}$ & $\begin{array}{l}\text { Edmundmasonaesporit } \\
\text { es Debi Mukh. }\end{array}$ & E. globulatus Debi Mukh. \\
\hline & & Trichosphaeriales & Trichosphaeriaceae $\mathrm{G}$. & Brachysporium & Brachysporisporites & B. antarcticus Z.C. Song \& Liu \\
\hline & & M.E, Barr & Winter & Sacc. & R.T. Lange \& P.H. Sm. & $\begin{array}{l}\text { Cao; B. atratus Kalgutkar; B. } \\
\text { bullatus Kalgutkar; B. catinus } \\
\text { (Elsik \& Janson.) Kalgutkar \& } \\
\text { Janson.; B. cotalis (Elsik \& Janson.) } \\
\text { Norris; B. fustitudinus G. Norris; }\end{array}$ \\
\hline
\end{tabular}


Table 4 Continued.

\section{Phylum}

Class

Order

Family

Modern genus

Fossil genus

B. grandus Z.C. Song \& Liu Cao;

B. inuvikensis M.G. Parsons \& G.

Norris; B. lageniformis Z.C. Song;

B. longovatus Z.C. Song \& Liu

Cao; B. magnus B. Samant in R.K.

Saxena; B. maximus (P. Ke \& Z.Y.

Shi) Kalgutkar \& Janson.; $B$.

opimus (Elsik \& Janson.) G. Norris;

B. ovoidus Z.C. Song \& Liu Cao; $B$

pyriformis R.T. Lange \& P.H. Sm.;

$B$. tenuis P. Kumar; $B$ thraceous

(V.S. Ediger) Kalgutkar \& Janson.

Xylariales Nannf. Xylariaceae Tul. \&

C. Tul.
Hypoxylon

Adans./Xylaria Hill

ex Schrank
Hypoxylonites Elsik an

Xylariasporites Debi

Mukh.
Kalgutkar \& Janson; $H$.

armentroutii Elsik; $H$. asymetricus (Sal.-Cheb. \& Locq.) Elsik; H. ater (P. Kumar) R.K. Saxena; $H$.

brazosensis Elsik; H. bhubanensis

Nandi \& Subhra Banerjee; $H$.

chaiffetzii Elsik; H. chuittensis

Elsik; $H$. claibornensis Elsik; $H$.

curvatus (Ramanujam \& K.P. Rao)

Elsik; $H$. edigeri Elsik; $H$.

elongatioides Elsik; H. ellipsoideus Sal.-Cheb. \& Locq. ex Kalgutkar \& Janson; H. eopleistocenicus Elsik;

H. felixii Elsik; H. foldexinus Elsik; $H$. fusiformis Elsik; $H$. foyelensis

Bianchin. et al.; H. gulfensis Elsik;

H. horowitzii Elsik; H. kumarii

Kalgutkar \& Janson.; H. lammonsii

Elsik; H. lineatus Elsik; H. magnus

Elsik; $H$. megaexinus Elsik; $H$.

minutus Elsik; H. miocenicus Elsik

$H$. neogenicus Nandi \& Subhra

Banerjee; H. ovaloides Elsik; $H$.

pirozynskii Elsik; $H$.

pirozynskioides Elsik: 
Table 4 Continued.

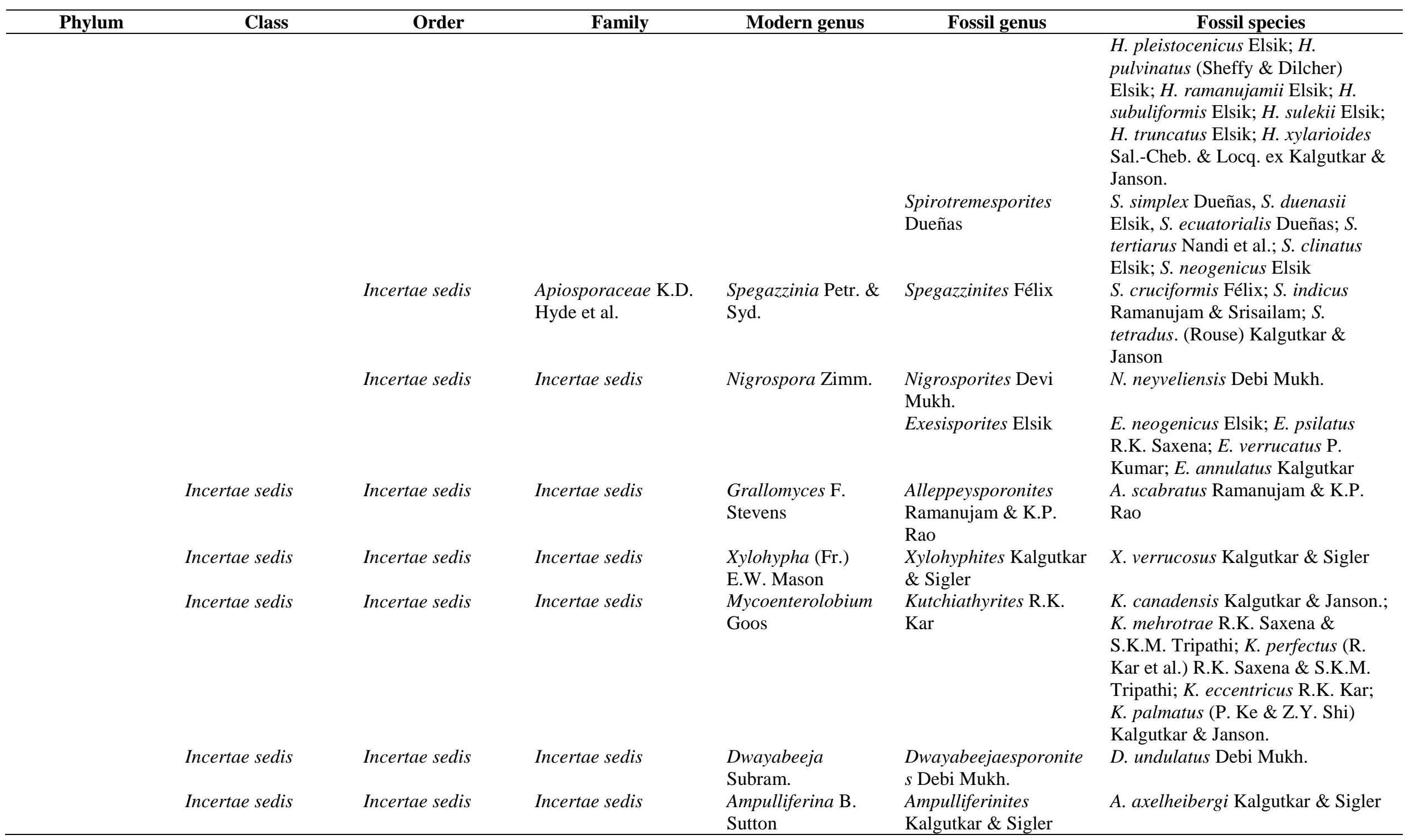


Table 4 Continued.

\begin{tabular}{|c|c|c|c|c|c|c|}
\hline Phylum & Class & Order & Family & Modern genus & Fossil genus & Fossil species \\
\hline \multirow{4}{*}{$\begin{array}{l}\text { Basidiomycota } \\
\text { Whittaker ex R.T. } \\
\text { Moore }\end{array}$} & Exobasidiomycetes & Exobasidiales & Graphiolaceae Clem. & Graphiola Poit. & Graphiolites Fritel & G. sabaleos Fritel \\
\hline & Begerow et al. & Henn. & \& Shear & & & \\
\hline & Pucciniomycetes $\mathrm{R}$. & Pucciniales Caruel & Pucciniaceae & Puccinia Pers. & Pucciniasporonites & P. arcotensis Ramanujam \& \\
\hline & Bauer et al. & & Chevall. & & $\begin{array}{l}\text { Ramanujam \& } \\
\text { Ramachar }\end{array}$ & Ramachar \\
\hline \multirow{4}{*}{$\begin{array}{l}\text { Basidiomycota } \\
\text { (unclassified) }\end{array}$} & - & - & - & - & *Basidiosporites Elsik & B. fournieri Elsik \\
\hline & & & & & *Diporisporites & D. ellipsoides (Sal.-Cheb. \& Locq.) \\
\hline & & & & & Hammen & $\begin{array}{l}\text { Kalgutkar \& Janson.; D. } \\
\text { naviculoides (Sal.-Cheb. \& Locq.) }\end{array}$ \\
\hline & & & & & & Kalgutkar \& Janson. \\
\hline Blastocladiomycota & Blastocladiomycetes & Blastocladiales & Coelomomycetaceae & Coelomomyces & Striadiporites C.P. & S. asper (P. Ke \& Z.Y. Shi) \\
\hline T.Y. James & Doweld & H.E. Petersen & Couch & Keilin & Varma \& Rawat & $\begin{array}{l}\text { Kalgutkar \& Janson.; S. bistriatus } \\
\text { (P. Ke \& Z.Y. Shi) G. Norris; S. } \\
\text { boletelloides Sal.-Cheb. \& Locq.; S. } \\
\text { californicus Elsik \& Janson.; S. } \\
\text { dolium (P. Ke \& Z.Y. Shi) } \\
\text { Kalgutkar \& Janson.; S. inflexus (P. } \\
\text { Ke \& Z.Y. Shi) G. Norris; S. } \\
\text { irregularis Kalgutkar; S. minor } \\
\text { (Z.C. Song \& Z.H. Sun) Z.C. Song } \\
\text { et al.; S. multistriatus (P. Ke \& Z.Y. } \\
\text { Shi) G. Norris; S. reticulatus C.P. } \\
\text { Varma \& Rawat; S. retistriatus (P. } \\
\text { Ke \& Z.Y. Shi) Kalgutkar \& } \\
\text { Janson.; S. sanctaebarbarae Elsik \& } \\
\text { Janson.; S. spiralis Kalgutkar \& } \\
\text { Janson.; S. taiwanensis T. C. Huang }\end{array}$ \\
\hline Incertae sedis & - & - & - & - & $\begin{array}{l}\text { Eoglobella W.H. } \\
\text { Bradley }\end{array}$ & E. longipes W.H. Bradley \\
\hline
\end{tabular}

Kalgutkar \& McIntyre (1991) described two helicosporous fungal types (now known as Helicoonites and Helicosporiates Kalgutkar \& Sigler, 1995) from the Eocene Eureka Sound Formation in the Canadian Arctic, that are morphologically similar to the extant warm-climate, subaqueousgeneric groups Helicoon-Helicodendron and Helicosporium, and used their presence to postulate pools of open water in a warm, humid palaeoenvironment of the region. 
The importance of fossil fungal distribution and their relative abundance in palaeoecological studies was recognized also by Elsik (1969). He interpreted the relative abundance of Exesiporites during the Pliocene of northern Gulf of Mexico, to indicate a warmer period, and the fluctuations before and afterward, therefore, as expressions of a cyclic climate. With reference to the ubiquitous Hypoxylon, Elsik (op. cit.) wrote that "The genus Hypoxylon, and even some of its species, are distributed world-wide. Some living species are restricted to the North Temperate zone, or occur outside that area only as varieties. Some species are restricted to local geographic regions. The tropics apparently support more varieties. These conclusions regarding Hypoxylon (Miller 1961) will have validity in the fossil record, once it is demonstrated that species diversity is reflected in spore morphology."

\section{Biostratigraphic Implications}

It is an established fact that fossils of all kinds, especially microfossils, are indispensable in biostratigrapic studies, e.g. biostratigraphic zonation and correlation, of sedimentary stratigraphic successions. These may either be subsurface stratigraphic sequences obtained from the boreholes or exposed sedimentary rocks obtained from variety of locations, e.g. road and stream cuttings, escarpments, sea cliffs and mine face sections. The main types of microfossils found in slides prepared for palynological studies are bryophytic and pteridophytic spores, gymnospermous and angiospermous pollen, dinoflagellate cysts and other micro-algae and fungal remains. In biostratigraphic studies, it is better to consider and apply data derived from all kind of microfossils. The inferences derived from multi-disciplinary cumulative data, i.e. a synergistic approach, are always more sound and reliable.

Fossil fungi are found in the form of spores, mycelia, sporophores and symbiotic associations, and are commonly observed in macerated residues prepared for palynological studies. Fossil records indicate that microthyriaceous fungi occur in the Cenozoic sedimentary rocks all over the world. Saxena \& Tripathi (2011) made an attempt to summarize the stratigraphic distribution of different fossil sporocarp genera recorded from the Indian Tertiary sequences (Saxena \& Tripathi 2011: 198, fig. 392). This shows that the taxa assigned to Callimothallus Dilcher 1965 and Cucurbitariaceites R.K. Kar et al. 1972 are long ranging and are recorded from Palaeocene to Pliocene sediments. Different species of Phragmothyrites W.N. Edwards mark their presence in Palaeocene to Miocene and Microthyriacites Cookson in Eocene to Miocene. Forms restricted to Miocene sequences only are: Asterothyrites Cookson, Euthythyrites Cookson, Parmathyrites K.P. Jain \& R.C. Gupta, Plochmopeltinites Cookson, Ratnagiriathyrites R.K. Saxena \& N.K. Misra, Trichopeltinites Cookson and Trichothyrites Rosend.

Although most of the fungal spore genera are long ranging and do not bear much stratigraphic significance, some are morphologically distinct and have a restricted range in geological time. Applicability of fungal spores in biostratigraphy has, therefore, increased with the record of such characteristic spores with limited stratigraphic ranges (Kalgutkar \& Jansonius 2000). Because of their wide geographic distributions, fungal spores commonly occur even in those samples in which other biostratigraphic markers are not present. The differentiation of dispersed ascospores and conidia becomes easier with increasing complexity of their morphology. Coiled helicospores and stellate staurospores are more distinctive than didymospores or amerospores. Some fungal spores, such as species of Ctenosporites Elsik \& Janson., Foveodiporites C.P. Varma \& Rawat, Dictyosporites Félix, Frasnacritetrus Taug., Fusiformisporites Rouse, Palaeoamphisphaerella Ramanujam \& Srisailam, Pesavis Elsik \& Janson., Striadiporites C.P. Varma \& Rawat, and helicoid spores like Involutisporonites R.T. Clarke, Helicosporiates Kalgutkar \& Sigler, Helicoonites Kalgutkar \& Sigler, Palaeocirrenalia Ramanujam \& Srisailam, Paleoslimacomyces Kalgutkar \& Sigler are so discrete that they are readily identified, and generally accepted as index fossils. However, detailed information on their stratigraphic ranges is a prerequisite for their application in biostratigraphic studies. (Kalgutkar \& Jansonius 2000).

Graham (1962) was amongst the pioneers to suggest the possibility of using fungal spores for supplementing age determinations in palynological studies. According to Elsik (1970), although a 
variety of fungal spores have been recorded from Mesozoic strata worldwide, their morphological complexity and frequency increase in the Cenozoic. He noted that Fusiformisporites Rouse and similar longitudinally ribbed forms appear to be restricted to the Cenozoic. Elsik (1970) further observed that fossil fungal spores described as Exesisporites which resemble the extant Hypoxylon type are more frequently recorded in Neogene sediments. Kalgutkar (1993) showed how some fungal species with records restricted to the Palaeocene through Eocene in other Palaeogene strata of Arctic Canada, were useful in arriving at an age of the Bonnet Plume Formation.

According to Kalgutkar \& Jansonius (2000), the highly distinct Pesavis tagluensis Elsik \& Janson. has been important in stratigraphic studies (Jansonius 1976, Staplin, 1976, Ioannides \& McIntyre 1980, Norris 1982, Young \& McNeil 1984). Elsik \& Jansonius (1974) and Lange (1978a, b) pointed out the importance of forms like P. tagluensis Elsik \& Janson. and Ctenosporites eskerensis Elsik \& Janson. in dating sediments in which other palynological fossils are rare. Jansonius (1976) reported the characteristic association of $P$. tagluensis Elsik \& Janson. with Striadiporites C.P. Varma \& Rawat spores in the Beaufort region, Mackenzie Delta region, Canada. Their highest occurrences were used to define the top of the Pesavis zone. The lower part of the zone exhibits great numbers and variety of septate, diporate ascospores, and the upper part an abundance of one-celled spores. Norris (1986) assigned a middle Eocene age to the Pesavis zone within the lower part of the Richards Formation, Mackenzie Delta region, Canada. Kalgutkar \& Sweet (1988) documented the first Maastrichtian occurrence of Pesavis in north-western Canada. They further developed the stratigraphic usefulness of Pesavis by documentating a phylogenetic lineage starting in the Maastrichtian with $P$. parvus Kalgutkar \& Sweet and extending into the Eocene with $P$. tagluensis Elsik \& Janson. Transitory stages, with changes in the morphology from $P$. parvus through P. tagluensis, were found in the Palaeocene. White (1990) used the presence of Ctenosporites eskerensis and Pesavis tagluensis, in combination with Tilia spp., to determine the age of an unnamed (Cretaceous-Tertiary) sedimentary unit in the Union Port Louis well (west coast of Graham Island, Queen Charlotte Islands, B.C., Canada), as well as of a float from the nearby Mud Bay Creek, which he estimated to be between early Eocene and early Oligocene in age. There is indication that the top of the range of P. tagluensis is somewhat younger in the more southern British Columbia sediments than it is in the Beaufort Sea region.

A similar observation of fungal spore populations in and above the Pesavis zone was presented by Staplin (1976). Fournier \& Elsik (1984) revealed the existence of hundreds of well preserved species of fungal spores from DSDP Site 493, Leg 66, and showed the stratigraphic value of some characteristic spores in early Miocene to Recent assemblages.

Kar (1979) recognized an assemblage zone, viz. Aplanosporites robustus Cenozone in the Maniyara Fort Formation (Oligocene) of Kutch, Gujarat, India on the basis of abundant occurrence of Aplanosporites robustus [Current name: Palaeomycites robustus (Kar) Kalgutkar \& Janson. 2000]. Kar (1990) also recognized this assemblage zone from the borehole sequences of Tripura, North-eastern India.

Ramanujam (1982) opined that maximum diversity in the morphology of fungal spores was attained by late Cretaceous and Early Tertiary. While evaluating the stratigraphic potential of fungal remains in Indian stratigraphic sequences, he further observed that spores with relatively simpler morphology (aporate, aseptate and essentially smooth) were recorded from the early Mesozoic and earlier strata. Ornamented spores appeared mostly in late Cretaceous. On the discoveries of diverse Tertiary horizons of India, Ramanujam (1982), noted that ornately sculptured walls were encountered consistently in the Neogene sediments, and that Neogene assemblages appeared to be different from those present in the Palaeogene.

Stratigraphic distribution of selected, commonly occurring, fossil fungal spore taxa (arranged age-wise, oldest at the bottom and youngest at the top) and their probable relationship with modern counterparts and location of occurrence is summarized in Table 5. 
Table 5 Stratigraphic distribution of selected, commonly occurring, fossil fungal spore taxa (arranged age-wise, oldest at the bottom and youngest at the top) and their probable relationship with modern counterparts and location of occurrence

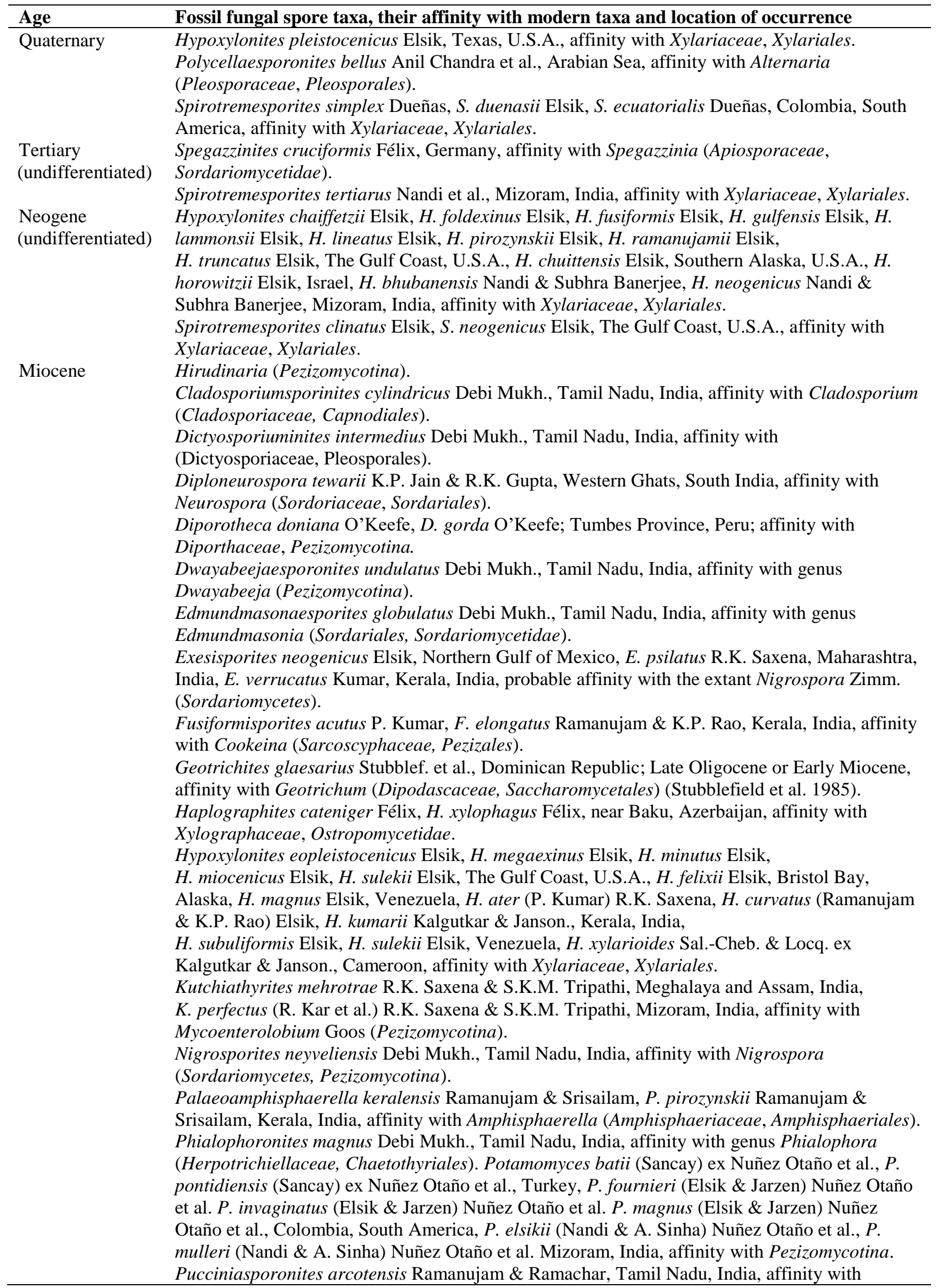


Table 5 Continued.

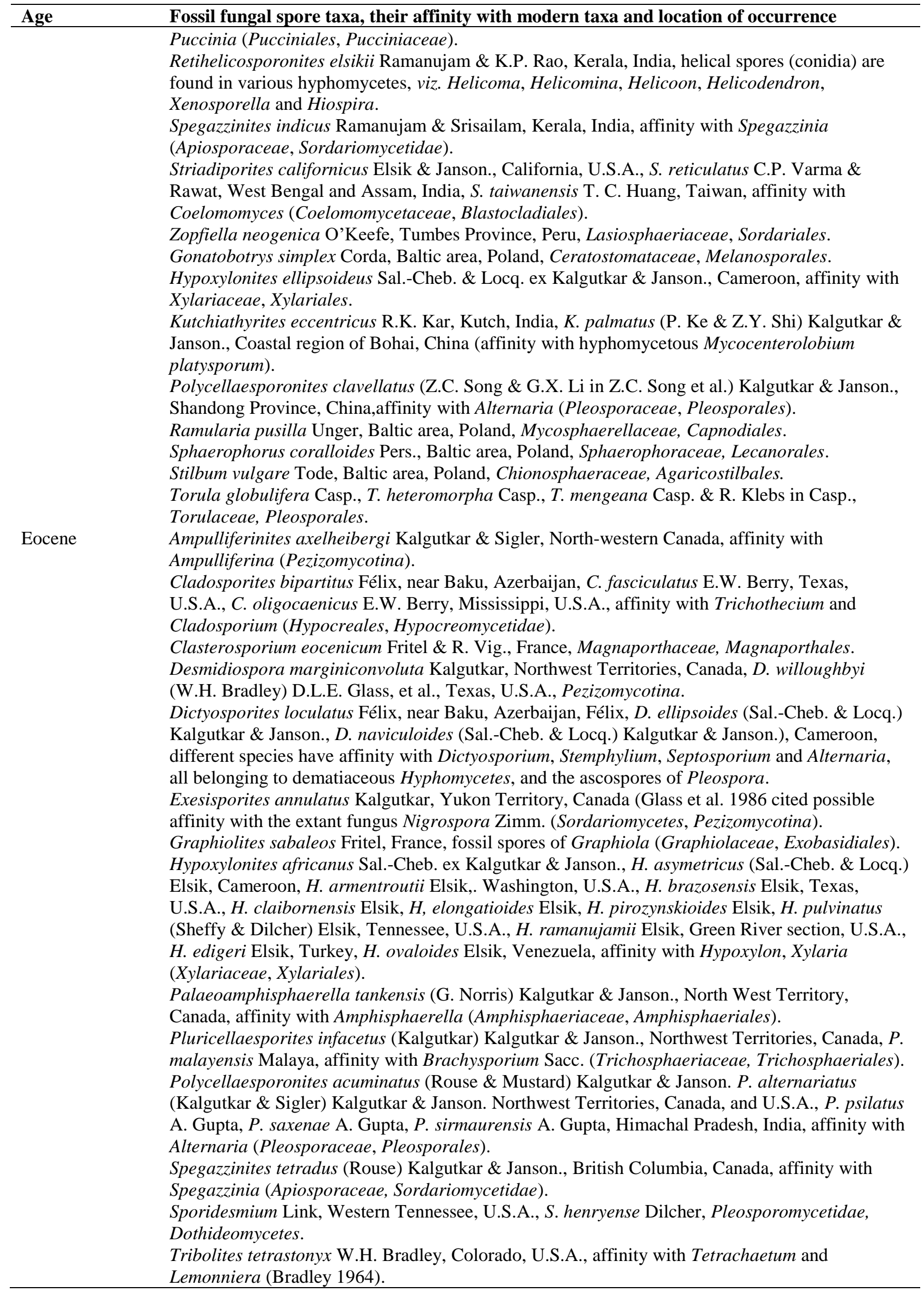


Table 5 Continued.

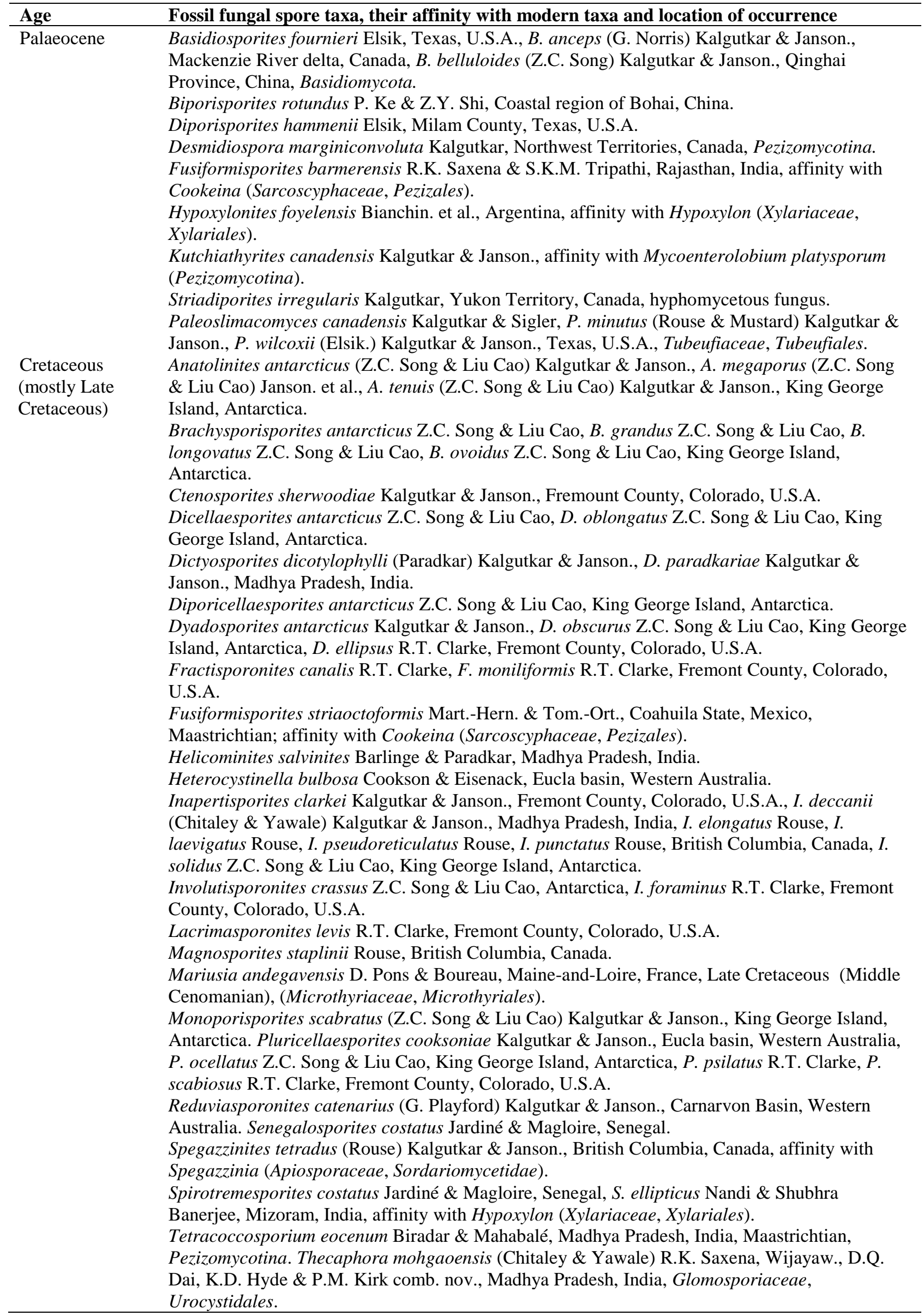


Table 5 Continued.

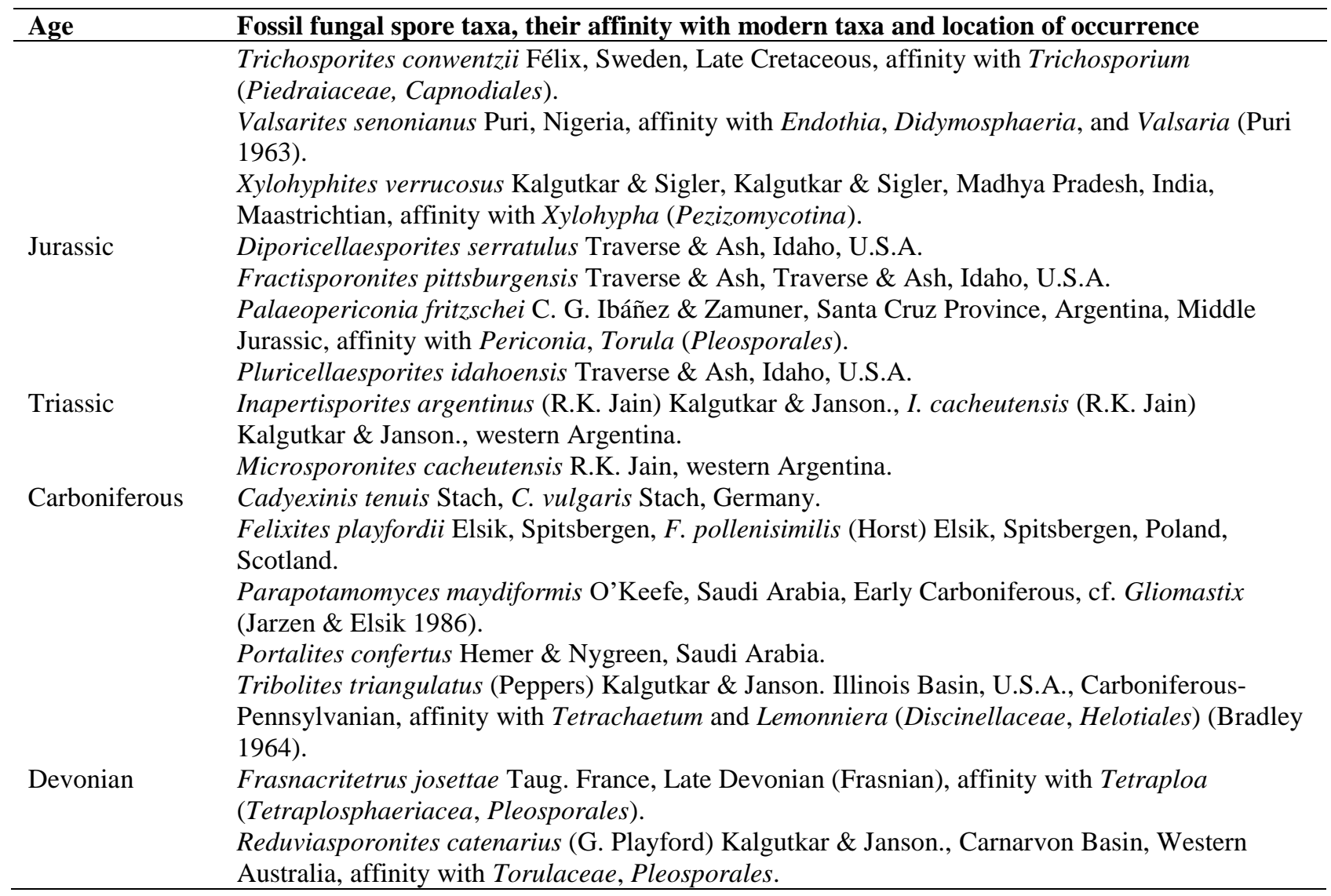

\section{Suggestions for future studies}

1. All microfossil (including fossil fungi) studies begin with field work and collection of samples. Therefore, a sound knowledge of basic principles of field geology and clear concept of various types of sedimentary rocks and stratigraphic units are essential for reliable results. However, it has been observed that in a number of cases fossil fungal remains have been recorded from the grab samples without their accurate stratigraphic locations. This makes them of limited value in biostratigraphic studies. Exploring the stratigraphic significance of fossil fungal taxa is an inviting task. In order to achieve this, it is necessary that samples for their studies must be collected from the measured stratigraphic sections with precise location of their positions in the stratigraphic column. Data obtained from such sections only can be relied for biostratigraphic inferences.

2. It is strongly felt that the data gathered so far from microfossil studies require more precision. To achieve this, a synergistic approach must be adopted. Fossil fungal data need be tagged, as far as possible, with data obtained from other disciplines in order to obtain better and more dependable results and conclusions.

3. Use of obsolete and invalidly published names of palynotaxa create problems and must be avoided. It is suggested that only current legitimate names of fossil fungal taxa must be used. Nomenclatural repositories, viz. Index Fungorum and MycoBank, are indispensable to find out the correct status of names of fungal taxa.

4. Sincere attempts must be made by expert mycologists to standardize the morphotaxonomy and character evaluation of fossil fungal taxa and to trace the link of fossil fungal remains with modern fungi. Such endeavour will help in elucidating the palaeoecology and evolutionary trends within this group.

5. Data interpretation for stratigraphy and palaeoecology must also take into account various factors operating for dispersal and deposition of microfossils. 
6. Recognition of recycled microfossils is very helpful in locating source area/ formation and in interpreting palaeogeography. However, non-recognition of such elements may lead to erroneous conclusions. Fluorescence microscopy is useful in detecting such fossils.

7. Subsurface samples, obtained from boreholes, usually represent uninterrupted sections, almost completely unaffected by weathering agencies. Such samples are particularly useful where some part of the sequence is eroded away or covered either by thick vegetation or by modern sediments. Their study requires to be intensified to evaluate subsurface data vis-à-vis that from surface sections.

8. A sound knowledge of various rules and regulations as laid down in the "International Code of Nomenclature for algae, fungi and plants" (Turland et al. 2018) is essential for bringing stability and discipline in the studies on fossil fungi. In addition, the articles and recommendations contained in Chapter $\mathrm{F}$ are indispensable and deserve special attention.

9. All fossil fungal taxa must be registered with fungal nomenclatural repositories, e.g. Index Fungorum/ MycoBank/ FungalNames to make its reference accessible world-wide. This will certainly help in ensuring that they are validly published and in avoiding unnecessary introductions of later homonyms.

10. Host-pathogen interaction is another aspect, which does not have basic information in the form of fossil evidence. The interaction of fungi with higher plants with reference to the palaeobotanical evidences need to be documented in appropriate manner by exploring more fossil fungi along with chemical and geological aspects.

\section{Acknowledgements}

Ramesh K. Saxena is grateful to the authorities of the Birbal Sahni Institute of Palaeosciences, Lucknow, India for library facilities and to Dr. S.K.M. Tripathi for making drawings of some fungal spores. Nalin N. Wijayawardene and Dong-Qin Dai would like to thank the National Natural Science Foundation of China (No. NSFC 31950410558, NSFC 31760013) and the High-Level Talent Recruitment Plan of Yunnan Provinces ("Young Talents" Program and "High-End Foreign Experts" Program) for support. This study was supported by the project of State Key Laboratory of Functions and Applications of Medicinal Plants, Guizhou Medicial University (No. FAMP201906K). Kevin D Hyde is thankful for the financial support from the Thailand Research grant "Impact of climate change on fungal diversity and biogeography in the Greater Mekong Subregion (grant no: RDG6130001)".

\section{References}

Ainsworth GC, Sparrow FK, Sussman AS. 1973 - (eds.) The fungi, an advanced treatise. Volume I-IVB, Academic Press, New York, 3416 p.

Alexopoulos CJ, Mims CW, Blackwell M. 1996 - Introductory Mycology, 4th Ed., John Wiley \& Sons Inc., New York.

Ambwani K. 1982 - Palynology of the Deccan Intertrappean Beds of Rajahmundry District, Andhra Pradesh. Palaeobotanist 30, 28-33.

Ambwani K. 1983 - Fungal remains from Neyveli lignite, South India. Palaeobotanist 31, 148-153. Baksi SK. 1962 - Palynological investigation of Simsang River Tertiaries, South Shillong Front, Assam. Bulletin of the Geological, Mining and Metallurgical Society of India 26, 1-22.

Barlinge SG, Paradkar SA. 1982 - Records of new fossil algal and fungal forms from the Deccan Intertrappean of Mohgaon Kalan, M.P., India. Botanique 10, 163-174.

Barnett HL. 1956 - Illustrated genera of imperfect fungi. Burgess Publishing Company, Minneapolis, $218 \mathrm{p}$.

Barnett HL. 1965 - Illustrated genera of imperfect fungi; Burgess Publishing Company, Minneapolis.

Batista AC, Peres GEP. 1965 - New Deuteromycetes of intercontinental mycogeography; Mycopathologia et Mycologia Applicata 25, 761-772. 
Batten DJ. 1996 - Green and blue-green algae, 7C - Colonial Chlorococcales; In Palynology: principles and applications, Volume 1; pp. 191-203 in Jansonius J \& McGregor DC (eds.) American Association of Stratigraphic Palynologists Foundation, Publishers Press, Salt Lake City, Utah, U.S.A.

Berkeley MJ. 1848 - On three species of mould detected by Dr. Thomas in the amber of East Prussia. Annals and Magazine of Natural History 2, 380-383.

Berry EW. 1916 - Remarkable fossil fungi. Mycologia 8, 73-79.

Biradar NV, Mahabale TS. 1974 - On the occurrence of an imperfect fungus Tetracoccosporium obtained from a fossil wood belonging to the Deccan Intertrappean Series (M.P.), India. Palaeobotanist 21, 223-226.

Bland CE, Couch JN. 1973 - Scanning electron microscopy of sporangia of Coelomyces. Canadian Journal of Botany 51, 1325-1330.

Bradley WH. 1931 - Origin and microfossils of the oil shale of the Green River Formation of Colorado and Utah. U.S. Geological Survey, Professional Paper 168, 58 p.

Bradley WH. 1964 - Aquatic fungi from the Green River Formation of Wyoming. American Journal of Science 262, 413-416.

Bradley WH. 1967 - Two aquatic fungi (Chytridiales) of Eocene age from the Green River Formation of Wyoming. American Journal of Botany 54, 577-582.

Butterworth MA, Williams RW. 1958 - The small spore floras of coals in the Limestone Coal Group and Upper Limestone Group of the Lower Carboniferous of Scotland. Transactions of the Royal Society of Edinburgh 63, Part 2, No. 17 (1957-58), 353-392.

Chandra A, Saxena RK. 1998 - Lithostratigraphy of the Car Nicobar Island, Andaman and Nicobar Islands, India. Geophytology 26, 33-38.

Chandra A, Saxena RK, Setty MGAP. 1984 - Palynological Investigation of the sediment cores from the Arabian Sea. 1. Fungal spores. Biovigyanam 10, 41-58.

Chitaley SD. 1978 - Fungal spores from the Deccan Intertrappean beds of Mohgaon Kalan, India. Proceedings of the IV International Palynological Conference, Lucknow (1976-77) vol. 1, 305-311.

Chitaley SD, Yawale NR. 1978 - Fungal remains from the Deccan Intertrappean Beds of Mohgaon Kalan, India. Botanique 7, 189-194.

Clarke RT. 1965 - Fungal spores from Vermejo Formation coal beds (Upper Cretaceous) of Central Colorado. Mountain Geologist 2, 85-93.

Conwentz H. 1892 - Untersuchungen über die fossilen Hölzer Schwedens. Kongliga Svenska Vetenskap-Akademiens Handlinger 24, 99 p.

Cookson IC. 1950 - Fossil pollen grains of proteaceous type from Tertiary deposits in Australia. Australian Journal of Science Research, 3, 166-177.

Cookson IC, Eisenack A. 1979 - Einige Algen aus Sedimenten der Kreide Australiens. Neues Jahrbuch für Geologie und Paläontologie, Monatshefte 2, 77-82.

Corda AJC. 1839 - Observations sur les Euastrées et les Cosmariées. Almanach de Carlsbad 9, 213-244.

Cugny C, Mazier F, Galop D. 2010 - Modern and fossil non-pollen palynomorphs from the Basque mountains (western Pyrenees, France): the use of coprophilous fungi to reconstruct pastoral activity. Vegetation History \& Archaeobotany 19, 391-408.

Deighton FC. 1960 - African fungi. I. Mycological Papers 78, 1-43.

Dilcher DL. 1965 - Epiphyllous fungi from Eocene deposits in western Tennessee, U.S.A. Palaeontographica Abt. B 116, 1-54.

Dilcher DL. 1973 - A revision of the Eocene flora of southeastern North America. Palaeobotanist 20, 7-18.

Doubinger J, Pons D. 1973 - Les champignons épiphylles du Tertiaire de Colombie. I. Le gisement de Cerrejón (Paléocène-Éocène). 96e Congrès national des Sociétés savantes, Toulouse 1971, Sciences 5, 233-252. 
Dueñas HJ. 1979 - Estudio palinologico de los 35 mts. superiores de la seccion Tarragona, Sabana de Bogata. Caldasia 12, 539-571.

Dutta SK, Sah SCD. 1970 - Palyno-stratigraphy of the Tertiary sedimentary formations of Assam: 5. Stratigraphy and palynology of south Shillong Plateau. Palaeontographica Abt. B 131, 172.

Ediger VS. 1981 - Fossil fungal and algal bodies from Thrace Basin, Turkey. Palaeontographica Abt. B 179, 87-102.

Ediger VS, Alisan C. 1989 - Tertiary fungal and algal palynomorphs biostratigraphy of the northern Thrace Basin, Turkey. Review of Palaeobotany \& Palynology 58, 139-161.

Edwards WN. 1922 - An Eocene microthyriaceous fungus from Mull, Scotland. Transactions of the British Mycological Society 8, 66-72.

Ellis MB. 1958 - Clasterosporium and some allied Dematiaceae-Phragmosporae. I. Mycological paper no. 70, Commonwealth Mycological Institute, Kew, England, 84 p.

Ellis MB. 1971 - Dematiaceous Hyphomycetes. Commonwealth Mycological Institute, Kew, England, 608 p.

Ellis MB. 1974 - Dematiaceous Hyphomycetes in Britain. Transactions of the British Mycological Society 62, 225-230.

Ellis MB. 1976 - More dematiaceous Hyphomycetes. Commonwealth Mycological Institute, Kew, $507 \mathrm{p}$.

Ellis MB, Ellis JP. 1985 - Microfungi on land plants: an identification handbook. Macmillan Publishing Company, New York, 818 p.

Elsik WC. 1968 - Palynology of a Palaeocene Rockdale lignite, Milam County, Texas. 1. Morphology and taxonomy. Pollen et Spores 10(2), 263-314.

Elsik WC. 1969 - Late Neogene palynomorph diagram, northern Gulf of Mexico. Transactions of Gulf Coast Association Geological Society 19, 509-528.

Elsik WC. 1976a - Fossil fungal spores. In Weber D.J. \& Hess W.H. (eds.), The fungal spore: form and function; (Second International Fungal Spore Symposium, Brigham Young University, 1974. The fungal spore.) John Wiley \& Sons, Inc., New York, p. 849-862.

Elsik WC. 1976b - Microscopic fungal remains and Cenozoic palynostratigraphy. Geoscience and Man 15, 115-120.

Elsik WC. 1990a. Hypoxylonites and Spirotremesporites form genera for Eocene to Pleistocene fungal spores bearing a single furrow. Palaeontographica Abt. B 216(1-6), 137-169.

Elsik WC. 1990b - The fungal morphotype Felixites n. gen. Pollen et Spores 31, 155-159.

Elsik WC. 1992 - The morphology, taxonomy, classification and geologic occurence of fungal palynomorphs. A short course presented under the auspices of the American Association of Stratigraphic Palynologists, Houston, Texas, 287 p. (Unpublished).

Elsik WC. 1999 - Reduviasporonites Wilson 1962: synonymy of the fungal organism involved in the late Permian crisis. Palynology 23, 37-41.

Elsik WC, Dilcher DL. 1974 - Palynology and age of clays exposed in Lawrence Clay Pit, Henry County, Tennessee. Palaeontographica Abt. B 146, 65-87.

Elsik WC, Ediger VS, Bati Z. 1990 - Fossil fungal spores: Anatolinites nov. gen.; Palynology 14, 91-103.

Elsik WC, Jansonius J. 1974 - New genera of Palaeogene fungal spores. Canadian Journal of Botany 52, 953-958.

Elsik WC, Jarzen DM. 2007 - New species of the late Cenozoic fungal formgenus Mediaverrunites Jarzen \& Elsik 1986 ex Nandi \& Sinha 2007. Palynology 33, 99-104.

Eriksson O. 1966 - On Anthostomella Sacc., Entosordaria (Sacc.) v. Hohn. and some related genera (Pyrenomycetes). Svensk Botanisk Tidskrift 60, 315-324.

Eriksson OE. 2005 - Origin and evolution of Ascomycota - the protolichenes hypothesis. Svensk Mykol Tidskr 26, 30-33.

Felix J. 1894 - Studien über fossile Pilze. Zeitschrift der Deutschen Geologischen Gesellschaft 46, 269-280. 
Foster CB. 1979 - Permian plant microfossils of the Blair Athol coal measures, Baralaba coal measures, and Basal Rewan Formation of Queensland. Queensland Department of Mines, Geological Survey of Queensland, Publication 372, Palaeontological Paper 45, $244 \mathrm{p}$.

Fournier GR, Elsik WC. 1984 - The stratigraphic value of Neogene fungal spores from DSDP Site 493, LEG 66. Palynology 8, 238-239.

Fritel PH. 1910 - Étude sur les vegetaux fossiles de l'étage sparnacien du Bassin de Paris; Mémoires de la Société géologique de France, Paléontologie 40, 5-37.

Ghosh AK, Chandra A, Saxena RK. 2004 - Middle Pliocene non-geniculate and geniculate coralline algae from the Car Nicobar Island, India; pp. 249-262 in Srivastava PC (ed.) Vistas in Palaeobotany and Plant Morphology: Evolutionary and Environmental Perspectives, Prof D.D. Pant Memorial Volume. U.P. Offset, Lucknow.

Glass DLE, Brown DD, Elsik WC. 1986 - Fungal spores from the Upper Eocene Manning Formation, Jackson Group, east and south-central Texas, U.S.A. Pollen et Spores 28, 403420.

Goos RD. 1970 - A new genus of the Hyphomycetes from Hawaii. Mycologia 62, 171-175.

Goos RD, Abdullah SK, Fisher PJ, Webster J. 1985 - The anamorph genus Helicodendron. Transactions of the British Mycological Society 84, 423-435.

Goos RD, Abdullah SK, Fisher PJ, Webster J. 1986 - The anamorph genus Helicoon. Transactions of the British Mycological Society 84, 423-435.

Gordon CC, Shaw CG. 1961 - A new genus of the Meliolaceae on the roots of Solanum species. Mycologia 52, 323-333.

Graham A. 1962 - The role of fungal spores in palynology. Journal of Palaeontology 36, 60-68.

Guan XT, Fan HP, Song ZC, Zheng YH. 1989 - Researches on late Cenozoic palynology of the Bohai Sea (in Chinese with English summary). Nanjing University Press, CenozoicMesozoic Palaeontology and Stratigraphy of East China, Series 4, 152 p.

Guimarães JTF, Nogueira ACR, Da Silva Jr JBC, Soares JL, Silveira R. 2013 - Fossil fungi from Miocene sedimentary rocks of the central and coastal Amazon Region, North Brazil. Journal of Palaeontology 87, 484-492.

Gupta A. 1984 - Dyadosporonites udarii: a new name for Dyadosporonites constrictus Kar 1979. Geophytology 14, 248.

Gupta A. 1985 - Inapertisporites udarii nom. nov. - a correction for Inapertisporites punctatus Chandra, Saxena and Setty 1984. Geophytology 15, 226.

Gupta A. 2002 - Algal/ fungal spores from Early Tertiary sediments of Sirmaur District, Himachal Pradesh, India. Tertiary Research 21, 123-153.

Haseldonckx P. 1973 - The palynology of some Paleogene deposits between the Rio Esera and the Rio Segre, Southern Pyrenees, Spain. Leidse Geologische Mededelingen 49, 145-165.

Hemer DO, Nygreen PW. 1967 - Algae, acritarchs and other microfossils incertae sedis from the Lower Carboniferous of Saudi Arabia. Micropaleontology 13, 183-194.

Hennelly JPF. 1959 - Spores and pollen from a Permian-Triassic transition, N.S.W. Proceedings of the Linnean Society of New South Wales 83, 363-369.

Hirmer M. 1927 - Handbuch der Paläobotanik (with collaboration of Julius Pia and William Troll).

Band I: Thallophyta - Bryophyta - Pteridophyta. R. Oldenbourg, München, 708 p.

Hopkins WS Jr. 1969 - Palynology of the Eocene Kitsilano Formation, southwest British Columbia. Canadian Journal of Botany 47, 1101-1131.

Horst U. 1943 - Mikrostratigraphischer Beitrag zum Vergleich des Namur von West Oberschlesien und Mährisch-Ostrau. Die Mega- und Mikrosporen der hauptsachlichen Flöze beider Reviere. Dissertation, Technische Hochschule zu Berlin. (Unpublished.)

Horst U. 1955 - Die Sporae dispersae des Namurs von Westoberschlesien und Mährisch-Ostrau; Palaeontographica Abt. B 98, 137-236.

Huang TC. 1981 - Miocene palynomorphs of Taiwan (6). Miscellaneous spores and pollen grains. Taiwania 26, 45-57. 
Hughes SJ. 1953 - Conidiophores, conidia, and classification. Canadian Journal of Botany 31, p. 577-659.

Hyde KD. 1995 - Tropical Australian freshwater fungi VII. New genera and species of ascomycetes. Nova Hedwigia 61, 119-140.

Ibañez CG, Zamuner AB. 1996 - Hyphomycetes (Deuteromycetes) in cones of Araucaria mirabilis (Spegazzini) Windhausen, Middle Jurassic of Patagonia, Argentina. Mycotaxon 59, 137-143.

Ibrahim AC. 1933 - Sporenformen des Aegrihorizonts des Ruhr Reviers. Diss Konard Triltsch Wurzburg, 1-47.

Ioannides NS, Mcintyre DJ. 1980 - A preliminary palynological study of the Caribou Hills outcrop section along the Mackenzie River, District of Mackenzie. Current Research Part A, Geological Survey of Canada, Paper 80-1A, 197-208.

Jain KP. 1974 - Fossil fungi; pp. 38-46 in Surange K.R. et al. (eds.) - Aspects and Appraisal of Indian Palaeobotany, Birbal Sahni Institute of Palaeobotany, Lucknow.

Jain KP, Gupta RC. 1970 - Some fungal remains from the Tertiaries of Kerala Coast. Palaeobotanist 18, 177-182.

Jain KP, Kar RK. 1979 - Palynology of Neogene sediments around Quilon and Varkala, Kerala coast, South India-I. Fungal remains. Palaeobotanist 26, 105-118.

Jain KP, Kar RK, Sah SCD. 1973 - A palynological assemblage from Barmer, Rajasthan. Geophytology 3, 150-165.

Jain RK. 1968 - Middle Triassic pollen grains and spores from Minas de Petroleo beds of the Cacheuta Formation (Upper Gondwana), Argentina. Palaeontographica Abt. B 122, 1-47.

Jansonius J. 1976 - Paleogene fungal spores and fruiting bodies of the Canadian Arctic. Geoscience and Man 15, 129-132.

Jansonius J, Hills LV. 1976 - Genera file of fossil spores. Special Publication, Dept. Geology, Univ. Calgary, Canada, 1-3287.

Jansonius J, Hills LV. 1980 - Genera file of fossil spores - supplement. Special Publication, Department of Geology, University of Calgary, cards 3629-3800.

Jansonius J, Hills LV. 1981 - Genera file of fossil spores-supplement. Special Publication, Dept. Geology, Univ. Calgary, Canada, 3801-3932.

Jansonius J, Hills LV. 1982 - Genera file of fossil spores-supplement. Special Publication, Dept. Geology, Univ. Calgary, Canada, 3933-4056.

Jansonius J, Hills L.V, Harkopf-Fröder C. 1998 - Genera file of fossil spores - supplement. Special Publication, Dept. Geology, Univ. Calgary, Canada, 5003-5310.

Jarzen DM, Elsik WC. 1986 - Fungal palynomorphs recovered from Recent river deposits, Luangwa Valley, Zambia. Palynology 10, 35-60.

Kalgutkar RM. 1993 - Paleogene fungal palynomorphs from Bonnet Plume Formation, Yukon Territory. Contributions to Canadian Paleontology, Geological Survey of Canada, Bulletin 444, 51-105.

Kalgutkar RM. 1997 - Fossil fungi from the lower Tertiary Iceberg Bay Formation, Eureka Sound Group, Axel Heiberg Lsland, Northwest Territories, Canada. Review of Palaeobotany \& Palynology 97, 197-226.

Kalgutkar RM, Jansonius J. 2000 - Synopsis of fungal spores, mycelia and fructifications. AASP Contribution Series 39, 1-423.

Kalgutkar RM, Mcintyre DJ. 1991 - Helicosporous fungi and Early Eocene pollen, Eureka Sound Group, Axel Heiberg Island, Northwest Territories. Canadian Journal of Earth Sciences 28, 364-371.

Kalgutkar RM, Nambudiri EMV, Tidwell WD. 1993 - Diplodites sweetii sp. nov. from the Late Cretaceous (Maastrichtian) Deccan Intertrappean beds of India. Review of Palaeobotany \& Palynology 77, 107-118.

Kalgutkar RM, Sigler L. 1995 - Some fossil fungal form-taxa from the Maastrichtian and Paleogene ages. Mycological Research 99, 513-522. 
Kalgutkar RM, Sweet R. 1988 - Morphology, taxonomy and phylogeny of the fossil fungal genus Pesavis from North-western Canada. Geological Survey of Canada, Bulletin 379, 117-133.

Kar R, Mandaokar BD, Kar RK. 2010 - Fungal taxa from the Miocene sediments of Mizoram, northeast India. Review of Palaeobotany \& Palynology 158, 240-249.

Kar RK. 1979 - Palynological fossils from the Oligocene sediments and their biostratigraphy in the District of Kutch, Western India. Palaeobotanist 26, 16-49.

Kar RK. 1990 - Palynology of Miocene and Mio-Pliocene sediments of north-east India. Journal of Palynology 26, 171-217.

Kar RK, Mandaokar BD, Kar R. 2005 - Mycorrhizal fossil fungi from the Miocene sediments of Mizoram, Northeast India. Current Science. 89, 257-259.

Kar RK, Mandaokar BD, Kar R. 2006 - Fossil aquatic fungi from the Miocene sediments of Mizoram, North-east India. Current Science 90, 291-292.

Kar RK, Saxena RK. 1976 - Algal and fungal microfossils from Matanomadh Formation (Palaeocene), Kutch, India. Palaeobotanist 23, 1-15.

Kar RK, Saxena RK. 1981 - Palynological investigation of a bore core near Rataria, southern Kutch, Gujarat. Geophytology 11, 103-124.

Kar RK, Sharma N, Agarwal A, Kar R. 2003 - Occurrence of fossil wood rotters (Polyporales) from Lameta Formation (Maastrichtian), India. Current Science 85, 37-40.

Kar RK, Sharma N, Kar R. 2004a - Occurrence of fossil fungi in Dinosaur Dung and its implication on food habit. Current Science 87, 1053-1056.

Kar RK, Sharma N, Verma UK. 2004b - Plant pathogen Protocolletotrichum from the Deccan Intertrappean Bed (Maastrichtian), India. Cretaceous Research 25, 945-950.

Kar RK, Singh RY, Sah SCD. 1972 - On some algal and fungal remains from Tura Formation of Garo Hills, Assam. Palaeobotanist 19, 146-154.

Ke P, Shi ZY. 1978 - Early Tertiary spores and pollen grains from the coastal region of the Bohai (in Chinese); Academy of Petroleum Exploration, Development and Planning Research of the Ministry of Petroleum and Chemical Industries and the Nanjing Institute of Geology, and Paleontology, Chinese Academy of Sciences, Kexue Chubanshe, Peking, 177 p.

Kemp EM. 1978 - Microfossils of fungal origin from Tertiary sediments on the Ninetyeast Ridge, Indian Ocean; pp. 73-81 in Belford DJ Scheibnerova V. (compilers) - The Crespin volume: essays in honour of Irene Crespin, Bureau of Mineral Resources, Geology and Geophysics, Bulletin 192.

Kendrick WB. 1958 - Helicoma monospora sp. nov. from pine litter. Transactions of the British Mycological Society 41, 446-448.

Kendrick WB, Carmichael JW. 1973 - Hyphomycetes; p. 323-509 in Ainsworth GC, Sparrow FK, Sussman AA. (eds.), The Fungi. An Advanced Treatise 4A, Academic Press, New York.

Kendrick WB, Nag Raj TR. 1979 - Morphological terms in Fungi Imperfecti, pp. 43-62 in B Kendrick (ed.) - The whole Fungus, Proceedings of the Second International Mycological Conference, Kananaskis, Alberta, published by the National Museums of Canada for the Kananaskis Foundation, Ottawa, Volume 1.

Kidston R, Lang WH. 1921 - On Old Sandstone plants showing structure, from the Rhynie Chert Bed, Aberdeenshire. Part V. The thallophyta occurring in the peat-bed; the succession of the plants through a vertical section of the bed, and the conditions of accumulation and preservation of the deposit. Transactions of the Royal Society of Edinburgh 52, 855-902.

Kirk PM. 1982 - New or interesting microfungi V. Microfungi colonizing Laurus nobilis leaf litter. Transactions of the British Mycological Society 78, 293-303.

Kumar P. 1990 - Fungal remains from the Miocene Quilon Bed of Kerala state, South India. Review of Palaeobotany \& Palynology 63, 13-28.

Lakhanpal RN, Maheshwari HK, Awasthi N. 1976 - A Catalogue of Indian Fossil Plants. Birbal Sahni Institute of Palaeobotany, Lucknow, India, 318 p.

Lange RT. 1978a - Southern Australian Tertiary epiphyllous fungi, modern equivalents in the Australasian region, and habitat indicator value. Canadian Journal of Botany 56, 532-541. 
Lange RT. 1978b - Correlation of particular southern and northern hemisphere Paleogene floras by the unusual fungal spores Ctenosporites and Pesavis tagluensis. Pollen et Spores 20, 399403.

Lange RT, Smith PH. 1971 - The Maslin Bay flora, South Australia. 3. Dispersed fungal spores. Neves Jahrb. Geol. Palaontol. Monatsh. 11, 663-681.

Lange RT, Smith PH. 1975 - Ctenosporites and other Paleogene fungal spores. Canadian Journal of Botany 53, 1156-1157.

Lücking R, Huhndorf S, Pfister DH, Plata ER, Lumbsch HT. 2009 - Fungi evolved right on track. Mycologia 101, 810-822.

Mahabalé TS. 1969 - On a fossil species of Diplodia from the Intertrappean Series, Madhya Pradesh, India. Palaeobotanist 17, 295-297.

Martinez MA, Virginia Bianchinotti M, Saxena RK, Elina Cornou M, Quattrocchio ME. 2016 Fungal spores from the Palaeogene El Foyel Group of Nirihuau Basin, Argentina. Papers in Palaeontology 2, 343-362.

Martínez-Hernández E, Tomasini-Ortiz AC. 1989 - Spores, hyphae and other fungal remains from the Fuentes-Rio Escondino Carboniferous basin (Campanian-Maastrichtian), Coahuila State, Mexico. Universidad Nacional Autonoma de Mexico, Instituto de Geologia, Revista 8, 235 242.

Mathur YK. 1966 - Studies in the fossil microflora of Kutch, India. II. On the microflora in the Supra-trappeans of western Kutch, India. Quarterly Journal of the Geological, Mining and Metallurgical Society of India 38, 33-51.

Mathur YK, Mathur K. 1969 - Studies in the fossil flora of Kutch (India) - 3. On the palaeopalynoflora in the Pliocene sediments of Naera-Baraia area, Kutch. Bulletin of the Geological, Mining and Metallurgical Society of India 42, 1-12.

Matsushima T. 1989 - Matsushima Mycological Memoirs no. 6; Matsushima Fungus Collection, Higashinada-Ku, Kobe, Japan, 100 p.

Menge A. 1858 - Beitrag zur Bernsteinflora. Schriften der naturforschenden Gesellschaft in Danzig 6, 3-18.

Meschinelli A. 1892 - Sylloge fungorum fossilium hucusque congnitorium; in Saccardo PA Sylloge Fungorum Omnium 10, 741-805.

Meschinelli A. 1902 - Fungorum fossilium omnium Iconographia; in Aedibus J. Galla, Vicetiae, $144 \mathrm{p}$.

Meyers SP, Moore RT. 1960 - Thalassiomycetes II. New genera and species of Deuteromycetes. American Journal of Botany 47, 345-349.

Miller JH. 1961 - A monograph of the world species of Hypoxylon. University of Georgia Press, Athens, $158 \mathrm{p}$.

Minter D. 1986 - Slimacomyces gen. nov. Bulletin of the British Mycological Society 20, 17-24.

Mukherjee B, Chakraborty K. 1984 - Palynology of the Calcutta peat with reference to its origin and environment of deposition; pp. 505-514 in Badve RM et al. (eds.) - Proceedings of the 10th Indian Colloquium on Micropaleontology and Stratigraphy, Pune 1982. Maharashtra Association for the Cultivation of Science, Pune.

Mukherjee D. 2012 - Facultative fungal remains from Miocene lignite coal of Neyveli Tamil Nadu India. International Journal of Geology, Earth and Environmental Sciences ISSN: 2277-2081 (Online). http://www.cibtech.org/jgee.htm 2012 2(2), 1-15.

Muller J. 1959 - Palynology of Recent Orinoco delta and shelf sediments: Reports on the Orinoco Shelf Expedition. Micropaleontology 5, 1-32.

Mustard PS, Rouse GE. 1994 - Stratigraphy and evolution of Tertiary Georgia Basin and subjacent Upper Cretaceous sedimentary rocks, southwestern British Columbia and North-western Washington State. Geological Survey of Canada, Bulletin 481, 97-169.

Nagy E. 1963 - Spores nouvelles des couches Néogènes de Hongrie. Pollen et Spores 5, 143-148.

Nandi B, Banerjee S, Sinha A. 2003 - Fossil Xylariaceae spores from the Cretaceous and Tertiary sediments of Northeastern India. Acta Palaeontologica Sinica 42, 56-67. 
Nandi B, Sinha A. 2007 - Validation of the Miocene fungal spore Mediaverrunites from Mizoram, India. Palynology 31, 95 - 100.

Norris G. 1982 - Spore-pollen evidence for early Oligocene high latitude cool climatic episode in northern Canada. Nature 297, 387- 89.

Norris G. 1986 - Systematic and stratigraphic palynology of Eocene to Pliocene strata in the Imperial Nuktak C-22 well, Mackenzie Delta Region, District of Mackenzie, N.W.T. Geological Survey of Canada Bulletin, Bulletin 340, 89 p.

Norris G. 1997 - Paleocene-Pliocene deltaic to inner shelf palynostratigraphic zonation, depositional environments and paleoclimates in the Imperial ADGO F-28 Well, BeaufortMackenzie basin. Geological Survey of Canada, Bulletin 523, $71 \mathrm{p}$.

Nuñez-Otaño N, di Pasquo M, Bianchinotti MV. 2017 - The occurrence of Potamomyces palmarensis sp. nov. in the Late Holocene of El Palmar National Park (Colón, Entre Ríos, Argentina) and transfer of fossil species of Mediaverrunites to Potamomyces. Palynology 41, 267-277.

O'Keefe JMK. 2017 - Fungal palynomorphs from the Miocene Heath Formation, Tumbes Province, Peru. Palynology 41(S1), 309-326

Pampaloni L. 1902 - I resti organici nel disodile di Melilli in Sicilia. Palaeontographica Italica 8, 121-130.

Paradkar SA. 1976 - Pollen and fungal spores association on a fossil leaf from the Deccan Intertrappean Beds of India. Journal of Palynology 10, 119-125.

Parsons MG, Norris G. 1999 - Paleogene fungi from the Caribou Hills, Mackenzie Delta, northern Canada. Palaeontographica Abt. B 250, 77-167.

Pathak NR, Banerjee M. 1984 - Fungal spores from the Neogene sediments of the eastern Himalayan foothills, Darjeeling District, pp. 245-259 in Badve RM et al. (eds.) - Proceeding of the $10^{\text {th }}$ Indian Colloquium on Micropalaeontology and Stratigraphy, Pune 1982, Maharashtra Association for the Cultivation of Science, Pune.

Peppers RA. 1964 - Spores in strata of late Pennsylvanian cyclothems in the Illinois Basin. Illinois State Geological Survey Bulletin 90, 89 p.

Peppers RA. 1970 - Correlation and palynology of coals in Carbondale and Spoon formations (Pennsylvanian) of the northeastern part of the Illinois Basin. Illinois State Geological Survey Bulletin 93, $173 \mathrm{p}$.

Pia J. 1927 - Thallophyta, in Hirmer M., Handbuch der Paläobotanik. Band I. Druck und Verlag von R. Oldenbourg, München und Berlin, 30-136.

Pierce RL. 1961 - Lower Upper Cretaceous plant microfossils from Minnesota. Bulletin of the Minnesota Geological Survey, University of Minnesota 42, p. 86 p.

Pirozynski KA. 1976a - Fossil fungi. Annual Review of Phytopathology 14, 237-246.

Pirozynski KA. 1976b - Fungal spores in the fossil record. Biological Memoirs (in collaboration with International Society of Applied Biology) 1, 104-120.

Pirozynski KA, Jarzen DM, Carter A, Day RG. 1988 - Palynology and mycology of organic clay balls accompanying mastodon bones - New Brunswick, Canada. Grana 27, 123-139.

Pirozynski KA, Weresub LK. 1979 - The classification and nomenclature of fossil fungi; pp. 653688 in B. Kendrick (ed.) - The whole fungus, the Sexual-Asexual Synthesis. Proceedings of the 2nd International Mycological Conference, University of Calgary, Kananaskis, Alberta, Canada, Volume 2,

Playford G. 1962 - Lower Carboniferous microfloras of Spitsbergen. Palaeontology 5, 550-618.

Playford G, Dring RS. 1981 - Late Devonian acritarchs from the Carnarvon Basin, Western Australia; Special Papers in Palaeontology 27, 1-78.

Poiteau MA. 1824 - Description du Graphiola, nouveau genre des plantes parasite de la famille des champignons. Annales des Sciences Naturelles, série no. 3, 473-476.

Pons D, Boureau E. 1977 - Les Champignons épiphylles d'un Frenelopsis du Cénomanien moyen de l'Anjou (France). Revue de Mycologie 41, 349-361. 
Potonié R. 1951 - Revision stratigraphisch wichtiger Sporomorphen des mitteleuropaischen Tertiars. Palaeontographica Abt. B 91, 131-151.

Potonié R. 1960 - Synopsis der Gattungen der sporae dispersae III. Teil: Nachtrage sporites, Fortsetzung Pollenites mit generalregister zu Teil 1-III. Beihefte zum Geologischen Jahrbuch 39, 1-189.

Potonié R. 1966 - Synopsis der Gattungen der sporae dispersae IV Teil: Nachtrage zu allen Gruppen (Turmae). Beihefte zum Geologischen Jahrbuch 72, 1-244.

Potonié R, Sah SCD. 1960 - Sporae dispersae of the lignites from Cannanore beach of the Malabar Coast of India. Palaeobotanist 7, 121-135.

Pound MJ, O'Keefe JMK, Nuñez Otaño NB, Riding JB. 2018 - Three new Miocene fungal palynomorphs from the Brassington Formation, Derbyshire, UK, Palynology,

Doi 10.1080/01916122.2018.1473300

Premaor E, Saxena RK, de Souza AP, Kalkreuth W. 2018 - Fungal spores and fruiting bodies from Miocene deposits of the Pelotas Basin, Brazil. Revue de micropaléontologie 61, 255-270.

Puri GS. 1963 - Some Plant-micro-fossils from the Cretaceous and Paleocene of Nigeria. University of Ibadan Botanical Studies, No. 10, 1-142.

Ramanujam CGK. 1982 - Recent advances in the study of fossil fungi; pp. 287-301 in Bharadwaj DC (ed.) - Recent Advances in Cryptogamic Botany 2, Palaeobotanical Society, Lucknow.

Ramanujam CGK, Ramachar P. 1963 - Sporae dispersae of the rust fungi (Uredinales) from the Miocene lignite of South India. Current Science 32, 271-272.

Ramanujam CGK, Ramachar P. 1980 - Recognizable spores of rust fungi (Uridinales) from Neyveli lignite, Tamil Nadu. Records of the Geological Survey of India 113, 80-85.

Ramanujam CGK, Rao KP. 1978 - Fungal spores from the Neogene strata of Kerala in South India; pp. 291-304 in Bharadwaj DC et al. (eds) - Proceedings of the 4th International Palynological Conference, Lucknow 1976-77, Volume 1, Birbal Sahni Institute of Palaeobotany, Lucknow.

Ramanujam CGK, Srisailam K. 1980 - Fossil fungal spores from the Neogene Beds around Cannanore in Kerala state. Botanique 9, 119-138.

Rao MR, Patnaik R. 2001 - Palynology of the Late Pliocene sediments of Pinjor Formation, Haryana, India. Palaeobotanist 50, 267-286.

Romero E, Castro MT. 1986 - Material fungico y granos de polen de angiospermas de la Formacion Rio Turbio (Eoceno), Provincia de Santa Cruz, Republica Argentina. Ameghiniana 23, 101-118.

Rouse GE. 1959 - Plant microfossils from Kootenay coal-measures strata of British Columbia. Micropaleontology 5, 303-324.

Rouse GE. 1962 - Plant microfossils from the Burrard Formation of Western British Columbia. Micropaleontology 8, 187-218.

Rouse GE, Mustard PS. 1997 - Nomenclatural note and corrections. Palynology 21, 207-208.

Roussel HFA. 1806 - Flore du Calvados et terrains adjacents, composée suivant la méthode de Jussieu., 1-372.

Saccardo PA. 1877-1882 - Fungorum Italicorum Autographice Delineatorum. Volume I, 1-1280.

Saccardo PA. 1882-1926 - Sylloge fungorum omnium hucusque cognitorum. Volume 1-25.

Sah SCD. 1967 - Palynology of an Upper Neogene profile from Rusizi Yalley (Burundi). Annls Mus. r. Afr. Cent., Ser. 8, Sci. geol. 57, 1-173.

Sah SCD, Kar RK. 1974 - Palynology of the Tertiary sediments of Palana, Rajasthan. Palaeobotanist 21, 163-188.

Salard-Cheboldaeff M, Locquin MV. 1980 - Champignons présents au Tertiaire le long du littoral de l'Afrique équatoriale. 105e Congrès National des Sociétés savantes, Caen 1980, Sciences, fascicule 1, 183-195.

Salmon ES. 1903 - Cercosporites sp., a new fossil fungus. Journal of Botany 41, 127-130.

Salujha SK, Kindra GS, Rehman K. 1974 - Palynology of the South Shillong Front. Part II: The Palaeogenes of Khasi and Jaintia Hills. Palaeobotanist 21, 267-284. 
Samant B. 2000 - Fungal remains from the Bhavnagar lignite, Gujarat, India. Geophytology 28, $11-18$.

Samant B, Tapaswi PM. 2000 - Fungal remains from the Surat lignite deposits (Early Eocene) of Gujarat, India. Gondwana Geological Magazine 15, 25-30.

Sancay RH. 2013 - The occurrence of Mediaverrunites in the Upper Miocene of the Black Sea, Turkey. Palynology 38, 28-37.

Saxena RK. 1981 - Stratigraphy of the area around Matanomadh in North-western Kachchh with special reference to the Matanomadh Formation. Palaeobotanist 27, 300-313.

Saxena RK. 1991 - A catalogue of fossil plants from India-Part 5B. Tertiary fungi. Special Publication, Birbal Sahni Institute of Palaeobotany, Lucknow, 19 p.

Saxena RK. 1992 - Hypoxylonites Elsik 1990, a correct name for Hypoxylonsporites Kumar 1990 and its Indian records. Geophytology 21, 211-212.

Saxena RK. 2000 - Palynological investigation of the Sindhudurg Formation in the type area, Sindhudurg District, Maharashtra, India. ONGC Bulletin 37, 157-166.

Saxena RK. 2006 - A Catalogue of Tertiary Fungi from India (1989-2005). Special Publication, Birbal Sahni Institute of Palaeobotany, Lucknow, 37 p.

Saxena RK. 2009 - Substitute names for later homonyms of five species and validation of the names of eight species of fossil fungi from Indian Tertiary sediments. Mycotaxon 110, 4751.

Saxena RK. 2012 - Validation of names of fossil fungi from Tertiary sediments of India. Novon 22, 223-226.

Saxena RK, Bhattacharyya AP. 1987 - Palynology of the Siwalik sediments of Kala Amb-Nahan area in Sirmaur District, Himachal Pradesh. Palaeobotanist 35, 187-195.

Saxena RK, Bhattacharyya AP. 1990 - Palynological investigation of the Dharmsala sediments in Dharmsala area, Kangra District, Himachal Pradesh. Geophytology 19, 109-116.

Saxena RK, Khare S. 1992 - Fungal remains from the Neyveli Fonnation of Tiruchirappalli District, Tamil Nadu, India. Geophylology 21, 37-43.

Saxena RK, Misra NK. 1990 - Palynological investigation of the Ratnagiri Beds of Sindhu Durg District, Maharashtra. Palaeobotanist 38, 263-276.

Saxena RK, Misra NK, Khare S. 1992 - Ratnagiri Beds of Maharashtra - lithostratigraphy, flora, palaeoclimate and environment of deposition. Indian Journal of Earth Sciences 19, 205-213.

Saxena RK, Ranhotra PS. 2009 - Palynofloral study of the intertrappean bed exposed at a new locality in Kutch District, Gujarat, India and its implications on palaeoenvironment. Journal of the Geological Society of India 74, 690-696.

Saxena RK, Sarkar S. 1986 - Morphological study of Frasnacritetrus Taugourdeau emend. from Tertiary sediments of Himachal Pradesh, India. Review of Palaeobotany \& Palynology 46, 209-225.

Saxena RK, Singh HP. 1983 - Palynological investigation of the Upper Siwalik sediments exposed along Hoshiarpur-Una Road Section in Punjab and Himachal Pradesh. Geophytology 12, 287-306.

Saxena RK, Singh HP, Rao MR. 1988 - Palynology of the Tatrot-Pinjor sequence exposed between Masol and Kiratpur in Ambala District, Haryana. Geophytology 17, 270-284.

Saxena RK, Tripathi SKM. 2011 - Indian Fossil Fungi. Palaeobotanist 60, 1-208.

Schmidt AR, Dörfelt H, Struwe S, Perrichot V. 2010 - Evidence of fungivory in Cretaceous amber forests from Gondwanaland and Laurasia. Palaeontographica Abt. B 283, 157-173.

Schmiedeknecht M, Schwab G. 1964 - Bulbillen fossiler Pilze aus einer tertiären Weichbraunkohle. Deutsche Akademie der Wissenschaften zu Berlin 6, 683-692.

Selkirk DR. 1972 - Fossil Manginula-like fungi and their classification. Proceedings of the Linnean Society of New South Wales 97, 141-149.

Sepúlveda EG. 1980 - Estudio palinológico de sedimentitas intercaladas en la "Serie Andesitica Andina", Cordon Oriental Futalaufquen, Chubut. [English translation: A palynological study of microsediments intercalated in the "Andean Andesitic Series", Eastern Futalaufquen range, 
Chubut Province Part 1: Fungal remains. Asociación Geológica Argentina, Revista 35, 248272.

Sharma C. 1976 - Some fungal spores from Quaternary deposits of Malvan, Gujarat. Palaeobotanist 23, 79-81.

Sharma N, Kar RK, Agarwal A, Kar R. 2005 - Fungi in dinosaurian (Isisaurus) coprolites from the Lameta Formation (Maastrichtian) and its reflection on food habit and environment. Micropaleontology 51, 73-82.

Sheffy MV, Dilcher DL. 1971 - Morphology and taxonomy of fungal spores. Palaeontographica Abt. B 133(1-3), 34-51.

Sierotin T. 1961 - Sporae dispersae im Rhät und Lias von Grossbellhofen (Mittelfranken). Inaugural-Dissertation zur Erlangung der Doktorwürde der MathematischNaturwissenschaftlichen Fakultät der Freien Universität Berlin, 77 p.

Singh HP, Saxena RK. 1981 - Palynology of the Upper Siwalik sediments in Una District, Himachal Pradesh. Geophytology 11, 173-181.

Singh HP, Saxena RK, Rao MR. 1986 - Palynology of the Barail (Oligocene) and Surma (Lower Miocene) sediments exposed along Sonapur-Badarpur Road Section, Jaintia Hills (Meghalaya) and Cachar (Assam). Part II. Fungal remains. Palaeobotanist 35, 93-105.

Singh RY, Dogra NN, Vimal KP. 1985 - Palynology of the Barail sediments in the states of Assam and Meghalaya, India. Journal of Palynology 21, 28-55.

Singhai LC. 1974 - Fossil fungi from the Deccan Intertrappean beds of Madhya Pradesh, India. Journal of Biological Sciences 17, 92-102.

Smith PH. 1978 - Fungal spores of the genus Ctenosporites from the early Tertiary of southern England. Palaeontology 21, 717-722.

Smith PH, Chaloner WG. 1979 - Is Piriurella Cookson \& Eisenack an alga or a fungus? Neues Jahrbuch für Geologie und Paläontologie, Monatshefte, no. 11, p. 701-704.

Song ZC. 1985 - A research on Tertiary palynology from the Qaidam Basin, Qinghai Province. Edited by Research Institute of Exploration and Development, Qinghai Petroleum Administration, [and] Nanjing Institute of Geology and Palaeontology, Academia Sinica, 297 p. (in Chinese). Petroleum Industry Press.

Song ZC, Cao L. 1994 - Late Cretaceous fungal spores from King George Island, Antarctica. Stratigraphy and Palaeontology of Fides Peninsula, King George Island, Antarctica, Monograph 3, 47-49.

Song ZC, Li GX, Cao L, Luo HC, Sun ZH. 1989 - Early Tertiary sporo-pollen assemblages from the Dongpu region; Edited by Research Institute of Exploration and Development, Zhongyuan Petroleum Exploration Bureau, Nanjing Institute of Geology and Palaeontology, Academia Sinica, $192 \mathrm{p}$.

Song ZC, Zheng YH, Li MY, Zhang YY et al. 1999 - Fossil spores and pollen of China. Vol. 1. The Late Cretaceous and Tertiary spores and pollen. Science Press [ISBN 7-03-006724-X]. Fungi: 1-59 p., 824-825. (English translation)

Soomro S, Leghari SM, Lashari R, Rajar AW, Abbasi QD. 2010 - Fossil fungal spores from brown coal of Sonda, District Thatta, Sindh, Pakistan. Sindh Univ. Res. Jour. (Sci. Ser.) 42, 73-84.

Srivastava R, Kapgate DK, Chatterjee S. 2009 - Permineralized fungal remains in the fossil wood of Barringtonia from the Deccan Intertrappean sediments of Yavatmal District, Maharashtra, India. Palaeobotanist 58, 11-19.

Srivastava SK. 1968 - Fungal elements from the Edmonton Formation (Maestrichtian), Alberta, Canada. Canadian Journal of Botany 46, 1115-1118.

Srivastava SK, Al-Tayyar H. 2013 - High resolution palynological and palynofacial sequence stratigraphy of an Aptian-Albian core from northern Arabian Gulf. Savitriana 3, 1-213.

Stach E. 1957 - Die Anschliff-Sporendiagnose des Ruhrkohlenflözes Baldur. Palaeontographica Abt. B 102, 71-95.

Stajich JE, Berbee ML, Blackwell M, Hibbett DS, James TY, Spatafora JW, Taylor JW. 2009 The Fungi. Current Biology 19, 840-845. 
Staplin FL. 1976 - Tertiary biostratigraphy, Mackenzie Delta region, Canada. Bulletin of the Canadian Petroleum Geology 24, 117-136.

Stubblefield SP, Miller CE, Taylor TN, Cole GT. 1985 - Geotrichites glaesarius, a conidial fungus from Tertiary Dominican amber. Mycologia 77, 11-16.

Stubblefield SP, Taylor TN 1988 - Tansley Review No. 12, Recent advances in Palaeomycology. New Phytology 108, 3-25.

Subramanian CV. 1971 - Hyphomycetes, an account of Indian species, except Cercosporae. Indian Council of Agricultural Research, New Delhi, 930 p.

Sutton BC. 1969 - Forest microfungi-I. Ampulliferina persimplex n. gen., n. sp. on leaves of Labrador tea. Canadian Journal of Botany 47, 609-616.

Szabó Z. von 1905 - Hedwigia, 77.

Taugourdeau P. 1968 - Sur un curieux microfossile incertae sedis du Frasnien du Boulonnais. Cahiers de Micropaléontologie, Série 1, no. 10 (Archives originales du Centre de Documentation du C.N.R.S. no. 452, 1-4.

Taylor TN, Krings M, Taylor EL. 2015 - Fossil Fungi. Academic Press, London, UK., 382 p. ISBN: 978-0-12-387731-4.

Thaxter R. 1891 - On certain new or peculiar North American Hyphomycetes. II. Helicocephalum, Gonatorrhodiella, Desmidiospora nov. genera and Everharti lignatilis n. sp. Botanical Gazette (Crawfordsville) 16, 201-205.

The A.A.S.P., INC. Workgroup on fossil fungal palynomorphs, William C. Elsik (Chairman). 1963 - Annotated glossary of fungal palynomorphs. AASP Contribution Series 11, 1-35.

Tiffney BH, Barghoorn ES. 1974 - The fossil record of the fungi. Occasional Papers of the Farlow Herbarium of Cryptogamic Botany 7, 1-42.

Traverse A, Ash SR. 1994 - Well-preserved fungal spores from Jurassic rocks of Hells Canyon on the Idaho-Oregon border. Journal of Paleontology 68, 664-668.

Tripathi SKM. 1995 - Techniques in palynological studies; pp. 35-49 in Tiwari RS. (ed) Coaliferous fuel resources of India: Parameters of studies in palynology and biopetrology, Birbal Sahni Institute of Palaeobotany, Lucknow.

Tripathi SKM. 2009 - Fungi from palaeoenvironments: their role in environmental interpretations; pp. 1-27 in Misra JK, Deshmukh S (eds.) - Fungi from different environments, Science Publishers Enfield, Hampshire, U.S.A.

Trivedi BS, Verma CL. 1970 - Fungal remains from Tertiary coal bed of Malaya. Journal of Palynology 5, 68-73.

Turland NJ, Wiersema JH, Barrie FR, Greuter W et al. (eds.) 2018 - (eds.) International Code of Nomenclature for algae, fungi, and plants (Shenzhen Code) adopted by the Nineteenth International Botanical Congress Shenzhen, China, July 2017. Regnum Vegetabile 159. Glashütten: Koeltz Botanical Books. Doi 10.12705/Code.2018+

Van Beverwijk AL. 1953 - Helicosporous Hyphomycetes-1. Transactions of the British Mycological Society 36, 111-124.

Van der Hammen T. 1954 - El desarrollo de la flora Colombiana en los periodos geologicos-1. Maestrichtiano hasta Terciaro mas inferior (Una investigacion Palinologica de la formacion de Guaduas y equivalentes). Boletin Geologico (Bogota) 2(1), 49-106.

Van der Hammen T. 1955 - Principios para la nomenclatura palinológica sistemetica. Boletin Geologico (Bogota) 2, 3-24.

Van der Hammen T. 1956 - A palynological systematic nomenclature. Boletin Geologico (Bogota) 4, 63-101.

Van Geel B, Bohncke SJP, Dee H. 1981 - A palaeoecological study of an upper Late Glacial and Holocene sequence from "De Borchert", The Netherlands. Review of Palaeobotany \& Palynology 31, 367-448.

Vánky K. 1998 - Taxonomical studies on Ustilaginales XVIII. Mycotaxon 69, 93-115.

Varma CP, Rawat MS. 1963 - A note on some diporate grains recovered from Tertiary horizons of India and their potential marker value. Grana Palynologica 4, 130-139. 
Varma YNR, Patil RS. 1985 - Fungal remains from the Tertiary carbonaceous clays of Tonakkal area, Kerala. Geophytology 15, 151-158.

Venkatachala BS, Rawat MS. 1973 - Palynology of the Tertiary sediments in the Cauvery Basin-2. Oligocene-Miocene palynoflora from the subsurface. Palaeobotanist 20, 238-263.

Wang KF, Zhang YL. 1986 - Palynological assemblages of crude oil from the oil fields in East China and the research of the oil source. Tongii University Press pp. 1-107.

Wetzel O. 1961 - New microfossils from Baltic Cretaceous flintstones. Micropaleontology 7, 337350.

White JM. 1990 - Evidence of Paleogene sedimentation on Graham Island, Queen Charlotte Islands, West Coast, Canada. Canadian Journal of Earth Sciences 27, 533-538.

Wijayawardene NN, Hyde KD, Al-Ani LKT, Tedersoo L et al. 2020a - Outline of Fungi and fungus-like taxa. Mycosphere 11, 1060-1456. Doi 10.5943/mycosphere/11/1/8

Wijayawardene NN, Hyde KD, Dai DQ, Tang LZ et al. 2020b - A dynamic portal for a community-driven, continuously updated classification of Fungi and fungus-like organisms: outlineoffungi.org. Mycosphere 11, 1514-1526, Doi 10.5943/mycosphere/11/1/11

Williamson WC. 1878 - On the organization of fossil plants of the Coal Measures. Part IX. Philosophical Transactions of the Royal Society of London 169, 319-364.

Williamson WC. 1880 - On the organization of the fossil plants of the Coal-Measures - Part X. Including an examination of the supposed radiolarians of the Carboniferous rocks. Philosophical Transactions of the Royal Society of London 171, 493-539.

Wilson LR. 1962 - A Permian fungus spore type from the Flowerpot Formation of Oklahoma. Oklahoma Geology Notes 22, 91-96.

Wolf FA. 1966a - Fungus spores in East African lake sediments. Bulletin of the Torrey Botanical Club 93, 104-113.

Wolf FA. 1966b - Fungus spores in East African lake sediments: II. The Journal of the Elisha Mitchell Scientific Society 82, p. 57-61.

Wolf FA. 1967a - Fungus spores in East African lake sediments. V. Mycologia 59, 397-404.

Wolf FA. 1967b - Fungus spores in East African lake sediments. VII. Bulletin of the Torrey Botanical Club 94, 480-486.

Wolf FA. 1968 - Fungus spores in Lake Singletary sediments. The Journal of the Elisha Mitchell Scientific Society 84, 227-232.

Wolf FA. 1970 - Reflections regarding nonpetrified fossils. Bulletin of the Association of Southeastern Biologists 17, 92-94.

Wolf FA, Cavaliere SS. 1966 - Fungus spores in East African lake sediments. III. The Journal of the Elisha Mitchell Scientific Society 82, 149-154.

Wood GD, Elsik WC. 1999 - Paleoecologic and stratigraphic importance of the fungus Reduviasporonites stoschianus from the 'early-middle' Pennsylvanian of the Copacabana Formation, Peru. Palynology 23, 43-53.

Young FG, Mcneil DH. 1984 - Cenozoic stratigraphy of the Mackenzie Delta, Northwest Territories. Geological Survey of Canada, Bulletin 336, 63 p.

Zhang ZY. 1980 - Lower Tertiary fungal spores from Lunpola Basin of Xizang, China (English summary). Acta Palaeontologica Sinica 19, 296-301. 